Florida International University

FIU Digital Commons

\title{
Volcanic History of the Izu Bonin Mariana Arc Prior to the First Arc Rift from Volcaniclastic Sediments of DSDP Site 296 and IODP Site 1438
}

Eshita Samajpati

Florida International University, esama005@fiu.edu

Follow this and additional works at: https://digitalcommons.fiu.edu/etd

Part of the Geochemistry Commons, Geology Commons, and the Volcanology Commons

\section{Recommended Citation}

Samajpati, Eshita, "Volcanic History of the Izu Bonin Mariana Arc Prior to the First Arc Rift from Volcaniclastic Sediments of DSDP Site 296 and IODP Site 1438" (2020). FIU Electronic Theses and Dissertations. 4408.

https://digitalcommons.fiu.edu/etd/4408

This work is brought to you for free and open access by the University Graduate School at FIU Digital Commons. It has been accepted for inclusion in FIU Electronic Theses and Dissertations by an authorized administrator of FIU Digital Commons. For more information, please contact dcc@fiu.edu. 


\title{
FLORIDA INTERNATIONAL UNIVERSITY \\ Miami, Florida
}

\begin{abstract}
VOLCANIC HISTORY OF THE IZU BONIN MARIANA ARC PRIOR TO THE FIRST ARC RIFT FROM VOLCANICLASTIC SEDIMENTS OF DSDP SITE 296
\end{abstract} AND IODP SITE 1438

\author{
A dissertation submitted in partial fulfillment of \\ the requirements for the degree of \\ DOCTOR OF PHILOSOPHY \\ in \\ EARTH SYSTEMS SCIENCE \\ by \\ Eshita Samajpati
}

2020 
To: Dean Michael R. Heithaus

College of Arts, Sciences and Education

This dissertation, written by Eshita Samajpati, and entitled Volcanic History of the Izu Bonin Mariana Arc Prior to the First Arc Rift from Volcaniclastic Sediments of DSDP Site 296 and IODP Site 1438, having been approved in respect to style and intellectual content, is referred to you for judgement.

We have read this dissertation and recommend that it be approved.

Andrew MacFarlane

Florentin Maurrasse

Grenville Draper

Jose Almirall

Rosemary Hickey-Vargas, Major Professor

Date of Defense: March 20, 2020

The dissertation of Eshita Samajpati is approved.

Dean Michael R. Heithaus

College of Arts, Sciences and Education

Andres G. Gil

Vice President for Research and Economic Development And Dean of the University Graduate School

Florida International University, 2020 
(C) Copyright 2020 by Eshita Samajpati

All rights reserved. 


\section{DEDICATION}

I dedicate my dissertation thesis to my parents for all their sacrifices and hard work in providing me the best and to my advisor, Dr. Rosemary Hickey-Vargas, for all the support and help during this journey. 


\section{ACKNOWLEDGMENTS}

I would like to thank my Advisor, Dr. Rosemary Hickey-Vargas, for mentoring me these past years as a doctoral student. Her guidance throughout these years has made me grow as a person and become a better researcher. Her positive criticism has always pushed me in the right direction by motivating me to achieve my goals. She has always been supportive throughout this journey and helped me in both academic and non-academic matters. I am grateful to have her as my mentor and major professor.

I would also like to thank all my committee members Dr. Florentin Maurasse, Dr. Jose Almirall, Dr. Andrew Macfarlane, and Dr. Grenville Draper for their guidance throughout the dissertation process. They have always helped me in answering my doubts and questions by giving invaluable suggestions and ideas.

I would like to thank my friends in the Earth and Environment department, Kimberly Beck, Maria Gudnitz, Vanessa Londono, and Jander Socorro for their support, encouragement and help in my research. The only friends in Miami who understand what I study, these people helped me keep my sanity.

I would like to thank the Earth and Environment department and the people, especially Gail Excell and her help throughout these years. Thomas Beasley for his help in my analysis and for teaching me how to use the instruments. I am also thankful to the Graduate School for awarding me the dissertation year fellowship, which gave me valuable time to finish my thesis. I am also thankful to the NSF grants to Dr. Rosemary HickeyVargas, OCE 1537786, which funded my analysis for this research and my research assistantship for a year and OCE 0931440 which allowed my advisor to get the core samples from Site 296 from the repository. 
Lastly, I would like to thank my family, my mom Dipti Kana Samajpati and my dad Rathin Samajpati for believing in me and letting me come so far to pursue my dreams. My brother, Rajarshi Samajpati, and my cousins for keeping me updated on the family fun that I am missing out. My boyfriend, Pushkar Bharambe, for motivating me to finish my thesis without giving any excuses. And my close friends, Tiyash Parira, Charles Rodrigues, Pritesh Pardeshi, and Kusha Kapoor for bearing with me throughout these years and helping me whenever I need. And lastly, the fur babies, Zara and Skye, for all their cuddles and help in de-stressing. 


\begin{abstract}
OF THE DISSERTATION
VOLCANIC HISTORY OF THE IZU BONIN MARIANA ARC PRIOR TO THE

FIRST ARC RIFT FROM VOLCANICLASTIC SEDIMENTS OF DSDP SITE 296
\end{abstract}

AND IODP SITE 1438

by

\title{
Eshita Samajpati
}

Florida International University, 2020

Miami, Florida

\section{Professor Rosemary Hickey-Vargas, Major Professor}

The Izu-Bonin Mariana (IBM) island arc in the western Pacific basin is a volcanic chain formed by subduction of the Pacific lithospheric plate beneath the Philippine Sea plate. Worldwide, subduction causes high-magnitude earthquakes and explosive volcanic activity in addition to forming the Earth's continental crust and major ore deposits, thus its understanding is important to human concerns. In the IBM, volcanic activity spans 50 million years to the present and the arc has undergone extension and periodic rifting, preserving remnants of its early history. The Kyushu Palau ridge (KPR), an inactive Oligocene remnant of the rifted IBM system, is a unique window to understanding the early subduction processes. In this work, contemporaneous volcaniclastic sediments drilled at Deep Sea Drilling Project (DSDP) Site 296, located in a basin at the crest of the northern KPR, and volcaniclastic sediments drilled at IODP (International Ocean Discovery Program) Site 1438, in the nearby Amami-Sankaku basin, were studied and compared to understand the early volcanic history of the IBM, from the early Oligocene to arc rifting and opening of the Shikoku basin in the early Miocene. Grains of feldspar, pyroxene and 
amphibole, together with enclosed melt inclusions, glass grains and lithic fragments were separated from the sediment at intervals along the drilled cores and analyzed for major and trace elements and radiogenic isotopes. In-situ analysis on minerals, glass grains and meltinclusions was performed using electron probe microanalysis (EPMA) and laser-ablation inductively coupled plasma mass-spectrometry (LA-ICPMS). Lithic fragments were dissolved and analyzed for elemental abundances by solution introduction ICP-MS and for isotopes by multi-collector-ICP-MS. Mineral compositions were used to calculate equilibrium magma compositions using major element matched partition coefficients, to compare with glass grains and lithic fragments. Findings show that magma compositions of the arc became progressively more water-rich with time, with periods of explosive eruption evidenced by pumice layers, stabilization of amphibole and Ca-rich plagioclase feldspar. Interspersed incompatible element-depleted mafic magmas at intermediate depths in the Site 296 core probably represent the initial intrusions associated with arc rifting which may have begun contemporaneously with arc volcanism. 


\section{TABLE OF CONTENTS}

CHAPTER

PAGE

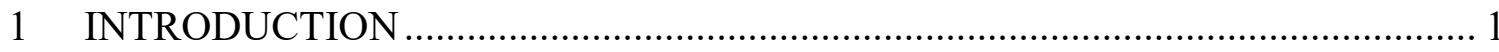

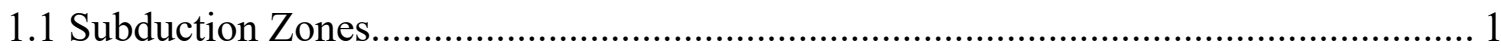

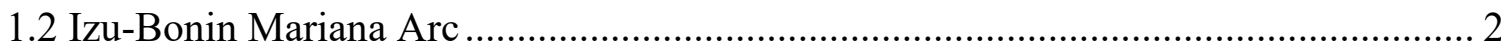

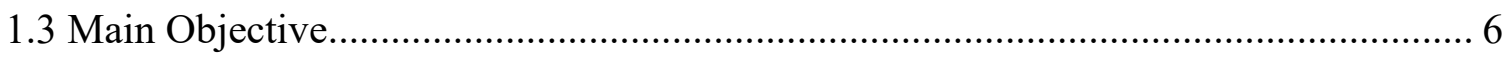

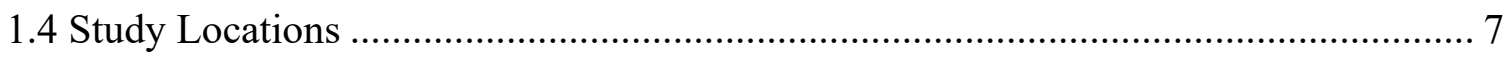

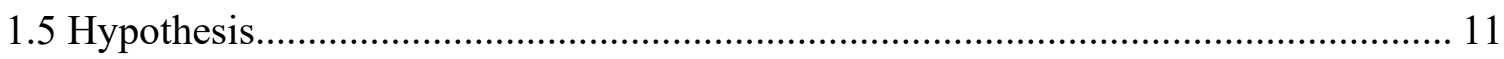

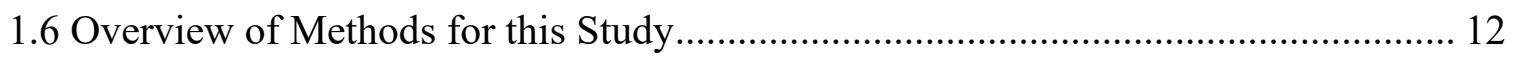

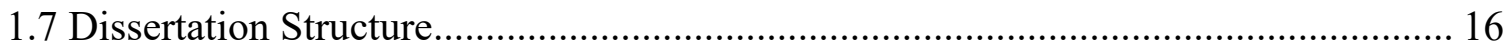

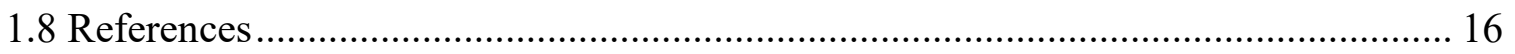

2 GEOCHEMISTRY OF VOLCANIC GLASS FROM OLIGOCENE DETRITAL SEDIMENTS AT DSDP SITE 296, KYUSHU PALAU RIDGE: INTERPRETING THE MAGMATIC EVOLUTION OF THE EARLY NORTHERN IZU BONIN

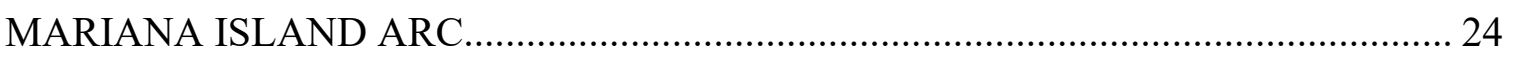

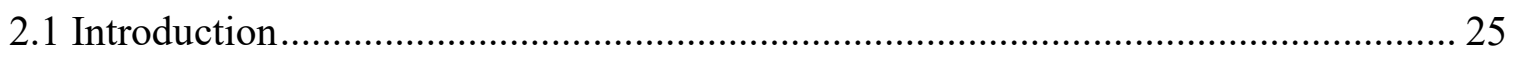

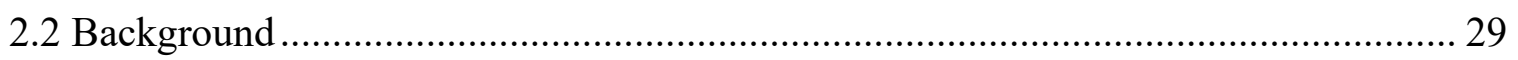

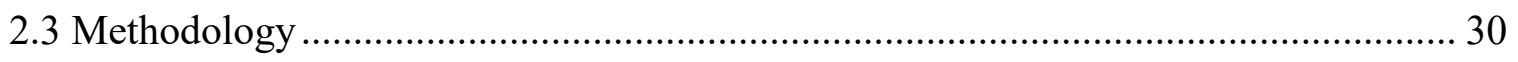

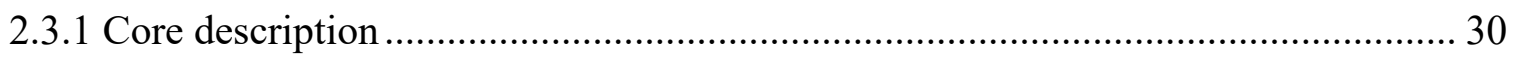

2.3.2 Analytical Techniques ................................................................................. 32

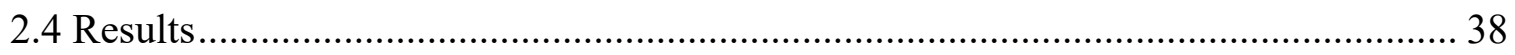

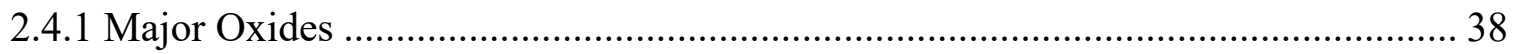

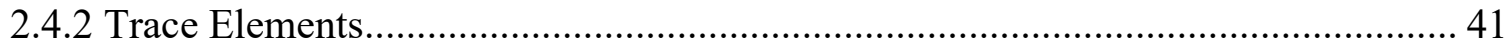

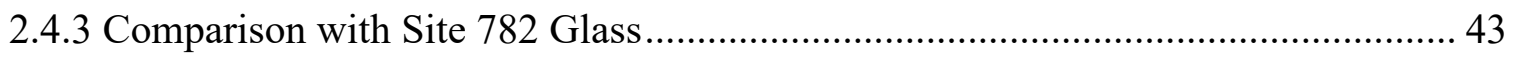

2.4.4 Comparison with Volcanic Rock fragments .......................................................... 46

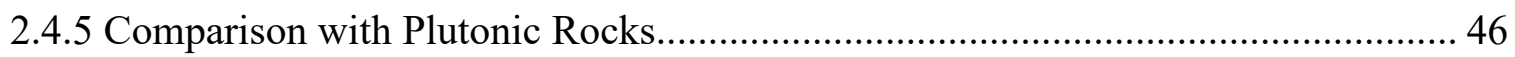

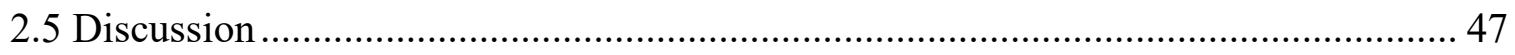

2.5.1 Interpretation of diverse igneous materials from the northernmost early IBM arc . 47

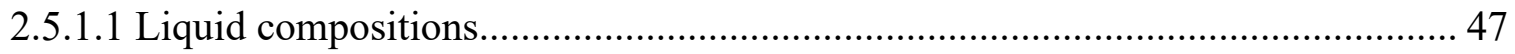

2.5.1.2 Method of recovery and time constraints......................................................... 49

2.5.1.3 Unequal record of mafic and felsic and intrusive and extrusive parts of volcanic systems. 


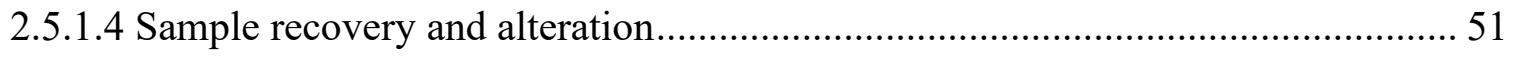

2.5.2 Inferences about the Evolution of the Oligocene IBM Arc ………........................ 52

2.5.2.1 Evidence for diverse parental magmas ............................................................ 52

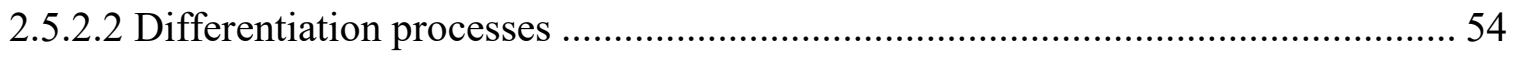

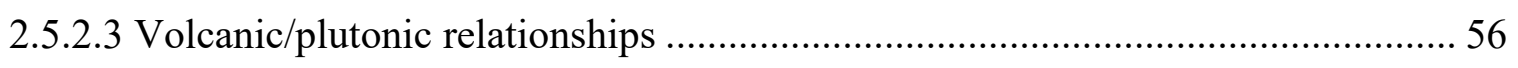

2.5.3 Geochemical Evolution of Magmas in KPR Segment 1..................................... 58

2.5.3.1 Mantle Fertility and Subduction inputs............................................................. 58

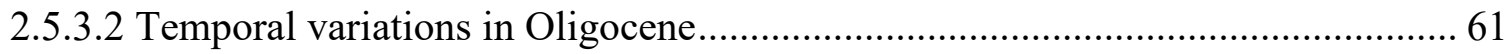

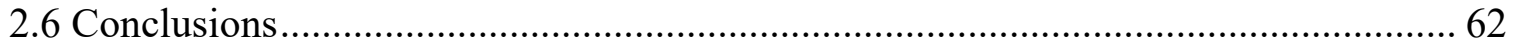

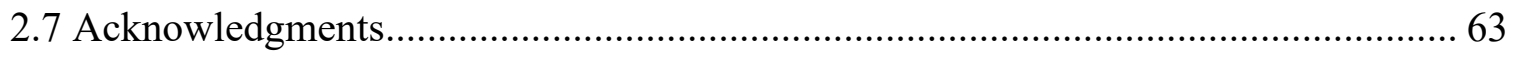

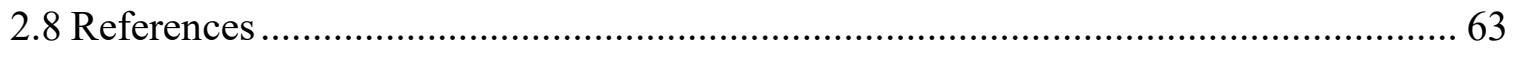

3 EARLY MAGMATIC HISTORY OF THE IBM ARC INFERRED FROM

VOLCANIC MINERALS AND MELT INCLUSIONS FROM EARLY- LATE OLIGOCENE DSDP SITE 296: A MINERAL-MELT PARTITION APPROACH ....... 73

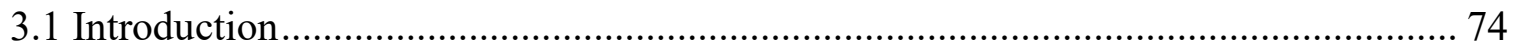

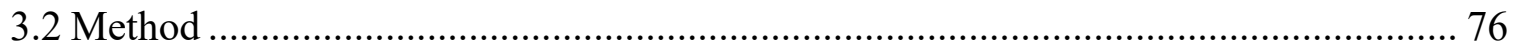

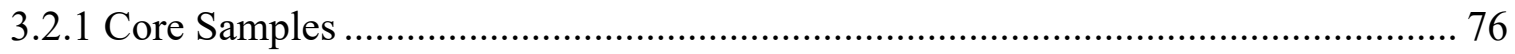

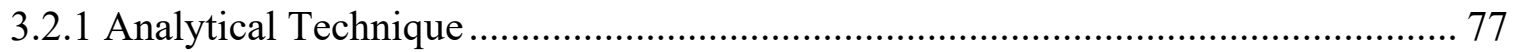

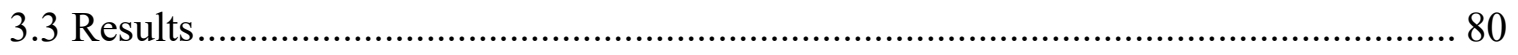

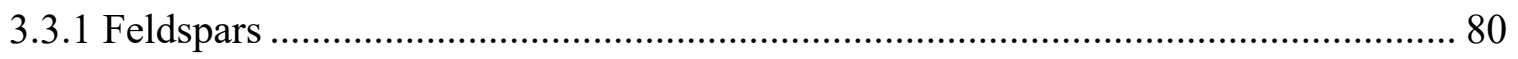

3.3.2 Pyroxenes .............................................................................................. 81

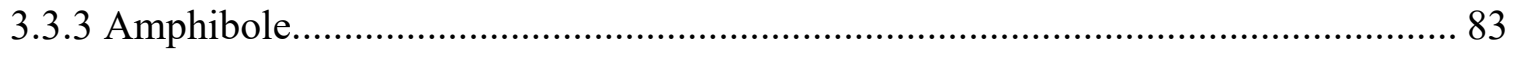

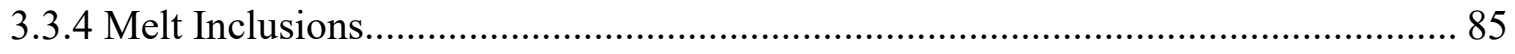

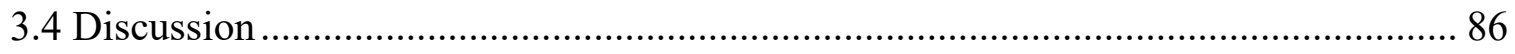

3.4.1 New Findings from Mafic Minerals at Site 296 ............................................. 86

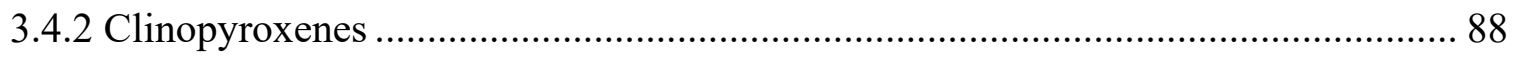

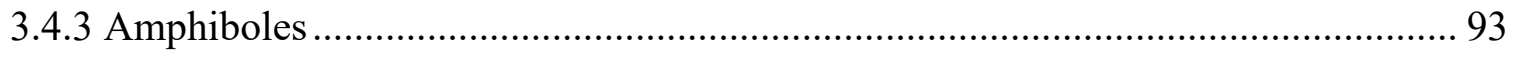

3.4.4 Magma Compositions Recorded at Site 296 ...................................................... 99

3.4.5 Temporal changes and Oligocene Rifting.......................................................... 104

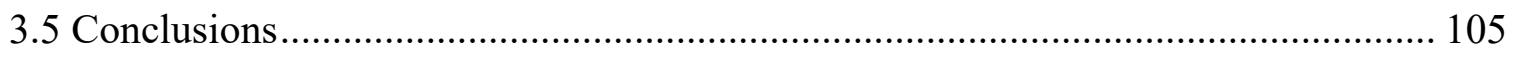

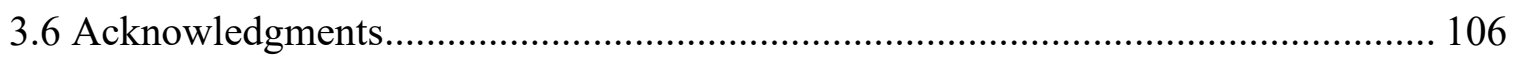

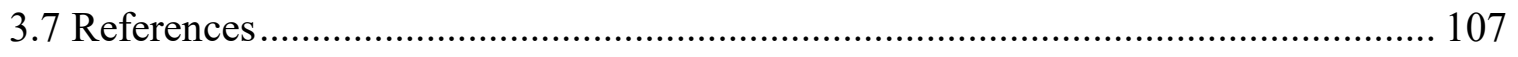


4 MAGMATIC EVOLUTION OF THE EARLY NORTHERN IZU-BONIN MARIANA ARC FROM SITE 1438 AND SITE 296 ROCKS AND MINERALS: A

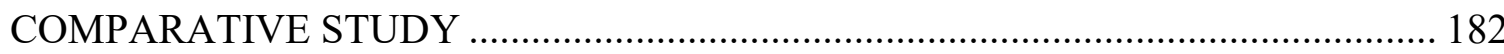

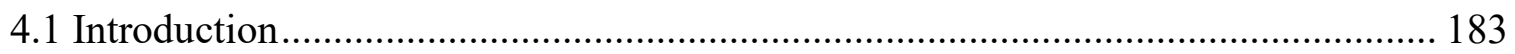

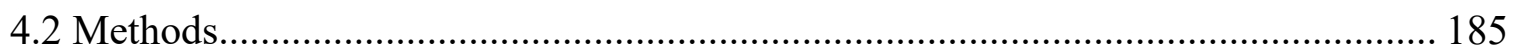

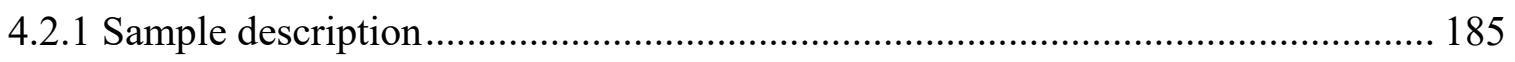

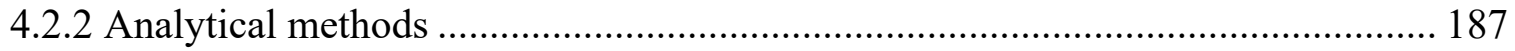

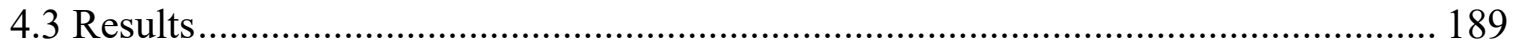

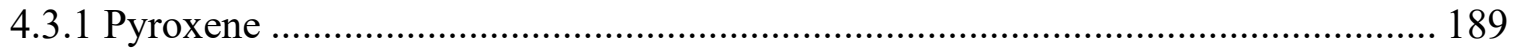

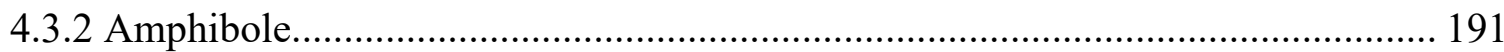

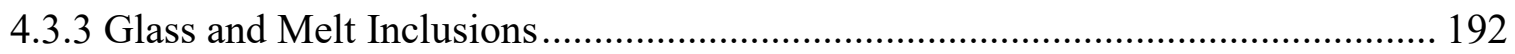

4.3.4 Lithic Fragments (Clasts) from Sites 1438 and 296 .......................................... 194

4.3.5 Mafic minerals of Site 1438 ............................................................................ 195

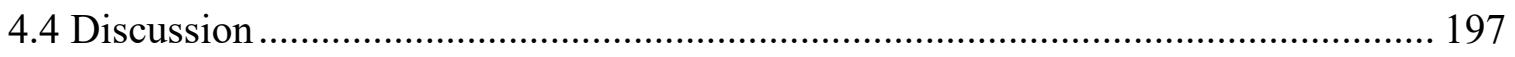

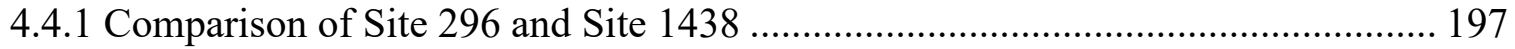

4.4.1.1 Location and physical characteristics .............................................................. 197

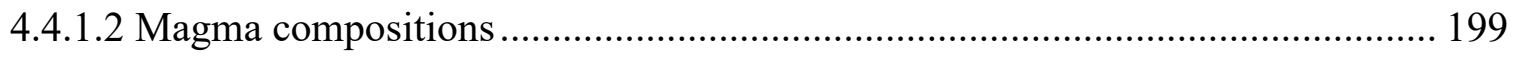

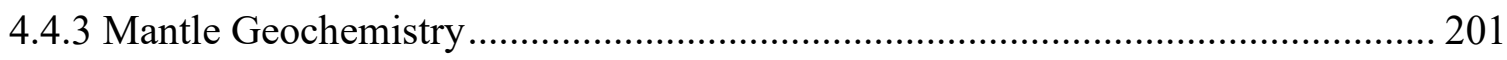

4.4.3 Temporal Variation and Correlation of the Sites ................................................. 205

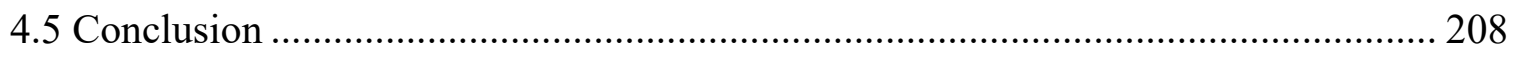

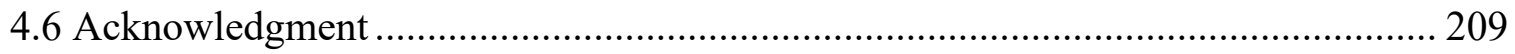

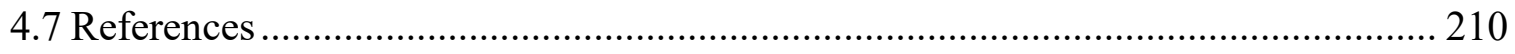

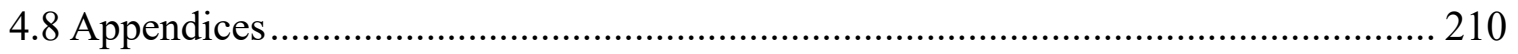

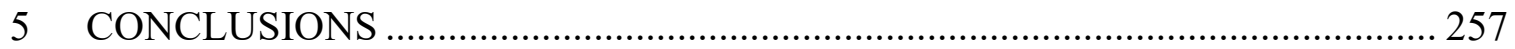

5.1 Model for Oligocene Evolution and Rifting based on Site 296 and Site 1438 ........ 257

5.2 Implication for the Evolutionary History of Izu Bonin arc.................................... 260

5.3 Future Research Direction ........................................................................... 262

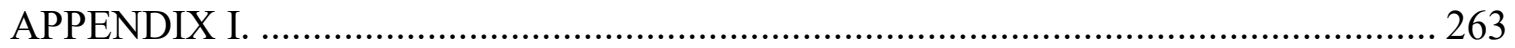

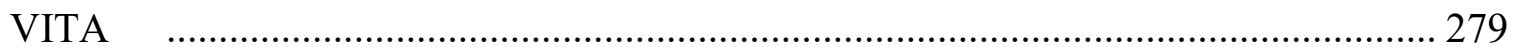




\section{LIST OF FIGURES}

Figure 1-1 Schematic diagram of a subduction zone and the different components.

(Stern, 2002)

Figure 1-2 (a) Tectonic evolution of the IBM (Stern et al., 2003); (b) paleoreconstruction of the Philippine sea plate from Hall (2002). 5

Figure 1-3 Map showing the location of Site 296 and Site 1438 (Arculus et al., 2015) .... 8

Figure 1-4 Seismic reflection profile across the KPR, near Site 296. Red line indicates

Site 296. (Ingle et al., 1975).

Figure 1-5 Seismic reflection image showing location of Site 1438, on the east of it lies the Kyushu Palau ridge (Arculus et al., 2015)

Figure 1-6 Profile line from Site 296 to Site 1438.

Figure 2-1 (a) Map of the Izu-Bonin Mariana (IBM) Arc region showing remnant arcs and back arc basins. The first remnant arc, the Kyushu Palau Ridge (KPR) has been divided into four segments after Ishizuka et al. (2011b); this study focuses on the first segment which is shown as an inset. (b) Close up map of Segment 1 of the KPR and the northern Izu Bonin arc showing the location of DSDP Site 296 and previously studied locations in that area. Green filled circles show study locations of Haraguchi et al. $(2003,2012)$ and purple filled circles are locations of rocks described in Ishizuka et al. (2011b)

Figure 2-2 Simplified history of the IBM arc system modified after Stern et al. (2003). Shaded areas are magmatically inactive, and cross-hatched areas are magmatically active. The approximate time period or stage of geochemical evolution studied in this paper is shown in panel $\mathrm{C}$

Figure 2-3 The stratigraphic column of DSDP Site 296 showing the lithological Unit 2, and $1 \mathrm{G}$ through $1 \mathrm{~A}$ and their biostratigraphic ages. The glass shards and the clasts in this work were sampled from Unit 2 and the lower part of Unit $1 \mathrm{G}$

Figure 2-4 Figure 2-4 Plot of depth vs. $\mathrm{SiO} 2$ content of glass shards in volcaniclastic sediments of DSDP Site 296.

Figure 2-5 (a-h) Harker plots showing the variation of major oxides with $\mathrm{SiO} 2$ for Site 296 glass, clasts, and previously studied volcanic materials from KPR Segment 1 and its analog in the Izu-Bonin forearc (Straub, 2003, 2010; Bryant et al., 2003; Ishizuka et al., 2011b; Haraguchi et al., 2003, 2012). Fields for the K2O-SiO2 plot are after Le Maitre et al. (1998). Vectors on the plot show the effect of mineral crystallization (see 
discussion). Data points are color-coded, with different symbols for different materials and locations.

Figure 2-6 Primitive mantle normalized elemental abundances for glass shards and lithic clasts from DSDP Site 296: a) basalt and basaltic-andesite; (b) andesite; (c) dacite and (d) rhyolite. Normalizing values from Sun and McDonough (1989)....

Figure 2-7 (a) Primitive mantle normalized elemental abundances for tephra and glass from ODP Site 782A, data from Straub et al., 2010 and Bryant et al., 2003.

(b) Primitive mantle normalized elemental abundances for Segment 1 volcanic rocks from Ishizuka et al., 2011b. Shaded area represents the compositional range of Site 296 glasses and clasts (c) Primitive mantle normalized elemental abundances for tonalites from Haraguchi et al., 2003. (d) Primitive mantle normalized elemental abundances for volcanic rocks from Haraguchi et al., 2012. Dark green colors represent the rocks from Nichinan seamout.

Figure 2-8 (a) Plot of Ba vs. Nb ; (b) Plot of La vs. Th and (c) Plot of Ba vs. Th for Site 296 and samples cited in Fig. 2-7 caption

Figure 2-9 (a) Logarithmic plot of $\mathrm{Th} / \mathrm{Yb}$ vs. $\mathrm{Nb} / \mathrm{Yb}$ showing depleted and enriched MORB fields (Pearce and Peate, 1995). (b) Ba/La vs. (La/Sm)N plot for all samples. (c) $\mathrm{Ba} / \mathrm{Th}$ vs. $(\mathrm{La} / \mathrm{Sm}) \mathrm{N}$ plot for the mafic glasses and volcanic rocks ....

Figure 2-10 (a) Olivine-Diopside-Quartz and (b) Olivine-Plagioclase-Quartz pseudo ternary projections showing glasses and rocks. The 1-atmosphere multiple saturation curve after Grove and Baker (1984) is shown on the Ol-Di-Q plot. The volcanic rocks are from Haraguchi et al. (2012) and Ishizuka et al. (2011b)

Figure 2-11 Schematic diagram of the origin of volcanic and plutonic materials discussed. The top panel (a) shows the active first arc prior to rifting with the drill sites 296 and 782 denoted by stars. The bottom panel (b) depicts the present-day geological setting with the subsided and inactive KPR stranded by rifting

Figure 2-12 (a) Plot of $\mathrm{Zr} / \mathrm{Sm}$ vs. $\mathrm{SiO} 2$ showing a slight increase in the ratio with differentiation. (b) Plot of $\mathrm{La} / \mathrm{Nb}$ vs. $\mathrm{SiO} 2$ showing no variation in the ratio with differentiation. (c) Plot of $\mathrm{Th} / \mathrm{La}$ vs. SiO2, showing a very slight increase to no variation with differentiation. Symbols as in Figure 2-5 caption 53

Figure 2-13 (a) Plot of $\mathrm{La} / \mathrm{Yb}$ vs. SiO2 showing the trends of garnet and amphibole fractionation with differentiation of magma (Davidson et al., 2007). La/ $\mathrm{Yb}$ increases during the fractionation of both garnet and amphibole with a greater increase in the ratio for garnet compared with amphibole. (b) Plot of $\mathrm{Dy} / \mathrm{Yb}$ vs. SiO2 showing the trends of garnet and amphibole fractionation with differentiation (Davidson et al., 2007). Dy/Yb increases with fractionation of garnet and decreases with amphibole fractionation. The dashed horizontal line shows the primitive mantle ratio from Sun and McDonough (1989). Symbols as in Figure 2-5 caption 
Figure 2-14 Primitive mantle normalized spider plots of tonalites and dacite glasses from Site 296 and 782, which show complementary features. Tonalites are shown in grey, Site 296 glasses in blue and Site 782 in orange.....

Figure 2-15 Plot of $(\mathrm{La} / \mathrm{Sm}) \mathrm{N}$ vs. age in Ma for tephra, volcanic, and plutonic rocks from KPR Segment 1. Some older Eocene Site 782 tephras are also plotted. The blue squares are the range of $(\mathrm{La} / \mathrm{Sm}) \mathrm{n}$ for glass shards and clasts from DSDP Site 296 using their early to late Oligocene depositional age. Symbols as in Figure 2-5 caption .. 60

Figure 3-1 (a) Map of the present day Izu-Bonin Mariana arc and features of the Philippine Sea plate. The Kyushu Palau ridge has been divided into 4 segments as per Ishizuka et al. (2011b). Red star shows the location of DSDP Site 296. (b) Lithostratigraphic sequence as defined by the Shipboard Party, DSDP Leg 31 (Ingle et al, 1975).

Figure 3-2 Depth vs. cumulative frequency of compositional range of plagioclase at different depths

Figure 3-3 (a) Ternary plot showing the composition of pyroxenes at Site 296 (b-d) Tectonic discrimination diagram based on clinopyroxene composition from Leterrier et al. (1982). Elements are expressed in cationic value from the structural formula of clinopyroxenes. Orange ones in $\mathrm{c}$ and $\mathrm{d}$ are the unusually high Mg\# clinopyroxenes..... 82

Figure 3-4 Primitive mantle normalized multi-elemental composition of some mafic clinopyroxenes. Normalizing values after Sun and McDonough (1989). Clinopyroxene with $\mathrm{Mg} \#>85$ is shown in orange; $\mathrm{Mg} \#$ 80-85 is shown in blue and Mg\# less than 80 is shown in yellow.

Figure 3-5 (a)Site 296 amphibole compositions plotted using cationic values based on 23 Oxygens after Leake et al. (1997). (b) Primitive mantle normalized trace element abundances in amphiboles; blue are magnesiohastingsites, yellow are edenites and the orange ones are magnesiohornblendes.

Figure 3-6 (a) $\mathrm{K}_{2} \mathrm{O}$ vs $\mathrm{SiO}_{2}$ showing Site 296 melt inclusions in clinopyroxene compared with detrital glass shards from Site 296. (b) Cationic Fe/Mg ratios for melt inclusions and host clinopyroxenes. Kd line for cpxs/melt is 0.27 after Putirka et al. (2008). Clinopyroxene Fe/Mg calculated from Site 296 glass shards and melt $\mathrm{Fe} / \mathrm{Mg}$ calculated from Site 296 clinopyroxenes are plotted on the equilibrium line. The melt inclusion which plots on the equilibrium line is of a basaltic composition. (c) Primitive mantle normalized trace element compositions of melt inclusions from clinopyroxenes (orange) and orthopyroxenes (purple).

Figure 3-7 Al2O3 vs Mg\# for Site 296 clinopyroxenes 89

Figure 3-8 Comparison of clinopyroxene/melt partition coefficients from published data and partition coefficients calculated from melt inclusions and host cpxs from Site 
296. For basaltic melts:-Rb-Klemme et al. (2002); Sr, Sm-Johnson (1994); Ce, YJenner et al. (1994); Ba, Zr, Hf- Hart and Dunn (1993); Th, U, La, Nd, Eu, Dy, Er, Yb, Lu- Hauri et al. (1994); Gd-Hack et al. (1994); Pb-Beattie (1993). For basalticandesite melts -Rb-Philpotts and Schnetzler (1970); Sr, Y, Zr, La, Ce, Nd, Sm, Dy, Er, Yb- Ronov and Yaroshevskiy (1976); Ba- Hart and Brooks (1974); Gd- Gallahan and Nielson (1992); Hf, Th, U- Dostal et al. (1983). For andesitic melts: La, Sm, Dy, YbNicholls and Harris (1980); Zr- Watson and Ryerson (1986); Rb, Pb, Sr, Y-Ewart and Griffin (1994); Ba, Nd- Luhr and Carmichael (1980); Th, Ce, Hf - Bacon and Druitt (1988) ; Er-Schnetzler and Philpotts (1970).

Figure 3-9 Primitive mantle normalized trace element abundances in melts calculated from Site 296 clinopyroxenes using cpx-basalt MI partition coefficients. Color-coded as figure 3-4. Grey shaded area at the back represents the trace element abundances of Site 296 glass shards. A high Mg andesite from Bonin Ridge Escarpment is shown in dark grey (Ishizuka et al., 2006).

Figure 3-10 (a) Primitive normalized trace element abundances in melts calculated from amphiboles using amphibole/melt partition coefficients from Nandedkar et al. (2016). The shaded field represents the trace element abundances of Site 296 glass shards. (b) Calculated melt compositions using the method of Humphreys et al. (2019). Y and Ho values produced anomalous elevated and depleted peaks and hence were removed.

Figure 3-11 Plot of $\mathrm{Al} / \mathrm{Si}$ and $\mathrm{Fe} / \mathrm{Mg}$ of Site 296 glass shards compared with melt compositions calculated from amphibole compositions. Open symbols are for calculated melts and closed symbols are for the glass shards.

Figure 3-12 Primitive mantle normalized REE plot for analyzed and calculated melts for all materials. Compositional ranges inferred from clinopyroxenes, amphiboles and analyzed melt inclusions are shown as shaded fields.

Figure 3-13 Logarithmic plot of $\mathrm{Th} / \mathrm{Yb}$ vs Nb/Yb for melt composition, both analyzed and inferred from mafic minerals; also includes high $\mathrm{Mg}$ andesite data from the Bonin Ridge Escarpment (BRE)

Figure 3-14 From left to right, plot showing the depth vs Mg\# of clinopyroxenes with their magmatic affinity; $\mathrm{SiO}_{2}$ content of melt in equilibrium with amphibole; $\mathrm{La} / \mathrm{Sm} N$ of mafic to intermediate glass shards and calculated melts from minerals; and $\mathrm{Nb} / \mathrm{Yb}$ of mafic to intermediate glass shards and calculated melts.

Figure 4-1Map showing the location of Site 296 and Site 1438 on KPR 184

Figure 4-2 Lithostratigraphic column of Sites 296 and 1438, red dashed lines correlate to similar biostratigraphic ages and the studied section 186

Figure 4-3 (a) $\mathrm{Mg} \#$ vs. $\mathrm{Al}_{2} \mathrm{O}_{3}(\mathrm{wt} \%$ ) of clinopyroxenes of Site 1438 , (b), \& (c) 
Tectonic discrimination diagram for clinopyroxenes from Leterrier et al. (1982).

Elements are expressed in atoms per formula unit. The shaded region in the background shows the composition of Site 296 clinopyroxenes

Figure 4-4 (a) Primitive mantle normalized trace element concentration of Site 1438 cpxs. Normalizing values after Sun and Mcdonough (1989) (b) Primitive mantle normalized trace element concentrations of Site 1438 amphiboles. Shaded regions are the composition of Site 296 minerals.

Figure 4-5 (a), (b), \& (c) $\mathrm{SiO}_{2}$ vs. other oxides (in wt\%) for glass, melt inclusion and clasts from Site 296 and Site 1438. Fields for $\mathrm{K}_{2} \mathrm{O}$ are from Peccerillo and Taylor (1976)

Figure 4-6 (a)Primitive mantle normalized trace element concentration of Site 1438 glass (orange), MI (blue) and clast (purple) (b) Primitive mantle normalized trace element concentration of new Site 296 glass (orange) and clast (purple). Shaded background is the composition of previously analyzed glass and clast composition from Site 296

Figure 4-7 ENd vs. EHf plot for Site 296 and Site 1438 clast. CHUR values used to calculate the $\varepsilon$ values are from Bouvier et al. (2008), mantle line from Pearce et al. (1999)

Figure 4-8 (a) Primitive mantle normalized calculated melt composition in equilibrium with mafic clinopyroxene from Site 1438 (b) Primitive mantle normalized calculated melt composition in equilibrium with amphiboles from Site 1438, blue are andesite, yellow are dacite and orange are rhyolite melt composition in equilibrium. The shaded background represents the calculated melt compositions from Site 296 minerals

Figure 4-9 (a) $\mathrm{SiO}_{2}$ vs FeOt/MgO plot distinguishing the tholeiitic (Th) and calcalkaline (Ca) fields (Miyashiro, 1974) for melt compositions represented by glass, MI and clasts from Site 296 and Site 1438 (b) Logarithmic plot of $\mathrm{Th} / \mathrm{Yb}$ and $\mathrm{Nb} / \mathrm{Yb}$ ratios for melts (c) $\mathrm{Ba} / \mathrm{Yb}$ vs Nb/Yb plot for the melt compositions

Figure 4-10 (a) Initial ${ }^{143} \mathrm{Nd} /{ }^{144} \mathrm{Nd}$ and ${ }^{176} \mathrm{Hf} /{ }^{177} \mathrm{Hf}$ isotope ratio evolution of IBM arc from 49 m.y to Neogene (b) Mixing curves between the mantle composition represented by Site 1438 basement, Pacific Ocean sediments, clay (CL), chert $(\mathrm{CH})$ and volcanic sediments $(\mathrm{V})$ and altered ocean crust (AOC)

Figure 4-11 (a)- (d) Trace element ratio vs. ${ }^{143} \mathrm{Nd} /{ }^{144} \mathrm{Nd}$ for mafic and intermediate clasts of Site 1438 and Site 296. Blue diamonds are also Site 296 clasts. Also shown are data from Laxton (2016) from same depth interval.

Figure 4-12 (a) La/SmN vs. depth (mbsf) of Site 296 mafic and intermediate melt compositions (b) La/SmN vs. depth of site 1438 mafic and intermediate melt 
compositions (c) $\mathrm{Nb} / \mathrm{Yb}$ ratio vs. depth of Site 296 melt compositions (d) $\mathrm{Nb} / \mathrm{Yb}$ ratio vs. depth of Site 1438 melt compositions. Both analyzed and calculated melt are shown.

Figure 5-1 Stratigraphic section studied from both Sites 296 and 1438 and the changes in mineralogy and geochemistry observed.

Figure 5-2 Schematic diagram showing the possible magma evolution of the northernmost IBM prior to rifting... 260 


\section{ABBREVIATIONS AND ACRONYMS}

$\%$
${ }^{\circ}$
${ }^{\circ} \mathrm{C}$

Al

$\mathrm{Al}_{2} \mathrm{O}_{3}$

$\mathrm{Al}^{\mathrm{T}}$

$\mathrm{Al}^{\mathrm{VI}}$

An

$\mathrm{Ar}$

$\mathrm{Ba}$

BHVO

$\mathrm{cm}$

$\mathrm{Ca}$

$\mathrm{CaO}$

$\mathrm{Ce}$

CHUR

Cpx

$\mathrm{Cr}$

$\mathrm{Cr}_{2} \mathrm{O}_{3}$

Cs

DI

Dy
Percent

Degrees

Degrees Celsius

Aluminum

Aluminium Oxide

Tetrahedral Aluminium

M site Aluminium

Anorthite

Argon

Barium

Basalt, Hawaiian volcanic observatory

Centimeter

Calcium

Calcium Oxide

Cerium

Chondritic Uniform Reservoir

Clinopyroxene

Chromium

Chromium (III) Oxide

Cesium

Deionized water

Dysprosium 


\begin{tabular}{|c|c|}
\hline EPMA & Electron probe micro-analyzer \\
\hline $\mathrm{Er}$ & Erbium \\
\hline En & Enstatite \\
\hline $\mathrm{Eu}$ & Europium \\
\hline $\mathrm{Fe}$ & Iron \\
\hline $\mathrm{FeO}$ & Iron (II) oxide \\
\hline Fig & Figure \\
\hline $\mathrm{Gd}$ & Gadolinium \\
\hline $\mathrm{HCl}$ & Hydrochloric acid \\
\hline Hf & Hafnium \\
\hline HFSE & High field strength element \\
\hline Ho & Holmium \\
\hline HREE & Heavy rare earth elements \\
\hline IBM & Izu Bonin Mariana \\
\hline In & Indium \\
\hline $\mathrm{K}$ & Potassium \\
\hline $\mathrm{K}_{2} \mathrm{O}$ & Potassium oxide \\
\hline Kbar & Kilobar \\
\hline $\mathrm{Kd}$ & Partition coefficient \\
\hline $\mathrm{km}$ & Kilometers \\
\hline KPR & Kyushu Palau Ridge \\
\hline $\mathrm{La}$ & Lanthanum \\
\hline $\mathrm{La} / \mathrm{Sm}_{\mathrm{N}}$ & Normalized ratio of lanthanum over samarium \\
\hline
\end{tabular}




\begin{tabular}{|c|c|}
\hline $\mathrm{La} / \mathrm{Yb}_{\mathrm{N}}$ & Normalized ratio of lanthanum over ytterbium \\
\hline LA-ICP-MS & Laser ablation inductively coupled plasma mass spectrometry \\
\hline LILE & Large ion lithophile element \\
\hline LREE & Light rare earth elements \\
\hline $\mathrm{Lu}$ & Lutetium \\
\hline $\mathrm{m}$ & Meter \\
\hline Ma & Mega annum \\
\hline Mbsf & Meters below sea floor \\
\hline $\mathrm{Mg}$ & Magnesium \\
\hline $\mathrm{Mg} \#$ & Magnesium number \\
\hline $\mathrm{MgO}$ & Magnesium oxide \\
\hline MI & Melt inclusion \\
\hline $\mathrm{MnO}$ & Manganese oxide \\
\hline MORB & Mid oceanic ridge basalt \\
\hline MREE & Middle rare earth elements \\
\hline m.y. & Millions of years \\
\hline $\mathrm{Na}$ & Sodium \\
\hline $\mathrm{NaO}$ & Sodium oxide \\
\hline $\mathrm{Nb}$ & Niobium \\
\hline $\mathrm{Nd}$ & Neodymium \\
\hline $\mathrm{Ni}$ & Nickel \\
\hline NIST & National Institute of Standards and Technology \\
\hline Opx & Orthopyroxene \\
\hline
\end{tabular}




\begin{tabular}{|c|c|}
\hline $\mathrm{P}_{2} \mathrm{O}_{5}$ & Phosphorus pentoxide \\
\hline $\mathrm{P}$ & Pressure \\
\hline $\mathrm{Pb}$ & Lead \\
\hline $\operatorname{Pr}$ & Praseodymium \\
\hline $\mathrm{Pm}$ & Promethium \\
\hline $\mathrm{PM}$ & Primitive mantle \\
\hline ppm & Parts per million \\
\hline $\mathrm{Rb}$ & Rubidium \\
\hline REE & Rare earth elements \\
\hline SEM-EDS & Scanning electron microscope with energy dispersive system \\
\hline $\mathrm{Si}$ & Silicon \\
\hline $\mathrm{SiO}_{2}$ & Silicon dioxide \\
\hline $\mathrm{Sm}$ & Samarium \\
\hline $\mathrm{Sr}$ & Strontium \\
\hline $\mathrm{T}$ & Temperature \\
\hline $\mathrm{Ta}$ & Tantalum \\
\hline $\mathrm{Tb}$ & Terbium \\
\hline Th & Thorium \\
\hline $\mathrm{Ti}$ & Titanium \\
\hline $\mathrm{TiO}_{2}$ & Titanium dioxide \\
\hline $\mathrm{U}$ & Uranium \\
\hline USGS & United States Geological Survey \\
\hline V & Vanadium \\
\hline
\end{tabular}




$\begin{array}{ll}\text { Wo } & \text { Wollastonite } \\ \text { wt\% } & \text { Weight percent } \\ \mathrm{Y} & \text { Yttrium } \\ \mathrm{Yb} & \text { Ytterbium } \\ \mathrm{Zr} & \text { Zircon }\end{array}$




\section{INTRODUCTION}

\subsection{Subduction Zones}

Convergent margins are the regions on the earth's surface where two lithospheric plates move towards each other. In the case of a convergence involving two oceanic lithospheres, one of the lithospheres will sink into the mantle because of its high density, forming a subduction zone (Fig. 1-1). Intra-oceanic arcs are an example of subduction zone systems where both the lithospheric plates converging is oceanic. During subduction, the downgoing oceanic lithosphere undergoes metamorphism, releasing water from hydrous minerals. The released water acts like a flux in melting the overlying rocks, forming volcanic chains along the length where subduction is occurring. Subduction has led to the growth of the continental crust, element recycling between the earth's surface to the interior, and is the driving force behind plate tectonics theory. Therefore, subduction and its related processes are critical phenomenons to understand what shapes our planet and how it evolves through time. Although we are quite familiar with what happens during subduction, there are still many questions yet to be answered. Many complexities are involved in the study of subduction zones, one of them being in most cases the initial volcanic records of an intra-oceanic arc remain buried and are challenging to study. The absence of initial records poses a challenge to understand how subduction initiates and how the arc system evolved to the current stage. The Izu Bonin Mariana (IBM) arc system in the West Pacific, is an example of an intra-oceanic arc which has been periodically rifted and its volcanic history from the initial to the active stage has been well exposed to be explored and understood. 


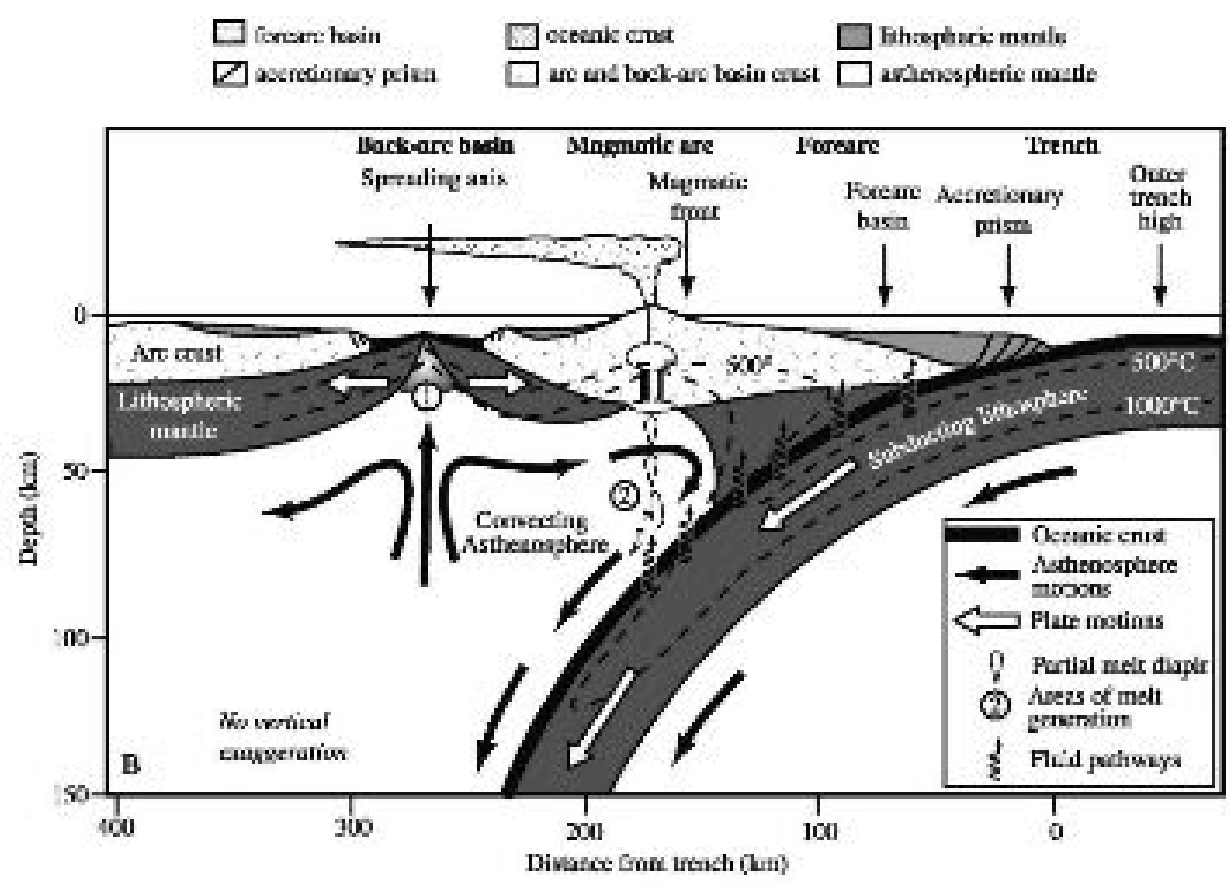

Figure 1-1 Schematic diagram of a subduction zone and the different components. (Stern, 2002)

\subsection{Izu-Bonin Mariana Arc}

The Izu-Bonin Mariana (IBM) arc is formed due to the subduction of the older Pacific plate under the Philippine plate. The arc is undergoing extension, which is not a consequence of trench rollback. Instead, the trench is moving towards Eurasia and the extensional regime is maintained by the rapid convergence between the Eurasian and Philippine plate (Scholz and Campos, 1995). Due to extensional stress in the back-arc region, the volcanic chain is rifted apart where one part becomes a remnant arc, and the other half becomes the active arc. The tectonic evolution of the IBM system is well known. According to Bloomer et al. (1995) and Stern and Bloomer (1992), the IBM subduction zone began with the subsidence of old and dense lithosphere in the western Pacific at $\sim 50$ Ma (Fig 1-2a). During this time, the forearc was the site of magmatic activity with the eruption of forearc basalt (FABs) consisting of low $\mathrm{K}$ and mid-ocean ridge like 
characteristics (Reagan et al. 2010; Ishizuka et al., 2011a) along with boninite, low-K tholeiite, and low-K rhyodacite (Hickey and Frey, 1982; Stern et al., 1991; Taylor et al., 1994; Reagan et al., 2010).

After 5 Ma had passed, the active magmatic front was localized, forming the first mature arc. This marked the transition from lithospheric subsidence to subduction, which probably began around $43 \mathrm{Ma}$, due to a major change in Pacific plate motion (Fig 1-2b) from a northerly to a westerly direction (Richards and Lithgow-Bertollini, 1996). This retreat of magmatism allowed the forearc lithosphere to cool. Arc volcanism continued until at least $30 \mathrm{Ma}$ when the arc was disrupted due to rifting to form the back-arc basins, Parece Vela Basin and Shikoku Basin (Taylor et al., 1992; Kobayashi et al., 1995). Parece Vela Basin and Shikoku Basin met at $\sim 20 \mathrm{Ma}$, disrupting the arc and stranding the KPR as a remnant arc. The lack of systematic age variations of volcanic rock along the KPR indicates that rifting was initiated almost concurrently along the entire ridge, this means that the initiation of the Shikoku and Parece Vela Basins and isolation of the KPR as a remnant arc occurred at about the same time. This back-arc basin spreading stopped at $\sim 15$ Ma, simultaneously with the opening of the Japan Sea, causing the northernmost IBM arc to collide with Honshu beginning at $\sim 15 \mathrm{Ma}$.

Arc magmatism was minimal or even absent from 25 to 15 Ma during the opening of the Shikoku Basin. A resurgence of arc volcanism began at $\sim 17$ Ma, slightly before the Shikoku Basin ceased spreading, and continued until $\sim 3$ Ma (Ishizuka et al., 1998, 2003b). A new episode of rifting of the southern IBM arc began at $\sim 7 \mathrm{Ma}$, with seafloor spreading to form the Mariana Trough back-arc basin beginning 3-4 Ma (Yamazaki and Stern, 1998). Current arc magmas in the Izu-Bonin section are low $\mathrm{K}$ and more depleted in 
incompatible elements than in the Mariana section where magmas are medium $\mathrm{K}$ and slightly more enriched (Taylor and Nesbitt, 1998; Ishizuka et al., 2003, 2008, 2011b). The evolution of the basins and remnant arcs in the Philippine Sea is said to be episodic (Karig, 1972). With new episodes of back-arc spreading and formation of a remnant arc, there is a period of almost no volcanism, which led Karig (1975) to conclude that marginal basins opened rapidly during the height of volcanic pulses along the associated arc system. He also proposed that any disruption in volcanism during back-arc spreading might be related to a physical separation of the near-vertical downgoing slab in the region of flexure (Kroenke and Scott, 1983), a period would then be required for the upper part of the subducting plate to reach a sufficient depth to produce magma. 


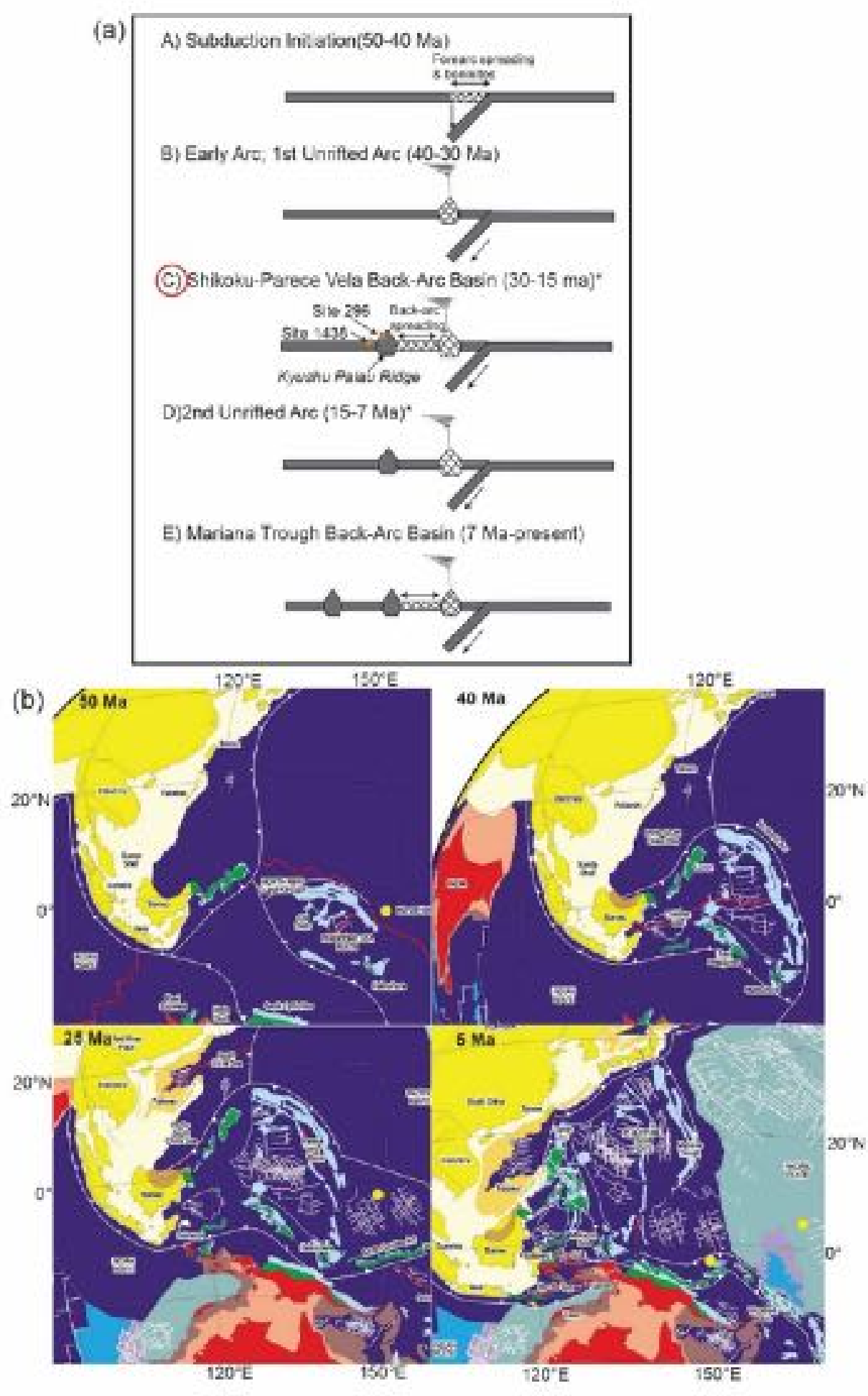

Figure 1-2 (a) Tectonic evolution of the IBM (Stern et al., 2003); (b) paleo-reconstruction of the Philippine sea plate from Hall (2002) 


\subsection{Main Objective}

The IBM system presents a remarkable opportunity to study subduction processes occurring at intraoceanic margins. Previous research has mainly focused on the IBM forearc and the magmatic evolution of the volcanic front through $50 \mathrm{Ma}$ (Bloomer et al., 1995; Stern and Bloomer, 1992; Hickey and Frey, 1982; Stern et al., 1991; Taylor et al., 1994; Ishizuka et al., 1998, 2003b). Compared to the forearc, the rear-arc IBM magmatic history has not been studied thoroughly despite its importance in understanding crustal evolution. Examination of early arc records can delineate the chemical changes seen from the trench to back-arc region, the history of mantle depletion and enrichment during arc evolution, and intracrustal differentiation. The recent focus of studies has, therefore, now shifted to the early evolutionary history of the IBM system. Recent IODP expedition like Leg 350, was drilled in the Izu-Bonin back-arc region to understand the evolution after the formation of the Shikoku basin and the resurgence of arc volcanism. In contrast, Leg 351 was drilled in the Amami Sankaku basin to follow the pre- subduction history and the evolution of the first IBM arc before the rifting event.

The main objective of this study is to understand the magmatic evolution in the northernmost section of KPR leading up to the rifting event, which separated the KPR from the IBM arc. KPR, which represents the initial arc of the IBM system, is a key to understand the early evolutionary history of the IBM arc. Study sites include two drilled sites, DSDP Site 296 and IODP Site 1438, which contains the contemporaneous record of the Oligocene volcanic evolution of the Izu-Bonin arc. A study by Ishizuka et al. (2011b) divided the KPR into four segments based on inflections and geologic features intersecting the ridge. Segment 1 is the northernmost segment extending southward to the intersection of Daito 
Ridge with KPR, and the rocks are mainly hornblende andesites. DSDP Site 296 and IODP Site 1438 both lie in segment 1, which corresponds to the early Izu-Bonin arc section before rifting. Thus, this study will add on to the knowledge of the early evolutionary history of the Izu-Bonin arc and interpret if any rifting related process may have affected the magma composition in terms of geochemistry or mineralogy.

\subsection{Study Locations}

The DSDP Site 296 (Fig. 1-3, 1-4, and 1-6) lies on a northwest west trending structural terrace on the northern part of the first remnant arc of the Izu-Bonin-Mariana, the Kyushu Palau Ridge (Ingle et al., 1975). It has records of volcanism, which date to the later part of the initial magmatic history, prior to the opening of the Parece Vela and Shikoku basin (Taylor, 1992; Kobayashi et al., 1995; Stern et al., 2003). The ridge is of Paleogene age, which has undergone subsidence, sometime in the Oligocene, in conjunction with rifting of the arc. Unit 1 of Site 296 is a $453 \mathrm{~m}$ thick layer of clayey nannofossil ooze/nannofossil clay (Ingle et al. 1975) with interbedded volcanic ash-rich zones from Late Oligocene to Pleistocene age, which has been divided into several subunits. Unit 2 consists of Early to Late Oligocene volcanic sandstones and lapilli tuffs with a thickness of around $634 \mathrm{~m}$. The interface between units 1 and 2 is interpreted to coincide with subsidence of the area following rifting and the opening of the Shikoku basin (Ingle et al. 1975).

The focus of this study is the base of unit $1 \mathrm{G}$ and unit 2 , where volcanic minerals and lithic clasts are abundant. In unit 2, cores 49 to 59 are lapilli and ash tuffs, which are poor to moderately sorted with mostly angular grains in a glassy matrix, are indicative of a direct deposition from volcanic eruptions (Ingle et al., 1975). Cores 60 to 65 are mainly 
volcanic sandstone, siltstone, and conglomerates, with moderate to good sorting, deposited from the eroded parts of ridges surrounding Site 296 (Ingle et al., 1975). Detailed lithologic and structural of the core samples studied can be found in the Appendix.
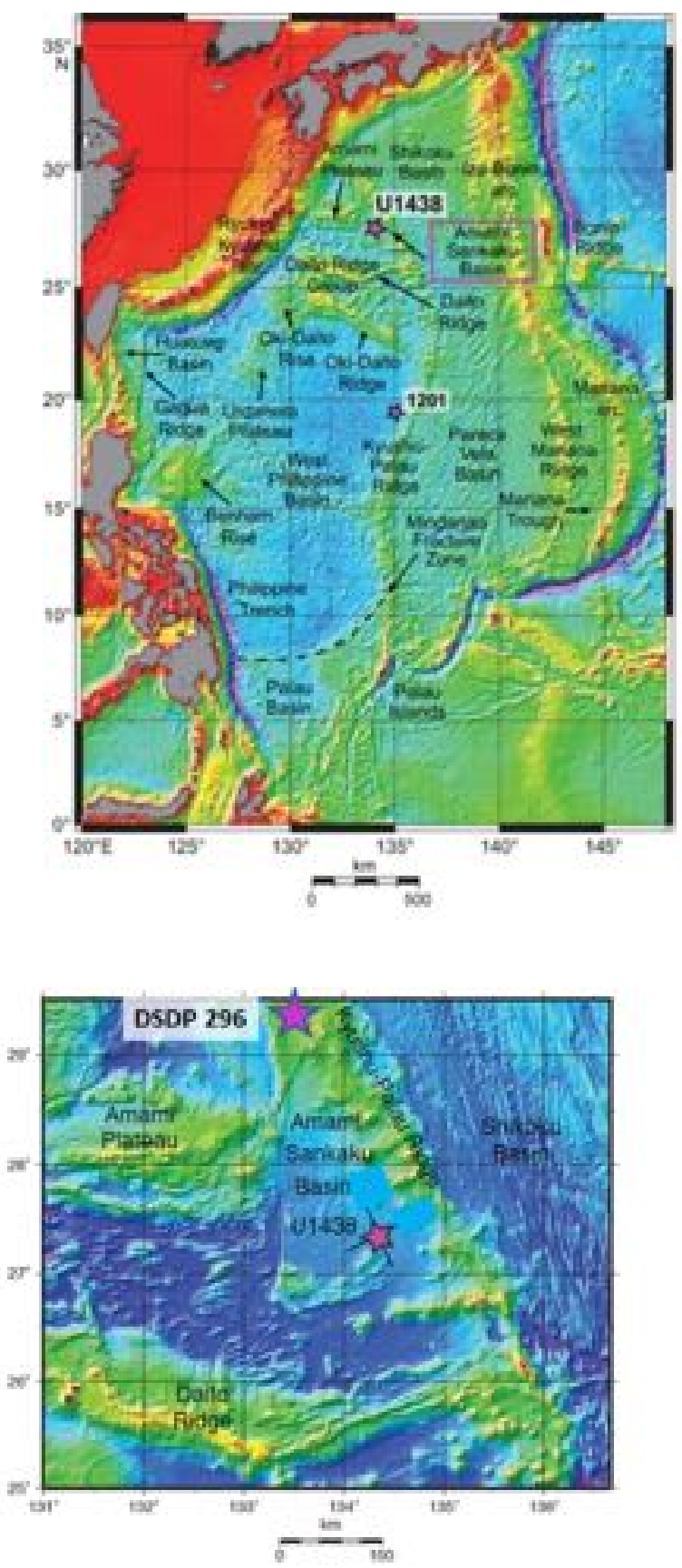

Figure 1-3 Map showing the location of Site 296 and Site 1438 (Arculus et al., 2015) 


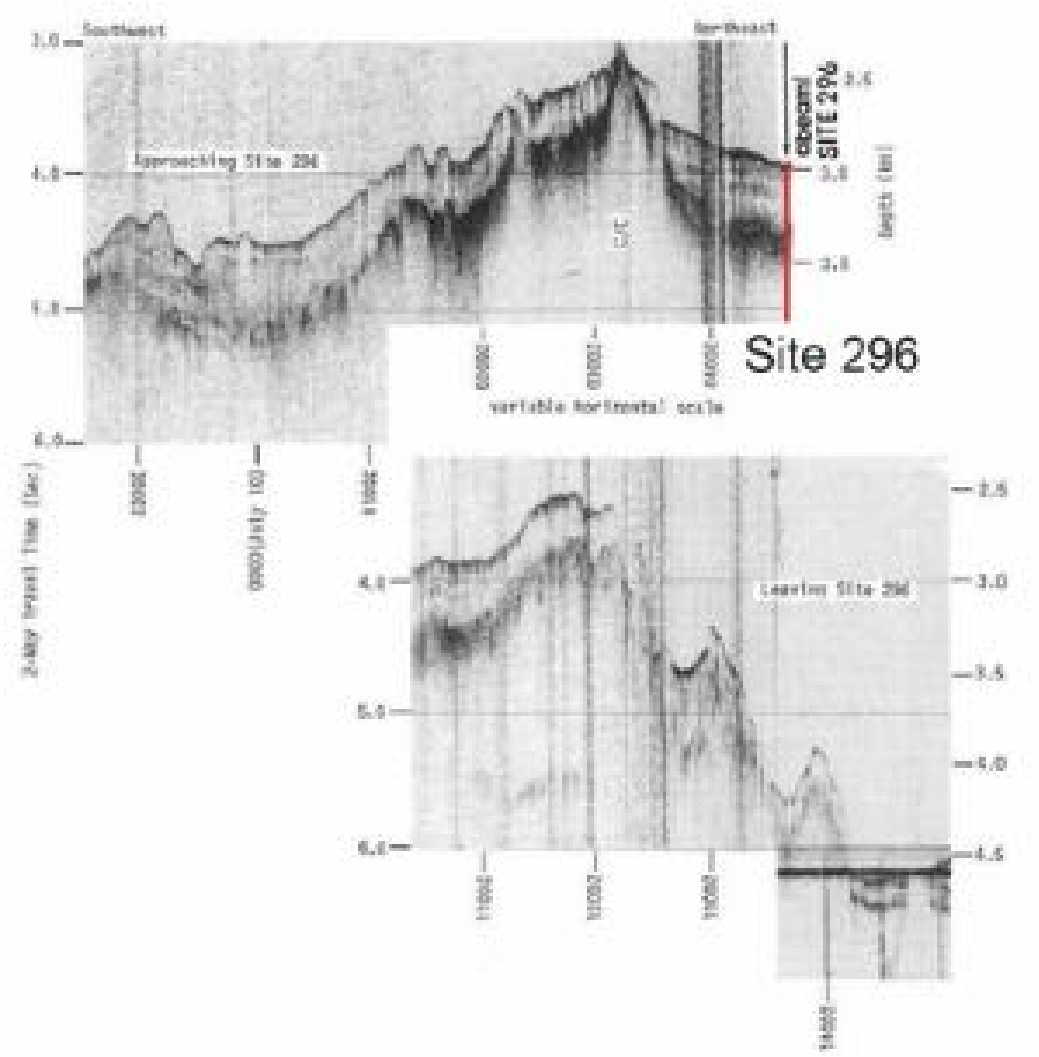

Figure 1-4 Seismic reflection profile across the KPR, near Site 296. Red line indicates Site 296. (Ingle et al., 1975)

The IODP Site 1438 lies in the Amami Sankaku basin (Fig.1-3, 1-5, 1-6), close to the western flank of the Kyushu Palau ridge. In the absence of other volcanic highs, the volcaniclastic sediments from the site are most probably shed from the KPR (Brandl et al., 2017). The lithology includes four sedimentary units (Arculus et al., 2015), Unit I (terrigenous, biogenic and volcaniclastic mud and oozes with interspersed ash layers), unit II (tuffaceous mudstone and siltstones), unit III (tuffaceous conglomerates, sandstone, with volcanic and sedimentary clasts), unit IV (radiolarian mudstone, sandstone, conglomerates, and tuffaceous siltstones) and the igneous basement unit 1 (Basalt). The total length drilled is 1461 mbsf, and the age ranges from recent Pleistocene to Eocene. Unit II and the top of unit III of Site 1438 overlaps in age with the base of unit $1 \mathrm{G}$ and unit 2 of DSDP Site 296 and hence is the focus of this study. In both the sites, the lithology changes from a 
volcaniclastic and tuffaceous unit to nannofossil oozes around late Oligocene/early Miocene, which marks the period when the KPR was completely rifted and became inactive. The main objective of Leg 351 which drilled Site 1438 was to understand the subduction initiation of IBM, the evolution of the first arc and the nature of the oceanic basement pre-subduction

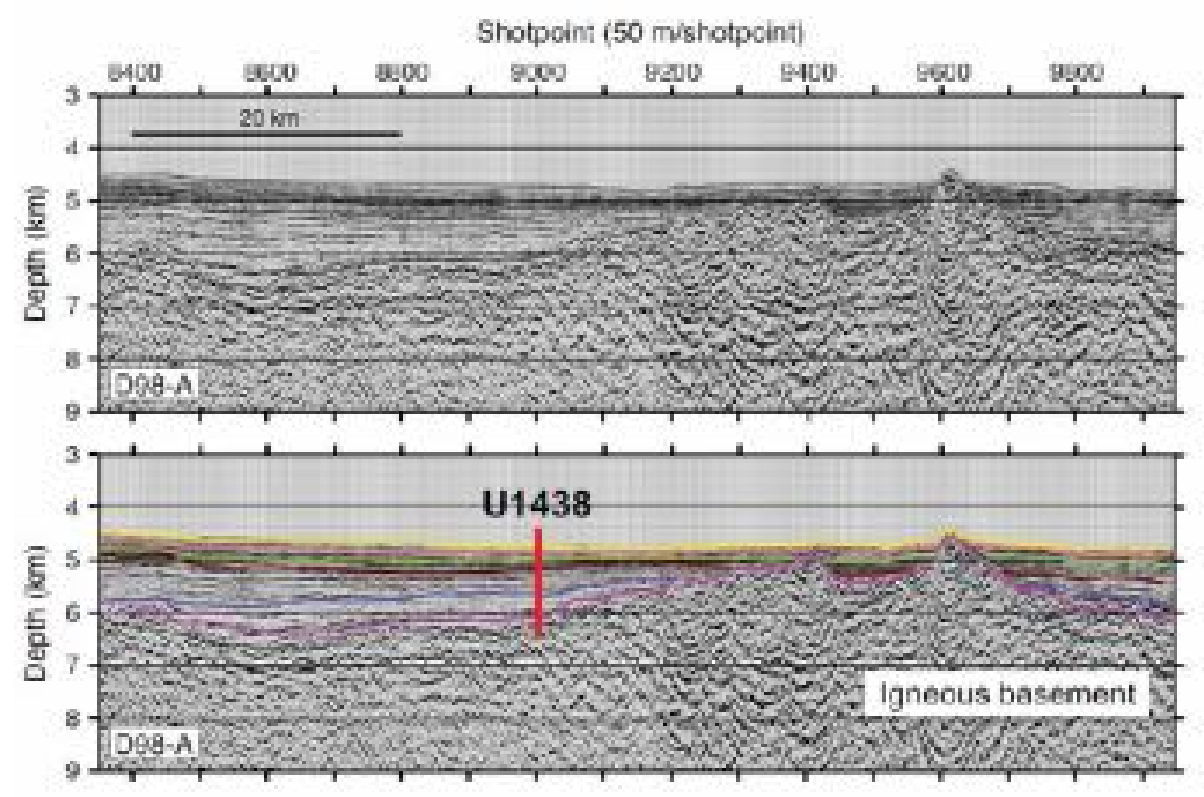

Figure 1-5 Seismic reflection image showing location of Site 1438, on the east of it lies the Kyushu Palau ridge (Arculus et al., 2015) 


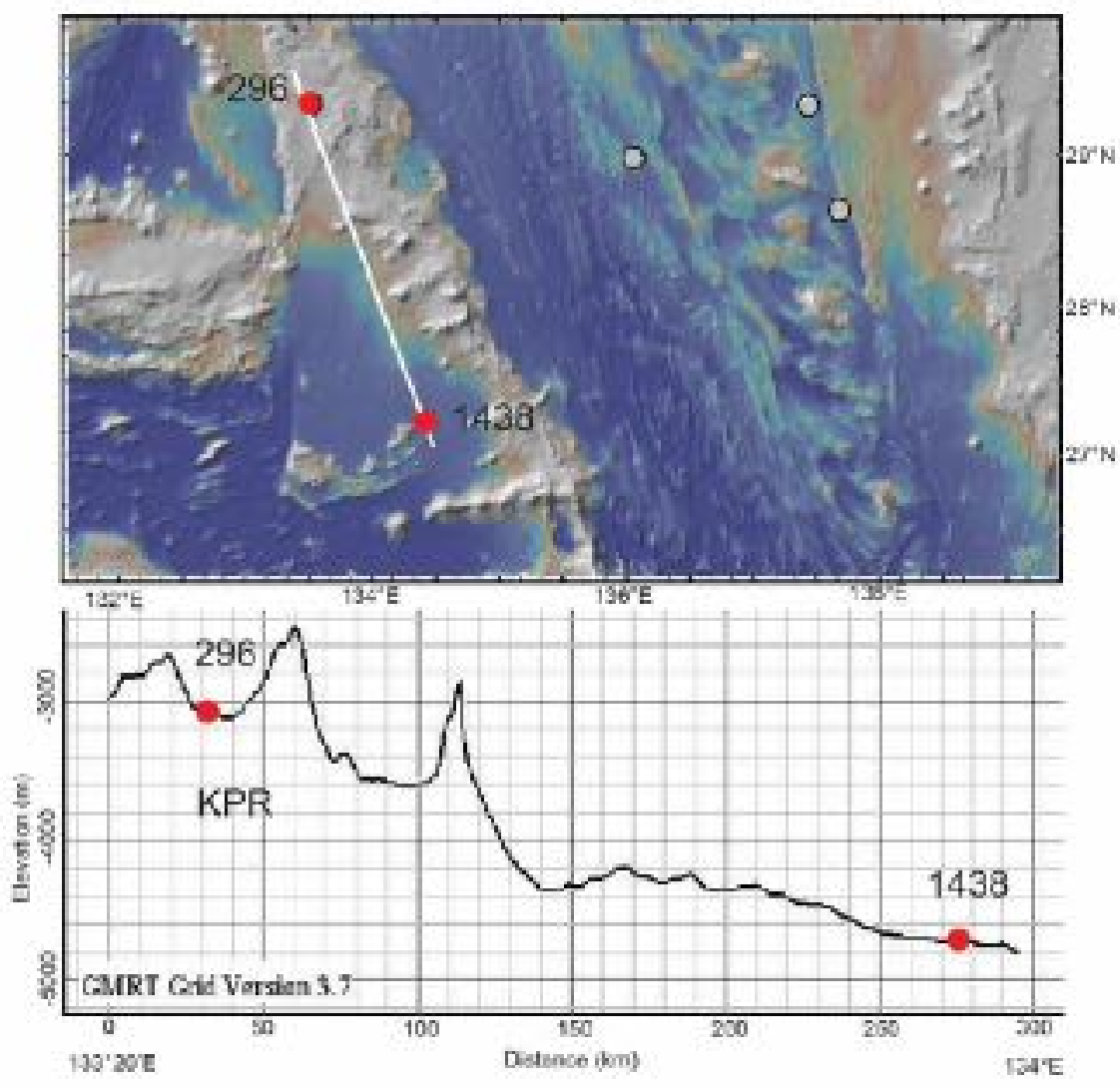

Figure 1-6 Profile line from Site 296 to Site 1438

\subsection{Hypothesis}

In the proposed study, the following hypothesis will be tested:

The chemical composition of arc magmas erupted on the early IBM/Kyushu Palau arc changed when rifting of the arc began.

Possible changes that might be observed include:

1) As the KPR started to rift and form the back-arc basins, there was a change of composition of the volcanic rock toward more siliceous rocks like dacite and rhyolite. Siliceous volcanism might appear due to the more extensive differentiation of arc mafic magmas as the arc magma supply diminished.

2) Back arc basin basalt (BABB), which forms in the rift basin, has a trace element 
signature between arc rocks and MORB. During rifting of the arc, there is the possibility that BABB have mixed with arc basalt. There will be a significant difference between the trace element composition of mineral derived from BABB and those from arc rocks.

\subsection{Overview of Methods for this Study}

A detailed study of the geochemistry of the volcanic grains using established analytical methods is one of the ways to investigate changes in arc magma geochemistry leading up to the rifting of the arc. For this study, unaltered feldspar, pyroxene, glass grains, and lithic fragments were separated from the sediment and analyzed for major and trace elements and isotope studies.

\section{Sample Preparation}

The core samples for Site 296 were sampled at the DSDP Repository in LaJolla, CA, by R. Hickey-Vargas. Samples were selected based on coarse grain size and also the presence of fresh, vitreous glass fragments that could be seen in the samples, both macroscopically and with a binocular microscope. The same procedure was repeated while selecting site 1438 samples. Selected core samples were crushed with a mortar and passed through a series of mesh sizes to separate the mineral and glass grains from the matrix. Depending on the size of the grain, different mesh sizes were used. The crushed samples were then wet sieved to remove the finer matrix, and then hand-picked. A preliminary study was done using a Scanning Electron Microscope with Energy Dispersive System (SEM-EDS) to identify the type of minerals and glass present in the samples. After the preliminary study was done, minerals and glass grains from specific core sections were picked out and set in epoxy. The epoxy buttons were polished using 600 and 1000 grit powder before moving on to final polishing using 3 and 1micron powder for Electron Probe 
Micro Analyzer (EPMA) analysis. After polishing, major element composition of the mineral grains, melt inclusion, and glass was analyzed using EPMA at FCAEM. Trace element compositions of minerals and glass were studied using the Laser Ablation ICP Mass Spectrometry (LA-ICP-MS) at Trace Evidence Analysis Facility (TEAF), FIU. Melt inclusion in pyroxene was studied using the EPMA for major elements, and if the size of the inclusions were large enough, they were further analyzed for trace elements using the LA-ICP-MS.

Selected unaltered lithic fragments or clasts from the core sample were cut out using a small rock saw, ultrasonicated in DI water, then powdered after drying for further analysis. Clast samples having sufficient material for accompanying $\mathrm{Hf}$ and $\mathrm{Nd}$-isotope study (200-400 mg) were selected for major and trace element analysis. From 10 to $50 \mathrm{mg}$ of the clast samples were digested for $\sim 12$ hours in a 1:2 $\mathrm{HF}: \mathrm{HNO}_{3}$ acid mix in capped savillex beakers, including 1 hour of ultrasonication. Samples were dried, redissolved in $8 \mathrm{~N} \mathrm{HNO}_{3}$, and dried again. Dried samples were picked up in $8 \mathrm{~N} \mathrm{HNO}_{3}$ and diluted to exactly $4000 \mathrm{X}$ by mass for trace element analysis and $1 \mathrm{X} 10^{6} \mathrm{X}$ by mass for major elements. Calibration curves were constructed with 8 rock standards dissolved and diluted with the samples: United States Geological Survey BIR-1, W-2, DNC-1, BHVO-2, BCR2, AGV-2, and Geological Survey of Japan JB-2 and JA-2. Solutions were run on the Elan DRC + quadrupole ICPMS in the Trace Evidence Analysis Facility (TEAF) at Florida International University. Instrument drift was monitored using In as an internal standard and intensities for rock standards run at fixed intervals. The $\mathrm{Nd}$ and $\mathrm{Hf}$ isotope ratios were analyzed by Thermo Neptune multicollector-inductively coupled plasma mass spectrometer (MC-ICP-MS) using methods described by Yogodzinski et al. (2018). 


\section{Review of Analytical Methods}

The Electron Probe Microanalysis is a technique used for analyzing samples chemically, by exciting X-rays with a focused electron beam. A qualitative analysis can be obtained by identifying the characteristic $\mathrm{X}$ rays from their wavelength spectrum, but a quantitative analysis could also be done if the intensities are compared with those emitted from a standard sample. The relative accuracy for major oxides approaches about $1 \%$ and detection limit down to tens of parts per million can be attained (Reed, 2005). The Scanning Electron Microscope (SEM) is similar to the EPMA but is designed primarily for imaging purpose rather than analysis. The SEM have an Energy Dispersive Spectrometer (EDS) system which can be used for analysis, but the resolution is lower than Wavelength Dispersive Spectrometry (WDS) system of EPMA. The WDS provides greater analytical precision, superior peak resolution and lower detection limit which can be used for quantitative analysis of glass, minerals and melt inclusions, as well as for mapping chemistry and distribution of mineral phases (Spray et al., 1995; Pownceby, 2006; Hayward, 2012; Helz et al., 2014). A detailed comparison between the analytical characteristic of the WDS and EDS system is also given by Potts (1987), remarking that the EDS analysis can be accurate and convenient provided the element measured is more than $1 \%$ (weight). For detection of amount below this limit, the accuracy and precision of the analysis decreases.

The Laser Ablation Inductively Coupled Plasma Mass Spectrometry (LA-ICP-MS) is an analytical technique which generates fine particle by focusing a laser beam on the sample in a process known as Laser Ablation. The ablated particles are then transported by a carrier gas to the secondary excitation source of the ICP-MS instrument for digestion and 
ionization of the sampled mass and subsequently introduced to a mass spectrometer detector for both elemental and isotopic analysis. The LA-ICP-MS has lower limits of detection than the EPMA (Jackson et al. 1992; Eggins 2003) which makes it more sensitive towards detection of trace elements in minerals and in melt inclusions. Halter et al. (2004) showed that LA-ICP-MS can be used for quantitative analysis of melt inclusions using an internal standard. The use of LA-ICP-MS technique has been well evaluated and proved to be capable of producing high precision and accurate data for a range of geologic materials (Jackson 2008; Arevalo et al. 2011; Russo et al. 2013; Almirall et al., 2016). A recent article by Jenner and Arevalo Jr. (2016) has also explained the methods and challenges for analyzing geologic material using LA-ICP-MS and its various applications in studying glasses, melt inclusions and experimental petrology.

The Multiple Collector Inductively Coupled Plasma Mass Spectrometry (MC-ICPMS) is an instrument used to measure the isotope abundances of an element in a sample. Traditional ICP-MS has a quadrupole analyzer which allows only single collector analysis, whereas the MC-ICP-MS has multiple collectors to analyze isotope ratios. The precision and resolution are also higher in MC-ICP-MS which are necessary to analyze some radiogenic isotopes. Simple sample introduction with high mass resolution and ionization efficiency, and flat topped peaks provide accurate and precise analysis of isotope ratios, with the precision reaching upto $0.001 \%$ (Yang, 2009). The application of MC-ICP-MS has been well studied in geoscience and has been used for precise measurement of radiogenic isotope ratios for geochemistry, cosmochemistry and geochronology (Halliday et al., 1998; Liang et al., 2003; Albarede et al., 2004) 


\subsection{Dissertation Structure}

The dissertation has been laid out into three chapters following the introduction and then a general conclusion. Each chapter is written in a manuscript style, which includes the objective, methods and results to answer questions about the early magmatic evolution of the IBM.

1) Chapter 2 -Composition of glass shards and lithic fragments from Site 296, which is compared to the other Oligocene and Eocene studies from Northern IBM to interpret the primary magmas of the IBM arc.

2) Chapter 3- Study of Site 296 detrital minerals, feldspars, pyroxenes and amphiboles and any melt inclusions within them. The minerals are used to interpret temperature and pressures of the magma and the composition of magma in equilibrium. These and including data from previous chapter interprets any temporal evolution observed at Site 296.

3) Chapter 4- Major and trace element compositions of mafic minerals from Site 1438 and lithic fragments, and $\mathrm{Nd}$ and $\mathrm{Hf}$ isotope ratios of the lithic fragments. The two Sites have been compared and together combined sums up the Oligocene evolution of the IBM arc before rifting.

4) Chapter 5- General conclusions

\subsection{References}

Albarede, F., Telouk, P., Blichert-Toft, J., Boyet, M., Agranier, A., and Nelson, B., 2004, Precise and accurate isotopic measurements using multiple-collector ICPMS: Geochimica et Cosmochimica Acta, v. 68, no. 12, p. 2725-2744. 
Almirall, J.R., Trejos, T., Sylvester, P.J., and Jackson, S.E., 2016, Applications of LA-ICPMS to forensic science: Elements, v. 12, no. 5, p. 335-340.

Arculus, R.J., Gill, J.B., Cambray, H., Chen, W., and Stern, R.J., 1995, Geochemical evolution of arc systems in the western Pacific; the ash and turbidite record recovered by drilling: Geophysical Monograph, v. 88, p. 45-65.

Arculus, R., Ishizuka, O., Bogus, K., et al., 2015, International Ocean Discovery Program Expedition 351 preliminary report; Izu-Bonin-Mariana Arc origins; continental crust formation at an intraoceanic arc; foundation, inception, and early evolution; 30 May30 July 2014: Preliminary Report (International Ocean Discovery Program), v. 351.

Bloomer, S.H., Taylor, B., MacLeod, C.J., Stern, R.J., Fryer, P., Hawkins, J.W., and Johnson, L., 1995, Early arc volcanism and the ophiolite problem; a perspective from drilling in the western Pacific: Geophysical Monograph, v. 88, p. 1-30.

Brandl, P.A., Hamada, M., Arculus, R.J., et al., 2017, The arc arises; the links between volcanic output, arc evolution and melt composition: Earth and Planetary Science Letters, v. 461, p. 73-84.

Eggins, S.M., 2003, Laser ablation ICP-MS analysis of geological materials prepared as lithium borate glasses: Geostandards Newsletter, v. 27, no. 2, p. 147-162.

Elliott, T., Plank, T., Zindler, A., White, W., and Bourdon, B., 1997, Element transport from slab to volcanic front at the Mariana Arc: Journal of Geophysical Research, v. 102, no. B7, p. 14-15,019. 
Hall, R., 2002, Cenozoic geological and plate tectonic evolution of SE Asia and the SW Pacific; computer-based reconstructions, model and animations: Journal of Asian Earth Sciences, v. 20, no. 4, p. 353-431.

Halliday, A.N., Lee, D., Christensen, J.N., et al., 1998, Applications of multiple collectorICPMS to cosmochemistry, geochemistry, and paleoceanography: Geochimica et Cosmochimica Acta, v. 62, no. 6, p. 919-940.

Halter, W.E., Pettke, T., and Heinrich, C.A., 2004, Laser-ablation ICP-MS analysis of silicate and sulfide melt inclusions in an andesitic complex; I, Analytical approach and data evaluation: Contributions to Mineralogy and Petrology, v. 147, no. 4, p. 385-396.

Hayward, C., 2012, High spatial resolution electron probe microanalysis of tephras and melt inclusions without beam-induced chemical modification: Holocene, v. 22, no. 1, p. 119-125.

Helz, R.L., Clague, D.A., Mastin, L.G., and Rose, T.R., 2014, Electron microprobe analyses of glasses from Kilauea tephra units, Kilauea Volcano, Hawaii: Open-File Report - U.S.Geological Survey.

Hickey-Vargas, R., 2005, Basalt and tonalite from the Amami Plateau, northern West Philippine Basin; new Early Cretaceous ages and geochemical results, and their petrologic and tectonic implications: Island Arc, v. 14, no. 4, p. 653-665.

Ingle, J.C.,Jr, Karig, D.E., Bouma, A.H., et al., 1975, Site 296: Initial Reports of the Deep Sea Drilling Project, v. 31, p. 191-274. 
Ishizuka, O., Oto, K., Yuasa, M., Hochstaedter, A.G., Stern, R.J., and Arima, M., 1998, KAr ages from seamount chains in the back-arc region of the Izu-Ogasawara Arc: Island Arc, v. 7, no. 3, p. 408-421.

Ishizuka, O., Tani, K., Reagan, M.K., et al., 2011, The timescales of subduction initiation and subsequent evolution of an oceanic island arc: Earth and Planetary Science Letters, v. 306, no. 3-4, p. 229-240.

Ishizuka, O., Taylor, R.N., Milton, J.A., and Nesbitt, R.W., 2003, Fluid-mantle interaction in an intra-oceanic arc; constraints from high-precision $\mathrm{Pb}$ isotopes: Earth and Planetary Science Letters, v. 211, no. 3-4, p. 221-236.

Jackson, S.E., 2008, Calibration strategies for elemental analysis by LA-ICP-MS: Short Course Series - Mineralogical Association of Canada, v. 40, p. 169-188.

Jackson, S.E., Longerich, H.P., Dunning, G.R., and Freyer, B.J., 1992, The application of laser-ablation microprobe; inductively coupled plasma-mass spectrometry (LAMICP-MS) to in situ trace-element determinations in minerals: The Canadian Mineralogist, v. 30, Part 4, p. 1049-1064.

Jenner, F.E., and Arevalo, R.D.,Jr, 2016, Major and trace element analysis of natural and experimental igneous systems using LA-ICP-MS: Elements, v. 12, no. 5, p. 311-316.

Karig, D.E., 1975, Basin genesis in the Philippine Sea: Initial Reports of the Deep Sea Drilling Project, v. 31, p. 857-879. 
Karig, D., 1971, Site surveys in the mariana area: United States (USA), Washington, d. c., u.s. govt. printing office.

Kelley, K.A., Plank, T., Ludden, J., and Staudigel, H., 2003, Composition of altered oceanic crust at ODP Sites 801 and 1149: Geochemistry, Geophysics, Geosystems G3, v. 4, no. 6 .

Kobayashi, K., Kasuga, S., and Okino, K., 1995, Shikoku Basin and its margins: New York, NY, United States (USA), Plenum Press, New York, NY.

Liang, X., Wei, G., Li, X., and Liu, Y., 2003, Precise measurement of Nd-144/Nd-143 and $\mathrm{Sm} / \mathrm{Nd}$ ratios using multiple-collector inductively coupled plasma mass spectrometry (MC-ICPMS): Diqiu Huaxue $=$ Geochimica, v. 32, no. 1, p. 91-96.

Potts, P.J., 1987, A handbook of silicate rock analysis: New York, NY, United States (USA), Chapman \& Hall, New York, NY, 622 p.

Pownceby, M.I., MacRae, C.M., and Wilson, N.C., 2007, Mineral characterisation by EPMA mapping: Minerals Engineering, v. 20, no. 5, p. 444-451.

Reagan, M.K., Ishizuka, O., Stern, R.J., et al., 2010, Fore-arc basalts and subduction initiation in the Izu-Bonin-Mariana system: Geochemistry, Geophysics, Geosystems G3, v. 11, no. 3, p. Citation Q03X12. 
Reed, S.J.B., 2005, Electron microprobe analysis and scanning electron microscopy in geology: Cambridge, United Kingdom (GBR), Cambridge University Press, Cambridge, $189 \mathrm{p}$.

Richards, M.A., and Lithgow-Bertelloni, C., 1996, Plate motion changes, the HawaiianEmperor bend, and the apparent success and failure of geodynamic models: Earth and Planetary Science Letters, v. 137, no. 1-4, p. 19-27.

Russo, R.E., Mao, X., Gonzalez, J.J., Zorba, V., and Yoo, J., 2013, Laser ablation in analytical chemistry: Analytical Chemistry, v. 85, no. 13, p. 6162-6177.

Savov, I.P., Hickey-Vargas, R., D'Antonio, M., Ryan, J.G., and Spadea, P., 2006, Petrology and geochemistry of West Philippine Basin basalts and early Palau-Kyushu Arc volcanic clasts from ODP Leg 195, Site 1201D; implications for the early history of the Izu-Bonin-Mariana Arc: Journal of Petrology, v. 47, no. 2, p. 277-299.

Scholz, C.H., and Campos, J., 1995, On the mechanism of seismic decoupling and back arc spreading at subduction zones: Journal of Geophysical Research, v. 100, no. B11, p. 22-22,115.

Scott, R.B., Kroenke, L., Balshaw, K.M., et al., 1980, Petrology and geochemistry of arc tholeiites on the Palau-Kyushu Ridge, Site 448, Deep Sea Drilling Project Leg 59: Initial Reports of the Deep Sea Drilling Project, v. 59, p. 681-692. 
Spray, J.G., Rae, D.A., Hawthorne, F.C., and Martin, R.F., 1995, Quantitative electronmicroprobe analysis of alkali silicate glasses; a review and user guide: The Canadian Mineralogist, v. 33, Part 2, p. 323-332.

Stern, R.J., 2002, Subduction Zones: Reviews of Geophysics, v. 40, no. 4, p. 3-1.

Stern, R.J., and Bloomer, S.H., 1992, Subduction zone infancy; examples from the Eocene Izu-Bonin-Mariana and Jurassic California arcs: Geological Society of America Bulletin, v. 104, no. 12, p. 1621-1636.

Stern, R.J., Fouch, M.J., Klemperer, S.L., and Eiler, J.M., 2003, An overview of the IzuBonin-Mariana subduction factory: Geophysical Monograph, v. 138, p. 175-222.

Stern, R.J., Morris, J.D., Bloomer, S.H., and Hawkins, J.W.,Jr, 1991, The source of the subduction component in convergent margin magmas; trace element and radiogenic isotope evidence from Eocene boninites, Mariana Forearc: Geochimica et Cosmochimica Acta, v. 55, no. 5, p. 1467-1481.

Sutter, J.F., Snee, L.W., Kroenke, L., et al., 1980, K/Ar and (super 40) Ar/ (super 39) Ar dating of basaltic rocks from Deep Sea Drilling Project Leg 59: Initial Reports of the Deep Sea Drilling Project, v. 59, p. 729-734.

Taylor, B., Fujioka, K., Janecek, T.R., et al., 1992, Rifting and the volcanic-tectonic evolution of the Izu-Bonin-Mariana Arc: Proceedings of the Ocean Drilling Program, Scientific Results, v. 126, p. 627-651. 
Taylor, R.N., Nesbitt, R.W., Vidal, P., Harmon, R.S., Auvray, B., and Croudace, I.W., 1994, Mineralogy, chemistry, and genesis of the boninite series volcanics, Chichijima, Bonin Islands, Japan: Journal of Petrology, v. 35, no. 3, p. 577-617.

Westgate, J.A., Perkins, W.T., Fuge, R., Pearce, N.J.G., and Wintle, A.G., 1994, Traceelement analysis of volcanic glass shards by laser ablation inductively coupled plasma mass spectrometry; application to tephrochronological studies: Applied Geochemistry, v. 9, no. 3, p. 323-335.

Yamazaki, T., Murakami, F., Stern, R.J., and Arima, M., 1998, Asymmetric rifting of the northern Mariana Trough: Island Arc, v. 7, no. 3, p. 460-471.

Yang, L., 2009, Accurate and precise determination of isotopic ratios by MC-ICP-MS: A review: Mass Spectrometry Reviews, v. 28, no. 6, p. 990.

Yogodzinski, G.M., Bizimis, M., Hickey-Vargas, R., et al., 2018, Implications of Eocene age Philippine Sea and fore-arc basalts for initiation and early history of the IzuBonin-Mariana Arc: Geochimica et Cosmochimica Acta, v. 228, p. 136-156. 


\title{
2 GEOCHEMISTRY OF VOLCANIC GLASS FROM OLIGOCENE DETRITAL SEDIMENTS AT DSDP SITE 296, KYUSHU PALAU RIDGE: INTERPRETING THE MAGMATIC EVOLUTION OF THE EARLY NORTHERN IZU BONIN MARIANA ISLAND ARC
}

Eshita Samajpati, Rosemary Hickey-Vargas. In revision, Island Arc

\begin{abstract}
Understanding the petrologic and geochemical evolution of island arcs is important for interpreting the timing and impacts of subduction and processes leading to formation of continental crust. The Izu-Bonin Mariana (IBM) arc, western Pacific, is an outstanding location to study arc evolution. The IBM first arc (45-25 Ma) followed a period of forearc basalt and boninite formation associated with subduction initiation (52-45 Ma). In this study, we present new major and trace element data for the IBM first arc from detrital glass shards and clasts from DSDP Site 296, located on the northernmost Kyushu-Palau Ridge (KPR). We synthesize these data with published literature for contemporaneous airfall ash and tephra from the Izu-Bonin forearc, dredge and piston core samples from the KPR, and plutonic rocks from the rifted eastern KPR escarpment, locations which lie within or correlate with KPR Segment 1 of Ishizuka et al. (2011b). Our objective is to test ways in which petrologic and chemical data for diverse igneous materials can be used to construct a complete picture of this section of the Oligocene first arc and to draw conclusions about its evolution. Important findings reveal that widely varying primary magmas formed and differentiated at various depths at this location during this period. Changes in key trace element ratios such as $\mathrm{La} / \mathrm{Sm}, \mathrm{Nb} / \mathrm{Yb}$ and $\mathrm{Ba} / \mathrm{Th}$ show that mantle sources varied in fertility and in the inputs of subducted sediment and fluids over time and space. Plutonic rocks appear to be related to early K-poor dacitic liquids represented by glasses sampled both in
\end{abstract}


the forearc and volcanic front. An interesting observation is that the variation in magma compositions in this relatively small segment encompasses that inferred for the IBM arc as a whole, suggesting that sampling is a key factor in inferring temporal, across arc and along-strike geochemical trends.

\subsection{Introduction}

The Izu-Bonin Mariana (IBM) island arc is one of the best-studied subductionproduced volcanic chains worldwide because it has unique features that make it ideal for investigating subduction processes (Stern et al., 2003). The arc is intra-oceanic (Fig. 2-1a), limiting sources of magma to oceanic mantle plus subducted oceanic crust and sediment. Arc growth since subduction inception at about $52 \mathrm{Ma}$ has been interrupted by rifting and back-arc spreading, stranding remnant arcs and back-arc basins of varying age behind the current active arc and trench (Fig. 1a,1b), thus providing a unique window into arc evolution through time (Stern et al., 2003). Understanding of many parameters of the active arc, such as crustal thickness and age, seismicity, and magma chemistry along strike, slab dip, convergence angle and rate, age and chemical character of the subducting Pacific plate has yielded a remarkable array of findings about the active arc processes that bear on the evolution of arcs over time (Woodhead, 1989; Arculus et al., 1992; Stern et al., 1993; Lee et al., 1995; Elliot et al., 1997; Taylor and Nesbitt, 1998; Pearce et al. 1999; Hochstaedter et al., 2001; Sun and Stern, 2001). 

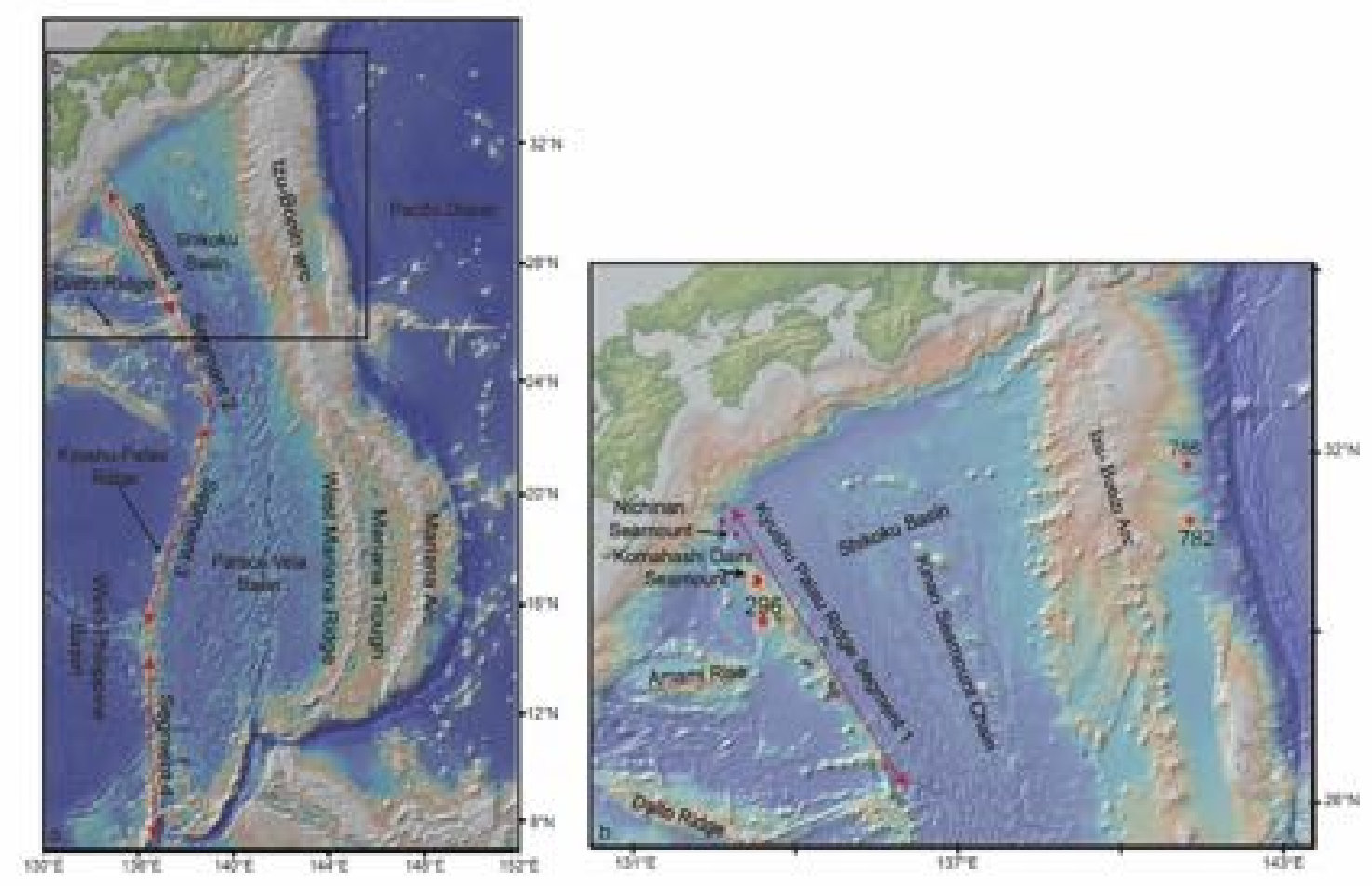

Figure 2-1 (a) Map of the Izu-Bonin Mariana (IBM) Arc region showing remnant arcs and back arc basins. The first remnant arc, the Kyushu Palau Ridge (KPR) has been divided into four segments after Ishizuka et al. (2011b); this study focuses on the first segment which is shown as an inset. (b) Close up map of Segment 1 of the KPR and the northern Izu Bonin arc showing the location of DSDP Site 296 and previously studied locations in that area. Green filled circles show study locations of Haraguchi et al. $(2003,2012)$ and purple filled circles are locations of rocks described in Ishizuka et al. (2011b)

The sequence of tectonic events affecting the IBM arc is relatively well understood (Fig. 2-2). Subduction initiated at about $52 \mathrm{Ma}$, apparently simultaneously along the boundary of the Philippine Sea and Pacific plates, with the eruption of forearc basalts or FABs, followed by boninites and transitional lavas (Stern et al., 1991; Taylor et al., 1994; Reagan et al., 2010; Ishizuka et al., 2011a; Arculus et al., 2015a, 2015b). These magmas erupted in an extensional forearc environment through a complex of linked spreading centers (Ishizuka et al., 2003; Arculus et al., 2015a). This initial stage of magmatism was 
followed by the construction of a chain of arc volcanoes and the eruption of typical arc magmas starting at about $45 \mathrm{Ma}$ (Fig. 2-2) (Stern et al., 2003). At 25-28 Ma, rifting and sea-floor spreading resulted in the opening of the Shikoku and Parece Vela basins (Taylor et al., 1992; Kobayashi et al., 1995), and distribution of former arc crust between the remnant Kyushu-Palau Ridge (KPR) (Fig. 2-2) and the present-day arc and forearc. A new arc front reformed at about $150 \mathrm{~km}$ from the trench, in some places on top of older arc structures. In the south, arc rifting and spreading of this arc occurred again at about $7 \mathrm{Ma}$, to form the Mariana Trough, and the remnant West Mariana Ridge and the active Mariana island arc (Yamazaki and Stern, 1997).

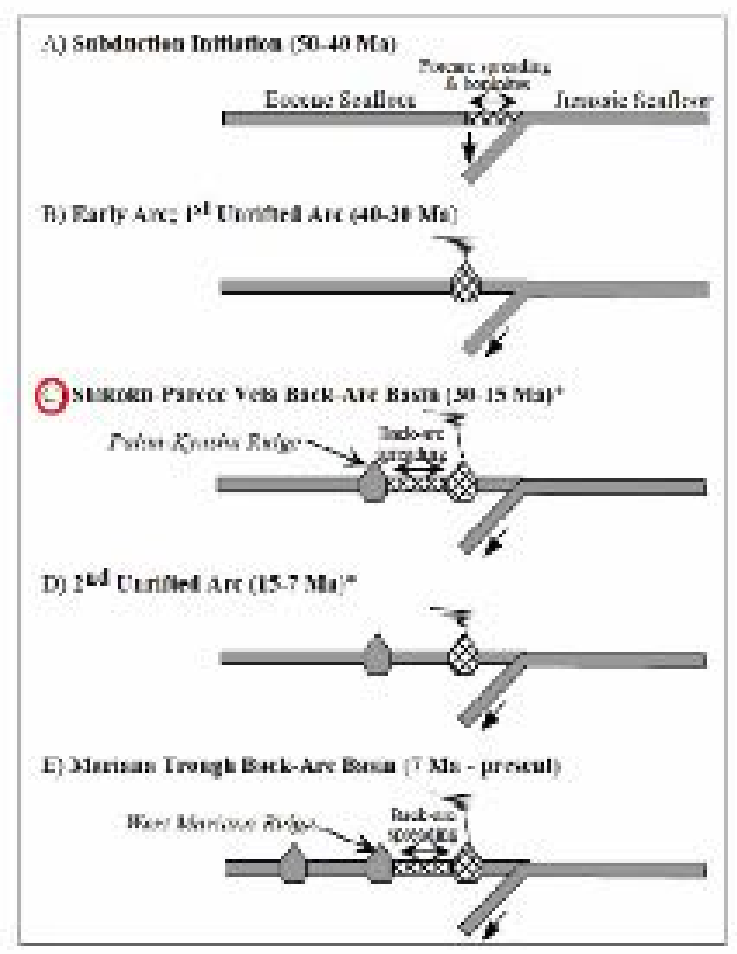

Figure 2-2 Simplified history of the IBM arc system modified after Stern et al. (2003). Shaded areas are magmatically inactive, and cross-hatched areas are magmatically active. The approximate time period or stage of geochemical evolution studied in this paper is shown in panel C 
The magmatic evolution and spatial and temporal variations in magma chemistry of the first IBM arc (45-25 Ma) are less well-understood than those of the active IBM arc. This is because most early arc materials are submarine, subaerially exposed only on the southernmost Mariana Islands and islands of the Bonin ridge. Submarine volcanic products have been drilled and dredged in both forearc and remnant arc settings and are primarily volcaniclastic. Researchers have used many strategies to understand the first arc using these materials. Lee et al. (1995), Straub 2003, Straub et al. $(2004,2010)$ and Bryant et al. (2003) used drilled fallout tephra layers in sediments to examine temporal geochemical trends of explosive volcanic eruptions. Drilled sections in the IBM forearc on DSDP Leg 60, ODP Legs 125 and 126 and IODP Expedition 352 recovered in-situ lavas that documented the transition from subduction initiation to early arc volcanism. Dredged suites from the KPR recovered both volcanic and plutonic rocks (Ishizuka et al., 2011b; Haraguchi et al., 2003), whereas drilling on the remnant KPR arc at DSDP Sites 296 and 448 recovered both lavas and volcaniclastic sediments. Broad syntheses of magma chemistry from these works have delineated possible temporal and along-strike variations in early IBM arc magmatism (Pearce et al., 2005; Straub et al., 2010, 2015; Ishizuka et al., 2011b) within the limitations of incomplete records and limited sampling.

In this paper, we focus on one heavily-sampled section of the first arc, as recovered from drilling and dredging in the northernmost KPR and Izu-Bonin forearc (Fig. 2-1b), using new and published geochemical data for diverse types of volcanic materials. Our objective is to examine the Oligocene volcanic products probably derived from a few early arc volcanoes, to provide a close-up view of geochemical variations that occurred in a 
spatially limited setting. We also consider and compare the kinds of geologic information that can be extracted from distinct types of material to build an improved understanding of early arc processes.

\subsection{Background}

The KPR, the remnant of the IBM first arc, was divided into four segments based on inflection points of the ridge and its intersection with other geologic features (Ishizuka et al., 2011b). This study focuses on Segment 1, extending on the KPR from the intersection of the Daito ridge in the south, to the northernmost tip of the KPR where it is subducted at the trench (Fig. 1b). Tectonic reconstructions of the early IBM arc by the closure of the Shikoku basin (Okino et al., 1994) indicate that this segment correlates with part of the northern Izu-Bonin arc where first arc materials were also recovered. New volcanic materials included in this study are Oligocene detrital volcaniclastic sediments drilled at DSDP Site 296, which is located near the KPR crest at $29^{\circ} 20.41^{\prime}$ N lat. Petrologic, major and trace element data for glass shards from this section are compared with published data for volcanic rocks recovered at piston core and dredge sites along KPR crest (Ishizuka et al., 2011b; Haraguchi et al., 2012), plutonic rocks dredged from the Komahashi Daini Seamount (Haraguchi et al., 2003), and ash layers and tephra from ODP Site 782A in the Izu-Bonin forearc (Straub, 2003; Straub et al., 2010; Bryant et al., 2003).

Segment 1 rocks studied by Ishizuka et al. (2011b) consist of olivine basalt and clinopyroxene-olivine basalt, recovered by drilling (at a depth of 5-10 m) using the deepsea boring machine system at flat ridge tops or gentle slopes and by dredging at steep escarpments. The volcanic and plutonic rocks studied by Haraguchi et al. $(2003,2012)$ were obtained by chain bag dredges from the northern KPR and Komahashi Daini 
seamount at steep escarpments. The volcanic rocks were classified into two-pyroxene and clinopyroxene basalt or basalt-andesite while the plutonic rocks were classified as biotitehornblende tonalite and hornblende tonalite based on mineral assemblages. ODP Site 782A is situated on the eastern margin of the Izu-Bonin forearc basin consists of a sedimentary unit (I) and a volcanic basement unit (II). The sedimentary unit consists of nannofossil chalks and marls with dispersed volcanic debris and 111 ash layers which become coarser and more abundant down core with some interbedded tuffaceous sediments.

Ages for some of these materials have been determined. Shibata et al. (1977) reported the K-Ar age of the tonalites between 37-38 Ma. The K-Ar age of the volcanic rocks from the Kita-Koho Seamount are between 25-26 Ma (Katsura et al., 1994), whereas volcanic rocks dredged from Miyazaki and Nichinan seamount and the Buzen knoll are reported to be 24 and 18 Ma. Ishizuka et al. (2011b) reported the Ar-Ar ages of the volcanic rocks from Segment 1 and its rear arc to be 24-28 Ma, with one sample (DS059BO) older at approximately $32.8 \mathrm{Ma}$. The ages of the ash layers from Site $782 \mathrm{~A}$ range from Pleistocene to middle Eocene inferred from nannofossil biostratigraphy (Xu et al., 1992); in this paper, only Oligocene tephras are compared.

\subsection{Methodology}

\subsubsection{Core description}

Deep Sea Drilling Project Site 296 is located in the northernmost Kyushu-Palau Ridge (Fig. 2-1a, 2-1b), on a sediment covered terrace on the western side at a water depth of 2,920 meters (Ingle et al., 1975). The Site 296 section consists of $453 \mathrm{~m}$ of Late Oligocene to Pleistocene nannofossil chalks and oozes (unit 1), overlying more than 634 
m of Early to Late Oligocene interbedded lapilli tuffs and volcanic sandstones (unit 2). The interface between the two units is interpreted to coincide with subsidence of the area following rifting and the opening of the Shikoku basin (Ingle et al. 1975). Depositional ages of the sediments are based on biostratigraphy. Ozima et al. (1977) reported an Ar/Ar age of 47.5 Ma for a volcanic clast in lapilli tuff from Core 63.

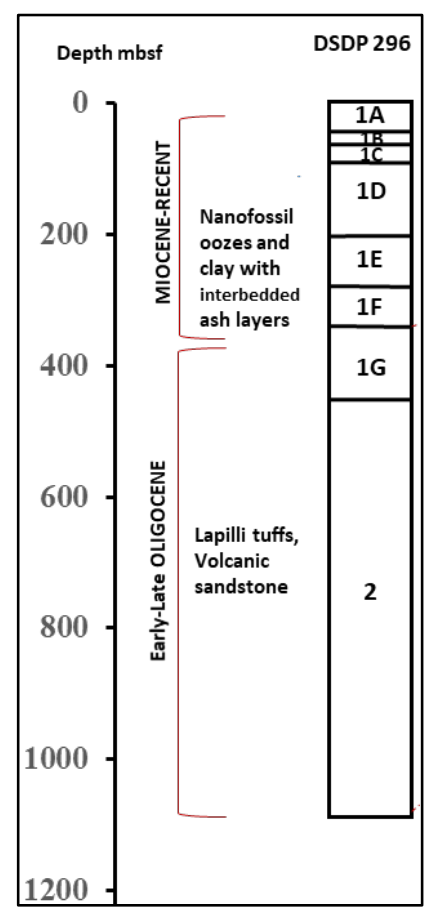

Figure 2-3 The stratigraphic column of DSDP Site 296 showing the lithological Unit 2, and $1 \mathrm{G}$ through $1 \mathrm{~A}$ and their biostratigraphic ages. The glass shards and the clasts in this work were sampled from Unit 2 and the lower part of Unit $1 \mathrm{G}$

Lapilli tuffs and sandstone constitute unit 2 of the section (Fig. 2-3). The lapilli tuffs consist of lithic fragments, glass shards, and mineral fragments (mainly feldspar, pyroxene, and magnetite, with some amphibole) in a matrix of green clay. The sandstones are similar, although clasts and the matrix are more oxidized, and glass is scarce. Clasts are mainly $1-5 \mathrm{~mm}$, pyroxene and plagioclase-bearing volcanic rock in which plagioclase and groundmass are strongly altered. Except for three unusually large $(3-5 \mathrm{~cm})$ clasts found in 
Core 55, this study focuses on glass fragments found loose in the matrix. In the lapilli tuffs and sandstones, the pyroxenes appear fresh, whereas magnetite surfaces are fully oxidized, and feldspars are cloudy and strongly altered.

\subsubsection{Analytical Techniques}

Tuff and sandstone samples were disaggregated by agitating them in deionized water using a mechanical wrist-arm shaker for times ranging from 2 to 100 hours. The resulting sediment was sieved, rinsed and handpicked at the 500 microns to 1-millimeter grain size for glass and minerals. In total, fresh glass fragments were identified in 15 different 2-cm segments of the lapilli tuff and sandstone (Fig. 2-3). Glass shards selected for analysis ranged in color from brown to colorless and were optically isotropic, with no evidence of devitrification. Some grains contained microlites which were visible in crosspolarized light and avoided during analyses. The grains were mounted in epoxy and polished for microprobe analysis. Parts of three unusually large clasts in Section 55-1, mentioned in Ingle et al. (1975), were cut from the core and powdered for bulk chemical analysis.

Glass fragments were first analyzed for major elements using the JEOL 8900 Superprobe EPMA at Florida Center for Analytical Electron Microscopy at Florida International University (FIU). To analyze non-volatile elements a 1-micron electron beam and $20 \mathrm{Amp}$ current were used. For $\mathrm{Na}$ and $\mathrm{K}$, the beam was diffused during analysis to minimize volatilization. At least three spots were analyzed on each grain and averaged. BHVO-2 glass was used as a calibration and quality control standard for glasses. After analysis, carbon coatings were removed, and glasses were further analyzed for trace 
elements Rb, Sr, Y, Zr, Nb, Ba, La, Ce, Nd, Sm, Eu, Gd, Dy, Er, Yb, Hf, Pb, Th and U by Laser Ablation ICP-MS using a New Wave $213 \mathrm{~nm}$ laser connected to a Thermo Element 2 HR ICP-MS at the Trace Evidence Analysis Facility at FIU. NIST 612 and BHVO-2 were used for calibration and data quality assessment, and Si and Ca were used as internal standards. At least two 55-micron spots were ablated on each grain, near microprobe analyses, and averaged. Three clasts from Core 55-1 were powdered, dissolved and analyzed for major elements and $\mathrm{Ni}, \mathrm{Cr}, \mathrm{Sc}, \mathrm{Sr}, \mathrm{Zn}, \mathrm{Co}, \mathrm{V}, \mathrm{Cu}, \mathrm{Zr}$, and Y, with a JobinYvon JY 70 ICPOES in the Earth Sciences Department at FIU, using techniques reported in Hickey-Vargas et al. (1995). Trace elements $\mathrm{Ba}, \mathrm{Nb}, \mathrm{Rb}, \mathrm{Cs}, \mathrm{La}, \mathrm{Ce}, \mathrm{Pr}, \mathrm{Nd}, \mathrm{Sm}, \mathrm{Eu}$, Gd, Tb, Dy, Ho, Er, Yb, Lu, Hf, Ta, Pb, Th and $\mathrm{U}$ were analyzed by solution introduction ICP-MS at Boston University, using methods published by Kelley et al. (2003). Data for glasses and clasts are listed in Table 1, and information about data quality for all the analyses are listed in Table 2. 
Table 2-1 Major oxide and trace element data for Site 296 glasses and clasts. Sample name starts with the core number, core section and the section depth in $\mathrm{cm}$ from which it was collected

\begin{tabular}{|c|c|c|c|c|c|c|c|c|}
\hline Major oxide & $47-1(117-$ & $47-1(117-$ & $47-1(117-$ & $49-1(24-27)$ & $49-1(24-27)$ & $50-1(122-$ & 54-1 (115- & $54-3(23-26)$ \\
\hline$(w t \%)$ & 119) Glass 1 & 119) Glass 2 & 119) Glass 3 & Glass 1 & Glass 2 & 124) Glass 1 & 118) Glass 3 & Glass 1 \\
\hline $\mathrm{SiO}_{2}$ & 60 & 75 & 52 & 53 & 52 & 57 & 49 & 53 \\
\hline $\mathrm{TiO}_{2}$ & 1.0 & 0.3 & 1.0 & 1.6 & 1.2 & 1.9 & 1.0 & 1.7 \\
\hline $\mathrm{Al}_{2} \mathrm{O}_{3}$ & 15 & 11 & 15 & 13 & 14 & 13 & 14 & 15 \\
\hline $\mathrm{FeO}$ & 10 & 2 & 13 & 15 & 13 & 15 & 16 & 12 \\
\hline $\mathrm{Na}_{2} \mathrm{O}$ & 10 & 2 & 13 & 15 & 13 & 15 & 16 & 12 \\
\hline $\mathrm{MnO}$ & 0.2 & 0.1 & 0.1 & 0.3 & 0.2 & 0.2 & 0.2 & 0.2 \\
\hline $\mathrm{MgO}$ & 2.5 & 0.1 & 4.6 & 4.2 & 4.9 & 3.0 & 5.7 & 4.1 \\
\hline $\mathrm{CaO}$ & 6 & 1 & 10 & 9 & 10 & 6 & 12 & 9 \\
\hline $\mathrm{K}_{2} \mathrm{O}$ & 0.9 & 3.6 & 0.5 & 0.9 & 0.8 & 0.8 & 0.4 & 1.4 \\
\hline $\mathrm{P}_{2} \mathrm{O}_{5}$ & 0.3 & 0.0 & 0.1 & 0.2 & 0.2 & 0.3 & 0.1 & 0.3 \\
\hline $\begin{array}{l}\text { Total } \\
\text { Trace } \\
\text { element } \\
(\mathrm{ppm})\end{array}$ & 106.1 & 96.5 & 109.8 & 111.1 & 109.8 & 112.7 & 113.6 & 109.4 \\
\hline $\mathrm{Rb}$ & 16 & 36 & 8 & 11 & 7 & 11 & 6 & 16 \\
\hline $\mathrm{Sr}$ & 243 & 122 & 169 & 252 & 270 & 254 & 180 & 213 \\
\hline $\mathrm{Y}$ & 38 & 69 & 19 & 33 & 19 & 42 & 17 & 26 \\
\hline $\mathrm{Zr}$ & 101 & 239 & 40 & 75 & 47 & 89 & 34 & 69 \\
\hline $\mathrm{Nb}$ & 2 & 6 & 1 & 1 & 1 & 1 & 0 & 3 \\
\hline $\mathrm{Ba}$ & 184 & 360 & 71 & 94 & 96 & 96 & 50 & 340 \\
\hline $\mathrm{La}$ & 8.5 & 18.4 & 3.1 & 5.8 & 5.0 & 6.0 & 2.7 & 16.7 \\
\hline $\mathrm{Ce}$ & 20 & 44 & 8 & 15 & 11 & 15 & 7 & 28 \\
\hline $\mathrm{Nd}$ & 16 & 31 & 7 & 13 & 8 & 17 & 6 & 16 \\
\hline $\mathrm{Sm}$ & 4.7 & 8.6 & 2.2 & 4.1 & 2.6 & 5.6 & 2.0 & 4.0 \\
\hline $\mathrm{Eu}$ & 1.6 & 2.1 & 0.9 & 1.4 & 0.8 & 2.0 & 0.7 & 1.4 \\
\hline $\mathrm{Gd}$ & 6.1 & 10.2 & 3.0 & 5.2 & 2.8 & 7.7 & 2.9 & 4.8 \\
\hline Dy & 6.5 & 13.3 & 4.0 & 5.2 & 3.2 & 8.8 & 3.5 & 5.8 \\
\hline $\mathrm{Er}$ & 4.1 & 8.2 & 2.8 & 3.4 & 2.1 & 5.7 & 2.4 & 3.5 \\
\hline $\mathrm{Yb}$ & 4.2 & 8.9 & 2.6 & 3.7 & 2.2 & 6.1 & 2.3 & 3.3 \\
\hline $\mathrm{Hf}$ & 3 & 8 & 2 & 2 & 1 & 4 & 1 & 2 \\
\hline $\mathrm{Pb}$ & 3.5 & 12.3 & 2.3 & 1.7 & 2.2 & 3.0 & 2.0 & 4.1 \\
\hline Th & 1.1 & 2.6 & 0.3 & 0.6 & 0.5 & 0.8 & 0.3 & 3.5 \\
\hline $\mathrm{U}$ & 0.4 & 1.0 & 0.1 & 0.2 & 0.2 & 0.3 & 0.1 & 0.9 \\
\hline
\end{tabular}




\begin{tabular}{|c|c|c|c|c|c|c|c|}
\hline $\begin{array}{l}\text { Major oxide } \\
\text { (wt } \% \text { ) }\end{array}$ & $\begin{array}{c}54-3(23-26) \\
\text { Glass } 2\end{array}$ & $\begin{array}{c}56-5(93-95) \\
\text { Glass } 1\end{array}$ & $\begin{array}{c}59-1(89-91) \\
\text { Glass } 1\end{array}$ & $\begin{array}{c}59-1(89-91) \\
\text { Glass } 2\end{array}$ & $\begin{array}{c}59-1(98-101) \\
\text { Glass } 1\end{array}$ & $\begin{array}{c}59-1(98-101) \\
\text { Glass } 2\end{array}$ & $\begin{array}{c}\text { 59-1 }(98-101 \\
\text { Glass } 3\end{array}$ \\
\hline $\mathrm{SiO}_{2}$ & 52 & 49 & 58 & 50 & 59 & 56 & 66 \\
\hline $\mathrm{TiO}_{2}$ & 1.6 & 1.0 & 1.0 & 0.9 & 0.9 & 1.0 & 0.6 \\
\hline $\mathrm{Al}_{2} \mathrm{O}_{3}$ & 15 & 14 & 15 & 14 & 15 & 15 & 14 \\
\hline $\mathrm{FeO}$ & 12 & 14 & 11 & 14 & 9 & 10 & 7 \\
\hline $\mathrm{Na}_{2} \mathrm{O}$ & 12 & 14 & 11 & 14 & 9 & 10 & 7 \\
\hline $\mathrm{MnO}$ & 0.2 & 0.2 & 0.1 & 0.1 & 0.2 & 0.3 & 0.2 \\
\hline $\mathrm{MgO}$ & 4.7 & 6.6 & 3.1 & 5.9 & 2.7 & 3.4 & 1.3 \\
\hline $\mathrm{CaO}$ & 9 & 12 & 7 & 11 & 6 & 7 & 4 \\
\hline $\mathrm{K}_{2} \mathrm{O}$ & 1.3 & 0.5 & 1.2 & 0.6 & 1.3 & 1.2 & 2.3 \\
\hline $\mathrm{P}_{2} \mathrm{O}_{5}$ & 0.4 & 0.1 & 0.3 & 0.2 & 0.4 & 0.5 & 0.2 \\
\hline $\begin{array}{l}\text { Total } \\
\text { Trace } \\
\text { element } \\
\text { (ppm) }\end{array}$ & 108.0 & 100.0 & 100.0 & 100.0 & 100.0 & 100.0 & 100.0 \\
\hline $\mathrm{Rb}$ & 19 & 5 & 20 & 9 & 21 & 19 & 23 \\
\hline $\mathrm{Sr}$ & 310 & 169 & 255 & 210 & 212 & 221 & 189 \\
\hline $\mathrm{Y}$ & 22 & 16 & 27 & 22 & 31 & 29 & 31 \\
\hline $\mathrm{Zr}$ & 70 & 33 & 113 & 52 & 125 & 118 & 136 \\
\hline $\mathrm{Nb}$ & 3 & 0 & 2 & 1 & 2 & 2 & 3 \\
\hline $\mathrm{Ba}$ & 349 & 41 & 285 & 125 & 276 & 259 & 325 \\
\hline $\mathrm{La}$ & 18.4 & 2.3 & 11.1 & 7.4 & 13.1 & 12.9 & 14.8 \\
\hline $\mathrm{Ce}$ & 33 & 6 & 23 & 15 & 26 & 26 & 28 \\
\hline $\mathrm{Nd}$ & 17 & 7 & 16 & 11 & 16 & 16 & 16 \\
\hline $\mathrm{Sm}$ & 3.7 & 2.1 & 4.0 & 2.9 & 4.2 & 3.7 & 3.8 \\
\hline $\mathrm{Eu}$ & 1.3 & 0.8 & 1.2 & 1.1 & 0.9 & 1.0 & 1.0 \\
\hline $\mathrm{Gd}$ & 4.2 & 3.0 & 5.1 & 3.4 & 4.7 & 4.3 & 4.1 \\
\hline Dy & 4.7 & 3.0 & 5.7 & 4.1 & 5.1 & 4.7 & 4.9 \\
\hline $\mathrm{Er}$ & 3.0 & 1.8 & 3.5 & 2.8 & 3.3 & 3.3 & 3.1 \\
\hline $\mathrm{Yb}$ & 3.0 & 2.0 & 3.0 & 2.8 & 3.5 & 3.1 & 3.3 \\
\hline Hf & 2 & 1 & 3 & 2 & 3 & 3 & 3 \\
\hline $\mathrm{Pb}$ & 4.8 & 1.7 & 4.6 & 2.5 & 4.4 & 3.2 & 4.0 \\
\hline Th & 4.3 & 0.3 & 2.2 & 0.8 & 2.1 & 1.9 & 2.1 \\
\hline $\mathrm{U}$ & 1.2 & 0.1 & 0.8 & 0.4 & 0.7 & 0.7 & 0.7 \\
\hline
\end{tabular}




\begin{tabular}{|c|c|c|c|c|c|c|c|}
\hline Major oxide & $61-1(39-41)$ & $61-1(39-41)$ & $61-2(38-40)$ & 63-1 (146- & 63-1 (146- & $63-2(31-34)$ & $63-2(31-34$ \\
\hline$(w t \%)$ & Glass 1 & Glass 2 & Glass 3 & 149) Glass 1 & 149) Glass 2 & Glass 1 & Glass 2 \\
\hline $\mathrm{SiO}_{2}$ & 74 & 74 & 52 & 51 & 50 & 50 & 54 \\
\hline $\mathrm{TiO}_{2}$ & 0.8 & 0.7 & 0.9 & 1.2 & 1.4 & 1.0 & 1.2 \\
\hline $\mathrm{Al}_{2} \mathrm{O}_{3}$ & 14 & 14 & 14 & 15 & 16 & 14 & 14 \\
\hline $\mathrm{FeO}$ & 4 & 5 & 15 & 12 & 12 & 15 & 12 \\
\hline $\mathrm{Na}_{2} \mathrm{O}$ & 4 & 5 & 15 & 12 & 12 & 15 & 12 \\
\hline $\mathrm{MnO}$ & 0.1 & 0.2 & 0.2 & 0.2 & 0.1 & 0.2 & 0.2 \\
\hline $\mathrm{MgO}$ & 0.5 & 0.6 & 5.2 & 5.5 & 5.6 & 6.0 & 5.1 \\
\hline $\mathrm{CaO}$ & 2 & 3 & 10 & 11 & 11 & 11 & 10 \\
\hline $\mathrm{K}_{2} \mathrm{O}$ & 3.6 & 3.3 & 0.5 & 0.7 & 0.6 & 0.6 & 0.7 \\
\hline $\mathrm{P}_{2} \mathrm{O}_{5}$ & 0.1 & 0.1 & 0.1 & 0.2 & 0.3 & 0.1 & 0.2 \\
\hline $\begin{array}{l}\text { Total } \\
\text { Trace } \\
\text { element } \\
\text { (ppm) }\end{array}$ & 100.0 & 100.0 & 100.0 & 100.0 & 100.0 & 100.0 & 100.0 \\
\hline $\mathrm{Rb}$ & 46 & 40 & 7 & 11 & 10 & 7 & 9 \\
\hline $\mathrm{Sr}$ & 147 & 159 & 229 & 289 & 296 & 205 & 224 \\
\hline $\mathrm{Y}$ & 40 & 47 & 19 & 22 & 23 & 17 & 22 \\
\hline $\mathrm{Zr}$ & 179 & 240 & 43 & 72 & 76 & 40 & 68 \\
\hline $\mathrm{Nb}$ & 3 & 5 & 1 & 2 & 3 & 1 & 1 \\
\hline $\mathrm{Ba}$ & 429 & 514 & 125 & 156 & 96 & 114 & 99 \\
\hline $\mathrm{La}$ & 15.8 & 25.5 & 4.5 & 10.6 & 10.6 & 4.2 & 7.4 \\
\hline $\mathrm{Ce}$ & 34 & 50 & 10 & 21 & 22 & 9 & 16 \\
\hline $\mathrm{Nd}$ & 22 & 29 & 8 & 13 & 14 & 7 & 11 \\
\hline $\mathrm{Sm}$ & 5.3 & 6.5 & 2.3 & 3.3 & 3.7 & 2.1 & 2.8 \\
\hline $\mathrm{Eu}$ & 1.2 & 1.5 & 0.9 & 1.1 & 1.3 & 0.8 & 1.1 \\
\hline $\mathrm{Gd}$ & 6.2 & 7.3 & 3.2 & 3.4 & 3.8 & 2.8 & 3.8 \\
\hline Dy & 7.7 & 9.7 & 3.7 & 4.7 & 4.9 & 3.1 & 4.3 \\
\hline $\mathrm{Er}$ & 5.6 & 6.5 & 2.5 & 2.9 & 3.0 & 2.0 & 2.7 \\
\hline $\mathrm{Yb}$ & 5.6 & 6.6 & 2.8 & 3.0 & 2.7 & 2.0 & 2.9 \\
\hline $\mathrm{Hf}$ & 6 & 7 & 1 & 2 & 2 & 1 & 2 \\
\hline $\mathrm{Pb}$ & 8.8 & 9.3 & 2.2 & 2.1 & 2.0 & 1.7 & 2.4 \\
\hline Th & 3.1 & 5.5 & 0.6 & 1.3 & 1.2 & 0.5 & 0.9 \\
\hline $\mathrm{U}$ & 1.3 & 1.8 & 0.3 & 0.4 & 0.4 & 0.2 & 0.3 \\
\hline
\end{tabular}


Major oxide $63-2(31-34) \quad 63-3(140-\quad 64-3(119-\quad 64-3(119-\quad 55-1(115-\quad 55-1(133-\quad 55-1(122-$ (wt $\%) \quad$ Glass 3

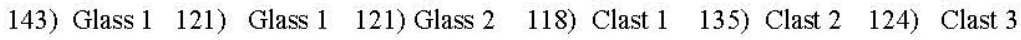

\begin{tabular}{|c|c|c|c|c|c|c|c|}
\hline $\mathrm{SiO}_{2}$ & 77 & 74 & 67 & 69 & 60 & 58 & 60 \\
\hline $\mathrm{TiO}_{2}$ & 0.6 & 0.7 & 0.6 & 0.8 & 0.6 & 0.7 & 0.7 \\
\hline $\mathrm{Al}_{2} \mathrm{O}_{3}$ & 14 & 15 & 15 & 15 & 17 & 18 & 17 \\
\hline $\mathrm{FeO}$ & 4 & 4 & 5 & 5 & 7 & 6 & 6 \\
\hline $\mathrm{Na}_{2} \mathrm{O}$ & 4 & 4 & 5 & 5 & 7 & 6 & 6 \\
\hline $\mathrm{MnO}$ & 0.1 & 0.2 & 0.2 & 0.1 & 0.2 & 0.1 & 0.1 \\
\hline $\mathrm{MgO}$ & 0.6 & 0.8 & 1.3 & 1.2 & 4.1 & 2.2 & 2.9 \\
\hline $\mathrm{CaO}$ & 2 & 3 & 5 & 4 & 7 & 8 & 6 \\
\hline $\mathrm{K}_{2} \mathrm{O}$ & 2.4 & 2.7 & 1.4 & 1.4 & 0.7 & 2.7 & 2.3 \\
\hline $\mathrm{P}_{2} \mathrm{O}_{5}$ & 0.1 & 0.2 & 0.2 & 0.2 & 0.2 & 0.7 & 0.3 \\
\hline $\begin{array}{l}\text { Total } \\
\text { Trace } \\
\text { element } \\
\text { (ppm) }\end{array}$ & 100.0 & 100.0 & 100.0 & 100.0 & 100.0 & 99.3 & 99.5 \\
\hline $\mathrm{Rb}$ & 29 & 27 & 10 & 11 & 21 & 96 & 87 \\
\hline $\mathrm{Sr}$ & 125 & 187 & 185 & 167 & 337 & 369 & 360 \\
\hline $\mathrm{Y}$ & 41 & 38 & 34 & 31 & 23 & 59 & 27 \\
\hline $\mathrm{Zr}$ & 183 & 170 & 75 & 75 & 106 & 153 & 163 \\
\hline $\mathrm{Nb}$ & 4 & 3 & 1 & 1 & 3 & 6 & 7 \\
\hline $\mathrm{Ba}$ & 472 & 415 & 125 & 131 & 271 & 847 & 840 \\
\hline $\mathrm{La}$ & 16.9 & 15.9 & 4.3 & 4.2 & 12.3 & 29.4 & 26.8 \\
\hline $\mathrm{Ce}$ & 34 & 34 & 11 & 11 & 25 & 47 & 46 \\
\hline $\mathrm{Nd}$ & 21 & 21 & 10 & 9 & 14 & 20 & 19 \\
\hline $\mathrm{Sm}$ & 5.1 & 5.4 & 3.1 & 3.2 & 3.3 & 3.9 & 3.7 \\
\hline $\mathrm{Eu}$ & 1.4 & 1.3 & 1.0 & 0.8 & 1.0 & 1.3 & 1.2 \\
\hline Gd & 6.0 & 5.9 & 4.0 & 3.8 & 3.3 & 4.3 & 3.6 \\
\hline Dy & 7.9 & 7.8 & 5.1 & 4.7 & 3.4 & 5.2 & 3.8 \\
\hline $\mathrm{Er}$ & 5.3 & 5.1 & 3.6 & 3.2 & 2.1 & 3.7 & 2.3 \\
\hline $\mathrm{Yb}$ & 5.4 & 4.9 & 3.4 & 3.1 & 2.2 & 3.8 & 2.5 \\
\hline $\mathrm{Hf}$ & 5 & 5 & 2 & 2 & 3 & 3 & 4 \\
\hline $\mathrm{Pb}$ & 8.3 & 8.0 & 4.0 & 3.8 & 3.0 & 5.7 & 7.3 \\
\hline Th & 2.9 & 2.7 & 0.3 & 0.3 & 2.5 & 7.8 & 8.1 \\
\hline $\mathrm{U}$ & 1.2 & 1.2 & 0.2 & 0.2 & 0.5 & 2.3 & 2.2 \\
\hline
\end{tabular}


Table 2-2 Accuracy and precision of EPMA and LA-ICPMS data for USGS standard BHVO-2 run with samples

$\begin{array}{lcccccc}\mathrm{EPMA} & \begin{array}{c}\text { Mean } \\ \text { of } 13\end{array} & \begin{array}{c}\text { Std } \\ \text { dev }\end{array} & \begin{array}{c}\% \\ \text { RSD }\end{array} & \begin{array}{c}\text { Recommended } \\ \text { values }\end{array} & \begin{array}{c}\text { Std } \\ \text { dev }\end{array} & \begin{array}{c}\% \\ \text { Bias }\end{array} \\ \mathrm{SiO} 2 & 49.31 & 0.45 & 0.9 & 49.90 & 0.6 & -1.2 \\ \mathrm{TiO} 2 & 2.69 & 0.06 & 2.1 & 2.73 & 0.04 & -1.6 \\ \mathrm{Al2O} 3 & 13.73 & 0.31 & 2.3 & 13.50 & 0.2 & 1.7 \\ \mathrm{FeO} & 10.83 & 0.33 & 3.1 & 11.00 & 0.2 & -1.6 \\ \mathrm{MnO} & 0.12 & 0.03 & 26.6 & & & \\ \mathrm{MgO} & 7.15 & 0.09 & 1.3 & 7.23 & 0.12 & -1.2 \\ \mathrm{CaO} & 11.28 & 0.16 & 1.4 & 11.40 & 0.2 & -1.1 \\ \mathrm{Na} 2 \mathrm{O} & 2.29 & 0.25 & 11.0 & 2.22 & 0.08 & 3.1 \\ \mathrm{~K} 2 \mathrm{O} & 0.49 & 0.09 & 17.7 & 0.52 & 0.01 & -6.5 \\ \mathrm{P} 2 \mathrm{O} 5 & 0.26 & 0.04 & 16.6 & 0.27 & 0.02 & -2.1 \\ \mathrm{Total} & 98.13 & 0.52 & 0.5 & & & \\ & & & & & & \\ \mathrm{LA}- & \mathrm{Mean} & \mathrm{Std} & \% & \text { Recommended } & \mathrm{Std} & \% \\ \mathrm{ICPMS} & 0 \mathrm{~F} 5 & \mathrm{dev} & \mathrm{RSD} & \text { values } & \mathrm{dev} & \mathrm{Bias} \\ \mathrm{Rb} & 9.2 & 0.69 & 7.5 & 9.8 & 1 & -6.2 \\ \mathrm{Sr} & 385 & 28.23 & 7.3 & 389 & 23 & -1.0 \\ \mathrm{Y} & 24.9 & 1.75 & 7.0 & 26 & 2 & -4.2 \\ \mathrm{Zr} & 159 & 9.38 & 5.9 & 172 & 11 & -7.8 \\ \mathrm{Nb} & 17.2 & 0.97 & 5.6 & 18 & 2 & -4.2 \\ \mathrm{La} & 15.4 & 0.96 & 6.2 & 15 & 1 & 2.4 \\ \mathrm{Ce} & 35.9 & 1.77 & 4.9 & 38 & 2 & -5.5 \\ \mathrm{Nd} & 24.1 & 1.07 & 4.4 & 25 & 1.8 & -3.6 \\ \mathrm{Sm} & 6.0 & 0.32 & 5.4 & 6.2 & 0.4 & -3.5 \\ \mathrm{Eu} & 2.0 & 0.10 & 4.9 & & & \\ \mathrm{Gd} & 6.1 & 0.34 & 5.6 & 6.3 & 0.2 & -2.5 \\ \mathrm{Dy} & 5.2 & 0.34 & 6.6 & & & \\ \mathrm{Er} & 2.5 & 0.19 & 7.6 & & & \\ \mathrm{Yb} & 2.0 & 0.20 & 9.6 & 2 & 0.2 & 2.4 \\ \mathrm{Hf} & 4.2 & 0.34 & 8.2 & 4.1 & 0.3 & 2.3 \\ \mathrm{~Pb} & 1.6 & 0.10 & 5.8 & & & \\ \mathrm{Th} & 1.2 & 0.13 & 11.2 & 1.2 & 0.3 & -0.5 \\ \mathrm{U} & 0.39 & 0.04 & 9.4 & & & \\ \mathrm{Ba} & 123 & 8.43 & 6.8 & 130 & 13 & -5.2\end{array}$

\subsection{Results}

\subsubsection{Major Oxides}

Site 296 glasses range from basalt to rhyolite $\left(48-78 \% \mathrm{SiO}_{2}\right)$ and are present throughout the core without any apparent pattern, although all felsic glasses except one are found at depth (Fig 2-4). Most glasses from Site 296 plot within the medium K series on a diagram of $\mathrm{K}_{2} \mathrm{O}$ vs. $\mathrm{SiO}_{2}$ (Fig. 2-5g). $\mathrm{Mg}$ numbers for basaltic glasses (48-52\% $\mathrm{SiO}_{2}$ ) range 
from 38 to 51, which are not primitive but similar to basalts from other continental and island arcs. The three clasts separated from core 55 are altered plagioclase aphyric andesites. On oxide-oxide plots, major element abundances of the clasts differ from the smooth trends formed by the glasses. Specifically, $\mathrm{TiO}_{2}$ and $\mathrm{FeO}$ are lower for a given $\mathrm{SiO}_{2}$ and $\mathrm{Al}_{2} \mathrm{O}_{3}$, and $\mathrm{K}_{2} \mathrm{O}$ is higher in clasts than glass shards. Based on their chemistry, the clasts would be classified as high-Al calc-alkaline andesites.

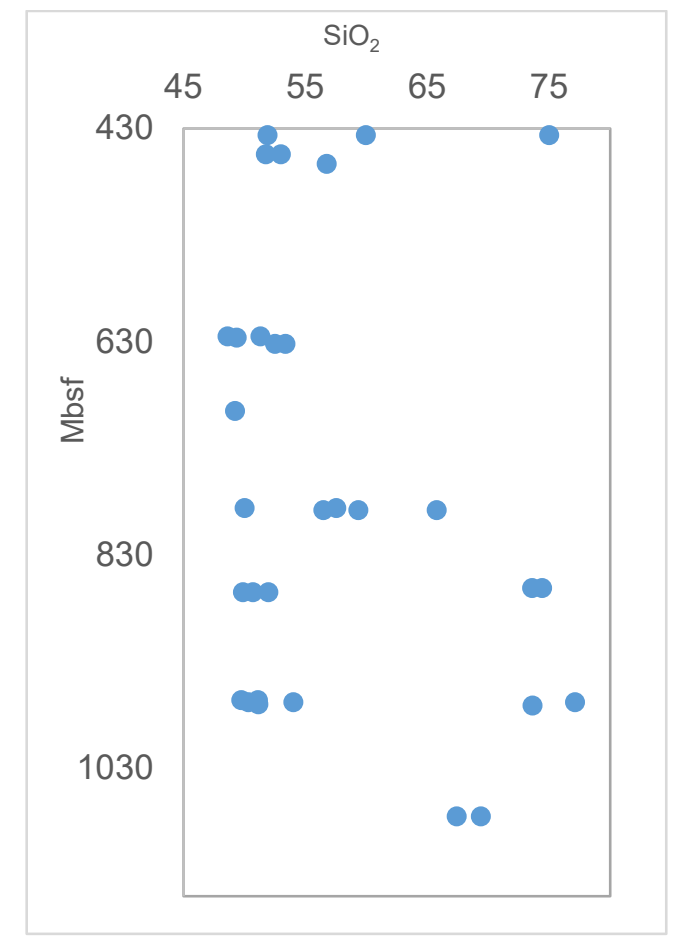

Figure 2-4 Figure 2-4 Plot of depth vs. SiO2 content of glass shards in volcaniclastic sediments of DSDP Site 296

Major elemental trends over the wide range of $\mathrm{SiO}_{2}$ emphasize differentiation processes controlling magma chemistry (Fig. 2-5). Decreases in $\mathrm{MgO}$ and $\mathrm{FeO}$ with increasing $\mathrm{SiO}_{2}$ concentration show the apparent saturation of olivine and pyroxene, decreasing $\mathrm{CaO}$ and level $\mathrm{Al}_{2} \mathrm{O}_{3}$ are consistent with plagioclase, clinopyroxene, and possible amphibole crystallization, while the increase and then decrease of $\mathrm{TiO}_{2}$ and $\mathrm{P}_{2} \mathrm{O}_{5}$ 
with $\mathrm{SiO}_{2}$ are consistent with the onset of titanomagnetite and apatite saturation in intermediate compositions. The vectors in Fig. 2-5 show an approximate direction the crystallization of the phases would shift the melt composition.

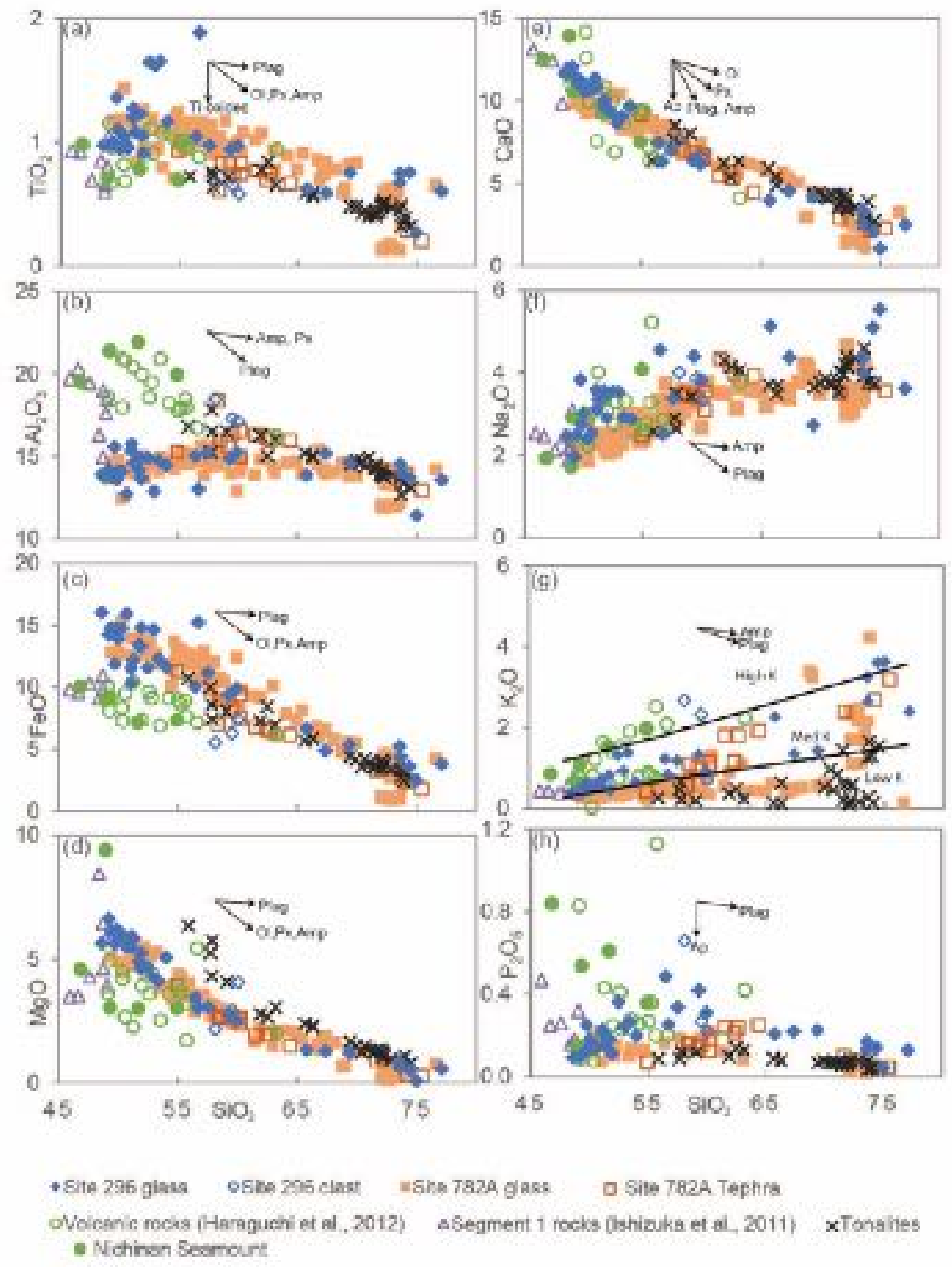

Figure 2-5 (a-h) Harker plots showing the variation of major oxides with $\mathrm{SiO} 2$ for Site 296 glass, clasts, and previously studied volcanic materials from KPR Segment 1 and its analog in the Izu-Bonin forearc (Straub, 2003, 2010; Bryant et al., 2003; Ishizuka et al., 2011b; Haraguchi et al., 2003, 2012). Vectors on the plot show the effect of mineral crystallization (see discussion). Data points are color-coded, with different symbols for different materials and locations 


\subsubsection{Trace Elements}

All glasses and clasts show diagnostic features of subduction magmas, such as $\mathrm{Nb}$ depletion and enrichment in Th and LILE (Fig. 2-6) when normalized to primitive mantle compositions. Highly incompatible trace element abundances are quite variable in the basaltic glasses $\left((\mathrm{La} / \mathrm{Yb})_{\mathrm{N}} 0.81-4.44\right.$ and $\mathrm{Ba} / \mathrm{La}$ 9.01-27.28) and suggest that primitive magmas, although arc-like in character, were diverse. Basaltic glass with low $\mathrm{TiO}_{2}$ and high $\mathrm{FeO}$ contents are relatively more depleted in incompatible elements than basaltic glasses with higher $\mathrm{TiO}_{2}$ content. Of the three andesite clasts, two clasts (55-1B and 551C) are enriched in incompatible elements $\left((\mathrm{La} / \mathrm{Yb})_{\mathrm{N}}\right.$ value of 5.50 and 7.57 and $\mathrm{Ba} / \mathrm{La}$ of 28.8 and 31.4) compared to the other andesitic clast $\left((\mathrm{La} / \mathrm{Yb})_{\mathrm{N}}=3.95\right.$ and $\left.\mathrm{Ba} / \mathrm{La}=22\right)$. However, none of the clasts has a negative Eu anomaly as seen for some andesitic glass shards. Two of the dacitic glasses have flat REE patterns and are similar to some of the more mafic glasses (Fig. 2-6c). 

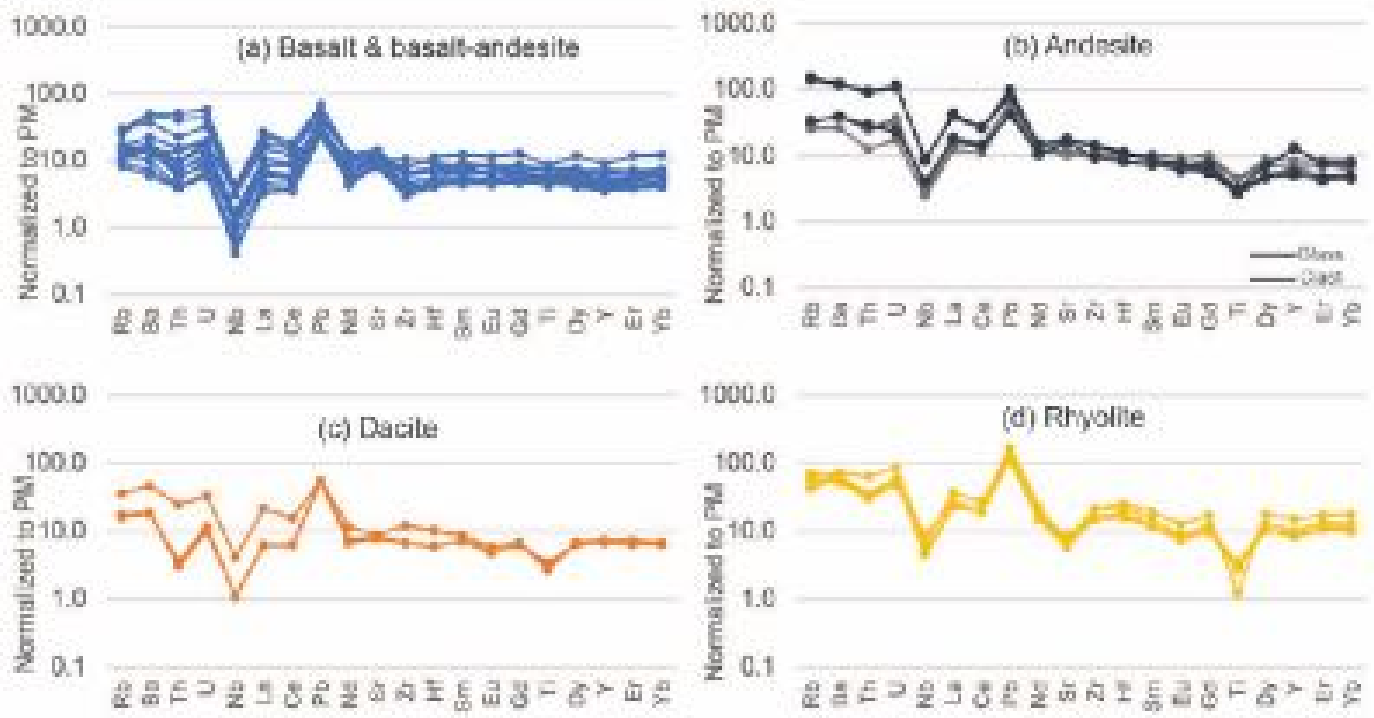

Figure 2-6 Primitive mantle normalized elemental abundances for glass shards and lithic clasts from DSDP Site 296: a) basalt and basaltic-andesite; (b) andesite; (c) dacite and (d) rhyolite. Normalizing values from Sun and McDonough (1989)
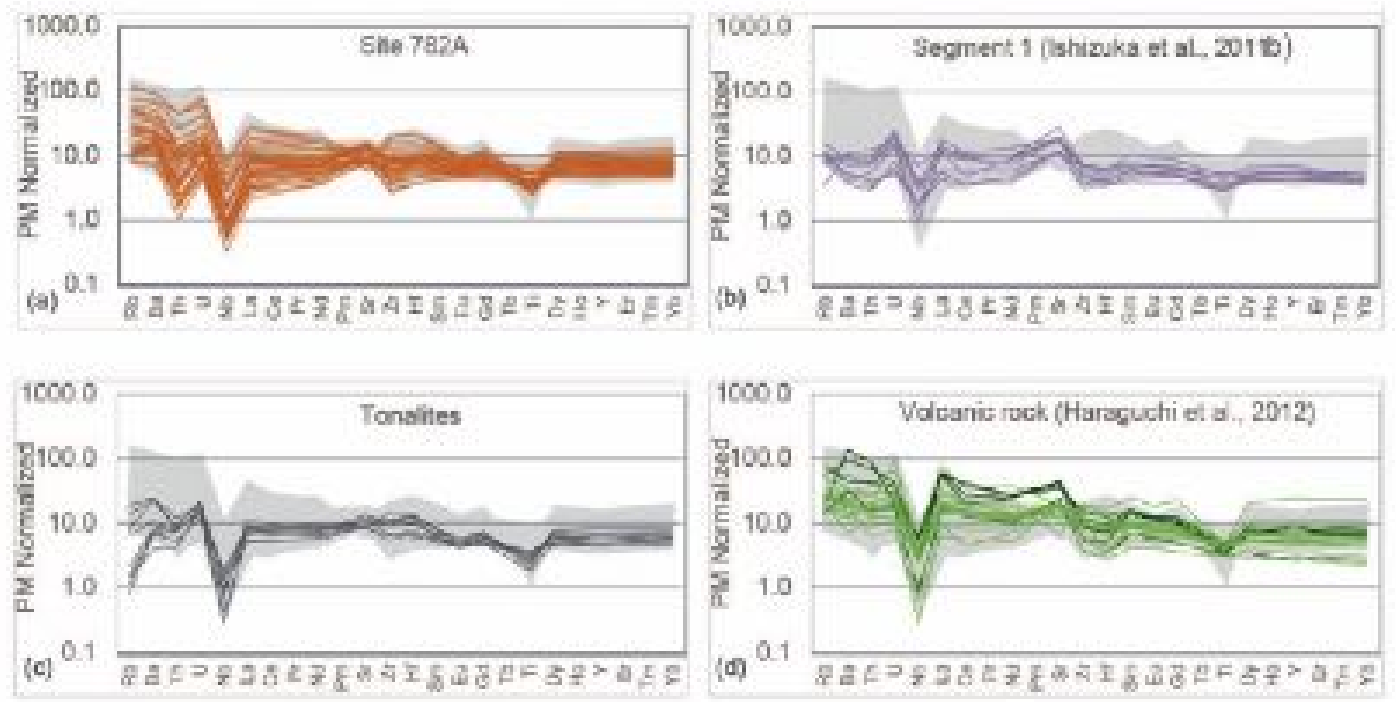

Figure 2-7 (a) Primitive mantle normalized elemental abundances for tephra and glass from ODP Site 782A, data from Straub et al., 2010 and Bryant et al., 2003. (b) Primitive mantle normalized elemental abundances for Segment 1 volcanic rocks from Ishizuka et al., 2011b. Shaded area represents the compositional range of Site 296 glasses and clasts (c) Primitive mantle normalized elemental abundances for tonalites from Haraguchi et al., 2003. (d) Primitive mantle normalized elemental abundances for volcanic rocks from Haraguchi et al., 2012. Dark green colors represent the rocks from Nichinan seamout 


\subsubsection{Comparison with Site 782 Glass}

Figures 5 and 7 show major and trace element plots of Site 296 glasses compared with materials from other locations of Segment 1 and its rifted counterpart. Glass from Site 782 fallout ash layers (Bryant et al., 2003; Straub, 2003) are similar to Site 296 glass trends for most oxides over the full range of $\mathrm{SiO}_{2}$ from $50-75$ (Fig. 2-5 a-h) although there is a slight depletion in $\mathrm{Na}_{2} \mathrm{O}, \mathrm{K}_{2} \mathrm{O}$ and $\mathrm{P}_{2} \mathrm{O}_{5}$ compared to Site 296 (Fig. 2-5 f-h). Mafic to intermediate glasses from Site 782 plot within the low K series and only rhyolite glasses show medium to high $\mathrm{K}$ content. Primitive mantle normalized trace elements are also like Site 296 glass (Fig. 2-7a), although some basalt and basalt-andesite glasses have more pronounced LREE depletion, e.g., $(\mathrm{La} / \mathrm{Sm})_{\mathrm{N}} 0.50$ to 0.88 compared to $(\mathrm{La} / \mathrm{Sm})_{\mathrm{N}} 0.69$ to 3.25 in Site 296 mafic glasses. Site 782 glasses also have low concentrations of $\mathrm{Nb}(0.23-$ $2.62 \mathrm{ppm})$ and Th (0.09- $3 \mathrm{ppm})$, except three felsic glasses, whereas Site 296 glasses have higher concentrations of $\mathrm{Nb}(0.3-6.43 \mathrm{ppm})$ and $\mathrm{Th}(0.26-4.34 \mathrm{ppm})$ (Fig. 2-8). Mafic glass from Site 296 also has higher $\mathrm{Th} / \mathrm{Yb}$ ratios $(0.13$ to 1.45$)$ compared to mafic glass from Site $782 \mathrm{~A}$ (0.03 to 0.16). In a Th/Yb vs. Nb/Yb plot (Fig. 2-9), Site 296 glass and Site 782 ash plots above both depleted and enriched MORB fields. 

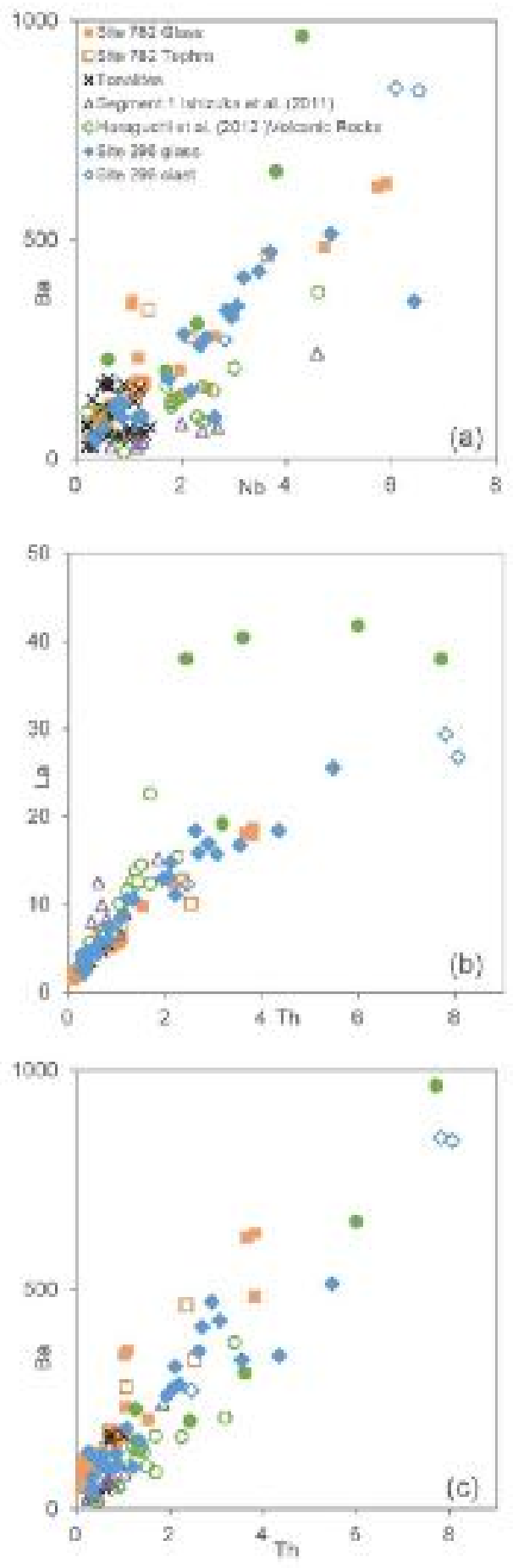

Figure 2-8 (a) Plot of Ba vs. Nb ; (b) Plot of La vs. Th and (c) Plot of Ba vs. Th for Site 296 and samples cited in Fig. 27 caption 

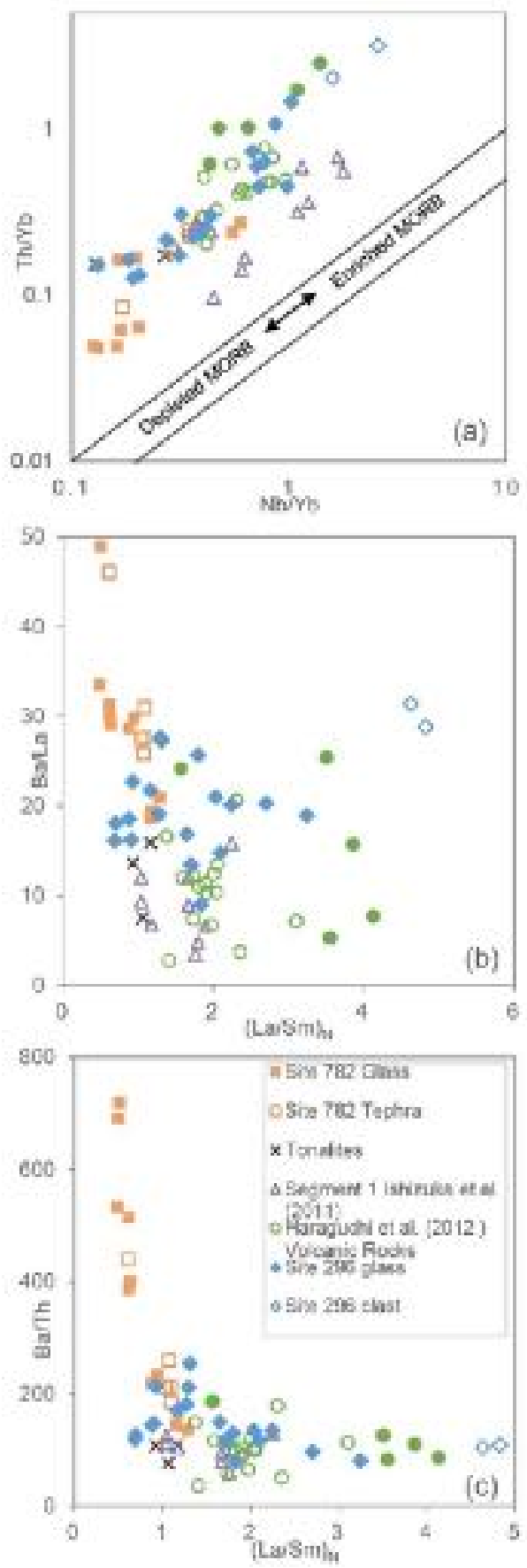

Figure 2-9 (a) Logarithmic plot of $\mathrm{Th} / \mathrm{Yb}$ vs. $\mathrm{Nb} / \mathrm{Yb}$ showing depleted and enriched MORB fields (Pearce and Peate, 1995). (b) Ba/La vs. (La/Sm)N plot for all samples. (c) $\mathrm{Ba} / \mathrm{Th}$ vs. (La/Sm)N plot for the mafic glasses and volcanic rocks 


\subsubsection{Comparison with Volcanic Rock fragments}

Volcanic rocks from northern KPR previously reported are basalt to andesitic composition (Ishizuka et al., 2011b; Haraguchi et al., 2012) whereas the lithic fragments from tephra fallout of Site 782A are intermediate to silicic in composition (Fig. 2-5). The $\mathrm{TiO}_{2}$ contents of the whole rocks and rock fragments, including Site 296 clasts, are lower than glasses of similar silica composition from Site 296 and 782A (Fig. 2-5a). Other disparities are lower $\mathrm{FeO}$ and $\mathrm{MgO}$ contents and higher $\mathrm{Al}_{2} \mathrm{O}_{3}$ contents for a given $\mathrm{SiO}_{2}$ in the volcanic rock fragments compared with glass from both Site 296 and 782A. (Fig. 2-5b, 5c, 5d). As shown in Fig. 5g the volcanic rocks mainly plot within the medium $\mathrm{K}$ series with a few basalts and andesites in the high $\mathrm{K}$ series. In the $\mathrm{Th} / \mathrm{Yb}$ vs. $\mathrm{Nb} / \mathrm{Yb}$ plot (Fig. 29a) the whole rocks have higher $\mathrm{Nb} / \mathrm{Yb}$ ratios compared to glasses of Site 296 and $782 \mathrm{~A}$. None of the whole rocks show a depletion in LREE compared to HREE, which is seen in both Site 296 and 782A mafic glass (Fig. 2-7b, 7c). Rock compositions from Haraguchi et al. (2012) vary in their trace elemental concentration, especially Nichinan seamount which has high concentrations of LREEs (shown as green filled circles in Fig. 2-8b).

\subsubsection{Comparison with Plutonic Rocks}

The silica content of tonalites dredged from Komahashi Daini seamount ranges from 56 to $74 \%$. Tonalites show trends in major oxides similar to the glass shards and volcanic rocks (Fig. 2-5 a-h). The tonalites have higher $\mathrm{MgO}$ and lower $\mathrm{TiO}_{2}$ content compared to the glasses from Site 296 and 782A, whereas $\mathrm{K}_{2} \mathrm{O}$ contents are low like Site 782A. Primitive mantle normalized REE show a concave upward pattern with MREE 
depletion (Fig. 2-7c). The tonalites also show arc-like features such as $\mathrm{Nb}$ depletion, but unlike their volcanic counterparts, they are depleted in $\mathrm{Rb}$ compared to $\mathrm{Ba}$ and enriched in $\mathrm{Zr}$ and Hf compared to LREEs (Fig. 2-7d).

\subsection{Discussion}

\subsubsection{Interpretation of diverse igneous materials from the northernmost early IBM $\operatorname{arc}$}

Diverse igneous materials were sampled from Segment 1 of the KPR by several different recovery methods, thus integrating their chemical characteristics to produce a coherent interpretation of arc processes is not straightforward. The origin of whole volcanic rocks, glasses, tephra, minerals, and plutonic rocks are different, and this will affect the chemistry of the sample and its interpretation. As a first step toward interpretation, we consider what the samples represent, constraints on their ages, and the effects of alteration.

\subsubsection{Liquid compositions}

Whole rock analyses may give the actual composition of the magma, or they may include entrained crystals of cognate or xenocrystal origin. Overall, the best proxy for melts or liquids is glass, either from tephra or detritus, when preserved. In Fig. 2-10a the composition of Site 296 and Site 782 glasses and volcanic rocks from the northern KPR are plotted on a mineral component diagram projected from plagioclase onto a Cpx-Ol-Qtz pseudo ternary diagram (Grove et al., 1982, 1983). Most of the Site 296 and Site 782 glasses follow a trend close to the one-atmosphere saturation curve of Grove and Baker (1984), commonly used for calc-alkaline rocks, and likely represent a liquid line of descent from parent magmas. While some of the volcanic rocks plots near the $\mathrm{Ol}+\mathrm{Cpx}$ saturation curve most plot towards the $\mathrm{Ol}$ apex. This shift most likely reflects olivine accumulation 
and excess olivine in the bulk analysis. On the mineral component diagram projected from diopside (Fig. 2-10b), volcanic rocks are shifted towards the plagioclase apex compared to the glasses. A similar disparity in composition has been observed in prior studies of the IBM arc; the alumina content of whole rocks is generally higher compared to glasses (Fig. 2-5b) which has been attributed to plagioclase accumulation (Lee et al., 1995; Straub, 2003). Therefore, when present in detrital sediments, glass shards, and volcanic ash provide better insight into the evolution of melt compositions than whole rock fragments.

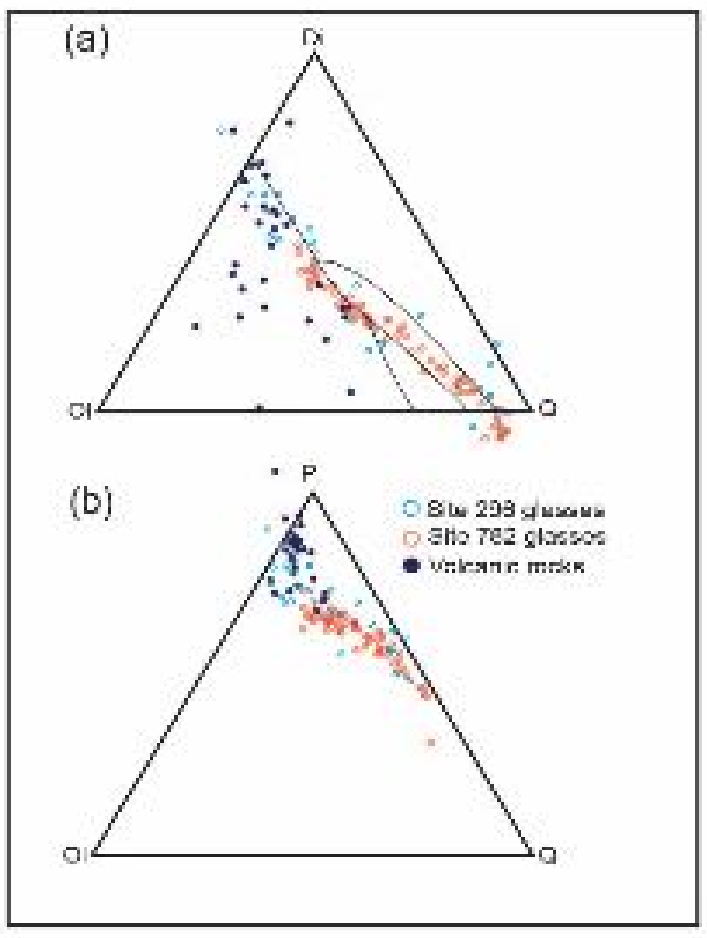

Figure 2-10 (a) Olivine-Diopside-Quartz and (b) Olivine-Plagioclase-Quartz pseudo ternary projections showing glasses and rocks. The 1-atmosphere multiple saturation curve after Grove and Baker (1984) is shown on the Ol-Di-Q plot. The volcanic rocks are from Haraguchi et al. (2012) and Ishizuka et al. (2011b) 


\subsubsection{Method of recovery and time constraints.}

The kind of samples studied and how they were acquired are essential factors to consider in our interpretation of the first IBM arc (Fig. 2-11). As noted by Straub (2003), fallout ash layers interbedded with volcaniclastic sediments provide a useful chronological tool. However, because ash layers represent only magmas that erupt explosively, ages are sporadic rather than continuous. Such magmas are also typically more silicic and form one end of the $\mathrm{SiO}_{2}$ series of KPR glasses. Glass shards in detrital sediments preserve the composition of diverse magmas but can be significantly older than their depositional age inferred from biostratigraphy or the age of bracketing ash layers. Erosion of volcanic edifices of different ages delivers sediment to fore arc, intra-arc, and back arc basins (Fig. 2-11). In drilled sediments, logically, older detrital fragments will be more abundant deep in the cores, whereas upper parts could be a wide range of ages up to the depositional age. At Site 296, the presence of a 47.5 Ma clast from Core 63 (around 966-975 meters below sea floor) implies that parts of the igneous basement and possibly Eocene "protoarc" volcanics were among sediments deposited in the Oligocene. In contrast, volcanic rocks dredged or drilled from near surface sediments from the northern KPR all have Ar/Ar ages between 24-28 Ma and appear to document only the later pre-rifting history of the first arc. If we assume that Site 296 glass shards were eroded and deposited shortly after their

solidification, which would explain their preservation, their ages could be a close match to the depositional age of the sediments. 


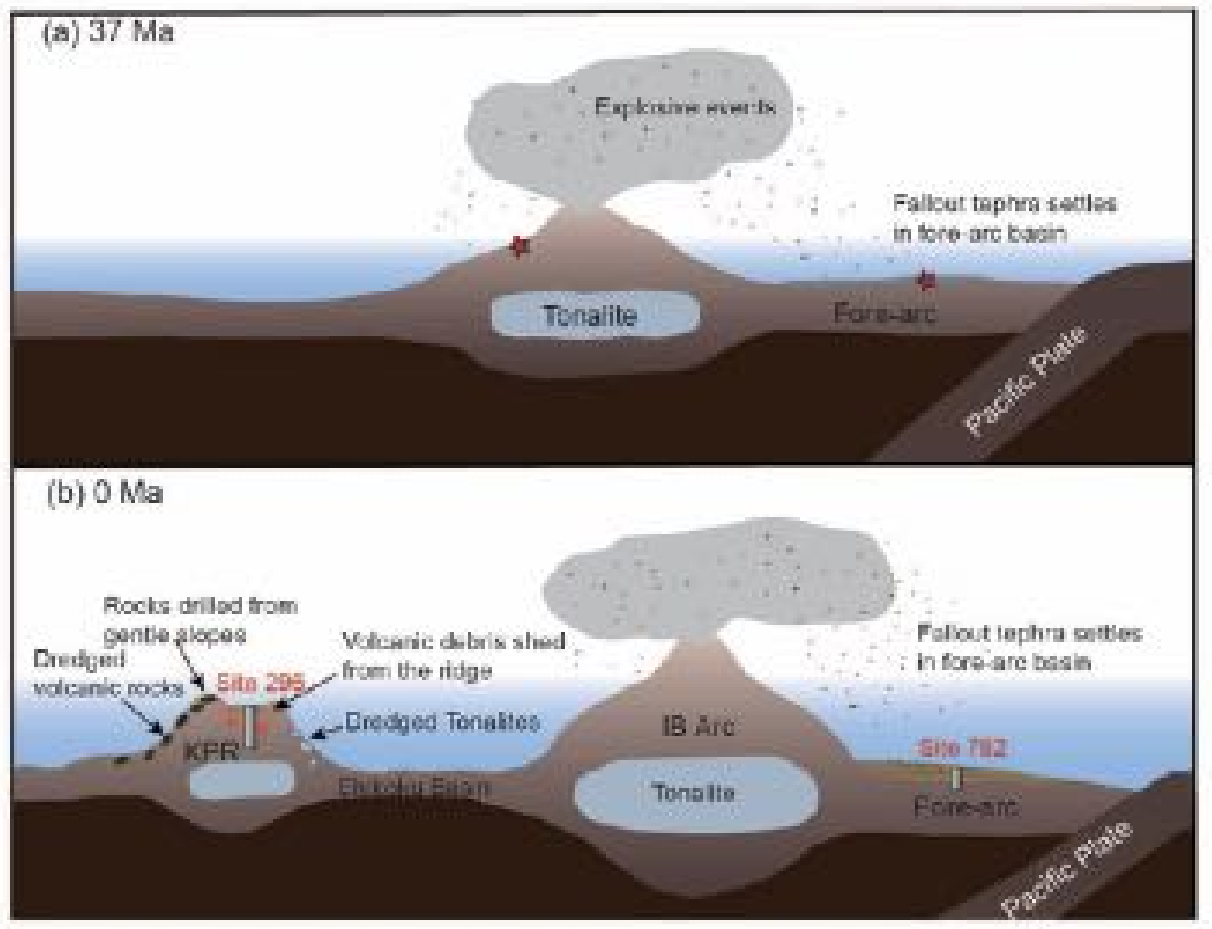

Figure 2-11 Schematic diagram of the origin of volcanic and plutonic materials discussed. The top panel (a) shows the active first arc prior to rifting with the drill sites 296 and 782 denoted by stars. The bottom panel (b) depicts the presentday geological setting with the subsided and inactive KPR stranded by rifting

\subsubsection{Unequal record of mafic and felsic and intrusive and extrusive parts of volcanic systems.}

Tephra and ash layers correspond to the explosive part of the volcanic history and may not sample the compositions of effusive eruptions, resulting in an incomplete evolutionary picture. Like the glass shards, lithic clasts from Site 296 and lithic surface debris recovered from the KPR in dredges and piston cores are more likely to include the complete range of magma chemistry. As discussed above, glasses represent homogenous liquids, whereas the rocks may contain excess crystals, and if these are unevenly distributed 
through a lava flow, the rock fragments may not even represent the composition of the larger rock unit from which they are eroded.

A second important aspect of arc evolution is understanding the relationship between volcanic and plutonic products. Recent studies have pointed out the importance of understanding the geochemical relationship and comparative volumes of volcanic and plutonic rocks in subduction settings (Bachmann and Bergantz, 2004; Eichelberger et al., 2006; Bachmann et al., 2007; Lundstrom and Glazner, 2016). Tonalites from dredged from the Komahashi Daini seamount are 37-38 Ma and could be contemporaneous with some Site 296 glasses and fallout ash and tephra from Site 782, whereas the rocks dredged and drilled from the KPR crest are all younger. Exposed plutonic rocks are rare in oceanic arc settings, despite evidence for a thick mid-crustal felsic layer (Nishizawa et al., 2016), thus comparing the glasses and contemporaneous KPR tonalites could provide a unique insight into arc crustal differentiation processes.

\subsubsection{Sample recovery and alteration}

All seafloor rocks are subject to alteration by reaction with seawater, especially when hydrothermal fluids are present. In general, loose debris on the ocean floor available for dredge sampling or shallow drilling is expected to be altered and possibly more altered than drilled core samples as the result of long-term contact with seawater. Elevated $\mathrm{P}_{2} \mathrm{O}_{5}$ in some of the KPR volcanic rock specimens $(>0.5 \%)$ compared to glasses $(<0.5 \%)$ suggest ocean floor alteration or mineralization (Fig. 2-5h). According to Haraguchi et al. (2003, 2012), less than half of the volcanic rocks, and only $10 \%$ of the tonalites recovered by dredging from the KPR were fresh enough to be studied. The preservation of fresh glass shards in Site 296 sediments indicates minimal interaction with water, suggesting an origin 
by an explosive eruption or rapid erosion, followed by rapid sedimentation. According to Straub (2003), glass in ash layers from Site 782 were also rapidly buried and therefore are preserved well. The instability of glass in the presence of water suggests that the ages of detrital glass shards, like fallout ash, are similar to the depositional age of the sediment.

\subsubsection{Inferences about the Evolution of the Oligocene IBM Arc}

\subsubsection{Evidence for diverse parental magmas}

An important feature of the Site 296 glass suite is that basaltic glasses have a wide range of incompatible element characteristics (Fig. 2-6a). Explanations for these differences include differing mantle sources, differing partial melting regimes, and/or differing interaction with arc crust. Since none of the mafic glasses have Mg-numbers's high enough to have equilibrated with mantle peridotite, both mantle and crustal processes must be considered. One line of evidence against early crustal assimilation is the lack of Eu anomalies in mafic glasses since arc crust is typically plagioclase-bearing.

The basaltic glasses of Site 296 fall into three groups of REE patterns: LREE depleted $(\mathrm{La} / \mathrm{Sm})_{\mathrm{N}}<1$, slightly LREE enriched $(\mathrm{La} / \mathrm{Sm})_{\mathrm{N}} 1-2$, and highly LREE enriched $(\mathrm{La} / \mathrm{Sm})_{\mathrm{N}}>2$, with a maximum value of 3.25. As shown in Figure 6a, REE patterns change curvature from LREE depleted to LREE enriched. It is notable that the range of REE pattern types continues through the differentiation sequence from basalt to andesite to dacite (Fig. 2-6 and 2-12). This feature strengthens the conclusion that the patterns in mafic glasses are primary and not related to differentiation by crystal fractionation and or crustal assimilation. La/Sm variation in primary arc magmas (Fig. 2-9) may result from variably enriched mantle sources, LREE-enriched inputs from the subducted slab or differences in 
the extent of mantle melting and differing mantle mineralogy. The extent of mantle melting is increased by the addition of $\mathrm{H}_{2} \mathrm{O}$, thus flatter REE patterns and indicators of slab influence are often correlated (Fig. 2-9c). Among Site 296 rocks there is also a strong correlation between LREE enrichment and Th enrichment (Fig. 2-6a), which might indicate that input of melted sediment from the slab produced the LREE enrichment (Pearce et al., 2005; Elliott et al., 1997; Plank and Langmuir, 1998).
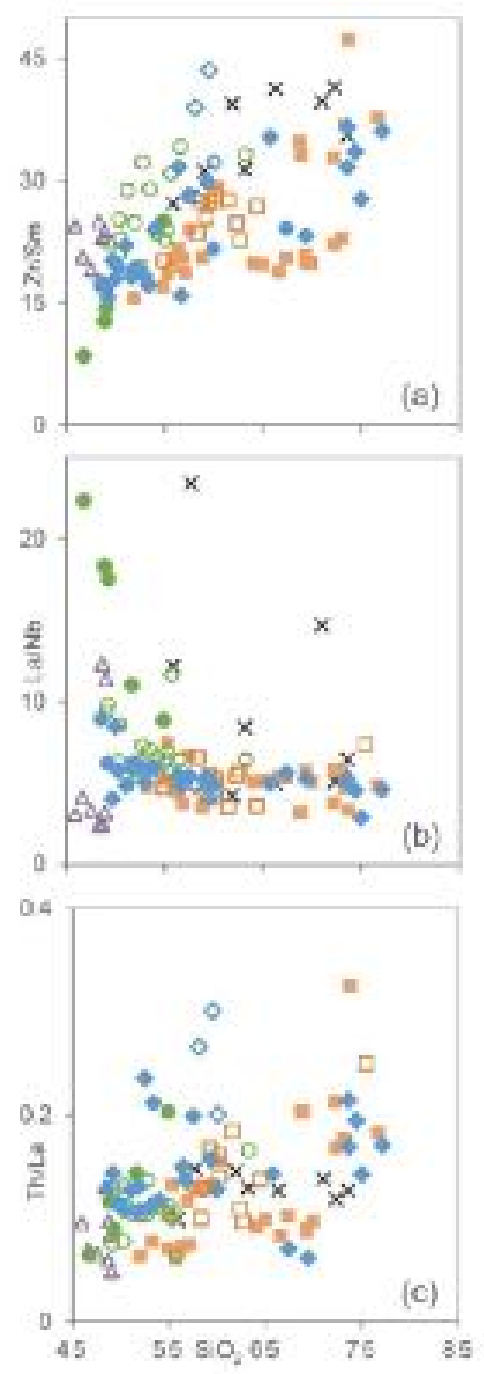

Figure 2-12 (a) Plot of $\mathrm{Zr} / \mathrm{Sm}$ vs. $\mathrm{SiO} 2$ showing a slight increase in the ratio with differentiation. (b) Plot of La/Nb vs. $\mathrm{SiO} 2$ showing no variation in the ratio with differentiation. (c) Plot of $\mathrm{Th} / \mathrm{La}$ vs. SiO2, showing a very slight increase to no variation with differentiation. Symbols as in Figure 2-5 caption 


\subsubsection{Differentiation processes}

Major element compositions for glasses from Site 296 follow trends indicating multiple saturation with clinopyroxene, olivine, and plagioclase (Fig. 2-10). Except for olivine, these are common phenocrysts in lithic fragments from the Site 296 core and are found loose in the sediment matrix. Trends on Harker diagrams support crystallization of these phases as a control on the composition of the glasses (Fig. 2-5). FeO, $\mathrm{MgO}$, and $\mathrm{CaO}$ decrease with $\mathrm{SiO}_{2}$ and $\mathrm{Al}_{2} \mathrm{O}_{3}$ is relatively constant through andesitic compositions. Roughly similar trends are seen in the Site 782 fallout ashes. Accessory minerals also affect major element trends for $\mathrm{TiO}_{2}$ and $\mathrm{P}_{2} \mathrm{O}_{5}$. Except for four mafic glasses with high $\mathrm{TiO}_{2}$, $\mathrm{TiO}_{2}$ decreases with $\mathrm{SiO}_{2}$, indicating crystallization of titano-magnetite. With increasing differentiation, the $\mathrm{P}_{2} \mathrm{O}_{5}$ in Site 296 glasses reaches its peak in the andesitic range, marking the onset of apatite crystallization. This trend is unique to Site 296 glasses and is not seen in Site 782 glasses (Fig. 2-5). Based on major oxides and an increasing presence of negative $\mathrm{Eu}, \mathrm{Sr}$ and Ti anomalies (Fig. 2-6a \& b), basalt through andesite differentiation was dominated by clinopyroxene and plagioclase crystallization, followed by magnetite in intermediate compositions. There is limited evidence in Site 782 tephra for plagioclase crystallization as not much variation in $\mathrm{Sr}$ is observed.

For magmas as silicic as dacite and rhyolite, crystallization of accessory minerals, such as zircon, ilmenite, apatite, and allanite, with significant partition coefficients for trace elements $\mathrm{Nb}, \mathrm{Zr}$, Ti, Hf, REE, U, Th, may influence incompatible element ratios (Fig. 212). For example, zircon crystallization will decrease $\mathrm{Zr} / \mathrm{Sm}, \mathrm{La} / \mathrm{Nb}$, and $\mathrm{Th} / \mathrm{La}$; allanite and apatite crystallization will increase $\mathrm{Zr} / \mathrm{Sm}$ and decrease $\mathrm{La} / \mathrm{Nb}$; allanite crystallization will increase Th/La. As shown in Fig. 12, only $\mathrm{Zr} / \mathrm{Sm}$ changes with increasing $\mathrm{SiO}_{2}$ toward 
slightly higher ratios; thus, the apatite crystallization indicated by decreasing $\mathrm{P}_{2} \mathrm{O}_{5}$ abundances may have affected MREE and HREE abundances (Fig. 2-5). In the absence of accessory mineral crystallization, the differences among dacites and rhyolites, especially LREE enrichment, $\mathrm{Th} / \mathrm{La}$ and $\mathrm{La} / \mathrm{Nb}$ ratios can be inferred to reflect differences among different primary basalts.

MREE and HREE contents can also be affected by amphibole or garnet crystallization or assimilation of crust with these phases in the residue during differentiation. A relative depletion of $\mathrm{Eu}, \mathrm{Gd}$, and $\mathrm{Sm}$ in the dacite glasses and two of the three clasts of Site 296 suggests that amphibole crystallized in these magmas (Fig.2-6 b \&c). Although none of the lithic fragments at Site 296 or dredged and drilled rocks are reported to contain amphibole, there are scattered amphibole grains in the sediments which must have originated in the arc magmas of the KPR. Plots of $\mathrm{La} / \mathrm{Yb}$ and $\mathrm{Dy} / \mathrm{Yb}$ with $\mathrm{SiO}_{2}$ (Fig. 2-13a, b) can reveal and distinguish the presence of amphibole or garnet as a fractionating phase or residue of partial melting and mixing processes (Davidson et al. 2007). The tonalites, which contain amphibole, and intermediate to silicic Site 782 samples follow a subtle trend of amphibole fractionation; relatively little change in $\mathrm{La} / \mathrm{Yb}$ and slightly decreasing $\mathrm{Dy} / \mathrm{Yb}$ with increasing $\mathrm{SiO}_{2}$.

For Site 296 glasses and dredged and drilled volcanic rocks, interpretations are complicated by the wide range of $\mathrm{La} / \mathrm{Yb}$ and $\mathrm{Dy} / \mathrm{Yb}$ at mafic compositions. Primary magmas for these rocks and glasses could have formed by partial melting at varying mantle depths with the presence or absence of residual garnet controlling the $\mathrm{La} / \mathrm{Yb}$ and $\mathrm{Dy} / \mathrm{Yb}$ ratios (Fig. 2-13). In this case, the different trends of the basaltic glasses of Site 296 would signify their origin at variable mantle depths. 

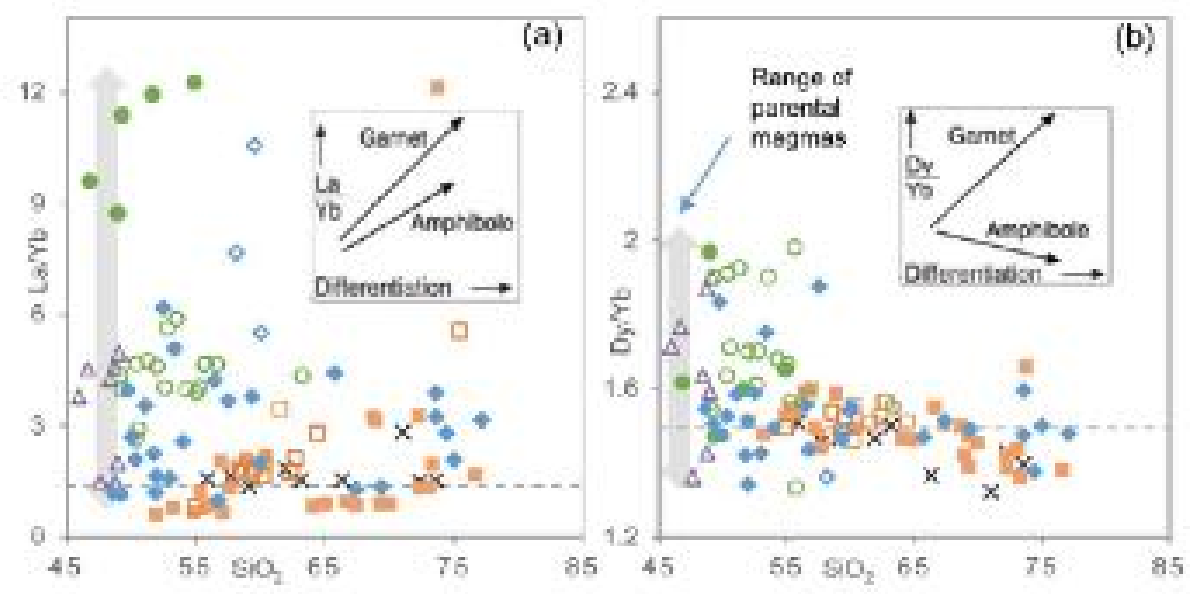

Figure 2-13 (a) Plot of $\mathrm{La} / \mathrm{Yb}$ vs. $\mathrm{SiO} 2$ showing the trends of garnet and amphibole fractionation with differentiation of magma (Davidson et al., 2007). La/Yb increases during the fractionation of both garnet and amphibole with a greater increase in the ratio for garnet compared with amphibole. (b) Plot of Dy/Yb vs. SiO2 showing the trends of garnet and amphibole fractionation with differentiation (Davidson et al., 2007). Dy/Yb increases with fractionation of garnet and decreases with amphibole fractionation. The dashed horizontal line shows the primitive mantle ratio from Sun and McDonough (1989). Symbols as in Figure 2-5 caption

\subsubsection{Volcanic/plutonic relationships}

The relationship between contemporaneous volcanic and plutonic rocks is a topic of interest in understanding the origin of the continental crust. The association is still not clear whether silicic volcanic and plutonic rocks are formed from crystal mushes or derived together from greater depth, or separate processes altogether (Lundstrom and Glazner, 2016). The recovery of 37-38 Ma old hornblende, biotite-hornblende, and hornblende-cpx tonalites from Komahashi Daini seamount (Haraguchi et al., 2003) in Segment 1 of the northern KPR, presents an unusual opportunity to compare volcanic and plutonic products from the early IBM and analyze possible relationships. Seismic data for this region shows that there is a developed mid-crust in the northern KPR, similar to that observed within the 
northern IBM arc (Kodaira et al., 2007; Suyehiro et al. 1996; Takahashi et al. 1998). The presence of hydrous minerals like hornblende and biotite in the tonalites displays one of the recognized disparities seen within the volcanic and plutonic rocks of island arcs; anhydrous versus hydrous assemblages. The anhydrous assemblage of volcanic rock is hypothesized to result from magma degassing during ascent through crust whereas the hydrous assemblage commonly seen in plutonic rocks are attributed to the formation from un-degassed water-rich magma which crystallizes hornblende at depth. There is limited evidence of hydrous minerals in volcanic rocks of the northern IBM, but depletion in MREEs in some dacite glass shards of Site 296 (Fig. 2-6c) and presence of hornblende grains in the volcaniclastic sediments from the core suggest otherwise.

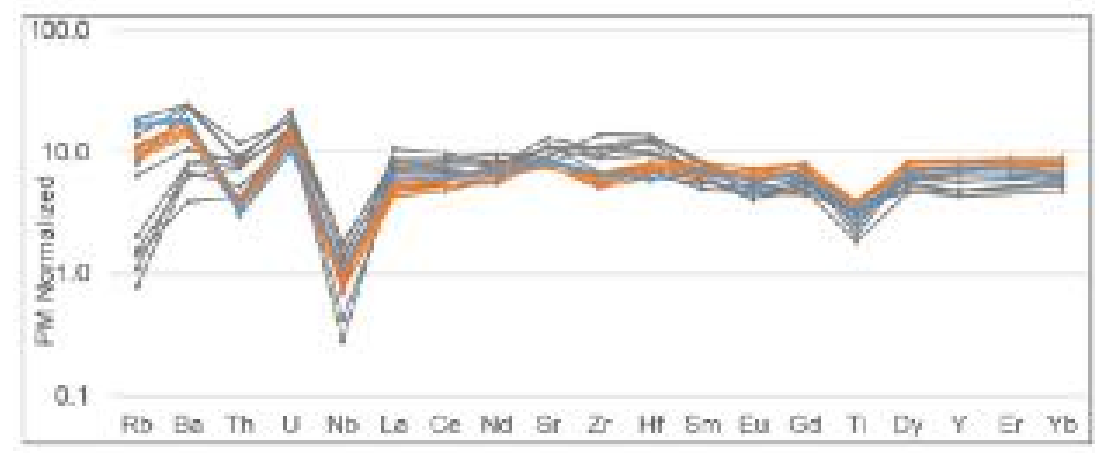

Figure 2-14 Primitive mantle normalized spider plots of tonalites and dacite glasses from Site 296 and 782 , which show complementary features. Tonalites are shown in grey, Site 296 glasses in blue and Site 782 in orange

In the crystal mush model, both volcanic and plutonic rocks are co-magmatic; melt extraction from the crystal mush forms silicic volcanic rock, while the residual crystal mush forms the plutonic rock (Bachmann and Bergantz, 2004; Eichelberger et al., 2006; 
Bachmann et al., 2007). Negative Rb anomalies, high $\mathrm{Ba}, \mathrm{Zr}$, and Hf concentrations with weak depletion in $\mathrm{Sr}, \mathrm{P}$, and $\mathrm{Ti}$ are commonly observed within the plutonic rocks whereas complementary volcanic rocks have excess $\mathrm{Rb}$ and maybe more depleted in $\mathrm{Ba}, \mathrm{Sr}, \mathrm{P}$, and Ti (Yan et al., 2016; 2018). This type of relationship is found between the Komahashi Daini tonalites and glasses from Site 296 (Fig. 2-7c). On Harker diagrams (Fig. 2-5), the more silicic tonalites have low K contents, more like the Site 782 tephra than Site 296 glass. This could indicate a relationship where tonalites and Site 782 glasses originated from an initially low K primary magma; alternatively, $\mathrm{K}$, like $\mathrm{Rb}$, may have been extracted from the crystal mush (Hickey-Vargas, 2005). Two dacite glasses from Site 296 and some dacite glasses from Site 782A show signatures similar to the tonalites (Fig. 2-14). Similar depletion in MREE like Gd and the trends of $\mathrm{La} / \mathrm{Yb}$ and $\mathrm{Dy} / \mathrm{Yb}$ with silica, together with

the high $\mathrm{Zr}$, Hf, and low $\mathrm{Rb}$ content of the tonalites, may point to a complementary relationship between the two. Despite the geochemical evidence, age relationships do not support actual coexistence of the tonalite magma and these Site 782A ashes, as the ash is 7-8 m.y. younger (Fig. 2-15). The tonalites are also older than the depositional ages of the Site 296 sediments. However, the two dacite glasses from Site 296 Core 64 ( $1075 \mathrm{mbsf})$ lie below a clast dated at $47.5 \mathrm{Ma}(\sim 970 \mathrm{mbsf})$; therefore, they may originate from Eocene lavas of similar age to that of the tonalites.

\subsubsection{Geochemical Evolution of Magmas in KPR Segment 1}

\subsubsection{Mantle Fertility and Subduction inputs}

At present, ODP Site 782 is located $830 \mathrm{~km}$ closer to the Izu-Bonin Trench than DSDP Site 296 (Fig. 2-11b). Assuming the sources of sediments for these sites were also 
spatially distinct, even before arc rifting (Fig. 2-11a), some geochemical differences can be attributed to distance from the convergent margin. Mafic Site 782 tephra and ash are more depleted in LREE compared to HREE $\left((\mathrm{La} / \mathrm{Yb})_{\mathrm{N}} 0.49\right.$ to 0.88$)$ than mafic Site 296 glass $\left((\mathrm{La} / \mathrm{Yb})_{\mathrm{N}}=0.70\right.$ to 4.44$)$. Differences in LREE-enrichment between the glasses from two drill sites may indicate volcanic front or forearc (Site 782) versus rear arc settings (Site 296), with greater input of slab-derived fluids causing a greater extent of melting or a more depleted mantle wedge near the plate boundary (Straub et al., 2003). Volcanic rocks dredged from the KPR crest are always enriched in LREE compared to HREE $\left((\mathrm{La} / \mathrm{Yb})_{\mathrm{N}}\right.$ $=1.05$ to 8.80 ). The absence of LREE depleted signatures may indicate that LREEenrichment increased and became more uniform in the later stages of early IBM magmatism (Fig. 2-15), since these rocks are younger. Haraguchi et al. (2012) proposed that an enriched MORB mantle source replaced a depleted MORB mantle from the west during rifting and opening of Shikoku basin which would result in more enriched volcanic products toward the end of the lifetime of the early IBM. Alternatively, replacement of enriched MORB mantle might have been a localized process that affected the sources of volcanic rocks from Nichinan Seamount (Haraguchi et al., 2012), and also possibly the sources of the Site 296 clasts. $\mathrm{Nb}$ enrichment in the rear arc, shown by higher $\mathrm{Nb} / \mathrm{Yb}$, may also reflect an increase in asthenosphere fertility (Pearce et al., 2005; Brandl et al., 2017). The reason for the increase in the fertility of asthenosphere is unsure, but the tectonic forces causing rifting may also have induced upwelling of asthenosphere from deeper and more enriched sources. 


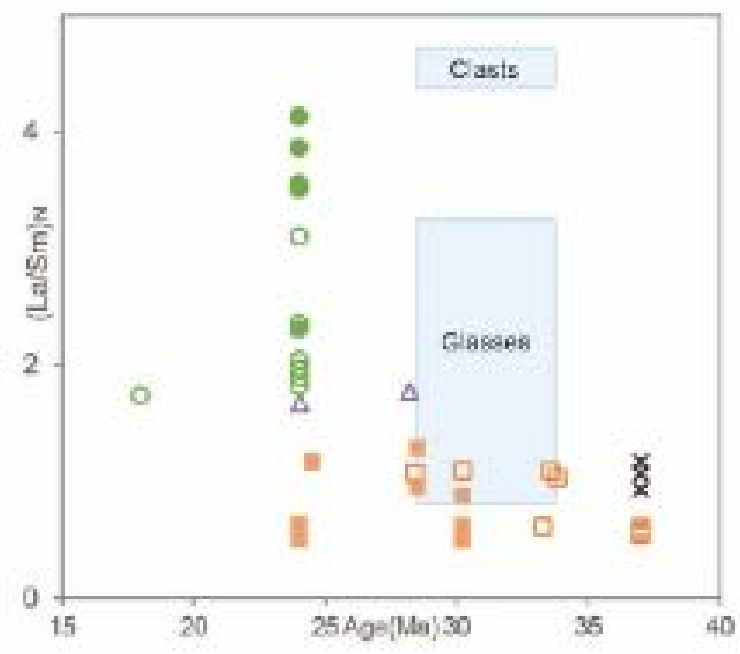

Figure 2-15 Plot of (La/Sm)N vs. age in Ma for tephra, volcanic, and plutonic rocks from KPR Segment 1. Some older Eocene Site 782 tephras are also plotted. The blue squares are the range of $(\mathrm{La} / \mathrm{Sm}) \mathrm{n}$ for glass shards and clasts from DSDP Site 296 using their early to late Oligocene depositional age. Symbols as in Figure 2-5 caption

The low K content of Site 782 glasses also stands out from the medium K content of the Site 296 glasses and the whole rocks. The low K content was attributed to the input of slab fluids together with high extents of mantle melting (shallow subduction) compared to input from both slab fluid and melt in the rear arc (deep subduction), which is also seen in the Quaternary Izu arc (Taylor and Nesbitt, 1998; Straub, 2003, 2008; Straub et al., 2010). According to Pearce et al. (2005), Ba enrichment is an indicator of input of slab fluids and shallow subduction, whereas Th is a component of the sediment melt which forms at depth. Among mafic samples, highest $\mathrm{Ba} / \mathrm{La}$ and $\mathrm{Ba} / \mathrm{Th}$, together with low $\mathrm{La} / \mathrm{Sm}$ and $\mathrm{Nb} / \mathrm{Yb}$ are found in tephra from Site 782 (Fig. 2-9), currently in the forearc, consistent with high fluid inputs, high extents of mantle melting and source depletion in this part of the arc. A subset of these samples overlaps with Site 296 glasses at intermediate $\mathrm{Nb} / \mathrm{Yb}$, $\mathrm{La} / \mathrm{Sm}, \mathrm{Ba} / \mathrm{La}$ and $\mathrm{Ba} / \mathrm{Th}$ (Fig. 2-9), suggesting that mantle inputs and melting regimes 
were similar in these locations at some point during their individual histories. Interestingly, rocks from the KPR crest have lowest $\mathrm{Th} / \mathrm{Yb}, \mathrm{Ba} / \mathrm{La}$, and $\mathrm{Ba} / \mathrm{Th}$ (Fig. 2-9). This feature may mark the waning of subduction inputs and the onset of arc extension and rifting.

Among rocks from the KPR crest, Ishizuka et al. (2011b) found small but systematic increases in $\mathrm{Ba} / \mathrm{La}$ and ${ }^{87} \mathrm{Sr} /{ }^{86} \mathrm{Sr}$ toward the south (2-10, and 0.7029-0.7032, respectively). These differences are small compared with the total range of Oligocene materials from Segment 1, but they could reflect subduction conditions that existed in the short time interval of 25-28 Ma. Assuming that their low Ba/La, Ba/Th, and Th/La indicate limited input from subducted materials compared with melts of depleted mantle, greater input of subduction fluids (high Ba and Sr) may have occurred toward the south. This variation along the volcanic front can be tested further with samples from the current IzuBonin arc basement.

\subsubsection{Temporal variations in Oligocene}

The biostratigraphic ages of Site 296 sediments, from Early to Late Oligocene (Ingle et al., 1975), are poorly constrained, and there might be older lithic fragments in the sediments as evidenced by the presence of the lithic fragment aged 47.5 Ma (Ozima et al., 1977). Although volcanic debris will be mixed during deposition, younger volcanic materials are expected up the core. In contrast, no systematic trace element variation was observed in the glasses up the Site 296 core. The volcanic rocks sampled from the surface of the northern KPR are all young (24-28 Ma) and show widely varying composition, from those poor in subduction indicators (see above) to the highly enriched rocks dredged from Nichinan seamount. Based on their similar age, it may be that mantle sources of the 
enriched seamount rocks are localized, caused by the invasion of enriched MORB sources (Haraguchi et al., 2012) in this location. The trend toward low subduction inputs in some of the KPR crest rocks could mark the effect of incipient rifting, with roll-back of the downgoing slab eliminating the source of subducted materials.

\subsection{Conclusions}

1. Glasses from a 653-meter section of volcaniclastic sediment recovered from DSDP Site 296 in Segment 1 of the northern KPR show a wide range of trace element variation, even among basaltic compositions. These are more likely to be related to different primary magmas than differentiation processes; this is also seen within glasses and tephras of forearc ODP Site 782. Therefore, it appears that the melting of compositionally diverse mantle sources occurred even in relatively small segments (approximately $540 \mathrm{~km}$ of $2600 \mathrm{~km}$ total arc length) of the early IBM arc.

2. Differentiation through rhyolite mostly retains the trace element features of basaltic magmas, such as high $\mathrm{Rb}, \mathrm{Ba}$ contents, and $\mathrm{La} / \mathrm{Nb}, \mathrm{Th} / \mathrm{La}$ and $\mathrm{La} / \mathrm{Sm}$ ratios. Fractionation of accessory apatite affected the signature of some silicic derivatives by producing higher $\mathrm{Zr} / \mathrm{Sm}$ and lower $\mathrm{La} / \mathrm{Yb}$ ratios. Hornblende was not a primary fractionating phase for basaltic magmas but may have played a role in the differentiation of silicic magmas.

3. Comparison of the compositions of broadly coeval Segment 1 volcanic suites with a plutonic suite exposed by arc rifting suggests that they are related. Tonalites were formed from low K primary magma, similar to some Site 296 and Site 782A glasses and differentiated at depth to stabilize hornblende and biotite. Crust building probably 
occurred by contemporaneous intrusive and extrusive activity, as evidenced by the similar radiometric ages of the tonalites, volcanic rocks and the tephra layers.

4. Within Segment 1 , the Oligocene IBM arc was characterized by chemically varying primary magma sources which may have been affected by rifting, the flow of localized enriched MORB mantle and/or varying additions of sediment and fluid to the melting mantle, processes which have been documented in other parts of the early arc. Based on this finding, the identification and interpretation of along-strike and across-strike trends for the entire early IBM arc may be premature and rest upon more thorough exploration and investigation.

\subsection{Acknowledgments}

This research was supported by NSF grants OCE 0931440 and OCE 15377861 to Rosemary Hickey-Vargas. We gratefully acknowledge the contribution of Mary White, Maria Pages, Carrie Rebenack and Donna Adams to prepare mineral and glass separates for this project, supported by NSF grant OEDG 0303173. We thank Thomas Beasley of the Florida Center for Analytical Electron Microscopy (FCAEM) at FIU for assistance with EPMA analyses and Dr. Tatiana Trejos of the Trace Evidence Analysis Facility (TEAF) at FIU for assistance with LA-ICPMS analyses

\subsection{References}

Arculus, R.J., Bloomfield, A.L., Fryer, P., et al., 1992, Major-element geochemistry of ashes from Sites 782, 784 and 786 in the Bonin forearc: Proceedings of the Ocean Drilling Program, Scientific Results, v. 125, p. 277-292. 
Arculus, R.J., Ishizuka, O., Bogus, K.A., et al., 2015, A record of spontaneous subduction initiation in the Izu-Bonin-Mariana Arc: Nature Geoscience, v. 8, no. 9, p. 728-733.

Arculus, R., Ishizuka, O., Bogus, K., et al., 2015, International Ocean Discovery Program Expedition 351 preliminary report; Izu-Bonin-Mariana Arc origins; continental crust formation at an intraoceanic arc; foundation, inception, and early evolution; 30 May30 July 2014: Preliminary Report (International Ocean Discovery Program), v. 351.

Bachmann, O., and Bergantz, G.W., 2004, On the origin of crystal-pore rhyolites; extracted from batholithic crystal mushes: Journal of Petrology, v. 45, no. 8, p. 1565-1582.

Bachmann, O., Miller, C.F., and de Silva, S.L., 2007, The volcanic-plutonic connection as a stage for understanding crustal magmatism: Journal of Volcanology and Geothermal Research, v. 167, no. 1-4, p. 1-23.

Brandl, P.A., Hamada, M., Arculus, R.J., et al., 2017, The arc arises; the links between volcanic output, arc evolution and melt composition: Earth and Planetary Science Letters, v. 461, p. 73-84.

Bryant, C.J., Arculus, R.J., and Eggins, S.M., 2003, The geochemical evolution of the IzuBonin Arc system; a perspective from tephras recovered by deep-sea drilling: Geochemistry, Geophysics, Geosystems - G3, v. 4, no. 11.

Davidson, J., Turner, S., Handley, H., Macpherson, C., and Dosseto, A., 2007, Amphibole "sponge" in arc crust?: Geology (Boulder), v. 35, no. 9, p. 787-790. 
Eichelberger, J.C., Izbekov, P.E., and Browne, B.L., 2006, Bulk chemical trends at arc volcanoes are not liquid lines of descent: Lithos (Oslo), v. 87, no. 1-2, p. 135-154.

Elliott, T., Plank, T., Zindler, A., White, W., and Bourdon, B., 1997, Element transport from slab to volcanic front at the Mariana Arc: Journal of Geophysical Research, v. 102, no. B7, p. 14-15,019.

Grove, T.L., Gerlach, D.C., and Sando, T.W., 1982, Origin of calc-alkaline series lavas at Medicine Lake Volcano by fractionation, assimilation and mixing: Contributions to Mineralogy and Petrology, v. 80, no. 2, p. 160-182.

Grove, T.L., Gerlach, D.C., Sando, T.W., and Baker, M.B., 1983, Origin of calc-alkalic series lavas at Medicine Lake Volcano by fractionation, assimilation and mixing; corrections and clarifications: Contributions to Mineralogy and Petrology, v. 82, no. 4, p. 407-408.

Grove, T.L., and Baker, M.B., 1984, Phase equilibrium controls on the tholeiitic versus calc-alkaline differentiation trends: Journal of Geophysical Research, v. 89, no. B5, p. 3253-3274.

Haraguchi, S., Ishii, T., Kimura, J., and Kato, Y., 2012, The early Miocene ( approximately $25 \mathrm{Ma}$ ) volcanism in the northern Kyushu-Palau Ridge, enriched mantle source injection during rifting prior to the Shikoku back-arc basin opening: Contributions to Mineralogy and Petrology, v. 163, no. 3, p. 483-504. 
Haraguchi, S., Ishii, T., Kimura, J., and Ohara, Y., 2003, Formation of tonalite from basaltic magma at the Komahashi-Daini Seamount, northern Kyushu-Palau Ridge in the Philippine Sea, and growth of Izu-Ogasawara (Bonin)-Mariana arc crust: Contributions to Mineralogy and Petrology, v. 145, no. 2, p. 151-168.

Hickey-Vargas, R., 2005, Basalt and tonalite from the Amami Plateau, northern West Philippine Basin; new Early Cretaceous ages and geochemical results, and their petrologic and tectonic implications: Island Arc, v. 14, no. 4, p. 653-665.

Hickey-Vargas, R., Abdollahi, M.J., Parada, M.A., Lopez-Escobar, L., and Frey, F.A., 1995, Crustal xenoliths from Calbuco Volcano, Andean Southern Volcanic Zone; implications for crustal composition and magma-crust interaction: Contributions to Mineralogy and Petrology, v. 119, no. 4, p. 331-344.

Hochstaedter, A., Gill, J., Peters, R., Broughton, P., Holden, P., and Taylor, B., 2001, Across-arc geochemical trends in the Izu-Bonin arc; contributions from the subducting slab: Geochemistry, Geophysics, Geosystems - G3, v. 2, no. 7, p. Citation 2000GC000105.

Ingle, J.C.,Jr, Karig, D.E., Bouma, A.H., et al., 1975, Site 296: Initial Reports of the Deep Sea Drilling Project, v. 31, p. 191-274.

Ishizuka, O., Tani, K., Reagan, M.K., et al., 2011, The timescales of subduction initiation and subsequent evolution of an oceanic island arc: Earth and Planetary Science Letters, v. 306, no. 3-4, p. 229-240. 
Ishizuka, O., Taylor, R.N., Milton, J.A., and Nesbitt, R.W., 2003, Fluid-mantle interaction in an intra-oceanic arc; constraints from high-precision $\mathrm{Pb}$ isotopes: Earth and Planetary Science Letters, v. 211, no. 3-4, p. 221-236.

Ishizuka, O., Taylor, R.N., Yuasa, M., and Ohara, Y., 2011, Making and breaking an island arc; a new perspective from the Oligocene Kyushu-Palau Arc, Philippine Sea: Geochemistry, Geophysics, Geosystems - G3, v. 12, no. 5, p. Citation Q05005.

Katsura, T., and Shimamura, K., 1994, Geological, geochemical research of bottom samples, from continental shelf surveys, H. D. Japan (part 1): preliminary study for ocean floor on the Japanese continental shelves (In Japanese): Rept Hydrogr Res, v. 30, p. 345-381.

Kelley, K.A., Plank, T., Ludden, J., and Staudigel, H., 2003, Composition of altered oceanic crust at ODP Sites 801 and 1149: Geochemistry, Geophysics, Geosystems G3, v. 4, no. 6 .

Kobayashi, K., Kasuga, S., and Okino, K., 1995, Shikoku Basin and its margins: New York, NY, United States (USA), Plenum Press, New York, NY.

Kodaira, S., Sato, T., Takahashi, N., Ito, A., Tamura, Y., Tatsumi, Y., and Kaneda, Y., 2007, Seismological evidence for variable growth of crust along the Izu intraoceanic arc: Journal of Geophysical Research, v. 112, no. B5, p. B05104. 
Lee, J., Stern, R.J., and Bloomer, S.H., 1995, Forty million years of magmatic evolution in the Mariana arc; the tephra glass record: Journal of Geophysical Research, v. 100, no. B9, p. 17-17,687.

Lundstrom, C.C., and Glazner, A.F., 2016, Silicic magmatism and the volcanic-plutonic connection: Elements, v. 12, no. 2, p. 91-96.

McDonough, W.F., and Sun, S.S., 1995, The composition of the Earth: Chemical Geology, v. 120 , no. $3-4$, p. $223-253$.

Miyashiro, A., 1974, Volcanic rock series in island arcs and active continental margins: American Journal of Science, v. 274, no. 4, p. 321-355.

Nishizawa, A., Kaneda, K., and Oikawa, M., 2016, Crust and uppermost mantle structure of the Kyushu-Palau Ridge, remnant arc on the Philippine Sea Plate: Earth, Planets and Space, v. 68, p. Article 30.

Okino, K., Shimakawa, Y., and Nagaoka, S., 1994, Evolution of the Shikoku Basin: Journal of Geomagnetism and Geoelectricity, v. 46, no. 6, p. 463-479.

Ozima, M., Kaneoka, I., and Ujiie, H., 1977, (super 40) Ar- (super 39) Ar age of rocks, and the development mode of the Philippine Sea: Nature (London), v. 267, no. 5614, p. 816-818.

Pearce, J.A., and Peate, D.W., 1995, Tectonic implications of the composition of volcanic arc magmas: Annual Review of Earth and Planetary Sciences, v. 23, p. 251-285. 
Pearce, J.A., Stern, R.J., Bloomer, S.H., and Fryer, P., 2005, Geochemical mapping of the Mariana arc-basin system; implications for the nature and distribution of subduction components: Geochemistry, Geophysics, Geosystems - G3, v. 6, no. 7.

Plank, T., and Langmuir, C.H., 1998, The chemical composition of subducting sediment and its consequences for the crust and mantle: Chemical Geology, v. 145, no. 3-4, p. $325-394$.

Reagan, M.K., Ishizuka, O., Stern, R.J., et al., 2010, Fore-arc basalts and subduction initiation in the Izu-Bonin-Mariana system: Geochemistry, Geophysics, Geosystems G3, v. 11, no. 3, p. Citation Q03X12.

Shibata, K., Mizuno, A., Yuasa, M., Uchiumi, S., and Nakagawa, T., 1977, Further K-Ar dating of tonalite dredged from the Komahashi-daini Seamount: Chishitsu Chosajo Geppo $=$ Bulletin of the Geological Survey of Japan, v. 28, no. 8, p. 1-4.

Stern, R.J., Fouch, M.J., Klemperer, S.L., and Eiler, J.M., 2003, An overview of the IzuBonin-Mariana subduction factory: Geophysical Monograph, v. 138, p. 175-222.

Stern, R.J., Jackson, M.C., Fryer, P., and Ito, E., 1993, O, Sr, Nd and Pb isotopic composition of the Kasuga Cross-Chain in the Mariana Arc; a new perspective on the K-h relationship: Earth and Planetary Science Letters, v. 119, no. 4, p. 459-475.

Stern, R.J., Morris, J.D., Bloomer, S.H., and Hawkins, J.W.,Jr, 1991, The source of the subduction component in convergent margin magmas; trace element and radiogenic 
isotope evidence from Eocene boninites, Mariana Forearc: Geochimica et Cosmochimica Acta, v. 55, no. 5, p. 1467-1481.

Straub, S.M., Layne, G.D., Schmidt, A., and Langmuir, C.H., 2004, Volcanic glasses at the Izu Arc volcanic front; new perspectives on fluid and sediment melt recycling in subduction zones: Geochemistry, Geophysics, Geosystems - G3, v. 5, no. 1.

Straub, S.M., 2008, Uniform processes of melt differentiation in the central Izu Bonin volcanic arc (NW Pacific): Geological Society Special Publications, v. 304, p. 261283.

Straub, S.M., 2003, The evolution of the Izu Bonin-Mariana volcanic arcs (NW Pacific) in terms of major element chemistry: Geochemistry, Geophysics, Geosystems - G3, v. 4, no. 2 .

Straub, S.M., Goldstein, S.L., Class, C., Schmidt, A., and Gomez-Tuena, A., 2010, Slab and mantle controls on the $\mathrm{Sr}-\mathrm{Nd}-\mathrm{Pb}-\mathrm{Hf}$ isotope evolution of the post $42 \mathrm{Ma}$ Izu-Bonin volcanic arc: Journal of Petrology, v. 51, no. 5, p. 993-1026.

Straub, S.M., Woodhead, J.D., and Arculus, R.J., 2015, Temporal evolution of the Mariana Arc; mantle wedge and subducted slab controls revealed with a tephra perspective: Journal of Petrology, v. 56, no. 2, p. 409-439.

Sun, C., and Stern, R.J., 2001, Genesis of Mariana shoshonites; contribution of the subduction component: Journal of Geophysical Research, v. 106, no. B1, p. 589-608. 
Sun, S.S., and McDonough, W.F., 1989, Chemical and isotopic systematics of oceanic basalts; implications for mantle composition and processes: Geological Society Special Publications, v. 42, p. 313-345.

Suyehiro, K., Takahashi, N., Ariie, Y., et al., 1996, Continental crust, crustal underplating, and low-Q upper mantle beneath an oceanic island arc: Science, v. 272, no. 5260, p. 390-392.

Takahashi, N., Suyehiro, K., Shinohara, M., Stern, R.J., and Arima, M., 1998, Implications from the seismic crustal structure of the northern Izu-Bonin Arc: Island Arc, v. 7, no. 3, p. 383-394.

Taylor, B., Fujioka, K., Janecek, T.R., et al., 1992, Rifting and the volcanic-tectonic evolution of the Izu-Bonin-Mariana Arc: Proceedings of the Ocean Drilling Program, Scientific Results, v. 126, p. 627-651.

Taylor, R.N., and Nesbitt, R.W., 1998, Isotopic characteristics of subduction fluids in an intra-oceanic setting, Izu-Bonin Arc, Japan: Earth and Planetary Science Letters, v. 164, no. 1-2, p. 79-98.

Taylor, R.N., Nesbitt, R.W., Vidal, P., Harmon, R.S., Auvray, B., and Croudace, I.W., 1994, Mineralogy, chemistry, and genesis of the boninite series volcanics, Chichijima, Bonin Islands, Japan: Journal of Petrology, v. 35, no. 3, p. 577-617.

Woodhead, J.D., 1989, Geochemistry of the Mariana Arc (western Pacific); source composition and processes: Chemical Geology, v. 76, no. 1-2, p. 1-24. 
Xu, Y., Wise, S.W.,Jr, Fryer, P., et al., 1992, Middle Eocene to Miocene calcareous nannofossils of Leg 125 from the western Pacific Ocean: Proceedings of the Ocean Drilling Program, Scientific Results, v. 125, p. 43-70.

Yamazaki, T., and Stern, R.J., 1997, Topography and magnetic vector anomalies in the Mariana Trough: JAMSTEC Journal of Deep Sea Research, v. 13.

Yan, L., He, Z., Beier, C., and Klemd, R., 2018, Geochemical constraints on the link between volcanism and plutonism at the Yunshan caldera complex, SE China: Contributions to Mineralogy and Petrology, v. 173, no. 1, p. Article 4.

Yan, L., He, Z., Jahn, B., and Zhao, Z., 2016, Formation of the Yandangshan volcanicplutonic complex (SE China) by melt extraction and crystal accumulation: Lithos (Oslo), v. 266-267, p. 287-308. 
3 EARLY MAGMATIC HISTORY OF THE IBM ARC INFERRED FROM VOLCANIC MINERALS AND MELT INCLUSIONS FROM EARLY- LATE OLIGOCENE DSDP SITE 296: A MINERAL-MELT PARTITION APPROACH Eshita Samajpati, Rosemary Hickey-Vargas (Contributions to Mineralogy and Petrology- Pending Submission)

\begin{abstract}
Detrital volcanic minerals from DSDP Site 296 on the Kyushu-Palau Ridge (KPR) present a unique opportunity to understand the early evolution of the Izu-Bonin Mariana (IBM) arc. In this research, we present major and trace element compositions of detrital amphiboles and pyroxenes with their melt inclusions and feldspar compositions. Mafic minerals are particularly important in this study, because we use their composition to predict the crystallization temperature and pressure in the most primitive magmas. We also use previous experimental partition coefficient and calculated coefficient from melt inclusion and its host clinopyroxene to get equilibrium melt compositions. Major findings include that most primitive magma which crystallized amphibole, had a basalt melt composition with crystallization temperatures of $1016{ }^{\circ} \mathrm{C}$. Melt composition from amphibole show slight to highly enriched characteristics $\left(\mathrm{La} / \mathrm{Sm}_{\mathrm{N}} 1-8\right)$, with some mafic amphibole showing high $\mathrm{Nb} / \mathrm{Yb}$ and $\mathrm{Th} / \mathrm{Yb}$ ratios (9 and 21) indicating mantle fertility and high subduction component. The amphibole in the core are present in close conjunction with some unusually high Mg\# clinopyroxenes (88-92), which have overall low REEs concentration; the calculated melt in equilibrium also show low trace element concentration and low $\mathrm{Nb} / \mathrm{Yb}(0.04-0.3)$ and low to moderate $\mathrm{Th} / \mathrm{Yb}(0-4.6)$ ratios which imply that some major mantle re-organization might have taken place during this period.
\end{abstract}




\subsection{Introduction}

The Izu-Bonin Mariana arc (Fig. 3-1a) in the Western Pacific is perhaps one of the best places to study and understand early arc evolution. Periodic rifting of the arc has formed inactive rifted arcs providing a window to early history. The tectonic history and active processes of IBM have been studied over the last few decades and are well understood. In short, IBM (Fig. 1a) started with lithospheric subsidence along a transform fault which separated the old Jurassic Pacific plate from a much younger Philippine plate around 50 Ma years ago; during this period, forearc was the region of magmatism with the eruption of forearc basalt, boninites, and low K tholeiites (Stern et al., 1991; Taylor et al., 1994; Reagan et al., 2010; Ishizuka et al., 2011a; Arculus et al., 2015a, 2015b). After 5 Ma, the magmatic arc was established and was active until $30 \mathrm{Ma}$ with eruption of typical arc magma (Stern 2003). Arc volcanism was disrupted by rifting and opening of the Parece vela in the South and Shikoku basin in the North, completely separating the Kyushu Palau Ridge from IBM Arc (Taylor et al., 1992; Kobayashi et al., 1995). After a period of back arc basin formation, arc volcanism again resumed around $17 \mathrm{Ma}$ and continued until $7 \mathrm{Ma}$, when another period of back arc basin formation in the south formed the Mariana Ridge (Yamazaki and Stern, 1997). 


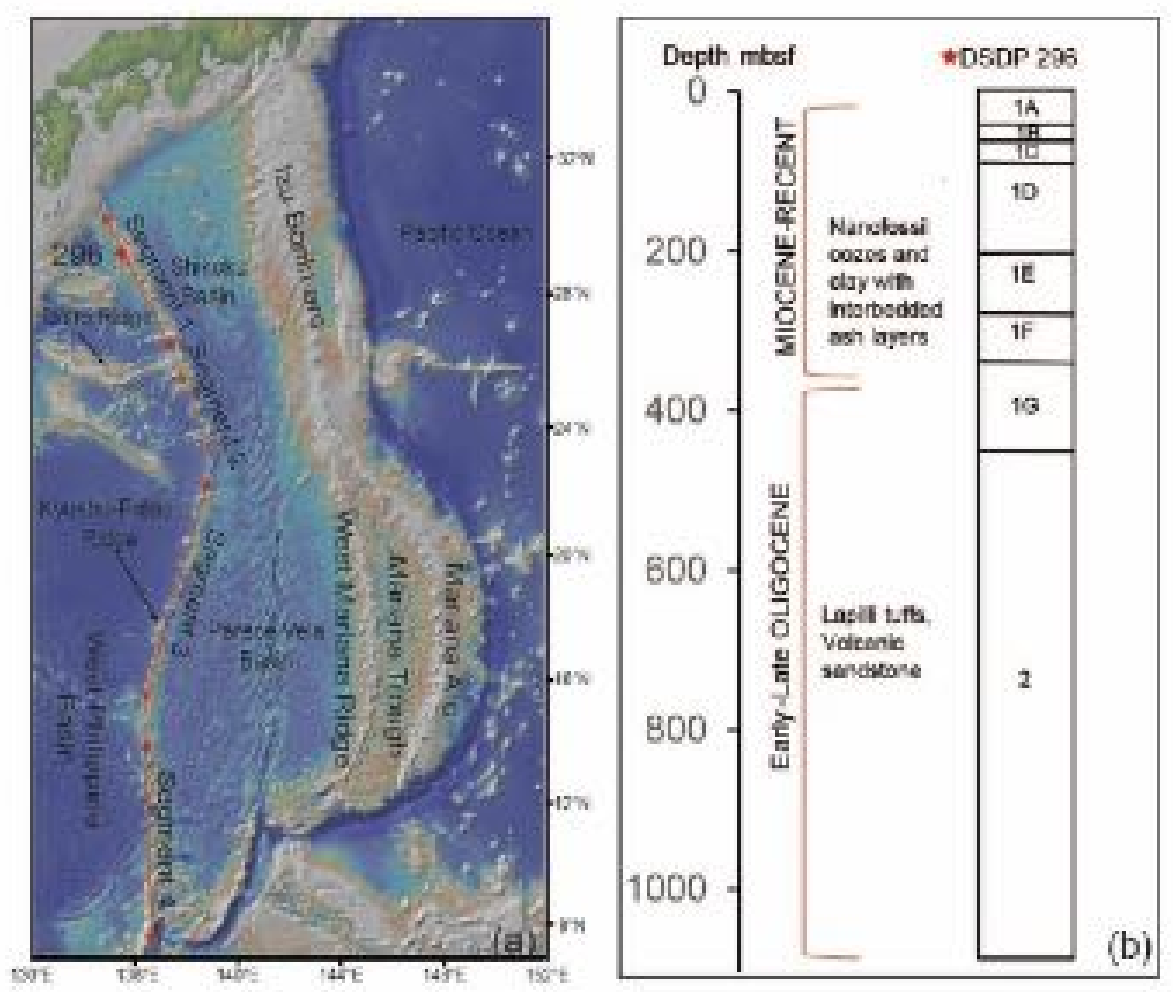

Figure 3-1 (a) Map of the present day Izu-Bonin Mariana arc and features of the Philippine Sea plate. The Kyushu Palau ridge has been divided into 4 segments as per Ishizuka et al. (2011b). Red star shows the location of DSDP Site 296. (b) Litho-stratigraphic sequence as defined by the Shipboard Party, DSDP Leg 31 (Ingle et al, 1975).

Compared to the active processes, early arc evolution is still studied, leading to a shift in the focus of study in the IBM to the back-arc regions like the Kyushu Palau Ridge (KPR). Earlier and previous studies come mainly in the form of dredged volcanic and plutonic rocks, glass, minerals, and melt inclusion studies from several drilled sites at the back arc and forearc regions. (Ishizuka et al., 2011; Brandl et al. 2017; Haraguchi et al. 2003, 2012; D’Antonio et al. 2006; Lee et al. 1995; Arculus et al., 2015). These studies have interpreted and revealed significant findings of the early arc chemistry, but more is required for a cohesive and complete understanding. Since the uncommon recovery of fresh lava hampers this knowledge, it is critical to utilize every possible method to detrital volcanic materials 
to get a significant finding. Detrital minerals especially early mafic ones like pyroxenes and amphibole, can be used to understand the nature of the magma. Recent and earlier studies have shown that these minerals can tell us about the temperature, and pressure of crystallization (Nimis and Ulmer 1995, Nimis 1999; Putirka 2003,2016; Putirka et al., 2008). Besides, the experimental partition coefficients between mineral-melt can also be used to predict the composition of the melt it crystallized from (Sisson and Grove, 1993; Nandedkar et al., 2016; Humphreys et al., 2019). In this study, we use major and trace elemental chemistry of pyroxene, amphibole, feldspar and melt inclusion within the pyroxene from DSDP Site 296, located in the northern KPR to model the possible composition of the melt in equilibrium and its pressure and temperature to understand a part of the early arc.

\subsection{Method}

\subsubsection{Core Samples}

Deep Sea Drilling Project Site 296 located in the northernmost Palau-Kyushu Ridge consists of two distinct lithological units, 1 and 2 (Fig 3-1b). Unit 1 comprises 453 meters of nannofossil chalks and oozes and is further divided into seven subunits. The biostratigraphic age of the unit is between Late Oligocene to Pleistocene. The base of unit 1 coincides with the rifting of the arc and opening of the Shikoku basin (Ingle et al., 1975). Unit 2 is 634 meters of Early to Late Oligocene interbedded lapilli tuffs and volcanic sandstone. The lapilli tuffs and sandstones of unit 2 consist of lithic fragments, glass shards, and volcanic minerals like plagioclase, pyroxenes, and titano-magnetite with a sparse amount of amphibole in a clayey or silty matrix. Plagioclase, pyroxene, and titano- 
magnetite are present throughout the core and in all the core samples studied, whereas amphiboles are only present at some intervals. The feldspar grains picked were usually clear and white without any signs of alteration; the pyroxenes were either black, green or brown-orange and were usually fresher than feldspars. Both orthopyroxene and clinopyroxenes were present. Clinopyroxenes were typically in shades of green or black, whereas orthopyroxenes were orange and brown. Both had inclusions of oxide, feldspar, and melt composition. Amphiboles were present as black grains slightly opaque than the pyroxene grains under a binocular microscope. The amphiboles had inclusions of feldspar, oxide, and apatite; melt inclusions were mostly absent.

\subsubsection{Analytical Technique}

Twenty-two core samples selected for their coarse grain size and fresh appearing detrital grains were disaggregated in deionized water; twenty were from Unit 2 and two from the base of unit $1 \mathrm{G}$. The resulting sediment was sieved, rinsed, and handpicked at 500 microns to 1-millimeter grain size. Minerals were first identified under a binocular microscope and later using SEM-EDS. The grains were then mounted in epoxy, polished, and carbon-coated for microprobe analysis. Melt inclusions inside the pyroxenes were first identified under backscattered electron imaging and then analyzed for major oxides. Melt inclusions (MIs), which were round and intact and did not show post entrapment crystallization, were analyzed. Large MIs were rare; the size of the melt inclusions analyzed was typically 30-60 microns. Major oxides of the minerals and melt inclusions were analyzed using JEOL 8900 Superprobe EPMA at Florida Center for Analytical Electron Microscopy at FIU. Standards were analyzed before and after each sample to 
check the quality of the analysis. The analysis was done using a 1-micron beam for minerals, 2.5 microns for MIs, at $20 \mathrm{nA}$ current, and $15 \mathrm{kV}$ with two spots analyzed per grain. For $\mathrm{Na}$ and $\mathrm{K}$, the beam was diffused during analysis to minimize volatilization. For feldspars and pyroxenes, the grains with a total in the range of $99-101 \%$ were considered; for melt inclusions, the totals were as low as $90 \%$ for some felsic ones. The amphiboles analyzed had totals between $94-98 \%$.

Trace elements, including the rare earth elements in the amphiboles, pyroxenes and melt inclusions, were analyzed by Laser Ablation ICPMS using the Elan 6100 ICP-MS at the Trace Evidence Analysis Facility at FIU, using a New Wave 213 nm laser. NIST 612 was used as a calibrator and BHVO-2 as the external standard. Spot size for minerals was 80 microns, and for melt inclusions, it was $40-55$ microns, with a $10 \mathrm{~Hz}$ rep rate and $100 \%$ output for both. The size of the inclusion didn't allow for more than one spot, and anything smaller than 40 microns was not analyzed. The data was then processed using the software Glitter, with $\mathrm{Ca}$ as the internal standard.

Smear slides were prepared for all the samples to compare mineral abundances in the coarse and fine sediments. The size of the grains used for making smear slides was in between 75-100 micron. Accuracy and precision for standard data using EPMA and LAICP-MS are listed in Table 1. The data for all the analysis is listed in the appendices. 
Table 3-1 Data quality of the standards used, major oxide data from EPMA and trace element from LA-ICP-MS

\begin{tabular}{|ccccc|}
\hline \multicolumn{5}{c|}{ Standard Kaersutite } \\
& Mean(25) & \%RSD & Rec Val & \%bias \\
$\mathrm{SiO}_{2}$ & 39.71 & 1.47 & 40.09 & -0.96 \\
$\mathrm{TiO}_{2}$ & 4.93 & 6.51 & 5.04 & -2.09 \\
$\mathrm{Al}_{2} \mathrm{O}_{3}$ & 12.29 & 1.76 & 12.36 & -0.58 \\
$\mathrm{Na}_{2} \mathrm{O}$ & 2.46 & 5.74 & 2.44 & 0.63 \\
$\mathrm{MnO}$ & 0.08 & 25.45 & 0.18 & -56.79 \\
$\mathrm{MgO}$ & 12.20 & 2.57 & 12.55 & -2.79 \\
$\mathrm{Cr}_{2} \mathrm{O}_{3}$ & 0.03 & & & \\
$\mathrm{~K}_{2} \mathrm{O}$ & 0.96 & 8.56 & 1.17 & -18.27 \\
$\mathrm{CaO}$ & 11.29 & 1.26 & 11.56 & -2.31 \\
$\mathrm{FeO}$ & 12.31 & 4.40 & 12.24 & 0.57 \\
\hline
\end{tabular}

\begin{tabular}{|c|c|c|c|c|}
\hline & \multicolumn{4}{|c|}{ Standard Enstatite } \\
\hline & Mean(25) & $\%$ RSD & Rec value & \%bias \\
\hline $\mathrm{SiO}_{2}$ & 54.96 & 1.94 & 54.31 & 1.20 \\
\hline $\mathrm{TiO}_{2}$ & 0.10 & 36.70 & 0.17 & -40.77 \\
\hline $\mathrm{Al}_{2} \mathrm{O}_{3}$ & 4.34 & 3.39 & 4.34 & 0.10 \\
\hline $\mathrm{Na}_{2} \mathrm{O}$ & 0.07 & 19.60 & 0.08 & -14.55 \\
\hline MnO & 0.08 & 17.97 & 0.16 & -49.26 \\
\hline $\mathrm{MgO}$ & 32.23 & 3.49 & 33.32 & -3.28 \\
\hline $\mathrm{Cr}_{2} \mathrm{O}_{3}$ & 0.28 & 18.72 & 0.30 & -5.07 \\
\hline $\mathrm{CaO}$ & 0.77 & 4.86 & 0.84 & -8.15 \\
\hline $\mathrm{FeO}$ & 6.91 & 3.32 & 6.35 & 8.83 \\
\hline
\end{tabular}

\begin{tabular}{|ccccc|}
\hline & \multicolumn{4}{c|}{ Standard BHVO-2 } \\
$\mathrm{SiO}_{2}$ & 50.32 & 1.79 & 49.60 & \%bias \\
$\mathrm{TiO}_{2}$ & 2.59 & 3.62 & 2.73 & -5.08 \\
$\mathrm{Al}_{2} \mathrm{O}_{3}$ & 13.61 & 1.73 & 13.44 & 1.25 \\
$\mathrm{Na}_{2} \mathrm{O}$ & 1.89 & 3.06 & 2.22 & -15.01 \\
$\mathrm{MnO}$ & 0.17 & 27.47 & 0.17 & 1.72 \\
$\mathrm{MgO}$ & 7.57 & 3.09 & 7.26 & 4.36 \\
$\mathrm{~K}_{2} \mathrm{O}$ & 0.50 & 1.45 & 0.51 & -2.93 \\
$\mathrm{P}_{2} \mathrm{O}_{5}$ & 0.27 & 9.39 & 0.27 & 0.87 \\
$\mathrm{CaO}$ & 11.45 & 1.12 & 11.40 & 0.45 \\
$\mathrm{FeO}$ & 10.71 & 2.20 & 11.07 & -3.27 \\
& & & & \\
\hline
\end{tabular}

\begin{tabular}{|crcrc|}
\hline & \multicolumn{4}{c|}{ Standard Plagioclase } \\
$\mathrm{SiO}_{2}$ & 54.31 & 1.06 & 54.21 & 0.18 \\
$\mathrm{Al}_{2} \mathrm{O}_{3}$ & 28.65 & 1.48 & 28.53 & 0.43 \\
$\mathrm{Na}_{2} \mathrm{O}$ & 4.09 & 3.80 & 4.35 & -6.06 \\
$\mathrm{MgO}$ & 0.03 & 149.40 & 0.13 & -80.00 \\
$\mathrm{~K}_{2} \mathrm{O}$ & 0.34 & 7.46 & 0.41 & -17.35 \\
$\mathrm{CaO}$ & 11.81 & 2.90 & 11.80 & 0.07 \\
$\mathrm{FeO}$ & 0.40 & 13.46 & 0.37 & 7.02 \\
\hline
\end{tabular}


Table 3-1 continued

\begin{tabular}{|c|c|c|c|c|}
\hline \multirow[b]{2}{*}{ Element } & \multicolumn{4}{|c|}{ Standard BHVO-2 } \\
\hline & Mean of 20 & $\%$ RSD & Rec Value & \%bias \\
\hline $\mathrm{Rb} 85$ & 7.56 & 6.30 & 9.26 & -18.4 \\
\hline Sr88 & 380.51 & 3.17 & 394.10 & -3.4 \\
\hline Y89 & 25.10 & 5.78 & 25.91 & -3.1 \\
\hline $\mathrm{Zr} 90$ & 147.79 & 5.67 & 171.20 & -13.7 \\
\hline $\mathrm{Nb} 93$ & 17.50 & 4.74 & 18.10 & -3.3 \\
\hline Cs133 & 0.08 & 48.00 & 0.10 & -23.5 \\
\hline $\mathrm{Ba} 137$ & 111.98 & 4.85 & 130.90 & -14.5 \\
\hline La139 & 15.85 & 7.94 & 15.20 & 4.3 \\
\hline $\mathrm{Ce} 140$ & 37.46 & 5.72 & 37.53 & -0.2 \\
\hline $\operatorname{Pr} 141$ & 5.10 & 6.28 & 5.34 & -4.5 \\
\hline Nd146 & 24.99 & 3.95 & 24.27 & 3.0 \\
\hline Sm147 & 6.13 & 7.25 & 6.02 & 1.7 \\
\hline Eu153 & 1.97 & 5.69 & 2.04 & -3.6 \\
\hline Tb159 & 0.91 & 11.21 & 0.94 & -3.2 \\
\hline Gd160 & 6.35 & 5.85 & 6.21 & 2.4 \\
\hline Dy163 & 5.43 & 8.78 & 5.28 & 2.8 \\
\hline Hol65 & 1.00 & 8.37 & 0.99 & 1.1 \\
\hline Er166 & 2.57 & 8.37 & 2.51 & 2.4 \\
\hline Yb1 72 & 2.04 & 22.20 & 1.99 & 2.2 \\
\hline Lu175 & 0.31 & 15.53 & 0.28 & 11.7 \\
\hline Hf1 78 & 4.49 & 10.33 & 4.47 & 0.5 \\
\hline Ta1 81 & 1.23 & 7.67 & 1.15 & 6.8 \\
\hline $\mathrm{Pb} 208$ & 1.21 & 16.88 & 1.65 & -27.0 \\
\hline Th232 & 1.25 & 7.77 & 1.22 & 1.7 \\
\hline U238 & 0.39 & 11.30 & 0.41 & -4.8 \\
\hline
\end{tabular}

\subsection{Results}

\subsubsection{Feldspars}

Feldspars had occasional melt inclusions and mineral inclusions of titanomagnetite, pyroxene, and apatite. Compositionally, all the feldspars analyzed were plagioclase with a bimodal distribution around $A_{45-60}$ and $A_{85-95}$, although intermediate varieties were also observed. Among the plagioclase analyzed, Andesine (38\%) is the most 
common type followed by Bytownite (23\%), Labradorite (21\%), and Anorthite (18\%) (Fig $3-2$ ). The $\mathrm{K}_{2} \mathrm{O}$ content of the plagioclases is $<0.6 \%$, which may be a result of preferential weathering of high $\mathrm{K}$ plagioclase in volcanic rocks (Maynard, 1984). $\mathrm{MgO}$ and $\mathrm{FeO}$ contents are less than $0.1 \%$ and $1 \%$ respectively, although few Bytownites have slightly higher $\mathrm{MgO}(0.2-0.8 \%)$ and $\mathrm{FeO}(2.3-4.7 \%)$ contents. The bimodal variation is observed throughout the core, but anorthite-rich plagioclase becomes more dominant towards the top of Unit 2 (Fig 3-2). The presence of $>\mathrm{An}_{90}$ is commonly attributed to high $\mathrm{H}_{2} \mathrm{O}$ content of arc magma as high-water content suppresses $\mathrm{Si}-\mathrm{O}-\mathrm{Si}-\mathrm{O}$ polymerization and favors crystallization of anorthite over albite (Sisson and Grove, 1993).

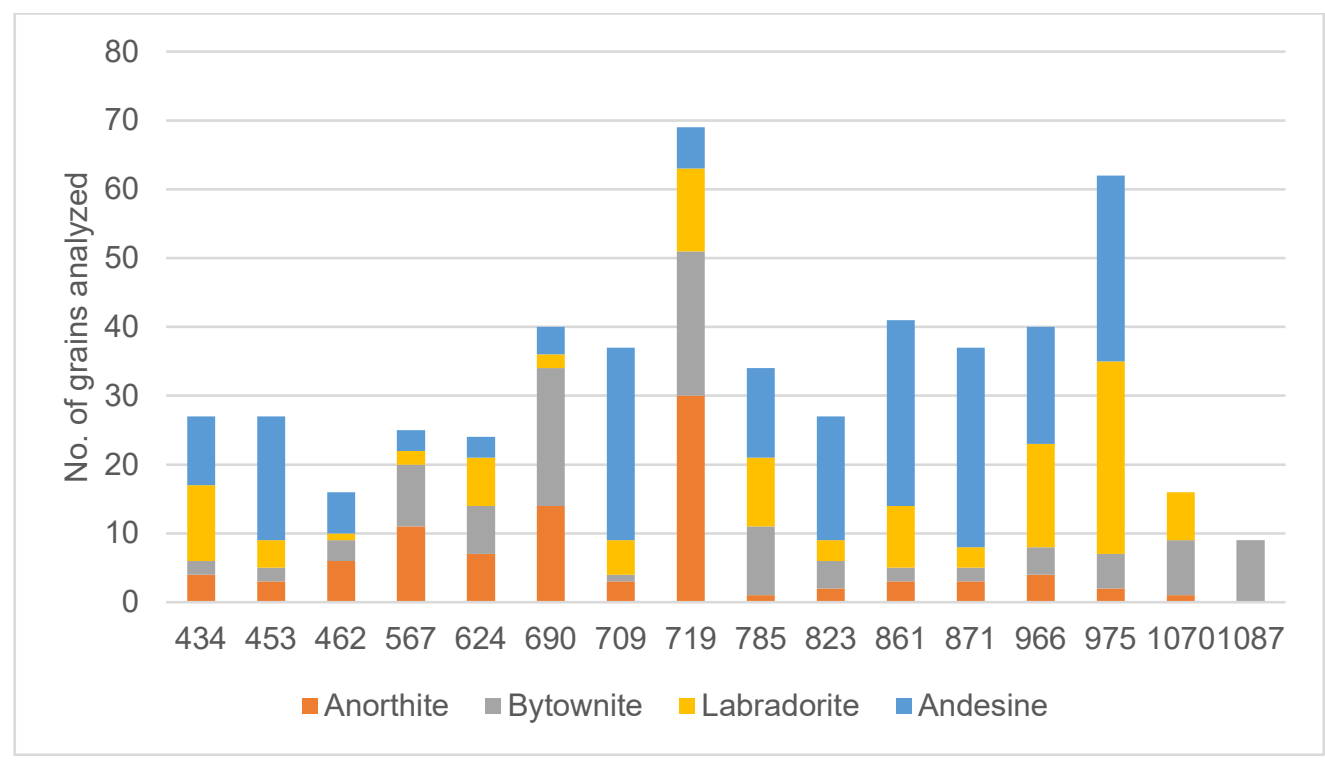

Figure 3-2 Depth vs. cumulative frequency of compositional range of plagioclase at different depths

\subsubsection{Pyroxenes}

Both clinopyroxenes (cpxs) and orthopyroxenes (opxs) are present in Unit 2, however, the presence of orthopyroxene is low and is found in a few samples only. Compositionally, opxs are Bronzite-Hypersthene with a composition of $\mathrm{En}_{54-73} \mathrm{Wo}_{2-4}$ (Fig. 3-3a); no magnesian enstatites, usually associated with boninites were seen. $\mathrm{Mg}$ numbers 
(Mg\#) of the opx are between 56 and 77. Cpxs falls mainly in the diopside and augite field (Fig. 3-3a), with compositions of Wo36-48En $36-50$ and Mg\#ranging from 61-92.

The composition of the cpxs was also used to distinguish the magmatic affinities of the cpxs (Fig. 3-3 b-d) using the discrimination diagram of Leterrier et al. (1982). The result shows that these cpxs are mostly from subalkaline magma, showing both calcalkaline and tholeiitic affinities, and few are MORB-like. Stratigraphically, calc-alkaline cpxs are more dominant at the bottom cores whereas tholeitic ones are more common at the top. The few MORB like cpxs also occurs at the top of the section.
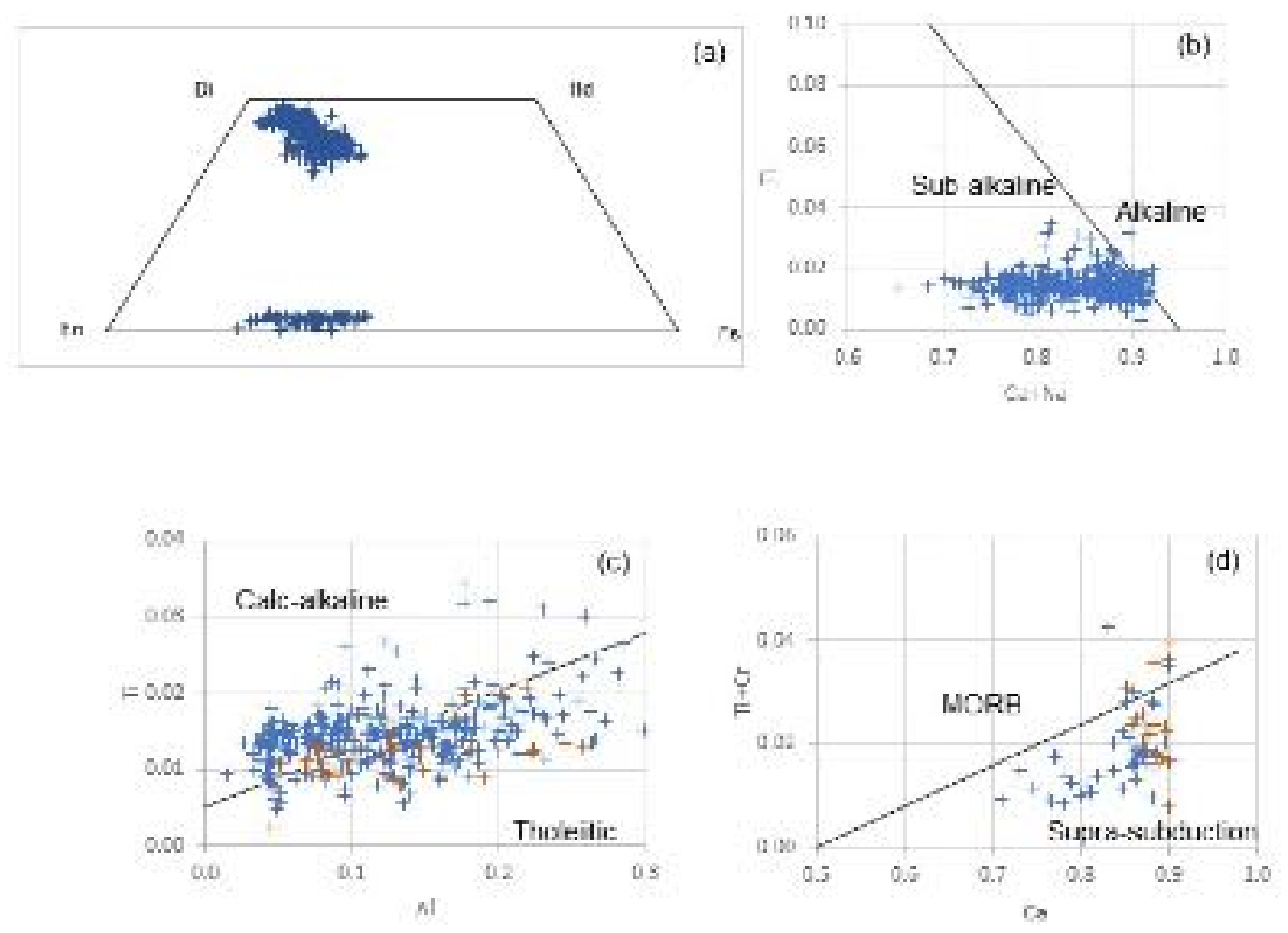

Figure 3-3 (a) Ternary plot showing the composition of pyroxenes at Site 296 (b-d) Tectonic discrimination diagram based on clinopyroxene composition from Leterrier et al. (1982). Elements are expressed in cationic value from the structural formula of clinopyroxenes. Orange ones in c and d are the unusually high Mg\# clinopyroxenes 
Normalized trace element patterns of all cpxs show $\mathrm{Nb}$ depletion, characteristic of island arc magma, light rare earth element (LREE) depletion compared to middle rare earth element (MREE) and heavy rare earth element (HREE), and Zr, Hf, and Th depletion compared to LREE (Fig 3-4). As seen from the plot, higher concentrations of incompatible trace elements are seen for low Mg\# grains and vice versa. Most high Mg\# cpxs have very low concentrations of LREE and other trace elements, sometimes close to the detection limit.

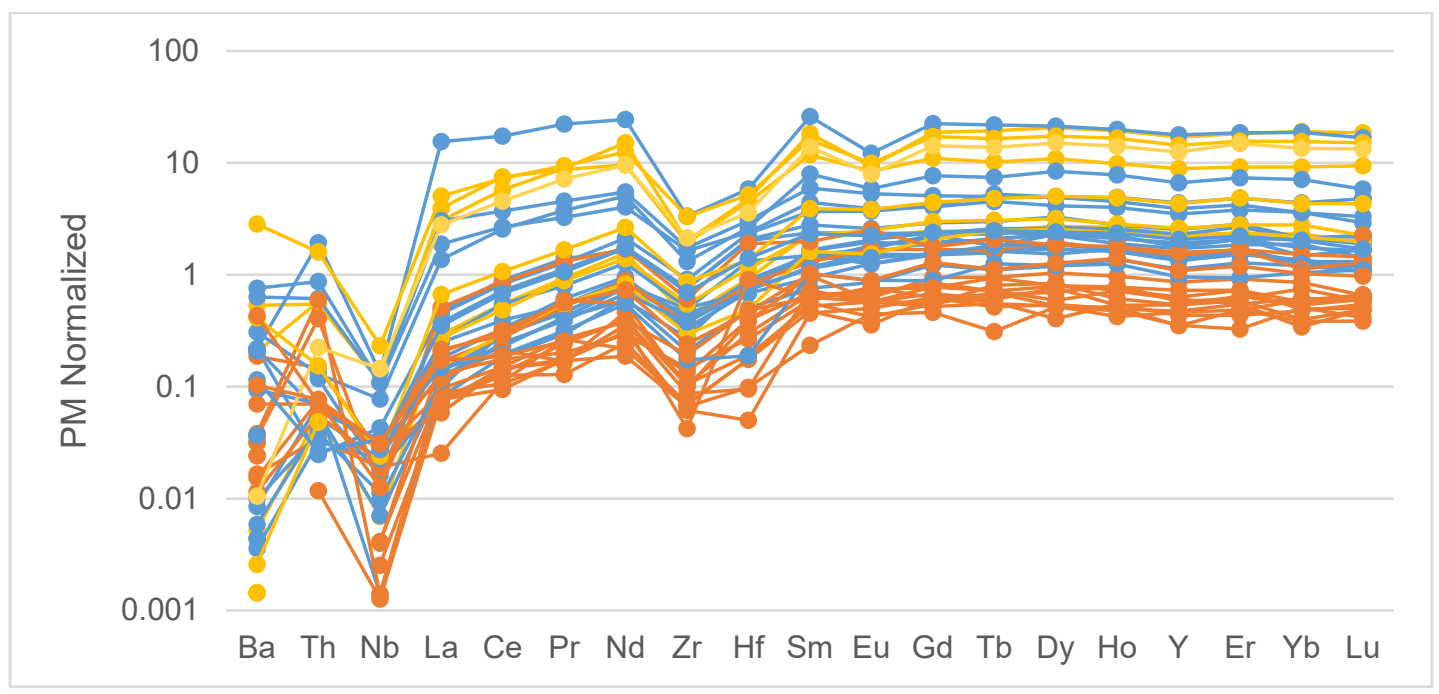

Figure 3-4 Primitive mantle normalized multi-elemental composition of some mafic clinopyroxenes. Normalizing values after Sun and McDonough (1989). Clinopyroxene with Mg\# > 85 is shown in orange; Mg\# 80-85 is shown in blue and $\mathrm{Mg} \#$ less than 80 is shown in yellow.

\subsubsection{Amphibole}

The amphiboles are not a common detrital mineral, but they are present in the upper part of Unit 2 from cores 49 to 57 (depth 453-719 m). Smear slides of the samples (75-100 microns) at deeper depth do not show any amphiboles. Smear slide of a sample from the upper part of core 60 had an amphibole but was absent in the larger grain fraction. Compositionally all the amphiboles are calcic amphibole (Fig 3-5a). Based on the chemical content, they can further be divided into magnesiohornblende, edenite, and 
magnesiohastingsites (Leake et al., 1997). The Mg\# of the amphiboles range from 57 to 73. The normalized trace element concentrations show a depletion of $\mathrm{Th}$ and $\mathrm{Nb}$ compared to LREEs and depletion of $\mathrm{Zr}$ and $\mathrm{Hf}$ compared to REEs (Fig. 3-5b). From the trace element concentration, there are two distinct groups of amphiboles, with some intermediates. One group is slightly depleted in LREE and HREE compared to MREE and shows enrichment of Ti and no Eu depletion. The other group is enriched in LREE compared to MREE, depleted in Eu and Ti, and has flat MREE and HREE.

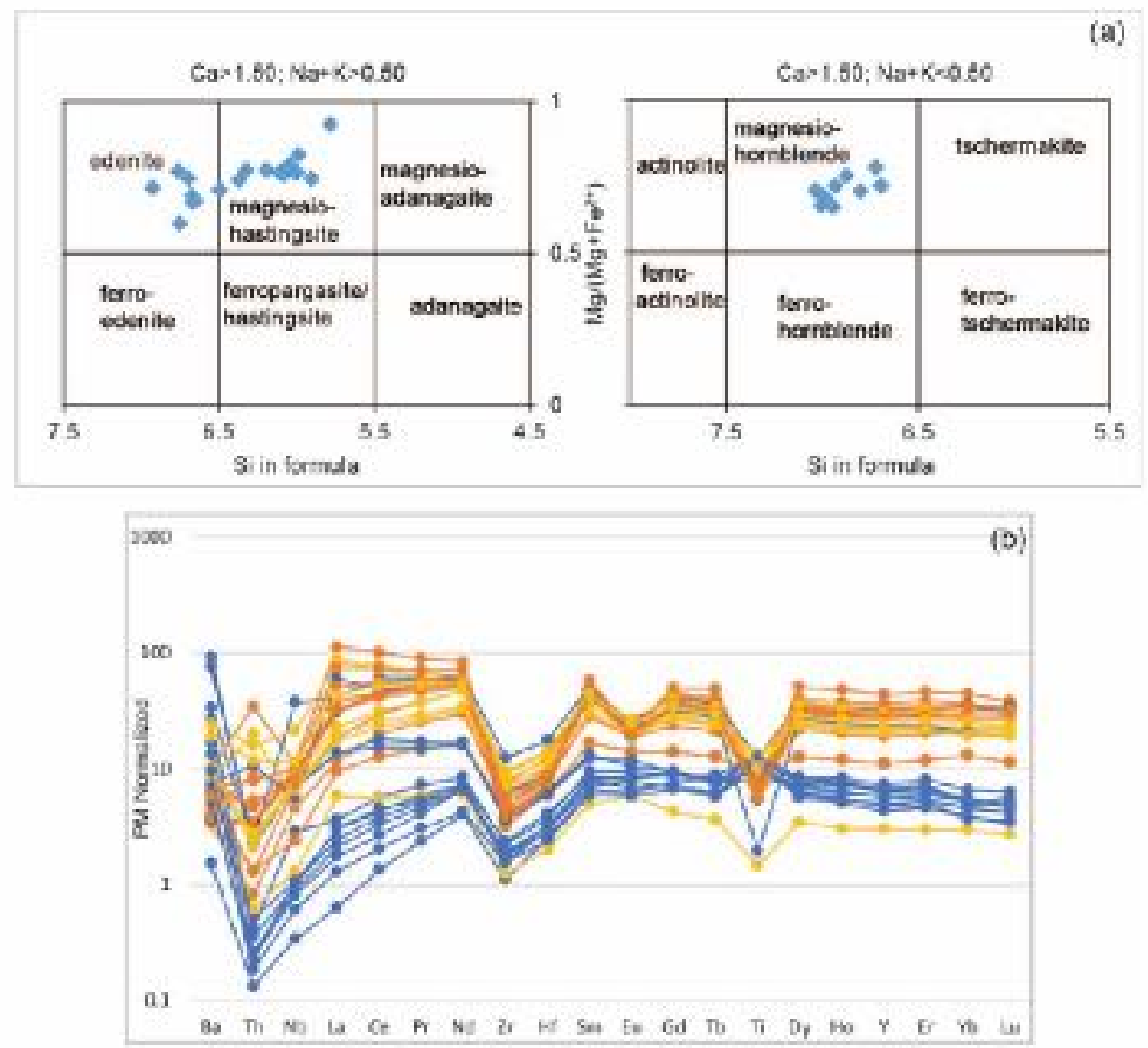

Figure 3-5 (a)Site 296 amphibole compositions plotted using cationic values based on 23 Oxygens after Leake et al. (1997). (b) Primitive mantle normalized trace element abundances in amphiboles; blue are magnesiohastingsites, yellow are edenites and the orange ones are magnesiohornblendes. 


\subsubsection{Melt Inclusions}

Melt inclusions within pyroxene are typically between 10-60-micron size ranges and are found in both orthopyroxenes and clinopyroxenes; only the largest ones were analyzed. Some pyroxene grains had more than one melt inclusion; when analyzed, they had similar major oxide compositions. $\mathrm{SiO} 2$ contents range from 47 to $73 \%$, while the $\mathrm{Mg \# s}$ of most basaltic MIs range from 39 to 53. The totals for some of the felsic MIs are as low as $90 \%$. All the MIs plot within the medium $\mathrm{K}$ series on a plot vs $\mathrm{SiO} 2$, similar to detrital glass shards from Unit 2 (Fig. 3-6a). There is disequilibrium between almost all MIs and host cpxs, as the $\mathrm{Kd}^{\mathrm{Fe}-\mathrm{Mg}}$ (Putirka et al., 2008) for the pairs are below the equilibrium line (Fig. 3-6b). Normalized trace element patterns show island arc features like $\mathrm{Nb}$ and $\mathrm{Ta}$ depletion compared with LREE and depleted to highly enriched LREE/MREE ( $\mathrm{La} / \mathrm{Sm}_{\mathrm{N}} 0.33$ to 4.03) (Fig. 3-6c). 

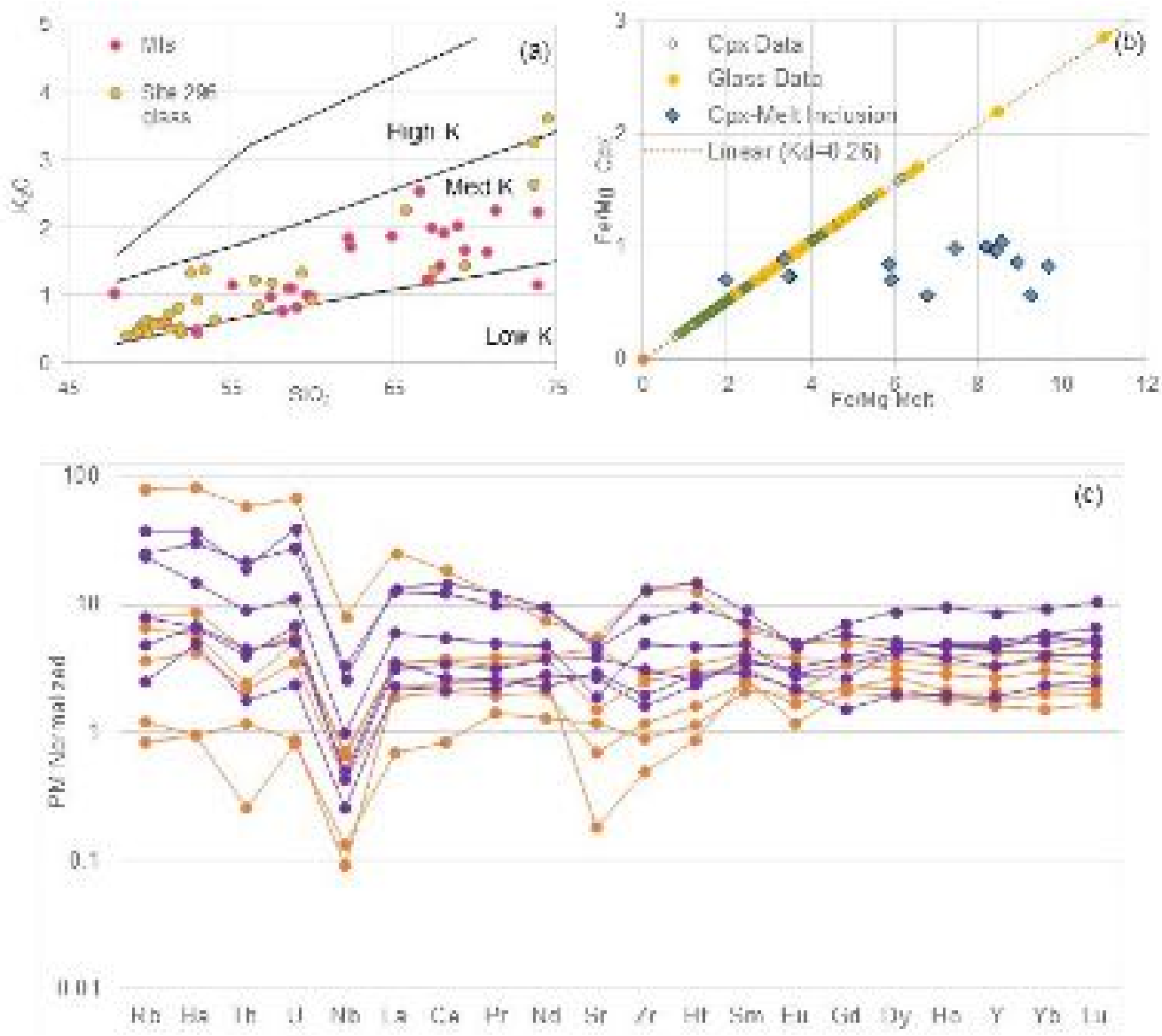

Figure 3-6 (a) $\mathrm{K}_{2} \mathrm{O}$ vs $\mathrm{SiO}_{2}$ showing Site 296 melt inclusions in clinopyroxene compared with detrital glass shards from Site 296. (b) Cationic Fe/Mg ratios for melt inclusions and host clinopyroxenes. Kd line for cpxs/melt is 0.27 after Putirka et al. (2008). Clinopyroxene Fe/Mg calculated from Site 296 glass shards and melt Fe/Mg calculated from Site 296 clinopyroxenes are plotted on the equilibrium line. The melt inclusion which plots on the equilibrium line is of a basaltic composition. (c) Primitive mantle normalized trace element compositions of melt inclusions from clinopyroxenes (orange) and orthopyroxenes (purple).

\subsection{Discussion}

\subsubsection{New Findings from Mafic Minerals at Site 296}

DSDP Site 296 presents a unique opportunity to study the evolution of Oligocene magma in the northernmost section of the KPR (segment 1 from Ishizuka et al. (2011b)).

Prior studies on the KPR in this region were made on dredged and piston core samples of plutonic and volcanic rocks (Haraguchi et al., 2012; Ishizuka et al., 2011b; Haraguchi et 
al., 2003). Other studies are from volcaniclastic sediments in the adjacent Amami-Sankaku basin drilled at IODP Site 1438 (Brandl et al., 2017; Arculus et al., 2015) and in the IBM forearc where Oligocene ashes and tephra were drilled at ODP Site 782 (Straub 2008, 2003; Bryant et al. 2003). Studying only uppermost volcanic and dredged rocks does not provide a complete timeline of arc magma evolution, whereas debris shed into a rear arc basin may not sample magma erupted during the rifting stages of the Oligocene arc. Because it is situated in a basin near the crest of the KPR, Site 296 records a continuous record of the magmatic evolution of the early-late Oligocene IBM arc, up until arc rifting and opening of the Shikoku basin.

When it comes to determining melt compositions, fresh glass shards like those found in Unit 2 at Site 296 provide the best magmatic record (Lee et al.,1995; Samajpati and Hickey-Vargas, 2020), but fresh and undevitrified glass in older volcaniclastic sediments is uncommon. Compared to glass, fresher mafic minerals like pyroxene and amphiboles which are more resistant to weathering, are readily available. Pyroxenes at Site 296 are the dominant mafic silicate grains and are present throughout the stratigraphic section. With more and improved experimental studies on mafic minerals in terms of mineral-melt partitioning and their temperature and pressure dependence, the cpxs can provide an extensive record of the magmatic history. For example, in Fig. 3-6b, the Mg\# of liquids inferred from the composition of Site $296 \mathrm{cpxs}$ is compared with the Mg\# of glass shards found in Unit 2. It is observed that the glasses do not record the more primitive melts inferred from the cpxs. Another observation is that cpxs apparently did not crystallize in extreme silicic melts represented by the glass shards. Amphiboles in early IBM magmas were associated with felsic melt composition (Straub 2008), and there is limited evidence 
of their crystallization in the Site 296 glass shards and lithic clasts found in Unit 2. In contrast, pristine amphibole crystals are found as detrital grains and suggest otherwise. In following sections, we utilize experimental tools to understand the origins of the minerals, which together with glass shard compositions, can redefine or add to our knowledge on the evolution of the early arc.

\subsubsection{Clinopyroxenes}

\section{Mg numbers of Cpxs and coexisting melts}

The partition coefficient $\left(\mathrm{K}_{\mathrm{d}}\right)$ of an element, defined as the ratio of its concentration in the mineral to its concentration in the melt, is a measure of the preference of that element in a given phase and can be used to model magmatic processes (O’Hara 1995; Shaw 2000). Studies defining the values of partition coefficients between mineral and melts under varying conditions can be used to understand the melt characteristics at Site 296. Using partition coefficient between $\mathrm{Fe}-\mathrm{Mg}$ in melt and pyroxene $\left(\mathrm{Kd}^{\mathrm{Cpxs}-\mathrm{liq}}=0.27\right)$ preferred by Putirka et al. (2008), the most primitive cpxs with Mg numbers of 88-92 were calculated to coexist in equilibrium with a melt of Mg numbers ranging between 67-73, which is higher than what is observed in the Oligocene IBM melts represented by either glass, ash or lava. Cpxs with Mg\# between 87- 61 is in equilibrium with a melt of Mg\# 65-30, which represents a suite of mafic to felsic arc lavas; some of the most primitive KPR basalt lavas reported by Haraguchi et al. (2012) and Ishizuka et al. (2011b) had Mg\# 65-63.

An interesting trend can be seen in the plot of $\mathrm{Al}_{2} \mathrm{O}_{3}$ vs. the $\mathrm{Mg \#}$ of the Cpxs (Fig 3-7). Overall, $\mathrm{Al}_{2} \mathrm{O}_{3}$ contents increase to a maximum of about $7 \mathrm{wt} \%$ at around $\mathrm{Mg} \# 80$ and then decrease at higher Mg\#s. That the alumina content of the most magnesian Cpxs 
increases as $\mathrm{Mg} \#$ decreases from 92 to 86 suggests that the magnesian Cpxs crystallized without accompanying plagioclase, consistent with the suppression of plagioclase crystallization at high pressure and water contents (Kay \& Kay, 1985; DeBari et al.,1987; DeBari \& Coleman,1989; Muntener et al., 2001). The broadly decreasing trend in the alumina content with further decreasing $\mathrm{Mg \#}$ may indicate the onset of plagioclase crystallization together with Cpxs during differentiation to form silicic magmas. The $\mathrm{Al}$ content in Cpxs also increases as a function of pressure (Nimis and Ulmer, 1999) such that low alumina contents of Cpxs may be related to lower pressures of crystallization. Using this reasoning, the highest Mg\# cpxs with low alumina could have crystallized in a shallow setting, whereas wide variation in $\mathrm{Al}$ contents at $\mathrm{Mg} \# 80$, could be a result of the generation of magma at different depths and or variable alumina contents of the magma it crystallized as the result of co-precipitation of plagioclase.

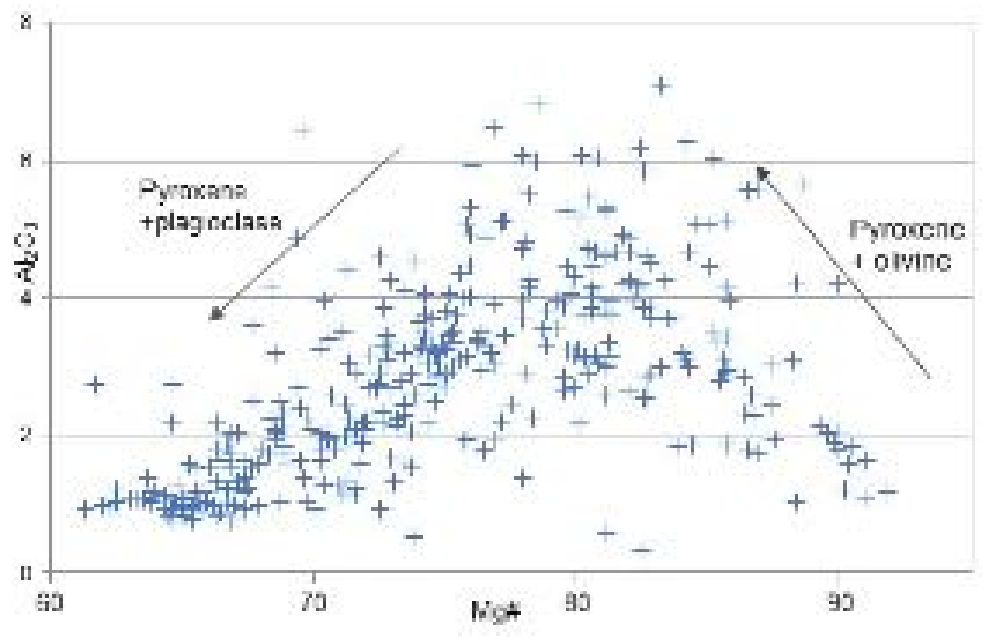

Figure 3-7 Al2O3 vs Mg\# for Site 296 clinopyroxenes 


\section{Pressure estimates using cpxs thermobarometry}

Pressure estimates from clinopyroxene are calculated as a linear function of cell site and M site volume (Nimis and Ulmer, 1999; Nimis, 1999). Both volumes decrease linearly with an increase in pressure as a combination of M1, M2, and T site exchanges, whereas at a given pressure, the volumes are inversely correlated (Nimis 1995; Nimis and Ulmer, 1998). In particular, $\mathrm{Al}_{\mathrm{M} 1}$ in clinopyroxene is directly related to the pressure. However, for hydrous magmas like those of subduction zones, the barometer is sensitive to the temperature of crystallization and a close estimation of temperature $\left( \pm 50{ }^{\circ} \mathrm{C}\right)$ is needed to give accurate pressure readings. Since these are detrital pyroxenes, it is difficult to estimate a temperature using other geothermometers. The temperature of the clinopyroxenes will be based on a previous temperature determined on lithic clasts from ODP Site 1201 near the KPR (D'Antonio et al., 2006) of $1155 \pm 56^{\circ} \mathrm{C}$ for the most primitive magmas. Using the cpxs geobarometer (Nimis, 1999) at temperatures of $1155^{\circ} \mathrm{C}$ some high $\mathrm{Mg \#}$ cpxs produced negative pressures, whereas most high $\mathrm{Mg}$ cpxs at $1100-1075^{\circ} \mathrm{C}$ give a pressure of crystallization of 0-2 kbar, and a few give 4-6 kbar pressure of crystallization (those with high $\mathrm{Al}$ content in Fig 3-7). Cpxs with lower Mg numbers between 78-84 gave pressures ranging from $0-8 \mathrm{Kbar}$ at temperatures of $1100-1075{ }^{\circ} \mathrm{C}$. Because of the sensitivity of the barometer to Al contents of magma, only mafic magmas provide a reasonable pressure estimate. Higher pressures are related to the high Al Cpxs; it is impossible to distinguish the case of crystallization in deeper magma reservoirs versus higher alumina parent magmas, since both would increase the $\mathrm{Al}_{\mathrm{M} 1}$ component. The cpxsbar program (Nimis, 1999) is sensitive to the Al contents, and high alumina basalts are not considered for pressure estimation. 


\section{Melt trace element concentrations and patterns estimated from clinopyroxene}

\section{partition coefficients}

Partitioning of trace elements between melt and crystal is affected by changes in pressure, temperature, the composition of magma and the structure of the phase (Blundy and Wood, 2003; Nandedkar et al., 2014, 2016; Shimizu et al., 2017; Humphreys et al., 2019). At subduction zones, water also plays a vital role in partitioning, as it may decrease the trace element activity in melts and cause fractionation of one valence from the other (Blundy and Wood, 2003). Numerous experiments have been conducted aimed at measuring partition coefficients of elements between the melt and mineral (Nandedkar et al., 2016; Shimizu et al., 2017; Humphreys et al., 2019), and these studies provide more reliable information than studies based on phenocryst-matrix measurements. However, few experiments cover multiple elements; for Cpx-melt Kds, experimental partition coefficients for trace elements and REE must be drawn from several different studies. The partition coefficients used here for basaltic and basaltic andesite liquids were taken from the Geochemical Earth Reference Model (GERM) Reservoir database and are mainly experimental. Kds for intermediate and felsic magmas are poorly constrained by experimental data. In order to improve our selection, we first calculated partition coefficients using melt inclusions and enclosing clinopyroxenes from this work. These are compared with published values in Fig. 3-8. Partition coefficients calculated from the mafic cpx-basaltic MIs that fall on the equilibrium KdFe-Mg line in Fig. 3-6b has a similar trace element $\mathrm{Kd}$ trend to those resulting from experiments (Fig. 3-8). Among other partition coefficients calculated from host-MI pairs, REE Kd's increase exponentially with more evolved melt inclusions, but this not observed for other trace elements. To calculate 
equilibrium melt compositions, we used the Kd's calculated from cpx and enclosed basaltic melt inclusion and we only infer the melt composition for mafic cpxs $(\mathrm{Mg \# s}>75)$ in equilibrium with melt Mg\#s of 45 and above, since it is difficult to determine the Kds for more evolved melts.

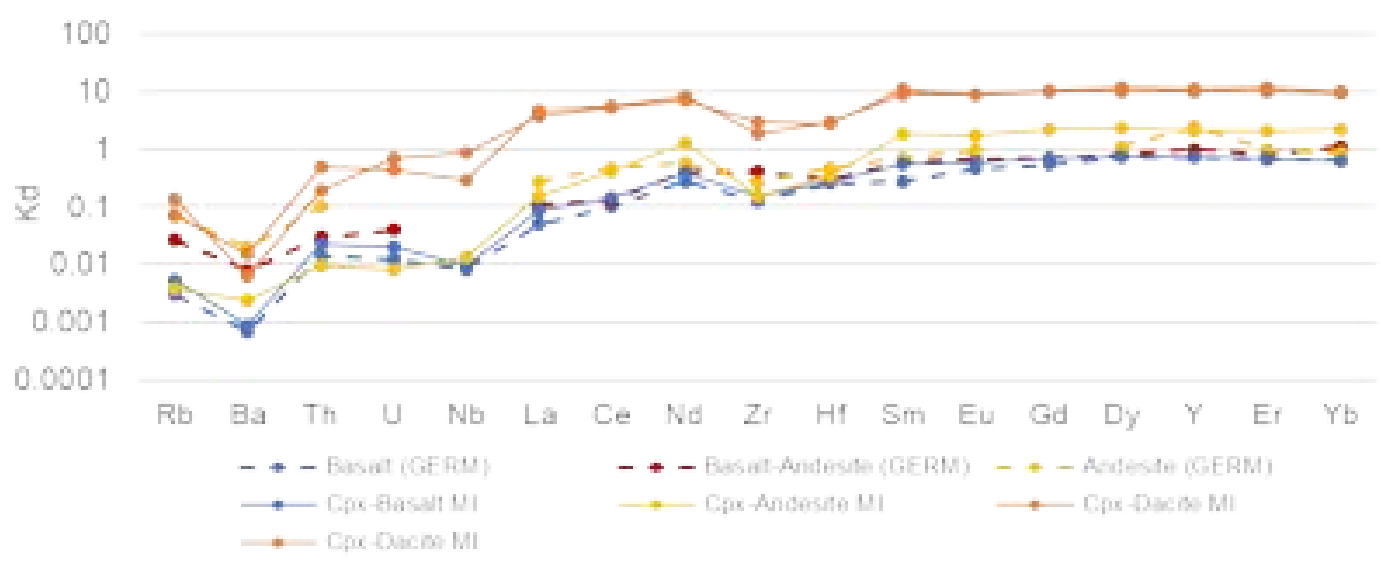

Figure 3-8 Comparison of clinopyroxene/melt partition coefficients from published data and partition coefficients calculated from melt inclusions and host cpxs from Site 296. For basaltic melts:-Rb-Klemme et al. (2002); Sr, SmJohnson (1994); Ce, Y-Jenner et al. (1994); Ba, Zr, Hf- Hart and Dunn (1993); Th, U, La, Nd, Eu, Dy, Er, Yb, Lu- Hauri et al. (1994); Gd-Hack et al. (1994); Pb-Beattie (1993). For basaltic-andesite melts -Rb-Philpotts and Schnetzler (1970); Sr, Y, Zr, La, Ce, Nd, Sm, Dy, Er, Yb- Ronov and Yaroshevskiy (1976); Ba- Hart and Brooks (1974); Gd- Gallahan and Nielson (1992); Hf, Th, U- Dostal et al. (1983). For andesitic melts: La, Sm, Dy, Yb- Nicholls and Harris (1980); ZrWatson and Ryerson (1986); Rb, Pb, Sr, Y-Ewart and Griffin (1994); Ba, Nd- Luhr and Carmichael (1980); Th, Ce, Hf - Bacon and Druitt (1988); Er-Schnetzler and Philpotts (1970).

Fig. 3-9 shows the calculated melt composition coexisting with the high Mg\# cpxs (88-92) and cpxs with Mg\# between 75 to 87 . The calculated trace element patterns for melts coexisting with the high $\mathrm{Mg} \#$ cpxs have a flat REE pattern and low concentrations of trace elements compared to glass shards from the Site 296 drill core (Samajpati and Hickey-Vargas, 2020). Calculated trace element patterns for melts coexisting with cpxs with Mg\# 75 to 85 vary widely, from flat REE patterns to LREE enriched patterns. Cpxs with Mg\# of 86-87 yield melt trace element patterns that are similar to those of the highest Mg\# cpxs and hence grouped in the trace element plot (Fig. 3-4). Some of these calculated 
melts have higher $\mathrm{Nb}$ contents than LREE in the normalized multi-element plot (Fig. 3-9) and therefore do not exhibit arc trace element characteristics.

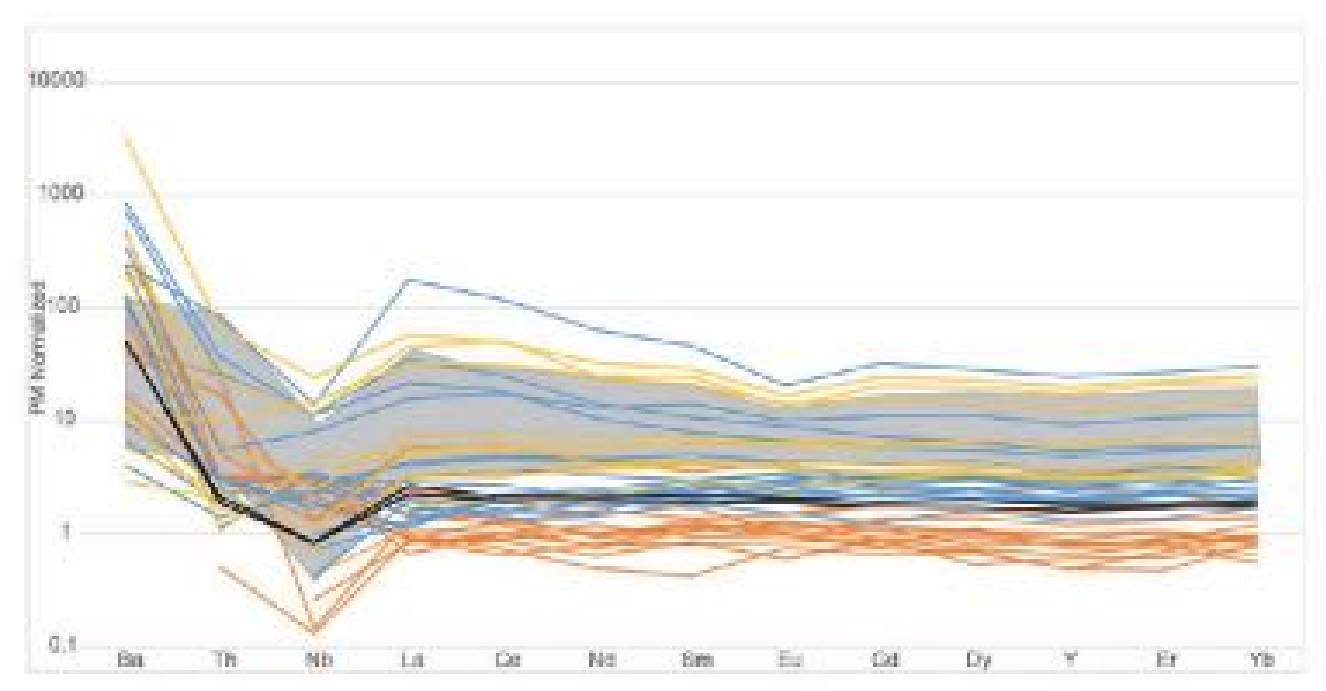

Figure 3-9 Primitive mantle normalized trace element abundances in melts calculated from Site 296 clinopyroxenes using cpx-basalt MI partition coefficients. Color-coded as figure 3-4. Grey shaded area at the back represents the trace element abundances of Site 296 glass shards. A high Mg andesite from Bonin Ridge Escarpment is shown in dark grey (Ishizuka et al., 2006).

\subsubsection{Amphiboles}

\section{Temperatures and magma compositions from amphibole compositions}

Recent studies in amphibole compositions have indicated that amphibole is not a suitable pressure indicator (Erdmann et al., 2014; Putirka, 2016) except at highly restrictive conditions like $\mathrm{T}<800{ }^{\circ} \mathrm{C}$ and $\mathrm{Fe} \#$ amp $<0.65$ (Anderson and Smith, 1995). Rather than pressure, amphiboles are more sensitive to temperature and liquid composition. In his paper, Putirka (2016) emphasized that amphibole barometers based on $\mathrm{D}_{\mathrm{Al}}$ (Ridolfi and Renzulli, 2011) are only successful when multiple $\mathrm{P}$ estimates for different compositions are averaged, without which there could be an error of $\pm 4 \mathrm{Kbar}$. Unlike $\mathrm{P}$, temperature estimates from amphibole compositions have a precision of $\pm 30{ }^{\circ} \mathrm{C}$. In this paper, we will 
use the P independent thermometer from Putirka (2016), given as Equation 5, to estimate the temperature and Equation 10 to determine the $\mathrm{SiO}_{2}$ content of the coexisting melt.

Using the pressure independent thermometer from Putirka (2016), we get a temperature of crystallization from 741 to $1016^{\circ} \mathrm{C}$ for the amphiboles. From this deduced temperature and amphibole compositions, the silica content of the melt from which the amphiboles crystallized ranges from basalt-andesite to rhyolite (52-75 wt\%). Magnesiohastingsites yield higher temperatures than magnesiohornblende. Magnesiohastingsites, crystallized at temperatures of $1016-872{ }^{\circ} \mathrm{C}$, are more common in mafic to intermediate magmas $\left(\mathrm{SiO}_{2}\right.$ 52-66 wt \%), whereas edenite and magnesiohornblendes are more common in silicic magmas $\left(\mathrm{SiO}_{2} 69-75 \mathrm{wt} \%\right)$. The amphiboles crystallizing in basalt andesite composition are henceforth referred as mafic amphiboles, these amphiboles do not have very high $\mathrm{Mg \# s}$ (62-67). Given the range of amphibole and melt bulk compositions, the trace element variation in the amphiboles (Fig. 3-5c) may be related to the magma composition. The amphiboles which show low incompatible trace element concentrations mainly crystallized from mafic and intermediate magma. Among the mafic amphiboles, the variation in LREE is probably related to the geochemical characteristics of their primary magmas as LREEs are incompatible in amphiboles. During differentiation from intermediate to silicic magma, plagioclase and titano-magnetite are major fractionating phases, and this might explain the depletions of $\mathrm{Eu}$ and $\mathrm{Ti}$ in the normalized trace element patterns for silicic amphiboles. Apatite crystallization in silicic magma can also affect rare earth elements (REE); magma crystallizing apatite may have low concentrations of REE, and this might explain the differences among the silicic amphiboles. 


\section{Melt trace element concentrations estimated from composition matched amphibole-melt}

partition coefficients

In the previous section, we saw that amphiboles from Site 296 could be linked to different magma composition. Using that information, we can also get the trace element abundances of the melt using composition matched partition coefficients, as given by Nandedkar et al. (2016) and Humphreys et al. (2019) (Fig. 3-10a \& b). We used both methods to get a better comparison of data and to model the maximum number of trace elements. The partition coefficient values can be found in Nandedkar et al. (2016) Table 5; partition coefficients used are RN8 inner for basalt-andesite, RN10s for andesite, RN12V2-2 for dacite, and RN14V2 for rhyolite composition. None of the calculated basaltandesite (mafic) melt compositions show LREE depletion which was seen in some basalt or basalt-andesite glass shards from Site 296 (Fig 3-10a). As seen on fig. 3-10, there are some highly LREE enriched melt composition inferred from amphibole composition; such highly LREE enriched melt composition was not observed within Site 296 glasses (shaded region in fig. 3-10).

We also used methods from Humphreys et al. (2019) to calculate melt compositions in equilibrium with the Site 296 amphiboles. When the two calculated melt compositions are compared, Kd values from Nandedkar et al. (2016) produced trends of highly elevated LREE over other rare earth elements (Fig. 3-10a) whereas using Humphreys et al. (2019) method, the melt compositions produced had slightly elevated LREEs and more depleted HREEs in some felsic melts (Fig 3-10b) when compared to Site 296 glass compositions. Overall trace element abundance patterns calculated using Kds from Humphreys et al. (2019) have a better fit to the range of Site 296 detrital glass shards. Calculated La/SmN values using Kds from Humphreys et al. (2019) for basalt-andesite are 1.1 to 7.2, indicating 
the magma crystallizing amphibole was enriched in LREEs. Calculated trace element patterns for basalt-andesite and andesite magmas using both sets of Kds have a positive $\mathrm{Sr}$ peak (Fig 3-10 a and b), indicating plagioclase was not an important phase in these magmas. In contrast, plagioclase was a major fractionating phase in the silicic magmas as inferred from the depletion of $\mathrm{Sr}$ in the plots.

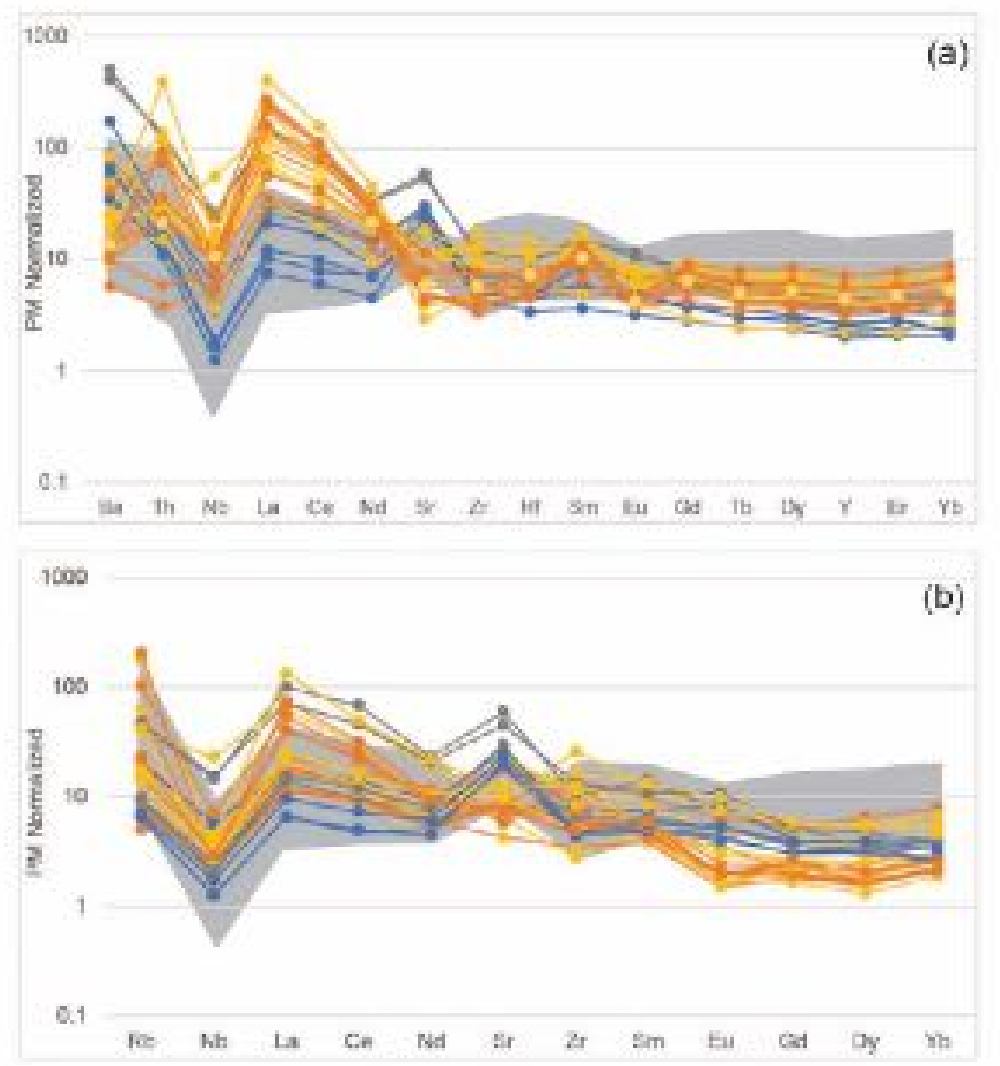

Figure 3-10 (a) Primitive normalized trace element abundances in melts calculated from amphiboles using amphibole/melt partition coefficients from Nandedkar et al. (2016). The shaded field represents the trace element abundances of Site 296 glass shards. (b) Calculated melt compositions using the method of Humphreys et al. (2019). Y and Ho values produced anomalous elevated and depleted peaks and hence were removed. 


\section{Amphiboles in Island Arcs}

Understanding amphibole stability in volcanic rocks and especially in island arcs is an issue of great importance in the evolution of the crust (Smith, 2014; Larocque, 2009). Stagnation of magma at intermediate crustal depths can stabilize amphiboles to a minimum of about 1.5-2 GPa (Allen and Boettcher, 1983) under water-saturated conditions but magma degassing during ascent can destabilize amphibole. A slow ascent can cause the amphibole to break down into anhydrous minerals and fluid. In arc magmas, amphiboles are more common in intermediate and felsic rocks presumably because these are cooler and may have higher water contents. Therefore, the presence of mafic amphiboles in equilibrium with melts $52-56 \mathrm{wt} \% \mathrm{SiO}_{2}$ at Site 296 is relatively unique. Experiments conducted to address amphibole stability in arc magma revealed that $\mathrm{Na}_{2} \mathrm{O}$ in addition to water contents of the magma are crucial factors in stabilizing amphibole (Sisson and Grove et al., 1993). In hydrous high alumina basalts and basalt andesites at low temperatures with at least $3 \mathrm{wt} \% \mathrm{Na}_{2} \mathrm{O}$, amphiboles can crystallize at the expense of olivine and $\mathrm{Ca}-$ plagioclase, whereas in lower $\mathrm{Na}_{2} \mathrm{O}$ magmas, amphiboles will only appear only when andesite compositions are reached (Sisson and Grove et al., 1993). Experiments of amphibole stability in primitive high $\mathrm{Mg}$ andesites and basaltic andesites in arc magmas at variable water, pressure and $\mathrm{OO}_{2}$ contents (Krawczynski et al., 2012) yielded high $\mathrm{Mg}$ amphiboles (Mg\#s 76-82) coexisting with olivines at pressures over $500 \mathrm{MPa}$ and temperatures of $975-1025{ }^{\circ} \mathrm{C}$ under high water contents $(10-14 \mathrm{wt} \%)$. Such high $\mathrm{Mg \#}$ amphiboles are absent in Site 296, thereby suggesting that such primitive magmas are not the origin for these amphiboles.

We used the $\mathrm{Kd}^{\mathrm{Fe}-\mathrm{Mg}}$ and $\mathrm{Kd}^{\mathrm{Al}-\mathrm{Si}}$ between amphibole and melt from Sisson and Grove (1993) to understand more about the composition of the melts. $\mathrm{Kd}^{\mathrm{Al}-\mathrm{Si}}$ is restricted to 0.94 
in different melt compositions but $\mathrm{Kd}^{\mathrm{Fe}-\mathrm{Mg}}$ between the amphibole/melt pairs vary from 0.30-0.38 in mafic and intermediate melts to lower values in silicic melts (Sisson and Grove, 1993). Putirka (2016) also reported a high variation in the partition coefficient of $\mathrm{Kd}^{\mathrm{Fe}-\mathrm{Mg}} 0.28 \pm 0.11$ between amphibole and melt. Here we have taken a $\mathrm{Kd}^{\mathrm{Fe}-\mathrm{Mg}}$ of 0.30 for mafic and intermediate composition and 0.2 for silicic composition as the Kd values. Fig. 3-11 shows $\mathrm{Fe} / \mathrm{Mg}$ and $\mathrm{Al} / \mathrm{Si}$ ratios of melts in equilibrium with the amphiboles; also plotted are date for Site 296 glass shards. The calculated melts from which the mafic and intermediate amphiboles crystallized have higher $\mathrm{Al} / \mathrm{Si}$ ratios than what is observed in the more mafic-intermediate glasses from Site 296. This could mean that the more mafic amphiboles crystallized from more alumina rich magmas than those represented by the Site 296 glass shards. Fe/Mg values, although biased as there is significant error for the $\mathrm{Kd}$, are similar or slightly lower in calculated melts compared with Site 296 glass shard compositions. We used the calculated major element melt composition from amphibole (Humphreys et al., 2019; Zhang et al., 2017) which yielded 18.01-18.70 wt $\% \mathrm{Al}_{2} \mathrm{O}_{3}$ and $\mathrm{MgO} 2.13-5.3 \mathrm{wt} \%$ for basalt-andesites. The composition is similar to the low Mg high alumina hornblende diorites (equivalent to basaltic andesite) from experiments by Sisson and Grove (1993), where amphiboles started crystallizing at $998^{\circ} \mathrm{C}$ with olivine and before plagioclase crystallization. Therefore, based on the major element calculated compositions and previous experimental studies, the mafic amphiboles might have crystallized in basalt andesite with high alumina, low to moderate $\mathrm{MgO}$ and at least $3 \mathrm{wt} \% \mathrm{Na}_{2} \mathrm{O}$ concentrations. 


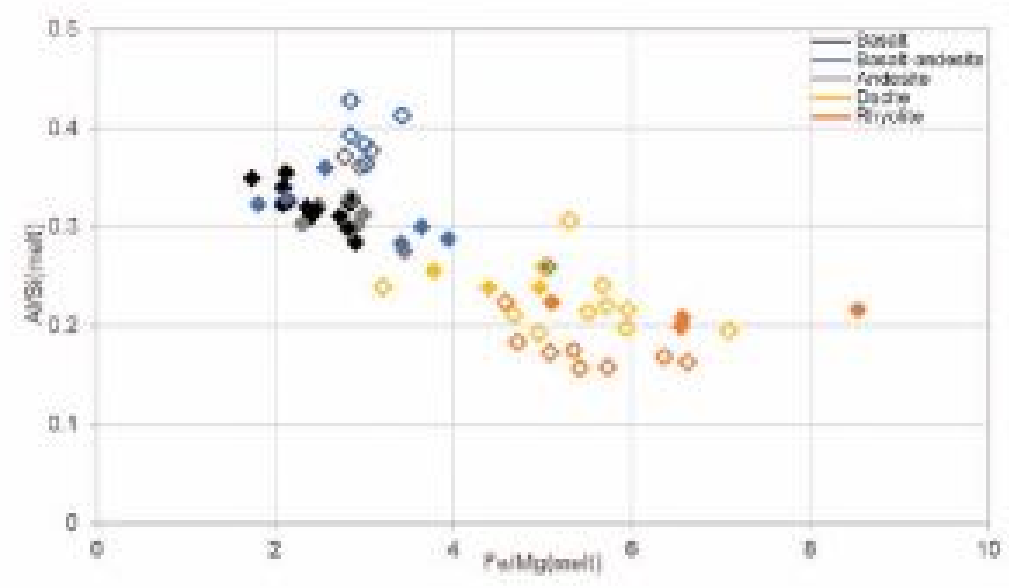

Figure 3-11 Plot of Al/Si and Fe/Mg of Site 296 glass shards compared with melt compositions calculated from amphibole compositions. Open symbols are for calculated melts and closed symbols are for the glass shards

\subsubsection{Magma Compositions Recorded at Site 296}

In this section, we have compiled all trace element information for the analyzed and calculated melts represented at Site 296 to understand the magmatic evolution recorded by the detrital sediments. For amphiboles, melt compositions using the Humphreys et al. (2019) method are shown, with Th partition coefficients from Nandedkar et al. (2016). Fig.

3-12 shows the compositional range of REE concentrations represented by the different materials. A significant observation is that the Site 296 glass shards and clasts represent only a fraction of the total geochemical variation of the Oligocene KPR arc magmas sampled at Site 296. The glass compositions do not include highly depleted magmas as calculated in equilibrium with high $\mathrm{Mg}$ cpxs and highly incompatible element enriched magmas ( $\mathrm{La} / \mathrm{SmN}>7)$ in equilibrium with some amphiboles (Fig. 3-12). 


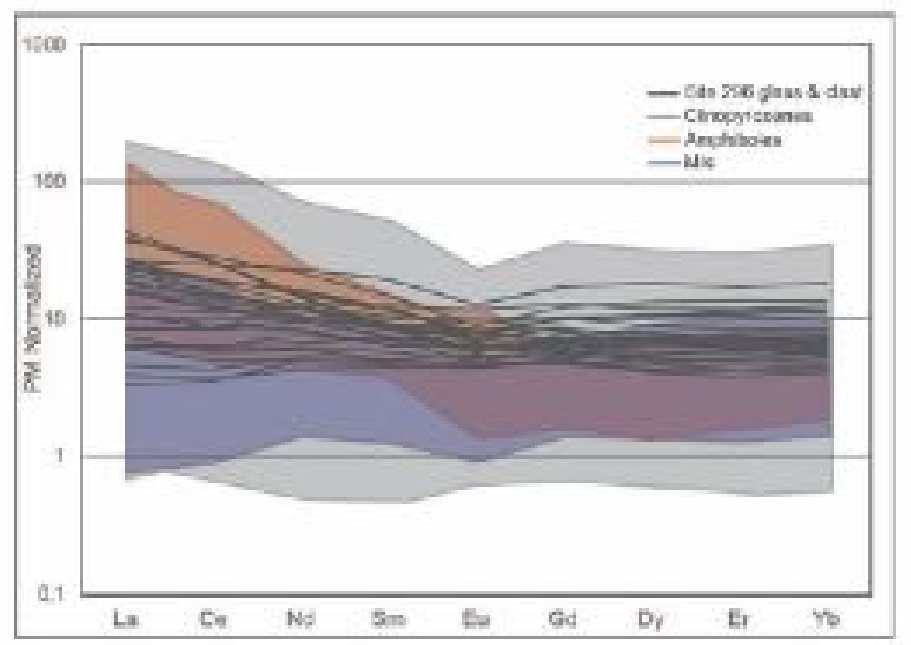

Figure 3-12 Primitive mantle normalized REE plot for analyzed and calculated melts for all materials. Compositional ranges inferred from clinopyroxenes, amphiboles and analyzed melt inclusions are shown as shaded fields.

\section{High Mg magmas}

Brandl et al. (2017) describe high-Mg cpxs (Mg\# 89 to 92) from the older $>37 \mathrm{Ma}$ section of IODP Site 1438 to be similar to plagioclase poor (1-4\%) high Mg andesites of the transitional suites at the Bonin Ridge Escarpment (BRE) (Ishizuka et al., 2006), which had K-Ar ages around $44 \mathrm{Ma}$ and represented the transition from forearc spreading to arc building. The melts that formed the Site 296 high Mg\# cpxs and BRE high Mg-andesites have high Sr contents compared to REE, suggesting these magmas were not saturated with plagioclase.

The high Mg\# cpxs do not appear throughout the core; they appear in the uppermiddle section of Unit 2 between cores 54 to upper 61 at approximate depths of $625-863$ $\mathrm{m}$, depths where lapilli and ash tuffs are common which indicates they are direct deposition from a volcanic event. In the oldest core (65), the most primitive cpxs has an $\mathrm{Mg \#}$ of around 87 and has a calculated melt trace element pattern similar to the other high $\mathrm{Mg \#}$ 
cpxs. Although sediments of different ages can be eroded from a volcanic edifice and deposited together, older sequences are limited to the lower section and younger sequences are expected toward the top. The stratigraphic gap between cores 65 and 61 suggests that the high Mg\# cpxs at the bottom and upper parts may not be related. It is possible the high

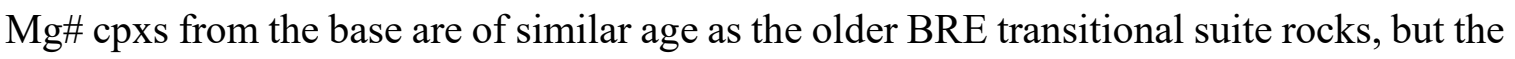
same can't be said with confidence for the ones at the top. When compared to high-Mg andesite from the BRE there are similarities in trace element concentration (Fig. 3-9), both have low concentrations of trace elements with flat REE patterns. However, in the normalized multi-element plot the calculated melts from high $\mathrm{Mg} \#$ Site $296 \mathrm{cpxs}$ (except one) have REE values close to 1, whereas the high Mg andesites plot higher than 1.

\section{Enriched magmas}

There is also evidence of LREE enriched magmas at Site 296. Some mafic and intermediate magma compositions inferred from amphiboles had REE patterns similar to enriched lithic clasts from Site 296 (Samajpati and Hickey-Vargas, 2020), these were hornblende-bearing andesites. LREE enriched compositions were also observed within inferred melts from two cpx grains (Mg\#s around 80 and 4-6 wt $\left.\% \mathrm{Al}_{2} \mathrm{O}_{3}\right)$ and, an andesite melt inclusion within a cpx which had $17.9 \mathrm{wt} \%$ alumina content. Highly enriched magmas were also observed at Nichinan seamount, located $160 \mathrm{~km} \mathrm{NW}$ relative to Site 296 (Haraguchi et al., 2012. All the above materials which point to LREE-enriched high Al magmas as their origin are present in the topmost section of Unit 2, core 49-57.

Our interpretation is that these enriched magmas were formed under high pressure and or water contents towards late Oligocene. Evidence for high water contents and/or a deeper magma reservoir is both the stabilization of amphibole and increasing dominance 
of calcic plagioclase at the middle to top of the stratigraphic section (Fig. 3-2). At high pressures and or water content amphiboles are stabilized, and plagioclase crystallization is suppressed as the volume of cpxs rather than calcic plagioclase is expanded (Yoder, 1965; Baker and Eggler, 1983). When plagioclase crystallizes, it is more Ca rich and Si poor with compositions of An90-95 (Arculus and Wills, 1980; Kuno 1950), as seen in Site 296. High water content also destabilizes orthopyroxene in favor of olivine (Kushiro 1969) which is also reflected in the absence of primitive opx at Site 296.

\section{Mantle enrichment}

In Fig. 20 the composition-matched trace element abundances of mafic and intermediate melts inferred from amphiboles using the method of Humphreys et al. (2019) vary from slightly to highly enriched in terms of $\mathrm{La} / \mathrm{Sm}_{\mathrm{N}}(1-7)$ and $\mathrm{Nb} / \mathrm{Yb}=0.9$ to 10.6 . Th concentrations for the melts are calculated using the composition-matched partition coefficients from Nandedkar et al. (2016), and these also vary widely (1-11 ppm) (Fig 20b). The most LREE-enriched mafic melt $\left(\mathrm{SiO}_{2} 54 \mathrm{wt} \%\right)$ have the highest $\mathrm{Nb}$ and $\mathrm{Th}$ concentrations and highest $\mathrm{Nb} / \mathrm{Yb}$ and $\mathrm{Th} / \mathrm{Yb}$ ratios (9 and 21 respectively), which indicates high mantle fertility in the first case and incorporation of a subduction component in the second case. Some felsic melts $\left(70 \mathrm{wt} \% \mathrm{SiO}_{2}\right)$ calculated from amphibole, are only slightly enriched $\left(\mathrm{La} / \mathrm{Sm}_{\mathrm{N}} \sim 1.2\right)$ at low $\mathrm{Nb} / \mathrm{Yb}$ and $\mathrm{Th} / \mathrm{Yb}$ ratios and plot close to the mantle array in Fig. 3-13. Since $\mathrm{La} / \mathrm{Sm}_{\mathrm{N}}$ values typically increase with differentiation, it is possible that the primary magma which evolved to form these amphiboles was depleted. 


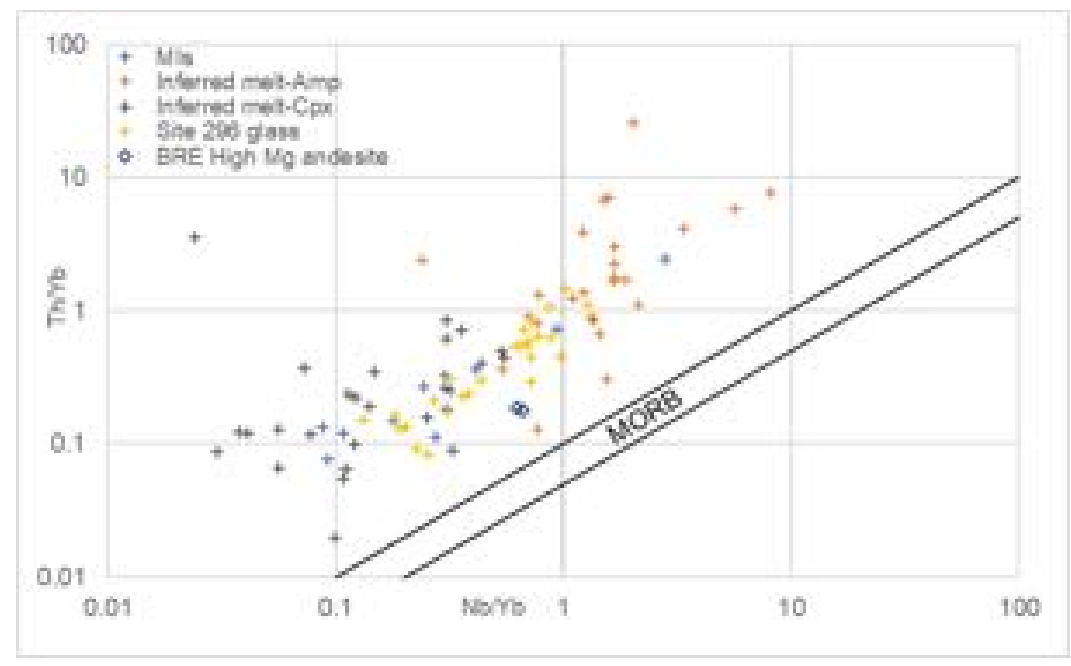

Figure 3-13 Logarithmic plot of $\mathrm{Th} / \mathrm{Yb}$ vs $\mathrm{Nb} / \mathrm{Yb}$ for melt composition, both analyzed and inferred from mafic minerals; also includes high Mg andesite data from the Bonin Ridge Escarpment (BRE)

The mafic melt compositions calculated from most cpxs show a range of depleted to enriched characteristics $\left(\mathrm{La} / \mathrm{Sm}_{\mathrm{N}}\right.$ values 0.5 -3.8). Cpxs having extremely low $\mathrm{Nb} / \mathrm{Yb}$ ratios (Fig. 3-13) are the unusually high $\mathrm{Mg \#}$ cpxs discussed above and their $\mathrm{Nb} / \mathrm{Yb}$ ratios are lower than the high $\mathrm{Mg}$ andesites from the Bonin ridge (Fig 3-13). Since $\mathrm{Nb}$ is an indicator of mantle fertility (Pearce et al., 2005), the wide variation of $\mathrm{Nb} / \mathrm{Yb}$ ratios suggests changes in mantle sources took place between the formation of enriched fertile magmas as inferred from amphiboles in cores 49-57 and depleted magmas inferred from cpxs (cores 54-61). In short, we can suggest towards the late Oligocene deep-seated magma storage or high-water contents of the magma may have led to the evolution of high Al magmas with variable $\mathrm{Mg}$ contents from a somewhat enriched source with the crystallization of high Al cpxs, amphiboles, and high calcic plagioclases. 


\subsubsection{Temporal changes and Oligocene Rifting}

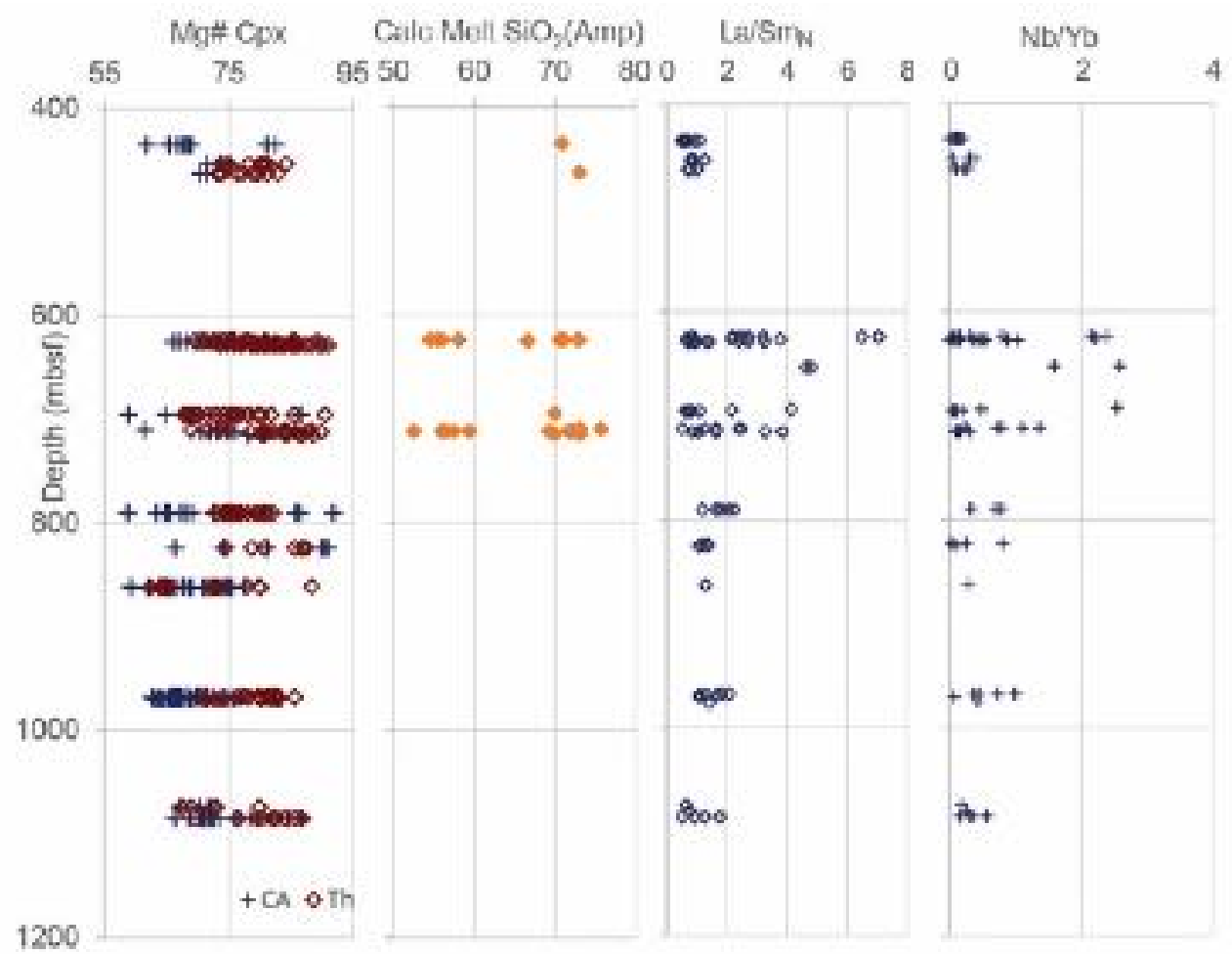

Figure 3-14 From left to right, plot showing the depth vs Mg\# of clinopyroxenes with their magmatic affinity; $\mathrm{SiO}_{2}$ content of melt in equilibrium with amphibole; $\mathrm{La} / \mathrm{Sm}_{\mathrm{N}}$ of mafic to intermediate glass shards and calculated melts from minerals; and $\mathrm{Nb} / \mathrm{Yb}$ of mafic to intermediate glass shards and calculated melts.

The KPR started rifted during the late Oligocene around $28 \mathrm{Ma}$, forming the Shikoku back arc basin (Ingle et al., 1975). Judging from the lowermost cores of Unit 1 and uppermost cores of Unit 2 at Site 296, there does not appear to be particular petrologic or geochemical signature that could be exclusively connected to rifting but rather a gradual change over time prior to rifting is seen. First, from the composition of the cpxs it is observed that the arc become more tholeiitic over time (Fig. 3-14). This same trend was noted by Brandl et al. (2017) in Site 1438 melt inclusions. The trace element compositions of inferred melts in equilibrium with these cpxs are also depleted $\left(\mathrm{La} / \mathrm{Sm}_{\mathrm{N}}\right.$ values $\left.<1\right)$, with low $\mathrm{Nb}$ and $\mathrm{Th}$ contents. The change from slightly enriched sources to more depleted sources (towards lower $\mathrm{Nb} / \mathrm{Yb}$ concentration in Fig. 3-13) together with a decrease in 
$\mathrm{Th} / \mathrm{Yb}$ values (4 to $\sim$ ) could reflect the decreasing subduction component and increasing MORB component. The high Mg cpxs plot at the boundary of calc-alkaline and tholeiitic (Fig. 3-3c) with relatively low crystallization pressures $\left(0-3 \mathrm{kbar}\right.$ at $\left.1100{ }^{\circ} \mathrm{C}\right)$. A second trend is that amphiboles, found only in cores 57 and above, crystallized in the arc magmas prior to rifting of the arc and that mafic amphiboles formed in mostly LREE enriched magmas. They reflect high water or pressure conditions that may have developed as the arc crust thickened and matured, and enrichment of water and fluid mobile elements from the subducted slab.

The melt compositions inferred from the unusually high Mg\# cpxs, although similar to the high $\mathrm{Mg}$ transitional suite seen in Bonin ridge which is a potential example of the earlier IBM magmas, have overall lower trace element concentrations (Fig. 3-9). These cpxs are not at the bottom of the core but in section 54-61, which suggests that they are not from the early rocks unless they are xenocrysts brought up in the amphibole-bearing enriched magmas. The early transitional BRE suites were associated with intra-arc rifting (Taylor and Nesbitt, 1995), therefore, magmas forming the high Mg\# cpxs may have formed during the rifting of the KPR in the Oligocene. One possibility is that there were multiple stages of rifting rather than one event, and one such rifting event could have produced high Mg melts from a depleted mantle source.

\subsection{Conclusions}

In conclusion, DSDP Site 296 presents unique findings on the early magmatic history of the IBM arc which are not well recorded in other sites:

1) Diverse primary magmas formed and differentiated at different depths $(0-30 \mathrm{~km})$ as indicated by the crystallization pressure of the mafic clinopyroxene. Based on 
clinopyroxene composition calc-alkaline magmas dominate the lowest sections of earlylate Oligocene Unit 2, followed by tholeiitic magmas.

2) At some point, highly enriched magmas formed from a fertile mantle source and crystallized mafic amphibole bearing lavas; this may have been a local source like that producing the enriched magmas from Nichinan Seamount (Haraguchi et al., 2012).

3) Slightly LREE enriched, high-Al melts formed at high water contents to form mafic amphiboles with clinopyroxenes and high An-plagioclase. These dominate the later period of deposition at Site 296.

4) Arc rifting probably occurred in multiple stages. Magma formed during one such step might have produced the unusually high-Mg\# cpxs from a depleted, MORB-like mantle source, similar to transitional suite rocks from the Bonin ridge escarpment.

5) The time scale for these events is uncertain; mafic amphiboles (late stage arc magmas) and high Mg cpxs (MORB-like magmas) coexist in some samples, so the possibility of deep-seated amphibole-bearing magmas carrying xenocrysts of older KPR rocks is also possible.

\subsection{Acknowledgments}

This research was supported by NSF grants OCE 15377861 to Rosemary Hickey-Vargas. We gratefully acknowledge the contribution of Gabriela Fernandez in preparing the smear slides for the core samples. We also thank Thomas Beasley of the Florida Center for Analytical Electron Microscopy (FCAEM) at FIU for assistance with EPMA analyses and Dr. Sarah Jantzi of the Trace Evidence Analysis Facility (TEAF) at FIU for assistance with LA-ICP-MS analyses. 


\subsection{References}

Anderson, J.L., and Smith, D.R., 1995, The effects of temperature and $\mathrm{f}$ (sub O2) on the Al-in-hornblende barometer: American Mineralogist, v. 80, no. 5-6, p. 549-559.

Arculus, R.J., Ishizuka, O., Bogus, K.A., et al., 2015, A record of spontaneous subduction initiation in the Izu-Bonin-Mariana Arc: Nature Geoscience, v. 8, no. 9, p. 728-733.

Arculus, R.J., and Wills, K.J.A., 1980, The petrology of plutonic blocks and inclusions from the Lesser Antilles island arc: Journal of Petrology, v. 21, no. 4, p. 743-799.

Arculus, R., Ishizuka, O., Bogus, K., et al., 2015, International Ocean Discovery Program Expedition 351 preliminary report; Izu-Bonin-Mariana Arc origins; continental crust formation at an intraoceanic arc; foundation, inception, and early evolution; 30 May30 July 2014: Preliminary Report (International Ocean Discovery Program), v. 351.

Bacon, C.R., and Druitt, T.H., 1988, Compositional evolution of the zoned calcalkaline magma chamber of Mount Mazama, Crater Lake, Oregon: Contributions to Mineralogy and Petrology, v. 98, no. 2, p. 224-256.

Baker, D.R., and Eggler, D.H., 1983, Fractionation paths of Atka (Aleutians) high-alumina basalts; constraints from phase relations: Journal of Volcanology and Geothermal Research, v. 18, no. 1-4, p. 387-404.

Blundy, J., and Wood, B., 1994, Prediction of crystal-melt partition coefficients from elastic moduli: Nature (London), v. 372, no. 6505, p. 452-454. 
Blundy, J.D., and Wood, B.J., 1991, Crystal-chemical controls on the partitioning of $\mathrm{Sr}$ and $\mathrm{Ba}$ between plagioclase feldspar, silicate melts, and hydrothermal solutions: Geochimica et Cosmochimica Acta, v. 55, no. 1, p. 193-209.

Brandl, P.A., Hamada, M., Arculus, R.J., et al., 2017, The arc arises; the links between volcanic output, arc evolution and melt composition: Earth and Planetary Science Letters, v. 461, p. 73-84.

D'Antonio, M., Savov, I., Spadea, P., Hickey-Vargas, R., and Lockwood, J., 2006, Petrogenesis of Eocene oceanic basalts from the West Philippine Basin and Oligocene arc volcanics from the Palau-Kyushu Ridge drilled at 20 degrees N, 135 degrees E (Western Pacific Ocean): Ofioliti, v. 31, no. 2, p. 173-187.

Debari, S.M., and Coleman, R.G., 1989, Examination of the deep levels of an island arc; evidence from the Tonsina ultramafic-mafic assemblage, Tonsina, Alaska: Journal of Geophysical Research, v. 94, no. B4, p. 4373-4391.

Debari, S., Kay, S.M., and Kay, R.W., 1987, Ultramafic xenoliths from Adagdak Volcano, Adak, Aleutian Islands, Alaska; deformed igneous cumulates from the Moho of an island arc: Journal of Geology, v. 95, no. 3, p. 329-341.

Dostal, J., Dupuy, C., Carron, J.P., Le Guen de Kerneizon, M., and Maury, R.C., 1983, Partition coefficients of trace elements; application to volcanic rocks of St. Vincent, West Indies: Geochimica et Cosmochimica Acta, v. 47, no. 3, p. 525-533. 
Erdmann, S., Martel, C., Pichavant, M., and Kushnir, A., 2014, Amphibole as an archivist of magmatic crystallization conditions; problems, potential, and implications for inferring magma storage prior to the paroxysmal 2010 eruption of Mount Merapi, Indonesia: Contributions to Mineralogy and Petrology, v. 167, no. 6.

Ewart, A., and Griffin, W.L., 1994, Application of proton-microprobe data to trace-element partitioning in volcanic rocks: Chemical Geology, v. 117, no. 1-4, p. 251-284.

Gallahan, W.E., and Nielsen, R.L., 1992, The partitioning of Sc, Y, and the rare earth elements between high-Ca pyroxene and natural mafic to intermediate lavas at 1 atmosphere: Geochimica et Cosmochimica Acta, v. 56, no. 6, p. 2387-2404.

Hack, P.J., Nielsen, R.L., and Johnston, A.D., 1994, Experimentally determined rare-earth element and Y partitioning behavior between clinopyroxene and basaltic liquids at pressures up to 20 kbar: Chemical Geology, v. 117, no. 1-4, p. 89-105.

Haraguchi, S., Ishii, T., Kimura, J., and Kato, Y., 2012, The early Miocene ( approximately $25 \mathrm{Ma}$ ) volcanism in the northern Kyushu-Palau Ridge, enriched mantle source injection during rifting prior to the Shikoku back-arc basin opening: Contributions to Mineralogy and Petrology, v. 163, no. 3, p. 483-504.

Haraguchi, S., Ishii, T., Kimura, J., and Ohara, Y., 2003, Formation of tonalite from basaltic magma at the Komahashi-Daini Seamount, northern Kyushu-Palau Ridge in the Philippine Sea, and growth of Izu-Ogasawara (Bonin)-Mariana arc crust: Contributions to Mineralogy and Petrology, v. 145, no. 2, p. 151-168. 
Hart, S.R., and Brooks, C., 1974, Clinopyroxene-matrix partitioning of K, Rb, Cs, Sr and Ba: Geochimica et Cosmochimica Acta, v. 38, no. 12, p. 1799-1806.

Hart, S.R., and Dunn, T., 1993, Experimental cpx/melt partitioning of 24 trace elements: Contributions to Mineralogy and Petrology, v. 113, no. 1, p. 1-8.

Hauri, E.H., Wagner, T.P., and Grove, T.L., 1994, Experimental and natural partitioning of $\mathrm{Th}, \mathrm{U}, \mathrm{Pb}$ and other trace elements between garnet, clinopyroxene and basaltic melts: Chemical Geology, v. 117, no. 1-4, p. 149-166.

Humphreys, M.C.S., Cooper, G.F., Zhang, J. et al., 2019, Unravelling the complexity of magma plumbing at Mount St. Helens: a new trace element partitioning scheme for amphibole.: Contributions to Mineralogy and Petrology, v. 174, no. 9.

Ingle, J.C.,Jr, Karig, D.E., Bouma, A.H., et al., 1975, Site 296: Initial Reports of the Deep Sea Drilling Project, v. 31, p. 191-274.

Ishizuka, O., Kimura, J., Li, Y.B., et al., 2006, Early stages in the evolution of Izu-Bonin Arc volcanism; new age, chemical, and isotopic constraints: Earth and Planetary Science Letters, v. 250, no. 1-2, p. 385-401.

Ishizuka, O., Taylor, R.N., Yuasa, M., and Ohara, Y., 2011, Making and breaking an island arc; a new perspective from the Oligocene Kyushu-Palau Arc, Philippine Sea: Geochemistry, Geophysics, Geosystems - G3, v. 12, no. 5, p. Citation Q05005. 
Jenner, G.A., Foley, S.F., Jackson, S.E., Green, T.H., Fryer, B.J., and Longerich, H.P., 1993, Determination of partition coefficients for trace elements in high pressuretemperature experimental run products by laser ablation microprobe-inductively coupled plasma-mass spectrometry (LAM-ICP-MS): Geochimica et Cosmochimica Acta, v. 57, no. 23-24, p. 5099-5103.

Johnson, K.T.M., 1994, Experimental cpx/ and garnet/melt partitioning of REE and other trace elements at high pressures; petrogenetic implications: Mineralogical Magazine, v. 58A, no. A-K, p. 454-455.

Karig, D.E., 1975, Basin genesis in the Philippine Sea: Initial Reports of the Deep Sea Drilling Project, v. 31, p. 857-879.

Kay, S.M., and Kay, R.W., 1985, Aleutian tholeiitic and calc-alkaline magma series; 1, The mafic phenocrysts: Contributions to Mineralogy and Petrology, v. 90, no. 2-3, p. 276-290.

Klemme, S., Blundy, J.D., and Wood, B.J., 2002, Experimental constraints on major and trace element partitioning during partial melting of eclogite: Geochimica et Cosmochimica Acta, v. 66, no. 17, p. 3109-3123.

Kobayashi, K., Kasuga, S., and Okino, K., 1995, Shikoku Basin and its margins: New York, NY, United States (USA), Plenum Press, New York, NY. 
Krawczynski, M.J., Grove, T.L., and Behrens, H., 2012, Amphibole stability in primitive arc magmas; effects of temperature, $\mathrm{H}$ (sub 2) $\mathrm{O}$ content, and oxygen fugacity: Contributions to Mineralogy and Petrology, v. 164, no. 2, p. 317-339.

Kushiro, I., 1969, The system forsterite-diopside-silica with and without water at high pressures: American Journal of Science, v. 267-A, p. 269-294.

Larocque, J., and Canil, D., 2010, The role of amphibole in the evolution of arc magmas and crust; the case from the Jurassic Bonanza Arc section, Vancouver Island, Canada: Contributions to Mineralogy and Petrology, v. 159, no. 4, p. 475-492.

Leake, B.E., Woolley, A.R., Arps, C.E.S., et al., 1997, Nomenclature of amphiboles; report of the subcommittee on amphiboles of the International Mineralogical Association, Commission on New Minerals and Mineral Names: The Canadian Mineralogist, v. 35, Part 1, p. 219-246.

Lee, J., Stern, R.J., and Bloomer, S.H., 1995, Forty million years of magmatic evolution in the Mariana arc; the tephra glass record: Journal of Geophysical Research, v. 100, no. B9, p. 17-17,687.

Leterrier, J., Maury, R.C., Thonon, P., Girard, D., and Marchal, M., 1982, Clinopyroxene composition as a method of identification of the magmatic affinities of paleo-volcanic series: Earth and Planetary Science Letters, v. 59, no. 1, p. 139-154. 
Luhr, J.F., and Carmichael, I.S.E., 1980, The Colima volcanic complex, Mexico; I, Postcaldera andesites from Volcan Colima: Contributions to Mineralogy and Petrology, v. 71, no. 4 , p. 343-372.

Maynard, J.B., 1984, Composition of plagioclase feldspar in modern deep-sea sands; relationship to tectonic setting: Sedimentology, v. 31, no. 4, p. 493-501.

Nandedkar, R.H., Hurlimann, N., Ulmer, P., and Muntener, O., 2016, Amphibole-melt trace element partitioning of fractionating calc-alkaline magmas in the lower crust; an experimental study: Contributions to Mineralogy and Petrology, v. 171, no. 8-9, p. Article 71.

Nandedkar, R.H., Ulmer, P., and Muntener, O., 2014, Fractional crystallization of primitive, hydrous arc magmas; an experimental study at $0.7 \mathrm{GPa}$ : Contributions to Mineralogy and Petrology, v. 167, no. 6 .

Nicholls, I.A., and Harris, K.L., 1980, Experimental rare earth element partition coefficients for garnet, clinopyroxene and amphibole coexisting with andesitic and basaltic liquids: Geochimica et Cosmochimica Acta, v. 44, no. 2, p. 287-308.

Nimis, P., 1995, A clinopyroxene geobarometer for basaltic systems based on crystalstructure modeling: Contributions to Mineralogy and Petrology, v. 121, no. 2, p. 115125. 
Nimis, P., 1999, Clinopyroxene geobarometry of magmatic rocks. Part 2. Structural geobarometers for basic to acid, tholeiitic and mildly alkaline magmatic systems: Contributions to Mineralogy and Petrology, v. 135, no. 1, p. 62-74.

Nimis, P., and Ulmer, P., 1998, Clinopyroxene geobarometry of magmatic rocks; Part 1, An expanded structural geobarometer for anhydrous and hydrous, basic and ultrabasic systems: Contributions to Mineralogy and Petrology, v. 133, no. 1-2, p. 122-135.

O'Hara, M.J., 1995, Trace element geochemical effects of integrated melt extraction and "shaped" melting regimes: Journal of Petrology, v. 36, no. 4, p. 1111-1132.

Pearce, J.A., Stern, R.J., Bloomer, S.H., and Fryer, P., 2005, Geochemical mapping of the Mariana arc-basin system; implications for the nature and distribution of subduction components: Geochemistry, Geophysics, Geosystems - G3, v. 6, no. 7.

Putirka, K., 2016, Amphibole thermometers and barometers for igneous systems and some implications for eruption mechanisms of felsic magmas at arc volcanoes: American Mineralogist, v. 101, no. 4, p. 841-858.

Putirka, K.D., Mikaelian, H., Ryerson, F., and Shaw, H., 2003, New clinopyroxene-liquid thermobarometers for mafic, evolved, and volatile-bearing lava composition, with applications to lavas from Tibet and the Snake River plain, Idaho: American Mineralogist, v. 88 , no. 10 , p. $1542-1554$.

Putirka, K.D., and Tepley, F.J.,III, 2008, Thermometers and barometers for volcanic systems: Reviews in Mineralogy and Geochemistry, v. 69, no. 1, p. 61-120. 
Ray, G.L., Shimizu, N., and Hart, S.R., 1983, An ion microprobe study of the partitioning of trace elements between clinopyroxene and liquid in the system diopside-albiteanorthite: Geochimica et Cosmochimica Acta, v. 47, no. 12, p. 2131-2140.

Reagan, M.K., Ishizuka, O., Stern, R.J., et al., 2010, Fore-arc basalts and subduction initiation in the Izu-Bonin-Mariana system: Geochemistry, Geophysics, Geosystems G3, v. 11, no. 3, p. Citation Q03X12.

Ridolfi, F., and Renzulli, A., 2012, Calcic amphiboles in calc-alkaline and alkaline magmas; thermobarometric and chemometric empirical equations valid up to 1.130 degrees C and 2.2 GPa: Contributions to Mineralogy and Petrology, v. 163, no. 5, p. 877-895.

Ronov, A.B., and Yaroshevskiy, A.A., 1976, A new model for the chemical structure of the Earth's crust: Geochemistry International, v. 13, no. 6, p. 89-121.

Samajpati, E., and Hickey-Vargas, R., 2020a, Geochemistry of Volcanic Glass from Oligocene Detrital Sediments at DSDP Site 296, Kyushu Palau Ridge: Interpreting the Magmatic Evolution of the Early Northern Izu Bonin Mariana Island Arc.

Schnetzler, C.C., and Philpotts, J.A., 1970, Partition coefficients of rare-earth elements between igneous matrix material and rock-forming mineral phenocrysts; II: Geochimica et Cosmochimica Acta, v. 34, no. 3, p. 331-340. 
Shimizu, K., Liang, Y., Sun, C., Jackson, C.R.M., and Saal, A.E., 2017, Parameterized lattice strain models for REE partitioning between amphibole and silicate melt: American Mineralogist, v. 102, no. 11, p. 2254-2267.

Shimizu, N., 1974, An experimental study of the partitioning of K, Rb, Cs, Sr and $\mathrm{Ba}$ between clinopyroxene and liquid at high pressures: Geochimica et Cosmochimica Acta, v. 38 , no. 12 , p. $1789-1798$.

Sisson, T.W., and Grove, T.L., 1993, Experimental investigations of the role of H (sub 2) $\mathrm{O}$ in calc-alkaline differentiation and subduction zone magmatism: Contributions to Mineralogy and Petrology, v. 113, no. 2, p. 143-166.

Stern, R.J., Fouch, M.J., Klemperer, S.L., and Eiler, J.M., 2003, An overview of the IzuBonin-Mariana subduction factory: Geophysical Monograph, v. 138, p. 175-222.

Stern, R.J., Morris, J.D., Bloomer, S.H., and Hawkins, J.W.,Jr, 1991, The source of the subduction component in convergent margin magmas; trace element and radiogenic isotope evidence from Eocene boninites, Mariana Forearc: Geochimica et Cosmochimica Acta, v. 55, no. 5, p. 1467-1481.

Straub, S.M., 2008, Uniform processes of melt differentiation in the central Izu Bonin volcanic arc (NW Pacific): Geological Society Special Publications, v. 304, p. 261283. 
Sun, S.S., and McDonough, W.F., 1989, Chemical and isotopic systematics of oceanic basalts; implications for mantle composition and processes: Geological Society Special Publications, v. 42, p. 313-345.

Taylor, B., Fujioka, K., Janecek, T.R., et al., 1992, Rifting and the volcanic-tectonic evolution of the Izu-Bonin-Mariana Arc: Proceedings of the Ocean Drilling Program, Scientific Results, v. 126, p. 627-651.

Taylor, R.N., Nesbitt, R.W., Vidal, P., Harmon, R.S., Auvray, B., and Croudace, I.W., 1994, Mineralogy, chemistry, and genesis of the boninite series volcanics, Chichijima, Bonin Islands, Japan: Journal of Petrology, v. 35, no. 3, p. 577-617.

Watson, E.B., and Ryerson, F.J., 1986, Partitioning of zirconium between clinopyroxene and magmatic liquids of intermediate composition: Geochimica et Cosmochimica Acta, v. 50, no. 11 , p. 2523-2526.

Yamazaki, T., and Stern, R.J., 1997, Topography and magnetic vector anomalies in the Mariana Trough: JAMSTEC Journal of Deep Sea Research, v. 13.

Zhang, J., Humphreys, M.C.S., Cooper, G.F., Davidson, J.P., and Macpherson, C.G., 2017, Magma mush chemistry at subduction zones, revealed by new melt major element inversion from calcic amphiboles: American Mineralogist, v. 102, no. 6, p. 1353-1367. 


\subsection{Appendices}

Refer to table 3-1 for precision data

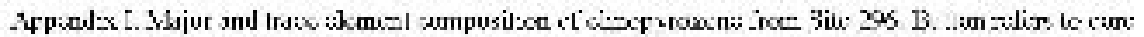

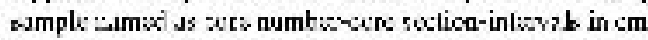

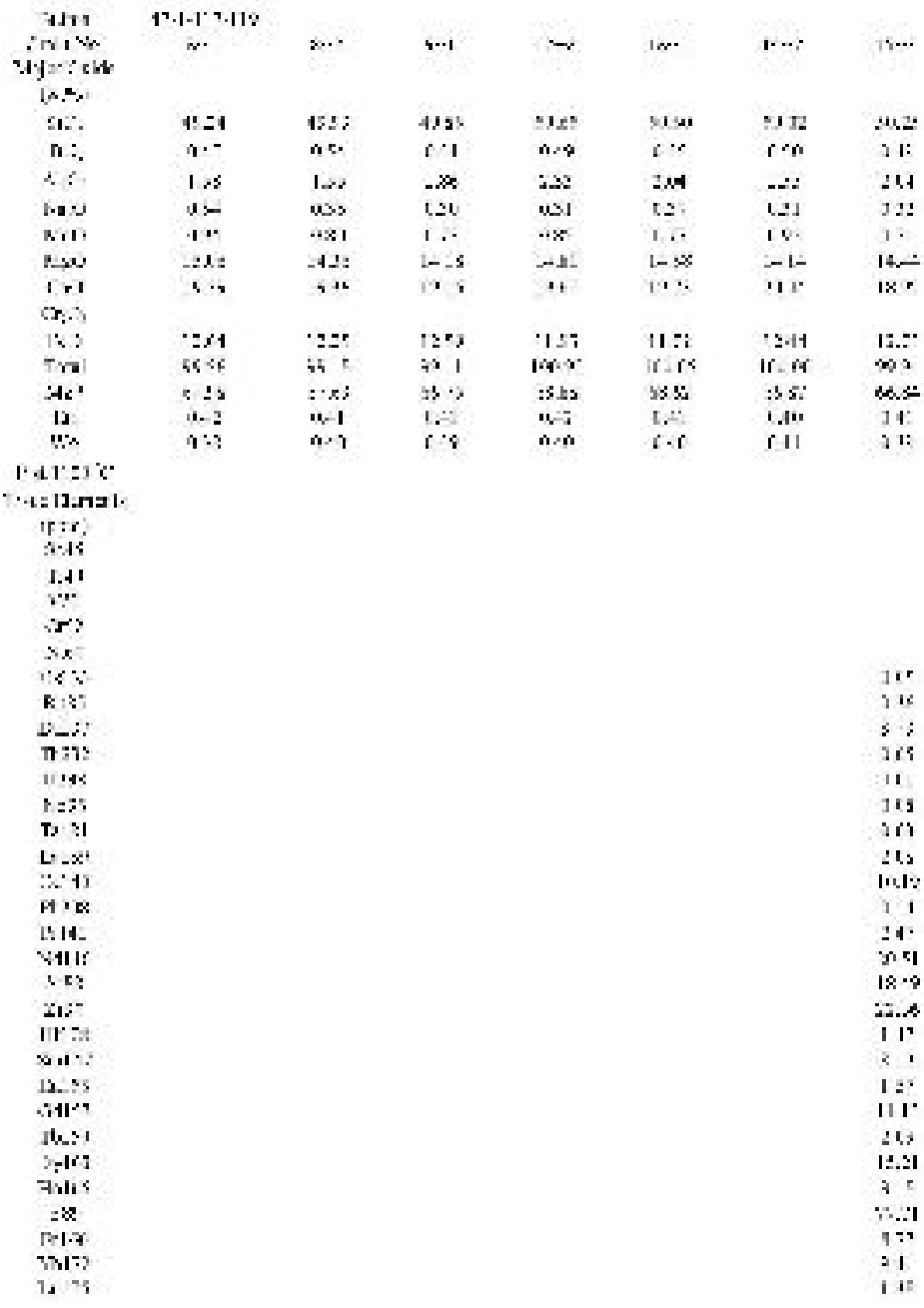




\begin{tabular}{|c|c|c|c|c|c|c|c|c|}
\hline \multicolumn{9}{|c|}{$49-1-24-23$} \\
\hline frovin wh. & $16-3$ & $\therefore-1$ & $18 x-1$ & $54-7$ & son: & -4 & $2-1$ & $x-3$ \\
\hline \multicolumn{9}{|l|}{ uyer osh } \\
\hline \multicolumn{9}{|l|}{ Inrs: } \\
\hline sei & suve & 23.45 & 48.15 & 213 & 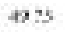 & 5207 & 5031 & 5105 \\
\hline 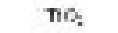 & 257 & $9=9$ & 071 & $0 \Leftrightarrow$ & pis & 653 & a 37 & 241 \\
\hline$A \cdot \gamma_{7}$ & 157 & 96 & 633 & $15 \%$ & 87 & to & 7) 4 & $x / 8$ \\
\hline $\mathrm{Na}: 0$ & 323 & $x 25$ & Q.1? & 031 & 0.6 & 12 & 129 & 631 \\
\hline$M a n$ & 351 & 275 & 893 & $0 \% 6$ & $6 x$ & t. 1. & 128 & 5.46 \\
\hline Ntopo & 14.23 & 2946 & 19.95 & 13.85 & 1322 & tons & $1 \leq A 0$ & 16.99 \\
\hline$\infty$ & $18 \times 8$ & 323 & 2217 & 1514 & 1836 & 1802 & 1991 & 1643 \\
\hline$a s$ & & & & & & & 300 & \\
\hline no & 12.00 & 7.22 & 601 & 12st & $1-11$ & touc & 34 & 11.50 \\
\hline Tal & $\mathrm{ICJ} \mathrm{CH}$ & 5235 & 35.12 & 527 & 10655 & $m: t$ & $m .5$ & nat: \\
\hline $\mathrm{Me}+4$ & a.5 & Si 73 & 1245 & 6553 & 5193 & 35 & 74.73 & 7189 \\
\hline $\mathrm{En}$ & 3.13 & $a=3$ & eas & $\infty 9$ & 628 & t.A2 & $3 \mathrm{H}$ & 6.47 \\
\hline Wh & $\Delta 3$ & $a n$ & 045 & $0+0$ & 0.18 & 635 & xil & 634 \\
\hline \multicolumn{9}{|l|}{ 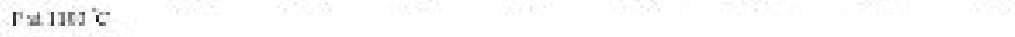 } \\
\hline \multirow{2}{*}{\multicolumn{9}{|c|}{$\begin{array}{c}\text { Tsoe lanats } \\
\text { ffer? }\end{array}$}} \\
\hline & & & & & & & & \\
\hline 4015 & & & & & & & 3915 & \\
\hline Tit & & & & & & & 577468 & \\
\hline vs1 & & & & & & & 135.98 & \\
\hline $\mathrm{Cr} 3$ & & & & & & & $52 \pi$ & \\
\hline $\operatorname{Nax}$ & & & & & & & 40.25 & \\
\hline $\mathrm{r} \times \mathrm{i}$ & & & & & & & $2 \omega$ & \\
\hline Rt 15 & & & & & & & 260 & \\
\hline Bas? & & & & & & & 3.04 & \\
\hline \multicolumn{9}{|l|}{ Thers? } \\
\hline \multicolumn{9}{|l|}{ L2נs } \\
\hline \multicolumn{9}{|l|}{$\mathrm{x}=53$} \\
\hline Tatsi & & & & & & & xe & \\
\hline Lisy & & & & & & & 310 & \\
\hline Cost3 & & & & & & & 391 & \\
\hline Ftors & & & & & & & 260 & \\
\hline 12:14: & & & & & & & 326 & \\
\hline Wiste & & & & & & & 236 & \\
\hline Sirss & & & & & & & 18.15 & \\
\hline $2 \mathbf{n s t}$ & & & & & & & 4.19 & \\
\hline $\mathrm{Hr} \times \mathrm{s}$ & & & & & & & 278 & \\
\hline $\operatorname{san} 172$ & & & & & & & 1.00 & \\
\hline Euls3 & & & & & & & 33 & \\
\hline QAis: & & & & & & & 116 & \\
\hline Tou:3 & & & & & & & 327 & \\
\hline Dylea & & & & & & & 200 & \\
\hline Hairs & & & & & & & 241 & \\
\hline ve: & & & & & & & 1045 & \\
\hline Elat & & & & & & & 119 & \\
\hline ทатב & & & & & & & 134 & \\
\hline 1 silt5 & & & & & & & atit & \\
\hline
\end{tabular}




\begin{tabular}{|c|c|c|c|c|c|c|c|c|}
\hline 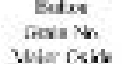 & $2-2$ & $5 \cdot 4$ & $6-2$ & $\% \alpha$ & $5-5$ & +3 & $35-1$ & $13-1$ \\
\hline \multicolumn{9}{|l|}{$\begin{array}{c}\text { Myar osk } \\
\text { inms. }\end{array}$} \\
\hline sis; & $2 t \leq 4$ & 21 ate & 9230 & $93 \times 3$ & 429 & 30.24 & $\$ 0.99$ & 2008 \\
\hline no: & 951 & $0: 8$ & 091 & $\theta \omega$ & pes & cif & 24 & sa \\
\hline$n b \alpha_{7}$ & 216 & $8 * 0$ & 200 & $\cos \theta$ & $4: 3$ & 350 & 337 & dis \\
\hline $\mathrm{Na}: 0$ & 924 & $\omega x$ & $6 z 2$ & $\alpha 2=$ & 622 & tas & 310 & e.29 \\
\hline$M a$ & $9 z i$ & WOO & 002 & a.s & $60 \%$ & 51. & 121 & 422 \\
\hline Atpo & 1928 & ניבג & use & LS:5 & ISLS & 14.2 & 1214 & $18+4$ \\
\hline$\infty 0$ & 530 & $2+62$ & 226 & 2115 & 3130 & sil 51 & 3013 & 310 \\
\hline$a_{0} \mathrm{O}$ & & & 025 & $\alpha>0$ & 0.12 & & & 9.34 \\
\hline No & 731 & 2.50 & s.ss & 67 & ext & 15: & 525 & $6 \mu$ \\
\hline Tal & 6.71 & 5232 & $100.1 \%$ & 20.17 & xะ $2 ?$ & $m .30$ & nose & $t \omega .3 t$ \\
\hline $\mathrm{Stg}+4$ & is.17 & 79 & 3134 & 4053 & $912 ?$ & 89 & 81.20 & sis? \\
\hline $\mathrm{Er}$ & $0+4$ & $0+4$ & ear & 025 & 644 & {$[.4]$} & 2.45 & 9.4 \\
\hline Wh & 9 in & $0-1$ & 645 & 010 & 64 & 60 & 215 & $8+5$ \\
\hline radistic & $\therefore 2 z$ & & 1.72 & $2 *$ & $2.8 \%$ & & 268 & $3 \pi$ \\
\hline \multicolumn{9}{|l|}{$\begin{array}{c}\text { 1sue IJariats } \\
\text { ipgr: }\end{array}$} \\
\hline$\leqslant 45$ & & & $1120 \%$ & iss in & 1Stst & & & 13601 \\
\hline Th & & & 1671 46 & $27 \times 53$ & $28 \times 55$ & & & jwstis \\
\hline v31 & & & 280.12 & $34.2 x$ & 373.19 & & & 3793 \\
\hline $\mathrm{c}: 3$ & & & 174134 & 17505 & seli11 & & & 96559 \\
\hline Nor & & & $148 x$ & $10 \times, w$ & 10453 & & & tats \\
\hline $\operatorname{coss}$ & & & & & & & & $\theta \mu$ \\
\hline R:35 & & & & & & & & 406 \\
\hline Das? & & & & 000 & & & & axt \\
\hline This: & & & o01 & & & & & $2 x$ \\
\hline 10233 & & & 001 & & & & & \\
\hline Noss & & & wat & & 601 & & & \\
\hline $\mathrm{Ta} 3 \mathrm{si}$ & & & & 091 & $\mathrm{en}$ & & & an \\
\hline 127 & & & $0 \mathrm{~s}$ & $\operatorname{ain}$ & mi & & & 40 \\
\hline $\mathrm{Cel} 43$ & & & 0.ss & $0<1$ & 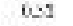 & & & 42 \\
\hline Ftsis & & & 001 & & nou & & & 460 \\
\hline 1914: & & & vors & 015 & 0.12 & & & 4.19 \\
\hline Mal4t & & & ast & 1.22 & 1.10 & & & tet \\
\hline 5,53 & & & 1205 & 1253 & 1830 & & & 13,4: \\
\hline $2.5 t$ & & & 152 & 4.61 & 420 & & & $39 t$ \\
\hline IIT 9 & & & 015 & $a s ;$ & a:t & & & ובם \\
\hline Swit? & & & 643 & $a m$ & $6 n$ & & & $a \leq 3$ \\
\hline Eulys & & & 6.14 & 031 & 626 & & & alt \\
\hline Gasis? & & & 077 & 18 & 117 & & & $4 \pi$ \\
\hline Thist & & & O12 & $a s$ & nßs & & & 417 \\
\hline$D ; 163$ & & & uss & 167 & 1.76 & & & $13 t$ \\
\hline Bales & & & 022 & $a b 5$ & $03 i$ & & & 435 \\
\hline$\$$ & & & 5.12 & 811 & 8.1: & & & 6.35 \\
\hline $121<6$ & & & $\omega s t$ & 1000 & 1000 & & & set \\
\hline עalt] & & & $\Delta s$ & $\alpha z$ & ass: & & & 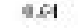 \\
\hline Laits & & & oas & a.12 & 0.12 & & & 9.5 \\
\hline
\end{tabular}




\begin{tabular}{|c|c|c|c|c|c|c|c|}
\hline \multirow{2}{*}{$\begin{array}{l}\text { Eutue } \\
\text { Foria in }\end{array}$} & \multicolumn{3}{|c|}{ ax-1zz-134 } & \multirow[b]{2}{*}{$2-2$} & \multirow[b]{2}{*}{$k-1$} & \multirow[b]{2}{*}{$10-2$} & \multirow[b]{2}{*}{$11-t$} \\
\hline & $34-3$ & $t-1$ & $2-2$ & & & & \\
\hline \multirow{2}{*}{\multicolumn{8}{|c|}{$\begin{array}{c}\text { Myer robu } \\
\text { morst }\end{array}$}} \\
\hline & & & & & & & \\
\hline sैe; & $\therefore x a$ & 31,97 & 52.12 & 20 & $2: 5 s$ & 9036 & 5217 \\
\hline $\mathrm{na}$ & $9+3$ & 250 & itit & 055 & $9<5$ & CAt & 021 \\
\hline$n b \alpha_{7}$ & $;>3$ & $73 x$ & 23 & ; a: & 501 & xis & 791 \\
\hline $\mathrm{N} 4: 0$ & 021 & $12 x$ & 428 & $\alpha s=$ & 223 & $\cos$ & $0=1$ \\
\hline $\mathrm{Man}$ & $0 \times 3$ & ats & 4.52 & $0.5=$ & $a=0$ & 5.45 & $00<$ \\
\hline Ntpo & 12.12 & 1611 & 162 & 19.76 & Iex. & W. & 16.45 \\
\hline$\infty 0$ & 5.67 & 210 & 1918 & 1780 & 312 & $18 \Leftrightarrow$ & 2205 \\
\hline $\mathrm{Cr}_{3}$ & & & & & & & 0.16 \\
\hline No & $6 x 5$ & 5 & 537 & 1:3: & s:s: & wast & 0.15 \\
\hline Tal & 621 & acose & 1613 & 10012 & lons: & 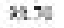 & $1000 \%$ \\
\hline $\mathrm{Stg}+4$ & sate & $x \neq 3$ & 771 & 7.35 & $x+27$ & 7323 & 8253 \\
\hline $\mathrm{Er}$ & 0.45 & 1.92 & $44^{7}$ & a-4s & $a=5$ & c.43 & 0.46 \\
\hline Wh & an & 317 & 435 & 932 & 9.1 & c18 & Q45 \\
\hline radistic & as: & 27 & 255 & & 1.22 & & ang \\
\hline \multicolumn{8}{|l|}{$\begin{array}{l}\text { 1soe IJariats } \\
\text { iper: }\end{array}$} \\
\hline 5015 & & & & & & & 1468 \\
\hline TiA & & & & & & & 2isic \\
\hline v31 & & & & & & & 30431 \\
\hline $\mathrm{c}: 3$ & & & & & & & lames: \\
\hline Nox & & & & & & & 12820 \\
\hline c25s & & & & & & & \\
\hline R:35 & & & & & & & 008 \\
\hline Das? & & & & & & & \\
\hline This: & & & & & & & \\
\hline 10233 & & & & & & & \\
\hline Noss & & & & & & & wet \\
\hline$T_{a} \mid 31$ & & & & & & & \\
\hline $12 \%$ & & & & & & & ain \\
\hline $\mathrm{Col} 4 \mathrm{~s}$ & & & & & & & 0.41 \\
\hline DtN3Is & & & & & & & 00 \\
\hline 1214: & & & & & & & 0.11 \\
\hline Mal4t & & & & & & & 0000 \\
\hline 5,53 & & & & & & & 13.35 \\
\hline 2.56 & & & & & & & sus \\
\hline IIT 9 & & & & & & & 0.29 \\
\hline Sald? & & & & & & & oris \\
\hline Eulys & & & & & & & $0=1$ \\
\hline Gas: & & & & & & & $0 \infty_{0}$ \\
\hline Thist & & & & & & & $0 \mid \mathrm{I}$ \\
\hline$D ; 163$ & & & & & & & 1.13 \\
\hline Bales & & & & & & & 093 \\
\hline 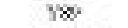 & & & & & & & $6 \leq 8$ \\
\hline $121<6$ & & & & & & & $a \pi$ \\
\hline ที丶 & & & & & & & Wers \\
\hline Lins & & & & & & & 0.10 \\
\hline
\end{tabular}




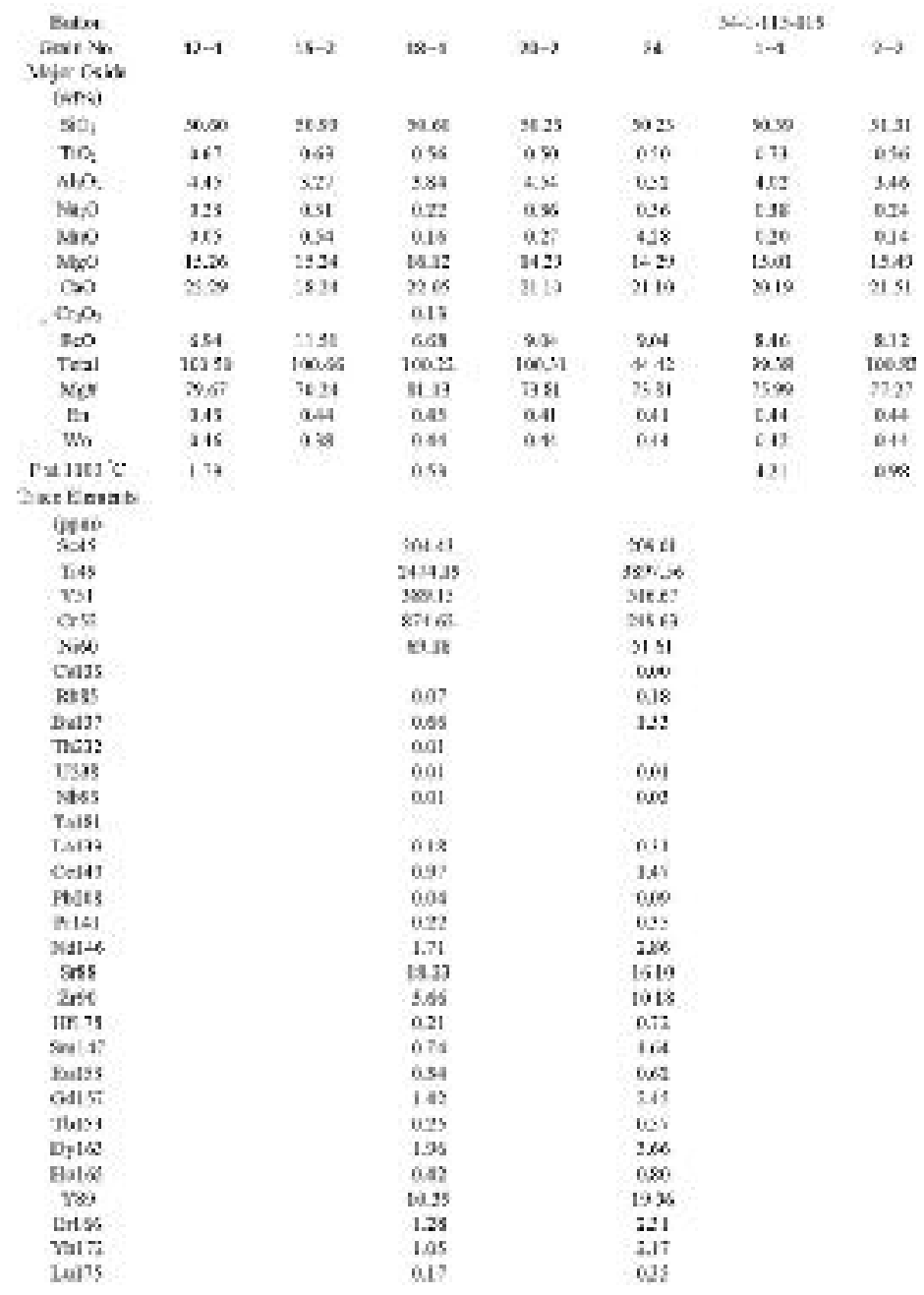




\begin{tabular}{|c|c|c|c|c|c|c|c|c|}
\hline $\begin{array}{l}\text { Eatxe } \\
\text { Farie th. }\end{array}$ & & $25-2$ \\
\hline \multicolumn{9}{|l|}{$x y=r<b y$} \\
\hline \multicolumn{9}{|l|}{ In $r$ s. } \\
\hline *ैंड & 2003 & 9333 & 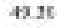 & 9195 & 139 & $a=7$ & 49.10 & 49.52 \\
\hline no: & 258 & $9+1$ & 00 & $0 \%$ & pat & {$[6]$} & 253 & $4 \leq 1$ \\
\hline$A b \gamma_{7}$ & 195 & 214 & $1 \omega 1$ & $3 * 8$ & $6 \%$ & 312 & $37 t$ & 487 \\
\hline Na:0 & $32 ?$ & 217 & 0.36 & $0 z$ & 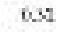 & [3] & 132 & ast \\
\hline$M a n$ & $36 ?$ & a1? & 627 & 02 & 0.11 & t9: & 3) & 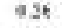 \\
\hline Atpo & $14: 4$ & $: 517$ & 24.25 & L: $: 3$ & $4 x$ & $1-20$ & 14_S1 & 14.10 \\
\hline$\infty 0$ & 361 & 3274 & 201 & 2372 & $215 ;$ & 1900 & $\$ 16 t$ & $19 \%$ \\
\hline 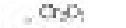 & & 94 & & & 0.6 & & & \\
\hline No & $7 A 2$ & 30 & 5.00 & 2.18 & 635 & tors & 350 & 11.00 \\
\hline Taal & cesss & 101.10 & $n \in 2$ & 16ed: & 5231 & $m: 1$ & $\operatorname{sen}$ & $t \in 21$ \\
\hline $\mathrm{xtg}+4$ & $x \geqslant 2$ & 54.78 & $72 \leqslant 2$ & 75 & $5+30$ & vat & ient & wis \\
\hline $\mathrm{Er}$ & 3.22 & $a v 0$ & Dal & $a=4$ & 64 & [A. & 34 & QAt \\
\hline Wh & 215 & $9=1$ & EAt & 04 & 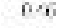 & (1) & 214 & 81 \\
\hline radiuts & 232 & tos & & $1 \%$ & 6.0 & & & \\
\hline \multicolumn{9}{|l|}{$\begin{array}{c}\text { Tsee laxiats } \\
\text { iper: }\end{array}$} \\
\hline 515 & & $5+18$ & & & 15343 & & & \\
\hline Tis & & $813 \%$ & & & $351 \times 00$ & & & \\
\hline vsi & & $1020 x$ & & & $3]: 24$ & & & \\
\hline$\infty 3$ & & 1621 is & & & $315 ; 56$ & & & \\
\hline \multirow{2}{*}{\multicolumn{9}{|c|}{ coss }} \\
\hline & & & & & & & & \\
\hline R:35 & & $\begin{array}{l}997 \\
0.12\end{array}$ & & & 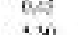 & & & \\
\hline $\begin{array}{l}\text { Dals? } \\
\text { moje }\end{array}$ & & 0.12 & & & $\begin{array}{ll}2 w \\
\text { con }\end{array}$ & & & \\
\hline $\begin{array}{l}\text { This: } \\
17233\end{array}$ & & & & & $6 x$ & & & \\
\hline Nass & & wit & & & wes & & & \\
\hline \multicolumn{9}{|l|}{$\mathrm{Ta} / 31$} \\
\hline $12 \%$ & & $\operatorname{an}$ & & & $1 \%$ & & & \\
\hline $\operatorname{Cel} 143$ & & 200 & & & 4.74 & & & \\
\hline Ftsis & & 901 & & & 011 & & & \\
\hline 1414: & & $w ?$ & & & $w 0$ & & & \\
\hline MdIAt & & aso & & & $2-4$ & & & \\
\hline Sr5s & & 2273 & & & 232 & & & \\
\hline $2 \mathrm{nst}$ & & $u=7$ & & & 4355 & & & \\
\hline IIT 9 & & aas & & & a.7 & & & \\
\hline Swali? & & 025 & & & 108 & & & \\
\hline Eulys & & $\omega n$ & & & wes. & & & \\
\hline Casis? & & $9 \div 2$ & & & $3<1$ & & & \\
\hline Thist & & $9 x$ & & & nes & & & \\
\hline Dy 163 & & 13! & & & $2 x$ & & & \\
\hline Bal65 & & $99 ?$ & & & $\log _{531}$ & & & \\
\hline $10 \%$ & & $\begin{array}{l}210 \\
2.25\end{array}$ & & & $\begin{array}{l}1531 \\
1 x\end{array}$ & & & \\
\hline ทat? & & a.18 & & & $1, \times 8$ & & & \\
\hline Lins & & a9s & & & $a x$ & & & \\
\hline
\end{tabular}




\begin{tabular}{|c|c|c|c|c|c|c|c|c|}
\hline 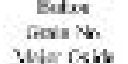 & $33-1$ & $2 k-1$ & $n+-1$ & kt -9 & $\omega-i$ & $\operatorname{sen} 2$ & 230 & $2 a-1$ \\
\hline \multicolumn{8}{|l|}{ Myer rab } & $\ln m \mathrm{n}$ \\
\hline अंड़; & $40 / 6$ & 2557 & $2 b x$ & 9233 & 5035 & $\operatorname{saz}$ & 4235 & 31.53 \\
\hline$n \infty$ & 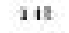 & $9: 1$ & 065 & $0<5$ & 086 & 655 & 261 & ats \\
\hline$A b \alpha_{7}$ & $s i ?$ & 275 & 824 & 191 & 416 & 59 & 189 & 257 \\
\hline $\mathrm{Na}: 0$ & 322 & ast & 09 ? & $0 \times s$ & 61 & 121 & 129 & 4.19 \\
\hline$M a n$ & $3-5$ & $\theta=?$ & 0.52 & 040 & $0 \leq 5$ & 5.84 & 368 & 425 \\
\hline Atpo & 14.78 & 2986 & $29 \mu$ & 1584 & $12 \pi$ & 1.xo & 14.AT & 16.72 \\
\hline$\infty$ & 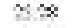 & 536 & $3 * 11$ & 196 & 320 & 1821 & 3066 & $37 \%$ \\
\hline \multicolumn{9}{|l|}{$a s$} \\
\hline No & 45 & st 25 & 18.11 & 2.16 & $8 w^{\prime}$ & 11.2 & 524 & 497 \\
\hline Tal & 16ב 15 & touts & tons? & 1600.15 & $m \geq$ & $\operatorname{man}$ & $m=$ & tenat \\
\hline $\mathrm{xtg}+4$ & $8: 34$ & 72.48 & 794 & 7571 & 758 & $1 \times 2$ & 1800 & $8 \times 13$ \\
\hline $\mathrm{Er}$ & 3.45 & $a+4$ & 0.44 & $a \pm 6$ & 641 & t.A1 & 342 & 47 \\
\hline Wh & $2 \mathrm{is}$ & $a \approx$ & 60 & $\theta=0$ & $\mathrm{CAt}^{2}$ & 675 & 247 & 846 \\
\hline radistic & 552 & & & 212 & 223 & & 250 & 4.05 \\
\hline \multirow{2}{*}{\multicolumn{9}{|c|}{$\begin{array}{l}\text { Tsee laxiate } \\
\text { iper: }\end{array}$}} \\
\hline & & & & & & & & \\
\hline \multirow{2}{*}{\multicolumn{9}{|c|}{$\begin{array}{l}\text { Sals } \\
\text { Tit }\end{array}$}} \\
\hline \multirow{2}{*}{\multicolumn{9}{|c|}{ vst }} \\
\hline \multirow{2}{*}{\multicolumn{9}{|c|}{ ais }} \\
\hline Nox & & & & & & & & \\
\hline c25s & & & & & & & & \\
\hline \multirow{2}{*}{\multicolumn{9}{|c|}{ R:35 }} \\
\hline \multirow{2}{*}{\multicolumn{9}{|c|}{ Dess? }} \\
\hline \multirow{2}{*}{\multicolumn{9}{|c|}{ Twis }} \\
\hline \multirow{2}{*}{\multicolumn{8}{|c|}{17233}} & \\
\hline \multirow{2}{*}{\multicolumn{8}{|c|}{ Noss }} & \\
\hline \multirow{2}{*}{\multicolumn{8}{|c|}{$\begin{array}{l}\text { Talsi } \\
12: \Rightarrow\end{array}$}} & \\
\hline \multirow{2}{*}{\multicolumn{9}{|c|}{ Cels? }} \\
\hline & & & & & & & & \\
\hline \multicolumn{9}{|l|}{ Dtuxs } \\
\hline \multicolumn{9}{|l|}{ 1914: } \\
\hline \multirow{2}{*}{\multicolumn{9}{|c|}{$\begin{array}{l}31140 \\
\text { Srs! }\end{array}$}} \\
\hline & & & & & & & & \\
\hline \multicolumn{9}{|l|}{$2 \mathbf{r 5 t}$} \\
\hline \multicolumn{9}{|l|}{ IIr $\%$} \\
\hline \multicolumn{9}{|l|}{ Sould? } \\
\hline \multirow{2}{*}{\multicolumn{9}{|c|}{$\begin{array}{l}\text { Eulys } \\
\text { Cals? }\end{array}$}} \\
\hline & & & & & & & & \\
\hline $\begin{array}{l}\text { Thist } \\
\text { Dis } 163\end{array}$ & & & & & & & & \\
\hline $\begin{array}{l}\text { Dited } \\
\text { Bales }\end{array}$ & & & & & & & & \\
\hline $\begin{array}{l}\text { Bales } \\
\text { Yos }\end{array}$ & & & & & & & & \\
\hline $12 \times 1<6$ & & & & & & & & \\
\hline ทа⿰工 & & & & & & & & \\
\hline Lins & & & & & & & & \\
\hline
\end{tabular}




\begin{tabular}{|c|c|c|c|c|c|c|c|c|}
\hline Eetes & $24-1-143-103$ & & & & & & & \\
\hline ferar sol & $3+1$ & $2-1$ & $6-2 x$ & $6 \cdots$ & $x-2$ & $2-2$ & $4-1$ & $16-3$ \\
\hline \multicolumn{9}{|l|}{$\begin{array}{c}\text { Wyar row } \\
\text { Int-i) }\end{array}$} \\
\hline 5) & $\therefore \%$ & 2356 & 91.4 & 95.33 & 507 & 3.28 & 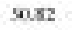 & 405: \\
\hline no. & 251 & $0 \times$ & 641 & 025 & eti & 678 & 37 & 443 \\
\hline 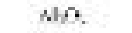 & 243 & zis & 1.95 & 4.20 & 228 & (s) & 44 & 126 \\
\hline Ne:0 & 354 & $05 ?$ & 023 & 0.18 & 6.11 & [9] & 3.14 & b12 \\
\hline$M a n$ & 127 & $0 n$ & 065 & ats & 0.1 & (5) & 316 & 6.1! \\
\hline Ntbo & $14 x 8$ & 2454 & 2930 & $12: 2$ & 1392 & $12: \pi$ & 10.35 & 15.3 \\
\hline$\infty 0$ & 5612 & 287 & $3 * \pi$ & 3231 & $31 \geqslant 0$ & Sibit & Yist & 30 \\
\hline \multicolumn{9}{|l|}{$\alpha ; \sigma_{3}$} \\
\hline $\mathrm{r}=0$ & 927 & $\therefore 14$ & 78.15 & ast & 722 & 105 & בד 5 & 501 \\
\hline Teal & 6.12 & 10000 & tonss & $55 !$ & $16 c 23$ & $m x$ & :2019 & mat \\
\hline $36=4$ & 71,06 & Q956 & $79 \%$ & 8261 & 322 & roin & 850 & 7500 \\
\hline tat & 343 & ars & 0.45 & ass & 0.44 & 5.10 & 346 & 61 \\
\hline Wh & 212 & $0 \%$ & 611 & ats & 0.44 & c 11 & 316 & 643 \\
\hline $\mathrm{r} \times 1 \mathrm{~s}$ (c) & & & & ai & 64 & & 185 & \\
\hline \multicolumn{9}{|l|}{$\begin{array}{c}\text { Dor Enat } \\
\text { fuste }\end{array}$} \\
\hline que & & & 165 Es? & & & & & \\
\hline Thes & & & 12,40 & & & & & \\
\hline$v s 1$ & & & 53555 & & & & & \\
\hline बr: & & & 138 & & & & & \\
\hline $\mathrm{NiN}$ & & & 27.4 & & & & & \\
\hline cass & & & ves & & & & & \\
\hline R:35 & & & 019 & & & & & \\
\hline Das? & & & 1.45 & & & & & \\
\hline This: & & & oes & & & & & \\
\hline 1033 & & & 0.1 & & & & & \\
\hline Noss & & & oes & & & & & \\
\hline Ta151 & & & 649 & & & & & \\
\hline TAsiti & & & 874 & & & & & \\
\hline Cests & & & בבד19 & & & & & \\
\hline Ftats & & & 0.22 & & & & & \\
\hline$A \geq 1$ & & & $2 n$ & & & & & \\
\hline Mal4t & & & 22.8 & & & & & \\
\hline Sns! & & & 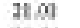 & & & & & \\
\hline $205 t$ & & & $11 \mu$ & & & & & \\
\hline IIT יר & & & 1.99 & & & & & \\
\hline Sol 1 ? & & & 532 & & & & & \\
\hline Eul9s & & & 1.A2 & & & & & \\
\hline colst & & & 657 & & & & & \\
\hline Thes:4 & & & 1.63 & & & & & \\
\hline$D y 163$ & & & $8=1$ & & & & & \\
\hline Elals & & & 162 & & & & & \\
\hline re: & & & tos & & & & & \\
\hline Litss & & & 4.43 & & & & & \\
\hline ทalา & & & +51 & & & & & \\
\hline Lul15 & & & 0.0 & & & & & \\
\hline
\end{tabular}




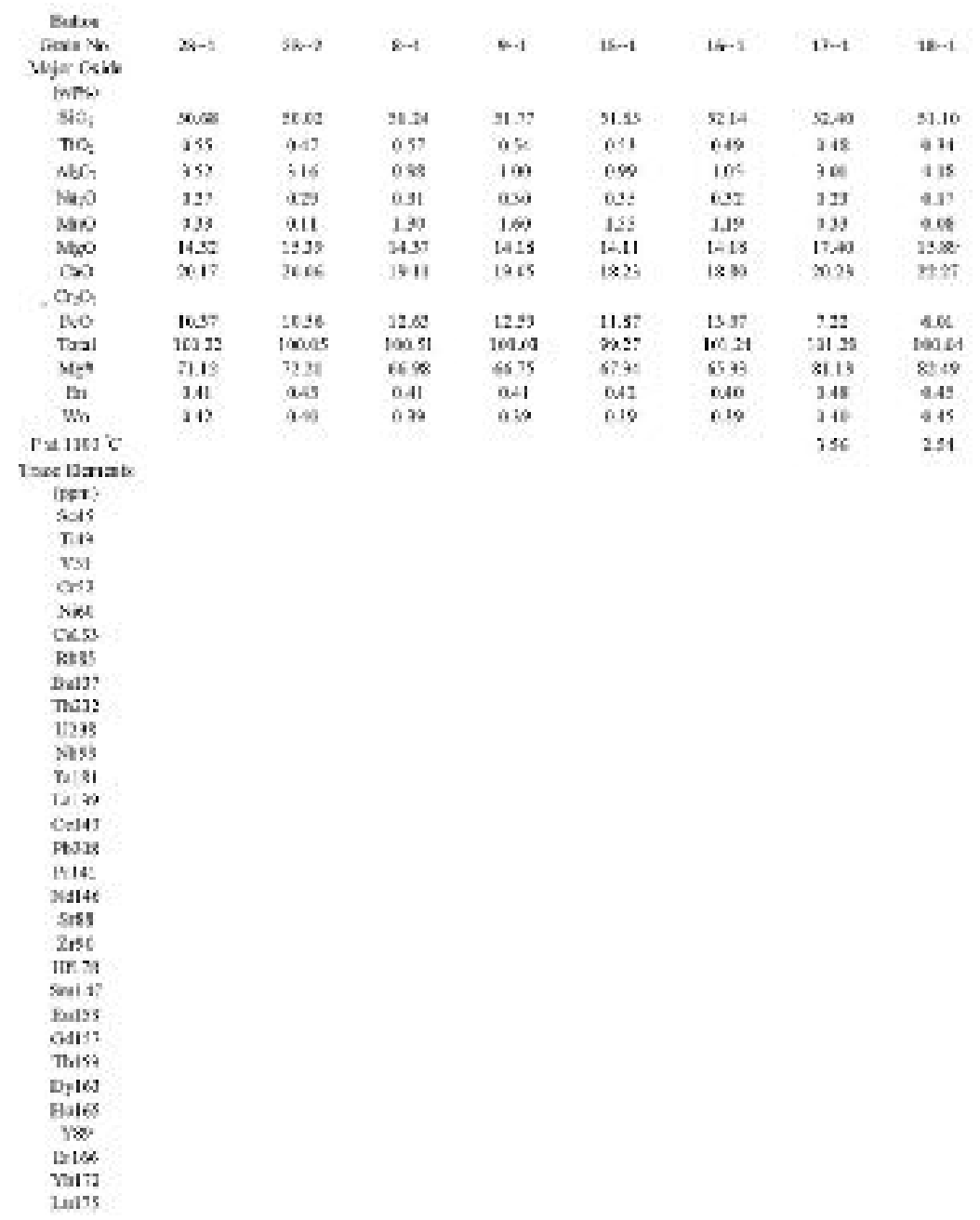




\begin{tabular}{|c|c|c|c|c|c|c|c|c|}
\hline Eutus & $9+2-23-20$ & & & & & & & \\
\hline Gervin No & $k=1$ & $8 \cdot 2$ & int-2 & $n t-3$ & $18-2$ & $16 \cdot 2$ & $15-1$ & $13 \cdot 4$ \\
\hline Wher robl & & & & & & & & \\
\hline Inrs: & & & & & & & & \\
\hline sैं; & נבנ2 & 1536 & 2354 & $2 t \leq t$ & 9163 & $31 \% 0$ & 20.24 & 40.3 \\
\hline no: & 277 & 983 & 053 & 09 & $9: 8$ & 617 & 254 & $\Delta 6$ \\
\hline$N b_{7}$ & 137 & $6 \times 5$ & 120 & 205 & $; 18$ & 36 & 204 & 55 \\
\hline $\mathrm{N} 4: 0$ & 315 & $x=28$ & 6.16 & $\alpha=21$ & $\alpha z$ & I & 137 & 4.12 \\
\hline Man & 313 & a.s & 025 & $\omega \omega$ & we & 524 & 132 & 4.38 \\
\hline Ntbo & 1724 & 312 & Is.]t & 12.31 & 2529 & Iove & IS.1.5 & 1S.AS \\
\hline$\infty 0$ & $\$ 245$ & 3173 & 2354 & 326 & $21: 7$ & 시 $\pi$ & $\geqslant x$ & 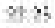 \\
\hline$a_{0} \mathrm{O}$ & 135 & 225 & e.45 & $\alpha>0$ & & {$[186$} & & \\
\hline No & 512 & $i \infty$ & 3.55 & 7.12 & $x a$ & $5 x]$ & 2.42 & 5.93 \\
\hline Taal & $\mathrm{K} . \mathrm{T}$ & 52.78 & $106 . x t$ & $\tan \theta=$ & lonsos & $162 \leq 1$ & :20is & $\%, 7$ \\
\hline $\mathrm{St}_{\mathrm{g}} \mathrm{t}$ & $8 \times 8$ & 7584 & F) 14 & 7973 & 7185 & soi.s & 36.22 & $8 \div 5:$ \\
\hline $\mathrm{ta}$ & 333 & $a-2$ & Q47) & $a=2$ & $a=2$ & {$[.42$} & $3 \mathrm{H}$ & 249 \\
\hline Wh & 215 & $9=15$ & 045 & 045 & $0=1$ & $6+1$ & 217 & 44 \\
\hline ratiste & 211 & 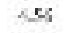 & & $10 t$ & & נגנ & 730 & 43: \\
\hline $\begin{array}{c}\text { Tsee lariats } \\
\text { Iper: }\end{array}$ & & & & & & & & \\
\hline 5015 & $1 \times 75$ & 185 & $x \in$ & $\sin a i$ & & $185 \leq 5$ & & \\
\hline Tit & ien II & 155565 & 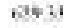 & 39619 & & $23 \times 58$ & & \\
\hline v31 & $2 \times 5.75$ & $5: 4,00$ & 5.84 & 3420. & & 42718 & & \\
\hline $\mathrm{Cr}$ & 216155 & 152265 & 105759 & $1312 \times$ & & 2115 & & \\
\hline Nakt & $-5 x \cdot 3$ & leos.s & $1 \times 1, A]$ & 64 & & $i 2 n c$ & & \\
\hline cess & & & & 001 & & & & \\
\hline R:35 & 317 & 925 & 005 & 001 & & 234 & & \\
\hline Das? & 151 & ang. & & & & 2.45 & & \\
\hline This: & 221 & & 601 & & & & & \\
\hline 1233 & & & 005 & & & 60 & & \\
\hline N53 & 332 & 201 & & $\omega 0 \mathrm{c}$ & & tes & & \\
\hline $\mathrm{Ta}: 31$ & & & & & & & & \\
\hline $12 \pi$ & at & $9: 7$ & nay & 012 & & 617 & & \\
\hline $\cos 143$ & 35t & $1 \times 3$ & 024 & $\omega \theta$ & & 0.0 & & \\
\hline Dt313 & ב ב ב & 991 & 005 & an & & [1] & & \\
\hline 1414: & 313 & $\cos$ & was & ar: & & t 13 & & \\
\hline MAIAt & 333 & 222 & 042 & 130 & & $\therefore .10$ & & \\
\hline 5,53 & $15 \% 5$ & כבנג & 1734 & 36 & & $1: \infty$ & & \\
\hline $2 n 5 t$ & 154 & 8.52 & Q45 & $3 *$ & & $2 \pm 3$ & & \\
\hline IIF 9 & 235 & 262 & ant & $a: 2$ & & [A] & & \\
\hline Swill? & 296 & 105 & 613 & 0.5 & & in & & \\
\hline Eulys & 313 & $a \rightarrow 1$ & oas & 0.38 & & 619 & & \\
\hline Gas? & 277 & $1 \neq 0$ & 025 & $\operatorname{lin}$ & & 36 & & \\
\hline Thist & רגב & $a \geqslant$ & 6at & $a>5$ & & $c \leqslant 0$ & & \\
\hline$D ; \xi 163$ & 351 & 1.92 & us2 & 1,16 & & 200 & & \\
\hline Bales & 313 & $\operatorname{anz}$ & 005 & $0: 1$ & & 631 & & \\
\hline $1 \times$ & 262 & (4) & $1 . x 2$ & $\%$ & & 8.78 & & \\
\hline $121<6$ & 333 & 1.04 & ats & $a x y$ & & $1: 5$ & & \\
\hline ทั17 & 237 & 190 & was & $a x^{*}$ & & ne & & \\
\hline Laivs & 334 & a.15 & oas & 0.19 & & 5.11 & & \\
\hline
\end{tabular}




\begin{tabular}{|c|c|c|c|c|c|c|c|c|}
\hline \multicolumn{9}{|l|}{ Butse } \\
\hline \multicolumn{9}{|l|}{$\begin{array}{l}\text { uyar rsw } \\
\text { inms. }\end{array}$} \\
\hline *ैंड; & $212 x$ & 2132 & 22.3 & $23: 3$ & 45.18 & s.s.4 & Selt2 & 3137. \\
\hline no: & 219 & 951 & 649 & $a+7$ & 0,1 & 678 & $2 \leqslant 5$ & 93 \\
\hline$N \in C_{7}$ & 395 & $; \infty$ & 42 & 305 & 68 & fs & 16 & $3 \pi$ \\
\hline $\mathrm{Na}, 0$ & 319 & 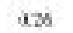 & 0.13 & 0.16 & 60 & tar & 12 & e. 1t \\
\hline Nan & $31 t$ & a.s & 024 & aL? & $6 w$ & 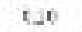 & 1.9 & 4.45 \\
\hline Atpo & les: & $: 9,46$ & $28,4 y$ & aיss & 13.52 & IX.21 & 18.72 & 28.11 \\
\hline$\infty$ & 5333 & 345 & $n \leq 4$ & 3215 & $\geqslant \geqslant 1 ?$ & $\leqslant x$ & $\$ 2 a$ & $n \leq 1$ \\
\hline$a_{0} 0$ & & & & ass & & t.15 & 305 & \\
\hline No & 431 & 7.13 & 432 & 3.85 & Q.12 & בגני & 5.3 & 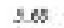 \\
\hline Tal Tal & 5021 & 100.8 & $100 \mathrm{As}$ & $1001 \%$ & mat & $152 a$ & 20017 & teach \\
\hline $\mathrm{St}_{5} \mathrm{C}$ & $8: 15$ & 74 & 85.7 & 8963 & $8 \%$ & wises & $8 \leqslant 05$ & 86.65 \\
\hline tai & 345 & $a+4$ & 647 & aso & 04: & t90 & 3.43 & 49 \\
\hline wh & I is & $9 \times 1$ & 645 & 615 & c.ts & C is & 245 & 446 \\
\hline radistic & 212 & $\therefore 11$ & 264 & 1.31 & Ads & .221 & $2 a t$ & 1.43 \\
\hline \multicolumn{9}{|l|}{$\begin{array}{l}\text { 1soe IJariats } \\
\text { iper: }\end{array}$} \\
\hline 5015 & & & & 66 & & $\times 14$ & s? 4 & \\
\hline TiA & & & & 107233 & & 67511 & 31965 & \\
\hline v31 & & & & $152 \omega \pi$ & & $x \in$ & $3 \times 93$ & \\
\hline $\mathrm{C}: 3$ & & & & 275292 & & $3>7526$ & $\sin 6$ & \\
\hline Nox & & & & mos & & $2918 ;$ & 4.90 & \\
\hline cess & & & & & & & 300 & \\
\hline R:35 & & & & axs & & $e x$ & 158 & \\
\hline Das? & & & & a.17 & & t.AS & 1.20 & \\
\hline muse & & & & & & [5: & 200 & \\
\hline 10233 & & & & 031 & & & 20 & \\
\hline Nos3 & & & & $a x$ & & $t x 2$ & 36 & \\
\hline \multicolumn{9}{|l|}{$T_{a}: 31$} \\
\hline 12 in & & & & $6:$ & & cis & 216 & \\
\hline Celas & & & & 0.56 & & CL 5 & 346 & \\
\hline Ftsis & & & & $0: 5$ & & 65 & 104 & \\
\hline 1214: & & & & was & & $t \pi$ & 132 & \\
\hline MalAt & & & & as & & ta: & 1.00 & \\
\hline 5.53 & & & & 3252 & & 1434 & 26.23 & \\
\hline $2 n s t$ & & & & 1.18 & & t. .4 & 566 & \\
\hline IIr $n$ & & & & 0.5 & & in & 311 & \\
\hline Swit? & & & & $0 \geqslant 2$ & & 10 & (4) & \\
\hline Eulys & & & & ats & & trs & 311 & \\
\hline Gals: & & & & $a b$ & & 635 & 39 & \\
\hline Thist & & & & ox & & $2 a$ & 215 & \\
\hline$D \xi 163$ & & & & $a+$ & & tas & 125 & \\
\hline Bales & & & & als & & tiss & 397 & \\
\hline 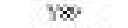 & & & & 2.6 & & -80 & 608 & \\
\hline $121<6$. & & & & a.3b & & tae & נד. & \\
\hline V) & & & & $a n$ & & cas & 267 & \\
\hline Laits & & & & $a x$ & & [I] & 306 & \\
\hline
\end{tabular}




\begin{tabular}{|c|c|c|c|c|c|c|c|c|}
\hline \multicolumn{6}{|l|}{ Eutes } & \multicolumn{3}{|c|}{$24 \cdot-24-25$} \\
\hline crovis in. & $26-1$ & $n-1$ & $=x-9$ & $n-2$ & $x-2$ & as -1 & $2-1$ & an-t \\
\hline \multicolumn{9}{|l|}{ Myer r s bu } \\
\hline \multicolumn{9}{|l|}{ Inrs: } \\
\hline *ैं। & 45.00 & $21 \mathrm{Al}$ & $92 \mathrm{nt}$ & 9322 & $2 \times 12$ & s.2. & ses? & 505 \\
\hline$n \in$ & 95 & $9 \div$ & 0.65 & $0<2$ & $\mathrm{BH}$ & 673 & 235 & 631 \\
\hline$n \cdot \theta_{7}$ & $5 \mathbf{2}=$ & 347 & 943 & 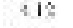 & $1 y^{2}$ & 357 & 334 & $3 \in t$ \\
\hline Ne:00 & 025 & 422 & 6.17 & $\alpha \vec{\alpha}$ & 0.16 & tat & 12) & 613 \\
\hline$M n$ & $02 s$ & $a 12$ & 0.65 & a.s & $6 \leq 6$ & t. & 315 & $\$ 11$ \\
\hline Ntpo & 1423 & $: 2.73$ & $17: 2$ & H:S & 1625 & $16 x$ & 16.52 & $18 \pi$ \\
\hline$\infty$ & 5.56 & 3245 & 230 & 2112 & $22 \%$ & Sos & 21.7 & 3) \\
\hline$a r$ & & & 0.35 & & 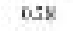 & & $11 x$ & 66 \\
\hline No & 815 & 8.15 & s.4? & 231 & $4 \pi 8$ & 1.00 & 935 & $2 A \varepsilon$ \\
\hline Tral & $\mathrm{k} \geq 1$ & 5258 & $n=51$ & 100us & mats & $m: 2$ & nos & $n k$ \\
\hline $3 \mathrm{sen}$ & $75 \leqslant 0$ & 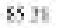 & 3945 & 3353 & 3:5: & Sisi & sed? & $836:$ \\
\hline $\mathrm{Br}$ & $0-41$ & $a+7$ & 0.45 & $0<1$ & 647 & [At & 347 & GA: \\
\hline Wh & 915 & 945 & 6.15 & oxe & 0.6 & 617 & 314 & 4.46 \\
\hline Fad is & 15 & 1.97 & a.s & & Nol & (5) & 133 & $1 A 2$ \\
\hline \multicolumn{9}{|l|}{$\begin{array}{c}\text { 1sue IJanats } \\
\text { ipgr: }\end{array}$} \\
\hline 6015 & & & $112: 1$ & & 11567 & & 2761 & \\
\hline TiA & & & $8 \operatorname{ses} 81$ & & $|2 \times 9 \times 9|$ & & ;wrts & \\
\hline vs! & & & 13000 & & 1893 & & 25535 & \\
\hline $\mathrm{c}: 3$ & & & $\operatorname{cas} 36$ & & 125051 & & 237 & \\
\hline Nox & & & Joses & & $129 x 2$ & & $1 \times 45$ & \\
\hline c<ess & & & & & wed & & 306 & \\
\hline R:35 & & & 041 & & 601 & & 311 & \\
\hline Das? & & & & & we & & 2.12 & \\
\hline Tus: & & & & & & & 200 & \\
\hline 10233 & & & & & & & 20 & \\
\hline Nos & & & & & wid & & 360 & \\
\hline $\mathrm{Ta}: 31$ & & & & & & & $\lambda e$ & \\
\hline 12 in & & & 045 & & nos & & $28 i$ & \\
\hline $\mathrm{Cel} 43$ & & & $0.2 z$ & & 614 & & 434 & \\
\hline Ft:315 & & & ost & & $\cos$ & & 311 & \\
\hline 1514: & & & ves & & wo & & 104 & \\
\hline Mal4t & & & 0.35 & & $6 \pm 4$ & & 558 & \\
\hline 5,53 & & & 1536 & & $12: 20$ & & 303 & \\
\hline $2 n 5 t$ & & & 0.73 & & 1.16 & & 14.70 & \\
\hline ITr 9 & & & oes & & $a n \%$ & & 280 & \\
\hline Sald? & & & 621 & & 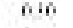 & & 759 & \\
\hline Eulys & & & aes & & 6.11 & & 155 & \\
\hline Casis? & & & 0.37 & & eso & & 157 & \\
\hline Thist & & & oes & & ores & & 28 & \\
\hline D; 163 & & & 633 & & 648 & & 5.15 & \\
\hline Bal65 & & & $\omega=$ & & Q.13 & & 138 & \\
\hline $1 \infty$ & & & 1.35 & & $1 \times 0$ & & solz: & \\
\hline 12106 & & & uzi & & $62:$ & & 324 & \\
\hline ที丶 & & & a.s & & ait & & 315 & \\
\hline Lais5 & & & ast & & 604 & & 343 & \\
\hline
\end{tabular}




\begin{tabular}{|c|c|c|c|c|c|c|c|c|}
\hline \multicolumn{9}{|l|}{ Butxe } \\
\hline \multicolumn{9}{|l|}{ uyer row } \\
\hline सैं & 45.79 & is es & wase & 4535 & b. & ax & 4805 & 503 \\
\hline no: & $9 t 2$ & $9=1$ & $0 \& 5$ & 061 & e.t & $6+10$ & 215 & $6+8$ \\
\hline$n \in C_{7}$ & ;8? & 532 & 484 & 510 & $\operatorname{sic}$ & 381 & 513 & 16: \\
\hline$N 4: 0$ & 927 & $2 x$ & vzs & azt & 60 & t.15 & $31 n$ & 619 \\
\hline Nan & 98 & ans & vil & a.1. & Q.11 & tit & 30 & eNA \\
\hline Atpo & $34: 2$ & Sבת & LAs & Has & 1316 & 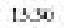 & 1sese & $15: 27$ \\
\hline sio & 54 & 345 & 224 & 2237 & $2 \geqslant 15$ & $2 \pi$ & 367 & $31 \otimes$ \\
\hline$a s$ & 015 & $2=1$ & o6s & $a \infty$ & ase & t.15 & 391 & \\
\hline No & $i \mathrm{t}$ & s.25 & SAt & 78 & 4.78 & $t 40$ & tes & 6.21 \\
\hline Taal & $5 \mathrm{sin}$ & 5913 & a.15 & secs & $202:$ & mals & $\operatorname{sen}$ & net; \\
\hline $\mathrm{se}=4$ & is 81 & Si JT & $n \leq s$ & 79 & 3: $x$ & sose & $x \in$ & sish \\
\hline tà & 0.45 & $a+4$ & eas & $a / 1$ & out & {$[. A]$} & 349 & EA: \\
\hline Wh & 915 & $9 \times 5$ & 647 & $0 \times 6$ & $6+4 i$ & 646 & 217 & 6.13 \\
\hline radistic & 15: & $\therefore 97$ & 675 & $a \%$ & 427 & $-c . s$ & 261 & 458 \\
\hline \multicolumn{9}{|l|}{$\begin{array}{l}\text { 1soe IJariats } \\
\text { iper: }\end{array}$} \\
\hline 515 & & $1 \times 04$ & & & & & & \\
\hline Tis & & $15+54 ?$ & & & & & & \\
\hline vst & & tex:2? & & & & & & \\
\hline $\mathrm{Cll}$ & & $171 ; 6$ & & & & & & \\
\hline NKA & & เu.u & & & & & & \\
\hline cess & & $w a 2$ & & & & & & \\
\hline \multicolumn{9}{|l|}{ R:35 } \\
\hline \multirow{2}{*}{\multicolumn{9}{|c|}{ mols: }} \\
\hline & & & & & & & & \\
\hline 10233 & & 991 & & & & & & \\
\hline Noss & & $a n$ & & & & & & \\
\hline $\mathrm{Ta}: 31$ & & 901 & & & & & & \\
\hline 12 is & & 936 & & & & & & \\
\hline Celas & & 1.27 & & & & & & \\
\hline Ft 132 & & 909 & & & & & & \\
\hline 1214: & & wst & & & & & & \\
\hline Nal4t & & 233 & & & & & & \\
\hline Sr5s & & 216 & & & & & & \\
\hline $2 n s t$ & & $3,-3$ & & & & & & \\
\hline IIr 7 & & $2 B$ & & & & & & \\
\hline Suld? & & 121 & & & & & & \\
\hline Eulys & & aAs & & & & & & \\
\hline CA1s? & & 179 & & & & & & \\
\hline Thist & & $a *$ & & & & & & \\
\hline$D \xi 163$ & & $2=2$ & & & & & & \\
\hline Bales & & $a s$ & & & & & & \\
\hline $1 \times$ & & $2 t s t$ & & & & & & \\
\hline 12106 & & 1.57 & & & & & & \\
\hline ที⿰氵丶 & & 1.95 & & & & & & \\
\hline 10175 & & 0.15 & & & & & & \\
\hline
\end{tabular}




\begin{tabular}{|c|c|c|c|c|c|c|c|c|}
\hline \multirow{2}{*}{$\begin{array}{l}\text { Eutus } \\
\text { Faria in }\end{array}$} & \multicolumn{5}{|c|}{$40-35.2$} & \multirow[b]{2}{*}{$11 \cdots 2$} & \multirow[b]{2}{*}{$33-1$} & \multirow[b]{2}{*}{$12-2$} \\
\hline & $13-3$ & S6-1 & $8-1$ & $4-1$ & tis-2 & & & \\
\hline \multicolumn{9}{|l|}{ Wyar rebs } \\
\hline \multicolumn{9}{|l|}{ Inrst } \\
\hline 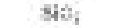 & $\therefore \leq 4$ & 2316 & 4958 & 9261 & $\tan \mathrm{x}$ & 31.12 & s0x & 51.27 \\
\hline no: & $9+1$ & $9=0$ & 059 & $0=1$ & $0<y$ & 679 & 215 & 650 \\
\hline$N b_{7}$ & 155 & 1 13 & 59 & $2 \%$ & $53 i$ & 218 & 134 & 194 \\
\hline Na:00 & ass & a.s & 6.22 & Q.1: & 6.19 & tat & $3 n$ & 693 \\
\hline $\operatorname{Man}$ & $\theta: B s$ & $a \equiv$ & QLs & $0 \omega 1$ & $\omega *$ & 5.40 & t.de & 0.19 \\
\hline Ntbo & 12.12 & 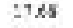 & Lat & 1553 & $24 \pi$ & 14.25 & 12.20 & 1391 \\
\hline$\infty 0$ & 5657 & 325 & 2211 & 2251 & 2216 & 175 & 1783 & 198 \\
\hline$C B$ & 015 & at2 & & & & [n? & & \\
\hline No & 251 & 214 & 703 & $4 . x 4$ & 6.42 & 1128 & 18.91 & 10.58 \\
\hline Taal & 62 & 55.35 & 32.31 & 3005 & 595 & $x: x$ & 9.73 & $x \approx$ \\
\hline $\mathrm{St}_{\mathrm{g}} \mathrm{t}$ & 73.79 & $\$ 535$ & TE:15 & 35,15 & 7396 & $\alpha \dot{\alpha}$ & 4878 & mosi \\
\hline thi & 0.45 & a.5 & e.t2 & ase & 6.42 & {$[.43$} & 337 & 6.41 \\
\hline Wh & $9+2$ & 945 & 047 & $04 i$ & $64 i$ & 677 & 275 & $64 ?$ \\
\hline radistic & & & 4.32 & 1.17 & $4 \lambda 2$ & & & \\
\hline \multicolumn{9}{|c|}{$\begin{array}{c}\text { Tsee laxiats } \\
\text { iper: }\end{array}$} \\
\hline sods & & 1584 & $\operatorname{lnt} x$ & & & 16254 & & \\
\hline Tit & & 1383 \&s & 262174 & & & $\sin 0$ & & \\
\hline v31 & & 212.70 & sis.as & & & 4tast & & \\
\hline $\mathrm{Cr}$ & & ICAs 72 & 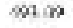 & & & $\mid 62 \leq 5$ & & \\
\hline NMK & & $w \cdot z)$ & 6t.5t & & & 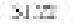 & & \\
\hline cess & & & wet & & & & & \\
\hline R:35 & & & 011 & & & Exy & & \\
\hline Das? & & $a \geq 2$ & & & & t.xt & & \\
\hline \multicolumn{9}{|l|}{ mis: } \\
\hline \multicolumn{9}{|l|}{1233} \\
\hline \multirow{2}{*}{\multicolumn{9}{|c|}{$\mathrm{Ta}: 31$}} \\
\hline & & & & & & & & \\
\hline $12 \pi$ & & 205 & 612 & & & CD & & \\
\hline $\cos 143$ & & ass & 0.45 & & & 632 & & \\
\hline Dtuss & & 911 & 042 & & & & & \\
\hline 1214: & & ans & Qta & & & tas & & \\
\hline MAIAt & & uAI & 1.13 & & & 222 & & \\
\hline 5,53 & & 2344 & $123 !$ & & & 5.43 & & \\
\hline $215 t$ & & $(.5)$ & 4.14 & & & 325 & & \\
\hline IIF $n$ & & 212 & 025 & & & D.2: & & \\
\hline Swill? & & $a \neq i$ & 653 & & & 57 & & \\
\hline Eulys & & ate & 0.25 & & & 120 & & \\
\hline Gas? & & 95 & 181 & & & 233 & & \\
\hline Thist & & 910 & 613 & & & 697 & & \\
\hline D; 163 & & 47 & 1.4 & & & ;s5 & & \\
\hline Bal65 & & 915 & 023 & & & 539 & & \\
\hline $1 \infty$ & & 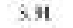 & $6 * 2$ & & & 552 & & \\
\hline $121<6$ & & $\mathrm{NH}$ & ast & & & 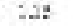 & & \\
\hline ทั1ว & & $a 12$ & $\alpha x$ & & & al & & \\
\hline Laiss & & a.s & o.11 & & & [.] 3 & & \\
\hline
\end{tabular}




\begin{tabular}{|c|c|c|c|c|c|c|c|c|}
\hline $\begin{array}{l}\text { Betixs } \\
\text { maris in. }\end{array}$ & \multicolumn{7}{|c|}{ Etest } & $n \cdots 2$ \\
\hline \multicolumn{9}{|l|}{ Wyar cobl } \\
\hline \multicolumn{9}{|l|}{$\ln r: 5$} \\
\hline sैड़; & $2[8]$ & 45. 39 & 919 & $3 t \in t$ & 9121 & 902 & -2.25 & $\sin 73$ \\
\hline $\mathrm{na}$ & $9 \leq 1$ & 921 & 055 & 05 & 064 & [s] & 258 & 644 \\
\hline$n b \alpha_{7}$ & 370 & $6 \pm 1$ & 405 & $3<9$ & 194 & 219 & 754 & $|9|$ \\
\hline $\mathrm{Na}, 0$ & $9+3$ & was & $6 z z$ & $\alpha 26$ & 60 & [.A3 & 168 & 6.12 \\
\hline $\operatorname{Man}$ & $9+1$ & $a=5$ & 023 & $0=1$ & 0.15 & 054 & 349 & 4.16 \\
\hline Ntpo & 11.15 & 2236 & 2425 & 14.43 & $25 x$ & 13.13 & 13.30 & $18 x y$ \\
\hline$\infty$ & $15+2$ & 3432 & 2655 & 3453 & 215 & 1385 & 1986 & son \\
\hline \multicolumn{9}{|l|}{ 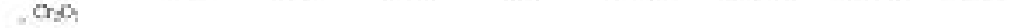 } \\
\hline tvo & $12.7 \%$ & 2053 & 205 & 8.02 & 787 & 11.14 & 11.20 & 60 \\
\hline Tal & $\mathrm{KS} S$ & 52.15 & 3550 & 522 & 5252 & $m=n$ & $m .30$ & 20.52 \\
\hline $\mathrm{Stg}+4$ & 647 & +354 & 3134 & 7122 & $15 \%$ & s: $x$ & $62 \times$ & $81 \%$ \\
\hline $\mathrm{Eni}$ & 05 & 257 & 042 & $a=2$ & 641 & [399 & 315 & 6.44 \\
\hline Wh & $9 \%$ & 94 & 649 & $0<$ & 046 & (1) & 243 & 46 \\
\hline radiute & & & & & 400 & & & 456 \\
\hline \multicolumn{9}{|c|}{$\begin{array}{c}\text { 1sue bariats } \\
\text { ipgr? }\end{array}$} \\
\hline 5015 & & & & & & & 3295 & \\
\hline Tia & & & & & & & 32198: & \\
\hline v31 & & & & & & & 253.43 & \\
\hline $\mathrm{c}: 3$ & & & & & & & 5 is & \\
\hline Nox & & & & & & & 2501 & \\
\hline \multicolumn{9}{|l|}{ crss } \\
\hline \multicolumn{9}{|l|}{ R:35 } \\
\hline Dus? & & & & & & & 3.00 & \\
\hline \multicolumn{9}{|l|}{ This: } \\
\hline \multicolumn{9}{|l|}{15233} \\
\hline \multirow{2}{*}{\multicolumn{9}{|c|}{$\begin{array}{l}\text { Noss } \\
\text { halsi }\end{array}$}} \\
\hline & & & & & & & & \\
\hline $12 \%$ & & & & & & & 38 & \\
\hline $\begin{array}{l}\text { Celd4 } \\
\text { Dt.313 }\end{array}$ & & & & & & & 300 & \\
\hline 1914: & & & & & & & 124 & \\
\hline Mal4t & & & & & & & 158 & \\
\hline 5,53 & & & & & & & 14.25 & \\
\hline $2 \mathrm{r} 5 \mathrm{t}$ & & & & & & & is: & \\
\hline ITr 9 & & & & & & & 239 & \\
\hline said? & & & & & & & 104 & \\
\hline Eulys & & & & & & & 3.21 & \\
\hline Gasis? & & & & & & & 174 & \\
\hline Thist & & & & & & & 217 & \\
\hline$D \xi 163$ & & & & & & & 233 & \\
\hline Bales & & & & & & & 346 & \\
\hline $1 \infty$ & & & & & & & 11.84 & \\
\hline 12106 & & & & & & & 134 & \\
\hline ทа⿰า & & & & & & & 135 & \\
\hline Lins & & & & & & & 327 & \\
\hline
\end{tabular}




\begin{tabular}{|c|c|c|c|c|c|c|c|c|}
\hline $\begin{array}{l}\text { Betixs } \\
\text { frovin th. }\end{array}$ & $3 z-1$ & $2 k-2$ & $x-3$ & $26-3$ & $\therefore 2$ & $2 \cdots \cdot 2$ & $38-1$ & $28-2$ \\
\hline \multicolumn{9}{|l|}{ Myer rsw } \\
\hline sis; & $2 \mathrm{t} . \pi t$ & 1359 & $92 \mathrm{ss}$ & $42 x 2$ & 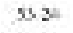 & 902 & 4041 & 4055 \\
\hline no: & $95 i$ & 90 & 045 & 05 & pis & 256 & 254 & $8+1$ \\
\hline$n \cdot \sigma_{7}$ & $\angle 10$ & 091 & $1 \$ 2$ & $60 \%$ & $18:$ & 157 & $2 \theta$ & 131 \\
\hline $\mathrm{N} 4: 0$ & 019 & ast & 6.1s & Q.1 & 0.18 & 134 & 119 & 616 \\
\hline $\mathrm{Man}$ & $0 \times 5$ & a.s.5 & 0.4 & $\omega \bar{c}$ & $6 \leq 4$ & 5.5 & 374 & 626 \\
\hline Ntpo & $12 \mathrm{nn}^{4}$ & $24 \mathrm{Na}$ & (5.) & LS.33 & $17 x$ & $1-30$ & $12 \times 0$ & 1358 \\
\hline$\infty 0$ & $3.6 \%$ & 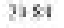 & 2237 & 2153 & $2 \geqslant \geqslant 0$ & 210 & $10 \%$ & $19: 4$ \\
\hline$a_{0} \mathrm{O}$ & & & e.17 & $\alpha \infty$ & $65 a$ & & & \\
\hline No & $2 x s$ & exs & 4.25 & 696 & 220 & 190 & Jox: & $10 x$ \\
\hline Taal & 58.75 & 5206 & 246 & nout & 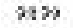 & $m=0$ & $\% .13$ & nos \\
\hline $\mathrm{Stg}+4$ & 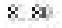 & 7252 & ksi & 7755 & 798 & 657 & 09.54 & $\cos 45$ \\
\hline $\mathrm{tin}$ & $0+4$ & $a=1$ & Q4. & $a=1$ & cus & [.A2 & 3.41 & 546 \\
\hline Wh & $9+6$ & $9+1$ & 6.5 & as? & $6+7$ & cis & 313 & 648 \\
\hline radistic & $\therefore 25$ & & all & $6=1$ & ads & 155 & & \\
\hline \multicolumn{9}{|l|}{$\begin{array}{l}\text { 1sue laxiats } \\
\text { iper: }\end{array}$} \\
\hline 515 & & & 1811 & $17 \pi$ & $8<14$ & & & \\
\hline TiA & & & $860<$ & 36258 & $\cos \leq 0$ & & & \\
\hline v31 & & & $13 \times 2 x$ & 392 & 125.73 & & & \\
\hline mis & & & 173737 & $5 \times 4$ & $6202 \geq 8$ & & & \\
\hline $\mathrm{Nax}$ & & & 11860 & $72 x 2$ & 25.20 & & & \\
\hline $\mathrm{Cr} 5 \mathrm{~s}$ & & & & & wol & & & \\
\hline R:35 & & & 041 & & 60 & & & \\
\hline Das? & & & avo & ave & & & & \\
\hline \multirow{2}{*}{\multicolumn{9}{|c|}{$\begin{array}{l}\text { Thus } \\
1573\end{array}$}} \\
\hline 12233 & & & & & & & & \\
\hline \multirow{2}{*}{\multicolumn{9}{|c|}{$\mathrm{Ta}: 31$}} \\
\hline & & & & & & & & \\
\hline $12 \%$ & & & 647 & $n=\dot{x}$ & $n \pi$ & & & \\
\hline Celds & & & 027 & $0<$ & $\begin{array}{l}\text { way } \\
\text { and }\end{array}$ & & & \\
\hline 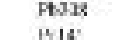 & & & 04 & $\begin{array}{l}01 \\
011\end{array}$ & we & & & \\
\hline $\begin{array}{l}\text { RTI4: } \\
\text { Nal4t }\end{array}$ & & & 0.1 & $a \cdot c$ & 642 & & & \\
\hline Srs! & & & 15.12 & 1957 & $1: 9$ & & & \\
\hline $2 \mathrm{r} 5 \mathrm{t}$ & & & a.s? & 4.25 & wee & & & \\
\hline ITr 9 & & & 065 & $a 2:$ & $a n c$ & & & \\
\hline Sald? & & & $6 \rightarrow 7$ & 05 & $n \leq 0$ & & & \\
\hline Eulys & & & a.to & $a v$ & $6 \%$ & & & \\
\hline Gasis? & & & $0 \mathrm{n}$ & 092 & 037 & & & \\
\hline Thist & & & 047 & ast & ori & & & \\
\hline$D>163$ & & & uss & $1=0$ & 640 & & & \\
\hline Bales & & & 607 & $a \approx 7$ & $\cos$ & & & \\
\hline $1 \infty$ & & & 1.45 & 625 & 1.12 & & & \\
\hline 12106 & & & uzs & $\alpha=6$ & 00 & & & \\
\hline Valา & & & 0.20 & of: & 0.17 & & & \\
\hline Li175 & & & 0.4 & an & 604 & & & \\
\hline
\end{tabular}




\begin{tabular}{|c|c|c|c|c|c|c|c|c|}
\hline Eutus & & & & & & & $27.1-20-3$ & \\
\hline charis ib. & $a:-3$ & $8:-1$ & $42-1$ & $46-3$ & Ar: : & $\sin 2$ & $t \rightarrow 0$ & $2-1$ \\
\hline $3 y=r a b$ & & & & & & & & \\
\hline $\ln r \leqslant \mid$ & & & & & & & & \\
\hline *⿻; & $25 \Delta 4$ & 2199 & ירני & $21 \times 3$ & 9155 & sese & 51.34 & $\sin x$ \\
\hline no: & 951 & 945 & $04 ?$ & $05 ;$ & est & $6 \$ 5$ & 278 & 453 \\
\hline$A \cdot \theta_{7}$ & $; \%$ & 232 & 987 & $3: 2$ & 315 & 317 & 27 & $4 x$ \\
\hline $\mathrm{Na}: 0$ & $v z$ & 0.4 & 627 & ase & 0.18 & 122 & 318 & 4.25 \\
\hline$M a n$ & $\theta j$ & ast & 013 & $\alpha s_{i}$ & 0.15 & 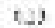 & 128 & 132 \\
\hline Atpo & 340 & 2484 & 421 & 1355 & 2958 & $1=34$ & 1ever & 12.58 \\
\hline$\infty$ & 5. 45 & 278 & 1472 & 3653 & $21 \%$ & $10 \%$ & 19:3? & 1919 \\
\hline$a r$ & & & & & & & Ine & \\
\hline No & 819 & $: 2.43$ & tost & 2.15 & $2 \times 1$ & 582 & 3.80 & 14.80 \\
\hline Taal & $5 S 52$ & 5236 & $35 \mathrm{st}$ & 562 & $52=$ & 227 & נובי & 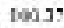 \\
\hline $\mathrm{Mt}=\mathrm{H}$ & is 35 & $\theta \leqslant 2$ & 7165 & 7253 & $53 x$ & $n s y$ & rest & 61 : 8 \\
\hline thi & 041 & $a+4$ & eaz & $0<1$ & 044 & [.A2 & 3.49 & 43 \\
\hline Wh & 915 & $9: 9$ & 641 & $0 x$ & $\mathrm{CA}^{\circ}$ & (1) & 34 & $\Delta+i$ \\
\hline radiusc & $1 \%$ & & & & 1.71 & & & \\
\hline 1sce laxiats & & & & & & & & \\
\hline iper: & & & & & & & & \\
\hline $5=15$ & & & & & & & & \\
\hline Tit & & & & & & & & \\
\hline vs! & & & & & & & & \\
\hline $\mathrm{c}: 3$ & & & & & & & & \\
\hline Nox & & & & & & & & \\
\hline c<5s & & & & & & & & \\
\hline R: 35 & & & & & & & & \\
\hline Das? & & & & & & & & \\
\hline This: & & & & & & & & \\
\hline 15233 & & & & & & & & \\
\hline Nos3 & & & & & & & & \\
\hline $\mathrm{Ta}: 31$ & & & & & & & & \\
\hline 12 iो & & & & & & & & \\
\hline Cel43 & & & & & & & & \\
\hline $5+313$ & & & & & & & & \\
\hline 1414: & & & & & & & & \\
\hline Mal4t & & & & & & & & \\
\hline $\begin{array}{l}5.53 \\
2.56\end{array}$ & & & & & & & & \\
\hline $\begin{array}{l}2 \mathrm{r} 5 \mathrm{t} \\
\mathrm{Itr} \times \mathrm{t}\end{array}$ & & & & & & & & \\
\hline Sould? & & & & & & & & \\
\hline Eulys & & & & & & & & \\
\hline CAIS? & & & & & & & & \\
\hline Thist & & & & & & & & \\
\hline Dy 163 & & & & & & & & \\
\hline Hales & & & & & & & & \\
\hline $1 \infty$ & & & & & & & & \\
\hline $121<6$ & & & & & & & & \\
\hline ทาเช & & & & & & & & \\
\hline Laits & & & & & & & & \\
\hline
\end{tabular}




\begin{tabular}{|c|c|c|c|c|c|c|c|c|}
\hline $\begin{array}{l}\text { Eutus } \\
\text { crovin th. }\end{array}$ & $4 \cdots t$ & $5 \cdot 2$ & $\Leftrightarrow \rightarrow$ & $7 \cdots 1$ & $x-5$ & $6-2$ & $11 \cdots$ & $\begin{array}{c}57-2.37 \cdot 160 \\
1 \rightarrow-3\end{array}$ \\
\hline Myer row & & & & & & & & \\
\hline inrs: & & & & & & & & \\
\hline sंड; & $51 / 2$ & 22.12 & 22:39 & $93: 2$ & $50 \mathrm{~V}$ & 31.70 & $20 . x 2$ & 51.56 \\
\hline $\mathrm{no}$ & 27 & 95) & 030 & $0=6$ & Cus & 639 & 253 & a 76 \\
\hline$N \in \delta_{7}$ & Ist & ;12 & is is & 301 & 356 & 369 & (1)6 & 15 \\
\hline $\mathrm{Na}: 0$ & $3 n$ & 2.13 & 093 & $0 \mathrm{~s}]$ & 6I: & tat & 12 & 4. 39 \\
\hline$M a n$ & 3.44 & 210 & 005 & $a j$ & 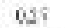 & 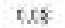 & 13 & 9.12 \\
\hline Atpo & 14.74 & $\therefore<16$ & $H .04$ & Lets & 1ss: & 16,57 & ISAT? & $14,-11$ \\
\hline$\infty 0$ & 1810 & 3817 & $34: 4$ & 1961 & (8) & 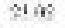 & 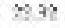 & 1951 \\
\hline 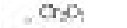 & $3 \mathrm{II}$ & 0.15 & & & & t30 & 100 & \\
\hline tvo & 11.57 & $\sin$ & ans & tacs & 1031 & 1s: & $1 \leqslant 2$ & 1008 \\
\hline Tal & בנבנCI & trowit & 10011 & $2 x: 1$ & xa 31 & $m=4$ & nax & $\% .52$ \\
\hline $\mathrm{St}=4$ & $\alpha \phi$ & S1]e & $716 t$ & 7317 & $7 \% 3$ & 83 & Dist & nos? \\
\hline tin & 3.42 & $a \div 5$ & 0.12 & $a 24$ & 046 & $\mathrm{CA}^{\mathrm{T}}$ & $1 \mathrm{H}$ & 9.42 \\
\hline Wh & 278 & $9 \sim 6$ & 0.12 & $0 \div \theta$ & $\omega: \overline{8}$ & Cif & 216 & 81 \\
\hline Fatuses ic & & $1 / 5$ & & & & C.A & 2.17 & \\
\hline 1sue lJants & & & & & & & & \\
\hline ires: & & & & & & & & \\
\hline 5015 & & & & & & & & \\
\hline TiA & & & & & & & & \\
\hline vst & & & & & & & & \\
\hline $\mathrm{c}: 3$ & & & & & & & & \\
\hline Nox & & & & & & & & \\
\hline cess & & & & & & & & \\
\hline R:35 & & & & & & & & \\
\hline Das? & & & & & & & & \\
\hline This: & & & & & & & & \\
\hline 15233 & & & & & & & & \\
\hline Noss & & & & & & & & \\
\hline $\begin{array}{l}7231 \\
12 \geqslant\end{array}$ & & & & & & & & \\
\hline Cel43 & & & & & & & & \\
\hline Ft:J13 & & & & & & & & \\
\hline 1414: & & & & & & & & \\
\hline MalAt & & & & & & & & \\
\hline 5,59 & & & & & & & & \\
\hline $2.5 t$ & & & & & & & & \\
\hline IIT 9 & & & & & & & & \\
\hline Sald? & & & & & & & & \\
\hline Eulys & & & & & & & & \\
\hline CAIS? & & & & & & & & \\
\hline Thist & & & & & & & & \\
\hline $\begin{array}{l}\text { Dy } 163 \\
\text { Byiks }\end{array}$ & & & & & & & & \\
\hline $\begin{array}{l}\text { Bal6s } \\
\text { yos }\end{array}$ & & & & & & & & \\
\hline $121<6$ & & & & & & & & \\
\hline $\begin{array}{l}\text { 12106 } \\
\text { val? }\end{array}$ & & & & & & & & \\
\hline Laivs & & & & & & & & \\
\hline
\end{tabular}




\begin{tabular}{|c|c|c|c|c|c|c|c|c|}
\hline \multicolumn{8}{|l|}{ Eutxe } & $33 \cdot 4$ \\
\hline \multicolumn{9}{|l|}{ wyer rab } \\
\hline \multicolumn{9}{|l|}{ Inrs: } \\
\hline sis; & $45 \mu$ & 2365 & $315 n$ & 432 & $45 \%$ & -057 & 20.17 & 4964 \\
\hline no: & $2+2$ & $0 \omega$ & $0 \leqslant 2$ & 112 & 100 & $0 \leqslant s$ & 131 & 97 \\
\hline$N \forall C_{7}$ & 517 & 467 & 812 & 53 & 391 & $8 \%$ & ins & 43 \\
\hline$N a, 0$ & 13? & u.21 & was & $\alpha 2=$ & 64 & 62 & $3 n$ & 4.3t \\
\hline $\operatorname{Man}$ & 315 & 0.10 & 025 & a.1. & $w 0$ & 0.16 & 150 & alt \\
\hline Ntbo & 12.40 & 350 & Lat & LAS4 & 1252 & $1-20$ & 15.0 & 26.76 \\
\hline$\infty$ & 58 & 2236 & 1365 & 2354 & 2115 & $21+1$ & 1003 & 30 \\
\hline$a_{3} 0$ & 141 & & & & & & & \\
\hline no & sst & 601 & to.23 & $x=3$ & $8: 4$ & 73 & 330 & $25 t$ \\
\hline Taal & $\operatorname{lin} 20$ & 595s: & $n s$ & loous & $m 25$ & locis & 520.3 & \$.17 \\
\hline xestet $x$ & $8+11$ & \$1 55 & 13 is & 7555 & 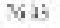 & $8 x$ & is.15 & $83: 37$ \\
\hline trin & 344 & a.s & eas & $a \leq 3$ & 642 & 641 & $3 \mathrm{H}$ & 247 \\
\hline Wh & 215 & 0.77 & 628 & $0+5$ & 044 & cif & It & 243 \\
\hline radiste & 315 & i.n: & & $2 \cdots$ & $1 . s t$ & 125 & 323 & 1.45 \\
\hline \multicolumn{9}{|l|}{$\begin{array}{l}\text { 1sue laxiats } \\
\text { ipgr: }\end{array}$} \\
\hline 4015 & $10^{1} \omega$ & & & & & & & \\
\hline Tit & $1<1.99$ & & & & & & & \\
\hline vsl & $\$ 01.12$ & & & & & & & \\
\hline $\mathrm{ar}$ & 22053 & & & & & & & \\
\hline Nat & LV:Q & & & & & & & \\
\hline coss & $33 t$ & & & & & & & \\
\hline REs5 & 317 & & & & & & & \\
\hline Das? & +4.45 & & & & & & & \\
\hline $\begin{array}{l}\text { This: } \\
12933\end{array}$ & 321 & & & & & & & \\
\hline $\begin{array}{l}1235 \\
\text { N.53 }\end{array}$ & 333 & & & & & & & \\
\hline Ta: 31 & a al & & & & & & & \\
\hline $12 \%$ & 328 & & & & & & & \\
\hline $\cos 143$ & 535 & & & & & & & \\
\hline Dtsus & 321 & & & & & & & \\
\hline 1914: & 125 & & & & & & & \\
\hline Mal4t & $24 t$ & & & & & & & \\
\hline Srss & 1329 & & & & & & & \\
\hline $2 r 5 t$ & $15 \pm t$ & & & & & & & \\
\hline IIr $n$ & 224 & & & & & & & \\
\hline sail? & 261 & & & & & & & \\
\hline Eulys & 331 & & & & & & & \\
\hline Gis? & $93 t$ & & & & & & & \\
\hline $\begin{array}{l}\text { Thise } \\
\text { Dy } 163\end{array}$ & $\begin{array}{l}151 \\
351\end{array}$ & & & & & & & \\
\hline $\begin{array}{l}\text { Dyles } \\
\text { Bales }\end{array}$ & 34 & & & & & & & \\
\hline $1 \times$ & 17,5 & & & & & & & \\
\hline $121<6$ & 232 & & & & & & & \\
\hline Valta & 175 & & & & & & & \\
\hline L1175 & 324 & & & & & & & \\
\hline
\end{tabular}




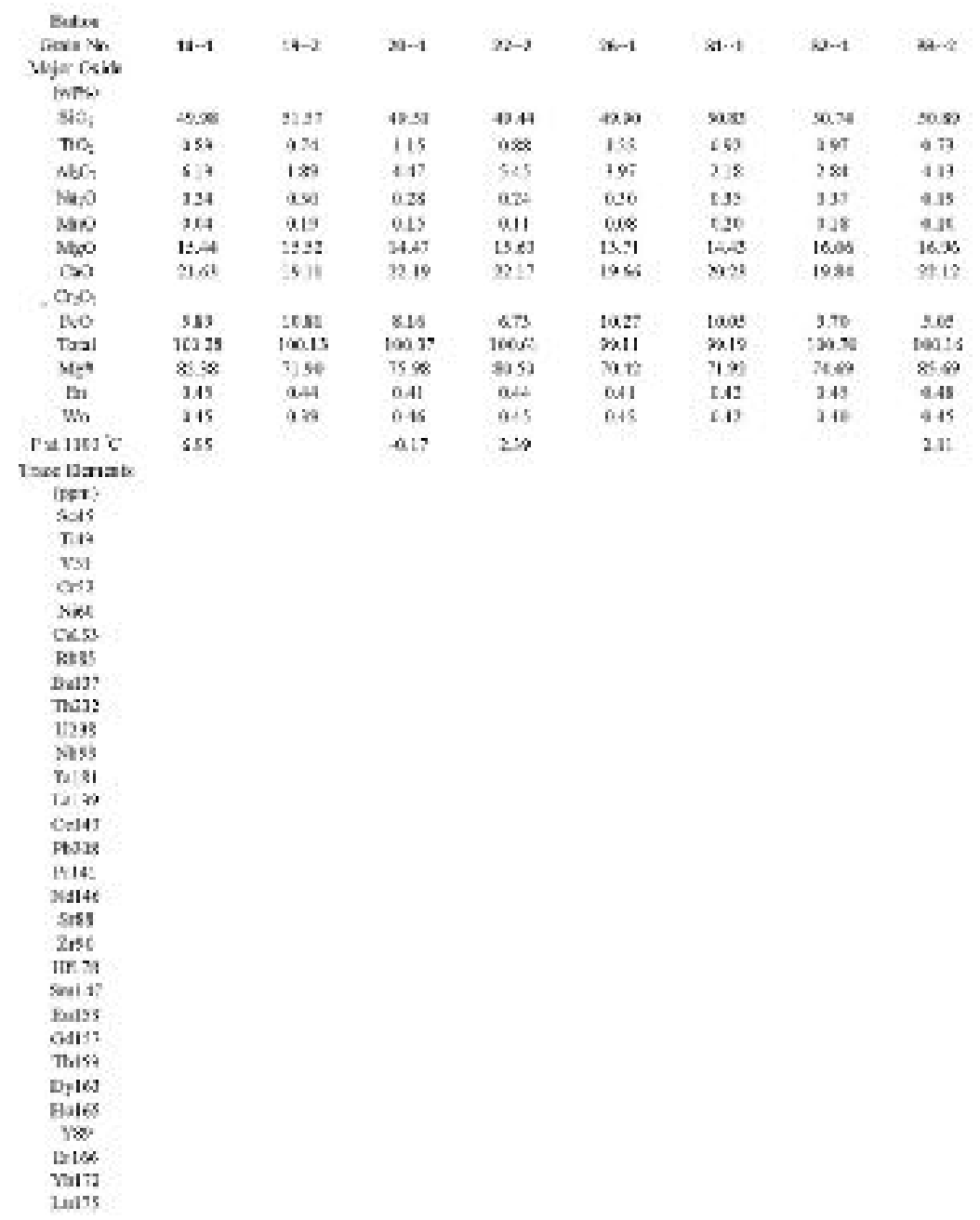




\begin{tabular}{|c|c|c|c|c|c|c|c|c|}
\hline Butus & & & & & & (2.3.28 & & \\
\hline Farie Nh & as-3 & $86-1$ & $46-1$ & $A x-3$ & art: & $t \rightarrow$ & $2 \rightarrow 3$ & +3 \\
\hline wyar row & & & & & & & & \\
\hline In $\mathrm{N}: \mathrm{s}$ & & & & & & & & \\
\hline sैं & swe & 2126 & $91 \leq 8$ & 9893 & 915 & 30.4 & to04 & 3051 \\
\hline no: & 255 & 972 & 0.6 & $0 \mathrm{~s}^{2}$ & $0<7$ & 617 & 265 & 648 \\
\hline$A b C_{7}$ & 528 & $c * A$ & 441 & 34 & 450 & 37 & iff & $5 E$ \\
\hline $\mathrm{Na}: 0$ & 321 & $x=1$ & 025 & $\alpha z$ & ( & $t 20$ & 32 & 612 \\
\hline$M a n$ & 313 & & 0.15 & & 0.12 & $t<0$ & 300 & 611 \\
\hline Ntopo & 1600 & :2.25 & תגנפ & 191 & $\because 12$ & 16,31 & 12.72 & 19.0S \\
\hline$\infty 0$ & 5504 & 3211 & $y 2: 8$ & 3232 & $22 \%$ & S18: & sios & 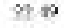 \\
\hline $\mathrm{Cr}_{3} \mathrm{O}$ & & & & & & & & bet \\
\hline tvo & 925 & 15s & 4.52 & 5.01 & $2 A I$ & נגי & 1.72 & $3 k$ \\
\hline Tal & Fote & towes & 10015 & 5.75 & 5252 & m.r & mas & res: \\
\hline 3604 & 8454 & Sity & $8 \pi 18$ & 8553 & s4 38 & si: & $\sin 66$ & $8 \times 5 ;$ \\
\hline $\mathrm{En}$ & 345 & $a+5$ & 0.9 & QAi & 049 & [. .2 & 349 & $6 A 6$ \\
\hline Wh & 215 & $9 \times 5$ & 641 & 64s & 046 & CII & 211 & 4.18 \\
\hline raturs c & isz & .492 & & 1.25 & $4 x-4$ & & 235 & cso \\
\hline $\begin{array}{c}\text { 1sue laxiats } \\
\text { [per: }\end{array}$ & & & & & & & & \\
\hline 545 & & & & & & & & 18616 \\
\hline Tit & & & & & & & & $814:$ \\
\hline v31 & & & & & & & & 485.29 \\
\hline $\mathrm{Cl3}$ & & & & & & & & 16636 \\
\hline NAR & & & & & & & & 2.12 \\
\hline $0<53$ & & & & & & & & \\
\hline$R: 35$ & & & & & & & & \\
\hline Das?? & & & & & & & & 6.11 \\
\hline This: & & & & & & & & 601 \\
\hline 10233 & & & & & & & & \\
\hline Nos & & & & & & & & 6.61 \\
\hline $\mathrm{Ta} / 31$ & & & & & & & & 601 \\
\hline $12 \%$ & & & & & & & & 03 \\
\hline $\cos 143$ & & & & & & & & 123 \\
\hline Ftsis & & & & & & & & 610 \\
\hline 1414: & & & & & & & & 196 \\
\hline Mal4t & & & & & & & & 220 \\
\hline S.r5s & & & & & & & & 2422 \\
\hline $2 \mathrm{r} 5 \mathrm{t}$ & & & & & & & & 6.96 \\
\hline III 9 & & & & & & & & bas \\
\hline Sald? & & & & & & & & 688 \\
\hline Eulys & & & & & & & & E.AI \\
\hline Gas? & & & & & & & & 166 \\
\hline Thist & & & & & & & & exs \\
\hline$D ; 16]$ & & & & & & & & 136 \\
\hline Eales & & & & & & & & 639 \\
\hline 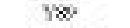 & & & & & & & & 145 \\
\hline $121<6$ & & & & & & & & 650 \\
\hline Valt] & & & & & & & & 699 \\
\hline Lits & & & & & & & & 630 \\
\hline
\end{tabular}




\begin{tabular}{|c|c|c|c|c|c|c|c|c|}
\hline Butes & & & & & A. SAS & & & \\
\hline frar in & 8 & $3 n-1$ & $n-1$ & $25-4$ & 1.3 & $2-3$ & 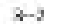 & $a-1$ \\
\hline $\begin{array}{l}\text { Myer rebl } \\
\text { intel }\end{array}$ & & & & & & & & \\
\hline 5기 & 51.46 & 2312 & $45 e s$ & $45 x$ & 9157 & 5152 & 49.900 & 5158 \\
\hline no: & 217 & 972 & $0 \% 2$ & $a s ?$ & $0 \leqslant 1$ & 647 & 25 & 657 \\
\hline $\mathrm{Al} / \mathrm{s}$. & 1.9: & sal & bas & 2.8 & $2 \infty x$ & $v x:$ & 34 & 1.20 \\
\hline Na:0 & 13: & 425 & 6.25 & $a z$ & 0.2 & 6.18 & 123 & 619 \\
\hline 1000 & L. & $a 21$ & oos & 90 & $0<5$ & 150 & 344 & 114 \\
\hline Atopo & 14.12 & $\therefore 935$ & 24.4 & $1: 32$ & 2555 & 13.52 & 14.67 & 148, \\
\hline$\infty 0$ & $x>$ & $25 \sqrt{2}$ & 9235 & 3267 & 233 & 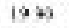 & 3100 & $18 \times 8$ \\
\hline$A \theta_{3}$ & & & & & & & & \\
\hline 700 & 7.4 & $<24$ & 4.85 & 410 & s.4: & $12 n$ & 56 & $11.5 \%$ \\
\hline Teal & $n . x$ & 5225 & 35.55 & sst: & $10 \mathrm{cos}$ & Incs2 & $2 \pi$ & nx: \\
\hline $\mathrm{Nes}$ & $2 \pi$ & 8507 & 148 & $56 \mathrm{sh}$ & $75 x$ & $\sin 40$ & is.14 & es: \\
\hline Ba & 3.45 & ass & e.4 & a.ts & 0,4 & 699 & 3.42 & 641 \\
\hline Wh & 215 & 90 & 043 & $a t s$ & $\omega s$ & $6+1$ & 214 & 640 \\
\hline Fadstes & & 500 & 716 & $5 n$ & $n s_{i}$ & & 217 & \\
\hline Sox Enab & & & & & & & & \\
\hline $\operatorname{los}_{x \rightarrow 4}$ & $1<21]$ & & & & & & & \\
\hline Ti4s & 31.4 & & & & & & & \\
\hline$v 31$ & 14523 & & & & & & & \\
\hline ↔s: & 177 & & & & & & & \\
\hline $\mathrm{Nin}$ & 352 & & & & & & & \\
\hline Cass & $3 x s$ & & & & & & & \\
\hline Ress & 327 & & & & & & & \\
\hline Das? & $1: 2 t$ & & & & & & & \\
\hline This: & $2 \pm 6$ & & & & & & & \\
\hline $1 \times 33$ & 216 & & & & & & & \\
\hline Noss & $3=3$ & & & & & & & \\
\hline Ta15i & 265 & & & & & & & \\
\hline Tastat & in/ai & & & & & & & \\
\hline Cel13 & $30 \times 6$ & & & & & & & \\
\hline $\begin{array}{l}\text { Fots } \\
x+1<1\end{array}$ & $3=4$ & & & & & & & \\
\hline $\begin{array}{l}\text { AI } \\
\text { Nat-1 }\end{array}$ & $\mathrm{BS}, \mathrm{k}$ & & & & & & & \\
\hline ass & sin & & & & & & & \\
\hline 2 rist & 3736 & & & & & & & \\
\hline IIT & 153 & & & & & & & \\
\hline Swi 1 ? & 1151 & & & & & & & \\
\hline Eul9s & 253 & & & & & & & \\
\hline CAIsi & $11: 8$ & & & & & & & \\
\hline Thess & $29 y$ & & & & & & & \\
\hline Dop 16 & 1471 & & & & & & & \\
\hline Balos & 335 & & & & & & & \\
\hline 1\%e & $a v e$ & & & & & & & \\
\hline Litss & 554 & & & & & & & \\
\hline Yal: & 231 & & & & & & & \\
\hline Lil15 & 121 & & & & & & & \\
\hline
\end{tabular}




\begin{tabular}{|c|c|c|c|c|c|c|c|c|}
\hline $\begin{array}{l}\text { Butse } \\
\text { frovin th. }\end{array}$ & $5-2$ & $5 \cdots-1$ & $6-1$ & n-3 & $11 \cdots$ & $13-1$ & $11-\bar{z}$ & $16-2$ \\
\hline \multicolumn{9}{|l|}{ Myer rsw } \\
\hline sै। & 31,48 & 2379 & 21.40 & $93: 5$ & 3152 & 51.25 & sexs & 3000 \\
\hline $\mathrm{no}$ & 251 & 044 & 059 & $0: 5$ & $04 \%$ & 643 & $2 \leqslant$ & 455 \\
\hline$n \cdot b_{7}$ & 164 & $3 \infty$ & 137 & 0.5 & esso & 30 & 76 & 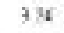 \\
\hline$N 4: 0$ & 132 & $6 z$ & 023 & $\alpha s \bar{z}$ & 621 & 12 & 314 & alt \\
\hline $\mathrm{Man}$ & $1 x 4$ & 0.14 & 032 & $10 \%$ & 106 & $t 22$ & 129 & 425 \\
\hline Ntpo & 1231 & 2924 & 4.70 & ISIS & $13-42$ & 14.5s & IS:5? & 13.12 \\
\hline So & 1958 & 237 & 3840 & 216 & 825 & 252 & 21 is & $31 \%$ \\
\hline \multicolumn{9}{|l|}{$O x$} \\
\hline No & 12.73 & :319 & ม2.T1 & 12.31 & 129 & 1.48 & $1 \pi$ & s.de \\
\hline Tal & icset & $52 \mathrm{KC}$ & 100.52 & 2009 & $10 \times 37$ & $m \leq 1$ & mos & $106 x:$ \\
\hline $\mathrm{Stg}+4$ & ast & 7258 & ET 35 & 6472 & 6515 & $x+1$ & sial? & $\pi \%$ \\
\hline $\mathrm{Er}$ & 333 & $0+4$ & 0.42 & $a s i$ & 638 & {$\left[. A^{\top}\right.$} & 249 & 9.43 \\
\hline Wh & 20 & $0 \times$ & $6 \times 3$ & 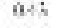 & $0+1$ & (t) & 344 & 4.15 \\
\hline radistic & & & & & & בנ: & $2 x$ & $45 i$ \\
\hline \multicolumn{9}{|l|}{$\begin{array}{l}\text { 1soe IJariats } \\
\text { iper: }\end{array}$} \\
\hline 5015 & & & & & & & 2566 & \\
\hline TiA & & & & & & & $\cos 350$ & \\
\hline v31 & & & & & & & 25834 & \\
\hline $\mathrm{c}: 3$ & & & & & & & 12.24 & \\
\hline Nox & & & & & & & $2 x a s$ & \\
\hline \multicolumn{9}{|l|}{ Cress } \\
\hline R:35 & & & & & & & 365 & \\
\hline Das? & & & & & & & 145 & \\
\hline muse & & & & & & & 200 & \\
\hline 12233 & & & & & & & $a b$ & \\
\hline Noss & & & & & & & is & \\
\hline$T_{a} \mid 31$ & & & & & & & 20 & \\
\hline $12 \pi$ & & & & & & & 215 & \\
\hline Celas & & & & & & & 106 & \\
\hline DtN3Is & & & & & & & 232 & \\
\hline 1414: & & & & & & & 135 & \\
\hline Mal4t & & & & & & & 100 & \\
\hline Sr5s & & & & & & & 1811 & \\
\hline 2.56 & & & & & & & 5.13 & \\
\hline ITr 9 & & & & & & & 239 & \\
\hline Sald? & & & & & & & 34 & \\
\hline Eulys & & & & & & & 310 & \\
\hline Gas: & & & & & & & $35 x$ & \\
\hline Thist & & & & & & & its & \\
\hline$D ; 163$ & & & & & & & 158 & \\
\hline Hales & & & & & & & 335 & \\
\hline $1 \times$ & & & & & & & 12.32 & \\
\hline $121<6$ & & & & & & & 206 & \\
\hline ที丶 & & & & & & & 306 & \\
\hline Lins & & & & & & & 331 & \\
\hline
\end{tabular}




\begin{tabular}{|c|c|c|c|c|c|c|c|c|}
\hline 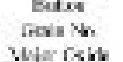 & $12-1$ & $8-1$ & $34-3$ & $2 t-2$ & $20-5$ & ske. -1 & $34-\bar{z}$ & 3s-t: \\
\hline \multicolumn{9}{|l|}{ Inrs: } \\
\hline sै। & 2035 & 93.03 & 210,90 & 2235 & 5036 & 50.17 & $20<0$ & 5568 \\
\hline $\mathrm{no}$ & 252 & 95 & 652 & 051 & $n=8$ & 279 & $x \Leftrightarrow$ & 63 \\
\hline$N \forall C_{7}$ & 29 & $(4)$ & 152 & $3 \%$ & 3.14 & 370 & 254 & 117 \\
\hline $\mathrm{Na}, 0$ & 325 & 230 & 693 & 0.18 & $\omega z$ & 13. & 314 & $=10$ \\
\hline $\mathrm{Man}$ & 233 & $a 24$ & $0 \pm 3$ & ats & w6 & $5<0$ & 156 & 56 \\
\hline Ntbo & 14.19 & $24: 5$ & H.T: & at:s & $1-53$ & $1-2: 8$ & 1523 & $18+i$ \\
\hline$\infty 0$ & 3111 & 32.38 & $38 \times$ & 3297 & $2 x$ & 202 & 3107 & 323 \\
\hline \multicolumn{9}{|l|}{$a \equiv$} \\
\hline No & 332 & s.5.5 & 2238 & 4.57 & $8 a t$ & 192 & $59 t$ & 292 \\
\hline Taal & $\%=2$ & 100.21 & 10027 & Sat & $m 2$ & mal1 & 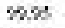 & $m a$ \\
\hline xestet $x$ & 530 & 356 & 6813 & 8635 & 7539 & $7+4$ & is 31 & $913:$ \\
\hline trin & 343 & $a=1$ & 0.82 & 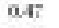 & 641 & [.41 & 343 & 621 \\
\hline Wh & 217 & 945 & $6 \times 3$ & 045 & $0+4$ & is & 29 & 6.15 \\
\hline radius c & & & & as: & as & CII & .243 & 4.17 \\
\hline \multirow{2}{*}{\multicolumn{9}{|c|}{$\begin{array}{l}\text { 1sue IJanats } \\
\text { iper: } \\
\text { tots }\end{array}$}} \\
\hline & & & & & & & & \\
\hline \multirow{2}{*}{\multicolumn{9}{|c|}{$\begin{array}{l}\text { Sods } \\
\text { T.14 }\end{array}$}} \\
\hline & & & & & & & & \\
\hline \multicolumn{9}{|l|}{$v_{31}$} \\
\hline \multicolumn{9}{|l|}{$\mathrm{Cs} 3$} \\
\hline \multirow{2}{*}{\multicolumn{9}{|c|}{$\begin{array}{l}\operatorname{Nak} \\
\mathrm{C} 258\end{array}$}} \\
\hline cess & & & & & & & & \\
\hline \multicolumn{9}{|l|}{ R:35 } \\
\hline \multicolumn{9}{|l|}{ Das? } \\
\hline \multicolumn{9}{|l|}{ This: } \\
\hline \multicolumn{9}{|l|}{15233} \\
\hline \multicolumn{9}{|l|}{ Noss } \\
\hline \multicolumn{9}{|l|}{$\begin{array}{l}7 a \mid 31 \\
12: 3\end{array}$} \\
\hline \multirow{2}{*}{\multicolumn{9}{|c|}{$\begin{array}{l}12 \pi \\
0.143\end{array}$}} \\
\hline \multirow{2}{*}{\multicolumn{9}{|c|}{ DtNIS }} \\
\hline & & & & & & & & \\
\hline \multicolumn{9}{|l|}{ 1214: } \\
\hline \multicolumn{9}{|l|}{ Malut } \\
\hline \multicolumn{9}{|l|}{ Sr5s } \\
\hline \multirow{2}{*}{\multicolumn{9}{|c|}{$\begin{array}{l}2056 \\
\text { IIr } n\end{array}$}} \\
\hline \multirow{2}{*}{\multicolumn{9}{|c|}{ Srald? }} \\
\hline & & & & & & & & \\
\hline Eulys & & & & & & & & \\
\hline Codis? & & & & & & & & \\
\hline Thist & & & & & & & & \\
\hline$D \div 163$ & & & & & & & & \\
\hline Bal6s & & & & & & & & \\
\hline 12166 & & & & & & & & \\
\hline ทaiา & & & & & & & & \\
\hline Luts & & & & & & & & \\
\hline
\end{tabular}




\begin{tabular}{|c|c|c|c|c|c|c|c|c|}
\hline 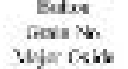 & $26-3$ & $2 x-2$ & $23-1$ & $2 t-3$ & $40-5$ & sa.t 1 & $21-\theta$ & $25-2$ \\
\hline \multicolumn{6}{|l|}{ |wrst } & & & \\
\hline अंड़; & 45200 & Gys & 9034 & $x=1$ & $12 \times$ & $90 z$ & 40.6 & 409 \\
\hline$n \infty$ & 958 & $9=4$ & 052 & 058 & $M s$ & 653 & 248 & eft \\
\hline$A b \alpha_{7}$ & 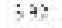 & $9 \times 8$ & 209 & $2 * \infty$ & 367 & 36 & 108 & 100 \\
\hline $\mathrm{Na}: 0$ & 927 & $x=3$ & 027 & $0.5 \overline{2}$ & 606 & 120 & 316 & 63 \\
\hline$M a n$ & 915 & $a v$ & vos & 061 & 0.16 & $t x$ & (1) & $|x|$ \\
\hline Atpo & $34 x$ & 2520 & 19.3s & 145 & $2 \cdot+b$ & 1. 13 & 12.40 & 1253 \\
\hline$\infty$ & 59 & 345 & 216 & 361 & 218 & $21 \%$ & 1850 & 1806 \\
\hline \multicolumn{9}{|l|}{$a s$} \\
\hline No & $7 y$ & 22.42 & $25 !$ & atss & 200 & 127 & 1390 & 15.52 \\
\hline Tal & 6 is & 5200 & 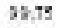 & 539 & 527 & $m=0$ & nose & $n s$ \\
\hline $\mathrm{xtg}+4$ & $i t 81$ & 6515 & 3146 & 72.12 & 7120 & v $\$$ & 6166 & $\$ 20$ \\
\hline $\mathrm{Er}$ & $0-42$ & a.5? & 045 & $a=2$ & 0.11 & {$[.43$} & 339 & 636 \\
\hline Wh & 945 & 919 & 649 & $0<3$ & 0.44 & C.11 & 278 & 638 \\
\hline radistic & $42:$ & & & & & & & \\
\hline \multirow{2}{*}{\multicolumn{9}{|c|}{$\begin{array}{l}\text { 1sue IJanate } \\
\text { iper: }\end{array}$}} \\
\hline & & & & & & & & \\
\hline \multirow{2}{*}{\multicolumn{9}{|c|}{$\begin{array}{l}5.15 \\
\text { Tit }\end{array}$}} \\
\hline \multirow{2}{*}{\multicolumn{9}{|c|}{ vsi }} \\
\hline \multirow{2}{*}{\multicolumn{9}{|c|}{93}} \\
\hline Nox & & & & & & & & \\
\hline c25s & & & & & & & & \\
\hline \multicolumn{9}{|l|}{ R:35 } \\
\hline \multirow{2}{*}{\multicolumn{9}{|c|}{ Dess? }} \\
\hline \multirow{2}{*}{\multicolumn{9}{|c|}{ Twis }} \\
\hline \multirow{2}{*}{\multicolumn{7}{|c|}{1233}} & & \\
\hline \multicolumn{8}{|l|}{ Noss } & \\
\hline \multirow{2}{*}{\multicolumn{9}{|c|}{$\begin{array}{l}7 a \mid 31 \\
12=0\end{array}$}} \\
\hline & & & & & & & & \\
\hline \multicolumn{9}{|l|}{ Cel14 } \\
\hline \multicolumn{9}{|l|}{ Dtuxs } \\
\hline \multicolumn{9}{|l|}{ 1914: } \\
\hline Mal4t & & & & & & & & \\
\hline Srs! & & & & & & & & \\
\hline \multicolumn{9}{|l|}{$2 n s t$} \\
\hline \multicolumn{9}{|l|}{ IIr $\%$} \\
\hline \multicolumn{9}{|l|}{ swid? } \\
\hline \multirow{2}{*}{\multicolumn{9}{|c|}{$\begin{array}{l}\text { Eulys } \\
\text { Cals? }\end{array}$}} \\
\hline & & & & & & & & \\
\hline $\begin{array}{l}\text { Thist } \\
\text { Dis } 163\end{array}$ & & & & & & & & \\
\hline $\begin{array}{l}\text { Dit163 } \\
\text { Elal6s }\end{array}$ & & & & & & & & \\
\hline $\begin{array}{l}\text { Bales } \\
\text { Yos }\end{array}$ & & & & & & & & \\
\hline $12 \times 1<6$ & & & & & & & & \\
\hline ทа⿰工 & & & & & & & & \\
\hline Lins & & & & & & & & \\
\hline
\end{tabular}




\begin{tabular}{|c|c|c|c|c|c|c|c|c|}
\hline 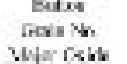 & $22-1$ & $54-2$ & $23-1$ & $a t-2$ & $\sin 2$ & C.t. & $15-1$ & $4 h-2$ \\
\hline \multicolumn{9}{|l|}{ Inrs: } \\
\hline sei & 25.45 & 2313 & 9657 & 9367 & 91.90 & $\operatorname{san}$ & $\$ 1.11$ & $\sin x$ \\
\hline no: & $9 \mathrm{vi}$ & 951 & 94 & 0.8 & $0: 0$ & $c 51$ & 26 & 646 \\
\hline$N \forall C_{7}$ & 28 & $; 75$ & 39 & $3: 1$ & 191 & 356 & 239 & 380 \\
\hline$N 4,0$ & 024 & 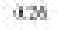 & 925 & $\alpha 26$ & $6.2 x$ & 231 & 125 & 0.18 \\
\hline $\mathrm{Man}$ & $9 \mathrm{LS}$ & $a \leq 2$ & ats & 000 & 13 & 824 & 159 & 160 \\
\hline Ntbo & 12.40 & Ase & $4 x$ & HAs? & $25 \cdot 4 b$ & 15.28 & 1538 & 1896 \\
\hline so & 51 . & 305 & $31 \%$ & 216 & 131 & in & 1853 & $3 \pi+?$ \\
\hline \multicolumn{9}{|l|}{$a \equiv$} \\
\hline No & $6 \pi 2$ & 3.52 & $35 s$ & 8.91 & 2528 & $1 \leq 4$ & 1050 & 652 \\
\hline Taal & 6.1: & 5234 & 100.35 & 100035 & 160012 & $m r$ & rose & nal \\
\hline xestet $x$ & ere & 3545 & 7158 & 7155 & 619 & yㅣㄹ & 7361 & 795 \\
\hline trin & $0+4$ & ans & Q4t & $a=2$ & 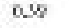 & [.AI & 349 & 642 \\
\hline Wh & $9 w$ & 947 & 911 & 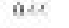 & $\omega \infty$ & is & 319 & 646 \\
\hline radiste & $2 \leq 1$ & 1.57 & & & & css & & $\Delta \alpha$ \\
\hline \multirow{3}{*}{\multicolumn{9}{|c|}{ 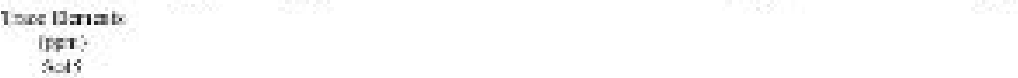 }} \\
\hline & & & & & & & & \\
\hline \multirow{2}{*}{\multicolumn{9}{|c|}{ Tis }} \\
\hline & & & & & & & & \\
\hline \multicolumn{9}{|l|}{ vsi } \\
\hline \multicolumn{9}{|l|}{$\mathrm{Os}$} \\
\hline \multirow{2}{*}{\multicolumn{9}{|c|}{$\begin{array}{l}x \times s \\
c<5 s\end{array}$}} \\
\hline \multirow{2}{*}{\multicolumn{9}{|c|}{ R:35 }} \\
\hline \multirow{2}{*}{\multicolumn{9}{|c|}{ Das? }} \\
\hline \multirow{2}{*}{\multicolumn{8}{|c|}{ This: }} & \\
\hline \multirow{2}{*}{\multicolumn{9}{|c|}{$\begin{array}{l}1233 \\
\text { N153 }\end{array}$}} \\
\hline \multirow{2}{*}{\multicolumn{9}{|c|}{$\begin{array}{l}\text { Niss } \\
\text { Ta:si }\end{array}$}} \\
\hline & & & & & & & & \\
\hline \multicolumn{9}{|l|}{$12 \%$} \\
\hline \multicolumn{9}{|l|}{ Colds } \\
\hline \multicolumn{9}{|l|}{ Ftsis } \\
\hline \multicolumn{9}{|l|}{ 1914: } \\
\hline \multirow{2}{*}{\multicolumn{9}{|c|}{$\begin{array}{l}\text { Mal4t } \\
\text { Srss }\end{array}$}} \\
\hline & & & & & & & & \\
\hline \multicolumn{9}{|l|}{$2 n 5 t$} \\
\hline \multicolumn{9}{|l|}{ IIr n } \\
\hline \multicolumn{9}{|l|}{ Swit? } \\
\hline \multicolumn{9}{|l|}{$\begin{array}{l}\text { Eulys } \\
\text { Cals? }\end{array}$} \\
\hline $\begin{array}{l}\text { Gis? } \\
\text { Thist }\end{array}$ & & & & & & & & \\
\hline $\begin{array}{l}\text { Thist } \\
\text { Dy } 163\end{array}$ & & & & & & & & \\
\hline $\begin{array}{l}\text { Dyles } \\
\text { Bales }\end{array}$ & & & & & & & & \\
\hline $\begin{array}{c}\text { Bal6s } \\
\text { Y\% }\end{array}$ & & & & & & & & \\
\hline $121<6$ & & & & & & & & \\
\hline ที17 & & & & & & & & \\
\hline Luts & & & & & & & & \\
\hline
\end{tabular}




\begin{tabular}{|c|c|c|c|c|c|c|c|c|}
\hline Eutes & $39:-3-12 \mathrm{C}$ & & & & & \multicolumn{3}{|c|}{ an- 3.11} \\
\hline fercin Wh. & $5-2$ & $4 m-1$ & $\Leftrightarrow$ & 28-1 & $14-2$ & $2 \operatorname{sen} 2$ & $t \rightarrow$ & $2-1$ \\
\hline \multicolumn{9}{|l|}{ wyer row } \\
\hline \multicolumn{9}{|l|}{ inrs: } \\
\hline no & 278 & 2310 & 21.12 & 317 & $50=$ & 5041 & 5003 & $50.5 \%$ \\
\hline$m_{2}$ & $\begin{array}{ll}173 \\
979\end{array}$ & 98 & $0+3$ & 083 & 208 & 62 & 270 & 255 \\
\hline & $3+1$ & 295 & 135 & 36 & 313 & (16i) & 276 & 355 \\
\hline$N a, 0$ & 1H & $2 z 2$ & 624 & $\alpha=1$ & 6.2 & $t .18$ & 316 & ه4 \\
\hline$M a n$ & 31? & $a s$ & $0: 14$ & wos & $0 \leq 5$ & tes & 160 & 422 \\
\hline Atpos & $1 \pm .45$ & 298 & 29.94 & 1554 & 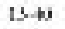 & 1..15 & IS.1. & $12 . \%$ \\
\hline$\infty 0$ & 8106 & 2234 & 3 st & 210 & 320 & 2273 & xil & $30 \pi$ \\
\hline \multicolumn{9}{|l|}{ 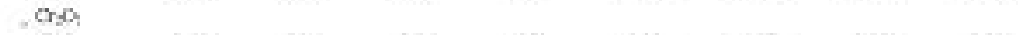 } \\
\hline wo & $5+5$ & sas & 7,95 & ars & gate & t:1 & 333 & 722 \\
\hline Tral & $: 2014$ & 52.12 & 10008 & 2057 & 10css & $m 25$ & nas & 10022 \\
\hline $\mathrm{Stg}-4$ & $\pi \in 5$ & 8571 & $7 \pi \%$ & 4073 & $x \geqslant 3$ & 31.13 & 2833 & $78 \% 8$ \\
\hline $\mathrm{tr}$ & 344 & as? & 0.45 & a.s & 642 & {$[.4]$} & 343 & 9.4 \\
\hline Wh & 217 & 945 & 645 & axt & $6+3$ & 647 & 3013 & $4+4$ \\
\hline ratuld & 134 & a: & $2 \pi$ & $21:$ & & $2 \pi$ & & 9.62 \\
\hline \multirow{2}{*}{\multicolumn{9}{|c|}{$\begin{array}{c}\text { 1soe IJariats } \\
\text { ipgr: }\end{array}$}} \\
\hline \multirow{2}{*}{\multicolumn{9}{|c|}{ :ats }} \\
\hline & & & & & & & & \\
\hline \multicolumn{9}{|l|}{ Tis } \\
\hline \multirow{2}{*}{\multicolumn{9}{|c|}{$\begin{array}{l}\text { vs } \\
\text { ciss }\end{array}$}} \\
\hline \multirow{2}{*}{\multicolumn{9}{|c|}{ Nox }} \\
\hline & & & & & & & & \\
\hline \multicolumn{9}{|l|}{ C<5s } \\
\hline \multirow{2}{*}{\multicolumn{9}{|c|}{$\begin{array}{l}\text { Rt35 } \\
\text { Das, }\end{array}$}} \\
\hline \multirow{2}{*}{\multicolumn{9}{|c|}{$\begin{array}{l}\text { Das? } \\
\text { Tnus? }\end{array}$}} \\
\hline \multirow{2}{*}{\multicolumn{9}{|c|}{$\begin{array}{l}\text { This } \\
11233\end{array}$}} \\
\hline \multirow{2}{*}{\multicolumn{7}{|c|}{ Niss }} & & \\
\hline & \multirow{2}{*}{\multicolumn{8}{|c|}{$\mathrm{Ta} / 31$}} \\
\hline \multirow{2}{*}{\multicolumn{9}{|c|}{$\begin{array}{l}12 \text { in } \\
\text { Col43 }\end{array}$}} \\
\hline & & & & & & & & \\
\hline \multicolumn{9}{|l|}{ Ftsus } \\
\hline \multicolumn{9}{|l|}{ 1414: } \\
\hline \multirow{2}{*}{\multicolumn{9}{|c|}{ MAILt }} \\
\hline \multicolumn{7}{|l|}{$\begin{array}{l}5.53 \\
850\end{array}$} & & \\
\hline \multirow{2}{*}{\multicolumn{9}{|c|}{$\begin{array}{l}205 t \\
\text { IIF }\end{array}$}} \\
\hline & & & & & & & & \\
\hline Sald? & & & & & & & & \\
\hline Fulys & & & & & & & & \\
\hline Gas? & & & & & & & & \\
\hline $\begin{array}{l}\text { Thisa } \\
\text { Deles }\end{array}$ & & & & & & & & \\
\hline $\begin{array}{l}\text { Dy } 163 \\
\text { Hales }\end{array}$ & & & & & & & & \\
\hline $\begin{array}{c}\text { Bales } \\
y \times\end{array}$ & & & & & & & & \\
\hline $12+1<$. & & & & & & & & \\
\hline נרוד & & & & & & & & \\
\hline La175 & & & & & & & & \\
\hline
\end{tabular}




\begin{tabular}{|c|c|c|c|c|c|c|c|c|}
\hline Besind & $2-2$ & $4 \cdots 4$ & $5-1$ & $6-2$ & $3-3$ & $8-1$ & $3 t-1$ & $11 \cdots 2$ \\
\hline \multicolumn{9}{|l|}{ Myjar rebu } \\
\hline $399_{i}$ & $2 \mathrm{t} 09$ & $21 \mathrm{ss}$ & st.T & $92 \mathrm{cs}$ & 52.45 & $52 \% 0$ & A3.71 & $n x$ \\
\hline $\mathrm{no}$ & as: & $n s$ & 042 & 08 & edi & [1] & 24 & $0 \% 8$ \\
\hline$A b C_{7}$ & 35 & 301 & 131 & $P \otimes$ & 343 & 3.75 & 154 & $3<1$ \\
\hline $\mathrm{Na}: 0$ & 025 & 0.18 & 035 & 0.18 & 0.16 & 0.19 & 12 & $\cos$ \\
\hline $\operatorname{Man} 0$ & $0 \mathrm{is}$ & a.11 & 690 & 0,3 & 061 & t 36 & 3.16 & eie \\
\hline Mtpo & 1206 & 2550 & 24.24 & 15:5 & 1730 & 17284 & 18.19 & 148 \\
\hline$\infty 0$ & 335 & 2231 & $38 \boldsymbol{A B}$ & 20 is & 2235 & 2203 & 3188 & $315:$ \\
\hline 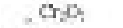 & & & & & & [37 & 3 es & \\
\hline Eso & 931 & sus & 22.80 & 680 & 4.44 & $3 \pm 0$ & 3.46 & 5.86 \\
\hline Tal & $5.5 x$ & 5250 & 100.45 & 5292 & mes: & mist & nal & $m .0$ \\
\hline $3 \mathrm{~s}^{4}$ & $71 \leq 0$ & $\$ 558$ & 663 & $31<3$ & $3: 35$ & 304 & 90,37 & 7626 \\
\hline $\mathrm{m}$ & 0.42 & 0 an? & 0.41 & $a 47$ & 0.48 & $1 \leq 0$ & 191 & 6.41 \\
\hline Wh & 94 & $0+5$ & $6 \times 3$ & aes & $m a$ & 645 & 241 & 644 \\
\hline Fat ats c & & $a n$ & & $2 a$ & ast. & -604 & 136 & \\
\hline \multicolumn{9}{|l|}{$\begin{array}{l}\text { Taue lanats } \\
\text { (per) }\end{array}$} \\
\hline 4015 & & & & & & $31 \%$ & 605 & \\
\hline Tit & & & & & & 2235 & 1493 & \\
\hline vs1 & & & & & & 12338 & 94.50 & \\
\hline a) & & & & & & 20,150 & 1917 78 & \\
\hline Nox & & & & & & $195 \geq 3$ & $102.0 \%$ & \\
\hline cess & & & & & & tes & I. & \\
\hline Rt35 & & & & & & 631 & 33 & \\
\hline Bas? & & & & & & tas & 32 & \\
\hline This: & & & & & & {$[\mathrm{sag}$} & 108 & \\
\hline 10233 & & & & & & $\epsilon 6$ & 306 & \\
\hline N2s3 & & & & & & $5 \mathrm{ec}$ & & \\
\hline $\mathrm{Ta}: 31$ & & & & & & $\operatorname{coc}$ & 260 & \\
\hline $12+3$ & & & & & & 6 is & a 68 & \\
\hline $\cos 143$ & & & & & & 02 & 331 & \\
\hline Ftoxis & & & & & & 6.13 & 216 & \\
\hline MI4: & & & & & & t.16 & 306 & \\
\hline Nalie & & & & & & t.72 & 3.45 & \\
\hline Sars! & & & & & & 17.19 & $1: 00$ & \\
\hline $2 n s t$ & & & & & & 2.10 & 345 & \\
\hline $\operatorname{Irn}: 9$ & & & & & & 6.12 & 215 & \\
\hline Sental? & & & & & & 644 & 278 & \\
\hline Eulss & & & & & & 6.10 & 318 & \\
\hline QA157 & & & & & & 611 & 27 & \\
\hline Thisa & & & & & & 606 & 266 & \\
\hline Dylles & & & & & & ces & 335 & \\
\hline Bal6s & & & & & & 6.36 & 365 & \\
\hline$Y \otimes$ & & & & & & 2,44 & 154 & \\
\hline ENe & & & & & & t2s & 323 & \\
\hline ทั17 & & & & & & 6.37 & 215 & \\
\hline waiาs & & & & & & cot & 366 & \\
\hline
\end{tabular}




\begin{tabular}{|c|c|c|c|c|c|c|c|c|}
\hline Eutus & & & & $51-3.934$ & & & & \\
\hline Taria Nh. & $16-2$ & $=3-2$ & $2 x-3$ & $1 \cdots \bar{z}$ & $7 \cdots / 2$ & $10 \cdot 2$ & $16-2$ & 2201 \\
\hline uher $r \sin$ & & & & & & & & \\
\hline InTs: & & & & & & & & \\
\hline sei & 24.06 & 22.42 & 22.46 & $2 t .51$ & 9125 & 51.18 & 2100 & 31.s \\
\hline $\mathrm{no}$ & 277 & 912 & 678 & $0<6$ & nes & 618 & 218 & as 5 \\
\hline$N \in \delta_{7}$ & 112 & ;79 & 828 & $4 \%$ & $1: 1$ & 239 & 736 & is 15 \\
\hline $\mathrm{Na}: 0$ & 313 & ass & 0.15 & 0.16 & 0.6 & 120 & 12 & 4 \\
\hline$M a n$ & 325 & aLs & out & a. ? & 1.0 & $=50$ & 3.9 & L:5 \\
\hline Atpo & 18.40 & tedg & 29.4 & $1 e .54$ & 243 & 13.5T & 1439 & 23.42 \\
\hline$\infty$ & 5950 & 2) 38 & $y 2+6$ & 3264 & 432 & $17 \%$ & Sires & 18 a : \\
\hline$a=0$ & 155 & & & $a x$ & & & & \\
\hline no & 525 & ast & 4.93 & 300 & $: 2<2$ & t 200 & 394 & $12.8 \%$ \\
\hline Talal & rosi & 10012 & $100: 12$ & tonse & lonet & $m=0$ & isus & $\operatorname{sen}$ \\
\hline $\mathrm{St}=4$ & $\sin$ & st 64 & 86.78 & 8531 & 655 & $65: 7$ & $i s \&$ & $6 t s 8$ \\
\hline tai & 331 & $a+s$ & 0.15 & $a<7$ & 0,1 & t.A0 & 3.41 & a.35 \\
\hline Wh & 211 & 947 & 64 & $0<7$ & $n: 0$ & 67 & 313 & 476 \\
\hline ratistic & 272 & 253 & 022 & wo & & & & \\
\hline $\begin{array}{l}\text { Tsee laxiats } \\
\text { iper? }\end{array}$ & & & & & & & & \\
\hline$\leqslant 15$ & 974 & & & 154 & & & & 23132 \\
\hline TiA & 1354 & & & $6561 \mathrm{~V}$ & & & & taes: it \\
\hline vsi & 643 & & & $2 \alpha, \pi$ & & & & 255 :S \\
\hline cis & 150111 & & & 157126 & & & & $34 \%$ \\
\hline Nox & $\therefore \Delta \|$ & & & $11 \%=6$ & & & & $12 \pm 0$ \\
\hline cess & 332 & & & & & & & \\
\hline R:35 & בוב & & & & & & & 136 \\
\hline Das? & 312 & & & 0.10 & & & & $12 . x$ \\
\hline mis: & 222 & & & & & & & a. 1 \\
\hline 10233 & al & & & 091 & & & & 215 \\
\hline Noss & 33 & & & $\omega 0 \mathrm{c}$ & & & & a.14 \\
\hline Tal 31 & 221 & & & & & & & $a \omega$ \\
\hline 12 is & 237 & & & $\mathrm{Alc}$ & & & & 745 \\
\hline $\mathrm{Cel} 4 \mathrm{~S}$ & 325 & & & $06=$ & & & & $12 \times 8$ \\
\hline Ft:Jis & נוב & & & $a n$ & & & & 4. 36 \\
\hline 1914: & 135 & & & $0.1=$ & & & & 20 \\
\hline MdIAt & 345 & & & $1, x$ & & & & dese \\
\hline Srs! & 1930 & & & Jes & & & & $6+\infty 6$ \\
\hline $2.56 t$ & 335 & & & us & & & & 37.t1 \\
\hline IIr 9 & 212 & & & als & & & & $1 a$ \\
\hline Sald? & 247 & & & $0 \leqslant 5$ & & & & 21 \\
\hline Eulys & 315 & & & 0.19 & & & & 1.67 \\
\hline Cals? & 225 & & & $a \approx$ & & & & 1024 \\
\hline Thist & 231 & & & 015 & & & & 175 \\
\hline$D \div 163$ & 313 & & & 1.12 & & & & $32 \pi$ \\
\hline Bales & 335 & & & $a s y$ & & & & $2 \pi$ \\
\hline$y$ & iss & & & 4.85 & & & & 6545 \\
\hline $121<6$. & 312 & & & ass & & & & 7.23 \\
\hline בנד & 213 & & & $a s 1$ & & & & $2 \times 1$ \\
\hline Lins & 332 & & & ans & & & & Bt: \\
\hline
\end{tabular}




\begin{tabular}{|c|c|c|c|c|c|c|c|c|}
\hline $\begin{array}{l}\text { Eutxe } \\
\text { forin th. }\end{array}$ & $32-1$ & $x-1$ & $x \rightarrow$ & $n-1$ & $n-2$ & sal-1 & 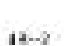 & 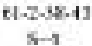 \\
\hline \multicolumn{9}{|l|}{$x y=r a b$} \\
\hline \multicolumn{9}{|l|}{ Inrs. } \\
\hline se; & 31.31 & 216 & nass & $2 L 51$ & 9190 & 9004 & 2000 & S1.4i \\
\hline $\mathrm{n} \sigma \mathrm{q}$ & 253 & $9 \div 2$ & osa & 061 & est & 653 & $2 A$ & a is \\
\hline$N \cdot \sigma_{7}$ & 13 & $c \Leftrightarrow$ & 47 & 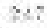 & esti & 237 & $9 \omega$ & i is \\
\hline $\mathrm{Na}, 0$ & $3 n$ & $x=1$ & 625 & 0 g & ובט & t25 & 119 & $43 t$ \\
\hline 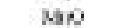 & (1) & $a z t$ & $\omega 02$ & $a t z$ & 1.5 & 15 & 344 & $9,0$. \\
\hline Atpo & $12 \pi 3$ & :9.97 & t.:24 & at 25 & $: 22$ & 13.1. & 1A.1s & 13.11 \\
\hline$\infty$ & 184 & 3454 & 2185 & 1472 & 1389 & $18 \times 5$ & 3053 & $190 \%$ \\
\hline \multicolumn{9}{|l|}{$a \rightarrow$} \\
\hline No & 12.26 & S31 & 751 & 8,2 & 2455 & 1280 & 3.0 & 13.5s. \\
\hline Taal & 16] 1 ? & Inown & n.17 & 55: & 5792 & $m: 7$ & Fast & twat \\
\hline $\mathrm{Mt}=4$ & 418 & 754 & 28 & 7152 & $5+x$ & $5: \alpha$ & itsi & $638 ?$ \\
\hline $\mathrm{thi}$ & 33 & $a+4$ & e.42 & 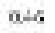 & 626 & [.35 & 343 & a.35 \\
\hline Wh & 274 & $9 \times 5$ & 645 & $0<4$ & 019 & cio & 313 & 476 \\
\hline radiute & & $\therefore a s$ & 2.22 & 29 & & & & \\
\hline \multirow{2}{*}{\multicolumn{9}{|c|}{$\begin{array}{c}\text { 1see bariats } \\
\text { iper: }\end{array}$}} \\
\hline & & & & & & & & \\
\hline \multirow{2}{*}{\multicolumn{9}{|c|}{$\begin{array}{l}\text { Tods } \\
\text { Tis }\end{array}$}} \\
\hline \multirow{2}{*}{\multicolumn{9}{|c|}{ vsi }} \\
\hline & & & & & & & & \\
\hline \multicolumn{9}{|l|}{$\mathrm{Cr}$} \\
\hline \multicolumn{9}{|l|}{$\begin{array}{l}\operatorname{Non} \\
\mathrm{C}<53\end{array}$} \\
\hline \multicolumn{9}{|l|}{$\begin{array}{l}\text { Cess } \\
\text { Rest }\end{array}$} \\
\hline \multirow{3}{*}{\multicolumn{9}{|c|}{$\begin{array}{l}\text { Dus? } \\
\text { Tus? }\end{array}$}} \\
\hline & & & & & & & & \\
\hline \multirow{2}{*}{\multicolumn{9}{|c|}{$\begin{array}{l}\text { This } \\
12233\end{array}$}} \\
\hline \multirow{2}{*}{\multicolumn{6}{|c|}{ Nass }} & & & \\
\hline & \multicolumn{8}{|c|}{ Talsi } \\
\hline \multicolumn{9}{|l|}{$12 \%$} \\
\hline \multicolumn{9}{|l|}{ Cel43 } \\
\hline \multicolumn{9}{|l|}{ Ftsis } \\
\hline \multirow{2}{*}{\multicolumn{9}{|c|}{$\begin{array}{l}\text { 1914: } \\
\text { NAIAt }\end{array}$}} \\
\hline \multirow{2}{*}{\multicolumn{9}{|c|}{$\begin{array}{l}31146 \\
5.59\end{array}$}} \\
\hline & & & & & & & & \\
\hline \multicolumn{9}{|l|}{$2 \mathbf{n s t}$} \\
\hline \multicolumn{9}{|l|}{ IIr 7} \\
\hline Sald? & & & & & & & & \\
\hline Eulys & & & & & & & & \\
\hline Gosis? & & & & & & & & \\
\hline Thist & & & & & & & & \\
\hline $\begin{array}{l}\text { Dyles } \\
\text { Byits }\end{array}$ & & & & & & & & \\
\hline $\begin{array}{c}\text { Bales } \\
y \infty\end{array}$ & & & & & & & & \\
\hline $\begin{array}{l}1 \times 4 \\
121<6\end{array}$ & & & & & & & & \\
\hline 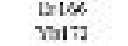 & & & & & & & & \\
\hline Linา & & & & & & & & \\
\hline
\end{tabular}




\begin{tabular}{|c|c|c|c|c|c|c|c|c|}
\hline 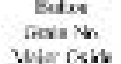 & $13-1$ & $=4-2$ & $\pm 0-1$ & $16-3$ & $12 \times 5$ & 10.1 & $x-2$ & 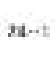 \\
\hline \multicolumn{3}{|l|}{$\ln m \mathrm{n}$} & & & & & & \\
\hline अंड़; & $51 / 2$ & 2236 & 21.12 & $2 t \times 3$ & 5153 & 51.51 & 4071 & $31.5 \%$ \\
\hline no: & 271 & $9 \div$ & $6 \times 2$ & $0: 1$ & Nis & 634 & 216 & 643 \\
\hline$A b \alpha_{7}$ & 163 & 925 & 094 & 291 & 100 & 237 & 299 & 138 \\
\hline Ne:0 & 133 & ast & 0.31 & ass & 62 & 120 & 32 & 536 \\
\hline$M a n$ & 154 & ass & 023 & 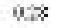 & $0 \leq 5$ & tal & 358 & 6.is \\
\hline Atpo & $12 / \mathrm{s}$ & 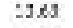 & H.20 & $1: 23$ & 1389 & 17000 & 1398 & $14 x$ \\
\hline$\infty$ & $19 \cdot 8$ & 531 & $14 / 8$ & 1562 & 1925 & $2 x$ & 1949 & $10 \%$ \\
\hline 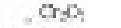 & & & & & & t.2. & & \\
\hline two & $12: 0$ & 24.70 & 13.48 & at. 5 & $13+4$ & נבי & 1300 & 10.72 \\
\hline Tal & 16225 & $\tan 00$ & 100.35 & 5.12 & 10622 & mal7 & mes & nss \\
\hline $\mathrm{xtg}+4$ & $\ddot{*}: 6$ & 6234 & $65: 3$ & 7255 & $45 x$ & 3210 & $\cos =0$ & 7127 \\
\hline $\mathrm{Er}$ & 337 & a.s & 0.5 & ats & $62 \mathrm{z}$ & [AE & 335 & 642 \\
\hline Wh & 210 & $9 \approx$ & 672 & $0: 0$ & 046 & on & 314 & 6.60 \\
\hline ratius & & & & & & is & & \\
\hline \multirow{2}{*}{\multicolumn{9}{|c|}{$\begin{array}{l}\text { Tsee laxiate } \\
\text { iper: }\end{array}$}} \\
\hline & & & & & & & & \\
\hline \multirow{2}{*}{\multicolumn{9}{|c|}{$\begin{array}{l}\text { Sod } \\
\text { Tis }\end{array}$}} \\
\hline & & & & & & & & \\
\hline \multicolumn{9}{|l|}{$\begin{array}{l}\text { vst } \\
\text { csis }\end{array}$} \\
\hline \multicolumn{9}{|l|}{$\cos ^{3}$} \\
\hline \multirow{2}{*}{\multicolumn{9}{|c|}{$\begin{array}{l}\text { Nkt } \\
\text { ckss }\end{array}$}} \\
\hline \multirow{2}{*}{\multicolumn{9}{|c|}{ R:35 }} \\
\hline \multirow{2}{*}{\multicolumn{9}{|c|}{ Das? }} \\
\hline & \multirow{2}{*}{\multicolumn{8}{|c|}{ thas: }} \\
\hline \multirow{2}{*}{\multicolumn{9}{|c|}{$\begin{array}{l}1033 \\
8753\end{array}$}} \\
\hline \multirow{2}{*}{\multicolumn{9}{|c|}{$\begin{array}{l}\mathrm{N} 153 \\
\mathrm{~T}: 31\end{array}$}} \\
\hline & & & & & & & & \\
\hline \multicolumn{9}{|l|}{$12 \%$} \\
\hline \multicolumn{9}{|l|}{ Cel43 } \\
\hline \multicolumn{9}{|l|}{ Ftons } \\
\hline \multirow{2}{*}{\multicolumn{9}{|c|}{$\begin{array}{l}\text { MIL: } \\
\text { Md14t }\end{array}$}} \\
\hline \multirow{2}{*}{\multicolumn{9}{|c|}{ siss }} \\
\hline & & & & & & & & \\
\hline \multicolumn{9}{|l|}{$2 r 5 t$} \\
\hline \multicolumn{9}{|l|}{ IIr $\%$} \\
\hline \multicolumn{9}{|l|}{ Swit? } \\
\hline \multicolumn{9}{|l|}{$\begin{array}{l}\text { Eulys } \\
\text { casis? }\end{array}$} \\
\hline \multirow{2}{*}{\multicolumn{9}{|c|}{$\begin{array}{l}\text { Casis? } \\
\text { Thist }\end{array}$}} \\
\hline & & & & & & & & \\
\hline Bales & & & & & & & & \\
\hline$x \times$ & & & & & & & & \\
\hline 12136 & & & & & & & & \\
\hline ทа⿰工 & & & & & & & & \\
\hline Lins & & & & & & & & \\
\hline
\end{tabular}




\begin{tabular}{|c|c|c|c|c|c|c|c|c|}
\hline 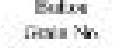 & $35-1$ & $2 n-2$ & $x<-3$ & $43-3$ & $k i-2$ & $s \cdot 1$ & $22-2=$ & $24-n$ \\
\hline Wyer osh & & & & & & & & \\
\hline |arsh & & & & & & & & \\
\hline sैड़; & 30.96 & 2356 & $91 / 2$ & 21.32 & 3183 & $a x$ & $20 \times 00$ & 31.24 \\
\hline $\mathrm{na}$ & 258 & 951 & 632 & $0+3$ & pio & 60 & 27 & $=36$ \\
\hline$n b \alpha_{7}$ & 323 & 210 & 189 & 217 & 100 & 319 & 247 & bet \\
\hline $\mathrm{N} 4: 0$ & 125 & $x=3$ & 032 & $02 i$ & $6=9$ & $12 Y$ & 120 & 63 \\
\hline$M a$ & 324 & 2026 & $0 \leq 9$ & $a 2 s$ & $0 \leqslant 9$ & $5: 0$ & 138 & s.ip \\
\hline Ntpo & $1: 23$ & 2944 & 29.8 & 1251 & $13 x$ & $13 \times x$ & $12: 40$ & 15.41 \\
\hline So & $18 \times t$ & 2965 & 1413 & 1451 & $19 t 3$ & $108:$ & 1900 & 1831 \\
\hline$a_{0} \mathrm{O}$ & & & & an & & & & \\
\hline No & 10.7 & :3se & 1334 & $2 \times$ & 1235 & $11 . x$ & 1000 & 14.55 \\
\hline Tal & nos & towe & 10059 & 555 & 16.12 & $m \div 0$ & $\sin$ & $n x$ \\
\hline $\mathrm{Stg}+4$ & 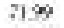 & 7316 & 65.18 & 7132 & 4565 & 850 & $i 2.04$ & 6) 45 \\
\hline $\mathrm{Er}$ & 3.4 & $a+4$ & 0.5 & at & 640 & $\mathrm{C} .4 \mathrm{CO}$ & 3.4 & eas \\
\hline Wh & 277 & $9 \approx$ & 672 & $6 n$ & 040 & (1) & 24 & 678 \\
\hline 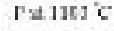 & & & & & & & & \\
\hline 1sue Ilax & & & & & & & & \\
\hline Ifer; & & & & & & & & \\
\hline 5015 & & & & & & & & \\
\hline TiA & & & & & & & & \\
\hline vs1 & & & & & & & & \\
\hline mis & & & & & & & & \\
\hline $\mathrm{Nax}$ & & & & & & & & \\
\hline $\cos 58$ & & & & & & & & \\
\hline R:35 & & & & & & & & \\
\hline Das? & & & & & & & & \\
\hline $\begin{array}{l}\text { This: } \\
15335\end{array}$ & & & & & & & & \\
\hline Nass & & & & & & & & \\
\hline Ta: 31 & & & & & & & & \\
\hline $12 \%$ & & & & & & & & \\
\hline Celds & & & & & & & & \\
\hline $5+313$ & & & & & & & & \\
\hline $1414:$ & & & & & & & & \\
\hline Nal4t & & & & & & & & \\
\hline 5,53 & & & & & & & & \\
\hline $2 r 5 t$ & & & & & & & & \\
\hline IIT 9 & & & & & & & & \\
\hline Sold? & & & & & & & & \\
\hline bulys & & & & & & & & \\
\hline $\begin{array}{l}\text { Casis? } \\
\text { Thist }\end{array}$ & & & & & & & & \\
\hline $\begin{array}{l}\text { Thist } \\
\text { Dyles }\end{array}$ & & & & & & & & \\
\hline $\begin{array}{l}\text { Dy } 163 \\
\text { Blales }\end{array}$ & & & & & & & & \\
\hline $\begin{array}{c}\text { Aales } \\
1 \times 5\end{array}$ & & & & & & & & \\
\hline $121<6$ & & & & & & & & \\
\hline V) & & & & & & & & \\
\hline Laits & & & & & & & & \\
\hline
\end{tabular}




\begin{tabular}{|c|c|c|c|c|c|c|c|c|}
\hline $\begin{array}{l}\text { Butxe } \\
\text { caria in. }\end{array}$ & $26-3$ & $4 ?-1$ & $2 x-3$ & $<4-1$ & art: & $\omega m z$ & $\Delta a-z$ & as-1 \\
\hline \multicolumn{9}{|l|}{ uyer rabs } \\
\hline *ैंड; & 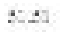 & $2 t \leq 4$ & stz & 93.5 & 3155 & 50.6 & S1.95 & $s 0 . x 0$ \\
\hline$n a$ & 121 & $9 \div 3$ & $96 t$ & $0 \%$ & 05 & C If & $x$ & 415 \\
\hline$n \cdot b_{7}$ & 127 & 13 & 174 & 3.2. & 18: & 313 & 164 & $4 n$ \\
\hline $\mathrm{Na}, \mathrm{N}$ & $32 y$ & ass & 927 & $\alpha z s$ & 60 & tso & 119 & a.st \\
\hline $\mathrm{Man}$ & 35? & $a s$ & 032 & a. ? & awo & t9. & 155 & 9.4 \\
\hline Atpos & 1320 & $=4$ & ห.ก & $15+3$ & $24 \times 5$ & $1 \mathrm{~s}=3$ & 14000 & 1305 \\
\hline$\infty$ & 1560 & $3 \times 14$ & $38 \cap 3$ & 21 is & 2316 & 1080 & 1911 & 1845 \\
\hline $\mathrm{Cr}_{0} \mathrm{O}$ & 334 & 005 & & & & & & 862 \\
\hline No & 13.42 & 2396 & 1938 & 87 & :192 & $58:$ & 13.55 & 16,00 \\
\hline Tral & $x .5 t$ & 586 & 10017 & 1600is & 10000 & mil & 5000 & teoce, \\
\hline $\mathrm{St}=4$ & ด 12 & 7. 54 & ES:3 & 1533 & $42 ?$ & 730 & A. 10 & $4 \%$ \\
\hline tai & 353 & $a-2$ & 042 & $a<3$ & $0<1$ & $5 . A 4$ & 346 & ינדם \\
\hline Wh & 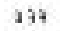 & $9=1$ & 979 & 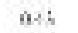 & $0<1$ & is & 374 & 475 \\
\hline \multicolumn{9}{|l|}{ ratistic } \\
\hline \multicolumn{9}{|c|}{ 1soc lanate } \\
\hline \multicolumn{9}{|c|}{ Ifer; } \\
\hline \multicolumn{9}{|l|}{$\Leftrightarrow=15$} \\
\hline \multicolumn{9}{|l|}{ Tis } \\
\hline \multicolumn{9}{|l|}{ vsi } \\
\hline \multicolumn{9}{|l|}{$\mathrm{cis}$} \\
\hline \multirow{2}{*}{\multicolumn{9}{|c|}{$\sin$}} \\
\hline \multirow{2}{*}{\multicolumn{4}{|c|}{$\begin{array}{l}\text { Cess } \\
\text { R:35 }\end{array}$}} & & & & & \\
\hline \multirow{2}{*}{\multicolumn{9}{|c|}{ Das? }} \\
\hline & & & & & & & & \\
\hline \multicolumn{9}{|l|}{ Thes: } \\
\hline \multicolumn{9}{|l|}{12233} \\
\hline \multicolumn{9}{|l|}{ Noss } \\
\hline \multicolumn{9}{|l|}{$\mathrm{Ta} / 31$} \\
\hline \multicolumn{9}{|l|}{$12 \Rightarrow$} \\
\hline \multicolumn{9}{|l|}{$\cos 14$} \\
\hline \multicolumn{9}{|l|}{ Fts13 } \\
\hline \multicolumn{9}{|l|}{ M14: } \\
\hline MalAt & & & & & & & & \\
\hline 5,59 & & & & & & & & \\
\hline $2 n s t$ & & & & & & & & \\
\hline IIr 9 & & & & & & & & \\
\hline sould? & & & & & & & & \\
\hline Eulys & & & & & & & & \\
\hline Gals: & & & & & & & & \\
\hline Thist & & & & & & & & \\
\hline$D ; 163$ & & & & & & & & \\
\hline Bales & & & & & & & & \\
\hline $1 \times$ & & & & & & & & \\
\hline $121<6$ & & & & & & & & \\
\hline ทาเม & & & & & & & & \\
\hline Liาs & & & & & & & & \\
\hline
\end{tabular}




\begin{tabular}{|c|c|c|c|c|c|c|c|c|}
\hline Butes & & & -1.125 & & & & & \\
\hline frar in & $46-3$ & $x-2$ & $1 \cdots 1$ & $3-1$ & $a-4$ & $6-3$ & $x$ & $3-1$ \\
\hline 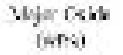 & & & & & & & & \\
\hline 5기 & $21 \leq 4$ & $23 \times 5$ & nas & 9345 & 5051 & 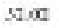 & 40.96 & $5157^{\circ}$ \\
\hline no: & 277 & $9+\infty$ & 054 & $0 \leq 7$ & 040 & 617 & 156 & 649 \\
\hline $\mathrm{Al} / \mathrm{s}$. & 13: & 1.75 & sus & 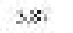 & 218 & $2 t$ & 132 & 1.18 \\
\hline $\mathrm{N} 4,0$ & 329 & 052 & $6 z z$ & azl & 6.19 & 12 & 33 & as \\
\hline $\operatorname{san}$ & 355 & 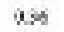 & ous & $a x$ & wis & $: 25$ & t 32 & $16 \%$ \\
\hline Atopo & 1220 & 2423 & L.T.5 & [S.3] & $13 y$ & $1 \pm 2$ & 1250 & $13 . \mathrm{v}$ \\
\hline$\infty 0$ & 1917 & 2916 & 2231 & 2213 & 213 & 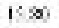 & $19: 34$ & $18 \%$ \\
\hline$\Delta \theta_{3}$ & 313 & $a_{2}$ & & & & & & \\
\hline 700 & $12 . x$ & $11 \mathrm{cs}$ & 6.12 & for & ras & $11 . \mathrm{M}$ & 12.13 & $12 \mathrm{n}$ \\
\hline Teal & Fosit & 5204 & $n .11$ & 160000 & $m s$ & w.r. & nose & $n \times$ \\
\hline $\mathrm{Nes}$ & 604 & $\$ 355$ & 12.13 & 45? 73 & 313 & $x+2$ & 6.13 & 6551 \\
\hline Ba & 357 & $a-2$ & eas & $a=4$ & $64:$ & 6.47 & 30 & 6.40 \\
\hline Wh & 213 & $a *$ & 0.45 & $0<5$ & 0.44 & $C 3$ & 24 & $6: 20$ \\
\hline $\mathrm{r} \times 1 \mathrm{~s}$ 'c & & & 183 & 60 & 211 & & & \\
\hline 2artEnab & & & & & & & & \\
\hline iste & & 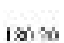 & & & & & & \\
\hline 4014 & & 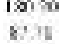 & & & & & & \\
\hline $\begin{array}{l}\mathrm{T} 145 \\
\gamma_{5}\end{array}$ & & $\begin{array}{l}810 \\
313 \times 66\end{array}$ & & & & & & \\
\hline $\begin{array}{l}\text { vst } \\
\text { crs: }\end{array}$ & & 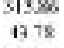 & & & & & & \\
\hline Nin & & $4 x$ & & & & & & \\
\hline cass & & win & & & & & & \\
\hline R:35 & & $2 / 4$ & & & & & & \\
\hline Das? & & as? & & & & & & \\
\hline This: & & av2 & & & & & & \\
\hline 1033 & & 293 & & & & & & \\
\hline No5s & & 210 & & & & & & \\
\hline TaIsi & & 991 & & & & & & \\
\hline TASTA & & 10 & & & & & & \\
\hline Cel43 & & $\times 10$ & & & & & & \\
\hline FWAt3 & & 013 & & & & & & \\
\hline$A \mid=1$ & & 1.9 & & & & & & \\
\hline NaIt4 & & $225 \%$ & & & & & & \\
\hline ass & & 360 & & & & & & \\
\hline $2 x t$ & & 2462 & & & & & & \\
\hline IIT 19 & & 1.11 & & & & & & \\
\hline Sol 1 ? & & $\begin{array}{l}\text { is } \\
1 \leq 1\end{array}$ & & & & & & \\
\hline $\begin{array}{l}\text { bulys } \\
\text { calsi }\end{array}$ & & 800 & & & & & & \\
\hline Jibses & & $1=5$ & & & & & & \\
\hline$D ; 163$ & & $2 t .16$ & & & & & & \\
\hline Ealse & & 231 & & & & & & \\
\hline re: & & iset & & & & & & \\
\hline Litss & & 7.12 & & & & & & \\
\hline Valtנ & & 361 & & & & & & \\
\hline Lul15 & & ans & & & & & & \\
\hline
\end{tabular}




\begin{tabular}{|c|c|c|c|c|c|c|c|c|}
\hline $\begin{array}{l}\text { Butse } \\
\text { movin th. }\end{array}$ & 4-5 & $3 n-1$ & $3 t-3$ & $14-3$ & $1+2$ & on -7 & $23-1$ & $24-1$ \\
\hline \multicolumn{9}{|l|}{$x y=r \sin$} \\
\hline \multicolumn{9}{|l|}{$\ln r: 5$} \\
\hline *⿻is & $20 x 8$ & 2357 & $96 x$ & $963 x$ & 5125 & 5131 & \&1.TI & 1930 \\
\hline no: & 265 & $9 \div 4$ & $0 \leqslant 2$ & $0 \%$ & 08 & 003 & 156 & बa \\
\hline$A b \alpha_{7}$ & $17 \%$ & $1 \%$ & 373 & \&: & $10:$ & 135 & $t 3 t$ & 5.19 \\
\hline $\mathrm{Na}: 0$ & 312 & $4 z$ & 0.14 & $\alpha 12$ & 622 & 62 & 316 & 9.15 \\
\hline $\operatorname{Man}$ & 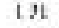 & 1.22 & 015 & $a z$ & $1.4:$ & 306 & $t 28$ & 4.58 \\
\hline Atpo & $14 \mu$ & 2421 & H:E & $1: .4$ & $1-4$ & $1-15$ & 180 & 24.7 \\
\hline$\infty$ & 1968 & 290 & 1214 & 3151 & $19 \%$ & $|8|$ & $19 \times 1$ & $7 x$ \\
\hline \multicolumn{9}{|l|}{$a s$} \\
\hline No & $11: 4$ & $\therefore 24$ & 6.23 & $6 x$ & II LS & 1254 & $10 x 3$ & 725 \\
\hline Tal & $5 \leq 2$ & 10000 & 10047 & 5.19 & 160.7 & $\operatorname{lnc} a$ & inss & 504 \\
\hline $\mathrm{xtg}+4$ & 1815 & E34 & 84.17 & 8031 & के? & sitl & i1. 18 & 773 \\
\hline $\mathrm{Er}$ & 311 & $a+1$ & 0.45 & a-s & 041 & 642 & 3.43 & 242 \\
\hline Wh & 211 & $a *$ & 0.5 & 045 & 041 & 6.18 & 24 & 245 \\
\hline radiuts & & & 432 & 257 & & & & 2.73 \\
\hline \multirow{2}{*}{\multicolumn{9}{|c|}{$\begin{array}{c}\text { 1sue IJanats } \\
\text { iper: } \\
\text { tods }\end{array}$}} \\
\hline & & & & & & & & \\
\hline \multirow{2}{*}{\multicolumn{9}{|c|}{$\begin{array}{l}5.15 \\
\text { Tit }\end{array}$}} \\
\hline & & & & & & & & \\
\hline \multicolumn{9}{|l|}{ vsi } \\
\hline \multicolumn{9}{|l|}{$\operatorname{cis}$} \\
\hline \multirow{2}{*}{\multicolumn{9}{|c|}{$\begin{array}{l}x \times 1 \\
c<5 s\end{array}$}} \\
\hline \multirow{2}{*}{\multicolumn{9}{|c|}{ R:35 }} \\
\hline \multirow{2}{*}{\multicolumn{8}{|c|}{ Das? }} & \\
\hline \multirow{2}{*}{\multicolumn{9}{|c|}{$\begin{array}{l}\text { This: } \\
17233\end{array}$}} \\
\hline & & & & & & & & \\
\hline \multicolumn{9}{|l|}{ Niss } \\
\hline \multicolumn{9}{|l|}{$\mathrm{Ta} 31$} \\
\hline \multicolumn{9}{|l|}{$12 \%$} \\
\hline \multicolumn{9}{|l|}{$\begin{array}{l}\text { Cel45 } \\
\text { Dt.313 }\end{array}$} \\
\hline \multicolumn{9}{|l|}{ Dtuse } \\
\hline \multicolumn{9}{|l|}{ 1414: } \\
\hline \multirow{2}{*}{\multicolumn{9}{|c|}{$\begin{array}{l}\text { Mal4t } \\
\text { Srst }\end{array}$}} \\
\hline \multirow{2}{*}{\multicolumn{9}{|c|}{$2 \mathrm{rst}$}} \\
\hline & & & & & & & & \\
\hline \multicolumn{9}{|l|}{ IIr $~ n$} \\
\hline \multicolumn{9}{|l|}{ sold? } \\
\hline $\begin{array}{l}\text { Eulys } \\
\text { casis? }\end{array}$ & & & & & & & & \\
\hline $\begin{array}{l}\text { Casis? } \\
\text { Thist }\end{array}$ & & & & & & & & \\
\hline $\begin{array}{l}\text { Thise } \\
\text { Dofles }\end{array}$ & & & & & & & & \\
\hline $\begin{array}{l}\text { Dited } \\
\text { Bales }\end{array}$ & & & & & & & & \\
\hline $\begin{array}{l}\text { Bales } \\
1 \times 5\end{array}$ & & & & & & & & \\
\hline $12 \times 1<6$ & & & & & & & & \\
\hline ทа⿰工 & & & & & & & & \\
\hline Lins & & & & & & & & \\
\hline
\end{tabular}




\begin{tabular}{|c|c|c|c|c|c|c|c|c|}
\hline $\begin{array}{l}\text { Eutxe } \\
\text { Fario th }\end{array}$ & $23-1$ & $26-2$ & $36-1$ & $A>-1$ & $\infty<-2$ & 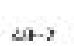 & $11 \cdots$ & $12-1$ \\
\hline \multicolumn{9}{|l|}{ uyer rabs } \\
\hline *ैंड; & :2.17 & 2336 & gnat & stes & 5152 & 2035 & 2224 & 30.4 \\
\hline$n a$ & $9 n$ & $9=1$ & 045 & os & 0.48 & 697 & 234 & $\Delta s$ \\
\hline$n \cdot b_{7}$ & $35:$ & $; 21$ & $1 \times 1$ & $1 \leqslant 3$ & 156 & 17 & 137 & 10 \\
\hline$N 400$ & vis & 218 & $6 z$ & 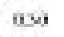 & 620 & 64 & 13s & 4. \\
\hline $\operatorname{san}$ & 915 & $a x$ & 002 & $18 \div$ & $18 \%$ & 1.70 & [9] & $13 t$ \\
\hline Atpos & Ie.A2 & (959 & teat & $19 x 2$ & $1-11$ & $1-55$ & $14.8 T$ & 24.10 \\
\hline$\infty$ & 510 & $233 \mathrm{t}$ & 9811 & 1631 & $19 \%$ & $185:$ & 1960 & 1861 \\
\hline \multicolumn{9}{|l|}{$a r s$} \\
\hline No & 619 & $\mathrm{MSH}$ & 751 & at:s & $12 \pi$ & $125 s$ & 11.3 & 12.61 \\
\hline Tral & 632 & $59 \mathrm{CC}$ & 35.56 & $5 \leq 1$ & 106.12 & 10031 & :al.7s & san \\
\hline $\mathrm{St}=4$ & $8 \leq 5$ & $\varepsilon_{2} \leqslant k$ & 176 & 76 & 497 & $\Delta x+2$ & $00 \times s$ & $\theta 050$ \\
\hline tai & $0-47$ & ats & 0.45 & a-s & 046 & 64: & 3.22 & Q.4: \\
\hline Wh & 919 & $9 / 5$ & 648 & $0 \div 0$ & 019 & ois & 34 & 436 \\
\hline radiste & 1.50 & 2.51 & on & & & & & \\
\hline \multirow{2}{*}{\multicolumn{9}{|c|}{$\begin{array}{l}\text { 1sue IJanats } \\
\text { iper: }\end{array}$}} \\
\hline & & & & & & & & \\
\hline \\
\hline \multicolumn{9}{|l|}{ Tis } \\
\hline \multicolumn{9}{|l|}{ vsi } \\
\hline \multicolumn{9}{|l|}{$\mathrm{C}: 3$} \\
\hline \multirow{2}{*}{\multicolumn{9}{|c|}{ Nin }} \\
\hline \multirow{2}{*}{\multicolumn{2}{|c|}{$\begin{array}{l}\text { Cess } \\
\text { R:35 }\end{array}$}} & & & & & & & \\
\hline \multirow{2}{*}{\multicolumn{9}{|c|}{$\begin{array}{l}\text { R:35 } \\
\text { Das? }\end{array}$}} \\
\hline & & & & & & & & \\
\hline \multicolumn{9}{|l|}{ This: } \\
\hline \multicolumn{9}{|l|}{12233} \\
\hline \multicolumn{9}{|l|}{ Noss } \\
\hline \multicolumn{9}{|l|}{$\mathrm{Ta}: 31$} \\
\hline \multicolumn{9}{|l|}{$12 \Rightarrow$} \\
\hline \multicolumn{9}{|l|}{$\cos 14$} \\
\hline \multicolumn{9}{|l|}{ Dtsus } \\
\hline \multicolumn{9}{|l|}{ M14: } \\
\hline \multicolumn{9}{|l|}{ MdIAt } \\
\hline 5,53 & & & & & & & & \\
\hline $2 n s t$ & & & & & & & & \\
\hline IIr $\rightarrow$ & & & & & & & & \\
\hline Sould? & & & & & & & & \\
\hline Eulys & & & & & & & & \\
\hline Casis? & & & & & & & & \\
\hline Thist & & & & & & & & \\
\hline Di163 & & & & & & & & \\
\hline $\begin{array}{c}\text { Bales } \\
\text { yoy }\end{array}$ & & & & & & & & \\
\hline $12=1<6$ & & & & & & & & \\
\hline ที丶 & & & & & & & & \\
\hline Laits & & & & & & & & \\
\hline
\end{tabular}




\begin{tabular}{|c|c|c|c|c|c|c|c|c|}
\hline Eutus & t5-2-31-54 & & & & & & & \\
\hline Gervin No & $s-2$ & $5 \cdots 1$ & $x-2$ & $12-1$ & $13-2$ & $21 \cdots 1$ & $33-2$ & $26-1$ \\
\hline veyer rabl & & & & & & & & \\
\hline Inrs: & & & & & & & & \\
\hline 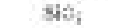 & $20 x$ & $93 \mathrm{cs}$ & $9 n e s$ & 9327 & 51.A1 & 5193 & $\therefore 100$ & 31.74 \\
\hline no: & 277 & 052 & 052 & $\theta \omega$ & $0<7$ & $0<7$ & $2 \leqslant$ & 441 \\
\hline$\Delta \cdot \theta_{7}$ & 121 & 117 & $1>1$ & $3: 2$ & $8 * 0$ & 177 & 10 & 10 \\
\hline 140,0 & $35 t$ & $\omega z$ & $6 z 5$ & $\alpha \vec{x}$ & 62 & 6.17 & 333 & 439 \\
\hline $\operatorname{Man}$ & 15) & 5.10 & 1.73 & as? & 000 & $0 \leq 6$ & 226 & 180 \\
\hline Ntbo & $13 \mathrm{ss}$ & $25 x 2$ & 1396 & $15: 4$ & $142 y$ & 1590 & $12: 20$ & $24.6 \mathrm{~K}$ \\
\hline$\infty 0$ & 1535 & 1918 & tk+15 & 1935 & $19 \mathrm{v}$ & $31+2$ & 1870 & $18: 5$ \\
\hline$\left.C_{B}\right)_{1}$ & & & & & & & & \\
\hline No & 1329 & 2.79 & 1357 & 2000 & $5 x$ & 649 & 13.15 & 11.16 \\
\hline Taal & 20212 & 52.73 & 375 & 2012 & Iecss & Imis & 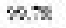 & {$[00 \mathrm{AI}$} \\
\hline setent $x$ & 058 & 556 & 6255 & 7463 & $7 \% 3$ & 3127 & 6361 & 70 is \\
\hline tri & 355 & $a x$ & ess & $a<s$ & $04:$ & cus & 315 & 8.43 \\
\hline Wh & (1) & 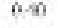 & $6 \%$ & 040 & 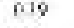 & cis & 216 & 416 \\
\hline radiuts c & & & & & & $1.5 \%$ & & \\
\hline 1 sue laxiats & & & & & & & & \\
\hline IFET: & & & & & & & & \\
\hline $4=15$ & & & & & & & & \\
\hline Tit & & & & & & & & \\
\hline vst & & & & & & & & \\
\hline $\mathrm{Cl3}$ & & & & & & & & \\
\hline 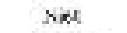 & & & & & & & & \\
\hline cess & & & & & & & & \\
\hline R:35 & & & & & & & & \\
\hline Das? & & & & & & & & \\
\hline This: & & & & & & & & \\
\hline 1233 & & & & & & & & \\
\hline Noss & & & & & & & & \\
\hline $\mathrm{Ta}: 31$ & & & & & & & & \\
\hline $12 \%$ & & & & & & & & \\
\hline $\cos 143$ & & & & & & & & \\
\hline FtJIs & & & & & & & & \\
\hline 1214: & & & & & & & & \\
\hline MalAt & & & & & & & & \\
\hline 5,53 & & & & & & & & \\
\hline $2 \mathbf{r s t}$ & & & & & & & & \\
\hline $\operatorname{IIr}=7$ & & & & & & & & \\
\hline Swill? & & & & & & & & \\
\hline Eulys & & & & & & & & \\
\hline CAs? & & & & & & & & \\
\hline Thist & & & & & & & & \\
\hline$D \div 163$ & & & & & & & & \\
\hline Elates & & & & & & & & \\
\hline$Y \otimes$ & & & & & & & & \\
\hline $121<6$ & & & & & & & & \\
\hline ทั1ว & & & & & & & & \\
\hline Lans & & & & & & & & \\
\hline
\end{tabular}




\begin{tabular}{|c|c|c|c|c|c|c|c|c|}
\hline 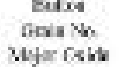 & $x-1$ & $n-1$ & $\infty e x-2$ & $A:-1$ & $\sin 2$ & $\infty-1$ & $26-1$ & $40-2$ \\
\hline \multicolumn{9}{|l|}{ (ans) } \\
\hline $49_{1}$ & $2(A)$ & 939 & $91.4 E$ & $91 \mathrm{ss}$ & $925 s$ & -2.15 & $\therefore$ \&.Tा & 3127 \\
\hline no: & $95:$ & $9+1$ & 052 & $0<6$ & $\mathrm{MAT}$ & 618 & 248 & 647 \\
\hline $\mathrm{Abr}_{7}$ & $\angle x$ & $a+2$ & 115 & $x x^{2}$ & 315 & ELE & 199 & 338 \\
\hline $\mathrm{Na}, 0$ & 052 & 2827 & 021 & $\alpha=2$ & 693 & tar & 121 & 6.14 \\
\hline $\sin \theta$ & 021 & 1.36 & 020 & 0.31 & 0.15 & tes: & 39 & 6.13 \\
\hline Mtho & 19.78 & 24.75 & 1632 & 14:3 & 2590 & $1=120$ & 1631 & 16.51 \\
\hline$\infty 0$ & 3143 & 334 & 2634 & 1532 & $1+x$ & $22: 57$ & $19=0$ & $329 ?$ \\
\hline \multicolumn{9}{|l|}{$Q_{B}=0$} \\
\hline Eso & 752 & 295 & 6.71 & s.ts & 8.79 & $t A 2$ & 5.74 & $45 t$ \\
\hline Talal & $5 \%$ & 5276 & 92.71 & 553 & 52.45 & $m a$ & $m 01$ & mss \\
\hline Mret & is 15 & 1257 & 637 & 75.12 & 7523 & $3 x y$ & 1688 & 85.9 \\
\hline $\mathrm{m}$ & 0.45 & $a+2$ & e.45 & $a+i$ & $64:$ & {$[.43$} & 3.46 & 546 \\
\hline Wh & 912 & 947 & 643 & 049 & 041 & 617 & 24 & 646 \\
\hline Fat 130 'c & $\therefore n$ & & 202 & 425 & 1500 & 1.11 & & AAE \\
\hline \multirow{2}{*}{\multicolumn{9}{|c|}{$\begin{array}{l}\text { Tawe Danats } \\
\text { (ppr) }\end{array}$}} \\
\hline & & & & & & & & \\
\hline \multicolumn{9}{|l|}{4015} \\
\hline \multicolumn{9}{|l|}{ Tit } \\
\hline vs1 & & & & & & & & \\
\hline \multicolumn{9}{|l|}{ mis } \\
\hline sin & & & & & & & & \\
\hline \multirow{2}{*}{\multicolumn{9}{|c|}{ R:35 }} \\
\hline \multirow{2}{*}{\multicolumn{9}{|c|}{ Bas? }} \\
\hline & & \multicolumn{7}{|c|}{ This: } \\
\hline \multicolumn{9}{|l|}{1233} \\
\hline \multicolumn{9}{|l|}{ N2s3 } \\
\hline \multicolumn{9}{|l|}{$\mathrm{Ta} \mid 31$} \\
\hline \multicolumn{9}{|l|}{12 in } \\
\hline \multicolumn{9}{|l|}{ Cel43 } \\
\hline \multicolumn{9}{|l|}{ Ptoxs } \\
\hline \multicolumn{9}{|l|}{ MI4: } \\
\hline \multicolumn{9}{|l|}{ NalAe } \\
\hline \multirow{2}{*}{\multicolumn{9}{|c|}{$\begin{array}{l}5 r 51 \\
2 \mathrm{rst}\end{array}$}} \\
\hline \multirow{2}{*}{\multicolumn{9}{|c|}{$\begin{array}{l}2 \mathrm{r} 5 \mathrm{t} \\
\mathrm{Im} \cdot \mathrm{s}\end{array}$}} \\
\hline & & & & & & & & \\
\hline satid? & & & & & & & & \\
\hline milss & & & & & & & & \\
\hline OAis7 & & & & & & & & \\
\hline $\begin{array}{l}\text { This? } \\
\text { Dy } 163\end{array}$ & & & & & & & & \\
\hline $\begin{array}{l}\text { Dyles } \\
\text { Bal6s }\end{array}$ & & & & & & & & \\
\hline$Y \otimes$ & & & & & & & & \\
\hline Lase & & & & & & & & \\
\hline Уы17 & & & & & & & & \\
\hline 1 wats & & & & & & & & \\
\hline
\end{tabular}




\begin{tabular}{|c|c|c|c|c|c|c|c|c|}
\hline Betset & t5.3-35.58 & & & & & & & \\
\hline Graia the & $31-3$ & $=t-2$ & $12-1$ & $16-2$ & $1<-5$ & $15 \cdot 2$ & $16-8$ & $13 \cdots 1$ \\
\hline Myor $C \mathrm{sh}$ & & & & & & & & \\
\hline |arns) & & & & & & & & \\
\hline $40_{i}$ & $2: x$ & 2358 & $51 \div 5$ & 9227 & 5127 & 31.4 & 51.52 & $31.5 s$ \\
\hline no: & 257 & 625 & 647 & 025 & P46 & 657 & 215 & 945 \\
\hline$\Delta b_{7}$ & 257 & 118 & 105 & 116 & 104 & 138 & 205 & in \\
\hline $\mathrm{Na}: 0$ & 327 & 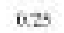 & 051 & $\alpha 26$ & ear & 130 & 36 & 431 \\
\hline $\operatorname{Man} 0$ & 325 & 02 & 062 & 0.60 & 046 & tSs & 369 & $1.3 t$ \\
\hline MtoO & $1 \in A 3$ & isus & 14.42 & H:S & $13 \times 6$ & $12 \times 5$ & 14.35 & 13,41 \\
\hline$\infty$ & 3. 57. & 1978 & las & $21 \%$ & $19+2$ & $19: 6$ & 1065 & $18 \%$ \\
\hline$a, 0$ & 313 & & & & & & 106 & \\
\hline Eco & 149 & נגנ2 & thes & $t a: t$ & 113 & 1197 & 1003 & 13.52 \\
\hline Tal & Ssss & $523 x$ & $n s$ & $1607 x$ & $m_{11}$ & mo & cass & 160 \\
\hline 3104 & 8.96 & 1165 & 888 & $\pi 19$ & $\$ \Leftrightarrow$ & 6357 & 21,43 & $663 ?$ \\
\hline $\mathrm{m}$ & 347 & 0.47 & Q.4I & $a+1$ & esto & 0.40 & 3.43 & 9.35 \\
\hline Wh & 217 & $0: 7$ & 65 & $0 \leq ;$ & 648 & ito & 24 & 936 \\
\hline Paturs ic & 13 & & & & & & & \\
\hline Toce Inat. & & & & & & & & \\
\hline (per) & & & & & & & & \\
\hline 4015 & & & & & & & & \\
\hline Tis & & & & & & & & \\
\hline vs1 & & & & & & & & \\
\hline mis & & & & & & & & \\
\hline$x+x$ & & & & & & & & \\
\hline ckss & & & & & & & & \\
\hline Rt35 & & & & & & & & \\
\hline Bas? & & & & & & & & \\
\hline This: & & & & & & & & \\
\hline 10233 & & & & & & & & \\
\hline $\mathrm{N} 253$ & & & & & & & & \\
\hline$T a: 31$ & & & & & & & & \\
\hline $12 \%$ & & & & & & & & \\
\hline $\cos 143$ & & & & & & & & \\
\hline Ftose & & & & & & & & \\
\hline MI4: & & & & & & & & \\
\hline Nalue & & & & & & & & \\
\hline Sis! & & & & & & & & \\
\hline $2 \mathrm{rst}$ & & & & & & & & \\
\hline $\operatorname{Irn}: \mathrm{x}$ & & & & & & & & \\
\hline seata? & & & & & & & & \\
\hline Eulss & & & & & & & & \\
\hline काडs & & & & & & & & \\
\hline Thist & & & & & & & & \\
\hline Dy $16 \mathrm{~s}$ & & & & & & & & \\
\hline Bal6s & & & & & & & & \\
\hline$Y \infty$ & & & & & & & & \\
\hline $\pm 1<$ & & & & & & & & \\
\hline ทา & & & & & & & & \\
\hline 1 1.175 & & & & & & & & \\
\hline
\end{tabular}




\begin{tabular}{|c|c|c|c|c|c|c|c|c|}
\hline \multicolumn{9}{|c|}{ QL- $\cdot 1=2-143$} \\
\hline frovin th. & $34-3$ & $24-1$ & $N-1$ & $x-3$ & $a-2$ & $\Leftrightarrow$ & $2-1$ & $x \rightarrow$ \\
\hline \multicolumn{9}{|l|}{ uyer raw } \\
\hline \multicolumn{9}{|l|}{ inrs: } \\
\hline अैके & $45 \leq 1$ & 2.39 & Yמa & 9151 & 51.30 & $\operatorname{sen} x t$ & $\$ 1.67$ & 40.55 \\
\hline no: & 955 & $9 \div 1$ & $09>$ & $05 \%$ & ndi & 660 & 20 & 47 \\
\hline$N \in C_{7}$ & 585 & 232. & 401 & $16:$ & $3: 4$ & 312 & 290 & 41 \\
\hline Na:0 & 927 & ass & 0.53 & $\cos \bar{z}$ & 026 & Ese & 36 & a $3 t$ \\
\hline Man & 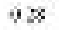 & $a \times b$ & 0.14 & $1 . \approx$ & $0 \leq 5$ & 5.12 & {$[y]$} & $9.4 t$ \\
\hline Atpo & 19.1e & $\therefore 2 A 5$ & te.7t & Has & 1S. 35 & I.SA & 13AT & 13.45 \\
\hline$\infty 0$ & 1517 & 561 & 2115 & 194 & siat & $10 \%$ & $30 \%$ & 90 \\
\hline$C_{3} 0$ & $9 n$ & & 053 & & & & & \\
\hline No & 15.14 & 2205 & 601 & 11.5 & exp & $\$ 53$ & 1120 & $9 \mu$ \\
\hline Taal & kxs & $5 s i c$ & $92 x$ & 10002 & xass & $m a$ & 500 & Res: \\
\hline $\mathrm{sec}=4$ & 5.7. & 7. 36 & 33.34 & 6551 & $3 x 25$ & $\nabla \infty$ & 674 & 73.27 \\
\hline $\mathrm{tai}$ & $0+$ & $a+4$ & e.47 & $a=2$ & 644 & C.A: & 135 & $9 . A L$ \\
\hline Wh & $9+1$ & 920 & 647 & 040 & $0.4 \div$ & (1) & 243 & $4+1$ \\
\hline Fad 130 & & & & & $4 S T$ & 3I: & & \\
\hline \multicolumn{9}{|l|}{$\begin{array}{l}\text { 1sue llanats } \\
\text { iper: }\end{array}$} \\
\hline $4=15$ & & $|8|$ s5 & & & & & & \\
\hline Tit & & 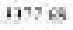 & & & & & & \\
\hline vst & & $+4 \times 23$ & & & & & & \\
\hline $\mathrm{OH}$ & & 1965 & & & & & & \\
\hline Nox & & 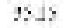 & & & & & & \\
\hline cess & & wh & & & & & & \\
\hline R:35 & & 235 & & & & & & \\
\hline Das? & & 255 & & & & & & \\
\hline \multirow{2}{*}{\multicolumn{9}{|c|}{1233}} \\
\hline & & & & & & & & \\
\hline \multirow{2}{*}{\multicolumn{9}{|c|}{ Ta: 31}} \\
\hline & & & & & & & & \\
\hline 120 & & $9=6$ & & & & & & \\
\hline $\operatorname{Cos} 4$ & & 1.50 & & & & & & \\
\hline $\begin{array}{l}\text { Dt } 313 \\
\text { in } 14:\end{array}$ & & $x_{1>3}$ & & & & & & \\
\hline $\mathrm{N} d \mathrm{I} 4 \mathrm{t}$ & & 3.5 & & & & & & \\
\hline Srs! & & 2144 & & & & & & \\
\hline $2 \mathrm{r} 5 \mathrm{t}$ & & 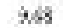 & & & & & & \\
\hline IIT $n$ & & a/2 & & & & & & \\
\hline Sald? & & 127 & & & & & & \\
\hline Eulys & & ast & & & & & & \\
\hline Gas? & & 265 & & & & & & \\
\hline Thist & & 95 & & & & & & \\
\hline$D ; 16]$ & & $3 \times 2$ & & & & & & \\
\hline Bales & & as) & & & & & & \\
\hline$y \otimes$ & & 2531 & & & & & & \\
\hline $121<2$ & & 24 & & & & & & \\
\hline ทั17 & & 212 & & & & & & \\
\hline Lints & & 952 & & & & & & \\
\hline
\end{tabular}




\begin{tabular}{|c|c|c|c|c|c|c|c|c|}
\hline 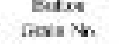 & $12-3$ & $: e-1$ & $24-3$ & $30-3$ & $2 x-2$ & sther 4 & $3 k-1$ & $n n-1$ \\
\hline \multicolumn{9}{|l|}{ viyer raw } \\
\hline \multicolumn{9}{|l|}{ inrs. } \\
\hline जैं। & $306 \%$ & $2: 36$ & 219 & 2125 & 1355 & $\operatorname{sen} x$ & 51.45 & 51.20 \\
\hline no: & a is & 957 & 064 & 045 & nei & cil & 253 & 243 \\
\hline$N b_{7}$ & 931 & 223 & 845 & 135 & $4<0$ & $c s i$ & 154 & a 75 \\
\hline $\mathrm{Na}, \mathrm{N}$ & 121 & ass & 0.35 & ess, & 6 & 12 & 34 & 932 \\
\hline $\operatorname{lan} 0$ & 395 & ait & 100 & 1.25 & 006 & $\therefore 0$ & 146 & L.35 \\
\hline Atbog & 14.7 & 22.24 & $24=4$ & 13.33 & 2955 & 13,4 & $18 \times 5$ & 13. \\
\hline sio & 310 & 749 & $x \notin 5$ & 150 & $225 \%$ & 1901 & 19 *3t & sois: \\
\hline \multicolumn{9}{|l|}{$a_{0}$} \\
\hline no & 313 & $\therefore 2.45$ & $2 A 5$ & 1219 & 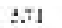 & 1212 & 12.35 & $11 . x$ \\
\hline Taal & 1CJes & 1000 & 100.32 & STAS & 5921 & $2 x: 7$ & 52032 & tenss \\
\hline $\mathrm{Se}_{\mathrm{g}}=\mathrm{H}$ & $3 \infty i$ & $653 T$ & 79.8 & 6.21 & $52 \% ?$ & $\sin$ & 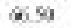 & कos: \\
\hline $\mathrm{ta}$ & 3.42 & ats & 0.45 & $a n$ & 0.44 & t.15 & 335 & a.s5 \\
\hline wh & 29 & $9+7$ & 642 & $6 n$ & $64 i$ & (I) & 211 & 843. \\
\hline radius c & & & & & 120 & & & \\
\hline \multirow{2}{*}{\multicolumn{9}{|c|}{$\begin{array}{l}\text { Isee lasiats } \\
\text { ipgr: }\end{array}$}} \\
\hline & & & & & & & & \\
\hline \multicolumn{9}{|l|}{$\begin{array}{l}\text { Tis } \\
\text { Tis }\end{array}$} \\
\hline \multirow{2}{*}{\multicolumn{9}{|c|}{$\begin{array}{l}\text { Tit } \\
\text { vis }\end{array}$}} \\
\hline & & & & & & & & \\
\hline \multicolumn{9}{|l|}{$\mathrm{mis}$} \\
\hline \multicolumn{9}{|l|}{ Nox } \\
\hline \multirow{2}{*}{\multicolumn{9}{|c|}{$\begin{array}{l}\text { Cess } \\
\text { R:35 }\end{array}$}} \\
\hline & & & & & & & & \\
\hline \multicolumn{9}{|l|}{ Deas? } \\
\hline \multicolumn{9}{|l|}{ This: } \\
\hline \multicolumn{9}{|l|}{1233} \\
\hline \multicolumn{9}{|l|}{ Noss } \\
\hline \multicolumn{9}{|l|}{ Ta: II } \\
\hline \multicolumn{9}{|l|}{ Tain } \\
\hline \multicolumn{9}{|l|}{ Col43 } \\
\hline \multicolumn{9}{|l|}{ Etsus } \\
\hline \multicolumn{9}{|l|}{ M14: } \\
\hline \multirow{2}{*}{\multicolumn{9}{|c|}{$\begin{array}{l}\text { Nates } \\
\text { Siss }\end{array}$}} \\
\hline & & & & & & & & \\
\hline \multicolumn{9}{|l|}{2,56} \\
\hline IIr 7 & & & & & & & & \\
\hline gate? & & & & & & & & \\
\hline bulys & & & & & & & & \\
\hline Cosis? & & & & & & & & \\
\hline This4 & & & & & & & & \\
\hline 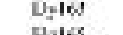 & & & & & & & & \\
\hline Bales & & & & & & & & \\
\hline 12166 & & & & & & & & \\
\hline ทaเม & & & & & & & & \\
\hline Lulvs & & & & & & & & \\
\hline
\end{tabular}




\begin{tabular}{|c|c|c|c|c|c|c|c|c|}
\hline 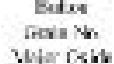 & $36-3$ & $\infty-2$ & $20-3$ & $84-1$ & $6-1$ & $\infty-1$ & $24-2$ & ab-: \\
\hline \multicolumn{9}{|l|}{ InTs| } \\
\hline अंड़ & 31.75 & 2136 & 21.7 & $92 \times 3$ & 31.75 & 5210 & $4=38$ & sos: \\
\hline$n \infty$ & 277 & $9=9$ & 916 & 052 & ars & $\cos$ & $24 T$ & $\$ 41$ \\
\hline$A b \delta_{7}$ & 259 & 989 & 944 & 119 & 188 & $68:$ & 289 & in \\
\hline $\mathrm{Na}, 0$ & 125 & ast & a.s: & $\alpha=0$ & 62 & 629 & 34 & 619 \\
\hline $\operatorname{Man}$ & 19? & $a+$ & 144 & 1.12 & $6 \times 4$ & 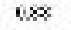 & tog & \$9! \\
\hline Atpo & $12 \mu$ & 25.15 & 2937 & IS:S & 1258 & 1355 & $12: 99$ & $12 \%$ \\
\hline$\infty$ & 1920 & 3376 & $14 \% 8$ & 1363 & 197 & 394 & 3036 & is $5:$ \\
\hline \multicolumn{9}{|l|}{ 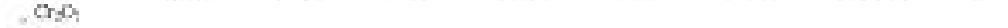 } \\
\hline No & $12 . x t$ & 2235 & 22.12 & $12: 3$ & $12 x_{2}$ & $12+4$ & 1250 & 1531 \\
\hline Tal & 1637 & 526 & 100is & 10005 & $m \geqslant$ & Inc:31 & $x \in 5$ & $n k$ \\
\hline $\mathrm{xtg}+4$ & 614 & $65 \$ 8$ & $6 x^{2}$ & 6551 & 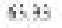 & 6531 & ats & 6305 \\
\hline $\mathrm{Er}$ & 315 & $a s$ & 2.35 & $a<0$ & 628 & $60 \mathrm{x}$ & 337 & 627 \\
\hline Wh & 24 & $9+2$ & 942 & $0 \div 0$ & $9+1$ & 640 & 213 & (1) \\
\hline \multicolumn{9}{|l|}{ Fatios } \\
\hline \multicolumn{9}{|c|}{ 1sue Ilanats } \\
\hline \multirow{2}{*}{\multicolumn{9}{|c|}{ 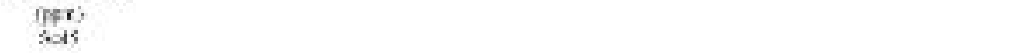 }} \\
\hline & & & & & & & & \\
\hline \multicolumn{9}{|l|}{ Tit } \\
\hline \multirow{2}{*}{\multicolumn{9}{|c|}{$\cos _{x \rightarrow 3}$}} \\
\hline & & & & & & & & \\
\hline \multirow{2}{*}{\multicolumn{9}{|c|}{$\begin{array}{l}x \times 1 \\
c<5 s\end{array}$}} \\
\hline \multirow{2}{*}{\multicolumn{9}{|c|}{ R:35 }} \\
\hline & \multirow{2}{*}{\multicolumn{8}{|c|}{ Das? }} \\
\hline \multirow{2}{*}{\multicolumn{9}{|c|}{ Thus }} \\
\hline \multirow{2}{*}{\multicolumn{8}{|c|}{10233}} & \\
\hline \multirow{2}{*}{\multicolumn{8}{|c|}{ Noss }} & \\
\hline \multirow{2}{*}{\multicolumn{7}{|c|}{$\begin{array}{l}T=31 \\
12: \Rightarrow 1\end{array}$}} & & \\
\hline \multirow{2}{*}{\multicolumn{9}{|c|}{ Celds }} \\
\hline & & & & & & & & \\
\hline \multicolumn{9}{|l|}{ Dtsus } \\
\hline \multicolumn{9}{|l|}{ 1914: } \\
\hline \multirow{2}{*}{\multicolumn{9}{|c|}{$\begin{array}{l}\text { Mal4t } \\
\text { Srsy }\end{array}$}} \\
\hline \multirow{2}{*}{\multicolumn{9}{|c|}{$2 n 5 t$}} \\
\hline & & & & & & & & \\
\hline \multicolumn{9}{|l|}{ IIr $n$} \\
\hline Sould? & & & & & & & & \\
\hline $\begin{array}{l}\text { Dulys } \\
\text { casis? }\end{array}$ & & & & & & & & \\
\hline $\begin{array}{l}\text { Masis } \\
\text { Thist }\end{array}$ & & & & & & & & \\
\hline $\begin{array}{l}\text { Thist } \\
\text { Dyl163 }\end{array}$ & & & & & & & & \\
\hline $\begin{array}{l}\text { Dited } \\
\text { Bales }\end{array}$ & & & & & & & & \\
\hline $\begin{array}{l}\text { Bales } \\
y \times 4\end{array}$ & & & & & & & & \\
\hline 12136 & & & & & & & & \\
\hline ทа⿰工 & & & & & & & & \\
\hline Lins & & & & & & & & \\
\hline
\end{tabular}




\begin{tabular}{|c|c|c|c|c|c|c|c|c|}
\hline $\begin{array}{l}\text { Eutxe } \\
\text { Garis in }\end{array}$ & $\begin{array}{c}(4 \cdot-1 \geq 4-121 \\
\$ x-2\end{array}$ & $2 \cdot-1$ & $8-1$ & ta-3 & 40.5 & $15 \cdots 2$ & $14-1$ & $15-1$ \\
\hline $\begin{array}{c}\text { Myer osh } \\
\text { inr:e }\end{array}$ & & & & & & & & \\
\hline sit; & 2208 & 9313 & 318 & 2155 & 9155 & $50-6$ & 5075 & 31.53 \\
\hline$n a$ & 272 & $0+5$ & 049 & $0 \%$ & 06 & 665 & 237 & a 15 \\
\hline$A b C_{7}$ & 315 & $1 \otimes$ & 165 & $|\dot{x}|$ & 157 & $3 n$ & $2) 3$ & 324 \\
\hline $\mathrm{Na}: 0$ & 322 & 0.54 & 623 & azs & $6.2 x$ & tas & 192 & e. $2 \mathrm{t}$ \\
\hline Nan & 313 & 0.50 & $02 ?$ & $a \times b$ & $0 \leq 8$ & 5.4. & 391 & 921. \\
\hline Atpo & 11.78 & 245 & Lo:s & 1515 & $25+b$ & $125 T$ & 14.58 & 18.73 \\
\hline$\infty$ & is is & 311 & $18 \mathrm{ch}$ & $19: 1$ & +12 & 1823 & $x \geqslant$ & 1085 \\
\hline 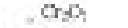 & 327 & oas & & 001 & $6 \pi$ & & $3 x$ & 9.63 \\
\hline tNo & 237 & : 121 & to.ss & {$[1 . A 3$} & 235 & 1271 & 11.75 & 10.50 \\
\hline Taal & $: 2 x y$ & 52.17 & 2051 & lonos & $1602 t$ & $m s:$ & sonses & 1621 \\
\hline $\mathrm{Stg}+4$ & 1585 & 341 & 1292 & 393 & $7 \times$ & $5: 15$ & $\alpha * s$ & 725 \\
\hline $\mathrm{tr}$ & 291 & 0.2 & Q45 & 043 & $0-4$ & [.A. & 2.41 & 9.44 \\
\hline$w h$ & $27 t$ & oni & 642 & $0: 0$ & $n: \phi$ & cis & 211 & $2+6$ \\
\hline ratustic & 523 & & & & & & & \\
\hline 1 sue IJanats & & & & & & & & \\
\hline isen: & & & & & & & & \\
\hline 5015 & & & & & & & & \\
\hline Tis & & & & & & & & \\
\hline vs1 & & & & & & & & \\
\hline $\mathrm{C}: 3$ & & & & & & & & \\
\hline NKR & & & & & & & & \\
\hline $0<58$ & & & & & & & & \\
\hline R:35 & & & & & & & & \\
\hline Das? & & & & & & & & \\
\hline This: & & & & & & & & \\
\hline 10233 & & & & & & & & \\
\hline Noss & & & & & & & & \\
\hline Tal 31 & & & & & & & & \\
\hline 12 i & & & & & & & & \\
\hline $\begin{array}{c}\operatorname{Col} 143 \\
5+132\end{array}$ & & & & & & & & \\
\hline $\begin{array}{l}P=313 \\
* 1 \leq 1\end{array}$ & & & & & & & & \\
\hline 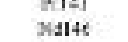 & & & & & & & & \\
\hline siss & & & & & & & & \\
\hline $2 \mathrm{rst}$ & & & & & & & & \\
\hline IIT 9 & & & & & & & & \\
\hline Swali? & & & & & & & & \\
\hline Eulys & & & & & & & & \\
\hline Casis? & & & & & & & & \\
\hline Thist & & & & & & & & \\
\hline$D_{y} 163$ & & & & & & & & \\
\hline Bales & & & & & & & & \\
\hline$x$ & & & & & & & & \\
\hline Linke. & & & & & & & & \\
\hline V) & & & & & & & & \\
\hline 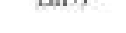 & & & & & & & & \\
\hline
\end{tabular}




\begin{tabular}{|c|c|c|c|c|c|c|c|c|}
\hline Eutut & \multicolumn{3}{|c|}{ 15.1.57-5i } & \multirow[b]{2}{*}{$2-4$} & \multirow[b]{2}{*}{$1-5$} & \multirow[b]{2}{*}{$6-3$} & \multirow{2}{*}{$6-3$} & \multirow[b]{2}{*}{$2-1$} \\
\hline 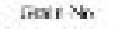 & $16-1$ & $1 \cdots 2$ & $3-1$ & & & & & \\
\hline \multicolumn{9}{|l|}{$\begin{array}{c}\text { Wyar } r<b \\
\text { lantil }\end{array}$} \\
\hline 5 ti & S1.2s & 2159 & 93.19 & 2133 & 52.5 & 3.17 & 51.95 & 51.52 \\
\hline no: & 471 & 959 & $04 ?$ & $0 \notin$ & 619 & $c \leqslant 1$ & 24 & 643 \\
\hline $\mathrm{N} / \mathrm{s}$. & iss & 2.4 & 1.14 & 2.55 & $12 \times 6$ & $2 n$ & 198 & 120 \\
\hline Na:0 & 129 & 2015 & 6.13 & 025 & 0.18 & {$[23$} & 119 & EI \\
\hline $\operatorname{Man}$ & 395 & $a \geq 3$ & 621 & 0.16 & 6.18 & $5 x$ & 134 & 1.44 \\
\hline Nt6o & 1426 & 245 & 1737 & $12: 23$ & iis & 16.8 & $14 x 2$ & 17.01 \\
\hline$\infty 0$ & $19 \times 6$ & 2323 & 215 & 3253 & $\geqslant \geqslant$ & $19 \times 5$ & 1754 & 1875 \\
\hline$\Delta \theta_{3}$ & 357 & 912 & 059 & $a \sqrt{2}$ & $0=6$ & & & \\
\hline 700 & 12.8 & a1s & 4.70 & all & \& & 9100 & 11.50 & sia \\
\hline Teal & 16ats & 100227 & $n+3$ & $100 \%$ & lecsi & $\% .2 t$ & $=2014$ & ms? \\
\hline $\mathrm{NeS}$ & Gi: & 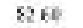 & 689 & S. 53 & 3585 & ovs & $x \in 3$ & 7555 \\
\hline Ba & 3.11 & $a+5$ & eaz & $a+$ & 0.48 & C.AE & 349 & EAR \\
\hline Wh & 274 & $a n t$ & 641 & ax & ness & $c .10$ & 216 & 627 \\
\hline \multirow{2}{*}{\multicolumn{9}{|c|}{ Dox Enats }} \\
\hline & & & & & & & & \\
\hline iste & & & & & & & & \\
\hline kats & & $12 \times 44$ & Kis & $181 a^{2}$ & 15512 & & & \\
\hline I.45 & & $125: 70$ & 20401 & $231: 5 i$ & $190 \times 644$ & & & \\
\hline$v 31$ & & 20.30 & 135ere & 304.2 & 2051 & & & \\
\hline$c^{2}$ & & 132076 & 501646 & 257915 & $1500:$ & & & \\
\hline $\mathrm{Nin}$ & & $100, t s$ & $2 e \times$ & $21: 3 y$ & $168 x 2$ & & & \\
\hline cass & & & waz & asI & owe & & & \\
\hline R:35 & & ass & 1.74 & 037 & 1,51 & & & \\
\hline Das? & & wst & 5,01 & 0.36 & $6: 2$ & & & \\
\hline This: & & & 6al & & 001 & & & \\
\hline 1093 & & 991 & 601 & & 60 & & & \\
\hline N5s & & $a n z$ & 002 & $a n$ & $\cos$ & & & \\
\hline TaISI & & 991 & 601 & & & & & \\
\hline TASTA & & 210 & 012 & $\omega x$ & 014 & & & \\
\hline $\cos 143$ & & $a s$ & 0.55 & 1.30 & wer & & & \\
\hline Ftuts & & als & 6.19 & $a x$ & 036 & & & \\
\hline$A \mid<1$ & & wh & $60 ?$ & 021 & 0.16 & & & \\
\hline $\mathrm{MdI}+6$ & & $a=4$ & 0.55 & 258 & 1200 & & & \\
\hline अ5s & & 253 & 32.75 & $3 x$ & 1017 & & & \\
\hline $2 n s t$ & & 1.75 & \$.15 & $+\ldots$ & $2 \theta \%$ & & & \\
\hline IIT & & asi & 015 & ats & 0.14 & & & \\
\hline $\sin 1$ ? & & 9.5 & $6>3$ & 192 & $64 \mathrm{~s}$ & & & \\
\hline Eul9s & & a.s & 0.15 & 0.5: & $6.1:$ & & & \\
\hline CAlsi & & 957 & 045 & 113 & 6ד & & & \\
\hline Thes:3 & & U1A & wa & w: & $\omega 2$ & & & \\
\hline Dop 12 & & 253 & 05 & 1.7 & $0 \leq 4$ & & & \\
\hline Ealos & & 221 & 013 & $a \geqslant 3$ & 033 & & & \\
\hline 1ros & & -4 & 323 & भal & 422 & & & \\
\hline Litss & & was & $0.5 s$ & 1.38 & 647 & & & \\
\hline Valz & & 251 & 021 & 1.01 & $0 \leq 1$ & & & \\
\hline Lats & & $9 \times 3$ & was & a.s & $w \pi$ & & & \\
\hline
\end{tabular}




\begin{tabular}{|c|c|c|c|c|c|c|c|c|}
\hline 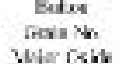 & $8-1$ & 0.1 & $23-1$ & $n t-1$ & $+2-2$ & $15 \cdot 2$ & $36-1$ & $180-5$ \\
\hline \multicolumn{4}{|l|}{$\ln m \mathrm{n}$} & & & & & \\
\hline अंड़; & S1.71 & 2236 & $22 \pi$ & 2235 & 91.8 & $\sec 21$ & 40.58 & 5112 \\
\hline no: & 255 & 961 & 08 & $0 \pm x$ & as & 658 & 247 & 853 \\
\hline$A b \alpha_{7}$ & 261 & 709 & 177 & 135 & $8 \%$ & 323 & 29 & 244 \\
\hline $\mathrm{Na}: 0$ & 133 & 057 & 023 & 0.19 & 608 & 121 & 122 & 63 \\
\hline $\operatorname{Man}$ & 322 & 035 & 0.34 & $a z$ & a.ri & 5.12 & 306 & 624 \\
\hline Atpo & leven & 24.72 & 28.ก & 16.43 & $: 130$ & 1628 & 1622 & 15.a1 \\
\hline$\infty$ & li 16 & SEE & 3891 & 3231 & 213 & $18 / t$ & 1780 & sidi \\
\hline \multicolumn{9}{|l|}{$a r$} \\
\hline No & $12, v t$ & נגבז: & 215 & $\Delta-1 t$ & 72 & 11.31 & 11.28 & 525 \\
\hline Tal & 16392 & town & 10032 & 552 & 5227 & $m a 0$ & 5021 & $n \pi$ \\
\hline $\mathrm{xtg}+4$ & $x=7$ & 72.51 & 7659 & 80113 & 7352 & 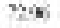 & ist & 7641 \\
\hline $\mathrm{Er}$ & 3.45 & avs & 0.47 & a.ts & $64:$ & t.At & 3.46 & 6.14 \\
\hline Wh & 275 & 91 & $6 \times 2$ & 045 & $6+1$ & 637 & 236 & 64 \\
\hline ratius & & & 2.04 & AII & $1.7 \mathrm{k}$ & & & 1.06 \\
\hline \multirow{2}{*}{\multicolumn{9}{|c|}{ 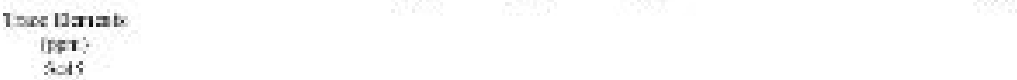 }} \\
\hline & & & & & & & & \\
\hline \multirow{2}{*}{\multicolumn{9}{|c|}{$\begin{array}{l}\text { Sod } \\
\text { Tis }\end{array}$}} \\
\hline & & & & & & & & \\
\hline \multirow{2}{*}{\multicolumn{9}{|c|}{$\begin{array}{l}\text { vst } \\
\text { csis }\end{array}$}} \\
\hline \multicolumn{8}{|l|}{$\cos 3$} & \\
\hline \multirow{2}{*}{\multicolumn{9}{|c|}{$\begin{array}{l}x \times 1 \\
\operatorname{coss}\end{array}$}} \\
\hline \multirow{2}{*}{\multicolumn{9}{|c|}{ R:35 }} \\
\hline \multirow{2}{*}{\multicolumn{9}{|c|}{ Das? }} \\
\hline \multirow{2}{*}{\multicolumn{8}{|c|}{$\begin{array}{l}\text { Thus } \\
1738 \text { s }\end{array}$}} & \\
\hline \multirow{2}{*}{\multicolumn{9}{|c|}{$\begin{array}{l}17233 \\
\text { N.53 }\end{array}$}} \\
\hline \multirow{2}{*}{\multicolumn{9}{|c|}{$\begin{array}{l}\text { Noss } \\
\text { Talsi }\end{array}$}} \\
\hline & & & & & & & & \\
\hline \multicolumn{9}{|l|}{$12 \%$} \\
\hline \multicolumn{9}{|l|}{ Celd } \\
\hline \multicolumn{9}{|l|}{ Dt313 } \\
\hline \multicolumn{9}{|l|}{ 1414: } \\
\hline \multirow{2}{*}{\multicolumn{9}{|c|}{$\begin{array}{l}\text { Mal4t } \\
\text { Srst }\end{array}$}} \\
\hline & & & & & & & & \\
\hline \multicolumn{9}{|l|}{$2 \mathrm{rst}$} \\
\hline \multicolumn{9}{|l|}{ IIr $~ n$} \\
\hline \multicolumn{9}{|l|}{ Sould? } \\
\hline \multicolumn{9}{|l|}{$\begin{array}{l}\text { Eulys } \\
\text { Cals? }\end{array}$} \\
\hline $\begin{array}{l}\text { Casis? } \\
\text { Thist }\end{array}$ & & & & & & & & \\
\hline $\begin{array}{l}\text { Thist } \\
\text { Dy } 163\end{array}$ & & & & & & & & \\
\hline $\begin{array}{l}\text { Dited } \\
\text { Bales }\end{array}$ & & & & & & & & \\
\hline $\begin{array}{l}\text { Bales } \\
\text { Yos }\end{array}$ & & & & & & & & \\
\hline $12 \times 1<6$ & & & & & & & & \\
\hline ทа⿰工 & & & & & & & & \\
\hline Lins & & & & & & & & \\
\hline
\end{tabular}




\begin{tabular}{|c|c|c|c|c|c|c|c|c|}
\hline \multicolumn{6}{|l|}{ Eutxe } & ism-1 & $3 n-8$ & 280.2 \\
\hline \multicolumn{9}{|l|}{ Wyar resh } \\
\hline सैं & $45 \geq 4$ & 2316 & 91.33 & $91=4$ & 9125 & 51.72 & 22.31 & 5209 \\
\hline$n a$ & $95:$ & 96 & 075 & $\omega \omega$ & $0: 4$ & 631 & 236 & 646 \\
\hline$A b C_{7}$ & $\therefore 12$ & $>\infty$ & 87 & $18:$ & $3: 6$ & 351 & 189 & 250 \\
\hline $\mathrm{Na}, 0$ & ys & 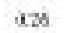 & 651 & $\alpha=$ & 6.32 & tar & 13 & $=16$ \\
\hline Nan & 073 & $a .52$ & 0.4? & $a \leqslant 0$ & 0.5 & 526 & 109 & 626 \\
\hline Atpo & $14 x$ & רינ & tose & Ls]? & 2555 & $1 / x \rightarrow 0$ & $16 x \mathrm{x}$ & 105 \\
\hline $\mathrm{Si}$ & 1768 & 213 & 1455 & 1919 & $3 y$ & zal & 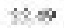 & 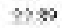 \\
\hline \multicolumn{9}{|l|}{$a r$} \\
\hline No & 13.43 & $2 t 36$ & 2.70 & 1153 & :392 & tet & 2.78 & $4 k$ \\
\hline Tral & 558 & 5293 & 92.79 & lonos & 10007 & $m=0$ & man & $n=$ \\
\hline $\mathrm{St}=4$ & of 15 & 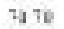 & 1335 & 383 & 1282 & $3 \geq \infty$ & $8<81$ & 8his: \\
\hline tà & 0.45 & $a+4$ & eas & 046 & 025 & t.At & 346 & EAT \\
\hline Wh & 935 & 90 & 641 & $0 \div 5$ & $0: 8$ & in & 215 & 646 \\
\hline Padute & & & & & & cas & & Aנs \\
\hline \multicolumn{9}{|l|}{ Tsee laxiats } \\
\hline \multicolumn{9}{|l|}{$\begin{array}{l}\text { ipgr: } \\
\text { ips: }\end{array}$} \\
\hline \multicolumn{9}{|l|}{$\leqslant 015$} \\
\hline \multicolumn{9}{|l|}{ Tis } \\
\hline \multicolumn{9}{|l|}{ vsi } \\
\hline \multicolumn{9}{|l|}{$\mathrm{ar}$} \\
\hline \multicolumn{9}{|l|}{ Nox } \\
\hline \multicolumn{9}{|l|}{ cess } \\
\hline \multicolumn{9}{|l|}{$\mathrm{R}: 35$} \\
\hline \multicolumn{9}{|l|}{ Das? } \\
\hline \multicolumn{9}{|l|}{ mols: } \\
\hline \multicolumn{9}{|l|}{10233} \\
\hline \multicolumn{9}{|l|}{ Noss } \\
\hline \multicolumn{9}{|l|}{ Talsi } \\
\hline \multicolumn{9}{|l|}{$12 \%$} \\
\hline \multicolumn{9}{|l|}{ Celds } \\
\hline \multicolumn{9}{|l|}{ Dtsus } \\
\hline 1414: & & & & & & & & \\
\hline $\mathrm{MdIAt}$ & & & & & & & & \\
\hline 585 & & & & & & & & \\
\hline $2 n s t$ & & & & & & & & \\
\hline $\mathrm{ITr}=$ & & & & & & & & \\
\hline Swald? & & & & & & & & \\
\hline Eulys & & & & & & & & \\
\hline casis? & & & & & & & & \\
\hline Thist & & & & & & & & \\
\hline$D ; 163$ & & & & & & & & \\
\hline Bates & & & & & & & & \\
\hline$y x$ & & & & & & & & \\
\hline $121<6$. & & & & & & & & \\
\hline ทatม & & & & & & & & \\
\hline Lins & & & & & & & & \\
\hline
\end{tabular}




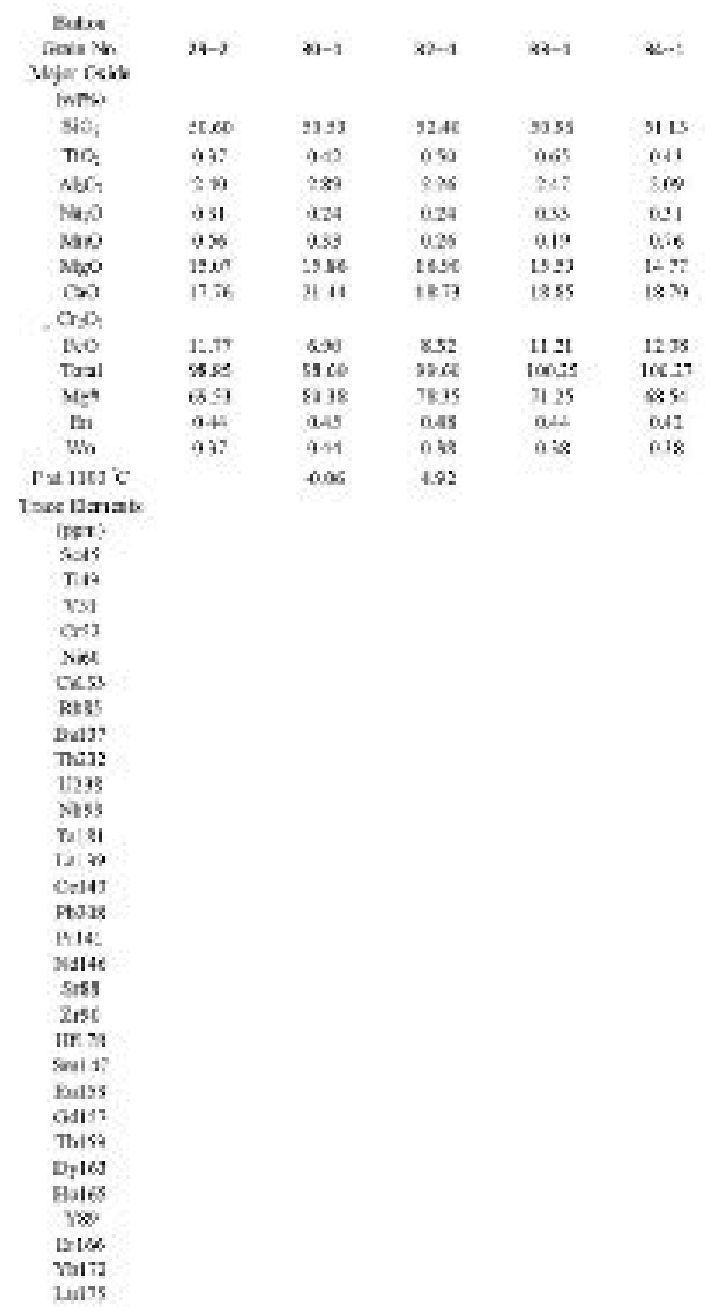




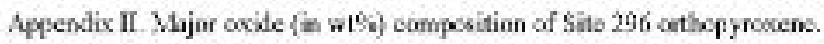

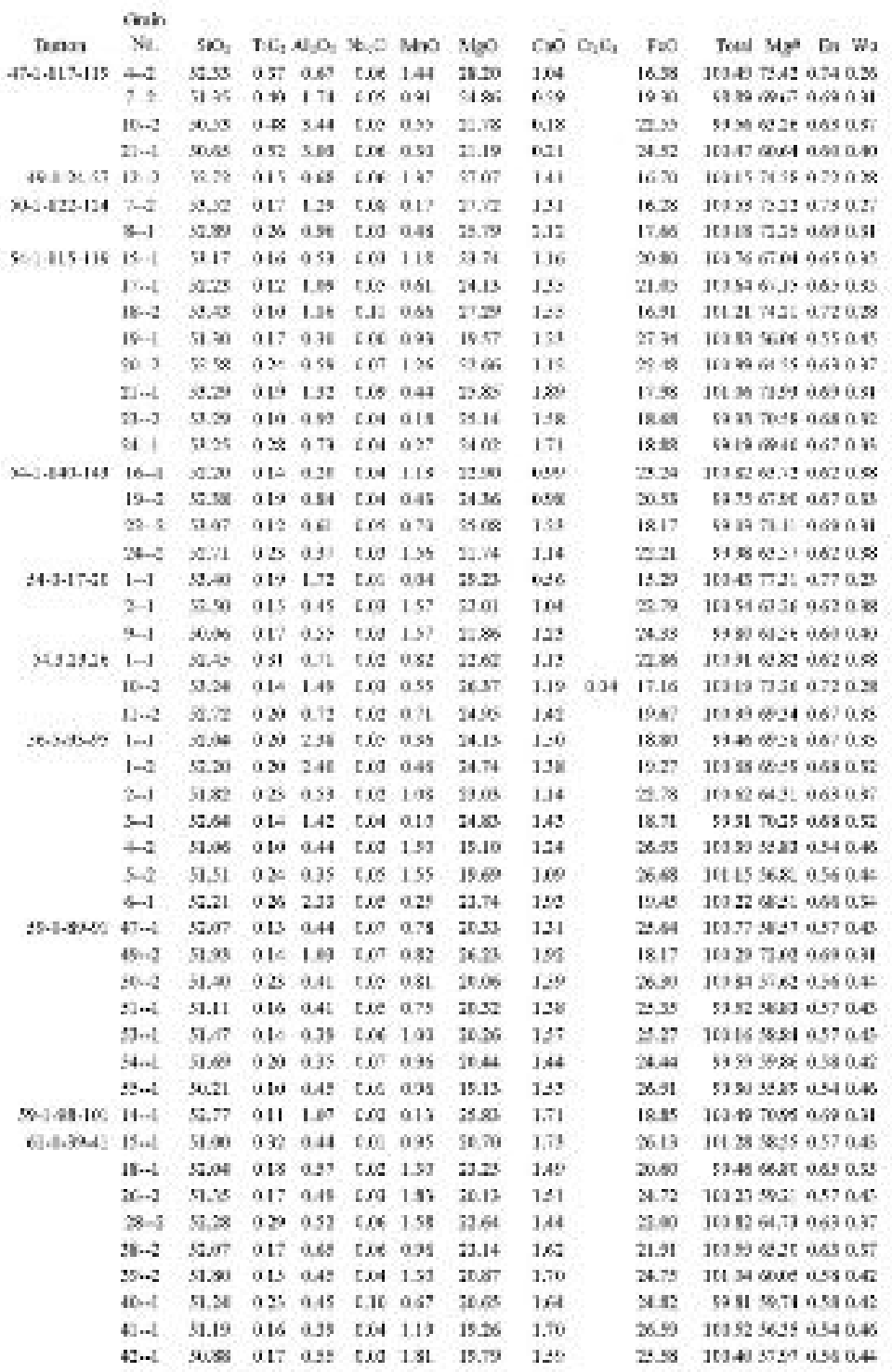




\begin{tabular}{|c|c|c|c|c|c|c|c|c|c|c|c|}
\hline \multirow{2}{*}{ Fan } & \multirow{2}{*}{ Wak } & \multicolumn{8}{|c|}{ - } & \multirow[b]{2}{*}{$F \infty$} & \multirow[b]{2}{*}{ Thel Nor Ea wa } \\
\hline & & $5 \mathrm{NO}_{2}$ & $\mathbf{n} r_{a}$ & $\omega, \theta_{2}$ & 100 & Nan & Ning & $r \times$ & Dafa & & \\
\hline \multirow{15}{*}{ S2:-2.16145 } & $6-1$ & $22 \mathrm{ct}$ & 023 & a.s1 & tie & 1.12 & 20.42 & $2 \pi$ & ass & 2.10 & It $1593: 3$ as7 0.8 \\
\hline & $8-1$ & $52+6$ & 035 & 1.31 & t.jt & 6.91 & 1584 & .35 & $a 11$ & 1.as & $53927252 a \times a \geqslant$ \\
\hline & $2-1$ & $: 234$ & 052 & 1.37 & tet & 1.08 & 2233 & $2 \mu$ & & 2.4 & $3 \mathrm{tL} 34643 \mathrm{~s}$ us2 a.s5 \\
\hline & $k \rightarrow$ & 2317 & $a \geq$ & a.t2 & ced & 1.51 & 15.46 & $\therefore 20$ & & 27.97 & 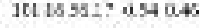 \\
\hline & $21-4$ & 5237 & $9 x_{2}$ & $9 s t$ & 500 & 112 & 1218 & 2.9 & & Is* & $74+36325051000$ \\
\hline & $2 x-1$ & 34 & $0 z$ & as) & tes & 145 & 1936 & -.18 & & 28.4 & 1035,3164 ase 018 \\
\hline & $+1-2$ & 212 & ats & a.91 & ten & 15 & 1520 & $2 e s$ & & 27.11 & 5355.5453 us5 U-7i \\
\hline & $15-1$ & 5155 & 927 & 0.42 & 60 & 13 & 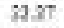 & 16 & & 200 & $161+869220 \leq 100$ \\
\hline & $15-2$ & st 34 & 02 & a.4t. & th & $1=8$ & 1258 & ist & & 202 & $3031+2 \cdot 04080$ \\
\hline & $16-2$ & It 4 & a3- & $a .4$ & $\cos$ & 1.10 & 32.24 & $=\ln$ & & 22.5 & $53 x 245.55$ a.s2 0.55 \\
\hline & $17-1$ & 5150 & 92 & a.5. & cois & 12 & {$[3.71$} & 35 & & 21.57 & 16226453059078 \\
\hline & $18-1$ & \$) 6 & $92 \xi$ & 0.42 & 5,04 & 16: & 2536 & 26 & & $246 ?$ & 533559410570.45 \\
\hline & 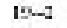 & $\$ 213$ & 021 & a.st & tee & $1.7 \pi$ & 31.96 & $t \leq x$ & & sust & 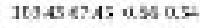 \\
\hline & $x-4$ & 510 & 015 & 9.35 & 250 & 257 & 30.17 & 28 & & 221 & 103260505042 \\
\hline & $21=1$ & $513 t$ & 922 & 2.43 & $6 x$ & 093 & 3247 & 2.7. & & 2. & $573261,1, a 520<5$ \\
\hline \multirow{15}{*}{$60.2 \cdot 51-24$} & $z-1$ & 2145 & 021 & Q.45 & te & 0.31 & 2007 & 26 & & 22.51 & $535 s+53$ ast 0.38 \\
\hline & $24-2$ & It 13 & ats & a.s4 & ted & 2.11 & 1902 & $\therefore$ & & $2: 25$ & Jtess.53As 4.57 Ue \\
\hline & $x=1$ & 5150 & 917 & a) 6 & 60 & 207 & 0.18 & CS5 & & 3063 & 572365.23055025 \\
\hline & $2\rceil-1$ & st ss & $0 z$ & ast & 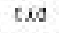 & $1.0 s$ & 12.28 & 29 & & $2.5 s$ & Jostueses usz u.ss \\
\hline & $2 x-1$ & 221 & $v 1-$ & att & {$[\mathrm{Na}$} & 1.78 & $12 \% 6$ & :ee & & 21.54 & 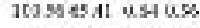 \\
\hline & $31-1$ & 1) 13 & 918 & 0.75 & col & 202 & inst & 1.79 & & Stat & 5551620 aso ad1 \\
\hline & $1-1$ & $\$ 325$ & $0 \mathrm{tz}$ & 0.53 & tie & 0.4 & 25.85 & 22 & & 18.51 & 103539.5 a.s 0.51 \\
\hline & $5-1$ & It 43 & $a z$ & a.4 & CNA & 157 & 22.6 & 2.72 & & z.ss & $1030044: 5$ a.s2 0.5s \\
\hline & $11-1$ & S1 55 & 6.1 & ass & cat & $10 n$ & in $x i$ & $2 / 5$ & & 2200 & 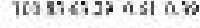 \\
\hline & $1 \pm-2$ & 5) 49 & a) 35 & 291 & (13) & 0.55 & IE 01 & 2015 & & 8.34 & 535392930.450 .56 \\
\hline & $14-1$ & 2149 & 023 & a.se & ret & 1.16 & 31.12 & $\therefore=t$ & & $2+4$ & 1632944.25 u.5s 0.57 \\
\hline & $16-1$ & 5350 & $93 i$ & 946 & ene & 222 & 3004 & 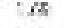 & & 2.25 & 163255939057 ad: \\
\hline & $17-4$ & $\$ 23 t$ & 012 & 2.45 & 50 & 13: & 12.44 & .26 & & 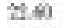 & $5+9962.4061000$ \\
\hline & $18-1$ & $53: 9$ & $a z$ & $a+4$ & tes & $15 s$ & 2200 & :.51 & & 271 & $55>0 \in 224$ ass $0+40$ \\
\hline & $2-2$ & S1 11 & ats & 0.52 & 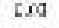 & 245 & 20.14 & $A t$ & & 2.59 & $1032702: 5054012$ \\
\hline \multirow[t]{7}{*}{ a.3.5is } & $s-1$ & 5272 & 016 & 065 & ine & $30:$ & 30 & $i \leq t$ & aas & 1079 & $(6)+16360030 x$ \\
\hline & $4-1$ & 2254 & 021 & 2.44 & tet & $1.4 t^{*}$ & 13.78 & is & as3 & 21.45 & (16)3765. as as \\
\hline & $2-1$ & 9225 & a1s & 0.93 & {$[s$} & 1.22 & 23.90 & 2.10 & a.2. & 21.55 & 1025265.11055028 \\
\hline & 6.3 & 5974 & 122 & 057 & $i n$ & 175 & $16 \mathrm{wi}^{2}$ & 17 & 001 & $s w$ & intasa 54057015 \\
\hline & $7+2$ & 5297 & 917 & as) & 60 & 030 & 125? & -6 & 033 & 219 & 313564506303 ? \\
\hline & $8-1$ & 9218 & 017 & asc & esd & 1.21 & 31.20 & :is & as: & sisl & 10056rat assor \\
\hline & $n-3$ & 5265 & $96 \mathbf{6}$ & 976 & 60 & 108 & 118 & .61 & a.3 & At as & $162+562+955035$ \\
\hline \multirow[t]{6}{*}{$5: 3.119 .13}$. & 4.4. & 5127 & $92 ?$ & as & 106 & $6 F^{2}$ & 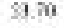 & St & & 2163 & $573365150540 \%$ \\
\hline & $6-1$ & 2173 & a:s & 13 & {$[34$} & $0 \%$ & 12.71 & ה & & 2267 & 163926413052085 \\
\hline & 71 & 5237 & 912 & $95 \mathrm{~s}$ & 60 & $08 \%$ & 96 & 15 & & 2t 18 & in) 76557055035 \\
\hline & Q.3 & 5211 & $02 \%$ & 966 & 26 & 68 & $30 \%$ & 15 & & 311 & 162176569055035 \\
\hline & $13-1$ & 9223 & 018 & a.9t & [se & $0 x$ & 23.56 & 2.42 & & 21.44 & 103556595 ess ass \\
\hline & $1 / 2-1$ & 8182 & 98 & $\cos t$ & ext & vos & 2280 & $\therefore$. At & & 21.12 & $5392+3.5055$ us. \\
\hline
\end{tabular}


Appendix III. Major oxide (in w' 'b) compasition af felatopars frem Site 295

\begin{tabular}{|c|c|c|c|c|c|c|c|c|c|c|}
\hline \multirow{28}{*}{$\begin{array}{l}\text { alka } \\
\text { cilliling }\end{array}$} & atintice. & $\operatorname{sen}$ & $\operatorname{kxv}$ & $c \ddot{v}$ & xan & $260_{3}$ & $\mathrm{ks}$. & $\mathrm{xtg}_{5} \mathrm{O}$ & vord & iu coekst. \\
\hline & $1=1$ & 563 & $m s$ & $10 ; 1$ & 198 & 270 & $\mathrm{C}: \mathrm{C}$ & & $\infty \times 0$ & $6 \$ 3$ \\
\hline & $2-2$ & 25.15 & $6-4$ & loss & 4.98 & 27.35 & $t \leq 2$ & & 9038 & $t \leq 3$ \\
\hline & $\therefore 2$ & 9956 & or & $25=$ & 1.87 & $3: 53$ & t:c & & longs & c.to \\
\hline & $4: 7$ & 6318 & $n s$ & $7 \%$ & 665 & 2511 & (1) & & $\infty 81$ & $6: 5$ \\
\hline & -1 & 979 & was & 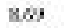 & $9.7 \pi$ & 36,35 & t.20 & & 9040 & t.A3 \\
\hline & $5-2$ & 1535 & aw & 17.21 & 102 & Fas & CI2 & crs & 100.1t & {$[.5]$} \\
\hline & 23 & ast & $0 ; 1$ & $6 * i$ & $6 \%$ & $3 \leqslant 1$ & 63 & & $\omega \geqslant 1$ & 616 \\
\hline & $x-1$ & 2934 & $v=4$ & 810 & $\cos$ & 2. 35 & tas & & 90.46 & 5.42 \\
\hline & $x-1$ & 1758 & was & 1600 & $3 . A 1$ & 8.47 & [I] & trs & $1000 \mathrm{t}$ & CST \\
\hline & $10-1$ & thich & $6=i$ & 1.84 & 096 & 35,35 & $t x 2$ & 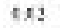 & מה & $x_{91}$ \\
\hline & $\mid 1 \cdots]$ & 29.12 & as: & $1 \omega 5 \pi$ & 400 & 27.52 & {$[23$} & $t x z$ & $\operatorname{sen} 2$ & $t: 0$ \\
\hline & $1>-4$ & 3585 & as & $10 \%$ & 9008 & 27.14 & {$[: 2]$} & $(6)$ & $1000 \mathrm{~A}$ & {$[2]$} \\
\hline & $15-1$ & $\$ 5.76$ & 00 & 1034 & 4.08 & 22.51 & t.t & tra & sous: & $t \leqslant 6$ \\
\hline & $1+2$ & 9528 & 6.61 & lavs. & $1.7 \%$ & $2: 24$ & cat & 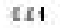 & $m=4$ & {$[21$} \\
\hline & 152 & 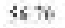 & 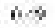 & $10 x$ & 150 & 2914 & 60 & 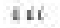 & $\omega s t$ & 69 \\
\hline & 17i.) & it5i & $\omega \omega$ & 153 & 3.92 & 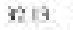 & 63 & 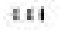 & 6854 & $t \hat{\mathbf{x}} \mid$ \\
\hline & 15e-1 & 93.79 & $6 x$ & $7 \%$ & c.19 & 25.26 & [21 & & कar & [A] \\
\hline & 193 & 5614 & $\omega \infty$ & 105 & $s a t$ & 2717 & 6.6 & 667 & $\sin i$ & 64 \\
\hline & $x-1$ & th $\&$ & $60 \%$ & $17: 2 x$ & 0.50 & 5553 & {$[x]$} & $8 x$ & 9005 & [e] \\
\hline & 21.9 & $35 \times 5$ & 6.31 & x.s. & t.om & 25.55 & [2] & tr: & 9040 & {$[.4]$} \\
\hline & $2 \cdot 2$ & 53.72 & $0=0$ & 800 & 5.16 & $\Delta+1$ ? & $5-4$ & ex. & wis & $t .46$ \\
\hline & $2 \cdot 2$ & 25.43 & $\omega * \infty$ & $x /=$ & $2 ., 22$ & I.S4 & ta: & $c x:$ & seat & t.A: \\
\hline & $36-1$ & Is 19 & os & $10 \%$ & $17 \%$ & 2755 & t:C & $c \sigma^{\circ}$ & roar & Lst \\
\hline & 27.2 & 5781 & nis & $\sin$ & 5.90 & 2655 & 6.1 & $\{53$ & 9950 & (A) \\
\hline & s: 2 & Is $T 9$ & oit & 17.7 & 0.21 & $2: 53$ & {$[12$} & $t r$ & m.7 & {$[.2 n$} \\
\hline & $\$ 3$ & 5700 & $0<1$ & $9: 1$ & $5 \times$ & 36 ate & 675 & $66 x$ & $\omega<8$ & $c<0$ \\
\hline & sel. & 3437 & 104 & $11.8:$ & 4.2 & 534 & cts & txy & 9000 & $2 x$ \\
\hline \multirow{27}{*}{$-51.24-27$} & $1-2$ & 2937 & wes & 810 & e.15 & 2.2.24 & ta4 & $t x t$ & 90.52 & 6.42 \\
\hline & $2-1$ & 5164 & $\mathrm{n}=\mathrm{H}$ & $\mathrm{s}: \mathrm{x}$ & 612 & 2577 & 633 & tof & 160.17 & $2+1$ \\
\hline & $-I$ & 4) $1 x$ & $\omega x$ & 180 & D.as & $\leqslant 37$ & [x. & $8 \times 4$ & $90 x$ & $\csc$ \\
\hline & -1 & 45.11 & are & $10=6$ & DUSS & 2. 51 & [I] & $t r 2$ & 90.7 & $t: 2$ \\
\hline & $6-7$ & 5638 & ast & 1015 & $\sin$ & 3615 & $6 \leq 3$ & $\{x\}$ & 90.13 & (21) \\
\hline & $10-1$ & 2336 & $b=2$ & sus & $0 \leq 4$ & $3=34$ & tat & $t x 2$ & $50 \%$ & 5.40 \\
\hline & $12-3$ & 9579 & 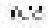 & as: & 6.10 & 26,4 & בני[ & 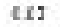 & $m: 1$ & C.At \\
\hline & 132 & Cas? & 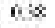 & 781 & 657 & 2019 & 627 & & 9021 & $x+5$ \\
\hline & $16-1$ & 9317 & ase & $n \times s$ & 6.57 & 2..31 & {$[22$} & & $90+8$ & {$[A]$} \\
\hline & 171 & $586 i$ & $6 / \mathrm{ai}$ & $10 / 4$ & 1801 & $2: 73$ & $6>5$ & 663 & wis & $c \leqslant 4$ \\
\hline & $18: 2$ & 2500 & $6 \times 8$ & 806 & 0.24 & 251 & r.34 & $t 5$ & $90 \times 4$ & t.43 \\
\hline & x-1 & tsot & 0.16 & $6 \% 2$ & $\operatorname{con}$ & $3-53$ & [.A3 & $\mathrm{Cr}_{\text {: }}$ & 90.19 & [39 \\
\hline & 28.1 & 45.15 & 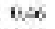 & $19, \mathrm{~m}$ & हब्रें & 3. $\mathbf{n}$ & $t: 2$ & 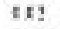 & 100.1 . & 50 \\
\hline & 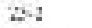 & 2939 & 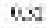 & 780 & 0.51 & 2.23 & ta, & ex & ws: & r.s \\
\hline & $x-1$ & $25 x$ & a.4 & $10 z$ & 2.90 & 27.24 & c:5 & $(x)$ & 100.15 & $0 \leq 1$ \\
\hline & 20.3 & 5658 & $0: i$ & $9: 8$ & 358 & 3676 & [2) & & 994 & 645 \\
\hline & $w-1$ & $23 \mathrm{kE}$ & 64 & Tas & ass & 26.30 & tal & & $90 x$ & tas \\
\hline & $2 \times-1$ & 15,67 & $a x$ & 16.7 & 1.61 & 3207 & [I] & tse & nert & iss \\
\hline & 202 & $3 t \pi$ & 65 & $11: 0$ & 165 & $\$ 19$ & 620 & & $\phi \alpha$ & $c \leqslant T$ \\
\hline & $31-2$ & 2934 & $0 x$ & 200 & 6.3s & $2=57$ & {$[20$} & & 90.11 & [.A] \\
\hline & $\therefore a$ & 5406 & 0.5 & 788 & 68: & $x<1$ & (3) & 463 & wa & t.1s \\
\hline & $s-2$ & $4 / 37$ & $6 / 2$ & $16, x$ & 1.54 & si: $>9$ & $x z$ & txs & $90.1 \mathrm{~V}$ & 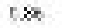 \\
\hline & $4 \cdot-2$ & 25.18 & $0=8$ & X.ss & 8.16 & 25.53 & t. 21 & & 9272 & C.A4 \\
\hline & 36) & 5981 & 031 & $7 \times 0$ & 655 & 25.25 & 635 & 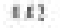 & 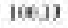 & 125 \\
\hline & $5 \cdots 2$ & $29 \pi$ & wi & sec & 6.45 & $\therefore 58$ & tas & $5 x$ & 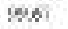 & 5.40 \\
\hline & $\% 1$ & 2534 & $w e$ & $x: 0$ & $t .12$ & 2.5. 59 & t.12 & & soles & C.44 \\
\hline & nal & 376 & ase & 7.72 & CAs: & 25.25 & cas & & most & 138 \\
\hline \multirow[t]{3}{*}{$304 \cdot 12=134$} & $1-1$ & 4.8 & wis & $18 \%$ & 0.09 & $35+4$ & csto & tx: & icoue & tet \\
\hline & $2-1$ & 39.11 & ase & $x=0$ & 3.62 & 27.97 & c:S 5 & CE: & $1005 x$ & C.AS \\
\hline & 3.3 & 1550 & $06 t$ & $17 \%$ & $n$ & $y=15$ & 667 & $\{6 ?$ & 10013 & 68 \\
\hline
\end{tabular}




\begin{tabular}{|c|c|c|c|c|c|c|c|c|c|c|}
\hline \multirow[t]{12}{*}{ Hes } & Gatn ke. & $50 \%$ & rk: & a:: & Na\% & $\mathrm{MLO}_{3}$ & $k>0$ & Mnis & Tral & As Caekas \\
\hline & $4-2$ & 45.54 & 0.4 & $18 / \pi$ & coss & 32.10 & tII & & $1004:$ & $t \leq 4$ \\
\hline & $3-2$ & 19.72 & ars & $2: 3$ & 6.18 & $3: 10$ & 62 & 2.53 & 10005 & C.A2 \\
\hline & a. 1 & $5 t 33$ & bit & $\mathbf{s} \times \mathbf{z}$ & 505 & 359 & 637 & 6: & 1645 & $k 41$ \\
\hline & $10-1$ & 456 & 0,6 & $18-8$ & 0.74 & 3.59 & tro & & 99.94 & {$[.93$} \\
\hline & 11.3 & 175 & $n \leq 1$ & |6is! & 1.71 & $x: 4$ & $c 0$ & & 100.75 & $c \& t$ \\
\hline & $12 \div-1$ & 438 & $v-4$ & $18: 2$ & D.SB & 50.39 & $x z$ & & $100 \times 2$ & res \\
\hline & $12 \cdots-1$ & $4+4$ & 0000 & 1X:se & os 2 & 25.55 & CI: & $\operatorname{crs}$ & $902 \pi$ & tes \\
\hline & 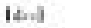 & 5837 & $0 x$ & 856 & 6.16 & 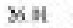 & (2) & $t \varepsilon_{-}$ & 99.8 & $\{4]$ \\
\hline & $12 \cdots-1$ & 95.06 & 60 & sass & evat & 36.25 & $t: 2$ & $t x:$ & 90.72 & t.AS \\
\hline & $16-1$ & $34 k 3$ & we & 11.2 & A.AT & 2s.ss & $t=0$ & $t r 2$ & 5008 & $\operatorname{tas}$ \\
\hline & $18-2$ & $n \propto$ & $n \pi$ & $18: 1$ & 0,78 & $x \geqslant 1$ & [I] & $t \in 1$ & $m: 1$ & $\cos$ \\
\hline \multirow[t]{25}{*}{$5 \cdot 1 \cdot 115-113$} & -1 & 4992 & $n=f$ & 17.7 & 0.50 & 384 & (x) & $t x s$ & loess & teg \\
\hline & $4-2$ & 1561 & 04 & 17.21 & 1.52 & 2:13 & [II & & wss & [.5T \\
\hline & 113 & 1735 & $0=1$ & 1721 & 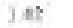 & $\approx 69$ & cif & $6 t+1$ & $\omega * \%$ & 687 \\
\hline & $12-1$ & 2554 & 620 & פרי & 2.00 & $2 \pi 12$ & $t-1$ & & 92. & $c .4 \mathrm{E}$ \\
\hline & $14-1$ & 1148 & 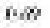 & $17 x$ & 362 & $n \geq 2$ & 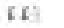 & 663 & 1000 & $C \& 7$ \\
\hline & $13-2$ & $46 \pm 0$. & 6. $*$ & $1 \times 6$. & 100 & $\approx z$ & & $t x$ & 100.4 . & r:4 \\
\hline & $17 \cdot-1$ & 1794 & whe & 17,8 & 2.08 & 5834 & & $t x z$ & 10045 & $t \leq 0$ \\
\hline & $\operatorname{ling} 3$ & it 68 & 3,35 & 166 & 1.13 & 7056 & 125 & 125 & 9081 & ts $\$$ \\
\hline & $18-1$ & As 37 & 63t & 18.72 & oest & 2.35 & t.se & $8 x z$ & $100 x$ & c.4 \\
\hline & $19-2$ & 15.88. & $a n$ & 18.2 & 0.70 & Kas & [. I2 & ESt & 106.15 & [.9.1 \\
\hline & $x-1$ & $1 \leqslant 76$ & $\cos$ & $18:-3$ & $0 x$ & i:s? & & & $100 x$ & $\operatorname{con}$ \\
\hline & $24-1$ & $49 \pi$ & 661 & $|5 \dot{s}|$ & 1.24 & 3658 & & $t x$ & 1006 & css \\
\hline & $2 \pi-1$ & 1375 & $a: c$ & $12 x$ & $12 x$ & sis & tre & & 100.46 & csa \\
\hline & $\infty 1$ & sa 13 & $n=4$ & wis: & 315 & at $\mathrm{th}$ & 665 & $2 t$ & 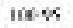 & $6 \mathrm{si}$ \\
\hline & $x-1$ & 4500 & $6 x$ & 180 & $0 \leq 6$ & $\sec \pi$ & 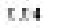 & $t \leq t$ & 9091 & ry: \\
\hline & $4,-1$ & is $\alpha$ & 6il & 1820 & 0.87 & $3 \times 2$ & {$[6]$} & cts & 100031 & {$[n$} \\
\hline & $\operatorname{sen} 1$ & $462 y$ & whe & $1 \times 4$ & nis & 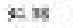 & $t: 4$ & $t x$ & lese.4t & teg \\
\hline & $-3-1$ & 4.12 & we & 18.12 & $2 \pi z$ & 53. 35 & t50 & $t x:$ & 100044 & $t \because]$ \\
\hline & Q.2 & 1536 & niil & $18 \%$ & Dose & K.52 & tro & $t x^{*}$ & 10005 & 6.9 \\
\hline & -3.4 & 58.06 & $0: 3$ & $96 \%$ & 5s 8 & 2635 & t.s & 6.13 & $1000]^{7}$ & (A5) \\
\hline & $-4 \cdot-1$ & 25.00 & $a=4$ & 237 & 2.183 & $\mathrm{Mr} r$ & t.:2 & $e x \mathrm{C}$ & $100 \Omega 3$ & 5.45 \\
\hline & $8-1$ & 1735 & we & 17.8 & 3.18 & 25 & CII & $6 x 2$ & $100: 5 s$ & css \\
\hline & $20-2$ & 23.46 & $\omega \infty$ & 12.57 & 3.88 & 293 & t.5 & ext & 10009 & t.67 \\
\hline & sh-1 & 1908 & as & $18 \%$ & 0.73 & 5.14 & {$[\mathrm{I}]$} & & 100.56 & [.. ] \\
\hline & 511 & 5145 & nis & 1821 & 705 & $m \geqslant$ & (d & & 10611 & ari \\
\hline \multirow[t]{5}{*}{$34-5 \cdot 1<-20$} & $\because-1$ & 4h.J6. & $w x$ & 1800 & 201 & s.s.ss & $x 2$ & & 9.14 & [9] \\
\hline & $3-2$ & 1783 & an & $17 \infty 6$ & $3.5 T$ & 51.25 & tII & txy & 90.35 & cxs \\
\hline & $12 \cdots-1$ & 4658 & whes & 1818 & 1.19 & 32.54 & (x) & $+x 3$ & 99.10 & $t .8 B$ \\
\hline & $x-1$ & 4530 & 04 & 15:z & 0.00 & 35.50 & t.20 & {$[x]$} & 9000. & tsa \\
\hline & $2-3$ & 17.15 & ars: & $17 / 6$ & $12 \%$ & $2: 11$ & cIs & cis & mals & CST \\
\hline \multirow[t]{18}{*}{$4.3 .25 \cdot 6$} & $1-2$ & $\$ 550$ & $0=4$ & 1600 & soi & 2321 & $5 x 5$ & (t) & 106.92 & 64 \\
\hline & $2-1$ & 92.94 & $n=1$ & $12 \pi$ & $1 . \%$ & 203 & c.:s & {$[1]$} & $\operatorname{sen}$ & 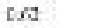 \\
\hline & $=2$ & 996 & $a s$ & $a: a$ & $2, \pi 7$ & 3:5: & [::2 & & 10605 & [.17 \\
\hline & 4.2 & 1633 & $0 \infty$ & $17<8$ & $1 \pi$ & yat1 & 64 & 6.8 & 940 & $68 \%$ \\
\hline & $s-1$ & 298 & as & $10 \mathrm{~s}$ & 9.20 & 27.45 & trs & $5 x 2$ & 925 & {$[\leq 2$} \\
\hline & $6 \cdot 1$ & 1513 & $n \rightarrow$ & $18 \%$ & $0 \$ 1$ & 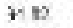 & $\cos$ & 66 & $\sin$ & $(\omega)$ \\
\hline & $i=z$ & 43.12 & $\theta=1$ & $1 \times 0$ & cos & $5 x \cdot n$ & $5 x$ & $5 x$ & $\omega \infty$ & 594 \\
\hline & $3-2$ & 1552 & wes & $17 . x$ & 1.4 & 58.57 & c.te & Cr: & נד. & tot \\
\hline & 2.) & 406 & $n=0$ & 1800 & 600 & 35.24 & $t .86$ & & sole & 594 \\
\hline & $10-1$ & 2987 & $\sin 2$ & $2 \mu$ & 2.91 & Sat? & t2: & & $90 \times 1$ & t.A3 \\
\hline & $15-2$ & 15 & a.s & 1800 & $0.5 \%$ & 2515 & tIS & {$[C]$} & wore & [se \\
\hline & 1!. 3 & 53.18 & $0-4$ & 14.31 & 2.900 & 31.36 & 615 & & 99.54 & 6.39 \\
\hline & $14-2$ & $4 \omega$ & as & 1ES: & $0 \leq 1$ & 3544 & tI9 & & w. & {$[.8 d$} \\
\hline & $1 \leqslant-2$ & 1534 & $a r$ & 16we & $13 t$ & 7241 & IIC & 261 & $1000 \mathrm{x}$ & c.5a \\
\hline & 16.3 & 524 & $n<1$ & $8 \otimes i$ & $\langle\infty$ & 365 & 6.7 & it & 90 & 18 \\
\hline & $1 \div-1$ & 9536 & $w e$ & 929 & 2.28 & $36 \times$ & tas & & 90.31 & $t=1$ \\
\hline & $18 \cdot \pi$ & 5587 & $\mathrm{mot}$ & $10 \%$ & 521 & 2576 & 633 & 663 & 681 & {$[2]$} \\
\hline & $15-1$ & 3434 & 1.18 & 1.28 & 4.00 & 35.97 & t. 45 & $(x)$ & 10003 & $t \mu$ \\
\hline
\end{tabular}




\begin{tabular}{|c|c|c|c|c|c|c|c|c|c|c|}
\hline \multirow[t]{2}{*}{ Ile1an } & Granke. & $\operatorname{seg}_{z}$ & Tk:: & a:: & Nao & $\therefore \mathrm{LO}_{3}$ & $k>0$ & Mno & Tral & has Caeka \\
\hline & 20.2 & $54: 4$ & $\theta=0$ & 1124 & 4.28 & 2575 & t.s & & 5012, & $t \leq k$ \\
\hline \multirow[t]{40}{*}{$20 \cdot 5-2=6$} & $\Sigma \cdots 1$ & ISAS & at & 18.10 & 0.72 & мat & $6 / 2$ & $t x 2$ & 10001 & $\cos 1$ \\
\hline & 22 & 5040 & $0 \times$ & 1016 & 216 & It 17 & 62 & 66 & 10041 & $k \pi$ \\
\hline & $1 \cdots 2$ & 25.45 & 0.66 & $11 \pi$ & 4.00 & 2513 & tas & & $90 \times 1$ & $t \leq 0$ \\
\hline & 12 & 1673 & $n \approx 0$ & $17 . x$ & 18\%? & inta & $\cot$ & 163 & 100.16 & $\cos$ \\
\hline & $2 \ldots 1$ & 2130 & 604 & 14.0 & 120 & s1 hs & $\mathrm{C}-\mathrm{I}$ & $x$ & lueat & c.re \\
\hline & $t=1$ & As:100 & $\omega 64$ & 17.82 & 0.97 & $34 \pi$ & tIt & & $100 \%$ & {$[2]$} \\
\hline & $3_{n l}$ & 5468 & nei & $\| \alpha$ & 436 & 2365 & (x) & & 9993 & 56 \\
\hline & $|\cdots|$ & 4754 & 671 & $16 x$ & 106 & 3293 & t.s & Ext & $90 x$ & $t x$ \\
\hline & $5 \cdots 2$ & 4.43 & w. & 17.17 & 3.28 & 53.31 & t.2 & $(x)$ & $\operatorname{cosec}$ & $t x \mathbf{S}$ \\
\hline & $23 \cdots 1$ & 1533 & nit & $18 / 8$ & 0.62 & 319 & CI2 & $6 \%$ & $m \pi$ & 694 \\
\hline & $-t=1$ & 95.76 & 622 & 881 & 897 & $25+5$ & 523 & & 100,45 & 0.44 \\
\hline & $2-2$ & Is 90 & was & $17:-8$ & 1.21 & 5323 & [I? & ER: & 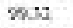 & cSE \\
\hline & 71 & St 94 & $0 \leq 1$ & $8: 3$ & $5 * 8$ & $25 \leqslant 9$ & 628 & & wa: & 6.45 \\
\hline & $24-1$ & $17=4$ & eñl & 17.2 & 1.20 & 3337 & t.54 & {$[x]$} & 160.1: & t28s \\
\hline & $5-1$ & 1794 & nese & 16: & 110 & $32+1$ & 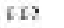 & 665 & was & $C \& 7$ \\
\hline & $\rightarrow-1$ & 4592 & wo: & 120 & 2.20 & $3: 34$ & 5,4 & $c x$ & 92.8 & $5 \times 8$ \\
\hline & $29-2$ & בתי4 & wis & 17.12 & 2.58 & 5233 & [. 24 & {$[x]$} & $100 \mathrm{t}$ & 50 \\
\hline & $\sin 2$ & 50 & $0 \pi$ & $17 \%$ & 1.80 & $33 \times 6$ & 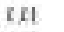 & & 9906 & ts: \\
\hline & $23-1$ & 4558 & weo & $17 \mu$ & 0.73 & 323 & cts & & 99.19 & {$[2$} \\
\hline & $22 \cdots 1$ & 1790 & $a c$ & $16 \pi$ & 2.25 & 3725 & (5) & GSS & $\cos$ & css \\
\hline & $21-1$ & 17.16 & $\cos$ & 17,6 & $1 \omega$ & พหม & [IT & & $m \pi$ & $c .6$ \\
\hline & $22-1$ & 59.72 & 64 & 795 & 6.14 & 2552 & $t 25$ & $t x 2$ & 9996 & t.41 \\
\hline & $23 \cdots 2$ & 1058 & $\alpha 2$ & $16 \% 2$ & 135 & $72 x$ & CEA & & mose & CST \\
\hline & 311 & 1717 & $m \approx \alpha$ & 17 is & 181 & 7957 & 661 & & 16053 & $i \mathrm{x}$ \\
\hline & $23 . .1$ & 45.14 & $6 \geqslant$ & $1 \times 20$ & 1.56 & 3515 & cts & $5 x 4$ & 100.45 & (x) \\
\hline & $35-2$ & 1757 & 6.4 & 17.1: & 1.28 & מ & EA & {$[6]$} & $1000 \mathrm{~s}$ & tss \\
\hline & $21-2$ & 4638 & $v=x$ & ixue & Dess & $335 ?$ & 03 & $2 x$ & 9000 & 1.94 \\
\hline & $25-2$ & 45.13 & $0 \leq 1$ & $1 \div=0$ & 0.71 & 34.94 & t.II & $t r:$ & 9087 & {$[\because]$} \\
\hline & $22-1$ & 1550 & 04 & 18.17 & 008 & 35: & int & & 100009 & 1.94 \\
\hline & 33.2 & 4700 & $0 x^{t}$ & 15.4 & $20 \mathrm{C}$ & 3379 & $t, 2$ & 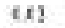 & 100.35 & 600 \\
\hline & $\pi t-1$ & 45.124 & we & 18.12 & 0.61 & $34+4$ & tra & $8 x d$ & $50 / 3$ & $0: 4$ \\
\hline & $12-1$ & 159 & $n=4$ & 17.28 & 1.25 & 3it & CIS & crs & mos & css \\
\hline & $23-1$ & 4.12 & $6 \pi$ & 16.9 & $1 ., A 1$ & $3: 44$ & trs & {$[x]$} & sele & (B) \\
\hline & $34-1$ & 45.23 & ovil & $17 . x$ & DAI & 313 & 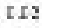 & IE & 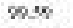 & {$[.92$} \\
\hline & 352 & SEA1 & $n=0$ & 90 & $56 \%$ & 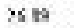 & 63 & & ind is & 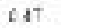 \\
\hline & $35-2$ & 49.46 & $\omega \infty$ & 12.24 & 190 & $31.9 \mathrm{~h}$ & t.tI & (x) & yose & $\operatorname{cxs}$ \\
\hline & $35 \cdots 1$ & (5.31 & $\alpha \pi$ & $16 / 2$ & $2.5 x$ & 3138 & t.14 & 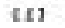 & 90.16 & [s] \\
\hline & $33-1$ & 4. 49 & ละ & 15.58 & 1.16 & 33.3 & $t \times 2$ & & $100 \mathrm{ds}$ & $t .8 \%$ \\
\hline & $13-1$ & 47.43 & ost & $17-5$ & 0.98 & 3355 & t. 5 & $e x t$ & 10008 & {$[2]$} \\
\hline & $12 \cdots 2$ & Is 58 & $\alpha=2$ & $17 . \%$ & 0.21 & 1726 & [C] & CIC & $1000 \mathrm{~s}$ & {$[.9]$} \\
\hline \multirow[t]{18}{*}{$57.1-26-16$} & $\approx * 2$ & 5537 & 634 & $9: 9$ & $56 t$ & 2635 & 523 & tr: & 106.18 & t.48 \\
\hline & $1 . .2$ & tos & $0 / 4$ & $2=0$ & 3.73 & 253 & [.]] & tr: & 100.15 & CA4 \\
\hline & $3 \ldots 1$ & 33.56 & $a \approx s$ & as? & $c \omega$ & 2522 & [2] & & lowec & CAI \\
\hline & 12 & 5t 15 & 0.50 & 160 & 53: & 2539 & 121 & 46 & $1005 s$ & 650 \\
\hline & $t \cdots 1$ & 95.13 & $0 * \pi$ & 295 & 9.4 & 2513 & c..27 & & loed: & $t \leq 0$ \\
\hline & $\Leftrightarrow 2$ & 5470 & 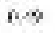 & $8 \times 1$ & 478 & 256 & (3) & 64 & 16077 & $c 46$ \\
\hline & .2 & $\sin$ & 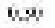 & 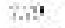 & D. 58 & 2423 & (2) & $5 x$ & 1000. & 53 \\
\hline & $5-1$ & 25.45 & $u z$ & 2.22 & 9.74 & 2530 & {$[1]$} & Crt & 5000 & t. At \\
\hline & 5.1 & 5941 & 0.37 & $88:$ & $58 \mathrm{i}$ & 2554 & f 21 & 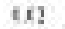 & 10035 & 5.45 \\
\hline & $23-2$ & 24.41 & $0=8$ & $16 \pi$ & $20 s$ & 297 & 5.5 & $t x$ & 10044 & $0 \leq 4$ \\
\hline & $\therefore-2$ & $155 x$ & 051 & $18 x$ & 0.5 & MAs & [I] & & 100013 & cse \\
\hline & $2-2-2$ & 5159 & $0<$ & 931 & 5.74 & 2616 & $t-3$ & 4. & $1003 t$ & 6.47 \\
\hline & $23-2$ & 9816 & ase & s: & 9.26 & 2531 & [.] & & $\% \%$ & c.A9 \\
\hline & $4 \cdots 1$ & 9236 & ace & 211 & cois & 2521 & I.:S & & 160035 & [As \\
\hline & 5.7 & $\{4,4\}$ & $n: 0$ & 891 & 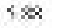 & 3594 & 623 & & 10004 & 685 \\
\hline & $25-1$ & 3936 & $\omega \times 0$ & $90 \mathrm{~s}$ & 2,77 & 2931 & t 22 & & 106043 & t.46 \\
\hline & $27-2$ & 6211 & $0: 8$ & $7: 7$ & 661 & 2127 & c $3 t$ & 66 & iceiti & 617 \\
\hline & $5-2$ & 45.00 & 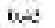 & $1:: 11$ & Dos & 33.4 & t.It & cr: & lowe & t:4 \\
\hline
\end{tabular}




\begin{tabular}{|c|c|c|c|c|c|c|c|c|c|c|}
\hline \multirow[t]{20}{*}{ Fuilon } & Conth Me. & 50 & Ik:: & a:: & Na八o & $\mathrm{MLO}_{3}$ & $k \neq 0$ & Mno & Tral & is Ciaks \\
\hline & $10-2$ & $\sin 3$ & a4 & $x_{0} 1=$ & e.as & $3=45$ & $t 24$ & es: & 10004 & t.4. \\
\hline & 30.1 & 5062 & $a: 1$ & 900 & 6.11 & $2 \times 1 a$ & 6.27 & & 1060: & C.AI \\
\hline & 31.1 & stil & $0 \infty 6$ & $\$ \omega$ & $\leqslant 6$ & was & (3) & & $1 \omega \epsilon t i$ & 6.48 \\
\hline & $23-21$ & $\sin 13$ & $0=0$ & 8.19 & $60 \mathrm{~s}$ & $2=35$ & t.24 & & 99.5 & {$[.42$} \\
\hline & is 5 & 54 is & $n: s$ & $\Leftrightarrow \Leftrightarrow$ & 578 & 2551 & C. 5 & & 1000 & CdT \\
\hline & $22-2$ & 25.5 & $\sin x$ & 900 & 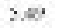 & 2.53 & ta: & & 2901 & c.45 \\
\hline & $26-2$ & 4535 & asi & 15.x & DST & 5.13 & tro & & 10021 & 0.94 \\
\hline & $\sin 2$ & $548 t$ & 0,4 & $13 \mu 1$ & 390 & 27.91 & 526 & & 9900 & $\{63$ \\
\hline & $78-2$ & 5956 & wa & 838 & e.so & 2.0 .5 & t2. & $x:$ & rovas: & [. .42 \\
\hline & $215-1$ & 5324 & $\cos \pi$ & 936 & 2.4 & 235 & t2: & & 100ue & t. $4 \mathrm{~s}$ \\
\hline & $30-2$ & 536 & $a i$ & sis & 390 & 25.46 & {$[30$} & If: & icours & [A6 \\
\hline & $21 \cdots 2$ & 5954 & $\theta=1$ & tas & bat & $2=4$ & (2) & ex. & 9ose & $t .40$ \\
\hline & $23-1$ & $55: 4$ & 0.57 & $2=$ & 25: & $2 \times 37$ & $1: 5$ & ex: & 10xe? & c.As \\
\hline & $\because 2$ & 5t55 & $\theta<y$ & $8 \% ?$ & 581 & 2551 & C.5 & & $\$ 81$ & 6.45 \\
\hline & $24 \%-1$ & 2294 & wa & 8.11 & 4.74 & 25.17 & tas & & $90 \pi$ & C.AT \\
\hline & 12. 5 & 5263 & 621 & $6 m$ & 715 & $2 ; \infty$ & $c \cdots$ & & 100 is & [13 \\
\hline & $20-1$ & 5125 & $v=2$ & IWLe & 490 & $2.3 n$ & $5-8$ & & 10025 & 04 \\
\hline & $27-1$ & 534 & $\omega s$ & 2.17 & $2 . \%$ & 36.10 & t.: & & $100: 3$ & t.At \\
\hline & $18+1$ & 5144 & 00 & $14 \%$ & 195 & 2015 & crs & tif & $100 s$ & $\{\pi$ \\
\hline \multirow[t]{40}{*}{$97-291.101$} & $1-2$ & 49.4 & $\cos 0$ & $18 . \mathrm{W}$ & $0 \times 1$ & $5=93$ & $\operatorname{cts} 2$ & ext & 100.45 & $\cos$ \\
\hline & $i-2$ & 1518 & $a z$ & 16.30 & 131 & zits & crs & & 100.15 & cse \\
\hline & $1-1$ & 5592 & wes & 11.84 & 1.77 & 27.24 & c. $c$ & 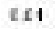 & $100: 13$ & $\csc$ \\
\hline & $4-2$ & 59et & $6 x$ & $9<0$ & 5,66 & 3695 & 622 & $t x:$ & 106.15 & t.47 \\
\hline & $\therefore-1$ & 51 is & 0,8 & 1201 & 2.76 & 3152 & cre & $6 x 2$ & $100 \%$ & c.7s \\
\hline & i1 & 5771 & $n: k$ & 10.10 & $\langle\dot{\theta} ?$ & $27 \mathrm{ta}$ & 6.7 & 453 & iness & $c<0$ \\
\hline & $\gamma=2$ & 4204 & 6.51 & 18184 & $0 . \pi$ & so. 15 & cro & $8 x$ & $1002 y$ & tys \\
\hline & $8-2$ & 5265 & 060 & 13.16 & $16 \%$ & pois & 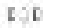 & {$[6]$} & 1000 & {$[\alpha$} \\
\hline & $\mu 2$ & $54 \pi$ & $\omega *$ & 12,4 & 4.10 & 2015 & $t \rightarrow 9$ & & 100.19 & 00 \\
\hline & $10-2$ & $45: 84$ & ws & $18: 4$ & $0 \leq T$ & 35.27 & t.t2 & & 1000 - & t:4 \\
\hline & $11 \cdots 1$ & 1765 & $n:$ & 15,91 & 3.si & $x: 43$ & IIS & & $1000 \mathrm{a}$ & ISTT \\
\hline & 13.2 & 474 & $0 x$ & 15.10 & 1.30 & 3650 & $\{x\}$ & $t .5$ & 10005 & 6.87 \\
\hline & $13 \cdots 1$ & 45e: & $0=6$ & 180 & 0.09 & 3.24 & t.20 & & 90081 & {$[2]$} \\
\hline & $1+-2$ & $45 x$ & ait & 16516 & 1.72 & $2: 12$ & CII & & loovs & CSI \\
\hline & $15-21$ & 4563 & $\omega t$ & $1 \times 2$. & 006 & sun? & tro & ers & $100 \mathrm{se}$ & $t \leq 4$ \\
\hline & $16-1$ & 45 & $6 \pi$ & 16e & $1.9 t$ & 3254 & III & & $1000 \mathrm{te}$ & cso \\
\hline & 171 & ISE & $n y$ & $18=7$ & Q⿻? & is 57 & $c a t$ & t $t$ & $160 \mathrm{n}$ & $(\theta)$ \\
\hline & $18-t$ & 3754 & wex & $9 \$ 5$ & 2,44 & 2.49 & $t \geq 2$ & & 1001 & $t=0$ \\
\hline & $19-1$ & 5357 & are & 20 . & e.1T & 25.25 & [I] & t.51 & 9oxe & [A] \\
\hline & I1... & 4665 & $6=4$ & 1806 & 1.11 & $3<56$ & Cx: & & lowas & 000 \\
\hline & $28 \cdots 2$ & 4536 & we & $18 \alpha$ & 0.7 & 28.15 & t.20 & & :1000 & {$[2]$} \\
\hline & $21-1$ & $45 \mathrm{es}$ & $a: 4$ & $16 \%$ & 1.00 & $2 x$ & [I] & Cx: & $100 \mathrm{~J}$ & css \\
\hline & $14-2 t$ & 4595 & wat & $\mid$ |\&.ŝ| & 6.8 & $3: 31$ & $6 x 2$ & it! & $100 \pm 14$ & tst. \\
\hline & is-a & 455 & $a c$ & 17.4. & $1 \mathrm{H}$ & $2: 56$ & [I] & trs & 10004 & css \\
\hline & $36-2$ & 145? & $a: 7$ & $18: 2$ & 0.72 & 3.32 & [II & GS: & $m s$ & {$[.9]$} \\
\hline & 371 & isst & 0.5 & $17 \%$ & pot & $y \leq 47$ & 615 & 665 & 10067 & $|\hat{y}|$ \\
\hline & $2 x-2$ & 4552 & ato & 15.57 & 0.70 & 35.23 & (I) & Er: & $1005 x$ & {$[.5$.} \\
\hline & 10.5 & $55 \omega$ & 051 & 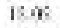 & $1 \%$ & $\geqslant 26$ & $c 05$ & & 10060 & $c \omega$ \\
\hline & $21-1$ & 4934 & $\operatorname{siv}$ & $1: 28$ & 2.58 & $52: 3$ & tx: & 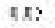 & Jue, 15 & 6. \\
\hline & $22 \cdots 2$ & 4553 & $\omega 4$ & $1 \mathrm{Nas}$ & Dos & 5.35 & CI: & & 100 ss & $t \leqslant 4$ \\
\hline & 13.1 & $45 \Omega 2$ & nat & 1881 & 608 & 35.24 & $(x)$ & tx. & $100 \mathrm{kS}$ & 694 \\
\hline & $24 \cdots 1$ & 9390 & ast & 18.12 & 2.00 & 3211 & tre & 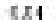 & $100 \Omega$ & c.73 \\
\hline & $23 \cdot 2$ & 53.45 & $a: s$ & a? & $\cos$ & 363 & {$[30$} & & looss & [.A] \\
\hline & $36-1$ & 4569 & $n \&$ & 1604 & 1.96 & 3239 & 616 & 851 & 100.13 & $6 x t$ \\
\hline & $2 k-2$ & 4532 & $\omega s 1$ & $18 / 2$ & 0.77 & 35.2 & [I] & {$[x]$} & 100025 & {$[.9]$} \\
\hline & $12-1$ & 52.43 & as: & $9 \pi 2$ & 9.60 & 274 & [2:7 & & $1000:$ & C.AS \\
\hline & th. 2 & 5185 & $n: 4$ & 1121 & 154 & $\geqslant 7$ & 6.1 & $t 21$ & foris & $t<8$ \\
\hline & $41-2$ & $49 \mathrm{se}$ & $\omega 1$ & $18 \%=$ & 0.71 & 32.44 & t.te & 181 & $100 \mathrm{st}$ & 594 \\
\hline & 12. & $5+67$ & 023 & 800 & 647 & 3612 & $63 i$ & 66 & 10075 & $6+10$ \\
\hline & $4: \cdots 1$ & 45.95 & $w 4$ & $17: 4$ & 2.00 & 30.25 & CI: & 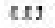 & 10023 & {$[2]$} \\
\hline
\end{tabular}




\begin{tabular}{|c|c|c|c|c|c|c|c|c|c|c|}
\hline \multirow[t]{21}{*}{ Fuilon } & Gati ke. & $\mathbf{5 0}$ & Ik: & $a:$ & NaO & $\mathrm{MLO}_{3}$ & $k>0$ & Mnos & Tral & da Caeks: \\
\hline & $46-2$ & $45+46$ & we & 18.12 & 0.24 & 3.34 & {$[x]$} & $8 x$ & lower & {$[2]$} \\
\hline & 47-2 & 55.15 & $a s$ & 11.27 & 122 & 2492 & 6.28 & $2 x 2$ & 10050 & [s? \\
\hline & 48.2 & 1565 & $\theta \otimes$ & 183 & ist & i: $: 13$ & $6 a$ & 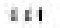 & 10032 & $68 t$ \\
\hline & $49-2$ & 4997 & 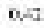 & Is:e & o.s. & 38.3 & {$\left[\mathrm{I}_{2}\right.$} & {$[x 3$} & 100.42 & c.9. \\
\hline & 50.2 & 1566 & $n \%$ & $18 \%$ & ore & $x=0$ & 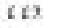 & tes & 10041 & $(4)$ \\
\hline & $\therefore 1-2$ & $32, \mathrm{~A}$ & $w x$ & 13.11 & 496 & $2 \times 4$ & $c_{-} g$ & & $100 x$ & $\therefore$ \\
\hline & $22-2$ & 5330 & 0.57 & 12.14 & 1.90 & 3035 & c.ss & & $100 \mathrm{Jt}$ & tel \\
\hline & 13al & 4525 & asi & $18: 6$ & 685 & 3493 & $5: 2$ & & 10006 & 592 \\
\hline & $\pm 4 \cdots 2$ & 4527 & we & 1834 & 0.73 & 32.22 & t. & & $100 x$ & 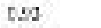 \\
\hline & $4 \cdots 2$ & 475 & $w e$ & 17.7 & 2.10 & 5.35 & tra & ext & 10004 & $t \leq 0$ \\
\hline & $26-2$ & 175 & $n=0$ & $16 . x$ & $7.7 \%$ & $3: 55$ & 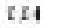 & 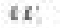 & 1000: & cst \\
\hline & $48-2$ & 4515 & 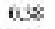 & 186 & Duss & 3572 & $\mathrm{x} x \mathrm{z}$ & & $100.1:$ & 64 \\
\hline & 20.2 & $15 x$ & $a v$ & 18:21 & $0.7 \%$ & Kis & tro & & 100.12 & {$[. s]$} \\
\hline & a.i & 517 & 0 it & 115 & 34: & 319 & 667 & $66 ?$ & 1000 & $i \theta$ \\
\hline & $61 \cdots 1$ & 4992 & 6.00 & IEN & $2.8 x$ & $52: 34$ & [f] & tx: & $90 \times 1$ & t.76 \\
\hline & Cक: 3 & 5245 & $\cos \theta$ & 1316 & 373 & $n \rightarrow 1$ & 630 & 663 & 10011 & 6,6 \\
\hline & $04-2$ & 4) 23 & wh & 1801 & $0 \times s$ & $\leqslant 9$ & $t \pi$ & $5 x 4$ & ניקנים & ryz \\
\hline & $u \cdots 1$ & 91.49 & wit & 14.7 & 2.xs & 51.27 & $5: 2$ & {$[x]$} & 100.15 & c.74 \\
\hline & $\alpha_{-1}$ & 565 & $0 / 8$ & 1000 & 300 & 27.35 & 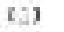 & 121 & ירינ & [3] \\
\hline & 6) $\ldots 2$ & 9155 & $6 \times 5$ & $14.2 \%$ & 2.46 & 31.59 & cre & exe & $100 x$ & c.72 \\
\hline \multirow[t]{9}{*}{$570-15 \cdot 2 n$} & $1-1$ & 13 $\mathrm{ES}$ & 0.2 & $12, \pi$ & $1 . m$ & 31.27 & [. 13 & $6[2$ & $\sin 2$ & {$[S]$} \\
\hline & $i-1$ & AsM & $\cos$ & $1 \operatorname{sen} \theta$ & DS: & $2: 73$ & crs & & wats & $\cos$ \\
\hline & $2-1$ & 4554 & 666 & 1596 & 6.78 & 35:33 & txt & $t x$ & $9 \% \omega$ & $(g)$ \\
\hline & $\therefore-1$ & $4 \leq n$ & $a *$ & $180 \mathrm{~A}$ & 0.90 & M.as & EII & & $m+1$ & {$[.21$} \\
\hline & $\therefore 1$ & 1663 & $n \in t$ & $178 t$ & (1) & $8 \div 46$ & $t a$ & 263 & $\omega \geqslant i$ & $i v$ \\
\hline & $4-1$ & 4734 & $\sin \theta$ & $1 \times \mu$ & 1.AT & ses? & [x] & & $\operatorname{sen}$ & cxr \\
\hline & $x-1$ & 43.46 & fort & $15 \pi$ & 2.51 & 3136 & trs & & 904 & c.76 \\
\hline & 1062 & 45 is & wer & $1 \times 16$ & n.7. & $\leq 4$ & $t: 4$ & & $90,4 x$ & tys \\
\hline & $11 \cdots 2$ & 9157 & we & $14: \approx$ & 2.80 & sess & tsts & $t x:$ & 90,41 & t.74 \\
\hline \multirow{15}{*}{52.1 .56 .21} & $2-2$ & 15.36 & $n: t$ & 1607 & 1.50 & 3156 & [It & {$[5]$} & 101.16 & $l, \pi \varepsilon$ \\
\hline & 4.2 & 573 & QSi & 1005 & 5.21 & 2772 & t:3 & $t:$ & 10035 & 53 \\
\hline & $8-2$ & 4792 & WGT & 180. & 134 & 32. 92 & {$[I 2$} & & 100.12 & ex \\
\hline & $a-2$ & 5635 & ore & $11 \div 8$ & 3.06 & 27.4 & c.2.2 & & 10004 & lse \\
\hline & 10.2 & 95.78 & wo & $93 \vec{i}$ & 28: & $25 i$ & t.2) & $t x$. & 106.41 & t.4e \\
\hline & $11 \cdots 2$ & 513 & os & 120 & 1.6t & 27.25 & {$[:]$} & tr: & roce & [ts \\
\hline & 131 & si ss & $\mathrm{nat}$ & $\mathbf{k}<\mathbf{1}$ & 377 & $n \pm$ & caf & $t 6=$ & 1611 & $i \pi$ \\
\hline & $16-2$ & 3168 & $2 \times \infty$ & 16.24 & $1 \times 0$ & 2.53 & $C-8$ & 824 & 100.25 & $5 x$ \\
\hline & $18-2$ & 1365 & aro & 17.40 & In & 5230 & {$[\mathrm{I}]$} & exz & 10034 & [XI \\
\hline & 19.1 & 4515 & $6 x$ & 150 & 136 & 35.15 & 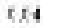 & $+x 3$ & 10032 & $t .88$ \\
\hline & $32 \cdots t$ & $47 n$ & wo & 1724 & 1.21 & 3.17 & t. 2 & $e x:$ & 10084 & t25 \\
\hline & 2a.2 & 5353 & $a r$ & 13.51 & 3.92 & $2 \times 11$ & c.25 & CX: & 10036 & crs \\
\hline & $11-2$ & 4956 & 67 & 11.7 & 1.88 & 33.19 & tr: & 85 & 10016 & $t s x$ \\
\hline & $22-1$ & 52.32 & $6 \geqslant 0$ & 14.15 & 3.16 & $n \rightarrow 3$ & c: 0 & {$[x]$} & 10100 & [.7) \\
\hline & $26-2$ & 5962 & $a: 8$ & 21 & 390 & 25.92 & {$[J t$} & $6 x$ & 100.11 & {$[A t$} \\
\hline \multirow[t]{15}{*}{$5+1.98101$} & $1 . t$ & is 64 & 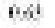 & $18>1$ & 181 & $3: 46$ & 62 & 66 & 10039 & 699 \\
\hline & $T-1$ & st 1 & $\omega S T$ & 7.97 & 6.26 & 2.55 & [2] & EIt & 100: & [.A] \\
\hline & 18.9 & 174 & 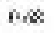 & $1+\theta$ & 362 & 7:55 & 66 & 663 & 16145 & $c s$ \\
\hline & $13-1$ & 2626 & wa & I $6 x$ & 8.16 & $2: \mathrm{n}$ & 5.8 & tx. & 10032 & 5,9 \\
\hline & $17 \cdots 1$ & 5744 & $\omega s$ & 1044 & 9.16 & 27.15 & [1: & Cr: & $100 \mathrm{Az}$ & $t \leq 0$ \\
\hline & 14.2 & 5954 & $0 \times 5$ & $8: 6$ & 608 & 3616 & 624 & & 10034 & 5.44 \\
\hline & $26-1$ & 93.45 & $a \rightarrow b$ & 209 & 2.74 & 3.2s & ta: & Cx: & יעבי & C.47 \\
\hline & $27 \cdot 4$ & 5356 & ari & 200 & 9.70 & 3612 & 521 & & 1005 & {$[.17$} \\
\hline & 30.1 & 5564 & $0=1$ & 952 & 5.72 & 2653 & $62 t$ & 6. & 10085 & 6.47 \\
\hline & $22-1$ & 55.42 & $\omega: t$ & $2 x:$ & 930 & 36.55 & [.25 & & 10039 & {$[ \pm 0$} \\
\hline & $24-2$ & 5311 & ace & 210 & $\cos$ & 3,16 & בנז & & 10051 & [AS \\
\hline & $k+1$ & SE:3 & frit & 9801 & $\leqslant x$ & $3 t$ & 637 & & 100 is & 648 \\
\hline & $26-2$ & 9535 & we & 260 & 256 & $36+5$ & tat & IX: & $100: 2$ & t.45 \\
\hline & $1: 1$ & 5573 & 051 & $1: 01$ & 153 & 283 & 6) 3 & 663 & $101 \div 6$ & c4s \\
\hline & $41 \cdots 1$ & 5736 & 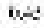 & 1602 & 2.27 & 27.39 & t.2. & $8 x 2$ & 10025 & $t \leq 2$ \\
\hline
\end{tabular}




\begin{tabular}{|c|c|c|c|c|c|c|c|c|c|c|}
\hline \multirow[t]{5}{*}{ Ile1an } & Gatinke. & $\mathrm{seO}_{2}$ & Tk:: & a:: & Na㭋 & $\therefore \mathrm{LO}_{3}$ & $k \rightarrow 0$ & Mas & Tral & has Caeka \\
\hline & $42 \cdots 2$ & $25 e$ & $a w$ & $16 / 4$ & 2.17 & 285 & $t-4$ & $r x$ & 10025 & $t \leqslant 2$ \\
\hline & $43-1$ & sos: & ors & $2: 5$ & $\cos$ & $2 s w$ & cas & & 100.16 & CAI \\
\hline & 4. 1 & $540 \mathrm{nt}$ & 0.51 & $95 ?$ & 553 & 2654 & 632 & 643 & 100.46 & 6.8 \\
\hline & $43--2$ & Is 11 & 0.4 & 16.31 & 9.27 & 2736 & $c>4$ & & 100003 & $0 \leqslant 2$ \\
\hline \multirow[t]{27}{*}{ n1:11 } & 1.2 & is of & $n$ & $|8| 1$ & os & Ma & $(6)$ & it & $\omega n$ & $(0)$ \\
\hline & $2-1$ & 25.04 & $\theta \rightarrow 6$ & $80 ;$ & 5.1 & 2634 & ta & $x$ & luese & c.4t \\
\hline & $2-2$ & 45.26 & az & towe & 1.5 & 3235 & c.5 & {$[x 3$} & 9258 & {$[x]$} \\
\hline & $4=2$ & 5533 & 065 & 886 & 5.77 & $255 ?$ & $\{23$ & $t x$ & 99.72 & t 45 \\
\hline & $t=1$ & 2306 & $6=1$ & 8.15 & 2.61 & 25.45 & tas & & 9030 & t.A4 \\
\hline & $b-1$ & 25.91 & $\omega \rightarrow 0$ & xas & 2.900 & 2951 & t.2? & $c r 2$ & 59.74 & t. .44 \\
\hline & $i-2$ & 596 & $0 \leqslant 1$ & $2 x$ & $39 ;$ & 2511 & {$[3]$} & $6[9$ & 10031 & IAS \\
\hline & $8-2$ & $\$ 234$ & $\theta=1$ & 2.19 & S.6T & 25.41 & 524 & & 99.2 & t.4T \\
\hline & $x-1$ & נגבי & as & 23 & $9: 20$ & $2 n$ & {$[2 ;$} & & 100.16 & {$[\leq 0$} \\
\hline & 101 & 5761 & $0<i$ & x<; & 500 & 2553 & 63 & $60 ?$ & $\omega \pi$ & 6.48 \\
\hline & $11 \ldots 2$ & $25 \pi$ & $k=1$ & $x \times 5$ & 2.70 & 2933 & t.25 & $4 x$ & $90 . \%$ & t.43 \\
\hline & 15.9 & 5169 & $n=4$ & $9:-$ & $5 \mathrm{wi}$ & 25 is & c35 & 663 & $\omega x$ & C.48 \\
\hline & $18 \cdots 2$ & 3942 & $\omega=x$ & ; 34 & $0.5 ?$ & 2331 & 53 & & $=0$ & 5.40 \\
\hline & $14 \cdots 1$ & $23 \pi$ & $\operatorname{lin} 2$ & s:3 & 2.34 & 2933 & 524 & $t x 2$ & 5029 & t.A4 \\
\hline & $15=2$ & 5518 & 04 & $90 \%$ & 3.25 & 2634 & (2) & & 9ous & CAS \\
\hline & $16-1$ & 4.73 & 664 & $16: 4$ & $2.5 t$ & 3317 & t.It & $8 x z$ & $100 \times$ & cre \\
\hline & $17 . .1$ & 9260 & ar & 2.00 & 3.31 & $2 s n$ & [2t & $6 \boldsymbol{C}:$ & lowo & C.15 \\
\hline & $12 .-1$ & 3789 & as & $\sin$ & 3.17 & 2536 & c.5 & tet & $m \%$ & $c 20$ \\
\hline & $10-2$ & $\$ 347$ & $6=4$ & $8 \hat{S}_{2}$ & 5.72 & $26+4$ & 624 & $\{x\}$ & 10015 & t.46 \\
\hline & $28-2$ & $35: 46$ & $0 \leqslant 1$ & 213 & ess & as as & [Is & {$[x]$} & lowas & [A] \\
\hline & $\& 23$ & 5406 & $n<4$ & $8 \%$ & $<\otimes$ & 26 at & 634 & & $100: 4$ & ct5 \\
\hline & 24.11 & 29.46 & wo & $8 \times 4$ & 2.7 & 2975 & c34 & & 100.10 & C.44 \\
\hline & $H * 1$ & 4567 & 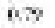 & $16-48$ & 1.90 & 5255 & t IS & {$[[]$} & ice is & tss \\
\hline & $2 x-1$ & 4521 & 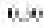 & 10,0 & 3.81 & 3258 & txs & $t x t$ & 9006 & $t \times s$ \\
\hline & $27 . .2$ & $4: 20$ & $6 \pi$ & $17 \mu$ & 2.01 & 33.42 & t.II & $c x$ & 90,4e & {$[\because]$} \\
\hline & 78.1 & $57 \pi$ & no 6 & 903 & 3.41 & 2676 & נגז & & 10000 & CAS \\
\hline & $3 a .2$ & 5683 & 00 & 1000 & 198 & $27+4$ & t:5 & $\{t\}$ & $908 \%$ & 63) \\
\hline \multirow[t]{28}{*}{6.1 .244} & $1-2$ & 9345 & ws & $x x=$ & 2.80 & 2951 & t27 & $e x:$ & 100.73 & c.44 \\
\hline & i-1 & $1 \leq 13$ & $a \geq 0$ & $18,8 \pi$ & $d x$ & ור & CI2 & $6 x 1$ & I00ss & {$[.5]$} \\
\hline & $2-1$ & 29.18 & $b=$ & 8.5 & 2.78 & 2993 & t34 & txt & 90.72 & t. .44 \\
\hline & $4-1$ & 9950 & ave & $2: 22$ & $9.7 n$ & 253 & [נ] & {$[x 1$} & iosu: & t.At \\
\hline & $\therefore 1$ & s1 ot & $n \neq v$ & $1 \leqslant 18$ & 37 & 78 & $c 25$ & $t a=$ & $i n s t$ & $6 x$ \\
\hline & $6-2$ & 2539 & $\theta=2$ & $9=$ & 2.35 & 2412 & t 22 & trt & 100.1: & C.AY \\
\hline & $7-1$ & is $\alpha$ & $\omega 0$ & $18 . x$ & 0.94 & 53 & {$[\mathrm{I} 2$} & {$[x]$} & $100 \mathrm{~s} t$ & {$[\mathscr{A}$} \\
\hline & $8-1$ & 5839 & $k=8$ & $98:$ & 5.26 & 2652 & 523 & & $100 \times 8$ & 020 \\
\hline & $y-1$ & 23.45 & $0-1$ & ses & 280 & 2530 & t.21 & & $100.1 \mathrm{te}$ & c.44 \\
\hline & 10.2 & 35.15 & 051 & x:s & $\operatorname{sen}$ & 2516 & 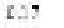 & & $m s$ & C.AS \\
\hline & $11-1$ & ta 38 & $6=7$ & $8<?$ & 606 & 2552 & $52 t$ & & 106.1: & t.43 \\
\hline & 13.1 & $95 \mathrm{ge}$ & ac & $x<:$ & $9 . x t$ & $25 n$ & [J2 & {$[x]$} & 1000 & CAS \\
\hline & $1+-1$ & $39 \mathrm{st}$ & 057 & $2: 2$ & SSM & 2511 & {$[22$} & {$[S]$} & 100001 & CAt \\
\hline & 152 & 5534 & 0.08 & $9 \times 8$ & 5.11 & 2523 & 631 & sti & $1004 t$ & $63]$ \\
\hline & $16-2$ & 9339 & $0-2$ & 2.12 & 9.48 & 2514 & c.25 & Er: & 100.75 & t.AX \\
\hline & 17.2 & $n+40$ & $0: 6$ & $8<1$ & \&\$2 & 2520 & 635 & & 10059 & 641 \\
\hline & $1 \%-2$ & $34 \%$ & $v=4$ & 11.21 & $4, A 8$ & $2: 34$ & $x-4$ & $5 x$ & $5 \%$ & $5 \div 8$ \\
\hline & $15-1$ & 27.97 & $\omega-7$ & $2: 23$ & 9.26 & 2533 & tat & $c r:$ & $1000 \mathrm{~s}$ & $t \leq 0$ \\
\hline & 30.2 & 5395 & 0.58 & 900 & 5,72 & 2554 & 626 & & 9908 & (A6 \\
\hline & $21 \cdots t$ & 23.40 & 002 & $x i s$ & 2.73 & 2955 & t25 & & 100ate & C.AS \\
\hline & i3.2 & casto & as & 201 & 0.16 & 2519 & $1: 2$ & & 160,17 & {$[]$.} \\
\hline & 32.1 & $596 \pi$ & cis & sis & 5.79 & 2539 & $6 \leq 9$ & & 10032 & 6.45 \\
\hline & $24-2$ & 92.31 & wo & 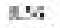 & 907 & 2573 & {$[25$} & Cr: & 1004: & C.A4 \\
\hline & $\because \because 1$ & 95.18 & $a \%$ & $x+2$ & 128 & 2521 & [ב2 & ec: & 100.17 & {$[20$} \\
\hline & 47.2 & SE 3 & $n: 0$ & 89: & $5 \pi$ & 2626 & 623 & $\{t\}$ & weint & ith \\
\hline & 28.1 & $4 \times 5$ & wor & $18 . x$ & D.xs & 3415 & {$[\mathrm{CS}$} & 184 & 9008 & {$[\because 2$} \\
\hline & 10.3 & $\operatorname{sen} x$ & $n-A$ & 90 & $5: 1$ & $25 \leqslant 1$ & 6): & 663 & $1004:$ & 648 \\
\hline & $21 \cdots 1$ & 2592 & ws & 201 & $2 \pi, 2$ & $25+4$ & tat & crt & 10042 & 5.47 \\
\hline
\end{tabular}




\begin{tabular}{|c|c|c|c|c|c|c|c|c|c|c|}
\hline \multirow[t]{14}{*}{ Heian } & Crata kie. & so. & Ik:: & a:: & Nao & $\mathrm{ALO}$ & $k \rightarrow 0$ & $\mathrm{M} \neq \mathrm{O}$ & Tral & As Coeka \\
\hline & $23 \cdot-t$ & 9308 & $\theta=8$ & s.25 & evot & 25.45 & (2) & & 100.1t & t. 42 \\
\hline & $2+\cdot 1$ & 9604 & ors & 11.21 & 158 & 2755 & 6.25 & aol & 1000 & cst \\
\hline & 15. & 54.16 & 0.57 & $9 \times \mathrm{si}$ & 566 & 2549 & 633 & & $10 \% s s$ & 645 \\
\hline & $26-2$ & 95.T6 & $0=2$ & 905 & 9.67 & 2958 & tas & $a x$ & $1000 \mathrm{se}$ & c.AC. \\
\hline & 17.5 & 518 & $n m$ & 11.18 & 1.55 & 2811 & $c \in 1$ & & $\infty$ is & c:s \\
\hline & $28-2$ & $25: 6$ & $\theta=0$ & $9 x z$ & 2.51 & $2 \pi z$ & $\mathrm{r}-\mathrm{s}$ & & $100 \times 5$ & c.45 \\
\hline & $20-1$ & 23.75 & $0=5$ & $x$ & 2.62 & 2575 & t31 & & 100ess & C.AZ \\
\hline & $40 \cdot 2$ & 5708 & 057 & $10 x$ & $5 \% 3$ & 2644 & (3) & & 994 & 632 \\
\hline & $41-.1$ & 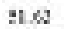 & oved & 14.4 & 2.800 & 3355 & t.ss & we & 100021 & 6.74 \\
\hline & $42-1$ & 290 & we. & $x=6$ & 4.28 & 2557 & t.25 & ace & 20.7 & {$[A]$} \\
\hline & d $2-2$ & 5968 & met & $\mathrm{s} m$ & 356 & 2534 & [:? & $\omega 0$ & mali & CAt \\
\hline & $44-. \mathrm{t}$ & 9314 & $0=4$ & $8 \% y$ & Sat & 2525 & $(2)$ & 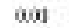 & $10044^{4}$ & t.4t \\
\hline & 42.2 & 9612 & $0 \%$ & $11 / 7$ & 151 & 2753 & $2: 3$ & $\omega 01$ & 100.72 & [.s \\
\hline \multirow[t]{37}{*}{$\omega \geqslant \& 46$} & $\$ 2$ & 5716 & $0 *$ & $96 i$ & $5 \% 5$ & $2 \leqslant 55$ & 625 & & $\omega+8$ & $1 \leqslant 0$ \\
\hline & $2-1$ & 9235 & 0,00 & $2=-2$ & 2.58 & 295 & t24 & are & 10012 & $t .48$ \\
\hline & +2 & 5115 & 0.51 & $88:$ & \$2: & 2654 & coss & $00 \mathrm{i}$ & 160 is & CAs \\
\hline & $\therefore \rightarrow 2$ & 391 & $\omega=8$ & $x \rightarrow 3$ & 294 & $2 \mathrm{n}$ ? & $9 x$ & we & $100-3$ & 5.43 \\
\hline & $<-1$ & 2585 & $\Leftrightarrow-7$ & $x / s$ & 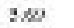 & 2525 & tas & we & 10002 & t.A2 \\
\hline & $7=2$ & 1596 & $0 \%$ & 1800 & 091 & 3123 & {$[x]$} & ast & $100+4$ & {$[9]$} \\
\hline & $8-2$ & 24.75 & 6.4 & $2 \pi$ & 3.54 & רי & tas & we & $50 \times 5$ & C.A5 \\
\hline & $x-2$ & $92: 13$ & 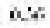 & 2.11 & ess & 2911 & לנ: & & 100.75 & [.17 \\
\hline & $10-2$ & $\sin x$ & ont & 201 & 9.08 & 2559 & [.J5 & ant & lowess & cds \\
\hline & 18.2 & 5336 & cat & 9.18 & 5.66 & 2911 & (23) & aid & 1008 & ${ }_{(4)}$ \\
\hline & $14 \cdots 1$ & 99.79 & $0 \rightarrow-3$ & $x$ & 152 & 2734 & {$[\therefore 3$} & anc & 100015 & C.AS \\
\hline & $1 \leqslant 1$ & stón & 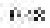 & $\phi<:$ & sat & 377 & 637 & & 16077 & cas \\
\hline & $16-2$ & 25.00 & $\omega *$ & $x: 5$ & .3.s & 2725 & taz & - & lowess & $t .46$ \\
\hline & $17-2$ & 1511 & 0.6 & 18.5 & 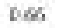 & 3553 & II) & an & $1013 t$ & {$[\%$} \\
\hline & $18-1$ & 5954 & 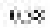 & $x \rightarrow z$ & $3 y_{i}$ & 2665 & $t a$ & $a . c$ & 1008 & t.45 \\
\hline & $19-1$ & $25 . \pi v$ & $0 \rightarrow 0$ & $x=6$ & $2 . x$ & 2735 & tas & - & 100.12 & t. .44 \\
\hline & i1. -1 & 59.44 & $m a$ & se & 5.74 & $2 \leqslant \leqslant 1$ & {$[32$} & , & 100019 & CAt \\
\hline & 33.4 & 58.18 & $\theta=\theta$ & 950 & 5.06 & 2657 & t26 & 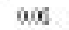 & 10037 & $f, A \&$ \\
\hline & $23 \cdots 2$ & בגנ: & 0 & 24 & 233 & 235 & [23 & 001 & 90.76 & C.4P \\
\hline & it-2 & $\sin 2 x$ & $a c$ & $8: 2$ & 351 & $2 \leq 10$ & cas & anc & 10001 & $B A C$ \\
\hline & $72-4$ & 25.76 & $k=2$ & $8 \%$ & 9.84 & 254 & (2) & & 1006: & $\mathrm{t} .44$ \\
\hline & $3 \times-2$ & $15 \%$ & 0,2 & 17,4 & 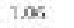 & 314 & [I? & and & 20.40 & c.50 \\
\hline & 873 & St if: & $n \in t$ & $9: 4$ & sei & 2730 & 63 & $a n t$ & iness & 647 \\
\hline & $2 x-2$ & 2462 & $6: 2$ & 11,7 & 4.18 & 243? & $\therefore$ & weis & 100.75 & $\cos$ \\
\hline & $29-2$ & 95.49 & 0.51 & $2+7$ & 9.27 & 274 & זבג & $a d c$ & 10055 & c.45 \\
\hline & $20-2$ & 45.61 & $00 \%$ & 10.12 & 386 & $33+6$ & $t .3$ & we & 100 is & $t x$ \\
\hline & $21 \cdots t$ & $29 \pi$ & 657 & $x 2$ &. .17 & 2734 & t.34 & we & lowere & $t \leq 0$ \\
\hline & 32.2 & $1 \leq 43$ & 071 & 17.20 & 0.91 & $3 \leq 5$ & cfl & are & looes & 6.81 \\
\hline & AL-t & 5944 & $0=1$ & 873 & $\$ 91$ & $26+3$ & 523 & ait & 100.13 & t.44 \\
\hline & $25-2$ & 99.16 & are & ars & 930 & 2713 & [ I t & & 10051 & $\cos 0$ \\
\hline & $26-2$ & 3978 & ars & $x=$ & 9.22 & 2752 & 6.9 & & 1000ss & {$[20$} \\
\hline & 971 & 5794 & 0.51 & $96:$ & 536 & 2738 & 6.7 & 091 & $100 \pi$ & 6.45 \\
\hline & $28-2$ & 99.92 & OLT & 10.14 & 4.sn & 277 & t.23 & ani & 2031 & {$[\leq 1$} \\
\hline & 40.1 & $\operatorname{sen}$ & $n \rightarrow 1$ & $8 \geqslant$ & 600 & 2557 & (3) & ani & 10045 & {$[A$} \\
\hline & $41-2$ & $\geqslant *$ & wes & $9>1$ & 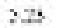 & $2, n$ & tat & we & 10009 & 5.49 \\
\hline & $43 .-1$ & 23.45 & $u s$ & $\mathrm{x}: \mathrm{z}$ & e.14 & $25 n$ & {$[23$} & wo & 100.17 & [.AI \\
\hline & 4.2 & 5969 & $n=1$ & 8.8 & 5.94 & 2624 & 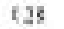 & $a \alpha$ & 100,75 & $\{A\}$ \\
\hline \multirow[t]{9}{*}{$60.2-51-24$} & $1-2$ & $2 x$ & 0.57 & $9 / \mathrm{s}$ & 2.74 & 2934 & $t-5$ & we & 5030 & C.A8 \\
\hline & $2-1$ & $9 \operatorname{sic}$ & 04 & leve & $35 \pi$ & $2 \leq s 3$ & $5: 5$ & $\omega$ & 1009 & c.AS \\
\hline & 41 & $5 t .17$ & 0.51 & 98 & 538 & 2667 & t.5 & $a x$ & ine:Ts & 6.5 \\
\hline & $\therefore-2$ & $19+4$ & $4 . \% 6$ & $17 / 8$ & 1.22 & 273 & t.25 & ase & $n \alpha$ & css \\
\hline & $f-1$ & 970 & are & $\ln \%$ & $1 . m$ & 2700 & I:? & & 10051 & [S4 \\
\hline & … & 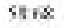 & nit & 1000 & 500 & 2637 & 65 & & 104 & $6 \%$ \\
\hline & $x-2$ & 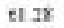 & we & $\operatorname{t.78}$ & 600 & 293 & t2s & & 10038 & tas \\
\hline & 2.1 & 1561 & $0 \%$ & $18 \%$ & cs: & 7iat & $(c)$ & 601 & 101 is & {$[9]$} \\
\hline & 10.2 & $45 \mathrm{Ka}$ & wis & $15: 1$. & $0.7 \pi$ & 3327 & 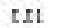 & $w$ & lowet & $t \leq 4$ \\
\hline
\end{tabular}




\begin{tabular}{|c|c|c|c|c|c|c|c|c|c|c|}
\hline \multirow[t]{32}{*}{ Ile1an } & Crati ke. & $\mathrm{Na}_{2}$ & I':2 & a:: & $\mathrm{NaO}$ & $\therefore \mathrm{LO}_{3}$ & $k \rightarrow 0$ & Mgo & Tral & ha Caeka \\
\hline & $11-\mu t$ & 4452 & $\theta=0$ & 11.5 & 4.66 & 29 & t23 & $C_{x}:$ & $1000 \mathrm{~s}$ & $t \leq t$ \\
\hline & $12 \cdot 1$ & 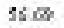 & $a s 1$ & 1021 & 9.18 & 2575 & [2] & 281 & 100.15 & {$[\leq]$} \\
\hline & 121 & 574 & 6 ot & 165 & 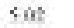 & 2714 & $t 22$ & 463 & 1609 & 69 \\
\hline & $14-21$ & בדת9 & $\cos 2$ & 10,51 & 920 & 2555 & t.25 & & 10018 & {$[\leq 1$} \\
\hline & (6) 5 & 5133 & 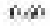 & 11.8 & $1 \%$ & $2+40$ & $6: 7$ & 163 & ws & C:s \\
\hline & $1 \ldots z$ & 25.74 & 6,64 & 909 & $2 x$ & 2531 & $t-5$ & $x$ & 100.14 & (4) \\
\hline & $18 \cdot 1$ & 23.14 & $\omega 30$ & 2.11 & 0.00 & 2533 & $1 ; 5$ & & $100 \mathrm{es}$ & C.A2 \\
\hline & 30.2 & 6004 & 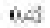 & 884 & 6.38 & 2547 & 527 & $t 6$ & 16034 & $\{A\}$ \\
\hline & $21 \cdots 2$ & $2 \pi \pi$ & won & $10 \times x$ & 2.15 & 2557 & $t:-4$ & $t x d$ & 106.13 & $t \leqslant 3$ \\
\hline & $23-1$ & 4500 & $w 3 x$ & $15: 2$ & 0.77 & 5414 & tLs & $\operatorname{trz}$ & $1003 t$ & 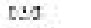 \\
\hline & $3+1$ & $626 \pi$ & $\alpha: 8$ & 791 & 6.52 & $25 \leqslant 2$ & [נ] & & 10.16 & 1.10 \\
\hline & $14 .-1$ & Is.44 & 664 & 2015 & 2.66 & 2951 & $t_{2} ?$ & & 100.15 & t.48 \\
\hline & Wat & $15 \% 9$ & $2 . x$ & $16 \%$ & 1.76 & 323 & EIs & 6.22 & 100us & {$[8]$} \\
\hline & 3.1 & ra 04 & $n-4$ & $8 * 0$ & 631 & 2512 & 622 & $6 \mathrm{~L}$ & 10016 & $\{43$ \\
\hline & $23-1$ & 2517 & 0.51 & 207s & 2,00 & 2332 & t... & 15: & 100,4 & t.AE \\
\hline & $16-1$ & 5616 & net & $10 \%$ & 317 & 27.27 & c: 2 & if & wa & $c 03$ \\
\hline & $21-1$ & 34.8 & wex & $12 . .8$ & 4.55 & 2558 & $5-7$ & $6 x$ & 1008 & 501 \\
\hline & $22 \cdots 1$ & $4,6]$ & $w s$ & 18.17 & 1.22 & 3259 & tIS & ts5 & 1004, & $\cos$ \\
\hline & $3 \sin 2$ & It 85 & $\theta \%$ & 17,17 & 790 & II 58 & ISA & $t x_{:}$ & 160.58 & {$[\times]$} \\
\hline & $27 \ldots 2$ & 4515 & $\theta \rightarrow 0$ & 1931 & 0.53 & 3530 & t.s & $8 x$ & 9028 & tse \\
\hline & $28-1$ & $96 \Omega$ & a. & $11 .-1$ & $1 . N$ & 279 & 2:It & CS: & 10uas & {$[2 c$} \\
\hline & 20.2 & $\sin$ & ost & $x=7$ & cos: & 2537 & l.'s & to & נהבסן & CAE \\
\hline & 40.2 & 59.46 & 6.54 & 1048 & $5 b 0$ & $2^{4} 16$ & $t=5$ & $\{x\}$ & iofic & $t \leq t$ \\
\hline & $42-1$ & 3358 & $a \%$ & axs & C.1T & 25.45 & [at & cr: & lowee & {$[A]$} \\
\hline & $1: 1$ & 5418 & $n<\bar{x}$ & $90 \mathrm{z}$ & fint & $25<7$ & 68 & $6 t$ & $160<6$ & 645 \\
\hline & 44.2 & 2798 & 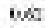 & 1600 & 2.51 & $25 \times 5$ & tas & $8 x$ & 10032 & $t \therefore$ \\
\hline & $H \cdots$ & 5516 & ovst & $11: 3$ & $90 \mathrm{z}$ & 2734 & 6. 2 & CE: & 10033 & css \\
\hline & $4 \times-1$ & $59 \div 2$ & awe & $9=$ & 8.28 & 2531 & tat & $2 x 3$ & 100.28 & (4) \\
\hline & $20-2$ & 2913 & wis & 20 & 2,61 & 2554 & $t: 3$ & $c r 2$ & 100xe & CAs \\
\hline & $26 r+1$ & 9648 & an & $90 \%$ & 3.90 & 2557 & 12.7 & $E x$ & sa: & cat \\
\hline & 37.2 & 5518 & 061 & 18.18 & 4.41 & 2536 & $t 23$ & (1) & jowit & 60 \\
\hline \multirow[t]{28}{*}{60.5 .56 .21} & $1-1$ & 290 & we & 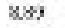 & 2.72 & 2532 & $t: 3$ & ex: & 5002 & c.te \\
\hline & $i-1$ & 53.18 & 0.1 & $12: 4$ & 1es & 2151 & $\cos 2$ & $\operatorname{cs} 1$ & wos & cas \\
\hline & $2-1$ & 3930 & $6 z$ & $T 200$ & 6.55 & 29.2 & t.s & $t r:$ & 90.48 & $\mathrm{C.40}$ \\
\hline & $\therefore-1$ & 1520 & $a=2$ & 1627 & 1.65 & 3214 & {$[2$} & $6 x^{7}$ & now & ces \\
\hline & 62 & $15 \%$ & 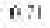 & $17:$ & 317 & พx? & $c a$ & 66 & $\infty 4$ & $c *$ \\
\hline & $11 \cdots 2$ & $37 x$ & ns & $9 \Leftrightarrow \Rightarrow$ & $2 . \mu s$ & 2939 & 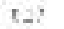 & [xs & 9098 & 5.48 \\
\hline & $12-2$ & 9516 & anis & 210 & 9.61 & 2575 & $\cos$ & t.6] & 90.21 & [.AT \\
\hline & 3.1 & 5346 & 651 & 9.11 & 5.45 & 2631 & $t-5$ & & seat & (4) \\
\hline & $1-2$ & 9537 & 657 & 261 & $4 . x$ & 2515 & t.23 & & 90200 & ts] \\
\hline & $2-1$ & $\operatorname{sen} 2 a$ & as & las: & 3,05 & 2525 & $\cos 3$ & & 10000 & {$[2]$} \\
\hline & t-t & $\$ 6.78$ & 6.57 & 160 & 4.71 & 2596 & $6: 3$ & 263 & 10000 & $t 46$ \\
\hline & $t-1$ & 1748 & $a .0$ & 17) & 13 & $72 * 3$ & Int & {$[5]$} & moss & css \\
\hline & $2-2$ & $\cos s$ & $a t$ & $2 \pi 2$ & ces & 3135 & [J] & 652 & 100.16 & cas \\
\hline & 6.2 & 58 14 & 0.50 & $93 ?$ & 578 & 2593 & t. 5 & 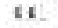 & $90<6$ & 6.45 \\
\hline & $2-1$ & 4564 & ase & $18.3 T$ & 0.61 & 3575 & $\mathrm{Cr} 2$ & (x) & mat & 5.94 \\
\hline & \%. & Stes & $m=1$ & $9: 1$ & 562 & 25 at & 632 & 66 & wa: & $6 A^{7}$ \\
\hline & $10-2$ & 30 & wor & 11.20 & 4,81 & $2: A y$ & tas & 5x. & 10024 & 52 \\
\hline & $11 \cdots 1$ & $95.7 e$ & us & $2+2$ & 235 & 2572 & $5: 2$ & (r) & 100ut & t. .49 \\
\hline & 13.4 & 5613 & $\theta=0$ & $11 \%$ & 159 & 2533 & 622 & $t x$. & 90.24 & 637 \\
\hline & 23.2 & 25.40 & wow & 200 & $2, A 1$ & 2950 & t.s & & 90.17 & t.As \\
\hline & 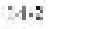 & $375 \pi$ & as & as: & 1.8i & 2551 & [at & $6[2$ & Won & c.As \\
\hline & 6.2 & 5699 & c.se & 10.19 & 5,08 & 2625 & C. -1 & 463 & 99.17 & tst \\
\hline & $5 \cdot 2$ & 9726 & as & 10.14 & 9.02 & $2 s s$ & [..S & tr: & m: & {$[\leq 1]$} \\
\hline & t.1.1 & $a \%$ & $a x$ & 7.12 & CA: & 2411 & [2] & & $\$ 0.15$ & 6.34 \\
\hline & +1 & St $\neq 4$ & 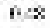 & $\omega 6 \mathrm{~A}$ & $5 \%$ & 958 & 623 & 167 & ioste & $t \leqslant 1$ \\
\hline & $23 \cdot 2$ & 9627 & wo & 11.11 & 4.06 & 2715 & $t=1$ & & 900 & $t=6$ \\
\hline & 31.1 & $5+76$ & $n \in 1$ & 885 & 587 & 2514 & c) & & 10033 & CAs \\
\hline & $22 \cdot 2$ & 2736 & $\omega s$ & 16.21 & 4.97 & 2575 & $t 23$ & tr: & 90:n & $t \leq 1$ \\
\hline
\end{tabular}




\begin{tabular}{|c|c|c|c|c|c|c|c|c|c|c|}
\hline \multirow[t]{7}{*}{ atsea } & Chan ke. & $500_{2}$ & Ik: & a:: & Naю & $\mathrm{ALO} \mathrm{O}_{3}$ & $k \neq 0$ & $\operatorname{Mno}$ & Tral & ha Caelas \\
\hline & $2 \cdot 1$ & es.14 & $\theta=0$ & 840 & 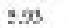 & 2...35 & $t 20$ & $8 \times 4$ & 10001: & t.44 \\
\hline & 24.2 & 2750 & $a$ & lown & 9.05 & $3: 21$ & 6.21 & IX: & h.m & ces \\
\hline & $\approx 2$ & St 6 & 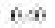 & 901 & 566 & 2525 & is & 625 & $\omega>1$ & 645 \\
\hline & $x-2$ & 2592 & 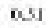 & 216 & 239 & 23.34 & $t=5$ & ex: & $90 \%$ & C.AT \\
\hline & $\approx 3$ & 5648 & $n \in$ & $10 s t$ & $1 \%$ & 2918 & $c 65$ & & mot & is \\
\hline & 24 & 320 & $v-4$ & 100 & 200 & $x>$ ? & $x$ & ix & 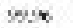 & $\therefore$ \\
\hline \multirow[t]{28}{*}{$62 \cdot 5 \cdot 1=0.145$} & $1-2$ & 9537 & ast & 261 & 4.28 & 36.15 & t.s & & 9020 & tA] \\
\hline & $s=1$ & 5789 & as & $16 x$ & $5 \mu s$ & $\$ 25$ & $5 \leq 3$ & & 10009 & 633 \\
\hline & $3-1$ & $\sin x$ & Wot & 1600 & 4.71 & 3..35 & $t: 2$ & {$[x]$} & $100 \mathrm{c}$ & $t \pm t$ \\
\hline & -1 & (2) 45 & u⿰v & $17 / / 4$ & 130 & 5241 & t.: & $\operatorname{crz}$ & sos: & $\mathrm{tax}$ \\
\hline & 5 & $\cos \theta$ & $m e x$ & $7 \omega 2$ & cest & 30.35 & [נ] & 657 & 160,06 & 698 \\
\hline & $s-1$ & is 15 & bis & 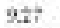 & 5.28 & 2.93 & $x \leq 2$ & ex: & 99.46 & t.45 \\
\hline & $i-1$ & 1538 & $a=1$ & 1600 & 3.74 & 31.14 & III & {$[6]$} & $\operatorname{ren}$ & [S9] \\
\hline & 83 & 1564 & as & $188 i$ & 061 & 3573 & 668 & 667 & $\omega<8$ & 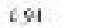 \\
\hline & $x-1$ & 2508 & $\theta=3$ & 230 & 200 & 2. 15 & $t 20$ & tx: & Fos & C.AT \\
\hline & $16-3$ & 5636 & 0.57 & 11.5 & 161 & 2745 & c:s & 66 & $100: 1$ & CNT \\
\hline & $11 \cdots$ & 25.8 & wex & $9=$ & $25 i$ & 2,2 & 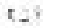 & $6 x^{2}$ & loest & 5.45 \\
\hline & $12-1$ & 2512 & wit & $112 \pi$ & $4=0$ & 36.53 & $t: 2$ & $t x:$ & 90.24 & t:4 \\
\hline & 13.3 & 5846 & $a \omega$ & 9.30 & S.at & 255 & r. 6 & & 9017 & c.48 \\
\hline & $14 \cdot 2$ & $29 \pi$ & ase & $9<3$ & 2.26 & 25.94 & ta2 & $8 x:$ & 9000 & t.A5 \\
\hline & $1:-1$ & 3558 & ase & $10 x:$ & 1.65 & 3iss & $6: 2$ & $6 \leq 2$ & $r e s$ & $t \leq c$ \\
\hline & $16=1$ & $3 \leqslant 60$ & $a v$ & 1018 & 9.08 & $3: 25$ & [.: 1 & {$[6]$} & m.17 & {$[\leq 1$} \\
\hline & 17.2 & $59 \pm 6$ & 6.5 & 16.14 & $s 0 t$ & 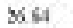 & $t=6$ & $t x$ & $99 . \mathrm{N}$ & 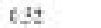 \\
\hline & 1s.1 & cos & $a r$ & 7.12 & $\cos$ & 3.11 & {$[2]$} & & 20.18 & [3T \\
\hline & 10.1 & St $* 4$ & $m<\bar{x}$ & $10 \% \mathrm{H}$ & $s 3 t$ & $25 \mathrm{Ei}$ & 630 & 267 & ineif & $6 \leqslant 1$ \\
\hline & $x=2$ & $3 \pi$ & $60 x$ & 11.11 & 4.60 & 25.5 & $c_{-}-4$ & & 9000 & $t<6$ \\
\hline & $21-1$ & 9276 & $\cos 1$ & 885 & 987 & 25.14 & [.] 5 & & 100033 & cts \\
\hline & D. & $5 / 46$ & $a x$ & 103 & $49 ;$ & 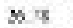 & $t \leq 9$ & $t x$ & wow & $x \Rightarrow$ \\
\hline & 2]-2 & en.14 & 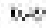 & $x \omega 0$ & 2.28 & 2. .56 & tat & 6.54 & 10002 & t.A4 \\
\hline & 3.3 & 5750 & nos & 1000 & 900 & $3 i 21$ & L: 1 & $E x$ & $\operatorname{sax}$ & 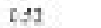 \\
\hline & As. & $5 s, 6$ & $\theta 00$ & 901 & 5.66 & 25.25 & $t: 8$ & txs & 903 & $f, 46$ \\
\hline & $x-1$ & 2592 & ws & 2.16 & 209 & 2.24 & t.25 & $e x:$ & 5000 & [.AT \\
\hline & s.1 & 39.13 & are & ass & 3.15 & 3424 & C.SI & {$[x]$} & w.s & {$[2]$} \\
\hline & 202 & 270 & 64 & 10.6 & gas & 3697 & $t \leq y$ & txy & $90 . \%$ & $t \leq 3$ \\
\hline \multirow[t]{16}{*}{.H.3.118-121 } & $1-1$ & 4541 & ovit & $16: x$ & 2.01 & 72.25 & [I] & & inos: & {$[8]$} \\
\hline & $\approx 1$ & $57 \pi$ & $n / 2$ & $1<\otimes 1$ & 79: & $m 15$ & CET & & inen. & chit \\
\hline & $x-1$ & 4508 & 6il & $|r| 1$ & 1.45 & ss. 18 & $t x$ & & 1000. & $8 x$ \\
\hline & $11 \cdots 1$ & 9524 & $a x$ & $12: 8$ & 1.24 & 2442 & [I] & & 106.t: & {$[Q 6]$} \\
\hline & $11 \ldots]$ & 5381 & $6=9$ & $12.2 y$ & 9.69 & 2414 & $\mathrm{Cx}^{2}$ & $8 x 4$ & $100 \mathrm{e}$ & 0.5 \\
\hline & $12 \cdots 3$ & 43.T2 & wa & 16.24 & 2.13 & 31.45 & & $e x z$ & 100.15 & {$[2]$} \\
\hline & $12-3$ & 3600 & $a t$ & 11.8 & A.4. & 22.25 & LIC & CX: & 100ss & $c=0$ \\
\hline & $14-1$ & 4691 & $6 \%$ & 17.98 & 124 & 35.43 & $\{x\}$ & 152 & 10012 & 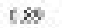 \\
\hline & $1:-2$ & $95 \pi$ & ast & $11 \pi$ & 4. 10 & 2796 & t::0 & & 100.15 & 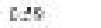 \\
\hline & $1 \%-1$ & 95.17 & as: & 12.3 & 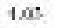 & 2459 & [. 19 & & losurs & $\cos$ \\
\hline & $x-1$ & $\operatorname{san} 6$ & $6 \theta i$ & $16 x$ & 2.09 & 31 i? & 6,1 & $t z$ & $1000 \mathrm{~s}$ & tis \\
\hline & $21-2$ & Н.T2 & 6.74 & 18.72 & 104 & 3.25 & [I] & & 90.46 & {$[.9]$} \\
\hline & 28.3 & 1435 & $\sigma \mathrm{N}$ & $16-1$ & j\$; & 214 & $(C)$ & 167 & $100+13$ & 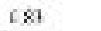 \\
\hline & $2 \cdots 2$ & 3120 & $\theta=0$ & $14,-2$ & g.0s & $\$ 2013$ & 522 & & when & 0.12 \\
\hline & $24-2$ & 343 & ust & 13.3 & 4.04 & 21.52 & cIs & & $1000 \mathrm{~s}$ & {$[R]$} \\
\hline & 20.3 & 473 & 06 & $18: 6$ & 3.14 & 33.76 & $f: 2$ & 85 & 10089 & 60 \\
\hline \multirow[t]{9}{*}{$4 \cdot 2 \cdot 34-57$} & $1-2$ & at .04 & was & 14.2 & 2.38 & 30.4 & ts: & $(x)$ & 100.12: & c.7 \\
\hline & $4-1$ & st $\approx 2$ & $a, 2$ & 18.1? & 2.es & э1. & III & {$[C 2$} & lowec & 6.77 \\
\hline & 3.2 & 1954 & 0.4 & 1600 & 206 & 31.26 & 615 & 851 & $100.4 t$ & $6 x$ \\
\hline & $\mid 1-1$ & $15 \%$ & $6: 4$ & $16 \pi$ & Iat & 3157 & tret & exz & $100 \mathrm{~m}$ & [A \\
\hline & $15-2$ & (2) 12 & $\omega x$ & $16 . x$ & 2.10 & 723 & [f] & & 100.15 & {$[.86]$} \\
\hline & 12.4 & $1+16$ & $6 . x$ & $16 .<4$ & zai & 317 & $6: 5$ & $\{6\}$ & 10053 & $\{8)$ \\
\hline & $14 *-1$ & 4961 & usi & 1601 & 2000 & 31.94 & [I] & try & 10120 & txa \\
\hline & $17 x$ & 5231 & 071 & 163 & 225 & $31 \mathrm{~W}$ & c SE & 661 & 10075 & $c ; s$ \\
\hline & 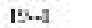 & 28,61 & was & 14.74 & 2.44 & sen & tS: & c.su & loose & c.77 \\
\hline
\end{tabular}


Appendix IV. Major oside and trace ekmert conzentration of molt incluaim inside clinogyrosene and onthepynoxene from Site 296 . First four number indicates the butsou and then minexl grain.

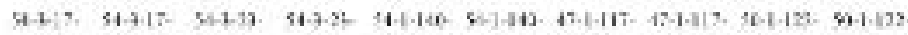

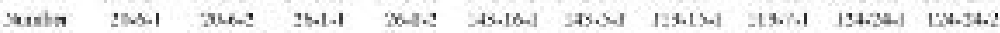
Nrorcodk

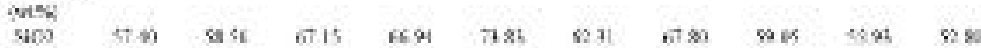

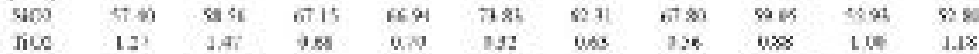

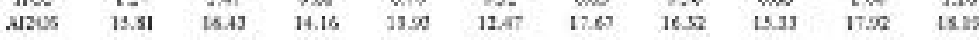

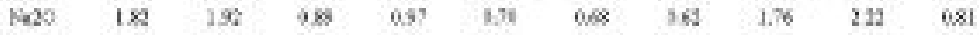

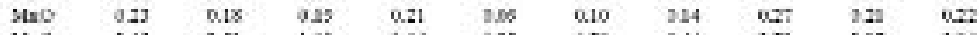

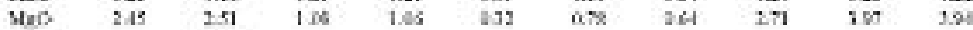

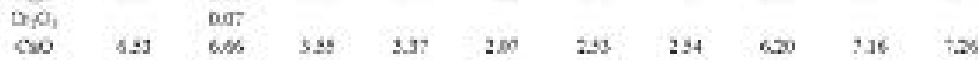

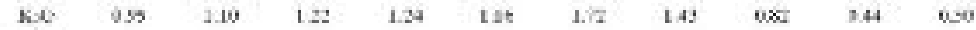

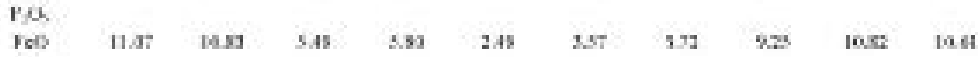

(x)

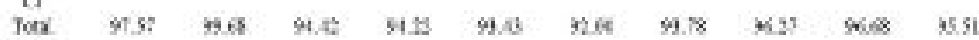

Trace

E exres:

"wn:

Sots

Tize

vat.

1560

Cals

ate

Eals:

$\operatorname{man}$

cos

Lalse

colo

tonse.

Find

sose

Y.s3

औก

$8 n 14$

ors?

Tyter

Done?

Ifoles

Yes
rote

7ы12

t.alns

\begin{tabular}{|c|c|c|}
\hline 16.36 & 31.15 & $\tan$ \\
\hline 18764 & 51.41 & $\Delta 360$ \\
\hline $2 \pi .1 \%$ & Is.as & $215 A t$ \\
\hline 2.15 & 211 & 3225 \\
\hline $4.8 t$ & 391 & 19,08 \\
\hline 1,18 & 213 & 201 \\
\hline 5181 & sis & 278 \\
\hline 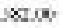 & 61.21 & 334 \\
\hline $\operatorname{sos}$ & 231 & 36 \\
\hline 1.45 & 113 & ing \\
\hline$\Delta x 1$ & 247 & 216 \\
\hline$a v$ & 260 & \\
\hline 17.54 & 244 & 3.48 \\
\hline 32.55 & $s c 5$ & 193 \\
\hline$\leq x$ & 205 & $2 x$ \\
\hline (3) & 292 & 346 \\
\hline 10.13 & 525 & 1.78 \\
\hline $116: 8$ & 4) $\theta$ & $8+10$ \\
\hline 14408 & $2 \pi$ & 1000 \\
\hline $3 x$ & 255 & 336 \\
\hline 281 & 142 & 299. \\
\hline ust & 232 & 234 \\
\hline 301 & 2.00 & 131 \\
\hline ast & 391 & 324 \\
\hline 3.11 & 227 & $15 x$ \\
\hline NGI & 246 & $2 x$ \\
\hline 1934 & $12 *$ & +89 \\
\hline 2.14 & 123 & 13 \\
\hline 807 & 147 & $1 \mathrm{in}$ \\
\hline axe & 220 & 216 \\
\hline
\end{tabular}




\begin{tabular}{|c|c|c|c|c|c|c|c|c|c|c|}
\hline Wenta & $\begin{array}{c}5 t-4-33 . \\
45-5-1\end{array}$ & $\begin{array}{c}57.3 .53 \\
-0.5 .2\end{array}$ & $\begin{array}{c}6.3 .115 \\
121.5\end{array}$ & $\begin{array}{l}01.2 .18 \\
11-12-1\end{array}$ & $\begin{array}{l}61-2-35 . \\
0-11-2\end{array}$ & $\begin{array}{l}6 \cdot 2 \cdot 58 \\
12-21-1\end{array}$ & $\begin{array}{l}51-2-36 . \\
0-17.1\end{array}$ & $\begin{array}{l}5 \leq 1-115 . \\
212-22\end{array}$ & $\begin{array}{l}51-1-39 . \\
-1-32 \cdot 4\end{array}$ & $\begin{array}{l}6.1-342 \\
12 \cdot 22 \cdot 2\end{array}$ \\
\hline \multicolumn{11}{|c|}{ 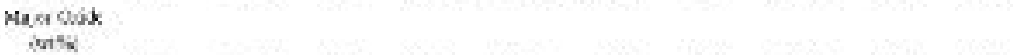 } \\
\hline $\operatorname{sic} x$ & 60.57 & x.12 & $t 00 \mathrm{~d}$ & 5ss? & 6ats & 4.8 & 5.85 & 21.26 & 40.57 & 57.2) \\
\hline$n \propto a$ & a.js & a:il & a. & o.ses & Q42 & 0.51 & 292 & man & 2.41 & neo \\
\hline AnOA & inse & 1640 & $18: 4$ & 1575 & 1697 & $5 \%$ & 1151 & $11 \mathrm{H}$ & 1452 & 158 \\
\hline $\mathrm{Na2} \mathrm{O}$ & 0.68 & 661 & 181 & $1 . n$ & 1.63 & 0.53 & 187 & 201 & 385 & 1.00 \\
\hline $\sin 0$ & 0.56 & a.10 & a.st & 0.16 & a., & a.15 & $2 k$ & a.10 & 2.13 & 0.10 \\
\hline $\mathrm{H}_{2} \mathrm{OH}$ & 936 & ess & ass & Dat & 245 & 0.53 & 92 & $0 \times 0$ & , 38 & was \\
\hline$x_{0} \times 0_{1}$ & $a k$ & & & & & ex? & 36 & $6 \bar{c}$ & & 607 \\
\hline $\cos$ & 151 & 1.7 & 369 & 1.10 & 1.87 & 257 & 177 & 1.72 & 223 & 2.15 \\
\hline$k_{2} \Omega$ & 167 & $16 t$ & ass & 204 & 1.51 & 1.39 & 212 & 2.27 & 283 & 200 \\
\hline $\mathrm{PMO}_{3}$ & & & 917 & oas & 967 & 021 & 217 & 000 & 23 & 605 \\
\hline res & 2.64 & 3.54 & 425 & $1.2 \mathrm{x}$ & sig & ..32 & 135 & 3.10 & $3 n$ & 2.95 \\
\hline $5 \mathrm{O}_{i}$ & & & 2.66 & cos & ans & ass & 260 & ons & 200 & 001 \\
\hline ct & & & 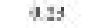 & 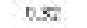 & $2 s$ & 0,00 & 123 & nes & 3.41 & 600 \\
\hline Tota. & 52.31 & $\mu \mathrm{Jt}$ & 51.12 & 3522 & $8=0$ & 54.10 & 2x.01 & $x .45$ & $20 \times 5$ & $x .95$ \\
\hline Trese & & & & & & & & & & \\
\hline \multicolumn{11}{|l|}{$\begin{array}{l}\text { Eoteris } \\
\text { Jen? }\end{array}$} \\
\hline 80.45 & 13.21 & & & 2351 & & & 1478 & is $\mathrm{nt}$ & & \\
\hline Tim & $4 x$ & & & 15s5 & & & $10.7 x$ & lass.3t & & \\
\hline Vsi. & $11 \%$ & & & 6.11 & & & if 4 ? & $1+8$ & & \\
\hline ar: & 934 & & & t. 2 & & & 49 & $1.2 i$ & & \\
\hline Nos & 034 & & & 0.26 & & & 591 & 13.52 & & \\
\hline csis & $9 \alpha$ & & & $\cos$ & & & 362 & 018 & & \\
\hline 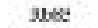 & נ2:3 & & & 234 & & & tel & $1-5 x$ & & \\
\hline $\mathrm{n}_{31}:$ & f\&s & & & 22,44 & & & nsi & $|n \in 5|$ & & \\
\hline $\mathrm{T} 2 \%$ & 9.36 & & & 0.18 & & & $2 n$ & 077 & & \\
\hline $0 \pm 28$ & $9 \varepsilon$ & & & cuss & & & 204 & 623 & & \\
\hline sas: & 9 & & & 0.51 & & & 212 & aาo & & \\
\hline 7 |si & 96 & & & 601 & & & 200 & $60 t$ & & \\
\hline Lalw & 125 & & & 1.25 & & & 391 & 4.11 & & \\
\hline caln & 434 & & & $1 \%$ & & & 154 & 975 & & \\
\hline itose & tes & & & tes & & & $12 z$ & 196 & & \\
\hline $\mathrm{r}$ ratt & $0 . \pi$ & & & 0.53 & & & 227 & 138 & & \\
\hline Mule is & 362 & & & 181 & & & 155 & 657 & & \\
\hline ross & $3 x$ & & & 1453 & & & 958 & suss & & \\
\hline zros & $5 A^{7}$ & & & las? & & & 566 & 5621 & & \\
\hline Fn 78 & 9.17 & & & 09 & & & 39 & 1.86 & & \\
\hline $3 n 14$ י & 1.97 & & & 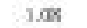 & & & 194 & 2.22 & & \\
\hline nales & ade & & & 0.22 & & & 215 & asc & & \\
\hline res? & 130 & & & 145 & & & 28 & 160 & & \\
\hline Thlys & ת & & & 0.2 & & & 113 & 631 & & \\
\hline Dge65 & 145 & & & 361 & & & 265 & 1.24 & & \\
\hline Hoses & 925 & & & 6.51 & & & 313 & uss & & \\
\hline vas & 725 & & & sos & & & 5.12 & $2 x y$ & & \\
\hline Driec & 981 & & & Q.x & & & 26 & 2.30 & & \\
\hline zbev? & 0.4 & & & 000 & & & iss & 288 & & \\
\hline Lat? & $9 x$ & & & c.15 & & & 30 & $t=8$ & & \\
\hline
\end{tabular}




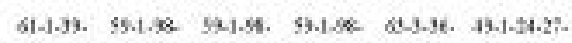

\begin{tabular}{|c|c|c|c|c|c|c|}
\hline Nenter & $41-21.3$ & $200-10$ & $20 t \cdot 1+-1$ & $100-14 \cdot 2$ & $35 \cdot 23$ & 2 \\
\hline \multicolumn{7}{|l|}{ 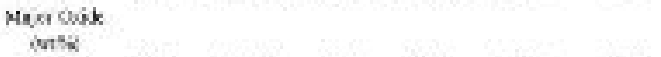 } \\
\hline siog & $e x, \pi z$ & 25.13 & se.7s & res & 2x.18 & $4+344$ \\
\hline$n \propto a$ & 034 & 13 & 050 & 0.76 & a.ss & 1.4 \\
\hline $\mathrm{ADOA}$ & 1325 & 1432 & $1<81$ & $15 \mathrm{ws}$ & 1537 & 1521 \\
\hline $\mathrm{N}_{2} \mathrm{O}$ & tit & 1.50 & 259 & 2.8 & 2.58 & 3.5 \\
\hline $\operatorname{sen} 0$ & 0.12 & 0.17 & 9.15 & 0.19 & a.11 & ats \\
\hline $\mathrm{SHO}_{\mathrm{O}}$ & $0 \leq 3$ & $2 x i$ & 15) & 1.86 & 3.34 & $a * L$ \\
\hline$x_{1}$ & 965 & & 96 & oves & & \\
\hline cos & 2.12 & 727 & 5.44 & 9.78 & $7+4$ & 12.16 \\
\hline $\mathrm{K}_{2} \mathrm{O}$ & 152 & 3.16 & int & 1.00 & atr & 1.63 \\
\hline $\mathrm{P}_{2} \mathrm{O}_{3}$ & 916 & ale & 942 & $0 \geqslant$ & 925 & \\
\hline $\mathrm{reO}$ & 3.45 & 11.13 & 739 & $T 34$ & 3.65 & 10.11 \\
\hline $50_{j}$ & 96 & 0.19 & a. & 6.14 & a.s & 922 \\
\hline ca & 0.35 & 0.16 & $92 t$ & 0.18 & ant & \\
\hline Tots. & 91.19 & 25.15 & 9.24 & Y...13 & $\operatorname{ses}$ & 5600 \\
\hline Trast & & & & & & \\
\hline \multicolumn{7}{|l|}{$\begin{array}{l}\text { Laveis } \\
\text { trent }\end{array}$} \\
\hline 845 & & & $14: 3$ & & & 12661 \\
\hline $\operatorname{Tin}$ & & & 1:eass & & & 13080.13 \\
\hline Vst & & & 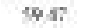 & & & 77859 \\
\hline ayz & & & $2 \times s$ & & & 4hass \\
\hline Mes & & & 432 & & & 111.75 \\
\hline Csis & & & 9.4 & & & a.t6 \\
\hline Hes & & & 300 & & & $4: 2$ \\
\hline Bal: & & & ta. $x$ & & & to:3 \\
\hline $\mathrm{T} 22 \%$ & & & 935 & & & 921 \\
\hline $0+28$ & & & ast & & & ant \\
\hline sans & & & $a x$ & & & a.st \\
\hline 7781 & & & & & & 044 \\
\hline Lalse & & & 2.42 & & & 232 \\
\hline cln & & & 431 & & & 667 \\
\hline Itwere & & & 0.35 & & & 143 \\
\hline $\mathrm{r}$ rat & & & $9 . \pi$ & & & Let \\
\hline Moe is & & & 39 & & & 5.47 \\
\hline ross & & & 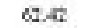 & & & 2433 \\
\hline $7 \mathrm{rns}$ & & & 22.07 & & & 3180 \\
\hline Hn $x$ & & & 987 & & & $1=1$ \\
\hline Bnil47. & & & 125 & & & 155 \\
\hline nalss & & & ינם & & & 0.4 \\
\hline Gas? & & & $9 \mathrm{w}$ & & & 266 \\
\hline These & & & a.) & & & (23). \\
\hline Dyens & & & 145 & & & 267 \\
\hline Hedes & & & 9.2 & & & ast \\
\hline$\gamma / 5$ & & & $3: 4$ & & & $14-38$ \\
\hline Diec & & & 955 & & & 16! \\
\hline xbst2 & & & 139 & & & LSS \\
\hline Lat 75 & & & 9.s & & & 924 \\
\hline
\end{tabular}


Appendis V. Major nxids and troce element eonesutration of amphiboles frotu Site 2NG.

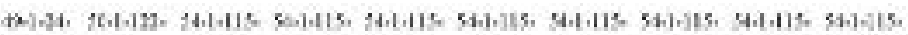

\begin{tabular}{|c|c|c|c|c|c|c|c|c|c|c|}
\hline $\begin{array}{l}\text { No. } \\
\text { Nrin } \\
\text { asid } \\
\text { intal }\end{array}$ & $27-12 \cdots 2$ & $134-5$ & $112-1+t$ & $223 \cdot 2-2$ & $11963+2$ & $\therefore 13.13$ & $115 \cdot 34$ & $11 x-1$ & $115 \cdot 15-1$ & $212-12$. \\
\hline sios & siget & 4593 & sest & $4+x^{3}$ & Ai.ts & 40,16 & $\neq 31$ & 445 & ثx혀 & 2539 \\
\hline no: & $a x$ & 600 & 12 & 2.17 & 133 & we1 & 1.22 & $2 x t$ & 217 & $1: 2$ \\
\hline$A_{3} O_{3}$ & 528 & 7,4 & $12 A$ & 569 & 722 & 113 & 153 & $7: 5$ & $12: 13$ & $33 \mathrm{AE}$ \\
\hline $\mathrm{Na}: \mathrm{O}$ & I.ss & 1.6 & 232 & LAS & 153 & 150 & $2: 3$ & 165 & $2 *$ & 2004 \\
\hline Mno & ast & $a x$ & $a n$ & 6.12 & 253 & colt & 255 & [as & axt & $60 \%$ \\
\hline$x+20$ & HASO & 19.10 & $1: 0$ & 1.72 & $14 . M$ & 11.70 & $1: \varepsilon a$ & $: 263$ & $1: 4$ & 12.50 \\
\hline $\mathrm{K} A \mathrm{O}$ & 029 & & 032 & E.14 & 325 & & & 6.96 & $0 x$ & 131 \\
\hline trov, & & & & & & & & cxs & 02 & out \\
\hline$\infty$ & 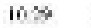 & 1356 & $\| \$$ & $6.7)$ & $19: 8$ & 1394 & $11 \div$ & 1252 & $11 \div 0$ & $1: 91$ \\
\hline Noo & $1: .28$ & 1438 & $126 \%$ & 2393 & $12, x$ & $12 \div 8$ & $15+1$ & 1256 & $12.1 \%$ & 1926 \\
\hline Tal & $\$ .57$ & s.33 & $962 x$ & 5785 & 27. 7 & nis & 2712 & 5552 & $x: 3$ & 6.7t \\
\hline$x_{6 t}$ & $\omega .10$ & 0.18 & 65.78 & $655 ?$ & s. 28 & $6: 2$ & st ts & 5565 & $\cos 26$ & 625 \\
\hline J & $74 C .42$ & 63.73 & $\operatorname{sen} x$ & $\operatorname{s:252}$ & 20004 & $525: 5$ & 5222 & 585.57 & 3ax & $54: 3$ \\
\hline Nol & 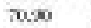 & 73.04 & $\operatorname{sia} 6$ & $1 \geq 25$ & $2 x$ & 2957 & 2053 & 754 & 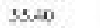 & 54.49 \\
\hline \multicolumn{11}{|l|}{$\begin{array}{l}\text { Zne } \\
\text { skased. }\end{array}$} \\
\hline Sots & $94 \approx 6$ & Ies.03 & Iखात & 22355 & si.s & esie & $113 x$ & $17 x$ & 12725 & 3200 \\
\hline nas & Ilenss & 1627520 & 1722500 & ::20045 & 2576.30 & $12 \% .25$ & lower is & $: 7211.97$ & 1stel es & $122 \% .17$ \\
\hline $\mathrm{Ni}$ & 24700 & $178 \mathrm{st}$ & $681 \pi$ & 5. 23 & W\| & 65 & 12501 & $5+25$ & woll & 5606 \\
\hline$\infty 2$ & 12.58 & 4.8 & Giso & $3: 53$ & $|u x\rangle$ & $\therefore$ & $5: 1$ & $\therefore 35$ & $\triangle 19$ & 6.48 \\
\hline$x=0$ & 5,17 & $6 \pi$ & $\cos 0$ & יניג & 253 & sest & 3930 & 2355 & 25.94 & 8.76 \\
\hline kuss & $a \times 2$ & us & 29 & $2 \theta$ & 334 & 804 & $2+3$ & 492 & 031 & 724 \\
\hline Inayr & T. 14 & $25 \leq t$ & 1Xe:T & $4: 5:$ & 2x.3s & eds ts & 2xaz & 257.93 & 슬 & 22123 \\
\hline nusiz & 220 & 0.11 & ass & c.1 & 937 & 0.18 & $3: 2$ & 131 & $0 \mathrm{~s}$ & ail \\
\hline t23s & $a>2$ & wod & 031 & $t \omega$ & 332 & wid & 34 & (3) & 631 & 601 \\
\hline Cass & ald & 601 & 13 & $c s$ & 322 & 601 & $a c 3$ & cIS & asz & 600 \\
\hline krwa & 27 & $18 i$ & $\hat{2} \mathrm{at}$ & $1 i c$ & 321 & 5.18 & Sili & $15] 2$ & $a 5$ & 150 \\
\hline $\tan$. & 019 & wes & 05 ? & ten & 311 & 6.18 & ats & CAS & uts & 6.14 \\
\hline 1.ง1ร & $x, 7$ & 13.7 & 250 & 636 & 335 & 631 & 2317 & $55>5$ & 237 & 636 \\
\hline Selut & 175.14 & 5313 & $a n$ & 336 & $351 ;$ & 17 & $10: 28$ & 270 & 75 & 37i \\
\hline Hass & ay & $\operatorname{cis} 8$ & 021 & tat & 315 & 1.12 & $3 \times y$ & 292 & 025 & 184 \\
\hline 7141 & 24.38 & If 37 & 233 & 404 & 553 & 416 & 1657 & 2553 & 153 & 4.19 \\
\hline Xi146 & 11.18 & 635 & $(1, a)$ & 2364 & sail & 12.48 & si: 3 ? & $35 \& 3$ & 985 & I. $A 2$ \\
\hline s.5s & 3.34 & 25.0 & 24.10 & 2515 & 4.11 & 435 II & 585 & 711 & נב.ב4 & $455 \geq 1$ \\
\hline 7800 & -4.71 & 653 & $2 \pi$ & 1532 & Silo & $f(\mathrm{~cm}$ & 1:als & 12216 & $5: 21$ & 4132 \\
\hline HA 11 & 1.33 & 2.11 & 115 & 18 & 244 & 184 & 543 & 4.7 & 1.86 & 150 \\
\hline 'rals' & 2.22 & 12.50 & $x \geqslant 1$ & גני & 1272 & 214 & 2227 & :s9s & 352 & 287 \\
\hline EDis7 & $\therefore 9$ & $1 \times 8$ & 157 & 315 & 717 & $16 \%$ & 437 & 73 & 17 & 1 is \\
\hline Mist & $y \times$ & 3535 & 533 & 513 & 1535 & 34 & $x<11$ & 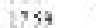 & $5 \%$ & 36 \\
\hline Tow9s & 2.32 & $\therefore 2$ & 951 & 121 & 224 & 620 & 353 & 2.13 & as: & $08 \pi$ \\
\hline $7 y 165$ & 2053 & $36 \%$ & 572 & 535 & 1524 & trs & $3 i s i$ & 1855 & 59 & 5.10 \\
\hline$\$ 0160$ & 6.14 & $\sqrt{x} \mathrm{x}$ & 12 & 192 & 324 & wev & 543 & $9 x$ & 117 & 698 \\
\hline$m$ & 163.74 & 15738 & $2 x$ & 9434 & S5: 35 & I: & {$[233]$} & 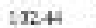 & $28 x$ & It is \\
\hline E1t 65 & 1855 & 32.12 & (3) & 5,65 & 357 & 131 & 1609 & 413 & 337 & 361 \\
\hline งulT2 & 17.29 & $1: x]$ & 2.58 & CA: & 335 & 184 & $16+5$ & 233 & 2.5 & 2.31 \\
\hline 10175 & 351 & $8 \%$ & $9 \neq 5$ & $i x$ & 117 & nss & 231 & $x$ & aจ & Dil \\
\hline
\end{tabular}




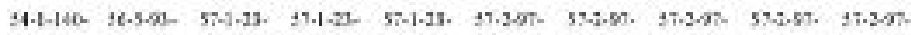

\begin{tabular}{|c|c|c|c|c|c|c|c|c|c|c|}
\hline \multicolumn{11}{|c|}{ 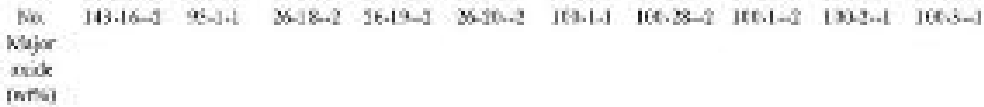 } \\
\hline ac. & 1708 & 1237 & 17is & $12+2$ & $6 \sin ^{2}$ & 1161 & $\Delta \leqslant$ & 45 is & $<a$ & AC Af \\
\hline$\pi r_{6}$ & $2 x s$ & ux: & $1.1 . \mathrm{V}$ & 1.10 & 1.51 & $5 x$ & 10 & 196 & 1.4 & $2 x+$ \\
\hline $\mathrm{Al}_{\mathrm{l}} \mathrm{O}_{3}$ & 2154 & 6.35 & 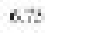 & 6.24 & $6 y 2$ & 1395 & 39 & suc & 755 & 12.46 \\
\hline $\mathrm{Ma}_{\mathrm{g}} \mathrm{a}$ & $3 \mathrm{KF}$ & 141 & 19 & 138 & is & 336 & 15 & 1.71 & 169 & 306 \\
\hline xaso & 624 & wos & 0.24 & 0.8 & $a s$ & tas & 3.43 & $w=1$ & 325 & we \\
\hline M⿻O & 2325 & IS.L4 & 1432 & 13.53 & 12.27 & :A.AS & 14.73 & $11 x 2$ & 14.44 & $13 \div 5$ \\
\hline$K_{f} a$ & $\cos \theta$ & ast & 6.24 & ais & $\alpha \geq$ & {$\left[A^{7}\right.$} & & 0.32 & 3 & $63:$ \\
\hline $\mathrm{MO}_{3}$ & & & & $60 \%$ & $a n$ & tes & & we & $3 \times 3$ & $\omega \omega 1$ \\
\hline$\infty$ & :asi & 10.12 & loss & 10.17 & 2.25 & 1102 & 1130 & ריר. & Iou & $1: \pi$ \\
\hline$\pi 00$ & ASA & 17.45 & 1439 & 1.5.5 & 16.90 & $: 237$ & 14sa & 1509 & 13.52 & $1: n$ \\
\hline Tal & SS:t & $x=15$ & $9 \times 46$ & xuss & K.17 & 55.43 & 9.79 & St.3s & $\times .15$ & 5.12 \\
\hline 3124 & $12 a$ & $5: 28$ & $6 \Omega$ & sost & seco & (9) & 8.50 & $6 \pi$ & 250 & 6.5 \\
\hline 7 & 53731 & 70113 & 78516 & 35035 & 2011 & 5130 & 873 be & \&i 28 & 58275 & $s \leqslant a$ \\
\hline $\mathrm{Mel}$ & ts $2 y$ & ress & 72.14 & 28.79 & 72.17 & S915 & was & 1232 & $\pi .13$ & 2947 \\
\hline \multicolumn{11}{|l|}{$\begin{array}{l}7 x a \\
\text { closen }\end{array}$} \\
\hline 8045 & 2104 & $92.6 \mathrm{t}$ & Twe & 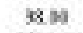 & 90.18 & 13541 & 846 & 459 & 14.39 & 1152 \\
\hline $\mathrm{Na} 3$ & $5522+4$ & 704t 56 & 71939: & ds+m & I0143i & Allsede & 2500035 & 1350en2 & $1 \times 180$ & 19134.71 \\
\hline 281 & $12: 15$ & $|x| r \mid$ & 30602 & 13. $2 a$ & $\operatorname{sen}$ & $\cos n$ & ifc.45 & 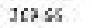 & $4: 2$ & 52572 \\
\hline$\infty 3$ & 365 & 718 & 16.4 & $\$ 48$ & $c 8$ & 6557 & 50.15 & 631 & 254 & 604 \\
\hline veb & 680 & 1.15. & ISAE & $1 \times 22$ & 2.22 & 4557 & 58 & 8.17 & 121 & 2586 \\
\hline Rass & $\cos t$ & 2.19 & 9.22 & as? & $a \pi$ & 1.3 & aes & 6s & 2.38 & atk \\
\hline Еงาว? & afs & 2569 & 5717 & to $\times 6$ & 58 & $52 \mathrm{is}$ & $517 t$ & it 11 & 6745 & $\$ 2 \%$ \\
\hline nas: & $\cos$ & $a z$ & 1.08 & wes & uss & cis & 35 & was & $3 x 5$ & wa \\
\hline טas & & $0 \%$ & 0.7 & 0.13 & 037 & $c 0$ & 2.5 & ort & $3 \mathrm{Al}$ & \\
\hline Cdss & $\mathrm{ON}$ & Q.10 & $0 x$ & w01 & an & $\mathrm{ces}$ & $3 \mathrm{tt}$ & & $\mathrm{mz}$ & \\
\hline Mt53 & 624 & 8.90 & 2.00 & 7.16 & 4.51 & c.79 & 355 & 205 & 353 & 642 \\
\hline Ta1ร! & $\cos$ & 6.19 & (1) & $\alpha: 2$ & aso & $c 00$ & ม. & Q.15 & 3 & 60 \\
\hline Laugs & C.A4 & 21.63 & IfSt & sals & 2.31 & Les & sust. & $13 \leq 2$ & $4 x 2$ & 608 \\
\hline Eelt & 235 & ross & 135.25 & $1 \operatorname{sen}$ & $2 \pi$ & c.71 & axs & $19: 2$ & 2.77 & 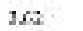 \\
\hline Ftras & $6] 7$ & 037 & 101 & $0+1$ & $a x$ & 639 & $2 A t$ & oss & 122 & 083 \\
\hline$A 141$ & (s) & Iast & 18ess & 1239 & II.AS & 1.40 & 13.79 & 800 & 182 & $6 \times 4$ \\
\hline Wilte & (5) & 7311 & $84: 3$ & 2521 & 6is: & 608 & 2136 & if 35 & 83 & $\sin 6$ \\
\hline 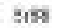 & 8159 & $2 a x$ & log. 12 & ab.45 & 5.21 & $25+31$ & $90 \times 8$ & 19354 & $3: 5 \times 9$ & Jes:25 \\
\hline $2 \mathrm{r} 90$ & 2217 & 41.53 & weet & $45+1$ & $x .28$ & :9A2 & ass & usat & 13.72 & 1930 \\
\hline un 78 & c.75 & 2.21 & 3.16 & 2.33 & 324 & {$[50$} & 273 & 328 & 312 & 674 \\
\hline Sult? & 252 & Das4 & 19.50 & $20+5$ & 19.16 & 3.16 & 1841 & 1933 & 2.9 & 261 \\
\hline nass & ixz & 2.20 & 2.57 & 2.71 & 3.52 & $: 20$ & 357 & $2 \pi t$ & 355 & 607 \\
\hline CAIST & 1.15 & 21.55 & $16 \%$ & 2535 & sus & $1 \times 0$ & 18.98 & 1553 & 233 & 3.98 \\
\hline Nouss & (52) & 1.99 & $1 / 60$ & $40 \%$ & (3) & 56 & 36 & 134 & $3 y$ & 667 \\
\hline $2 y 165$ & c.2 & $x=1$ & $17 / 5$ & 27.45 & $2 \mathrm{z} . \%$ & 4.14 & 1956 & 1925 & 295 & 436. \\
\hline ظ) & 36 & sa? & $i v$ & 56 & cs: & 680 & iat & 153 & 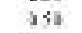 & now \\
\hline trs & 3255 & 15xis & was & 1.80 .44 & 12284 & 2933 & $103 \infty$ & (2, 4 & $12 \infty$ & $22 x$ \\
\hline Btics & 351 & 1556 & 1003 & 1655 & 13.57 & $3=0$ & 1135 & IC 3 & 1.32 & 340 \\
\hline Y⿹勹 12 & 324 & $t 2.3 t$ & jose & I: $\mathrm{H}$ & $12 A$ & 19 & 1000 & 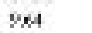 & L.4h & 2.28 \\
\hline 1ning & 6.17 & 217 & 1,20 & 2.12 & $1 . n$ & tis & 141 & 1 it & נו & 601 \\
\hline
\end{tabular}




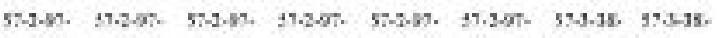

\begin{tabular}{|c|c|c|c|c|c|c|c|c|}
\hline \multicolumn{9}{|c|}{ 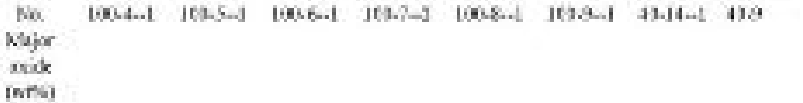 } \\
\hline $\mathrm{na}$ & 471 & $12 \mathrm{a}$ & 404 & 1165 & $\sin$ & 1151 & $\Delta<\omega$ & 4155 \\
\hline $\operatorname{mos}$ & 2.15 & 121 & t51 & 228 & 1.95 & 228 & 142 & 120 \\
\hline $\mathrm{Al}_{4} \mathrm{O}_{3}$ & 831 & cess & 1281 & Ist & 11.38 & 1134 & 722 & $8 \mathrm{sin}$ \\
\hline $\mathrm{Ma}_{6} \mathrm{~d}$ & 111 & 198 & 226 & 253 & $2: 4$ & 8.87 & 117 & 185 \\
\hline $\mathrm{Mas}$ & u.3o & was & 336 & 620 & $w 97$ & wos & 33 & 1.12 \\
\hline M⿻O & 12.24 & 13.98 & 11.61 & $23: 5$ & 12.72 & 1435 & 1327 & 14.4 \\
\hline 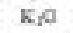 & 9.35 & ass & 3.45 & [3] & 0.5 & 009 & 235 & \\
\hline$m_{0} O_{1}$ & & & 3) & $\mathrm{Cs}$ & & $6 \omega ?$ & 3es & \\
\hline$\infty$ & $16 x$ & 10.28 & 11.78 & (1) & $11 \Leftrightarrow$ & IIII & lom & $1:$ Is \\
\hline$\pi 00$ & $1: A 1$ & $14=3$ & 12.28 & 2566 & 13.18 & 1215 & $13, \pi$ & vis \\
\hline Inal & $\alpha 20$ & sis & 92.49 & 5536 & 26.66 & 3525 & $\$ 000$ & 9.95 \\
\hline 3124 & $5 \% 0$ & 5211 & $\alpha \operatorname{ses}$ & 6253 & a.s & 574 & sase & 73.45 \\
\hline 7 & $81) 35$ & $97: 21$ & $1916 \%$ & $s \%)$ \&s & As it & 1607 * & 8036 & $5 x 572$ \\
\hline Mel & 71.94 & 21.58 & $\therefore 2,4 Z$ & $3 \in$ & 5046 & 6337 & 72.13 & 0552 \\
\hline \multicolumn{9}{|l|}{$\begin{array}{l}7 x a \\
\text { chosed }\end{array}$} \\
\hline 3045 & 115.71 & 32.48 & 12737 & 251.53 & $145 \pm 2$ & 15.64 & sols? & $87.3 t$ \\
\hline $\mathrm{Na} 3$ & Iatses & 127224 & 1273589 & $252+2.55$ & 1:721.5s & zsste.78 & $121 x+9$ & 13256.04 \\
\hline 281 & xess & 213.42 & $\operatorname{sinss}$ & 1S1.25 & 24.75 & 7135: & 155.46 & 3635 \\
\hline$\infty 3$ & 323 & 338 & 337 & (3) & $2 \theta_{2}$ & 31152 & 350 & $T, x$ \\
\hline xeb & MSI & 1563 & 13.21 & 2153 & 11.50 & 115.54 & 755 & 1233 \\
\hline Rass & 057 & 167 & 124 & [5] & $a n s$ & 02 & 251 & 1.55 \\
\hline Еงาว? & wos & $7 w$ & 11514 & 7269 & aill & $7 \mathrm{itd}$ & 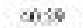 & 19281 \\
\hline Nas? & v21 & wis & 3 & $\operatorname{ts} 8$ & $\omega r_{2}$ & we & 345 & 120 \\
\hline b.75 & 037 & 0.16 & Ias & CII & & & 369 & 63) \\
\hline cxss & $a x$ & Q.jo & & ExI & 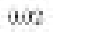 & $w e$ & 36 & 66 \\
\hline Mt53 & 25 & $\therefore .19$ & ass & tad & was & $0 \leq 7$ & 579 & x.13 \\
\hline Ta:ร! & als & 0.19 & an & [ג] & ans & 601 & 329 & 003 \\
\hline Lxiss & 11,00 & 2o.ts & 211 & 25.4 & 1,25 & $1 \pm 1$ & \$6.19 & 15.44 \\
\hline ELUt & Wal & nss: & sas & ssca & 821 & 4,70 & min & gass \\
\hline Ptyas & 917 & $34 \%$ & 293 & 615 & 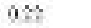 & 0.19 & 394 & 17 \\
\hline A141 & ZAR & 15.52 & L.A6 & :349 & 1.25 & 1.14 & $18 \pi 0$ & 14.43 \\
\hline Wilte & $4+4$ & $92 \mathrm{k}$ & 257 & 675 & 871 & gre & 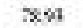 & 7352 \\
\hline 298 & 90.11 & St.2s & 251.04 & 5151 & 2990 & $1: 8: 86$ & 4.13 & yoss \\
\hline $2 n 50$ & 7..34 & 52.22 & 1527 & 5395 & 19.0 & 2116 & 430 & $\operatorname{lts} 52$ \\
\hline un 75 & 231 & 261 & 130 & 130 & $\alpha x$ & 000 & 272 & 437 \\
\hline Ent4? & 12.20 & 1933 & 355 & 2316 & $(6)$ & 266 & 1940 & 1552 \\
\hline nass & 3.31 & 235 & 113 & 4:2 & I.35 & 1,41 & $39 t$ & 4.12 \\
\hline CAIST & 1600 & 21.13 & די4 & 2755 & 531 & 8.16 & 2139 & 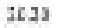 \\
\hline Touss & 285 & $2 \pm 4$ & 356 & $3: 5$ & 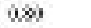 & 095 & 332 & 2.20 \\
\hline $2 y 165$ & 17.5 & 2245 & AA2 & 2531 & $3 x_{i}$ & $\cos$ & $21 . \%$ & $1: 28$ \\
\hline Fies & 35 & 470 & ats & SIf & 131 & $1: 5$ & 156 & I If \\
\hline ysy & 34.97 & $126 / 24$ & 12.16 & 23255 & $2 \times 9$ & s) 35 & 12139 & $1: 3 y ?$ \\
\hline Bri 65 & $\ln x$ & 1434 & 216 & 539 & 3.45 & 340 & 1362 & 13.15 \\
\hline $361 / 2$ & 231 & 1259 & 15: & 2313 & $z=2$ & 5.4 ? & 12.7 & 1259 \\
\hline $11 \mathrm{ing}$ & $1 \%$ & 2.16 & $32 c$ & 55 & a:? & d: & 201 & 1.77 \\
\hline
\end{tabular}




\title{
4 MAGMATIC EVOLUTION OF THE EARLY NORTHERN IZU-BONIN MARIANA ARC FROM SITE 1438 AND SITE 296 ROCKS AND MINERALS: A COMPARATIVE STUDY
}

\author{
Eshita Samajpati, Rosemary Hickey-Vargas
}

\begin{abstract}
Evolution of island arcs has always been an important topic to understand arc building and formation of the continental crust. However, the initial arc stages which are crucial to understand these processes has always been challenging to study because of the lack of volcanic records. The Izu-Bonin Mariana (IBM) arc and its rifted remnant arcs thus present an opportunity to explore early arc evolution. IODP Site 1438 and DSDP Site 296 which contains contemporaneous volcanic debris from the first remnant arc of IBM, Kyushu Palau Ridge (KPR), records the early magmatic history in the form of volcanic minerals, glass and lithic fragments. Major oxide, trace elements, and ${ }^{143} \mathrm{Nd} /{ }^{144} \mathrm{Nd}$ and ${ }^{176} \mathrm{Hf} /{ }^{177} \mathrm{Hf}$ isotope ratios reveal a significant piece of this information which is also used to compare the two sites. Lithic fragments or clasts from both the Sites indicate an Indian-type MORB origin, although higher variation in $\mathrm{Nd}$ isotope ratios is observed within Site 296 clasts in the late stages perhaps due to mixing of Pacific sediments. The mantle source becomes more enriched towards the last stages of arc evolution, evidenced by $\mathrm{Nd}$ isotope ratios of Site 296 clasts at high $\mathrm{La} / \mathrm{Sm}_{\mathrm{N}}(3.7-4.8)$ and $\mathrm{Nb} / \mathrm{Yb}(2-4)$ ratios, and such features are not seen Site 1438 compositions which indicate a possible rifting related event which may have missed in the rear arc side. However, an enrichment in fluid mobile elements like Ba and $\mathrm{Rb}$ prior rifting is observed within the amphibole composition of Site 1438.
\end{abstract}




\subsection{Introduction}

IODP Site 1438, located in the Amami Sankaku Basin (Fig. 4-1), contains volcaniclastic sediments derived from the Kyushu Palau Ridge (KPR), a remnant of the first rifted arc of the Izu-Bonin Mariana (IBM) arc. The IBM provides a remarkable opportunity to study both active and past processes because of its unique extended nature. The volcanic and tectonic history of the IBM has been well studied and can be found in previous studies (Stern et al., 2003; Straub et al., 2010; 2015; Ishizuka et al., 2011a), although compared to the recent activities, the initial history is still being explored and comprehended. IODP Site 1438 was drilled to answer essential questions about early subduction processes, mainly arc inception and subsequent evolution of the IBM. Drilled samples from Site 1438 included the basement ocean crust and subsequent sedimentary deposits which comprises volcanic products shed from the KPR until it rifted. Site 1438 is also adjacent to another drill site, DSDP Site 296 located on the upper eastern flank of the ridge, and thus may have contemporaneous volcanic sediments (Fig. 4-2), which together can reveal some of the early evolutionary history of the IBM arc. In addition, the two Sites can also reveal any spatial differences seen between a proximal site (Site 296) and a distal site (Site 1438) and may be useful in the future when addressing questions in a similar setting. 


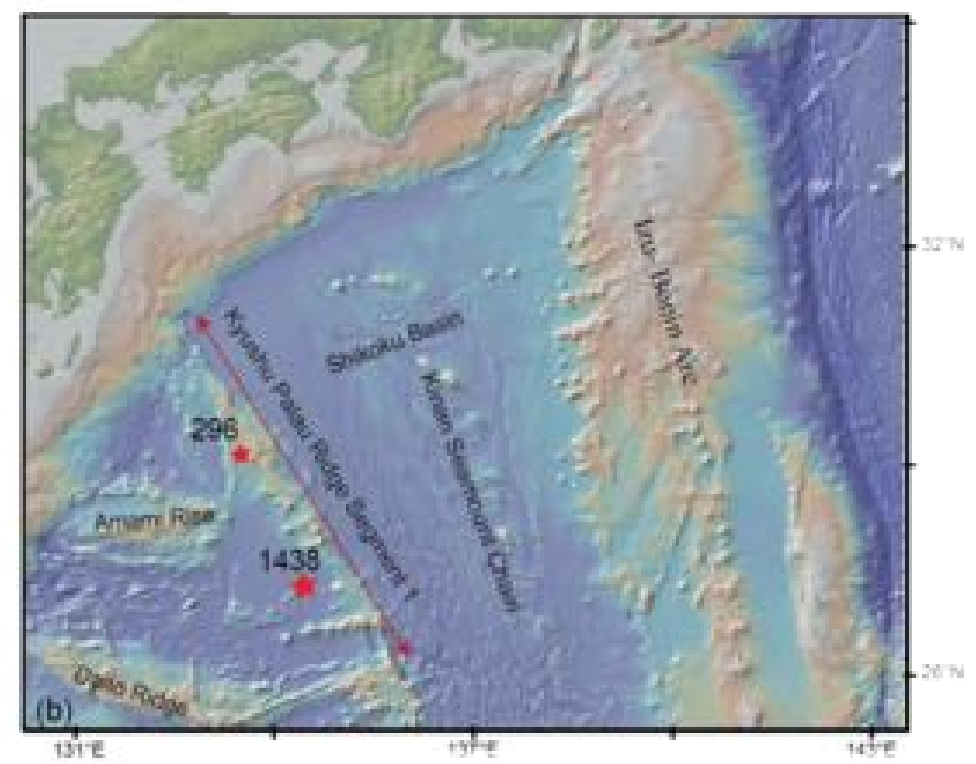

Figure 4-1Map showing the location of Site 296 and Site 1438 on KPR

The main objective of this study is to understand part of the early history of the IBM arc by comparing sediments from the two Sites, focusing mainly on the last stages of the magmatic evolution of the arc just prior rifting. For Site 1438, we present new major and trace element data for glass and mafic minerals, pyroxene and amphibole, and melt inclusions. Additionally, we also have new major, trace elements and $\mathrm{Nd}-\mathrm{Hf}$ isotope data for lithic fragments from both Site 296 and 1438. These results, together with previous data from Site 296: 1) glass and three andesite clast compositions (Samajpati and HickeyVargas, 2020a) and 2) melt compositions calculated from mafic minerals (Samajpati and Hickey-Vargas, 2020b), will be used to interpret the magmatic evolution at the northernmost section of IBM, segment 1 of Ishizuka et al. (2011b). 


\subsection{Methods}

\subsubsection{Sample description}

The drilled section from Site 1438 (Fig 4-2) was divided into four sedimentary units (Unit I-IV) and the basement igneous unit (Unit 1) (Arculus et al., 2015a). The samples studied for this research are from Unit II (Cores 21F-30X) and the upper part of Unit III (Cores 12R-30R). Six samples studied from Unit II were mostly intervals of coarse unconsolidated sediments, with silty to clayey matrices. Minerals grains were loose in the sediments, and the grain size becomes finer up the core. Unit III samples are described as either turbidites or debrites (Johnson et al., 2017) and consist mostly tuffaceous mudstone, sandstone or breccia-conglomerate containing pumice and volcanic minerals. The biostratigraphic ages of the studied core samples from Site 1438 is early to late Oligocene, same as Site 296 (Ingle et al., 1975; Arculus et al., 2015a). Samples with large mafic lithic fragments or clasts were rare.

Samples containing a representative range of large lithic fragments, pyroxenes and amphiboles were selected for further analysis. Amphiboles were quite common in the Site 1438 samples, unlike Site 296, and they become more abundant upward, especially in Unit II sections 30X-6W $(86-88 \mathrm{~cm})$ and 30X-7W $(13-15 \mathrm{~cm})$. In these core sections amphiboles were the primary mafic phenocryst in the sediments rather than pyroxenes. Twelve Site 1438 samples were lightly crushed in plastic with a hammer and then disaggregated in DI water. After drying, pyroxenes and amphiboles were picked out from the samples and set in epoxy for chemical analysis. 
Lithic fragments from Unit III, Site 1438, and Unit 2, Site 296 were cut from slabs using a small rock saw, then the outer layer was ground away using a grit paper followed by washing and ultrasonication in DI water. Samples were then dried and powdered for further analysis. Fifteen lithic fragments from Site 296 and 6 lithic fragments from Site 1438 were selected for the study. Out of the 21 samples, eight samples for Site 296 and four samples from Site 1438 were also analyzed for $\mathrm{Nd}$ and $\mathrm{Hf}$ isotope ratios. Also, some amphibole separates from 30X-7W (13-15) were picked for isotopic analysis.

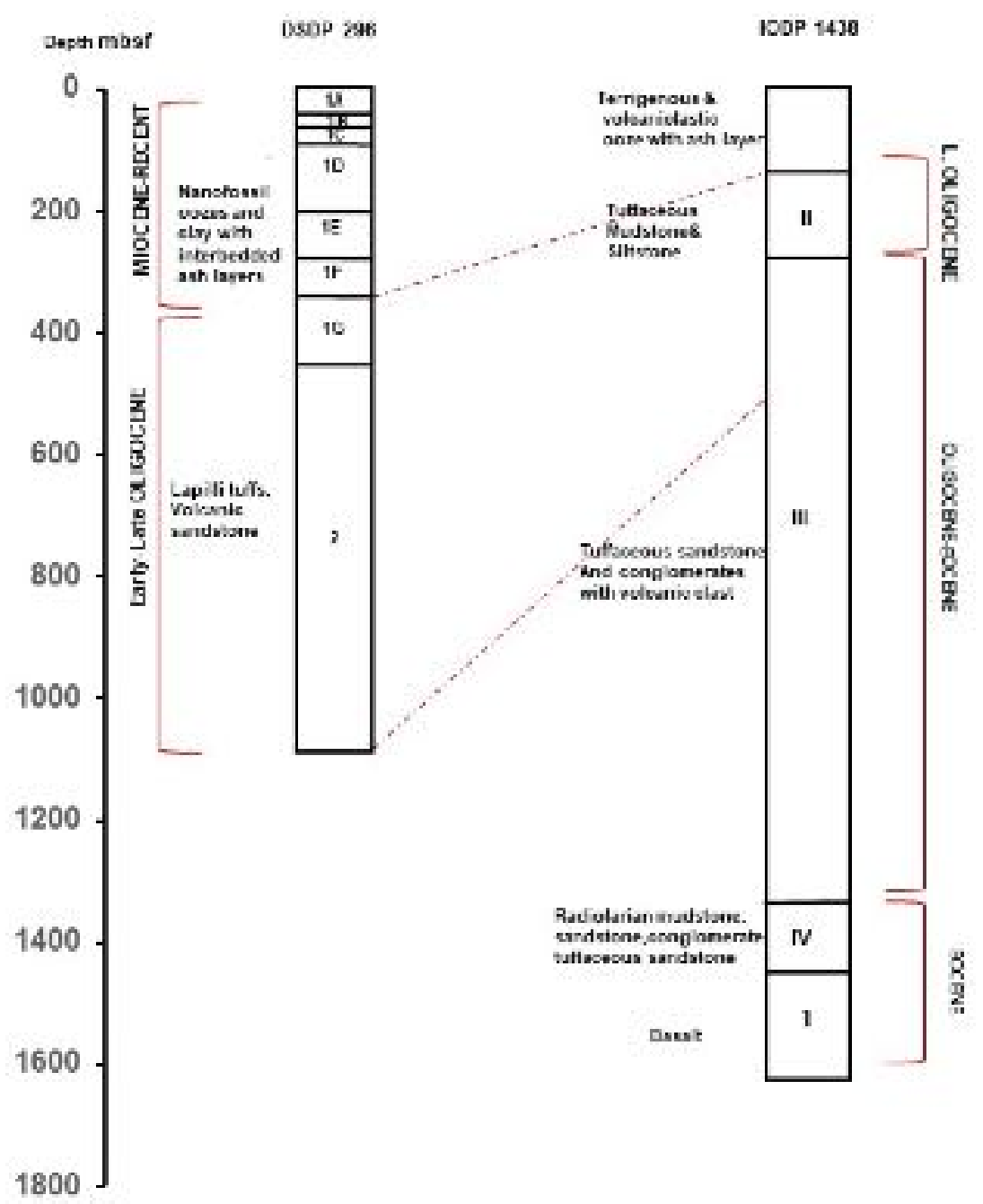

Figure 4-2 Lithostratigraphic column of Sites 296 and 1438, red dashed lines correlate to similar biostratigraphic ages and the studied section 


\subsubsection{Analytical methods}

Pyroxenes and amphiboles from Units II and III were analyzed for major elements at FCAEM, Florida International University (FIU) using a JEOL 8900R superprobe instrument. Minerals were analyzed at an accelerating voltage of $15 \mathrm{kV}$ and $20 \mathrm{nA}$ beam current using a $1 \mu \mathrm{m}$ electron beam; for melt inclusion within pyroxene, the electron beam was defocused. Major elements were measured for15-30 seconds and data were corrected using the ZAF correction method. The accuracy of measurements for major oxides was better than $5 \%$, trace elements in the minerals close to the detection limit had a higher error. Minerals were analyzed in back-scattered electron mode to reduce the possibility of analyzing inclusions; two points per grain close to the core were analyzed and averaged. Repeated analysis of standards FIU enstatite STD 350, BHVO-2 and Kaersutite (\#AS1200AB) was carried out at the beginning, middle and end of the analysis to check for data quality and account for any instrument drift.

Trace elements including rare earth elements (REEs) were analyzed by Laser Ablation ICP-MS using the Elan 6100 ICP-MS at the Trace Evidence Analysis Facility at FIU, using a New Wave $213 \mathrm{~nm}$ laser. NIST 612 was used as a calibrator and BHVO-2 as the external standard. Spot size for minerals was 80 microns, and for melt inclusions, it was 40-55 micron with a $10 \mathrm{~Hz}$ rep rate and $100 \%$ output for both. Two points per grain were analyzed for minerals; the average values are reported. The data was then processed using the software Glitter, with $\mathrm{Ca}$ as the internal standard. Melt inclusions smaller than 40 microns were not analyzed. Table 1 . lists the data quality for the trace elements. 
Table 4-1 Data quality of USGS standard BHVO-2 for trace elements using LA-ICP-MS and SI-ICP-MS methods

LA-ICP-MS (Trace elements in ppm)

$\begin{array}{ccccc}\text { Element } & \text { Mean of } 20 & \text { \%RSD } & \text { Rec value } & \text { \%bias } \\ \text { Rb85 } & 7.72 & 4.7 & 9.261 & -16.6 \\ \text { Sr88 } & 379.57 & 3.6 & 394.100 & -3.7 \\ \text { Y89 } & 24.98 & 6.1 & 25.910 & -3.5 \\ \text { Zr90 } & 146.82 & 6.4 & 171.200 & -14.2 \\ \text { Nb93 } & 17.35 & 6.2 & 18.100 & -4.1 \\ \text { Cs133 } & 0.09 & 26.8 & 0.100 & -8.5 \\ \text { Ba137 } & 112.69 & 4.5 & 130.900 & -13.9 \\ \text { La139 } & 15.80 & 8.2 & 15.200 & 3.9 \\ \text { Ce140 } & 37.25 & 6.8 & 37.530 & -0.7 \\ \text { Pr141 } & 5.09 & 6.5 & 5.339 & -4.6 \\ \text { Nd146 } & 24.75 & 4.4 & 24.270 & 2.0 \\ \text { Sm147 } & 6.03 & 9.3 & 6.023 & 0.2 \\ \text { Eu153 } & 1.94 & 6.1 & 2.043 & -4.7 \\ \text { Tb159 } & 0.89 & 11.9 & 0.939 & -4.7 \\ \text { Gd160 } & 6.27 & 7.0 & 6.207 & 1.1 \\ \text { Dy163 } & 5.44 & 8.6 & 5.280 & 3.0 \\ \text { Ho165 } & 0.97 & 11.2 & 0.989 & -1.2 \\ \text { Er166 } & 2.54 & 8.9 & 2.511 & 1.4 \\ \text { Yb172 } & 2.09 & 11.2 & 1.994 & 5.1 \\ \text { Lu175 } & 0.30 & 16.2 & 0.275 & 10.0 \\ \text { Hf178 } & 4.41 & 10.7 & 4.470 & -1.3 \\ \text { Th208 } & 1.31 & 11.8 & 1.653 & -20.2 \\ \text { Th2 } & 1.23 & 8.2 & 1.224 & 1.1 \\ \text { } 1.39 & 14.0 & 0.412 & -4.5\end{array}$

SI-ICP-MS (Trace elements in ppm)

\begin{tabular}{|c|c|c|c|c|}
\hline Element & Mean of 3 & $\% \mathrm{RSD}$ & Rec value & $\%$ bias \\
\hline Rb85 & 10.07 & 1.1 & 9.261 & 8.8 \\
\hline Sr88 & 370.44 & 3.1 & 394.100 & -6.0 \\
\hline Y89 & 27.22 & 2.3 & 25.910 & 5.1 \\
\hline Zr90 & 169.03 & 1.2 & 171.200 & -1.3 \\
\hline $\mathrm{Nb93}$ & 17.86 & 0.3 & 18.100 & -1.3 \\
\hline Cs 133 & 0.25 & 1.6 & 0.100 & 156.1 \\
\hline Ba137 & 138.82 & 0.9 & 130.900 & 6.0 \\
\hline La139 & 14.72 & 0.6 & 15.200 & -3.1 \\
\hline $\mathrm{Ce} 140$ & 36.22 & 0.9 & 37.530 & -3.5 \\
\hline Pr141 & 5.14 & 1.2 & 5.339 & -3.7 \\
\hline Nd146 & 23.49 & 2.5 & 24.270 & -3.2 \\
\hline $\mathrm{Sm} 147$ & 6.08 & 0.8 & 6.023 & 1.0 \\
\hline Eu153 & 1.72 & 1.7 & 2.043 & -15.7 \\
\hline Tb159 & 0.90 & 2.9 & 0.939 & -3.3 \\
\hline Gd160 & 6.11 & 1.9 & 6.207 & -1.5 \\
\hline Ho165 & 0.98 & 1.3 & 0.989 & -0.8 \\
\hline Dy 163 & 5.27 & 1.6 & 5.280 & -0.2 \\
\hline Er166 & 2.31 & 2.7 & 2.511 & -8.0 \\
\hline Yb172 & 1.99 & 3.2 & 1.994 & 0.1 \\
\hline Lu175 & 0.29 & 3.1 & 0.275 & 5.7 \\
\hline Hf178 & 4.06 & 2.0 & 4.470 & -9.0 \\
\hline Ta181 & 1.27 & 0.6 & 1.154 & 10.5 \\
\hline $\mathrm{Pb} 208$ & 2.56 & 1.3 & 1.653 & 55.1 \\
\hline Th232 & 1.26 & 1.4 & 1.224 & 3.6 \\
\hline U238 & 0.45 & 2.0 & 0.412 & 11.1 \\
\hline
\end{tabular}

Powdered lithic fragments $(0.2$ to $5 \mathrm{~g})$ were dissolved for major oxide and trace elements using methods described in Laxton (2016) and analyzed using solution introduction ICP-MS at FIU. Seven standards were analyzed as a measure for quality and to calculate the calibration curve. Major oxide data for standards analyzed as unknowns had percent bias less than 5 .

Analysis of $\mathrm{Nd}$ and $\mathrm{Hf}$ isotope ratios for some of the lithic fragments were carried out at the University of South Carolina using a Thermo Finnigan Neptune MC-ICP-MS, 
methods are mentioned in Yogodzinski et al. (2018). Amphibole separates from Unit II sample 30X-7F-13-15 was also analyzed for $\mathrm{Nd}$ and $\mathrm{Hf}$ isotopes. The results were normalized to the standards La Jolla for ${ }^{143} \mathrm{Nd} /{ }^{144} \mathrm{Nd}$ and JMC-457 for ${ }^{176} \mathrm{Hf} /{ }^{177} \mathrm{Hf}$. USGS standards, AGV-1 and BCR-2 analyzed as unknowns agree with published reference values of Weis et al. $(2006,2007)$ for Hf isotope ratios but are slightly high for $\mathrm{Nd}$ isotope ratios; within-run 2 sigma of the mean errors are within 0.000008 . Data for all analyses are listed in the appendices.

\subsection{Results}

\subsubsection{Pyroxene}

Both orthopyroxene and clinopyroxene are present in the samples; some of the pyroxenes had melt inclusions. Clinopyroxene (cpx) has a composition range of $\mathrm{Wo}_{38-}$ ${ }_{45} \mathrm{En}_{39-46}$ and magnesium numbers (Mg\#) of 56-85, whereas orthopyroxene (opx) was Wo1${ }_{4} \mathrm{En}_{57-69}$ and Mg\# between 58-72. Unusually high-Mg cpxs which were found in Site 296 samples are absent (Samajpati and Hickey-Vargas, 2020b). In the alumina vs. Mg\# plot for cpx (Fig. 4-3a), the alumina in cpx increases until Mg\# 80, where a high variation of alumina content is seen, and after which the alumina content seems to decrease. However, for Site 1438 cpxs this is not as apparent as in Site 296, where high-Mg\# low Al cpxs are present. Using a discrimination diagram from Leterrier et al. (1982), nearly all cpxs from Site 1438 have a tholeiitic affinity with subduction features; no calc-alkaline or MORB like cpxs are present (Fig 4-3b \& c). In comparison, cpxs from Site 296 straddle the tholeiite/calc-alkaline boundary and a few have MORB-like characteristics. 
Primitive mantle normalized trace element concentrations of cpxs is shown in Fig. 44a. All cpxs show $\mathrm{Nb}$ depletion. Low Mg\# cpxs (60-70), most likely from felsic magmas, have increasing $\mathrm{Eu}, \mathrm{Zr}$ and $\mathrm{Hf}$ depletion, probably reflecting the crystallization of plagioclase, apatite and Fe-Ti oxides. Site 1438 cpxs fall entirely within the compositional range observed within Site 296 cpxs.
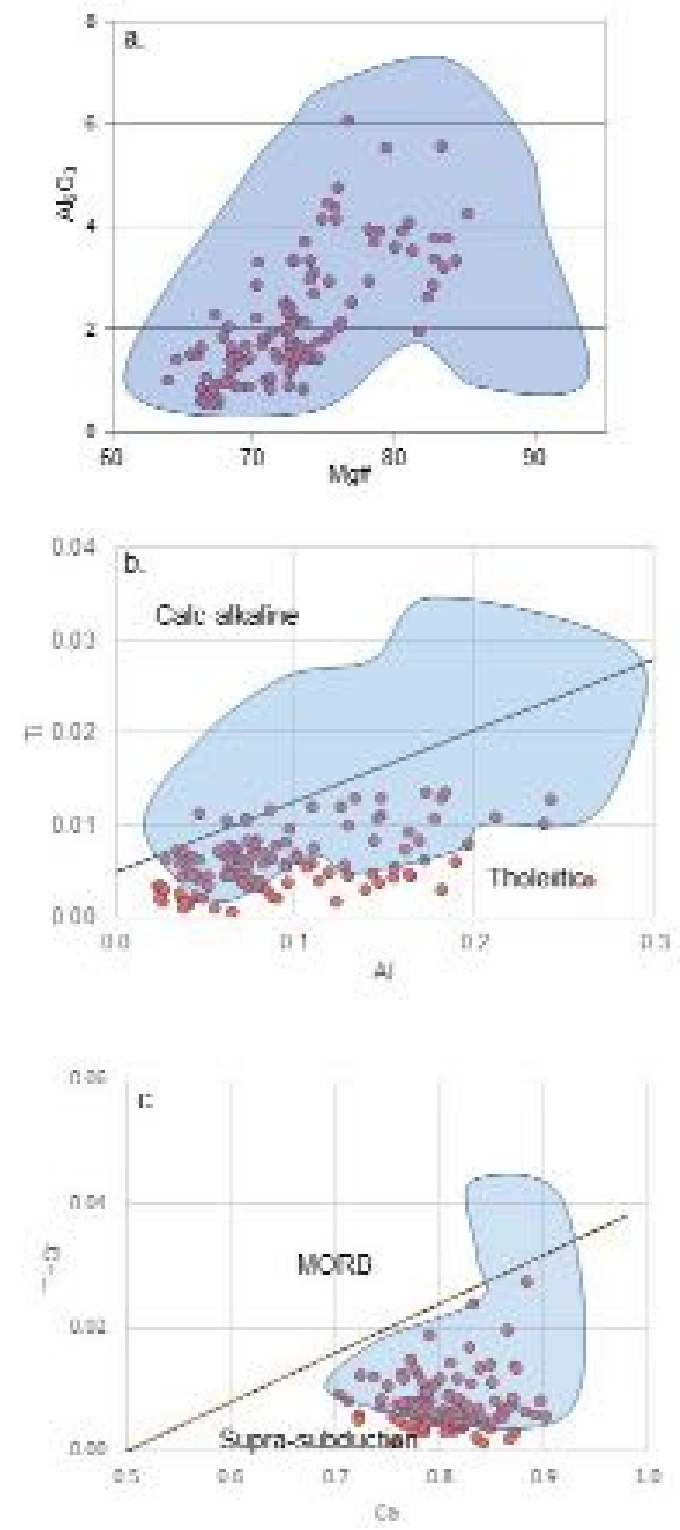

Figure 4-3 (a) $\mathrm{Mg} \#$ vs. $\mathrm{Al}_{2} \mathrm{O}_{3}(\mathrm{wt} \%$ ) of clinopyroxenes of Site 1438 , (b), \& (c) Tectonic discrimination diagram for clinopyroxenes from Leterrier et al. (1982). Elements are expressed in atoms per formula unit. The shaded region in the background shows the composition of Site 296 clinopyroxenes 

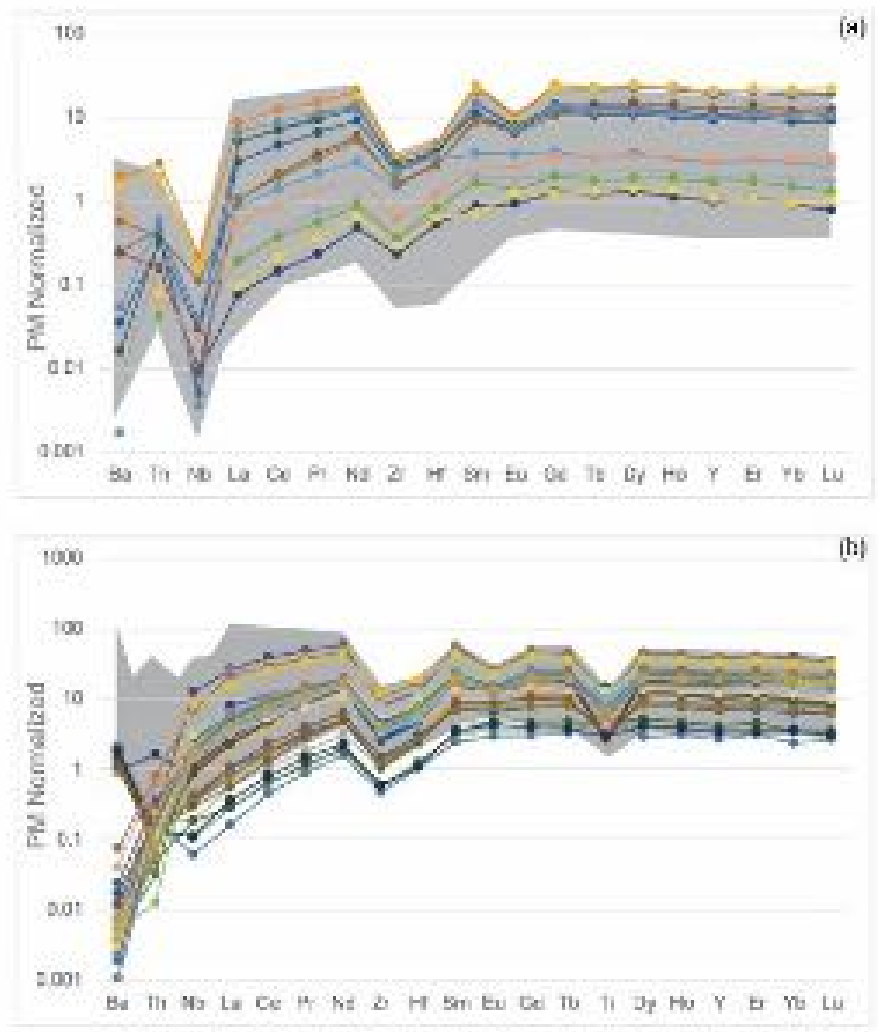

Figure 4-4 (a) Primitive mantle normalized trace element concentration of Site 1438 cpxs. Normalizing values after Sun and Mcdonough (1989) (b) Primitive mantle normalized trace element concentrations of Site 1438 amphiboles. Shaded regions are the composition of Site 296 minerals

\subsubsection{Amphibole}

Amphiboles analyzed are from both units II and III, Site 1438. According to the Leake et al. (1997) classification, the amphiboles from Site 1438 are of the varieties magnesiohornblende, edenite, tshermakite, and magnesiohastingsite. Normalized trace element abundances among the amphiboles (Fig. 4-4b) show a generally similar trace element pattern with few differences. One is variable Eu depletion and the other is $\mathrm{Ti}$ depletion and enrichment. These differences are related to magma composition; amphiboles from felsic magma will have higher overall REE concentration, with Eu and 
Ti depletion as the result of crystallization of plagioclase and Fe-Ti oxides. More mafic magma will form amphibole with low trace element concentrations and Ti peaks indicating Fe-Ti oxides did not yet saturate in the magma. A second prominent difference is the high variation in LILE elements, $\mathrm{Ba}$ and Th. Higher $\mathrm{Ba}$ and Th concentrations are seen in Unit II amphiboles. Unlike Site 296, Unit 2 amphiboles, there are no LREE, Ba, and Th enriched amphiboles in Site 1438 Units II and III. Also, Site 1438 amphiboles range to lower overall concentrations of trace elements compared with amphiboles from Site 296.

\subsubsection{Glass and Melt Inclusions}

Individual detrital glass shards were rare in Site 1438 sediments. Of the few that were found, $\mathrm{SiO}_{2}$ content ranges from 63 to $74 \mathrm{wt} \%$ and $\mathrm{Mg} \# \mathrm{~s}$ are 13 to 58 . Glassy melt inclusions enclosed in pyroxene, both cpx and opx, have $\mathrm{SiO}_{2}$ contents of 52 to $73 \mathrm{wt} \%$ and Mg\#s of 11 to 67. Among both glass shards and MIs, some andesitic and dacitic compositions show high Mg\#s. Glass shards from Site 1438 plot mainly within the low K magma series whereas the MIs plot both in low and medium K fields (Fig. 4-5a). Glass shards and MIs from Site 296 were medium $\mathrm{K}$. $\mathrm{TiO}_{2}$ contents for glass shards and MIs from both Sites are similar but high variation is observed in the $\mathrm{MgO}$ contents of MIs and glass from Site 1438 (Fig. 4-5b \& c). Broadly two groups can be seen, one is a high-MgO series ( $7.8 \mathrm{wt} \%$ in basalt to $2 \mathrm{wt} \%$ in rhyolite) and the other is low $\mathrm{MgO}$ series ( $3.4 \mathrm{wt} \%$ in basalt to $0.3 \mathrm{wt} \%$ in rhyolite).

Normalized trace element concentrations of glass shards and MIs (Fig 4-6a) show $\mathrm{Nb}$ depletion throughout a wide variation in trace element concentrations, including $\mathrm{La} / \mathrm{Sm}_{\mathrm{N}}$ values from 0.5 to 3.3. $\mathrm{Zr}$ and $\mathrm{Hf}$ concentrations also vary relative to REE, which 
may be due to crystallization of apatites, which remove REE, in intermediate to felsic magmas. The compositional range of the glass shards and MIs falls within the analyzed Site 296 melt compositions (Samajpati and Hickey-Vargas, 2020a).

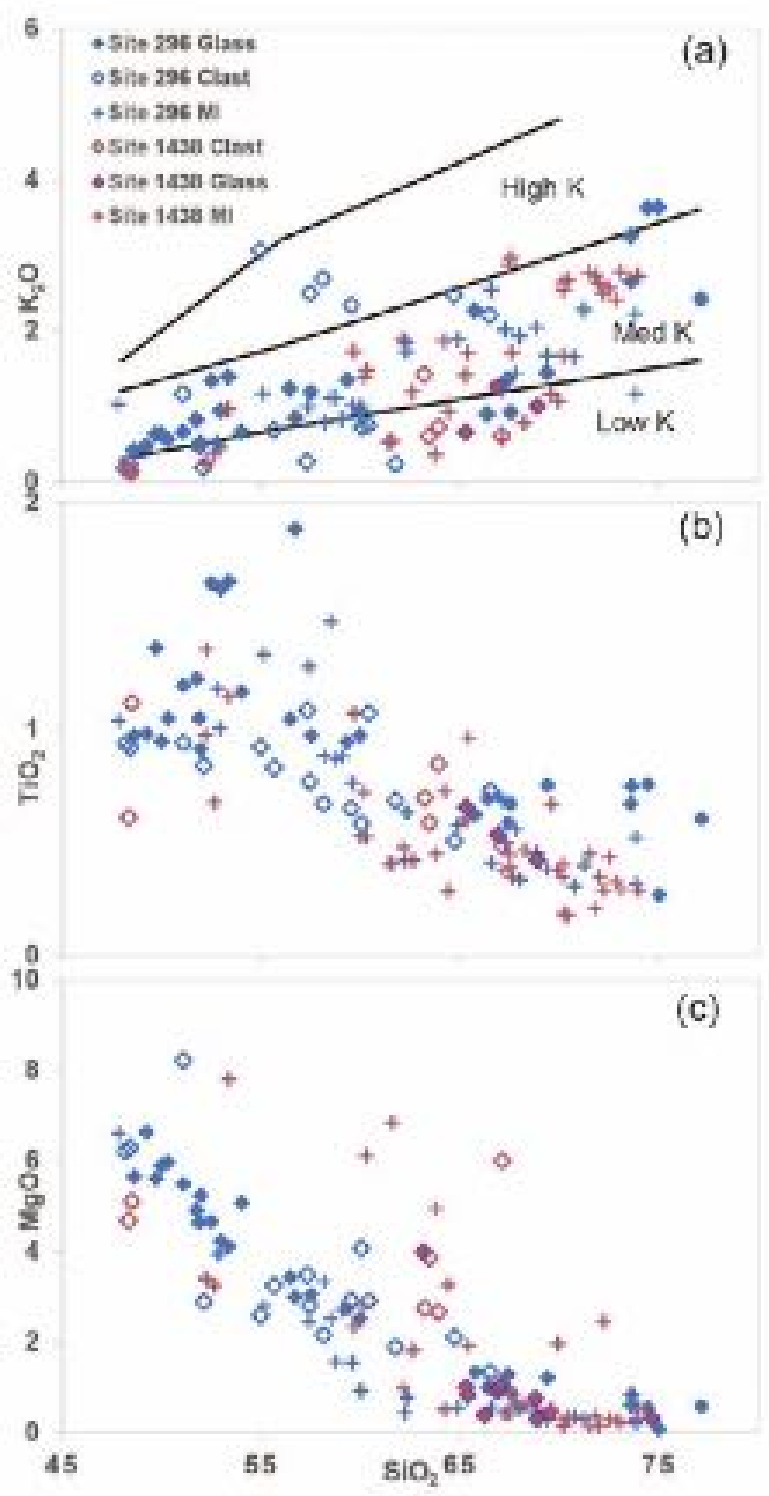

Figure 4-5 (a), (b), \& (c) $\mathrm{SiO}_{2}$ vs. other oxides (in wt\%) for glass, melt inclusion and clasts from Site 296 and Site 1438. Fields for $\mathrm{K}_{2} \mathrm{O}$ are from Peccerillo and Taylor (1976) 

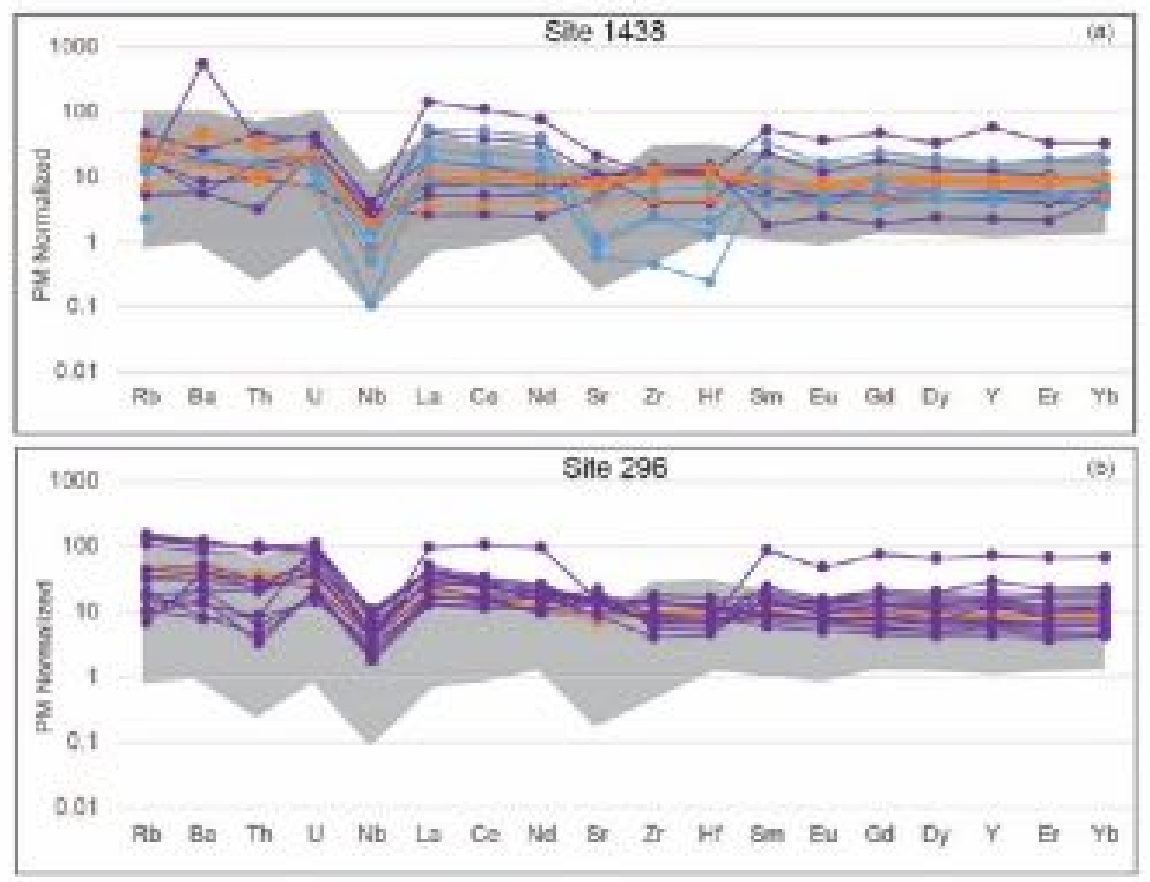

Figure 4-6 (a)Primitive mantle normalized trace element concentration of Site 1438 glass (orange), MI (blue) and clast (purple) (b) Primitive mantle normalized trace element concentration of new Site 296 glass (orange) and clast (purple). Shaded background is the composition of previously analyzed glass and clast composition from Site 296.

\subsubsection{Lithic Fragments (Clasts) from Sites 1438 and 296}

Site 296 clasts reported in this paper plot within low $\mathrm{K}$ to shoshonite fields on a $\mathrm{K}_{2} \mathrm{O}$ vs. $\mathrm{SiO}_{2}$ plot (Fig. 4-5a), whereas clasts from Site 1438 plot in low to medium $\mathrm{K}$ magma fields. Except for one high $\mathrm{MgO}$ basalt clast, most Site 296 clasts have $\mathrm{MgO}$ concentrations (6.3 to $1.3 \mathrm{wt} \%$ ) similar to previously reported glass shards and clasts (6.6 to $0.9 \mathrm{wt} \%$ ) (Samajpati and Hickey-Vargas 2020a). Site 1438 clasts have similar $\mathrm{MgO}$ contents (6.0 to $2.7 \mathrm{wt} \%$ ), except for a high-MgO dacite (Fig. 4-5c).

Normalized trace element patterns for Site 296 clasts show typical arc features, such as negative $\mathrm{Nb}$ anomalies (Fig. 4-6b) and slightly depleted to highly enriched LREE ( $\mathrm{La} / \mathrm{Sm}_{\mathrm{N}}$ values 0.6 to 4.8). In contrast, clasts from Site 1438 have flat to slightly enriched LREE (Fig. 4-6b) (La/Sm values of 1 to 2.7$)$. 
${ }^{143} \mathrm{Nd} /{ }^{144} \mathrm{Nd}$ and ${ }^{177} \mathrm{Hf} /{ }^{176} \mathrm{Hf}$ ratios measured in clasts from Site 296 and 1438 are plotted in Fig. 4-7, using epsilon notation. In the ENd vs. EHf plot, all but one clast plots within the Indian MORB field (Fig. 4-6). Site 296 clasts range to lower ${ }^{143} \mathrm{Nd} /{ }^{144} \mathrm{Nd}$ at a similar ${ }^{177} \mathrm{Hf} /{ }^{176} \mathrm{Hf}$ ratio compared with Site 1438 clasts. The amphibole separate from Site 1438 Unit II (30X-7F-13-15) had a small Hf signal, therefore, a large 2 sigma error of 0.00005.

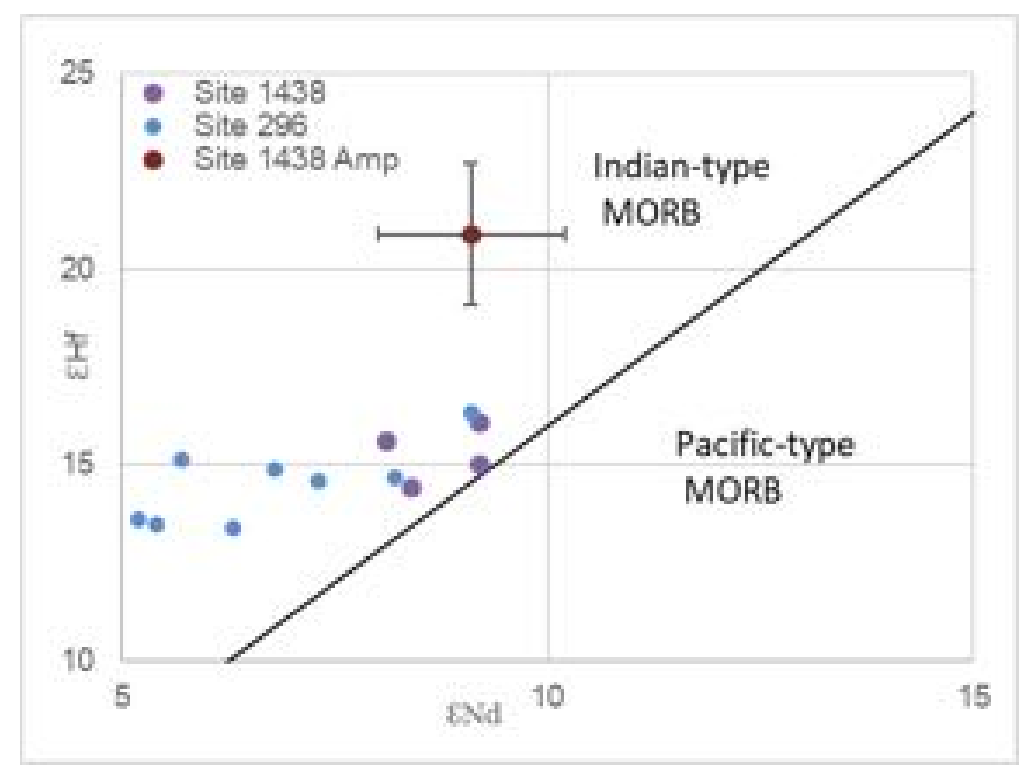

Figure 4-7 ENd vs. EHf plot for Site 296 and Site 1438 clast. CHUR values used to calculate the $\mathcal{E}$ values are from Bouvier et al. (2008), mantle line from Pearce et al. (1999)

\subsubsection{Mafic minerals of Site 1438}

Trace element abundances for melts in equilibrium with mafic clinopyroxenes were calculated using partition coefficients calculated from a Site $296 \mathrm{cpx}$ and basalt melt inclusion pair (Samajpati and Hickey-Vargas, 2020b). Clinopyroxenes with Mg\#s greater than 75 (Mg\# 45 in the liquids, Putirka et al., 2008) were used to infer equilibrium trace element contents. Normalized trace element concentration (Fig 4-8a) for the equilibrium melts have a $\mathrm{La} / \mathrm{Sm}_{\mathrm{N}}$ ratios of 0.5 to 1.7 . This composition range for the melts falls within the compositional range of inferred Site 296 melts (Fig. 4-8a). High Mg\# (88-92) cpx 
grains from Site 296, which had unusually low melt trace concentrations, are excluded from this comparison. Two Site 1438 cpx with Mg\#s 75 and 80 had normalized melt $\mathrm{Nb}$ concentrations slightly higher than La; these cpxs may have formed during rifting stage which could lead to higher $\mathrm{Nb}$ concentrations of the melt.

Using equations for temperature and melt silica content in equilibrium with amphibole from Putirka (2016), the Site 1438 amphiboles yield a crystallization temperature of 750 to $1006{ }^{\circ} \mathrm{C}$ and melt $\mathrm{SiO}_{2}$ contents 54 to $75 \mathrm{wt} \%$, although felsic melts are more common. Inferred melt compositions for these amphiboles were calculated using methods from Humphreys et al. (2019). $\mathrm{La} / \mathrm{Sm}_{\mathrm{N}}$ values for these magmas range from 0.27 to 6.78 (Fig. 4-8b). La/Sm $\mathrm{N}$ values for magmas in equilibrium with the amphibole decreases up the core such that Unit II amphiboles have $\mathrm{La} / \mathrm{Sm}_{\mathrm{N}}$ less than or close to 1 . In constrast, $\mathrm{Rb}$ concentrations are higher than unit III amphibole inferred melts from Site 1438 (Fig. 4-8b). Since Unit II amphiboles had higher Ba concentration than the Unit III amphiboles, the magmas which crystallized these amphiboles will also have higher Ba values. Melts in equilibrium with Unit III amphiboles have lower Rb concentrations but at a higher $\mathrm{La} / \mathrm{Sm}_{\mathrm{N}}$ ratio. 

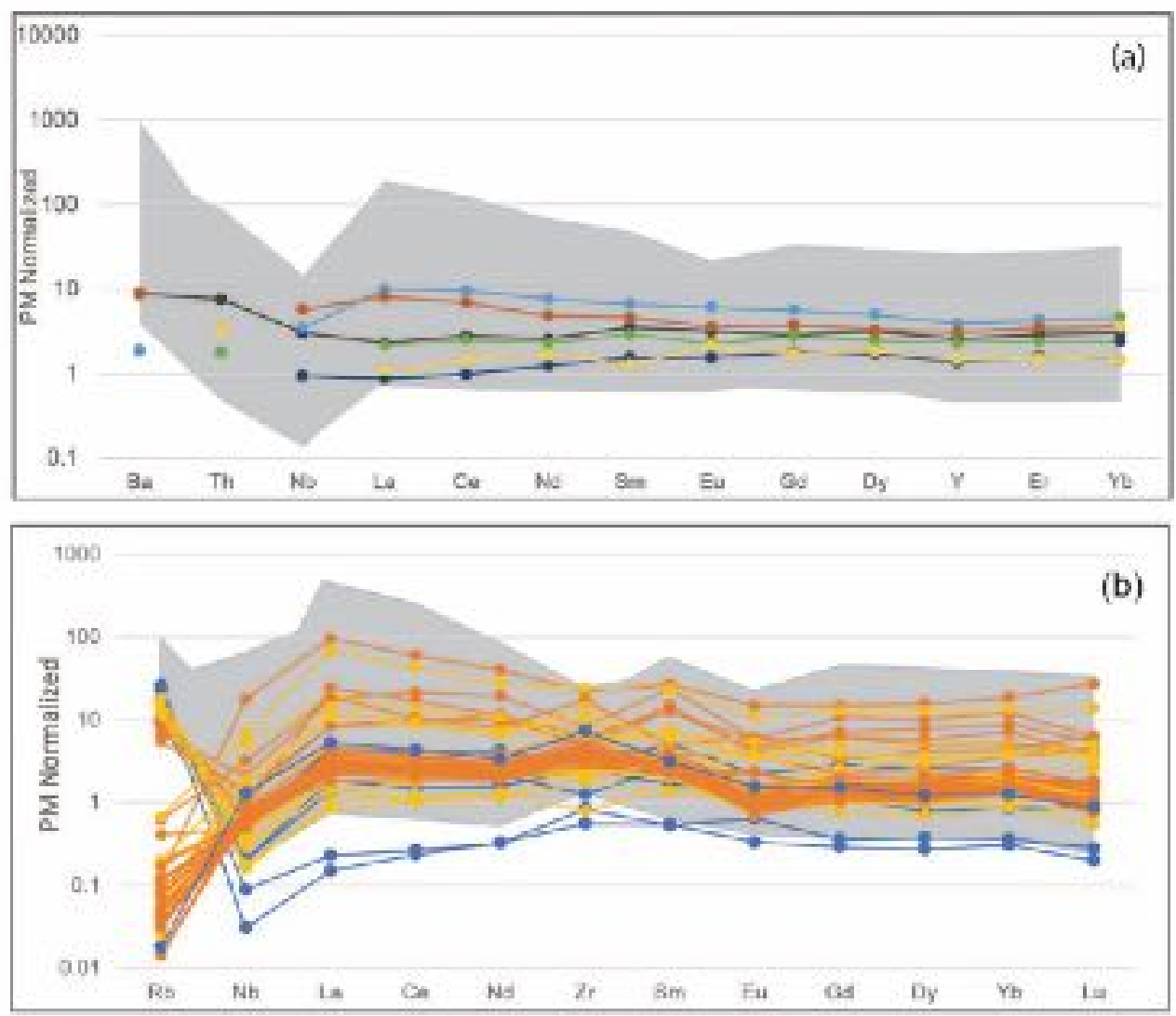

Figure 4-8 (a) Primitive mantle normalized calculated melt composition in equilibrium with mafic clinopyroxene from Site 1438 (b) Primitive mantle normalized calculated melt composition in equilibrium with amphiboles from Site 1438, blue are andesite, yellow are dacite and orange are rhyolite melt composition in equilibrium. The shaded background represents the calculated melt compositions from Site 296 minerals

\subsection{Discussion}

\subsubsection{Comparison of Site 296 and Site 1438}

\subsubsection{Location and physical characteristics}

The drilled Units studied from Sites 296 and 1438 are similar in that both are interpreted as turbidites containing lithic fragments, volcanic glass and minerals and eroded from the KPR. Nonetheless, there are significant differences between the sites based on the composition of fragments, grain size, and compactness of the core samples. Site 296 is 
located on a structural terrace in the western side of KPR, where the upper part of Unit 2, consisting mainly of poorly to moderately sorted lapilli tuffs, were described as direct products from active eruptive processes. In contrast, the lower part of Unit 2 samples were volcanic sandstones, where volcanic materials shed from either side of the terrace were reworked and deposited (Ingle et al., 1975). Lithic fragments change from more pumice or felsic dominated to more mafic or andesitic dominated up the core, with the concentrations of felsic clasts at specific intervals. The grain size of the minerals is also larger in Site 296 samples compared with Site 1438, and in most samples the matrix has been vitrified making it challenging to disintegrate some of the core samples.

Site 1438 located on the Amami Sankaku basin is a distal location relative to the KPR source and volcanic debris is deposited by downslope migration of arc deposits as a result of the steepening of the slopes (Brandl et al., 2017). Studied Unit III samples from Site 1438 were interpreted as debrites with interbedded turbidites (Johnson et al., 2018). The studied samples were not as compact as Site 296 samples, the mineral grains were smaller, and the major lithic fragments observed was pumice; mafic clasts were mostly absent until Core 30 at approximately 490 meters. Another significant difference observed between the two sites is the distribution of types of lithic fragments. Site 1438 samples were repeated units of very coarse pumice-bearing conglomerates which transitioned to finer-grained sandstones upward. Since pumice was the significant lithic fragment observed at Site 1438, unlike in upper Site 296 Unit 2 lapilli tuffs, the question arises if the upper unit III are just turbidites and debrites or the product of explosive volcanism of the last stages of Oligocene IBM arc. Since pumice is also light, it can float until settling in suspension to form normal graded sedimentary units. 
A last significant difference seen between the two sites may be rifting related changes. Since Site 1438 is situated on the rear arc side, magmatism accompanying arc rifting and arc subsidence may not be recorded. In contrast, debris collecting at Site 296 on the eastern side of the ridge at shallower water depths could show petrologic and geochemical signatures related to rifting. Indeed, some clinopyroxenes from Site 296 had MORB like features (Fig. 4-3c) and unusually high Mg clinopyroxenes present in Site 296, but such materials were absent in Site 1438.

\subsubsection{Magma compositions}

Overall, magma compositions from glass, melt inclusions and clasts of the northernmost IBM arc are predominantly medium $\mathrm{K}$ with the presence of both high and low $\mathrm{K}$ magmas. Although very mafic clasts or minerals are not common in upper Site 1438, some felsic low K melts (Fig 4-4a) from Site 1438 have high Mg\#s (50-60). In the FeOt/MgO vs. $\mathrm{SiO}_{2}$ (Fig. 4-9a) these melts plot in the calc-alkaline field or at the boundary line. Based solely on the compositions of clinopyroxenes from two sites, cpxs from Site 1438 are of tholeiitic type (Fig 4-3b) whereas both types were present in Site 296, with more calc-alkaline cpx at the bottom cores and tholeiitic cpx in the upper ones. However, as shown in Fig 4-9a from glass, MI and clast data, calc alkaline melts were also present in Site 1438. A few calc-alkaline, andesitic clasts and a melt inclusion from Site 296 Unit 2 have the highest $\mathrm{La} / \mathrm{Sm}_{\mathrm{N}}$ ratios (4-4.8) observed at either site, with high $\mathrm{Ba}$, $\mathrm{Th}$ and $\mathrm{Nb}$ concentrations (Fig. 4-9 b,c). Such LREE enriched mafic or intermediate magmas are absent in Site 1438 (both from analyzed and calculated), which makes the enriched magmas in Site 296 unique to the two sites. Some MIs from Site 1438 have the highest $\mathrm{Th} / \mathrm{Yb}$ ratios at similar $\mathrm{Nb} / \mathrm{Yb}$ ratios compared with Site 296 melts (Fig. 4-9b). Except for one basalt clast from Site 1438, 
which shows very high Ba concentration (Fig. 4-9c), most melts from Site 1438 have lower $\mathrm{Ba}$ and $\mathrm{Nb}$ concentrations than Site 296 melt compositions. Amphiboles in Unit II, Site 1438 , which represent the last stage of IBM arc activity, concurrent or prior to rifting have higher $\mathrm{Ba}$ concentrations than the amphiboles from Unit III (Fig. 4-3b), indicating the magma it crystallized from also had high Ba concentrations. Ba add to the mantle sources of arc magma by hydrous fluids derived from subducted sediment, a process which occurs at the arc front and at shallower depths than sediment melting (Pearce et al., 2005). Therefore, an increase in Ba concentration in the last stage magma could be related to either increased contribution of fluids or an originally Ba-enriched mantle source. $\mathrm{Nb}$ concentrations of Site 296 magmas are also higher than Site 1438 magmas. $\mathrm{Nb}$ and high $\mathrm{Nb} / \mathrm{Yb}$ indicates asthenosphere fertility, therefore the mantle sources for Site 296 primary magmas could be from a more fertile asthenosphere than those for contemporaneous magmas represented by sediments at Site 1438 . 

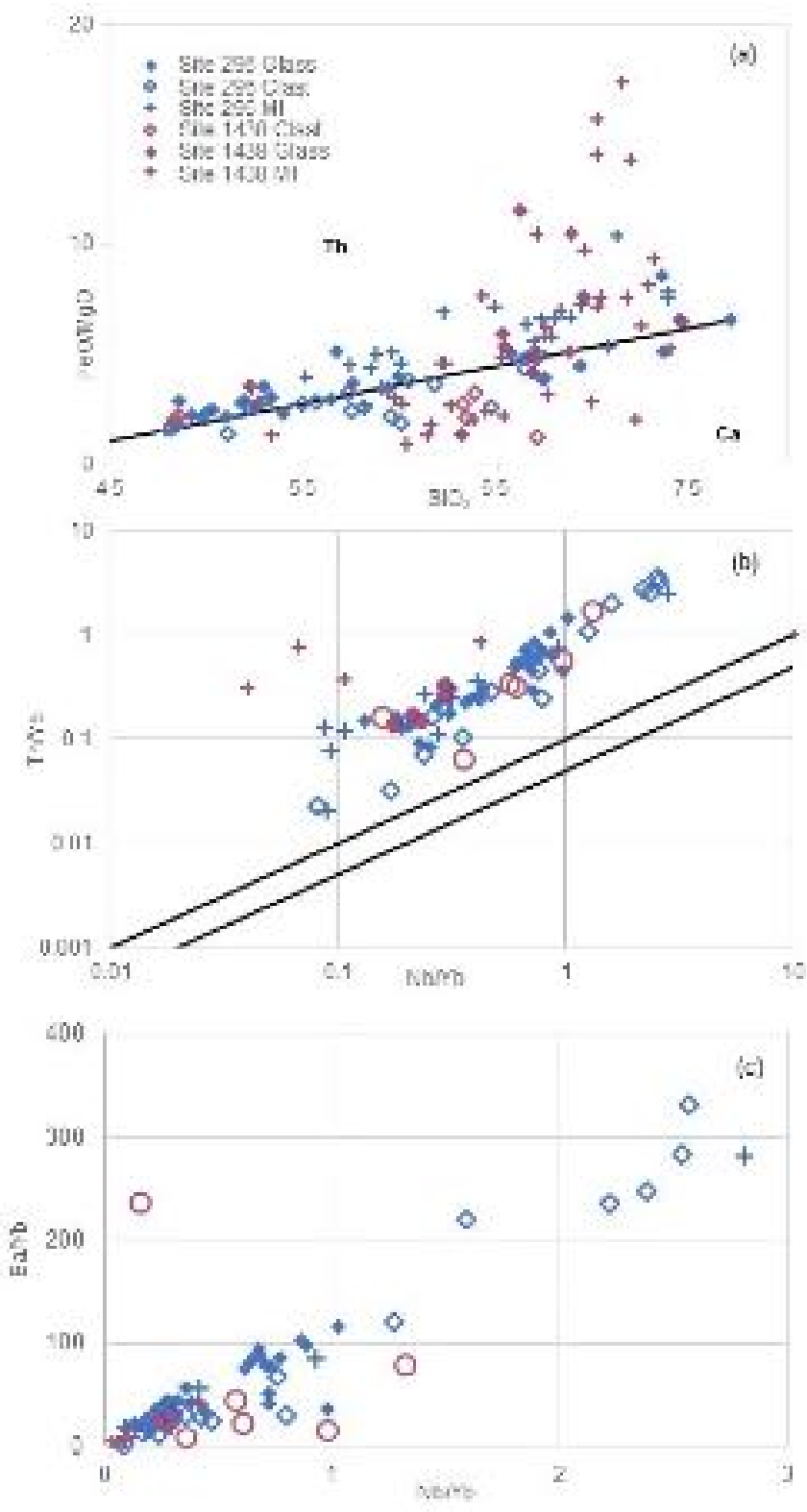

Figure 4-9 (a) $\mathrm{SiO}_{2}$ vs FeOt/MgO plot distinguishing the tholeiitic (Th) and calc-alkaline (Ca) fields (Miyashiro, 1974) for melt compositions represented by glass, MI and clasts from Site 296 and Site 1438 (b) Logarithmic plot of Th/Yb and $\mathrm{Nb} / \mathrm{Yb}$ ratios for melts (c) $\mathrm{Ba} / \mathrm{Yb}$ vs $\mathrm{Nb} / \mathrm{Yb}$ plot for the melt compositions

\subsubsection{Mantle Geochemistry}

Figure 4-10a show the initial ${ }^{143} \mathrm{Nd} /{ }^{144} \mathrm{Nd}$ and ${ }^{176} \mathrm{Hf} /{ }^{177} \mathrm{Hf}$ isotope ratios the IBM arc through time, as inferred from data from DSDP Site 296 and 1438. Data for Site 1438 basement and Unit IV sills are from Yogodzinski et al. (2018), Shikoku basin, and Neogene 
Izu arc data from fallout tephras are from Site 782 (Straub et al., 2010) and some Unit III Site 1438 samples are from Laxton (2016). Overall there is an increase in ${ }^{143} \mathrm{Nd} /{ }^{144} \mathrm{Nd}$ isotope ratios from the Oligocene arc to the Neogene arc, suggesting either mantle depletion with time or a shift in mantle source compositions. Interestingly, $\mathrm{Nd}$ isotope ratios for the Site 296 clasts show a wide range of values which may result from mixing of the sub-arc mantle with Pacific Ocean sediments or the subducting altered crust. Compared to the $\mathrm{Nd}$ isotope ratios, $\mathrm{Hf}$ isotope ratios of the IBM arc have not undergone much change. This may reflect the common assumption that Hf isotopes are not very affected by subduction processes, and that $\mathrm{Hf}$ isotopes of the arc volcanic materials reflect that of the mantle source (e.g., Pearce et al., 1999).

To further assess whether mixing of mantle and subducted materials leading to the isotopic composition of these clasts is plausible, mixing curves calculated between the subarc mantle, sediments, and the altered oceanic crust (Fig. 4-10b). The mantle values have been inferred from the average basement data of Site 1438 assuming a 5\% batch melting of an upper mantle composition of olivine:opx:cpx:spinel $=58: 27: 12: 3$ and mineral-melt partition coefficients from Donnelly et al. (2004). Pacific sediments, clay (CL), chert (CH) and volcanic sediment (V), data for trace elements are from Elliot et al. (1997) and isotopes are from Pearce et al. (1999). Altered Oceanic Crust (AOC) data are from Kelley et al. (2003) for trace elements and Chauvel et al. (2009) for isotopes. Two mixing lines between the mantle compositions and the sediments are constructed, and one between the mantle and a mix of volcanic sediment and the AOC. Based on the calculations, the Site 1438 magma is derived from the mantle with inputs from Pacific volcanic sediments and the AOC (2-5\%), whereas Site 296 magma composition have similar mantle sources, but 
mixing trends with Pacific volcanic sediments $(2 \%)$, AOC and volcanic sediments $(5 \%)$ and Pacific pelagic sediment $(\mathrm{CH})(2 \%)$ (Fig. 4-10b). The input from pelagic sediments observed within Site 296 are present towards the top of Unit 2.
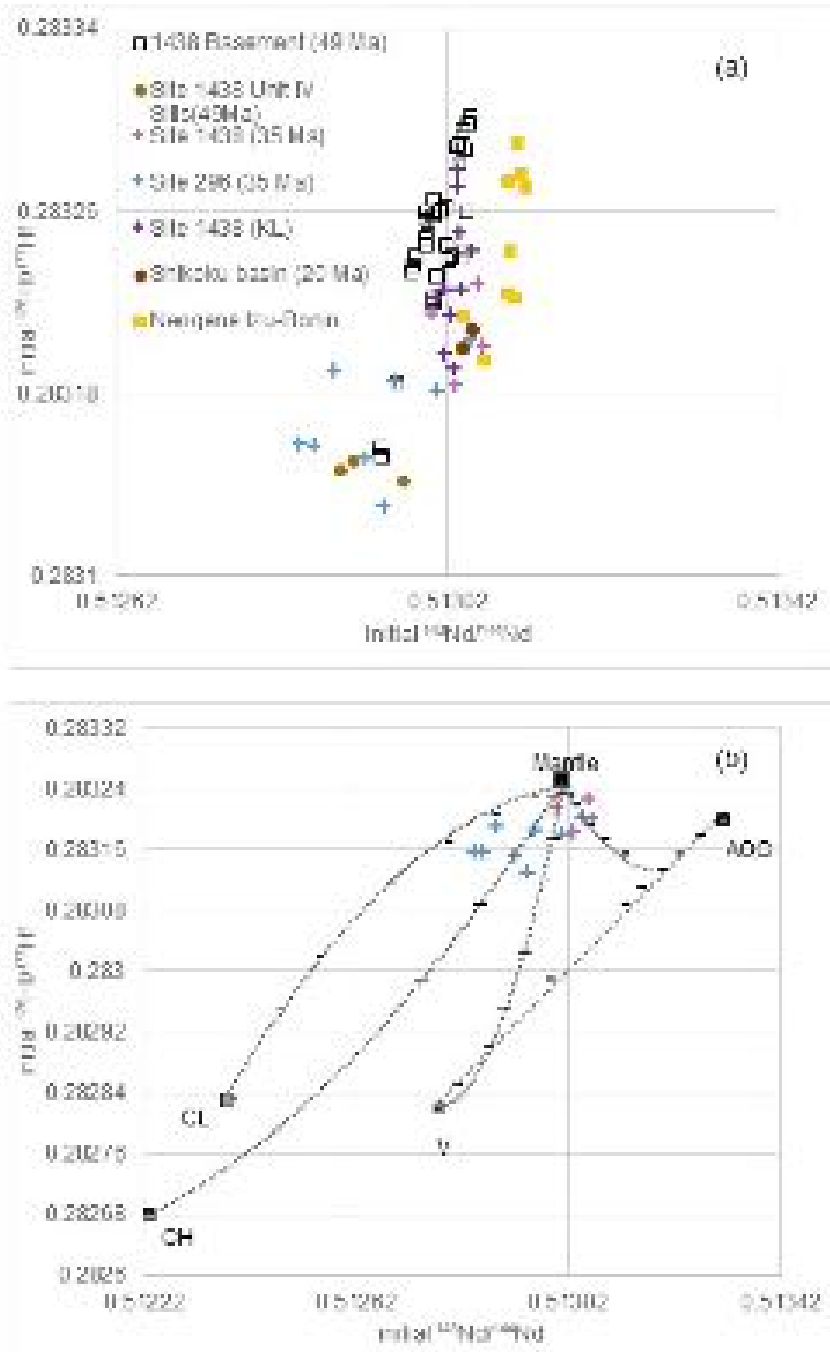

Figure 4-10 (a) Initial ${ }^{143} \mathrm{Nd} /{ }^{144} \mathrm{Nd}$ and ${ }^{176} \mathrm{Hf} /{ }^{177} \mathrm{Hf}$ isotope ratio evolution of IBM arc from $49 \mathrm{~m} . y$ to Neogene (b) Mixing curves between the mantle composition represented by Site 1438 basement, Pacific Ocean sediments, clay (CL), chert $(\mathrm{CH})$ and volcanic sediments $(\mathrm{V})$ and altered ocean crust (AOC) 


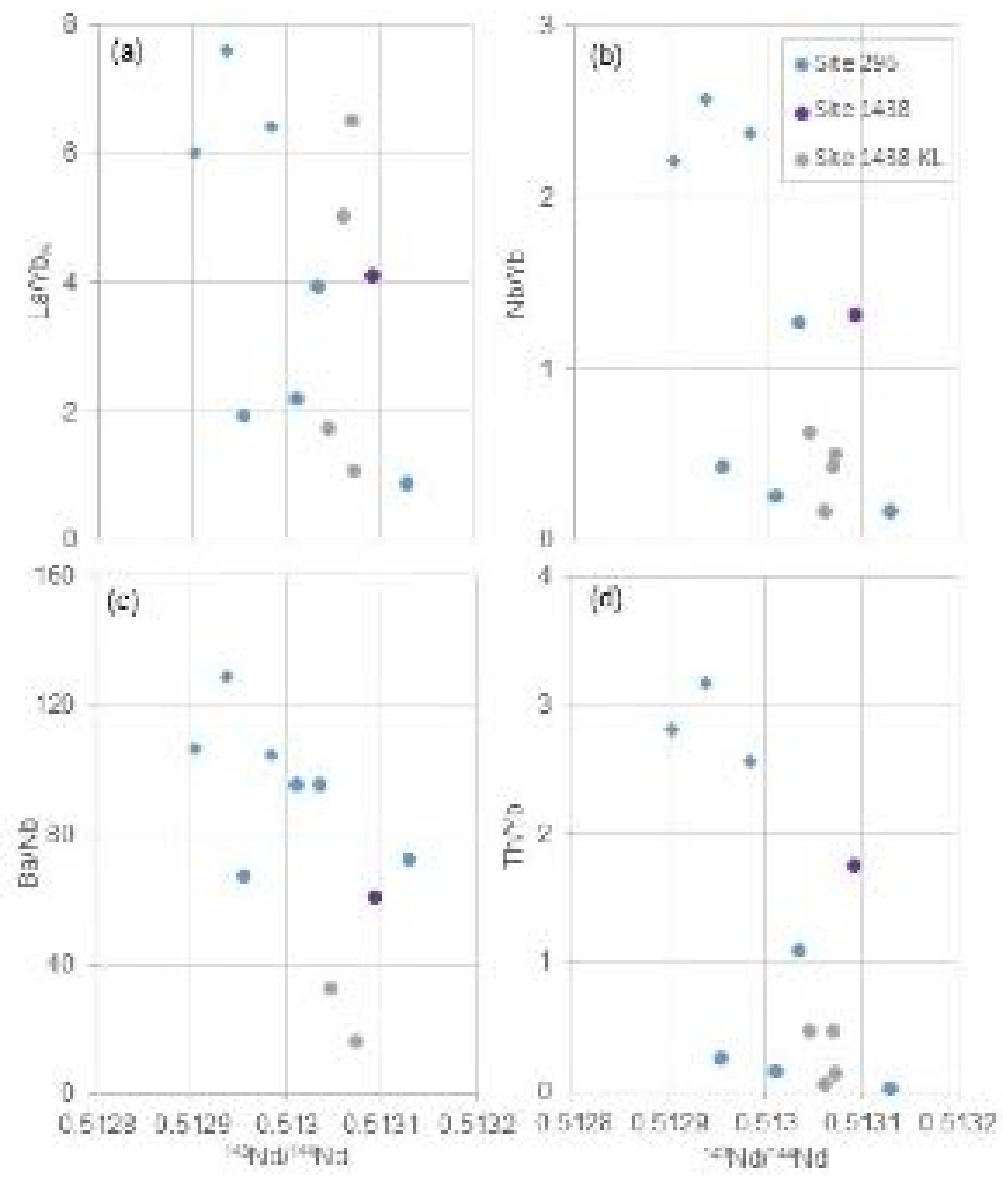

Figure 4-11 (a)- (d) Trace element ratio vs. ${ }^{143} \mathrm{Nd} /{ }^{144} \mathrm{Nd}$ for mafic and intermediate clasts of Site 1438 and Site 296. Blue diamonds are also Site 296 clasts. Also shown are data from Laxton (2016) from same depth interval.

Trace element ratios vs. ${ }^{143} \mathrm{Nd} /{ }^{144} \mathrm{Nd}$ isotope ratios for intermediate and mafic clasts from Site 296 and 1438 are shown in figure 4-11 a-d. In Site 296, Nd isotope ratios decreases up the core indicating an increasing mantle enrichment; clast from core 64, Site 296 has the highest $\mathrm{Nd}$ isotope ratios or derived from the most depleted mantle source. Clasts from the lower cores section of Unit II, Site 296 are isotopically similar to Site 1438 samples; these are the volcanic sandstones where pumice is the major clast type. Highly enriched magmas $\left(\mathrm{La} / \mathrm{Sm}_{N}>4\right)$ from Site 296, are from a fertile mantle source with high Th and $\mathrm{Nb}$ concentration (Blue diamonds in Fig 4-11 a,b \& d) and have relatively lower 
${ }^{143} \mathrm{Nd} /{ }^{144} \mathrm{Nd}$. The mafic Site 1438 clast has relatively higher ${ }^{143} \mathrm{Nd} /{ }^{144} \mathrm{Nd}$, but $\mathrm{Th} / \mathrm{Yb}$ ratio is higher, and $\mathrm{Ba} / \mathrm{Nb}$ lower than other clasts (Fig 4-11). Nd isotope ratio of clasts (Site 1438) from Laxton (2016) from the same depth interval, show similar isotope ratio as the Site 1438 clast from this study, but at lower $\mathrm{Nb} / \mathrm{Yb}$ and $\mathrm{Th} / \mathrm{Yb}$ values (Fig. 4-11 b,d); 2 clasts from Laxton (2016) has high $\mathrm{La} / \mathrm{Yb}$ values (Fig 4-11a) and very high Ba values (not shown in fig. 4-11c)

\subsubsection{Temporal Variation and Correlation of the Sites}

Together, volcanic sediments from Sites 1438 and 296 represent the volcanic history of the early IBM arc before rifting. The upper section of Site 1438, Unit II and Unit III correlate in time with Site 296 Unit 2. Although there are few differences observed within the two sites, there are also many similarities. Rocks and minerals from Site 1438 are mostly of felsic composition with few intermediate and rare mafic compositions which present a challenge in distinguishing source characters from magmatic differentiation. Based on the inferred composition of melts in equilibrium with Unit II Site 1438 amphiboles, the latest stage magmas become enriched in $\mathrm{Rb}$ and $\mathrm{Ba}$, but have low $\mathrm{La} / \mathrm{Sm}_{\mathrm{N}}$ ratios for intermediate and felsic magmas (0.2 to 1.9$)$. This contrast with felsic melts in equilibrium with amphiboles from Unit III which have lower Ba and Rb concentration and low to high $\mathrm{La} / \mathrm{Sm}_{\mathrm{N}}$ ratios (0.5 to 6.8$)$. Also, amphiboles become predominant mafic minerals in Unit II rather than pyroxenes which is usually the dominant mafic mineral in the core samples from both the Sites.

Site 296 sediments show a wider variation in magma and source compositions compared with Site 1438. The compositional range represented by trace element concentrations (both 
calculated and analyzed) of Site 1438 magma falls within the Site 296 magma compositions. Very depleted and enriched trace element concentrations are uncommon in Site 1438. Previous and new data (mafic to intermediate clasts) from Site 296 indicate that the magma composition became more LREE enriched with time and with increasing mantle fertility (Fig. 4-11a, c) possibly due to an enriched mantle source. This trend is not very apparent in Site 1438 (Fig. 4-11b, d), although there were not many mafic and intermediate magma compositions to provide a thorough comparison. The previous study of melt inclusions from Brandl et al. (2017) on Site 1438, Unit III concludes that magma composition does become more enriched during the last stages of the Oligocene IBM arc, $<37 \mathrm{Ma}$. Isotope composition of Site 296 also becomes more enriched up the core as suggested by lower $\mathrm{Nd}$ isotope ratios, with the most enriched mantle sources coinciding with high $\mathrm{La} / \mathrm{Sm}_{\mathrm{N}}$ and $\mathrm{Nb} / \mathrm{Yb}$ ratios (Fig. 4-11a, b). The enrichment of $\mathrm{Nd}$ isotope ratios could be because of mixing of pelagic sediments in the later stages as observed in Site 296 compositions. 


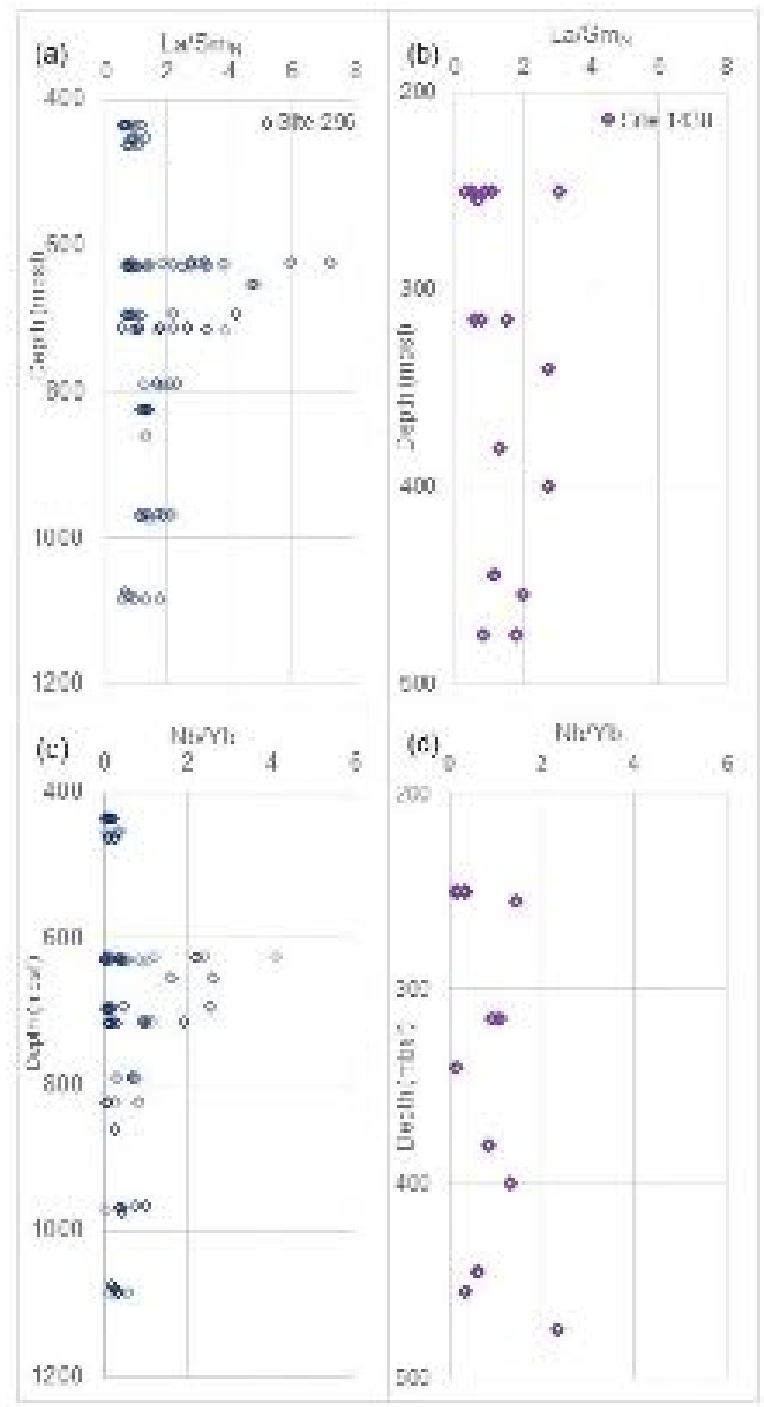

Figure 4-12 (a) La/SmN vs. depth (mbsf) of Site 296 mafic and intermediate melt compositions (b) La/SmN vs. depth of site 1438 mafic and intermediate melt compositions (c) Nb/Yb ratio vs. depth of Site 296 melt compositions (d) Nb/Yb ratio vs. depth of Site 1438 melt compositions. Both analyzed and calculated melt are shown.

The biostratigraphic ages of Unit 2, Site 296 and Units II and upper Unit III, Site 1438 is early to late Oligocene; both are within the $<37$ Ma group described by Brandl et al. (2017). Correlating Sites 296 and 1438 is problematic, although it seems that before the appearance of highly enriched magma (around $700 \mathrm{~m}$, Site 296) magma compositions were similar at both Sites, in terms of both trace element composition and isotopic ratios. The 
core samples in both the sites, below $700 \mathrm{~m}$ in Site 296 and Site 1438, also are rich in pumice clasts; therefore, they may be contemporaneous and represent a more explosive eruptive stage of the arc. Around $700 \mathrm{~m}$ and above in Site 296, the core samples are lapilli tuff which is said to be direct deposition of the volcanic activity (Ingle et al., 1975). These are the units where enriched mafic amphiboles and depleted unusually high $\mathrm{Mg} \#$ cpxs are common. Considering that Site 1438 may not have any evidence rifted related magmatic activity since it is on the rear arc side, the magmas which formed these features at Site 296 may be associated with the initiation of rifting. During true rifting and opening of the Shikoku Basin, the magma composition in Site 296 may have become more depleted and cpxs with high Mg\#s, MORB affinity, and depleted trace element compositions crystallized. The change from fluid mobile element (like $\mathrm{Ba}$ and $\mathrm{Rb}$ ) depleted amphibole in Unit III to higher concentration in Unit II also reflects a high influx of fluid between the two units of Site 1438. At the last stages of arc magma evolution as recorded in Site 1438, high fluid content lead to the stabilization of amphiboles with high concentration of fluid mobile elements.

\subsection{Conclusion}

In summary, Site 296 and Site 1438 reveal the magmatic evolution of the early to late Oligocene IBM arc ( $\sim 28$ to $36 \mathrm{Ma})$. Volcaniclastic materials reveal some significant similarities and difference which can be related to the location of these sites on KPR. Site 1438 located on the rear arc side contains pumice as the major lithic fragments whereas Site 296 situated on the ridge contains both mafic and pumice clasts; this may be due to higher mobilization of pumice over mafic clasts during deposition in Site 1438. The lower

section of Unit 2, Site 296 and the upper studied section of Site 1438 correlate in terms of 
the abundance of pumice clast in the core samples, these are either volcaniclastic sandstone or breccias. The trace element composition and the isotope ratios are also similar in these sections from the two sites, which suggests a possible correlation between the two. Towards the last stage of arc evolution, there were high input of fluid or water which led to crystallization fluid mobile ( $\mathrm{Ba}$ and $\mathrm{Rb}$ ) enriched amphiboles in unit II, Site 1438 which are slightly depleted in LREE. Evidence of high-water content of magma in upper unit 2, Site 296 is also present inferred from increasing abundance of anorthite plagioclase and amphiboles. However, there are features unique to Site 296 which are present towards the top of Unit 2, such as magmas from an enriched mantle source leading to the evolution of highly LREE enriched magmas at high $\mathrm{Nb} / \mathrm{Yb}$ ratios, which also crystallized some mafic amphiboles in Site 296 magmas. Around the same time, there were also REE depleted high $\mathrm{Mg}$ magmas which formed some very high $\mathrm{Mg}$ clinopyroxenes. Indication of these late magma types is absent in Site 1438 which suggest that these magmas evolved during rifting stages and therefore maybe absent in the rear arc.

\subsection{Acknowledgment}

This research was supported by NSF grants OCE 15377861 to Rosemary HickeyVargas. We gratefully acknowledge the contribution of Gabriela Fernandez for her help in sample disintegration and minerals separation and Ryan Waldman for his help with sample preparation for isotope analysis. We also thank Thomas Beasley of the Florida Center for Analytical Electron Microscopy (FCAEM) at FIU for assistance with EPMA analyses and Dr. Ping Jiang of the Trace Evidence Analysis Facility (TEAF) at FIU for assistance with ICP-MS analyses and lastly, the people at Centre for Elemental Mass Spectrometry, University of South Carolina for their help in analyzing the sample. 


\subsection{References}

Arculus, R., Ishizuka, O., Bogus, K., et al., 2015, International Ocean Discovery Program Expedition 351 preliminary report; Izu-Bonin-Mariana Arc origins; continental crust formation at an intraoceanic arc; foundation, inception, and early evolution; 30 May30 July 2014: Preliminary Report (International Ocean Discovery Program), v. 351.

Bouvier, A., Vervoort, J.D., and Patchett, P.J., 2008, The Lu-Hf and Sm-Nd isotopic composition of CHUR; constraints from unequilibrated chondrites and implications for the bulk composition of terrestrial planets: Earth and Planetary Science Letters, v. 273, no. 1-2, p. 48-57.

Brandl, P.A., Hamada, M., Arculus, R.J., et al., 2017, The arc arises; the links between volcanic output, arc evolution and melt composition: Earth and Planetary Science Letters, v. 461, p. 73-84.

Chauvel, C., Marini, J., Plank, T., and Ludden, J.N., 2009, Hf-Nd input flux in the IzuMariana subduction zone and recycling of subducted material in the mantle: Geochemistry, Geophysics, Geosystems - G3, v. 10, no. 1, p. Citation Q01001.

Donnelly, K.E., Goldstein, S.L., Langmuir, C.H., and Spiegelman, M., 2004, Origin of enriched ocean ridge basalts and implications for mantle dynamics: Earth and Planetary Science Letters, v. 226, no. 3-4, p. 347-366. 
Elliott, T., Plank, T., Zindler, A., White, W., and Bourdon, B., 1997, Element transport from slab to volcanic front at the Mariana Arc: Journal of Geophysical Research, v. 102, no. B7, p. 14-15,019.

Hickey-Vargas, R., Abdollahi, M.J., Parada, M.A., Lopez-Escobar, L., and Frey, F.A., 1995, Crustal xenoliths from Calbuco Volcano, Andean Southern Volcanic Zone; implications for crustal composition and magma-crust interaction: Contributions to Mineralogy and Petrology, v. 119, no. 4, p. 331-344.

Humphreys, M.C.S., Cooper, G.F., Zhang, J. et al., 2019, Unravelling the complexity of magma plumbing at Mount St. Helens: a new trace element partitioning scheme for amphibole.: Contributions to Mineralogy and Petrology, v. 174, no. 9.

Ingle, J.C.,Jr, Karig, D.E., Bouma, A.H., et al., 1975, Site 296: Initial Reports of the Deep Sea Drilling Project, v. 31, p. 191-274.

Ishizuka, O., Tani, K., Reagan, M.K., et al., 2011, The timescales of subduction initiation and subsequent evolution of an oceanic island arc: Earth and Planetary Science Letters, v. 306, no. 3-4, p. 229-240.

Ishizuka, O., Taylor, R.N., Yuasa, M., and Ohara, Y., 2011, Making and breaking an island arc; a new perspective from the Oligocene Kyushu-Palau Arc, Philippine Sea: Geochemistry, Geophysics, Geosystems - G3, v. 12, no. 5, p. Citation Q05005. 
Johnson, K., Waldman, R., and Marsaglia, K.M., 2017, Data report: sedimentary columns with facies and bedding for Units II-IV at IODP Site U1438: Proceedings of the International Ocean Discovery Program, v. 351.

Kelley, K.A., Plank, T., Ludden, J., and Staudigel, H., 2003, Composition of altered oceanic crust at ODP Sites 801 and 1149: Geochemistry, Geophysics, Geosystems G3, v. 4, no. 6 .

Laxton, K., 2016, Petrological and geochemical evolution of the Kyushu-Palau (early IBM) volcanic arc, Western Pacific, University of Leeds, 2016.

Leake, B.E., Woolley, A.R., Arps, C.E.S., et al., 1997, Nomenclature of amphiboles; report of the subcommittee on amphiboles of the International Mineralogical Association, Commission on New Minerals and Mineral Names: The Canadian Mineralogist, v. 35, Part 1, p. 219-246.

Leterrier, J., Maury, R.C., Thonon, P., Girard, D., and Marchal, M., 1982, Clinopyroxene composition as a method of identification of the magmatic affinities of paleo-volcanic series: Earth and Planetary Science Letters, v. 59, no. 1, p. 139-154.

Miyashiro, A., 1974, Volcanic rock series in island arcs and active continental margins: American Journal of Science, v. 274, no. 4, p. 321-355.

Pearce, J.A., Kempton, P.D., Nowell, G.M., and Noble, S.R., 1999, Hf-Nd element and isotope perspective on the nature and provenance of mantle and subduction 
components in Western Pacific arc-basin systems: Journal of Petrology, v. 40, no. 11, p. $1579-1611$.

Pearce, J.A., Stern, R.J., Bloomer, S.H., and Fryer, P., 2005, Geochemical mapping of the Mariana arc-basin system; implications for the nature and distribution of subduction components: Geochemistry, Geophysics, Geosystems - G3, v. 6, no. 7.

Peccerillo, A., and Taylor, S.R., 1976, Geochemistry of Eocene calc-alkaline volcanic rocks from the Kastamonu area, northern Turkey: Contributions to Mineralogy and Petrology, v. 58, no. 1, p. 63-81.

Putirka, K., 2016, Amphibole thermometers and barometers for igneous systems and some implications for eruption mechanisms of felsic magmas at arc volcanoes: American Mineralogist, v. 101, no. 4, p. 841-858.

Putirka, K.D., and Tepley, F.J.,III, 2008, Thermometers and barometers for volcanic systems: Reviews in Mineralogy and Geochemistry, v. 69, no. 1, p. 61-120.

Samajpati, E., and Hickey-Vargas, R., 2020b, Early magmatic history of the IBM arc inferred from volcanic minerals and melt inclusions from Early- Late Oligocene DSDP Site 296: a mineral-melt partition approach.

Samajpati, E., and Hickey-Vargas, R., 2020a, Geochemistry of Volcanic Glass from Oligocene Detrital Sediments at DSDP Site 296, Kyushu Palau Ridge: Interpreting the Magmatic Evolution of the Early Northern Izu Bonin Mariana Island Arc. 
Stern, R.J., Fouch, M.J., Klemperer, S.L., and Eiler, J.M., 2003, An overview of the IzuBonin-Mariana subduction factory: Geophysical Monograph, v. 138, p. 175-222.

Straub, S.M., Goldstein, S.L., Class, C., Schmidt, A., and Gomez-Tuena, A., 2010, Slab and mantle controls on the $\mathrm{Sr}-\mathrm{Nd}-\mathrm{Pb}-\mathrm{Hf}$ isotope evolution of the post $42 \mathrm{Ma}$ Izu-Bonin volcanic arc: Journal of Petrology, v. 51, no. 5, p. 993-1026.

Straub, S.M., Woodhead, J.D., and Arculus, R.J., 2015, Temporal evolution of the Mariana Arc; mantle wedge and subducted slab controls revealed with a tephra perspective: Journal of Petrology, v. 56, no. 2, p. 409-439.

Sun, S.S., and McDonough, W.F., 1989, Chemical and isotopic systematics of oceanic basalts; implications for mantle composition and processes: Geological Society Special Publications, v. 42, p. 313-345.

Weis, D., Kieffer, B., Hanano, D., et al., 2007, Hf isotope compositions of U. S. Geological Survey reference materials: Geochemistry, Geophysics, Geosystems - G3, v. 8, no. 6, p. Citation Q06006.

Weis, D., Kieffer, B., Maerschalk, C., et al., 2006, High-precision isotopic characterization of USGS reference materials by TIMS and MC-ICP-MS: Geochemistry, Geophysics, Geosystems - G3, v. 7, no. 8 .

Yogodzinski, G.M., Bizimis, M., Hickey-Vargas, R., et al., 2018, Implications of Eocene age Philippine Sea and fore-arc basalts for initiation and early history of the IzuBonin-Mariana Arc: Geochimica et Cosmochimica Acta, v. 228, p. 136-156. 


\subsection{Appendices}

Refer table 3-1 for major oxide precision and table 4-1 for trace element precision i.

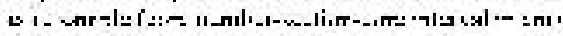

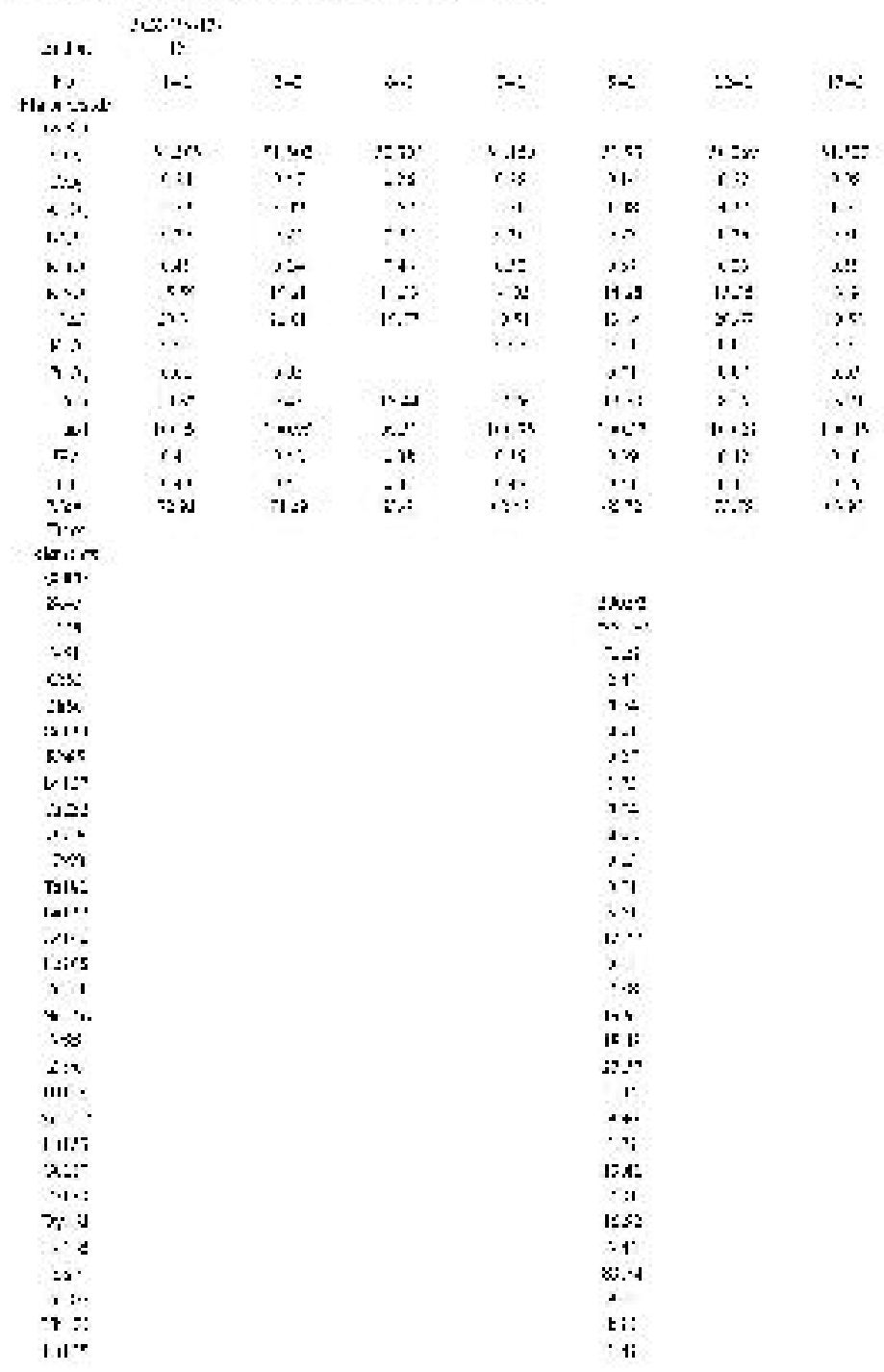




\begin{tabular}{|c|c|c|c|c|c|c|c|}
\hline \multicolumn{8}{|l|}{ Besce } \\
\hline 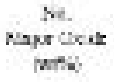 & $18-2$ & $21-2$ & $23 . .1$ & $34-2$ & $25-1$ & $x-2$ & 245 \\
\hline $3 \mathrm{in}_{2}$ & 5111 & 51217 & Sol 10 & 97.172 & 5. $97 v$ & 574 ! & 51.74 \\
\hline$v_{k v_{3}}$ & are & 021 & 0.17 & 5.16 & 0.13 & 221 & נבם \\
\hline$x_{1} 0$. & $25:$ & 24 & 2.33 & 329 & 200 & 1.44 & 1.4 \\
\hline sapo & 9.5 & 923 & 0.13 & $6 \pm 1$ & ist & $2 \pm t$ & $43 t$ \\
\hline Mnd & 94. & $9+4$ & 6.15 & t.15 & 68 & 354 & 4.44 \\
\hline $\mathrm{St}_{4} \mathrm{O}$ & $16 \pi$ & $11<5$ & 631 & 1628 & 1591 & 1602 & $15 \%$ \\
\hline 100 & $212 x$ & $15=55$ & $22: 1$ & 21.55 & susi & 15001 & $15: 35$ \\
\hline $\mathrm{K}_{2} \mathrm{O}$ & ar: & & & & & & ax \\
\hline$\alpha_{1} \rho$. & ass & out & wos & tod & & & \\
\hline Fet: & 56 & $12 \mathrm{~m}$ & $s ;$ & 718 & inid & $+\infty$ & $108:$ \\
\hline Toral & 9906 & lonlo & Iforis & $160+8$ & $200 \pi$ & $13 \leq 5$ & $99>1$ \\
\hline $\mathrm{Xb}_{6}$ & 011 & 972 & $\omega \times 6$ & CAt & $\cos$ & 216 & 435 \\
\hline L & o.Ae & $0.4 t$ & $n \rightarrow s$ & t.As & 0.42 & M4: & Q.A3 \\
\hline$M$ & $\sec x$ & (5) & 5131 & nis & 797 & 74.15 & $71 \%$ \\
\hline \multirow{2}{*}{\multicolumn{8}{|c|}{$\begin{array}{l}\text { Trox } \\
\text { Awawis }\end{array}$}} \\
\hline & & & & & & & \\
\hline \multicolumn{8}{|l|}{ wo: } \\
\hline sots & & & & & & & 25ses \\
\hline$n \pm n$ & & & & & & & $190 \mathrm{~d} / \mathrm{N}$ \\
\hline vat & & & & & & & 60.00 \\
\hline $\mathrm{Cr} 2$ & & & & & & & שבנ \\
\hline Nos & & & & & & & $13:$ \\
\hline Csiss & & & & & & & E. 36 \\
\hline Juse: & & & & & & & 231 \\
\hline Ral: & & & & & & & 13.27 \\
\hline Drat? & & & & & & & 454 \\
\hline 0258 & & & & & & & 56 \\
\hline $\sin 2$ & & & & & & & e.15 \\
\hline Taisi & & & & & & & 46 \\
\hline Lalse & & & & & & & $5 y$ \\
\hline Cstn & & & & & & & 21.52 \\
\hline Phives & & & & & & & $4 \pi$ \\
\hline Fist & & & & & & & 411 \\
\hline Nolse & & & & & & & 2530 \\
\hline$n \rightarrow \infty$ & & & & & & & $B<x$ \\
\hline 7ow & & & & & & & $k<2$ \\
\hline Mn: $>$ & & & & & & & 12 \\
\hline $3 n 147$ & & & & & & & 104 \\
\hline Ruis: & & & & & & & 16 \\
\hline talus? & & & & & & & $14=$ \\
\hline ToLo & & & & & & & 2.44 \\
\hline Dyls; & & & & & & & $182:$ \\
\hline Hedes & & & & & & & $3 x$ \\
\hline ras & & & & & & & ros \\
\hline wiet & & & & & & & 1600 \\
\hline $\mathrm{x}=12$ & & & & & & & 3020 \\
\hline Lul?s & & & & & & & 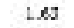 \\
\hline
\end{tabular}




\begin{tabular}{|c|c|c|c|c|c|c|c|}
\hline Besce & & & & & $\begin{array}{c}\operatorname{acc} c 0 x-51 \\
56\end{array}$ & & \\
\hline $\begin{array}{l}\text { Ne. } \\
\text { Napr Cisiz } \\
\text { partis }\end{array}$ & so-2 & $34 . . \mathrm{L}$ & $21 . .1$ & 3s-1 & $1 \cdots 1$ & $2 \cdots 2$ & $9 . .1$ \\
\hline $\mathrm{sio}_{2}$ & ועצ וצ & 505 & s.1:8 & s: 501 & 3036 & 52.465 & 5237 בר \\
\hline $\mathrm{vkj}_{3}$ & 0.2: & 021 & 0.15 & [es & 6.21 & 0.16 & 4.17 \\
\hline$x_{1} 6$ & 253 & 155 & $2 / 22$ & {$[2]$} & 2.7 & 100 & $2 . x$ \\
\hline wa & 923 & 929 & 6.16 & 6.34 & cts & $3 D t$ & 411 \\
\hline $\mathrm{MrO}$ & 926 & ass & 6.12 & 5.18 & $1 \leq 0$ & $35 i$ & 43 \\
\hline $\mathrm{M}_{4} \mathrm{CO}$ & $1<<x$ & 1156 & 651 & $1 \geq 11$ & $1=20$ & 1150 & 1455 \\
\hline 100 & $2 x \mu 4$ & $2 x+5$ & 2151 & $1 x=5$ & $21 . x$ & 20.23 & $19: 20$ \\
\hline $\mathrm{K}_{0} \mathrm{O}$ & & aJI & & & & 201 & \\
\hline $\mathrm{r}_{1} \mathrm{O}$ & & 038 & all & & & & $\cos$ \\
\hline Fai & Ait & 427 & $\therefore \Leftrightarrow$ & IAIA & 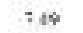 & 1067 & $16 \mathrm{st}$ \\
\hline Toal & $10 x: 1$ & $\log 20$ & Ifexi) & 162.11 & $m A$ & 9997 & $90 ; ?$ \\
\hline $\mathrm{x}_{6}$ & 013 & a1? & $a m$ & 619 & ces & 211 & 44 \\
\hline$x$ & $0 . A 3$ & 0.42 & $w \rightarrow b$ & 126 & 0.43 & 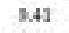 & eAZ \\
\hline$M=0$ & 79,1 & 7253 & 5212 & $5: 36$ & $7 \times .4$ & Tas? & 7.12 \\
\hline \multicolumn{8}{|l|}{$\begin{array}{l}\text { Trkx } \\
\text { duevat is }\end{array}$} \\
\hline & \\
\hline 5045 & 16475 & & & 251.73 & & & \\
\hline$n+y$ & zat, 3 & & & 1712.25 & & & \\
\hline VSL & 35551 & & & $5 x y 2$ & & & \\
\hline $\mathrm{Cr2}$ & 27,4 & & & 231 & & & \\
\hline Nes & 21.5 & & & 3.14 & & & \\
\hline Csiss & $a x !$ & & & 606 & & & \\
\hline Juse & axt & & & $2 x$ & & & \\
\hline Ral: & alt & & & 1as: & & & \\
\hline Dres? & $45 ?$ & & & 5.36 & & & \\
\hline 0258 & & & & tex & & & \\
\hline $\sin x$ & a.t & & & c.12 & & & \\
\hline Taisi & a4? & & & col & & & \\
\hline Lal3s & 0.1 & & & 1.14 & & & \\
\hline Csln & ב.ד. & & & 1.25 & & & \\
\hline Phives & at3 & & & 647 & & & \\
\hline Fis 4 & a). & & & 310 & & & \\
\hline Nobit & 134 & & & DSI2 & & & \\
\hline$n * 8$ & $17 n$ & & & 21.72 & & & \\
\hline 7ows & 966 & & & $7 \div 17$ & & & \\
\hline ant $>8$ & $0.2 x$ & & & 251 & & & \\
\hline $3 n 147$ & ass & & & 581 & & & \\
\hline Buts: & 933 & & & 250 & & & \\
\hline Evis? & L.s & & & 12,51 & & & \\
\hline totso & 0.24 & & & 136 & & & \\
\hline Dyle; & 1.75 & & & 127 & & & \\
\hline Hedes & as. & & & $\sin 0$ & & & \\
\hline ras & 5.93 & & & sx:7 & & & \\
\hline Iriee & ass & & & 10.54 & & & \\
\hline $\mathrm{xb} x \mathrm{z}$ & 054 & & & 1614 & & & \\
\hline Lults & 0.2 & & & $2 \mu$ & & & \\
\hline
\end{tabular}




\begin{tabular}{|c|c|c|c|c|c|c|c|}
\hline \multicolumn{8}{|l|}{ Besce } \\
\hline \multicolumn{8}{|l|}{$\begin{array}{c}\text { Napr Clede } \\
\text { perfis }\end{array}$} \\
\hline $3 \mathrm{io}_{2}$ & 52335 & 51357 & 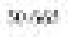 & 5:, 310 & 5. 600 & 51 a.s & 52651 \\
\hline $\mathrm{vkt}_{3}$ & $0: 7$ & a17 & as & t.19 & 030 & $\ln 2$ & ase \\
\hline$x_{1} \mathrm{O}$ & 1A: & 145 & 2.35 & 2.49 & 2.72 & 1.6 & 0.75 \\
\hline wa & 9.25 & 032 & $0 \Rightarrow$ & 621 & 649 & 291 & 5.16 \\
\hline Mro & $9 k^{3}$ & 952 & $\theta=2$ & $t \times$ & 6.44 & 3st & 46 \\
\hline $3 \mathrm{H}_{2} \mathrm{O}$ & $1<\infty$ & 1545 & 1565 & 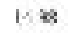 & 1425 & $1<>1$ & 13.9 \\
\hline 100 & 15:7 & zt.7t & $23 \mathrm{cs}$ & 30.71 & suss & 2005 & $2 w_{27}$ \\
\hline $\mathrm{K}=\mathrm{O}$ & & & & & & $2 \infty \mathrm{t}$ & \\
\hline $\mathrm{r}_{1} \mathrm{O}$ & & & $\omega=$ & & $\cos$ & & \\
\hline Fet: & 1612 & if 58 & 34 & 540 & mas & 48 & insi \\
\hline Teral & 10312 & 101.10 & 100.16 & $m \pi$ & $2 \cos \theta$ & $\tan 66$ & 1ext? \\
\hline $\mathrm{x} 6$ & $a u$ & a11 & 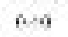 & 618 & $(t)$ & nis & 41 \\
\hline L & $0 . A 4$ & 0.45 & $n=$ & t. .43 & 0.42 & $M 42$ & 025 \\
\hline$M 0$ & $\neg \%$ & $725 s$ & 7251 & $\because x$ & $n 25$ & 7.21 & $a \sim m$ \\
\hline \multirow{2}{*}{\multicolumn{8}{|c|}{$\begin{array}{l}\text { Trax } \\
\text { Auar is }\end{array}$}} \\
\hline & & & & & & & \\
\hline \multicolumn{8}{|l|}{ wo: } \\
\hline \multicolumn{8}{|l|}{5045} \\
\hline \multicolumn{8}{|l|}{ 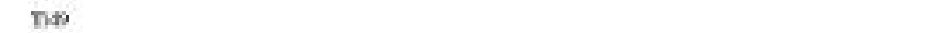 } \\
\hline \multicolumn{8}{|l|}{ vst } \\
\hline \multicolumn{8}{|l|}{$\mathrm{cs}$} \\
\hline \multicolumn{8}{|l|}{ Nes } \\
\hline \multirow{2}{*}{\multicolumn{8}{|c|}{ Csiss }} \\
\hline \multirow{2}{*}{\multicolumn{7}{|c|}{ unse }} & \\
\hline \multirow{2}{*}{\multicolumn{8}{|c|}{ Ral: }} \\
\hline \multirow{2}{*}{\multicolumn{8}{|c|}{ Don? }} \\
\hline \multirow{2}{*}{\multicolumn{8}{|c|}{0258}} \\
\hline \multirow{2}{*}{\multicolumn{8}{|c|}{$\sin x$}} \\
\hline \multirow{2}{*}{\multicolumn{8}{|c|}{ Taisi }} \\
\hline \multirow{2}{*}{\multicolumn{8}{|c|}{ Lalss }} \\
\hline \multirow{2}{*}{\multicolumn{8}{|c|}{ caln }} \\
\hline \multirow{2}{*}{\multicolumn{8}{|c|}{ Perves }} \\
\hline \multirow{2}{*}{\multicolumn{8}{|c|}{ Fris }} \\
\hline Nulat & & & & & & & \\
\hline 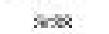 & & & & & & & \\
\hline 7ow & & & & & & & \\
\hline Mn:s & & & & & & & \\
\hline $3 n 147$ & & & & & & & \\
\hline Ruis: & & & & & & & \\
\hline Evia?: & & & & & & & \\
\hline Tblso & & & & & & & \\
\hline Dystis? & & & & & & & \\
\hline Hodes & & & & & & & \\
\hline ras & & & & & & & \\
\hline Iries & & & & & & & \\
\hline ches 12 & & & & & & & \\
\hline Lul & & & & & & & \\
\hline & & & & & & & \\
\hline
\end{tabular}




\begin{tabular}{|c|c|c|c|c|c|c|c|}
\hline \multirow{2}{*}{$\begin{array}{l}\text { Besce } \\
\text { Ne. } \\
\text { Diapr cicus } \\
\text { partis. }\end{array}$} & \multicolumn{3}{|c|}{ SIF-iW-3x-3s } & \multirow[b]{2}{*}{ at } & \multirow[b]{2}{*}{$13-1$} & \multirow[b]{2}{*}{$11-2$} & $\begin{array}{c}1 \mathrm{R} \cdot \mathrm{TR} \cdot \mathrm{m} \\
100\end{array}$ \\
\hline & 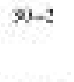 & $5-2$ & $3-2$ & & & & $1 \cdot \cdot 1$ \\
\hline $3 \mathrm{in}_{2}$ & 51319 & क) 213 & 20458 & 45.794 & 5) 417 & $51 \mathrm{TE}$ & 45.76 \\
\hline $\mathrm{vkj}_{3}$ & $a: 2$ & 027 & $\infty 1$ & c.sk & 0.17 & 220 & ess \\
\hline$x_{1}, 6$ & 1s: & 137 & $1 . x$ & 2.73 & 201 & 1.67 & $25 t$ \\
\hline sa & 93. & 925 & $6 z 2$ & 619 & is & $b x$ & 4.12 \\
\hline $\mathrm{MnO}$ & 9.75 & 947 & t.bs & $5,4:$ & 0.48 & 356 & t.12 \\
\hline $\mathrm{H}_{4} \mathrm{C}$ & $14 \%$ & 1589 & 1571 & 1637 & 1512 & 1481 & 158: \\
\hline 120 & 2621 & 15.15 & 15s5 & 125s & $12 x$ & IS:SI & Jow: \\
\hline $\mathrm{K}_{0} \mathrm{O}$ & & & & tol & & & $\cdot$ \\
\hline$x_{1} \%$ & & & wus & & & & eve \\
\hline $\mathrm{Fel}$. & $16 \%$ & if $s$ & 135 & $5 \%$ & $\ln 97$ & 11 SA & 4ต \\
\hline Tral & $90: 8$ & 557 & 583 & mis & mis & 9697 & 9610 \\
\hline $\mathrm{x}_{6}$ & 01 & 972 & $a: 8$ & 230 & 646 & $=16$ & 44 \\
\hline L & OAZ & $v+4$ & $n-$ & t.4S & 0.44 & 1.43 & EAt \\
\hline$M e$ & ravg & 73.17 & ו & 5.9 & 7.12 & $\cos 51$ & $\pi x$ \\
\hline \multirow{2}{*}{\multicolumn{8}{|c|}{$\begin{array}{l}\text { Ther } \\
\text { Duavis }\end{array}$}} \\
\hline & & & & & & & \\
\hline \multicolumn{8}{|l|}{ was: } \\
\hline \multicolumn{8}{|l|}{ sects } \\
\hline \multicolumn{8}{|l|}{$n+3$} \\
\hline \multicolumn{8}{|l|}{ 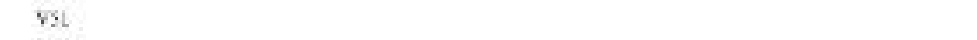 } \\
\hline \multicolumn{8}{|l|}{$\mathrm{Cs}$} \\
\hline \multicolumn{8}{|l|}{ Nos } \\
\hline \multicolumn{8}{|l|}{ Csiss } \\
\hline \multicolumn{8}{|l|}{ uses: } \\
\hline \multicolumn{8}{|l|}{ Ral: } \\
\hline \multicolumn{8}{|l|}{ Din: } \\
\hline \multicolumn{8}{|l|}{0265} \\
\hline \multicolumn{8}{|l|}{$\sin x$} \\
\hline \multicolumn{8}{|l|}{ Talsi } \\
\hline \multicolumn{8}{|l|}{ Lalse } \\
\hline Celn & & & & & & & \\
\hline Phive & & & & & & & \\
\hline Fis 4 & & & & & & & \\
\hline Nobit & & & & & & & \\
\hline $\sin 2$ & & & & & & & \\
\hline 7001 & & & & & & & \\
\hline ant:8 & & & & & & & \\
\hline Snit7 & & & & & & & \\
\hline Ruis: & & & & & & & \\
\hline telas? & & & & & & & \\
\hline ToLso & & & & & & & \\
\hline Dyl67 & & & & & & & \\
\hline Hedes & & & & & & & \\
\hline ras & & & & & & & \\
\hline inet & & & & & & & \\
\hline $\mathrm{x} b \mathrm{~s} 2 \mathrm{z}$ & & & & & & & \\
\hline Lul?s & & & & & & & \\
\hline
\end{tabular}




\begin{tabular}{|c|c|c|c|c|c|c|c|}
\hline \multicolumn{8}{|l|}{ Besce } \\
\hline $\begin{array}{c}\text { Ne. } \\
\text { Napr Ciscis } \\
\text { portis }\end{array}$ & $2 * 1$ & $9-2$ & $7-1$ & $x-1$ & $b_{-1}$ & $12-2$ & $1+-1$ \\
\hline $3 \mathrm{BO}_{3}$ & $453: 5$ & 51231 & 5.118 & 021 & $m 51$ & 4.1515 & $51 \times 7$ \\
\hline $\mathrm{vkt}_{3}$ & $0.1 t$ & 022 & $02:$ & L.A? & $\cot$ & a.s & 4.1: \\
\hline$x_{1}, 0$ & s9: & 213 & wes & 4.13 & 283 & t.Te & 1.5 \\
\hline wa & $9 \perp 1$ & 012 & 6.10 & $60 \%$ & 0.17 & .18 & tis \\
\hline Mro & $9 x 6$ & 023 & 625 & 5.14 & 0.18 & 20 & tes \\
\hline $3 \mathrm{H}_{2} \mathrm{O}$ & $1<s$ & 1586 & 1169 & 157 & $1<28$ & 1635 & 16 in \\
\hline 100 & 2ม.x & It & 432 & tusz & 19.ss & 20.24 & 2138 \\
\hline $\mathrm{K}_{0} \mathrm{O}$ & & 012 & 601 & - & . & . & ex \\
\hline $\mathrm{r}_{1} \mathrm{o}_{\mathrm{z}}$ & $a .3 t$ & . & $\omega=$ & $t=0$ & $\omega \omega$ & 3.00 & eal \\
\hline Fet: & 561 & if $<1$ & 252 & $54 t$ & 1081 & 1082 & 6.1 \\
\hline Toral & $96 \%$ & $100 \%$ & 5717 & $m \geq 3$ & m>5 & $94: 7$ & 9015 \\
\hline $\mathrm{x}_{6}$ & a if & a11 & $0: 9$ & $c 40$ & $6: 19$ & 210 & 647 \\
\hline L & oA: & $0+4$ & $\omega-2$ & C.AS & 0.44 & $=4.4$ & eAt \\
\hline $\mathrm{M} N$ & $\operatorname{six}$ & 73 & isci & M. 15 & $\pi \mathrm{n}$ & $72 \pi$ & 21.7e \\
\hline \multicolumn{8}{|l|}{$\begin{array}{l}\text { Trax } \\
\text { Auaras }\end{array}$} \\
\hline \multicolumn{8}{|l|}{ was: } \\
\hline socts & 1513 & & & & & & 1435 \\
\hline 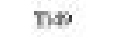 & 375.43 & & & & & & 155811 \\
\hline$v: t$ & 34483 & & & & & & $257+1$ \\
\hline $\mathrm{Cr} 2$ & 422520 & & & & & & sase? \\
\hline Nes & (7) & & & & & & Thas \\
\hline \multicolumn{8}{|l|}{ Csiss } \\
\hline abs: & $0 \pm 3$ & & & & & & $\cos$ \\
\hline Ral: & $a x$ & & & & & & \\
\hline \multicolumn{8}{|l|}{ Dris? } \\
\hline \multicolumn{8}{|l|}{ U253 } \\
\hline $\sin x$ & a.t & & & & & & \\
\hline \multicolumn{8}{|l|}{ Taisi } \\
\hline Lalbs & ass & & & & & & 4.13 \\
\hline Coln & $2.1 t$ & & & & & & ess \\
\hline Phines & $0 \leq 7$ & & & & & & $4 r$ \\
\hline Fris & $0 \leq 5$ & & & & & & 4 is \\
\hline Nabit & 4x: & & & & & & t.15 \\
\hline 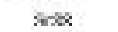 & nexi & & & & & & $139:$ \\
\hline 7ros & 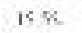 & & & & & & 76 \\
\hline Hil $: 8$ & 054 & & & & & & ess \\
\hline Snlt7 & 160 & & & & & & 6.73 \\
\hline Rats: & as: & & & & & & 67 \\
\hline sias: & 234 & & & & & & tst \\
\hline totso & 0.34 & & & & & & e.15 \\
\hline Dyls; & 276 & & & & & & 136 \\
\hline Hodes & as. & & & & & & 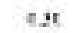 \\
\hline ras & 12.7 & & & & & & 743 \\
\hline Wiet & 1.41 & & & & & & $d x$ \\
\hline$x \operatorname{len} 2$ & 1.42 & & & & & & e.jy \\
\hline Lults & 018 & & & & & & $e x$ \\
\hline
\end{tabular}




\begin{tabular}{|c|c|c|c|c|c|c|c|}
\hline \multirow{2}{*}{ 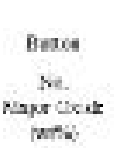 } & \multirow[b]{2}{*}{$\mathrm{L}-\mathrm{Z}$} & \multirow[b]{2}{*}{$1 / \ldots 2$} & \multirow[b]{2}{*}{$18 \ldots 1$} & \multicolumn{3}{|c|}{$\begin{array}{c}1+\mathrm{R} \cdot 2 \mathrm{~W} \cdot 9 \cdot \\
5 \mathrm{~B}\end{array}$} & \multirow[b]{2}{*}{$1 . .2$} \\
\hline & & & & -3.-1 & $2 \cdots 1$ & $m 2$ & \\
\hline $3 \mathrm{in}_{2}$ & 53512 & $514 x$ & eqA:s & 45.178 & 45.780 & 5135 & 456 \\
\hline $\mathrm{vkj}_{3}$ & 0.25 & $012:$ & $a w$ & {$[27$} & coso & 0.17 & e.1e \\
\hline$x_{1} \sigma$ & iss & 135 & $2: 00$ & 283 & 234 & 1.48 & $2 . A 3$ \\
\hline Sip & 9.8 & 922 & 605 & 6.19 & 634 & 2,49 & 421 \\
\hline $\mathrm{MrO}$ & 922 & 022 & 605 & 50 & 156 & 3. 5 & e.jt \\
\hline $\mathrm{SH}_{4} \mathrm{C}$ & 156 & 1567 & 1575 & 1576 & $1: 27$ & 1459 & $14 \%$ \\
\hline 100 & ince & $15: 2$ & $22 \times 5$ & 2219 & Iets & Stos & $150 \%$ \\
\hline $\mathrm{K}_{2} \mathrm{C}$ & 0.53 & 035 & 601 & [xa & 500 & bot & \\
\hline $\mathrm{r}_{1} \mathrm{O}$ & . & 034 & - & t.12 & & & ext \\
\hline Fed: & $16<1$ & $1 \leqslant 8$ & isi & 711 & 54 & 1165 & $111 \mathrm{in}$ \\
\hline Tral & 95,8 & $5 s$ & 5011 & ICC.17 & $\% 9$ & 100.41 & 9601 \\
\hline $\mathbf{x} 6$ & $0 I$ & 972 & a.s & cis & $c \pm 0$ & 211 & $4 \pi$ \\
\hline L & 0.43 & v-45 & $n-$ & $\mathrm{t} .44$ & 0.4 & M.43 & EAZ \\
\hline$M=$ & 7.57 & til is & 5351 & $5 x$ & $\pi . n$ & mo: & $\omega: 2$ \\
\hline \multirow{2}{*}{\multicolumn{8}{|c|}{$\begin{array}{l}\text { Trox } \\
\text { dueiats } \\
\text { ivos: }\end{array}$}} \\
\hline $\begin{array}{l}\text { wa: } \\
\text { sots }\end{array}$ & & & $1 e_{n}-6$ & & & 277ut & \\
\hline$n+3$ & & & כווריו & & & $2018 \times 3$ & \\
\hline V3L & & & Fue & & & 6.as & \\
\hline $\mathrm{Crz}$ & & & $x \cos 3$ & & & 25 & \\
\hline Nes & & & 5261 & & & bx & \\
\hline Csiss & & & & & & , 16 & \\
\hline Juse: & & & & & & 9.18 & \\
\hline Ral $:$ & & & & & & 1.54 & \\
\hline Dars? & & & & & & oil & \\
\hline 02:5 & & & & & & ned & \\
\hline $\sin x$ & & & 6al & & & 501 & \\
\hline Talsi & & & & & & & \\
\hline Jalsy & & & 6.5 & & & $9 . \pi$ & \\
\hline Csln & & & 625 & & & $3 \Omega$ & \\
\hline Phive & & & & & & sie & \\
\hline Fris & & & 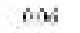 & & & $0 \%$ & \\
\hline Nobit & & & coss & & & 5.7 & \\
\hline $\sin$ & & & 169 & & & 1402 & \\
\hline 704 & & & 85 & & & 1782 & \\
\hline HAn $>8$ & & & 0.16 & & & $3 x 1$ & \\
\hline Snit7 & & & ov & & & $4 H$ & \\
\hline Ruts: & & & $0 \mathrm{Bg}$ & & & 116 & \\
\hline Evia? & & & $6 \div \div$ & & & 138 & \\
\hline DoLso & & & 0.13 & & & 1.30 & \\
\hline Dyls; & & & 6.95 & & & 1091 & \\
\hline Hedes & & & 6.18 & & & $2 x 6$ & \\
\hline ras & & & 4.52 & & & $\therefore A 2$ & \\
\hline Iried & & & 0.53 & & & 537 & \\
\hline xtes 12 & & & $6=5$ & & & $5 \times 1$ & \\
\hline Lul?s & & & wos & & & $n g$ & \\
\hline
\end{tabular}




\begin{tabular}{|c|c|c|c|c|c|c|c|}
\hline \multicolumn{8}{|l|}{ Besce } \\
\hline $\begin{array}{c}\text { Ne. } \\
\text { Napr Ciscil } \\
\text { portis }\end{array}$ & LE-? & $1:-2$ & Jt..1 & $-1-1$ & $y-1$ & 5400 & $23-2$ \\
\hline $3 i_{2}$ & 10.8 & 5142 & 40,21 & $45+10$ & $48 \pi$ & & 51 151 \\
\hline $\mathrm{vkj}_{3}$ & 0.35 & 021 & 62 & {$[.46$} & cus & & eI: \\
\hline$x_{1}, 6$ & 1.AZ & 125 & $1-7$ & 2.44 & 4.12 & & $2: 2$ \\
\hline wa & 925 & 034 & $6=1$ & 62 & 649 & & 4.78 \\
\hline Mro & 034 & ats & $68:$ & $\mathrm{f} . \mathrm{\theta}$ & 0.19 & & $4 \leq$ \\
\hline $\mathrm{SH}_{4} \mathrm{C}$ & $1<w$ & 1146 & 1764 & 1.11 & $1 \div 41$ & & $161:$ \\
\hline 100 & The & 2t.x & 4521 & $x \geq 1$ & $20 \times 0$ & & $15: 2$ \\
\hline $\mathrm{K}_{0} \mathrm{C}$ & & & $\omega=$ & t.13 & cee & & $6 x 4$ \\
\hline $\mathrm{x}_{1} \mathrm{O}$ & & ojs & & $\cos$ & & & \\
\hline $\mathrm{Fec}$. & oif & 947 & 273 & \|\| & 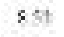 & & 50 \\
\hline Tral & 1033 & 535 & 5165 & 2319 & 9045 & & spss \\
\hline $\mathrm{x}_{6}$ & $a t$ & 919 & $a: a$ & $c 40$ & 643 & & 41 \\
\hline b & 0.44 & 0.41 & $u-1$ & t.A1 & D.A3 & & sat \\
\hline$M$ & $74 \Omega$ & $72 \mathrm{sI}$ & is: 1 & sen & ins & & $T E x:$ \\
\hline \multicolumn{8}{|l|}{$\begin{array}{l}\text { Traxt } \\
\text { Dueiats }\end{array}$} \\
\hline war: & & & & & & & \\
\hline 5045 & $24 x 0$ & & & & & 245.13 & \\
\hline$n+3$ & 349.14 & & & & & $m+\infty$ & \\
\hline Vst & $a_{b}, i_{4}$ & & & & & 81.16 & \\
\hline $\mathrm{Cr} 2$ & $4: 23$ & & & & & 3.14 & \\
\hline Nes & 3001 & & & & & 139 & \\
\hline Csis3 & ats & & & & & 30 & \\
\hline Juse & 2.85 & & & & & 3.T2 & \\
\hline Ral: & $18 \pi \vec{z}$ & & & & & $3 \%$ & \\
\hline Drat? & $92 \%$ & & & & & 60 & \\
\hline v25s & ast & & & & & 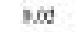 & \\
\hline $\sin x$ & $0.3 t$ & & & & & 100 & \\
\hline Taisi & as? & & & & & oin & \\
\hline Lal 38 & 151 & & & & & a.7i & \\
\hline Cstm & $4: 2$ & & & & & 3.40 & \\
\hline Phive & $a x=$ & & & & & 18 & \\
\hline Fis & ast & & & & & 87 & \\
\hline Nodest & 2.4 & & & & & 737 & \\
\hline$n * 2$ & xis: & & & & & 1921 & \\
\hline 704 & bia: & & & & & 1800 & \\
\hline Mn:s & 0.94 & & & & & 184 & \\
\hline Snit7 & ass & & & & & $3 \%$ & \\
\hline Buts: & a:? & & & & & $t \omega t$ & \\
\hline telas? & ass & & & & & or & \\
\hline totso & 0.4 & & & & & t.a4 & \\
\hline Dylas & 166 & & & & & 276 & \\
\hline Hedes & a.2 & & & & & 19i & \\
\hline ras & 853 & & & & & $470:$ & \\
\hline wee & 0.52 & & & & & 5.70 & \\
\hline $\mathrm{xtan} 2 \mathrm{z}$ & 182 & & & & & 540 & \\
\hline Lul?s & a.s & & & & & 3.12 & \\
\hline
\end{tabular}




\begin{tabular}{|c|c|c|c|c|c|c|c|}
\hline Besce & & $\begin{array}{c}7 \mathrm{k} \cdot 1 \% \mathrm{~s} \\
36\end{array}$ & & & & & \\
\hline $\begin{array}{l}\text { Ne. } \\
\text { Napr Cisiz } \\
\text { partis }\end{array}$ & 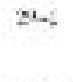 & --1 & $2-2$ & $3-9$ & $6-1$ & $\%$ & $8-1$ \\
\hline $3 \mathrm{in}_{2}$ & 51535 & 51211 & $48 \times 6$ & 1:.747 & secos & 5214 & 51525 \\
\hline $\mathrm{vkj}_{3}$ & 0.27 & 027 & $0 / 5$ & c.26 & c.16 & 2.13 & 4.12 \\
\hline$x_{1} \sigma$ & 1A: & 205 & 200 & 220 & 254 & 2.45 & 1..8 \\
\hline$x \rightarrow 0$ & 92. & 923 & $6<1$ & 62 ? & byt & 2.40 & 4.2 \\
\hline $\mathrm{MnO}$ & ast & 025 & 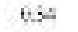 & 5,49 & 0.47 & 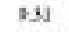 & 1.28 \\
\hline 340 & 1324 & $16+1$ & 137 & 1.8 & $1: 67$ & 1575 & $16 \%$ \\
\hline 120 & $1 \mathrm{ves}$ & $15 \mathrm{NC}$ & 2555 & 120 & susz & 1952 & 15.15 \\
\hline $\mathrm{K}_{0} \mathrm{C}$ & 0.14 & & 602 & & & 201 & $6 x-4$ \\
\hline $\mathrm{r}_{1} \mathrm{O}$ & 9.53 & 013 & wos & & 0.00 & sos & ess \\
\hline Fed: & 1105 & $\Delta 12$ & 275 & $11 \leqslant$ & $: \pi$ & 1055 & 48 \\
\hline Tral & 905 & 556 & אדי & IfC.11 & 97,35 & 9905 & sois \\
\hline $\mathbf{x} 6$ & a 35 & 972 & $6 x$ & $c 40$ & 643 & 1010 & 43 \\
\hline La & a.At & $0-4$ ? & $w=2$ & [. .41 & 0.45 & 1.44 & eA) \\
\hline$M=$ & 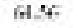 & $7 c .12$ & 11 נד & stat & $x .20$ & 72.11 & 79.17 \\
\hline \multicolumn{8}{|l|}{ Trax } \\
\hline \multirow{2}{*}{\multicolumn{8}{|c|}{$\begin{array}{l}\text { duarts } \\
\text { iys: }\end{array}$}} \\
\hline & & & & & & & \\
\hline 5045 & & & $12 x: 74$ & & & & \\
\hline$n+3$ & & & 55 & & & & \\
\hline VSL & & & 2450 & & & & \\
\hline $\mathrm{Cr} 2$ & & & 335 & & & & \\
\hline Nes & & & 3267 & & & & \\
\hline \multicolumn{8}{|l|}{ Csiss } \\
\hline Juse & & & wes & & & & \\
\hline Ral $:$ & & & 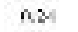 & & & & \\
\hline Drat? & & & 603 & & & & \\
\hline \multicolumn{8}{|l|}{0263} \\
\hline $\sin x$ & & & 6092 & & & & \\
\hline \multicolumn{8}{|l|}{ Taisi } \\
\hline Lal3s & & & 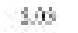 & & & & \\
\hline Csln & & & 8.16 & & & & \\
\hline Phive & & & Mas & & & & \\
\hline Fist & & & $|s|$ & & & & \\
\hline Nobit & & & 233 & & & & \\
\hline$n * 2$ & & & 751 & & & & \\
\hline 704 & & & 3175 & & & & \\
\hline Mn:s & & & 1.18 & & & & \\
\hline $3 n 147$ & & & $4 n$ & & & & \\
\hline Buts: & & & 115 & & & & \\
\hline Evias: & & & ث: & & & & \\
\hline Totso & & & 1.14 & & & & \\
\hline Dylls; & & & 20 & & & & \\
\hline Hedes & & & 1.00 & & & & \\
\hline ras & & & 11 55 & & & & \\
\hline Iriee & & & 4.77 & & & & \\
\hline 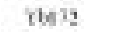 & & & 450 & & & & \\
\hline Lults & & & wo: & & & & \\
\hline
\end{tabular}




\begin{tabular}{|c|c|c|c|c|c|c|c|}
\hline \multicolumn{8}{|l|}{ Besce } \\
\hline \multicolumn{8}{|l|}{ 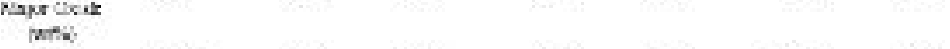 } \\
\hline $3 \mathrm{in}_{2}$ & 5) $5: 1$ & se 64 & 534 & 975 & sis & 4077 & $\sin$ \\
\hline $\mathrm{vkj}_{3}$ & $a t e$ & 039 & ad & c.21 & $\cos 8$ & 2.15 & 0.11 \\
\hline$x_{1}, 6$ & 5.97 & 155 & 405 & 2.12 & 23 & $3 x$ & $23:$ \\
\hline sa & 9.15 & 925 & $6 z$ & 629 & 6,47 & 9.42 & s.tst \\
\hline Mro & 9.9 & ass & 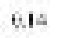 & tas & 150 & का & 42 \\
\hline $\mathrm{S}_{4} \mathrm{CO}$ & $1 \leqslant \%$ & 115 & 1535 & $15 \%$ & $1: 20$ & 1104 & $15 \alpha$ \\
\hline 120 & $21 x$ & שגו & $21 \%$ & tras & Is.15 & 20.72 & 11.76 \\
\hline $\mathrm{K}_{0} \mathrm{C}$ & & 9נ1 & & & 100 & $n \infty$ & ers \\
\hline $\mathrm{x}_{1} \mathrm{O}$ & an: & ass & $\omega w$ & $\mathrm{CNT}$ & 604 & nst & 6.00 \\
\hline $\mathrm{Fat}$. & 553 & 1715 & $0: ?$ & 1925 & 1007 & 746 & $11 \mathrm{x}$ \\
\hline Teal & 960 & 5534 & 5261 & $m \| 1$ & 90.26 & 583 & spins \\
\hline $\mathrm{x}_{6}$ & 0.15 & 977 & $0 \times 5$ & 616 & 640 & 214 & 435 \\
\hline L & o.At & 042 & $u-$ & t.As & 0.4 & 1.44 & eA3 \\
\hline$M$ & $\operatorname{san}, \mathrm{r}$ & $a$ is & 5167 & $\because n$ & $\pi n$ & 7816 & $m: t$ \\
\hline \multirow{2}{*}{\multicolumn{8}{|c|}{$\begin{array}{l}\text { Trax } \\
\text { Auevats }\end{array}$}} \\
\hline & & & & & & & \\
\hline \multicolumn{8}{|l|}{ wo: } \\
\hline \multicolumn{8}{|l|}{5045} \\
\hline \multicolumn{8}{|l|}{$n \neq$} \\
\hline \multicolumn{8}{|l|}{ vat } \\
\hline \multicolumn{8}{|l|}{$\mathrm{Cs} 2$} \\
\hline \multicolumn{8}{|l|}{ Nes } \\
\hline \multicolumn{8}{|l|}{ Csis3 } \\
\hline \multicolumn{8}{|l|}{ Muse } \\
\hline \multicolumn{8}{|l|}{ Tal: } \\
\hline \multicolumn{8}{|l|}{ Din: } \\
\hline \multicolumn{8}{|l|}{ vets } \\
\hline \multicolumn{8}{|l|}{$\sin x$} \\
\hline \multicolumn{8}{|l|}{ Taisi } \\
\hline \multicolumn{8}{|l|}{ Lal3s } \\
\hline \multicolumn{8}{|l|}{ Cston } \\
\hline \multicolumn{8}{|l|}{ Parits } \\
\hline \multicolumn{8}{|l|}{ Fos } \\
\hline \multicolumn{8}{|l|}{ Nabit } \\
\hline 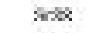 & & & & & & & \\
\hline 7ows & & & & & & & \\
\hline Anl $>8$ & & & & & & & \\
\hline $3 n 147$ & & & & & & & \\
\hline Buts: & & & & & & & \\
\hline Evias: & & & & & & & \\
\hline Tolso & & & & & & & \\
\hline Dylas & & & & & & & \\
\hline Hedts & & & & & & & \\
\hline ras & & & & & & & \\
\hline miet & & & & & & & \\
\hline kbis & & & & & & & \\
\hline Lut 78 & & & & & & & \\
\hline
\end{tabular}




\begin{tabular}{|c|c|c|c|c|c|c|c|}
\hline \multicolumn{8}{|l|}{ Besce } \\
\hline $\begin{array}{l}\text { Ne. } \\
\text { Napr Cisiz } \\
\text { partis }\end{array}$ & $16-:$ & $18-1$ & $15 . .1$ & $23 . .1$ & $21-1$ & $22-2$ & $23-1$ \\
\hline $30_{3}$ & 5010 & 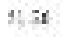 & 9355 & 075 & 51.53 & STAS & 9.35 \\
\hline $\mathrm{Vkj}_{3}$ & 0.31 & 022 & 011 & [.A3 & 327 & 0.12 & 2.5 \\
\hline $\mathrm{s}_{1} \mathrm{O}$. & 3.72 & 215 & 2.13 & $2 x s$ & {$[. A 1$} & t.16 & $2 x$ \\
\hline sio & $93^{7}$ & 035 & $6 \varkappa$ & 619 & $33 \pm$ & 235 & 42 \\
\hline $\mathrm{MrO}$ & 92. & 024 & t.1s & 526 & 398 & 3S1 & 457 \\
\hline $\mathrm{SH}_{4} \mathrm{O}$ & $14: 6$ & if 4 & 1631 & 1511 & 1487 & 1145 & $16: 1$ \\
\hline 100 & 247 & 15.45 & $2 t \mathrm{et}$ & IS5 & Iess & 12,43 & 18.16 \\
\hline$x_{0}=0$ & & 935 & $\omega=$ & & 500 & $1 \infty x$ & ext \\
\hline $\mathrm{x}_{1} \mathrm{O}$ & axt & 032 & ull & & $\cot$ & 3.06 & $6 x$ \\
\hline Fet: & $\theta<$ & 93 & 371 & 11 si & 1077 & 1132 & 110 \\
\hline Toal & 990 & $5 s \mathrm{~s}$ & 5133 & $m x$ & $58: 34$ & 9991 & 909 \\
\hline $\mathbf{x} 6$ & 917 & 911 & $0 \times 4$ & 638 & 210 & \pm 46 & 437 \\
\hline L & a.AZ & 0.45 & wis & t.A4 & 2.43 & 1.43 & eAt \\
\hline$M \infty$ & 7.71 & $\pi$ is & 5752 & $\sin$ & 71.as & 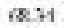 & $\pi c$ \\
\hline \multicolumn{8}{|l|}{$\begin{array}{l}\text { Traxi } \\
\text { Dueiats }\end{array}$} \\
\hline 5045 & & & & & $20+42$ & & \\
\hline$n+3$ & & & & & moe 92 & & \\
\hline$v: L$ & & & & & 20589 & & \\
\hline $\mathrm{crs}$ & & & & & 2.21 & & \\
\hline Nes & & & & & 50.50 & & \\
\hline Csis & & & & & 601 & & \\
\hline Juse & & & & & cos & & \\
\hline Ral: & & & & & 0.11 & & \\
\hline Drat? & & & & & 60 & & \\
\hline 0263 & & & & & 601 & & \\
\hline \multicolumn{8}{|l|}{$\sin x$} \\
\hline \multicolumn{8}{|l|}{ Talsi } \\
\hline Lalsy & & & & & $3 \leq 4$ & & \\
\hline Coln & & & & & 12.15 & & \\
\hline Paves & & & & & $t m$ & & \\
\hline Fris 4 & & & & & 356 & & \\
\hline Nodete & & & & & Iran & & \\
\hline sise & & & & & IEsa & & \\
\hline 7ows & & & & & $\approx N$ & & \\
\hline Mn:s & & & & & 2.19 & & \\
\hline Snit7 & & & & & 618 & & \\
\hline Ruis: & & & & & 11 10 & & \\
\hline Evis? & & & & & 8.1 & & \\
\hline toLso & & & & & 2.40 & & \\
\hline Dyis; & & & & & 678 & & \\
\hline Hedts & & & & & -99 & & \\
\hline ras & & & & & -7.54 & & \\
\hline inee & & & & & 2.49 & & \\
\hline kbis & & & & & $48 i$ & & \\
\hline Lulzs & & & & & c.x1 & & \\
\hline
\end{tabular}




\begin{tabular}{|c|c|c|c|c|c|c|}
\hline \multirow{2}{*}{$\begin{array}{c}\text { Busce } \\
\text { Ne. } \\
\text { papr Cicie } \\
\text { partis. }\end{array}$} & \multicolumn{3}{|c|}{$\begin{array}{c}\text { ME }- \text { W-18 } \\
21\end{array}$} & \multicolumn{3}{|c|}{$212-10:-4.18$} \\
\hline & 24 & +-2 & $1-1$ & $1-2$ & 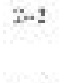 & $5 \omega 2$ \\
\hline $3 \mathrm{in}_{2}$ & $50+8$ & $9 ; 3$ & 45.35 & 3238 & 525 & 3) $-\pi$ \\
\hline $\mathrm{Vkj}_{3}$ & 0.21 & 021 & 225 & 0.19 & $\operatorname{con}$ & azs \\
\hline$x_{1}, 6$ & 153 & 033 & 223 & 0.23 & cxs & $5: 34$ \\
\hline sia & 932 & 923 & 3.3 & 0.33 & $6 \leq 4$ & a.15 \\
\hline SeD & 935 & 93? & 33 & 0.45 & $5-20$ & ats \\
\hline 340 & $14 \%$ & 11,5 & $15 \ldots$ & 1789 & 1. $\mathrm{BS}$ & $15 a^{\circ}$ \\
\hline 100 & 17.27 & $2 x .12$ & 11.78 & at.at & 345 : & 21.9 \\
\hline $\mathrm{x}_{0} \mathrm{C}$ & & & - & & ces & 260 \\
\hline$\alpha_{1} \sigma$ & $a x s$ & . & $3 \mathrm{CH}$ & & $\cos$ & ant \\
\hline Fei: & 1961 & 18 & $\theta+s$ & 935 & $6 \leqslant 4$ & 615 \\
\hline Teal & 96.19 & 566 & Ss, 75 & 4531 & 205 & 58.73 \\
\hline $\mathbf{x}_{6}$ & ax & a12 & 375 & 041 & $C+1$ & 946 \\
\hline L & 0.42 & $0-4 t$ & 143 & Q.43 & 6.47 & 2.44 \\
\hline$M \infty$ & เก $x$ & 65.77 & 616 & 7291 & $r s$ & 81.27 \\
\hline \multicolumn{7}{|l|}{$\begin{array}{l}\text { Trax } \\
\text { Juaw } 15\end{array}$} \\
\hline \multicolumn{7}{|l|}{ wo: } \\
\hline \multicolumn{7}{|l|}{ sots } \\
\hline \multicolumn{7}{|l|}{ 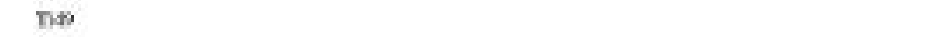 } \\
\hline \multicolumn{7}{|l|}{ vst } \\
\hline \multicolumn{7}{|l|}{$\mathrm{Cr} 2$} \\
\hline \multicolumn{7}{|l|}{ Nes } \\
\hline \multicolumn{7}{|l|}{ Csis3 } \\
\hline \multicolumn{7}{|l|}{ uss: } \\
\hline \multicolumn{7}{|l|}{ Ral: } \\
\hline \multicolumn{7}{|l|}{ Dow? } \\
\hline \multicolumn{7}{|l|}{ U2:5 } \\
\hline \multicolumn{7}{|l|}{$\sin x$} \\
\hline \multicolumn{7}{|l|}{ Taisi } \\
\hline \multicolumn{7}{|l|}{ Lalsy } \\
\hline \multicolumn{7}{|l|}{ coln } \\
\hline \multicolumn{7}{|l|}{ Phives } \\
\hline \multicolumn{7}{|l|}{ Fris } \\
\hline \multicolumn{7}{|l|}{ Nobet } \\
\hline $\sin x$ & & & & & & \\
\hline 7ow & & & & & & \\
\hline ant:8 & & & & & & \\
\hline $3 n 147$ & & & & & & \\
\hline Buis: & & & & & & \\
\hline Evias: & & & & & & \\
\hline Totso & & & & & & \\
\hline Dyles & & & & & & \\
\hline Hedes & & & & & & \\
\hline ras & & & & & & \\
\hline Diee & & & & & & \\
\hline $\mathrm{xb} x 2$ & & & & & & \\
\hline Lut? & & & & & & \\
\hline
\end{tabular}




\begin{tabular}{|c|c|c|c|c|c|c|}
\hline \multicolumn{7}{|l|}{ Besce } \\
\hline $\begin{array}{l}\text { Ne. } \\
\text { vipur cicue } \\
\text { partis }\end{array}$ & $x$ & $11-2$ & $12 \cdot .1$ & -4.4 & $16-2$ & s...1 \\
\hline $30_{3}$ & 5235 & 1) 36 & $\operatorname{sen} 5$ & 5150 & 3129 & 3301 \\
\hline$v_{k i_{1}}$ & wori & 017 & a.2: & 6.12 & $a . t e$ & $n: 2$ \\
\hline $\mathrm{s}_{1} \mathrm{C}$ & 6.4 & $3 n$ & 3.20 & $2 \mu$ & Lese & $4 ;-5$ \\
\hline $\mathrm{san}$ & 08 & 923 & $a z$ & $5: 15$ & 918 & 0 \\
\hline Mno & $\theta \infty$ & gut & $a z$ & $5: 4$ & 43 & 61 \\
\hline $\mathrm{H}_{40} \mathrm{O}$ & 1054 & $15 \%$ & 106 & $1 ; 81$ & 1115 & 1 , \\
\hline$\infty 0$ & 2152 & 21. & 2t.7t & 1055 & thos & 214 \\
\hline $\mathrm{K}_{0} \mathrm{C}$ & 601 & & & & $a x$ & \\
\hline$\alpha_{i} \sigma$. & $w e$ & 038 & ass & 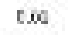 & & 6.11 \\
\hline Fai: & 1135 & $5 \mathrm{Hi}$ & 711 & $11 *$ & $A<s$ & $8: 1$ \\
\hline Teal & 9332 & 981 & 456 & $x: \nexists 1$ & 9693 & 5956 \\
\hline $\mathrm{x}_{6}$ & aes & 946 & $\theta *$ & (A) & 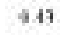 & 0.5 \\
\hline L & wst & u-ts & $u+$ & C.4. & A.AL & $w-2$ \\
\hline$M \infty$ & G:AI & sas: & 5.53 & ate & $72 C$ & 5 \\
\hline \multirow{2}{*}{\multicolumn{7}{|c|}{$\begin{array}{l}\text { Ther } \\
\text { Aasar is }\end{array}$}} \\
\hline & \\
\hline Sots & & & & & 174t2 & \\
\hline$n *$ & & & & & 1993.8 & \\
\hline 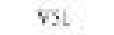 & & & & & LSs 32 & \\
\hline $\cos$ & & & & & $7: 1$ & \\
\hline Nes & & & & & 10.3 & \\
\hline \multicolumn{7}{|l|}{ Cis: } \\
\hline wos: & & & & & ass & \\
\hline Ralnt & & & & & ינד & \\
\hline Det? & & & & & 466 & \\
\hline 0268 & & & & & ase & \\
\hline \multicolumn{7}{|l|}{$x+2 x$} \\
\hline Ta181 & & & & & tod & \\
\hline Jalbs & & & & & 1St & \\
\hline $\mathrm{csln}$ & & & & & 19.9 & \\
\hline Phines & & & & & $A m$ & \\
\hline Foll & & & & & 784 & \\
\hline Natest & & & & & $1 \mathrm{k} . \mathrm{zI}$ & \\
\hline 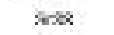 & & & & & 1122 & \\
\hline 7010 & & & & & tas & \\
\hline An $>8$ & & & & & the & \\
\hline Snit7 & & & & & sit & \\
\hline guts: & & & & & 116 & \\
\hline Evay? & & & & & 160 & \\
\hline tols & & & & & $12 t$ & \\
\hline Dystes & & & & & 168 & \\
\hline Hedes & & & & & L* & \\
\hline ros & & & & & te.16 & \\
\hline Wiet & & & & & 912 & \\
\hline xtes? & & & & & Set & \\
\hline Lults & & & & & 9.3 & \\
\hline
\end{tabular}




\begin{tabular}{|c|c|c|c|c|c|c|}
\hline \multicolumn{7}{|l|}{ Besce } \\
\hline \multicolumn{7}{|l|}{$\begin{array}{c}\text { Papr Ciscil } \\
\text { partis }\end{array}$} \\
\hline $30_{2}$ & 5117 & 5) 91 & 51 45 & 5137 & 391 & 9354 \\
\hline $\mathrm{vkj}_{3}$ & $\alpha z$ & on & ax: & 6.11 & 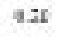 & 0.17 \\
\hline$x_{1}, 6$ & $1 \Omega$ & 057 & 1.77 & 2.10 & $2 A:$ & 2.65 \\
\hline sa & 62 & 931 & 023 & 524 & $9 y$ & $a s$ \\
\hline Mro & 60 & ass & $a *$ & $t 26$ & 928 & bis \\
\hline $\mathrm{S}_{4} \mathrm{CO}$ & 11 21 & 1360 & 1165 & $1-7$ & IS 06 & $\mid 151$ \\
\hline 120 & 1911 & at:o & $15 x$ & $\operatorname{sos}$ & $15 \times 1$ & 2393 \\
\hline $\mathrm{K}_{0} \mathrm{C}$ & $6 v 1$ & & a.31 & & & wol \\
\hline $\mathrm{x}_{1} \mathrm{O}$ & we & 015 & axs & 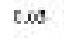 & 2.45 & \\
\hline $\mathrm{Fat}$. & 1512 & it sit & 1546 & 58 & $16 \% 7$ & $8 \otimes_{i}$ \\
\hline Tral & 160 at & $5 \pi \pi$ & $95 . A 6$ & $x \in$ \& & sens & 5145 \\
\hline $\mathrm{x}_{6}$ & $0 \times 0$ & 941 & $6 \pm 1$ & {$[4]$} & $A A$ & $c \times 3$ \\
\hline L & $w x$ & 053 & uss & $\mathrm{C} .43$ & 9.44 & $u=2$ \\
\hline$M N$ & $5: 41$ & 15.18 & $\operatorname{sen}$ & 7291 & $\pi 2 \%$ & 427 \\
\hline \multirow{2}{*}{\multicolumn{7}{|c|}{$\begin{array}{l}\text { Traxt } \\
\text { Ausia is }\end{array}$}} \\
\hline & & & & & & \\
\hline \multicolumn{7}{|l|}{ wo: } \\
\hline \multicolumn{7}{|l|}{5045} \\
\hline \multicolumn{7}{|l|}{$n \neq$} \\
\hline \multicolumn{7}{|l|}{ vat } \\
\hline \multicolumn{7}{|l|}{$\mathrm{csz}$} \\
\hline \multicolumn{7}{|l|}{ Nes } \\
\hline \multicolumn{7}{|l|}{ Csis3 } \\
\hline \multicolumn{7}{|l|}{ Muse } \\
\hline \multicolumn{7}{|l|}{ Tal: } \\
\hline \multicolumn{7}{|l|}{ Dow? } \\
\hline \multicolumn{7}{|l|}{ U2:s } \\
\hline \multicolumn{7}{|l|}{$\sin x$} \\
\hline \multicolumn{7}{|l|}{ Taisi } \\
\hline \multicolumn{7}{|l|}{ Lal3s } \\
\hline \multicolumn{7}{|l|}{ Cston } \\
\hline \multicolumn{7}{|l|}{ Perits } \\
\hline \multicolumn{7}{|l|}{ Fos } \\
\hline \multicolumn{7}{|l|}{ Nodete } \\
\hline 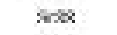 & & & & & & \\
\hline 7ows & & & & & & \\
\hline Hin $: 8$ & & & & & & \\
\hline $3 n 147$ & & & & & & \\
\hline Buts: & & & & & & \\
\hline Evias: & & & & & & \\
\hline tolso & & & & & & \\
\hline Dylat & & & & & & \\
\hline Hedes & & & & & & \\
\hline ras & & & & & & \\
\hline Iriee & & & & & & \\
\hline kbis & & & & & & \\
\hline Lut 78 & & & & & & \\
\hline
\end{tabular}




\begin{tabular}{|c|c|c|c|c|c|c|}
\hline \multirow{2}{*}{$\begin{array}{c}\text { Besce } \\
\text { Ne. } \\
\text { Napr cicis } \\
\text { parts. }\end{array}$} & \multicolumn{3}{|c|}{ 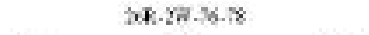 } & \multirow[b]{2}{*}{$4-1$} & \multirow[b]{2}{*}{ 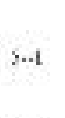 } & \multirow[b]{2}{*}{ in: } \\
\hline & $1 \cdots$ & $2-2$ & $5-5$ & & & \\
\hline $30_{3}$ & 5133 & 1) 68 & 566 & 511 & sate & 5103 \\
\hline $\mathrm{Vk}_{1}$ & $a x$ & an & a.1 & $\mathrm{cm}$ & a.xt & 0.22 \\
\hline $\mathrm{s}_{1} \mathrm{C}$. & ax: & $0 \mathrm{ss}$ & as & $t \pm t$ & an & $\omega=$ \\
\hline $\sin 0$ & 0.14 & 917 & 6.18 & 6.15 & 9.15 & 6.14 \\
\hline Mno & $6: x$ & 957 & $a x_{2}$ & 83 & 9.4 & us \\
\hline $\mathrm{M}_{4} \mathrm{O}$ & 1.74 & 1016 & $10 \%$ & $1 \times 32$ & $138 \%$ & tas \\
\hline$\infty$ & $30+4$ & $15: 31$ & $2 t d t$ & susz & 15:ss & 213 \\
\hline $\mathrm{K}_{2} \mathrm{E}$ & - & & a.31 & - & . & - \\
\hline$\sigma_{1} \sigma$. & - & Он & - & cese & ast & 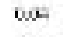 \\
\hline Fai: & 1111 & 1364 & 135 & 127 & 1255 & $3 a$ \\
\hline Toal & 953 & s.:it & 9534 & $m v$ & w:1 & 5957 \\
\hline $\bar{x}_{6}$ & aes & 938 & $6 * n$ & (4) & A1 & $\cdots 1$ \\
\hline L & $w-1$ & 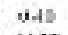 & $\omega \rightarrow \omega$ & c.40 & ass & $\sin$ \\
\hline$M \infty$ & 072 & ac: & 6915 & aish & $6 \%$ & ins \\
\hline \multirow{2}{*}{\multicolumn{7}{|c|}{$\begin{array}{l}\text { Thex } \\
\text { Alavar is }\end{array}$}} \\
\hline \multirow{2}{*}{\multicolumn{7}{|c|}{$\begin{array}{l}\text { Luavis } \\
\text { Wwa: }\end{array}$}} \\
\hline & & & & & & \\
\hline \multicolumn{7}{|l|}{$\operatorname{lot}_{15}$} \\
\hline \multicolumn{7}{|l|}{$n *$} \\
\hline \multicolumn{7}{|l|}{ vst } \\
\hline \multirow{2}{*}{\multicolumn{7}{|c|}{$\begin{array}{l}\mathrm{Cs} \\
\mathrm{Nes}\end{array}$}} \\
\hline \multirow{2}{*}{\multicolumn{7}{|c|}{$\begin{array}{l}\text { Nos } \\
\text { Csiss }\end{array}$}} \\
\hline & & & & & & \\
\hline \multicolumn{7}{|l|}{ uss: } \\
\hline \multicolumn{7}{|l|}{ Ral: } \\
\hline \multicolumn{7}{|l|}{ Dres: } \\
\hline \multirow{2}{*}{\multicolumn{7}{|c|}{$\begin{array}{l}0263 \\
\$ 120\end{array}$}} \\
\hline \multirow{2}{*}{\multicolumn{7}{|c|}{$\begin{array}{l}\text { She } \\
\operatorname{Ta1} 181\end{array}$}} \\
\hline \multirow{2}{*}{\multicolumn{7}{|c|}{ Jalse }} \\
\hline & & & & & & \\
\hline \multicolumn{7}{|l|}{ celn } \\
\hline \multicolumn{7}{|l|}{ Phines } \\
\hline \multicolumn{7}{|l|}{ Fris } \\
\hline \multirow{2}{*}{\multicolumn{7}{|c|}{$\begin{array}{l}\text { Natest } \\
\text { twas }\end{array}$}} \\
\hline & & & & & & \\
\hline 7001 & & & & & & \\
\hline Mn: & & & & & & \\
\hline $\begin{array}{l}\text { Snit7 } \\
\text { Rats: }\end{array}$ & & & & & & \\
\hline was? & & & & & & \\
\hline woLs & & & & & & \\
\hline Dyal6; & & & & & & \\
\hline Hedes & & & & & & \\
\hline ros & & & & & & \\
\hline $\begin{array}{l}\text { bree } \\
\text { the }\end{array}$ & & & & & & \\
\hline Luly & & & & & & \\
\hline
\end{tabular}




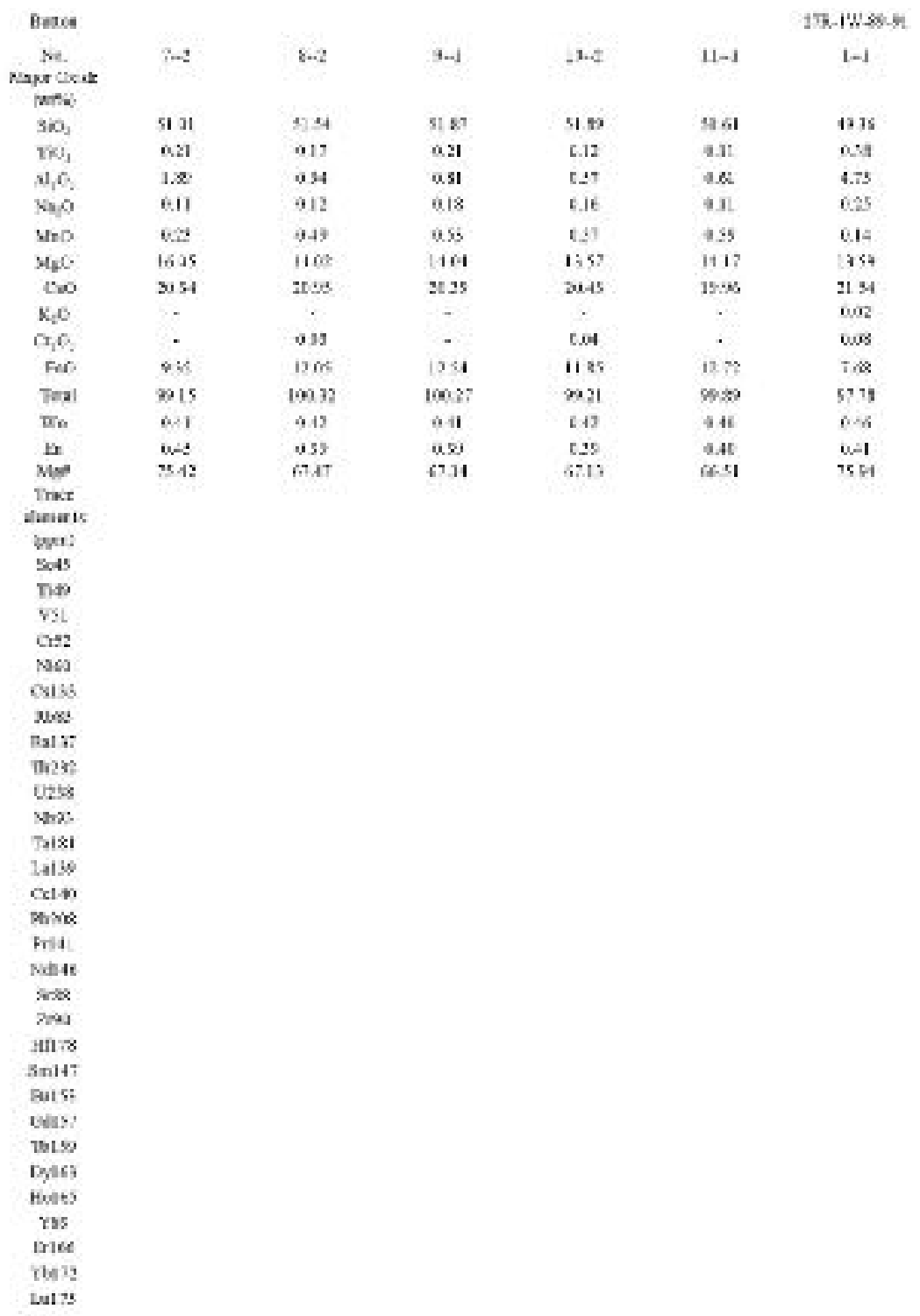




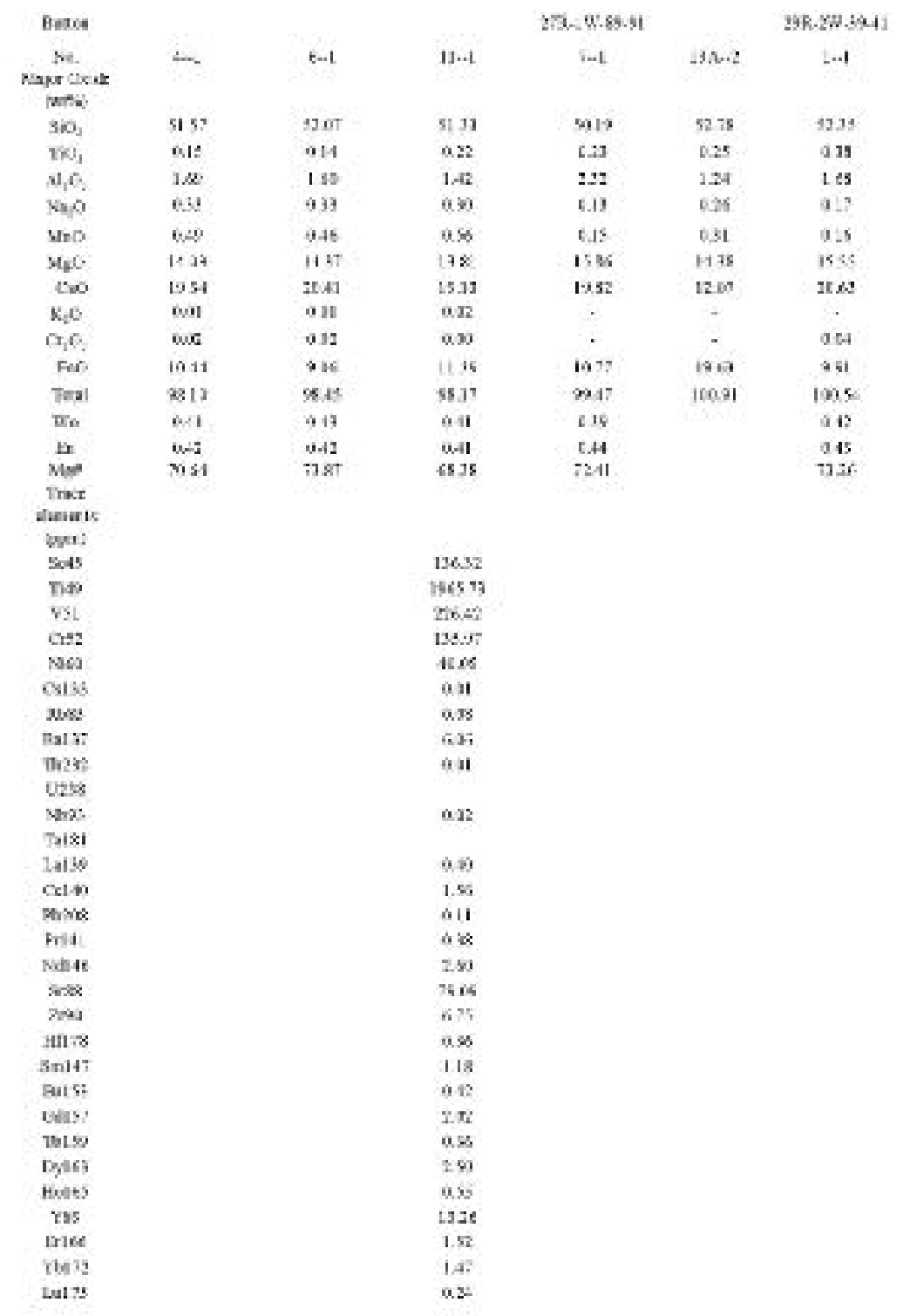




\begin{tabular}{|c|c|c|c|c|}
\hline \multicolumn{5}{|l|}{ Bence } \\
\hline 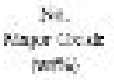 & -2 & $4 \cdots 1$ & $5-1$ & $i=1$ \\
\hline $3 b_{3}$ & 5139 & f) 58 & 456 & 595 \\
\hline $\mathrm{VKN}_{1}$ & a.t & נונם & a.s & c.11 \\
\hline $\mathrm{s}_{1} \mathrm{C}$. & 2.4. & 195 & a.xs & 43 \\
\hline \$wo & 0.0 & 913 & 0.12 & 50 \\
\hline Mno & 811 & 924 & QSW & 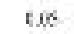 \\
\hline $\mathrm{r}_{40} \mathrm{O}$ & 1631 & 1537 & $10 x$ & 1615 \\
\hline is & 2153 & 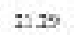 & $n$ & $2 x$ \\
\hline $\mathrm{K}_{2} \mathrm{E}$ & . & . & a.3 & . \\
\hline$\sigma_{1} \sigma$. & $6 x$ & 03 & a.to & tot \\
\hline Fai: & $s \omega$ & it $\%$ & $82 i$ & $51\}$ \\
\hline Teal & 837 & 10050 & 10016 & {$[E]$} \\
\hline $\bar{x}_{6}$ & o.t & 913 & ous & ctit \\
\hline 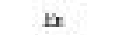 & wes & vat & wat & t.At \\
\hline$M \infty$ & x:95 & $72 \% 0$ & $c \pi$ & 2514 \\
\hline \multirow{2}{*}{\multicolumn{5}{|c|}{$\begin{array}{l}\text { Trax } \\
\text { dievaris }\end{array}$}} \\
\hline & & & & \\
\hline \multicolumn{5}{|l|}{ wo: } \\
\hline sots & Jit 24 & & & :2196 \\
\hline$n * s$ & 158231 & & & 183.8 \\
\hline$v s t$ & 2065 & & & $233 \mathrm{sz}$ \\
\hline $\mathrm{Cs}$ & tones & & & 53920 \\
\hline Nes & 145. & & & 1252 \\
\hline Cis: & 0.00 & & & $t \omega$ \\
\hline woss & $0: 2$ & & & we \\
\hline Ral: & $\omega s:$ & & & \\
\hline Dor? & & & & $c k$ \\
\hline \multicolumn{5}{|l|}{ Q26s } \\
\hline 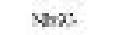 & wot & & & \\
\hline Ta181 & $6 x$ & & & \\
\hline Lalse & $6: 8$ & & & tite \\
\hline $\mathrm{celn} n$ & $1 . x$ & & & c.35 \\
\hline Pantes & sat & & & $t i s$ \\
\hline Fis & $0<5$ & & & 616 \\
\hline Nibet & 1.4 & & & tst \\
\hline $\sin x$ & 2511 & & & 1225 \\
\hline 7010 & 1283 & & & Iif \\
\hline Mn:s & we & & & 0.15 \\
\hline Snit7? & 1.14 & & & {$[32$} \\
\hline guis: & $0: 5$ & & & (6) \\
\hline tain? & 1.2. & & & t. .2 \\
\hline tolso & 62 & & & 5.14 \\
\hline Dylat & 184 & & & $m$ \\
\hline Hedes & 6 & & & ta2 \\
\hline ros & loss & & & 4.7e \\
\hline wee & 1.17 & & & cts \\
\hline 2tos? & 1.18 & & & 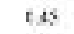 \\
\hline Lualy & 0.17 & & & $\mathrm{cst}$ \\
\hline
\end{tabular}


Apperdix to Major cecide (in a $\mathrm{r}^{\circ}$ )

\begin{tabular}{|c|c|c|c|c|c|c|c|c|c|c|c|c|c|c|c|}
\hline $\begin{array}{l}\text { Trane } \\
217 \text {. }\end{array}$ & wo & 500 & $\mathbf{n o} \mathbf{j}_{1}$ & $A O_{i}$ & $\mathrm{~m}_{\mathbf{a}} / 0$ & Wrot: & $\mathrm{se} ; 0$ & $c \times 0$ & $\boldsymbol{k} ; 0$ & 20 & Ex. & Tow I & Hot & $\omega r$ & $\mathrm{ra}$ \\
\hline \multirow{5}{*}{$\begin{array}{c}w-\alpha \\
*\end{array}$} & $\ldots 1$ & 5151 & 0.15 & ass & 604 & $-k$ & $21 . x$ & 18. & & $a n$ & 225? & joeid & 06 & cos & Uhit \\
\hline & $2 . .1$ & 92.16 & 6.12 & $1 \div 1$ & $\mathrm{wos}$ & c.7t & 2434 & $1 \mu$ & & & 1325 & nu: & tes & $\cos$ & as? \\
\hline & 42 & का & Cil & as? & nos & $t \times$ & 33.16 & $1 x^{2}$ & & & 2252 & wit & 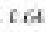 & $c m$ & n\&? \\
\hline & $2 \cdots 1$ & $x 2.49$ & 121 & 1.1 & 60 & tes & ו & 100 & & ass & 15:-1 & ate.w & $\cos$ & es & W:A \\
\hline & $+\ldots 2$ & yos & $\mathrm{c} 2 \mathrm{z}$ & 054 & $w e$ & $2 x$ & 2200 & 1.72 & tse & & 2217 & sen & 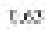 & ess & Dat \\
\hline \multirow{5}{*}{$\begin{array}{c}200- \\
6 N-80 \\
\$ \infty\end{array}$} & & & & & & & & & & & & & & & \\
\hline & $10:-$ & 5150 & c: $i s$ & 051 & wol & $: 21$ & $23: 9$ & $|\omega|$ & $\operatorname{coc}$ & & 2232 & $200 \pi$ & $\cos$ & $6 x$ & ast \\
\hline & $1 \Leftrightarrow 3$ & 5231 & $C N$ & 055 & $\cos$ & 136 & अ & $1 x$ & & 011 & 3257 & $306 \times i$ & $\cos$ & 60 & 0.63 \\
\hline & $1 x-1$ & 3054 & tat & osy & $w e$ & $\operatorname{sen}$ & 22.46 & 138 & & & 2525 & $200 \times 0$ & $(8)$ & 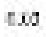 & vos \\
\hline & $=-1$ & 5257 & c.st & OA: & wot & $: 22$ & 22.41 & 1.12 & & & 2133 & ave.se & $\mathrm{t}, 28$ & $\mathrm{cs}$ & uss \\
\hline \multirow{15}{*}{$\begin{array}{c}206- \\
7 \cdots 13 \\
\text { is }\end{array}$} & & & & & & & & & & & & & & & \\
\hline & 12 & sase & cos & as: & $\cos 2$ & t. 6 & 3124 & 1.14 & 461 & & $25 \mathrm{Lt}$ & 10046 & cso & $c 00$ & $n s 8$ \\
\hline & $\times 1$ & 5178 & $c \mathrm{it}$ & $a \div c$ & nos & $t \pi$ & 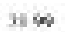 & $1 \%$ & & & $x+15$ & ireis & $6 \ldots$ & 619 & $n \leq 1$ \\
\hline & $10-$ & 5028 & t.tt & $0 \leq 5$ & 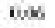 & $5 x$ & 119s & $1, \approx 8$ & & & $23 \mathrm{tI}$ & 25.29 & {$[x 3$} & 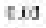 & ast \\
\hline & $1<-1$ & 5158. & $c x$ & 0.4 & $\sin 2$ & c.75 & 11.To & $1 \pi$ & & & 2312 & $1065 \%$ & $\csc$ & $c s$ & $n \in A$ \\
\hline & 16 & 5236 & $\mathrm{CMI}$ & os! & nil & in & ראר & 1.12 & & als & 2115 & 306.16 & $\cos$ & $\csc$ & $n \leqslant 1$ \\
\hline & $16-2$ & 5.31 & C.15 & 0.45 & $\cos 5$ & $t \Delta t$ & 26.72 & 1.16 & 50 & & $252 ?$ & 9055 & $0 \%$ & is & oss \\
\hline & $1 \pi-2$ & 2234 & ted & $0 . x$ & ewal & 520 & $21 \times 4$ & 1.16 & & & 2423 & $100.3 y$ & WB1 & $\operatorname{cs}$ & WA \\
\hline & $30-2$ & $52 \mu s$ & tex & 6.74 & wers & $t \mu$ & 24.84 & $1 / 20$ & & ant & $15 \leqslant 5$ & 2x]? & 0.00 & csa & uss \\
\hline & $x=$ & 9378 & & 45 & & 149 & 300 & 1,3 & & aM & 2511 & 100,5 & $\omega \infty$ & 60 & 0.5 \\
\hline & 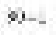 & 9241 & 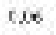 & Les & 60 & 1.16 & 22 ts & 1.20 & & & $22 \times 5$ & 100.16 & wot & $\omega$ & What \\
\hline & $31-2$ & $51 \mathrm{Az}$ & tex & $0 A 3$ & wes & 222 & 25.12 & $13 x$ & $t .01$ & an & $25 \mathrm{t2}$ & Ous: & $t \approx 9$ & $\mathrm{ced}$ & $\omega s$ ? \\
\hline & $\pi-2$ & 5151 & cos & 192 & $\cos$ & 167 & 29.06 & $1.2 \mathrm{a}$ & $\sec$ & & 1325 & noss & t.70 & $\cos$ & oss \\
\hline & at- 3 & $51 \mathrm{es}$ & $\mathrm{COH}$ & as: & nas? & 164 & $37 \leq 8$ & $1 m$ & & & $21<9$ & $\rightarrow$ is & $c \ldots$ & 600 & 061 \\
\hline & $*-1$ & |f 51 & t.15 & as: & $w$ & $t \times 4$ & $29=6$ & 184 & 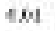 & an & 155s, & joesis & t. 1 & $\mathrm{CH}$ & Uas \\
\hline \multirow{3}{*}{$\begin{array}{c}138- \\
2 W-0 \\
120\end{array}$} & & & & & & & & & & & & & & & \\
\hline & $9 . .2$ & 5121 & tDI & 121 & was & $\tan$ & 2138 & 1,3 & 501 & - & 1357 & 306.4 & txat & cso & Q.5? \\
\hline & $16-2$ & sist & c:se & 126 & - & $\cos$ & 2234 & 1.24 & $|m|$ & aal & 217 & Jobinl & $\csc$ & 69 & $0<2$ \\
\hline \multirow{12}{*}{ s2. } & & & & & & & & & & & & & & & \\
\hline & -.1 & 5130 & t.1t & 18 & wes & 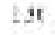 & 29100 & 1.20 & & & 2589 & $100-34$ & $\operatorname{cs} 8$ & $\mathrm{HS}$ & uss \\
\hline & 62 & y29x & (2) & aks & was & ist & 211 & $1 . x$ & ese & & 2245 & $100 x$ & $1 \times 4$ & ths & unz \\
\hline & $5 \cdot 2$ & 5118 & C.11 & 0.47 & $60 \mathrm{~s}$ & 1.33 & 1200 & 1.57 & & & 2295 & nst & 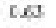 & 600 & 0.61 \\
\hline & 113 & 5214 & C.II & 245 & nos & ca & 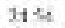 & 1.8 & 461 & & $12<8$ & कo it & $\cos$ & 69 & $0 \leqslant 3$ \\
\hline & 12. & ts $6 \mathrm{~T}$ & $\cos$ & 674 & 697 & $\pi$ & 3796 & 13 & 411 & & i1 3 & 2757 & 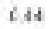 & $6 n$ & $0 d 7$ \\
\hline & $17=$ & 9236 & $2 x$ & 0.75 & 0.00 & 1.24 & 21.43 & 1200 & 60 & & 2281 & 30030 & $\omega$ & tos & 0.51 \\
\hline & $18-2$ & 51.51 & & $0.9 t$ & & 2.26 & 2280 & 1.11 & 601 & & ני וב & mil & cas & $6 x$ & $0 \leqslant 1$ \\
\hline & $21-$ & 51.16 & C.11 & 0.57 & wis & L.Ti & $13 \mathrm{No}$ & $1.5 \%$ & 401 & a.s & $22: 2$ & 7.sa & कat & 200 & $0 \leqslant 5$ \\
\hline & $2<-2$ & 5,54 & t.14 & 1.21 & 0.16 & $t, 61$ & $22 / 45$ & 1.96 & $\sec$ & 0.35 & 1397 & 95 & 667 & 504 & 0.65 \\
\hline & $x-1$ & 9128 & c.19 & est & 0.10 & 221 & 21.13 & 1.20 & & anz & 2925 & 200.50 & $t \Omega 8$ & 620 & ass \\
\hline & $2 \pi$ & 9.11 & C.19 & $a \& 3$ & nowi & t. It & 15.31 & $1 . x$ & $6 \mathrm{sin}$ & & $27 \%$ & $m A 1$ & ns & $\csc$ & $n \times s$ \\
\hline
\end{tabular}




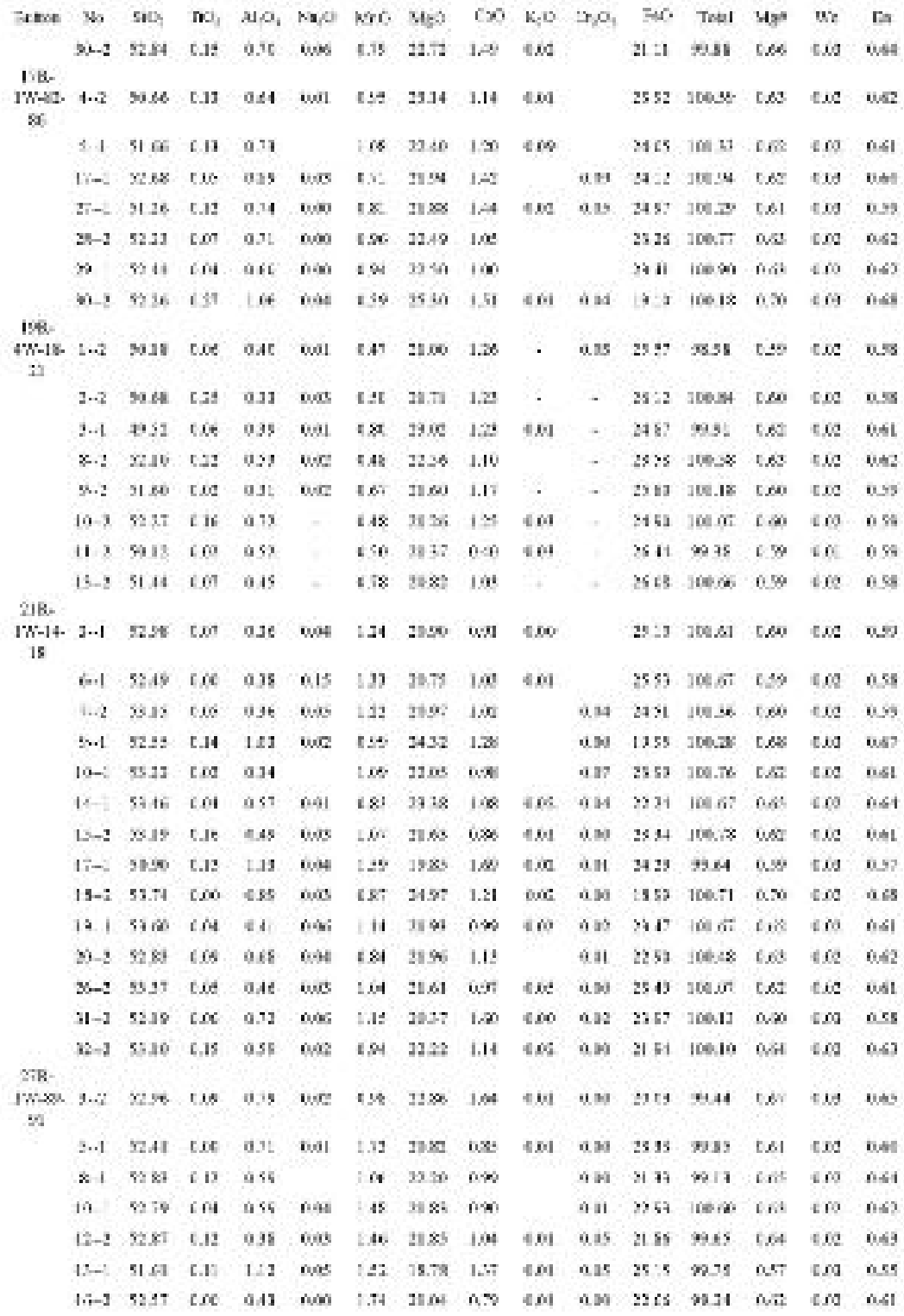




\begin{tabular}{|c|c|c|c|c|c|c|c|c|c|c|c|c|c|c|c|}
\hline ince & w & $\mathrm{Su} \mathrm{Cl}_{4}$ & $\mathrm{mos}_{3}$ & $x \sigma_{i}$ & $\mathrm{~N}_{\mathbf{a}} / 0$ & Mrr: & $\sec 0$ & $c x$ & $x ; 0$ & $\because x \mathrm{O}_{1}$ & EN. & Tow I & SW & $\mathrm{w}$ & $\mathrm{ra}$ \\
\hline $\begin{array}{l}\text { YFB- } \\
1 \%- \\
15 . \\
31\end{array}$ & $7 \approx$ & 5560 & 617 & ass & & $\{4\}$ & $32 \mathrm{~m}$ & 10 & & & $31 \leqslant 5$ & ine $x$ & 6,6 & 60 & 6SA \\
\hline & 5.1 & 58.61 & t.J & 0.71 & . & $t 4^{2}$ & 1199 & $\omega \%$ & $4 a$ & ass & 2275 & 306,48 & 628 & tes & 0.2 \\
\hline & $k=1$ & 2817 & t.13 & 054 & wol & t. & 21.17 & we & . & - & $21: 5$ & xust & tes & $c \mu$ & us \\
\hline & $2-2$ & 52.11 & ces & $0 . A t$ & - & 567 & $21.4 t$ & $0=6$ & 501 & ast & $24: 3$ & ross & {$[86]$} & $6 x$ & 0.6 \\
\hline 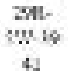 & 5. 1 & 5536 & ( is & 053 & 6a? & 63 & 3487 & $1 \%$ & $\cos$ & & 1968 & $360 \mathrm{~s}$ & $c: s$ & 200 & $0 \mathrm{x}$ \\
\hline & x.1 & 9591 & t15 & ast & $\cos$ & I.AS & 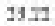 & 1.17 & 6.24 & $a \pi z$ & 2E.S & $106 x$ & $c x$ & ex & 0.4 \\
\hline & 9.2 & 5256 & [.11 & 0.33 & fous & {$[s / s$} & 2125 & wy: & . & all & 254 & $106 \pi$ & {$[\%]$} & $\csc$ & o.s \\
\hline & $1:-2$ & 5.100 & C.15 & $1 \mathrm{cc}$ & 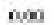 & 6.5 & 21.76 & $1 . \pi$ & . & . & רנב2 & seesc & $\cos$ & $69]$ & $0 \leq 5$ \\
\hline
\end{tabular}




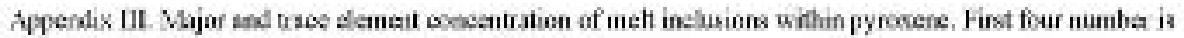
the cocs sample then the minerial and bstly the inclusion

\begin{tabular}{|c|c|c|c|c|c|c|c|}
\hline Na. & $\begin{array}{c}\text { wx-Tw-1:- } \\
\mid \text { |S.9-1 }\end{array}$ & $\underset{15-21-1}{200-211}$ & 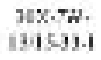 & $\underset{1 \leq x-1}{a x-12}$ & $\begin{array}{c}1+7-3 w: 31 . \\
5 \leq-4-1\end{array}$ & $\begin{array}{c}14 k \cdot 2 \pi \cdot 51 \cdot \\
51-32+1-1\end{array}$ & $\begin{array}{l}\text { A6-iW:1. } \\
50-10:\end{array}$ \\
\hline \multicolumn{8}{|l|}{$\begin{array}{l}\text { Ylow } \\
\text { soud: } \\
\text { rentis }\end{array}$} \\
\hline $\mathrm{sO}_{3}$ & $\csc 2$ & 55.95 & 58 & 6.14 & 43 & 2023 & 13. $x=$ \\
\hline$T x_{3}$ & 2.46 & as? & $t .88$ & 395 & $67 s$ & t $t z$ & \\
\hline $\mathrm{u}_{3} \mathrm{O}_{\mathrm{\gamma}}$ & 13.16 & $13: 4$ & $\mid k, 2)$ & t6.11 & 2215 & Iuss & 24.ss \\
\hline No 0 & 9.25 & $1 . \pi 7$ & $2 k \mathrm{~s}$ & 123 & 1.25 & 200 & ast \\
\hline Mnd & 914 & ax & 63 & 3's & 612 & $\cos$ & an \\
\hline$x_{5}=0$ & 202 & $0 \times z$ & 196 & $3 H$ & $6 x_{2}$ & $\bullet .11$ & ast \\
\hline 600 & 3.46 & 3.13 & יני & $5+7$ & 2.72 & 524 & : 8.11 \\
\hline $\mathrm{K} \infty \mathrm{C}$ & 27 & 1.1.5 & 826 & 38 & 1.85 & $24 r$ & ats \\
\hline $\mathrm{C}_{1} \mathrm{~B}_{1}$ & & aas & $6 / 6$ & $x: 3$ & bos & on & \\
\hline$D$, & 9 is & 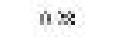 & A IT & 158 & $\mathrm{BI}$ & C to & \\
\hline The. & 491 & sits. & 500 & 435 & $2 \%$ & צy & 031 \\
\hline a & 43 & 621 & til & 332 & $0 x$ & is & $\operatorname{ac}$ \\
\hline 509 & $9: 6$ & $\alpha q$ & c3s & $a[3$ & $\cos$ & {$[0]$} & 94 \\
\hline $\tan x$ & ns? & 32.4 & tis. $x$ & \%.dy & 85.7 & $\$ 90$ & y8.5I \\
\hline \multirow{2}{*}{\multicolumn{8}{|c|}{$\begin{array}{l}\text { Twos } \\
\text { daval. }\end{array}$}} \\
\hline & & & & & & & \\
\hline \multirow{2}{*}{\multicolumn{8}{|c|}{$\begin{array}{l}\text { TEN } \\
\text { Sxis }\end{array}$}} \\
\hline & & & & & & & \\
\hline \multicolumn{8}{|l|}{ Tes } \\
\hline \multicolumn{8}{|l|}{ VS1 } \\
\hline \multicolumn{8}{|l|}{$\mathrm{Crs} 2$} \\
\hline \multicolumn{8}{|l|}{ MaE } \\
\hline \multicolumn{8}{|l|}{ CSLSS } \\
\hline \multicolumn{8}{|l|}{ sess } \\
\hline \multicolumn{8}{|l|}{ Eat3? } \\
\hline \multicolumn{8}{|l|}{$\mathrm{T} 252$} \\
\hline \multirow{2}{*}{\multicolumn{8}{|c|}{ 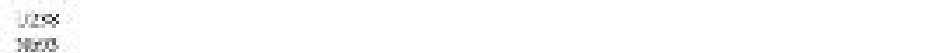 }} \\
\hline \multirow{2}{*}{\multicolumn{8}{|c|}{ Sisi }} \\
\hline & & & & & & & \\
\hline \multicolumn{8}{|l|}{ salso } \\
\hline \multicolumn{8}{|l|}{ disi } \\
\hline \multicolumn{8}{|l|}{ SOSOS } \\
\hline \multicolumn{8}{|l|}{ Priat } \\
\hline \multirow{2}{*}{\multicolumn{8}{|c|}{$\begin{array}{c}\text { Nest } \\
\text { Sett }\end{array}$}} \\
\hline & & & & & & & \\
\hline \multicolumn{8}{|l|}{$x>0$} \\
\hline \multicolumn{8}{|l|}{ Itams } \\
\hline \multicolumn{8}{|l|}{5 Sn147 } \\
\hline natss & & & & & & & \\
\hline colst & & & & & & & \\
\hline Iblas & & & & & & & \\
\hline$D_{2} 163$ & & & & & & & \\
\hline itedes & & & & & & & \\
\hline$\gamma 58$ & & & & & & & \\
\hline buses. & & & & & & & \\
\hline rtass & & & & & & & \\
\hline 2.3125 & & & & & & & \\
\hline
\end{tabular}




\begin{tabular}{|c|c|c|c|c|c|c|c|}
\hline Na. & 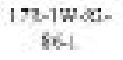 & 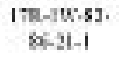 & $\begin{array}{c}16 x .72 .17 \\
15.162\end{array}$ & $\begin{array}{c}14 \pi-2 . W 61- \\
\$ 3.1-1\end{array}$ & $\begin{array}{c}1-7-36:-31- \\
39.11-1\end{array}$ & $\begin{array}{c}14 \mathrm{k} \cdot 2 \mathrm{2W} \cdot 51 \cdot \\
53.17 \cdot 2\end{array}$ & $\begin{array}{c}210.1 W-1< \\
\text { is.3.1 }\end{array}$ \\
\hline \multicolumn{8}{|l|}{$\begin{array}{l}\text { Show } \\
\text { soud: } \\
\text { rets }\end{array}$} \\
\hline $\mathrm{SN}_{2}$ & 9367 & 52.16 & $55+4$ & 4.40 & 6129 & S1At & א \\
\hline $\mathrm{TAO}$ & $166^{\circ}$ & $\mu \neq s$ & +20 & 123 & 62 & {$[4]$} & $2: 3$ \\
\hline $\mathrm{A}_{3} \mathrm{O}_{\mathrm{\gamma}}$ & $34 \times 2$ & $15: 32$ & 1-1. & $12 . \mu 1$ & 2352 & 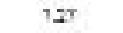 & :1.מ1 \\
\hline Nipo & 3.34 & 3.45 & 257 & $1 \pi$ & 2.65 & 23 & 115 \\
\hline Hes & 915 & a.21 & C.13 & 345 & (1)25 & 168 & $a u$ \\
\hline$x_{50}$ & 294 & wes & $1 / 2$ & 325 & 281 & 1005 & 245 \\
\hline 600 & $-2: 4$ & 3.15 & 2.1: & 221 & 4.11 & 233 & LAT \\
\hline$K \circ$ & 1.12 & $1 . x$ & 2.6 & 35: & 15i & $t \leq 2$ & 290 \\
\hline$c_{p} b_{1}$ & $a m$ & aos & $\cos$ & III & & & 960 \\
\hline$D \Omega$ & 467 & o19 & 6.14 & 36 & $\mathrm{Ast}$ & 607 & 901 \\
\hline 70,0 , & $\Delta y$ & 4. $x$ & 4.14 & 251 & $\forall:$ & 12,73 & $\triangle \boldsymbol{p}$ \\
\hline$a$ & 455 & a) & tSA & 325 & $0 \times 0$ & is & $a x$ \\
\hline sca & $9 \mathrm{~m}$ & $a x$ & $\cos$ & III & $\cos$ & rot & ab \\
\hline $\tan x$ & 55.18 & 92.45 & 4.3. & sent & $54, \mathrm{t}$ & $\alpha+1$ & yijos \\
\hline \multirow{2}{*}{\multicolumn{8}{|c|}{$\begin{array}{l}\text { Twe: } \\
\text { danal. } \\
\text { Trm! }\end{array}$}} \\
\hline & & & & & & & \\
\hline So:15 & & & & & $52 \theta$ & & \\
\hline $\mathrm{T} D \mathrm{~J}$ & & & & & 422335 & & \\
\hline Vsi & & & & & 171.72 & & \\
\hline $\mathrm{Crs2}$ & & & & & 1151 & & \\
\hline NaE & & & & & 57 & & \\
\hline Criss & & & & & $v=z$ & & \\
\hline Mess & & & & & $\because: 21$ & & \\
\hline Eat3? & & & & & 5952 & & \\
\hline Ta2s: & & & & & nev; & & \\
\hline$x<\infty$ & & & & & $v=x$ & & \\
\hline wars & & & & & $a r y$ & & \\
\hline 7131 & & & & & 813 & & \\
\hline Ialso & & & & & 602 & & \\
\hline oist & & & & & 1337 & & \\
\hline SNOS & & & & & 12 & & \\
\hline mat & & & & & 1.20: & & \\
\hline Neste & & & & & 5.93 & & \\
\hline sets & & & & & 2152 & & \\
\hline$x \geqslant 0$ & & & & & ists & & \\
\hline בละ & & & & & 2.14 & & \\
\hline $5 n \mid 47$ & & & & & 1.25 & & \\
\hline tratss & & & & & $a \geqslant$ & & \\
\hline Golst & & & & & $3 \%$ & & \\
\hline Thlos & & & & & $\omega=2$ & & \\
\hline$D_{3} 163$ & & & & & 150 & & \\
\hline Iteses & & & & & $\omega$ & & \\
\hline$\gamma s 8$ & & & & & 1972 & & \\
\hline Euses. & & & & & 2.59 & & \\
\hline rtass & & & & & 3. -1 & & \\
\hline 20125 & & & & & 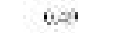 & & \\
\hline
\end{tabular}




\begin{tabular}{|c|c|c|c|c|c|c|c|}
\hline Na. & $\begin{array}{c}217-1 w \cdot 14- \\
13.3 .2\end{array}$ & $\begin{array}{c}218-16:-1 \\
18-6\end{array}$ & $\begin{array}{c}2 \mathrm{TR} \cdot 1 \mathrm{R} \cdot 1 \mathrm{C} \\
13.14 \mathrm{C}\end{array}$ & ${ }_{18,4}^{21}-1 \%-14-$ & $\begin{array}{c}217-w: 34- \\
16.15-1\end{array}$ & $\begin{array}{c}21 k \cdot 1 \pi+14 . \\
13-16-4\end{array}$ & $\begin{array}{c}21 k \cdot 1 W \cdot 1< \\
18-16-2\end{array}$ \\
\hline \multicolumn{8}{|l|}{$\begin{array}{l}\text { Your } \\
\text { soud: } \\
\text { retsin }\end{array}$} \\
\hline $\mathrm{SNO}_{3}$ & 73.92 & $71 \mathrm{sx}$ & 2019 & $7 \pi 20$ & 22 & .5 .52 & \\
\hline $\operatorname{Tx})_{3}$ & 0.25 & 021 & t.19 & 345 & 6.18 & 1.44 & $a x$ \\
\hline $\mathrm{U}_{3} \mathrm{O}_{\mathrm{\gamma}}$ & 11.23 & $12: 3$ & 122. & $12 \mu \mathrm{E}$ & $2 \mathrm{tt}$ & $12 x$ & 31.07 \\
\hline Nopo & 1.53 & 253 & $1 . \pi$ & $3: 5$ & $12 \pi$ & 2.44 & 146 \\
\hline $\mathrm{MnD}$ & aII & 8.11 & 6.54 & $3 \mathrm{CH}$ & $6 \%$ & cot & a:1 \\
\hline$x_{50}$ & ast & as: & 5.16 & $3 \cdot 3$ & $u=$ & 520 & 223 \\
\hline 600 & 1.45 & 1.7 & $2 x$ & 151 & 1.72 & $2 \mu$ & 1.50 \\
\hline$k \in$ & $2 \pi 2$ & $2 n$ & $2 x 4$ & 275 & $2.5 \mathrm{i}$ & 2.6 & $24 t$ \\
\hline$a_{y} a_{1}$ & & & & & oos & & \\
\hline$D \Omega$, & $46 \pi$ & 60: & 64 & 362 & $\mathrm{nat}$ & $\mathrm{cot}$ & 96 \\
\hline 70,6 & 280 & 2.8 & 2.44 & $2: 4$ & 2.05 & $2 x$ & 216 \\
\hline a & ast & 627 & $t 50$ & 323 & $0 \times$ & 615 & 93 \\
\hline 509 & 9.4 & 000 & {$[m]$} & $35 s$ & 692 & r no & 9: \\
\hline Ivex & $56 \leq 1$ & 92,24 & 31.2 & $24: 1$ & 32.25 & ?4:3? & 54.75 \\
\hline \multicolumn{8}{|l|}{$\begin{array}{l}\text { Twor: } \\
\text { danal. } \\
\text { Trat! }\end{array}$} \\
\hline se:15 & & 160 & nas: & & & & \\
\hline 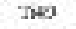 & & 200.23 & $18 \pi .11$ & & & & \\
\hline Vsi & & נג & $51 / 25$ & & & & \\
\hline Crs2 & & 1.91 & 544 & & & & \\
\hline NaEs & & 97 & 317 & & & & \\
\hline CSLES & & wots & 5.48 & & & & \\
\hline Mess & & 1.- 2 & 21.46 & & & & \\
\hline Eat3? & & 648 & its is & & & & \\
\hline $\mathrm{Tn} 252$ & & ast & 23 & & & & \\
\hline ves & & 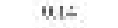 & 124 & & & & \\
\hline swese & & $u \pi$ & :.14 & & & & \\
\hline ડisi & & 001 & 40 & & & & \\
\hline Ja1so & & 1755 & $5 \%$ & & & & \\
\hline$\alpha(s)$ & & 7616 & $1: 31$ & & & & \\
\hline SOSOS & & QLL & 2.4 & & & & \\
\hline Frit! & & t5: & $3 x$ & & & & \\
\hline Nest & & $26: 2$ & 110 & & & & \\
\hline stet & & 1220 & 4211 & & & & \\
\hline $8 \geqslant 0$ & & suts & 4,13 & & & & \\
\hline $\sin x$ & & $a \pi$ & 1.72 & & & & \\
\hline $5=147$ & & 530 & 160 & & & & \\
\hline natss & & ast & 636 & & & & \\
\hline Cots? & & $\$ 51$ & $2 \mathrm{M}$ & & & & \\
\hline THLSS & & 0.4 & 520 & & & & \\
\hline $\mathrm{C}_{3} 163$ & & 4.51 & $2, \pi 3$ & & & & \\
\hline Iteses & & uss & 524 & & & & \\
\hline$\gamma 58$ & & 21.9 & 1.22 & & & & \\
\hline buses. & & $2 x:$ & 2.12 & & & & \\
\hline rtass & & 13 & 267 & & & & \\
\hline -at2s & & $\alpha=$ & 5,44 & & & & \\
\hline
\end{tabular}




\begin{tabular}{|c|c|c|c|c|c|c|c|}
\hline Na. & $\begin{array}{c}217-1 w \cdot 14- \\
13.30\end{array}$ & $\begin{array}{c}218-10:-1 \\
1 \leqslant-3)\end{array}$ & 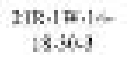 & $\underset{181.1}{210-1}$ & $\begin{array}{c}217-6: 34 \\
15.31-2\end{array}$ & $\begin{array}{c}210 \cdot 1 \% \cdot 14 \\
13.45-2\end{array}$ & $\begin{array}{c}21 \mathrm{k} \cdot 1 \mathrm{~W} \cdot 1 \\
18.39 .3\end{array}$ \\
\hline \multicolumn{8}{|l|}{$\begin{array}{l}\text { Ylow } \\
\text { voud: } \\
\text { retis }\end{array}$} \\
\hline $\mathrm{SO}_{2}$ & 72.18 & $52: 1$ & 5230 & 627 & 677 & $71 . x$ & 1.00 \\
\hline $\operatorname{Tn} \hat{O}_{3}$ & 2.4t & 1.55 & tys & 34 & $6+5$ & t 35 & 2.25 \\
\hline $\mathrm{Al}_{3} \mathrm{O}_{\mathrm{z}}$ & 1124 & te.ss & $14 \pi$ & T111 & 2351 & 12.25 & 21.00 \\
\hline Noso & 3.06 & 256 & 2.74 & 353 & 2.00 & 127 & 262 \\
\hline $\mathrm{MnD}$ & 965 & avi & 638 & 395 & 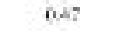 & 100 & $a w$ \\
\hline$x_{50}$ & 9.15 & 3al & $3: 42$ & 584 & 4.5 & t.1. & a.s \\
\hline 600 & 3.45 & 7.38 & $7 x=$ & $5: 5$ & 2.25 & $22 \pi$ & 1.54 \\
\hline$k 0$ & 2.4 & $u z$ & r.2 & 392 & cos & 260 & $2 \pi$ \\
\hline$C_{1} b_{1}$ & & & $\cos$ & & & iot & \\
\hline$D A$, & 13 & $\hat{a}<k$ & $t \omega_{i}$ & 265 & oin & $c a$ & \\
\hline 706, & $z s t$ & 112 & 12x & $11: \%$ & $-35 s$ & 2.11 & 20 \\
\hline$a$ & 93 & ois & t. 10 & 3.7 & 013 & 615 & 924 \\
\hline 509 & 960 & $a y$ & 634 & 304 & 697 & $5 n$ & $9: 4$ \\
\hline Iute & 5613 & 3e. & $\Delta x$ & 9,4 ? & $5: 75$ & $\alpha \cdot 2$ & Se.so \\
\hline Two & & & & & & & \\
\hline \multicolumn{8}{|l|}{$\begin{array}{l}\text { danal. } \\
\text { TFW! }\end{array}$} \\
\hline sels & $s \leqslant 1$ is & & & & & & \\
\hline 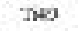 & 2355.7 & & & & & & \\
\hline VSI & 1005? & & & & & & \\
\hline crs2 & 912 & & & & & & \\
\hline NaE & 1781 & & & & & & \\
\hline CiLSS & $a w^{\prime}$ & & & & & & \\
\hline Mess & 5.120 & & & & & & \\
\hline Eat3? & 39.95 & & & & & & \\
\hline 73252 & 447 & & & & & & \\
\hline$x \in \infty$ & $x:$ ? & & & & & & \\
\hline $\operatorname{sers}$ & a.27 & & & & & & \\
\hline \multicolumn{8}{|l|}{ DI31 } \\
\hline Salso & $17: 3$ & & & & & & \\
\hline$\alpha(s)$ & 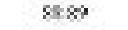 & & & & & & \\
\hline NOSOS & In: & & & & & & \\
\hline Fritl & 12.1\% & & & & & & \\
\hline Nest & 2501 & & & & & & \\
\hline sets & $11 / 20$ & & & & & & \\
\hline$y \geqslant 0$ & 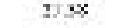 & & & & & & \\
\hline ata & 9.37 & & & & & & \\
\hline 5 Sn 147 & 3495 & & & & & & \\
\hline ratss & 275 & & & & & & \\
\hline Do:57 & $11 \%$ & & & & & & \\
\hline ralse & 221 & & & & & & \\
\hline$D_{3} 163$ & $14: 38$ & & & & & & \\
\hline Iteses & 3.43 & & & & & & \\
\hline$\gamma 55$ & 12.76 & & & & & & \\
\hline buses & x.t & & & & & & \\
\hline rtasz & 1.35 & & & & & & \\
\hline 20125 & lit & & & & & & \\
\hline
\end{tabular}




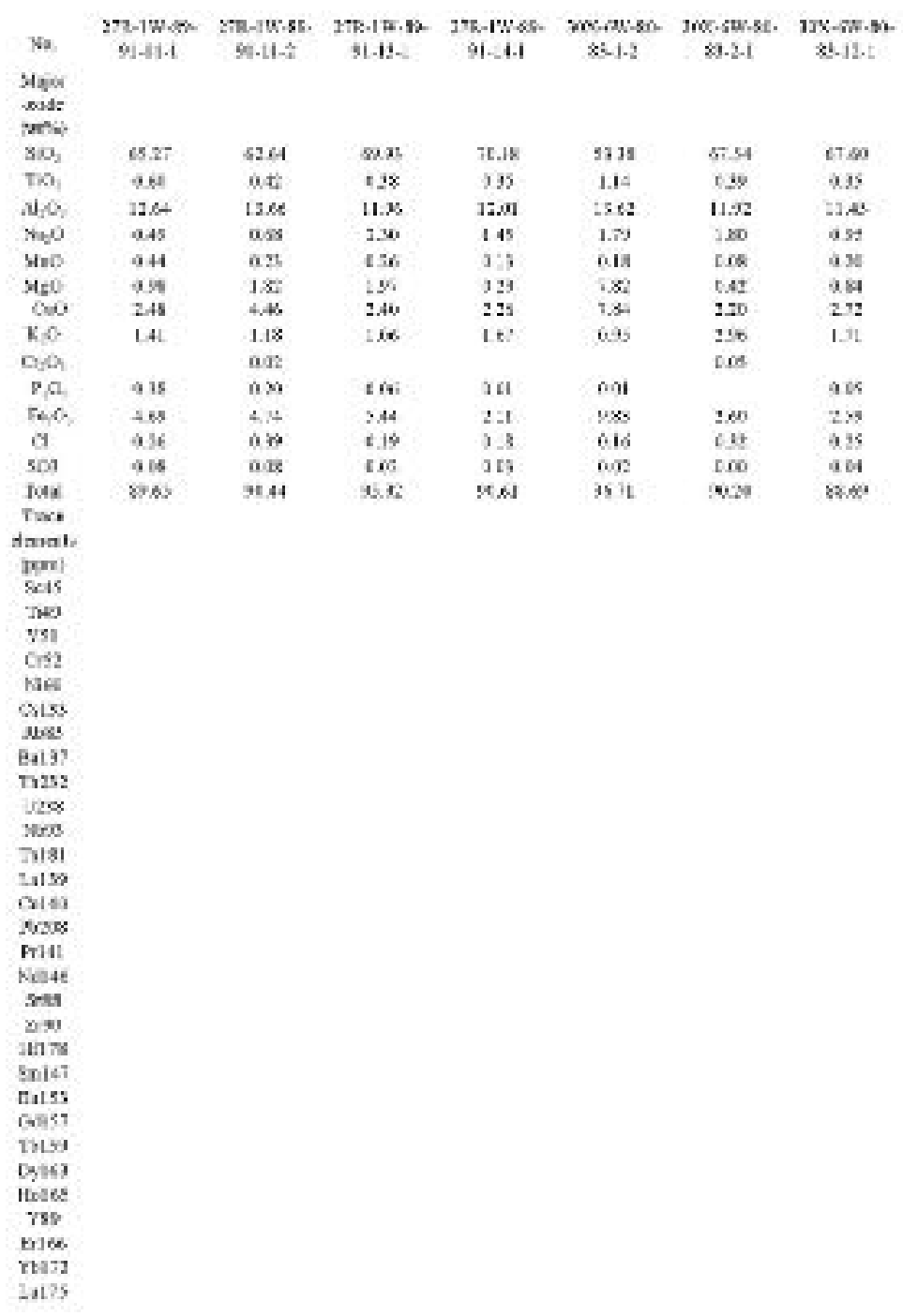




\begin{tabular}{|c|c|}
\hline Wis & 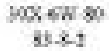 \\
\hline $\begin{array}{l}\text { Mask } \\
\text { madk } \\
\text { turses }\end{array}$ & \\
\hline $5 B_{3}$ & 676 \\
\hline $\mathrm{mon}_{1}$ & 0.45 \\
\hline $\mathbf{u}_{j} \mathbf{C}_{1}$ & 12.12 \\
\hline Niso & 135 \\
\hline 360 & a. is \\
\hline Steb & 0.45 \\
\hline $\mathrm{Cro}$ & 219 \\
\hline$k_{p} c$ & 257 \\
\hline $\mathrm{Cr}_{3} \mathrm{C}_{3}$ & 06 \\
\hline$P_{1} O_{3}$ & 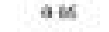 \\
\hline $\mathrm{Fe}_{\mathrm{e}} \mathrm{O}_{\mathrm{H}}$ & 247 \\
\hline a & 932 \\
\hline 509 & aes \\
\hline Tat & 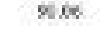 \\
\hline Trik: & \\
\hline t'mats & \\
\hline qैiो & \\
\hline 8.45 & \\
\hline $7 n$ & \\
\hline V5i & \\
\hline$\square 52$ & \\
\hline Nite & \\
\hline Cuss & \\
\hline ates & \\
\hline $\begin{array}{l}\text { Ual } 57 \\
\text { meng }\end{array}$ & \\
\hline $\begin{array}{l}\mathrm{n} 2 \mathrm{k} 2 \\
\text { บขอ }\end{array}$ & \\
\hline Won & \\
\hline Talsi & \\
\hline Ial 69 & \\
\hline$C t+\infty$ & \\
\hline Fose & \\
\hline frat & \\
\hline Mat is & \\
\hline $3 \% 8$ & \\
\hline $2 r 20$ & \\
\hline $\mathrm{Hn} \approx 8$ & \\
\hline $\operatorname{sen} 14 t$ & \\
\hline Eals3 & \\
\hline Cat 9 . & \\
\hline 77199 & \\
\hline Dy:s3 & \\
\hline How 65 & \\
\hline rss & \\
\hline Erief & \\
\hline nerz & \\
\hline Lalps & \\
\hline
\end{tabular}




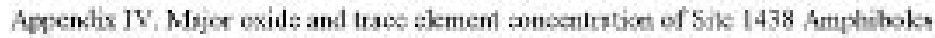

\begin{tabular}{|c|c|c|c|c|c|c|c|}
\hline Batsxt & $\begin{array}{c}50060 \mathrm{w}-\mathrm{se} . \\
35\end{array}$ & & & & & & \\
\hline $\mathrm{Nr}$ & 5. 1 & 6 & $\mathrm{~s}$ & 11.1 & $1 \geq-1$ & 17.2 & 16.1 \\
\hline \multicolumn{8}{|c|}{$\begin{array}{c}\text { Wyar Colsk } \\
\text { fortel }\end{array}$} \\
\hline 80 & $45 x \cdot 1$ & 2937 & 2335 & V. 32 & 13.23 & 4320 & 4563 \\
\hline no: & as2 & ass & 11 & 15 & 177 & 135 & 19: \\
\hline$A b O_{2}$ & 14 & 10uve & 13.30 & 7.44 & :3AZ & 12.61 & 11.et \\
\hline$N, 0$ & 132 & $2 I^{*}$ & $\therefore i$ & 1.12 & 121 & 170 & $1 \Omega$ \\
\hline Mino & as? & 331 & 5.13 & $\theta \geqslant$ & $a 5$ & 9.88 & 0.20 \\
\hline Mteo & $x \leq 1$ & 1628 & | Kst & 15.41 & 8503 & 19.36 & 15,7 \\
\hline se: & 168 & $10 \%$ & $1 \geqslant 16$ & 1117 & 330 & 1962 & 1153 \\
\hline$E, 0$ & ats & $3 x 5$ & 528 & wes & a.s & 921 & $5.1 x$ \\
\hline${ }^{\prime} \sigma_{1}$, & & and & & 001 & & $a k e$ & $\sin$ \\
\hline Fed & 1324 & $129 i$ & 12.15 & 1.323 & .1 .35 & 199 & 1241 \\
\hline Tobd & 58.72 & $\operatorname{sen}$ & st.t2 & 3759 & 5384 & $5.5:$ & 95:55 \\
\hline Mgrt & css:sa & W: & ce:15 & s:55 & 7234 & (t)al & Cos \\
\hline $\mathbf{T}$ & 735.46 & 5330 & 9.155 & 817,65 & 93.00 & $\$ 55.56$ & $526.4 !$ \\
\hline Mea & $73 A$ ? & $G x$ & 31.5 & 3512 & $\operatorname{caz} 20$ & $35: 20$ & 6517 \\
\hline \multicolumn{8}{|c|}{$\begin{array}{c}\text { Tnes daskas } \\
\text { cperi }\end{array}$} \\
\hline Tus & $\sin \alpha$ & $210 \mathrm{CAS}$ & $\min \alpha$ & $\sin 21$ & (522 13 & $\cos x$ & $\sec 2 x$ \\
\hline vil & $175+1$ & 73145 & 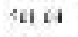 & $1 \times 18$ & $5: 041$ & tor is & $185 \ll$ \\
\hline $\operatorname{cry} z$ & 34 & a.t & $4 \therefore$ & 6,4 & 2100 & es.st & 231 \\
\hline Kiss & 175 & 531 & $t x$ & $\therefore 31$ & 1242 & 31.50 & 5.17 \\
\hline Cel1s & ant & ord & $\cos$ & $\omega x$ & a.d2 & 9.61 & 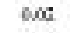 \\
\hline Rls & $a ! 1$ & 9.1 & 61 & 611 & $9 x$ & 471 & 67 \\
\hline Balst & 567 & 752 & 15.75 & 786 & 2.18 & 19.28 & 134 ? \\
\hline $\mathrm{m} 2 \mathrm{~s} 2$ & $a x 2$ & ar: & exd & $\operatorname{sen}$ & adi & $9 \mathrm{ks}$ & 601 \\
\hline cons & all & ar & $e n$ & $m$ & הal & 069 & $\infty m$ \\
\hline $\mathrm{NW}$ & $a n$ & נגם & 6.11 & 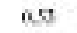 & OM & 967 & a.: \\
\hline Tak: & ats & 0.3 & in & 604 & a.4 & $9: 1$ & wed \\
\hline Lasas & 234 & a.'s & t25 & $1+3$ & wat & a.t? & 6.71 \\
\hline telue & 16.76 & $5.4 t$ & t:25 & 5.80 & $a r y$ & 1.14 & $3 x$ \\
\hline Pt:se & $a 67$ & $3 x 5$ & t.JE & (1) & 913 & Q311 & 6.16 \\
\hline NLII & (b) & 3s: & 5.45 & 2.38 & $a 24$ & $92 \%$ & 691 \\
\hline$x+1=5$ & 30.34 & $3=1$ & 427 & 165 & $2 r 2$ & 20 & the \\
\hline ghy & $3 t \leq 4$ & exte & 14592 & 032 & $1-0.30$ & t47.07 & 32.17 \\
\hline $\operatorname{srn} 0$ & um & 16.8 & 1158 & 71a & 539 & 660 & 1663 \\
\hline in is & 131 & 15 & $6 \pi$ & $1: 3$ & 977 & 410 & $|c|$ \\
\hline Mand? & 893 & 424 & : $x$ & $\gamma .90$ & 1. 15 & 132 & 3.13 \\
\hline Dulss & 225 & 135 & t.75 & 2.16 & 093 & 963 & 1.16 \\
\hline Gat15: & 12.37 & 511 & 2.8 & 1078 & 1.51 & 230 & 4.4 \\
\hline miss & 214 & 15 & its & 101 & 475 & 444 & 687 \\
\hline DF563 & $15 \leq 8$. & $33 t$ & $3 \leqslant 8$ & 1046 & 215 & 253 & $60 i$ \\
\hline Hatss & 531 & 1s: & t $x$ & $2 \mu$ & ust & ves & 1.24 \\
\hline vas & ss.se & 42 & 1242 & 7yss & 2.19 & 1925 & 3051 \\
\hline Fints & 252 & 535 & 3.16 & 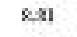 & 152 & 176 & 3.46 \\
\hline $\min$ & 333 & $4: 5$ & 260 & ross & 1.15 & 162 & 3.11 \\
\hline LaI? & 145 & oي: & יבז & 1.2 & $\alpha 23$ & 921 & 0,4 \\
\hline
\end{tabular}




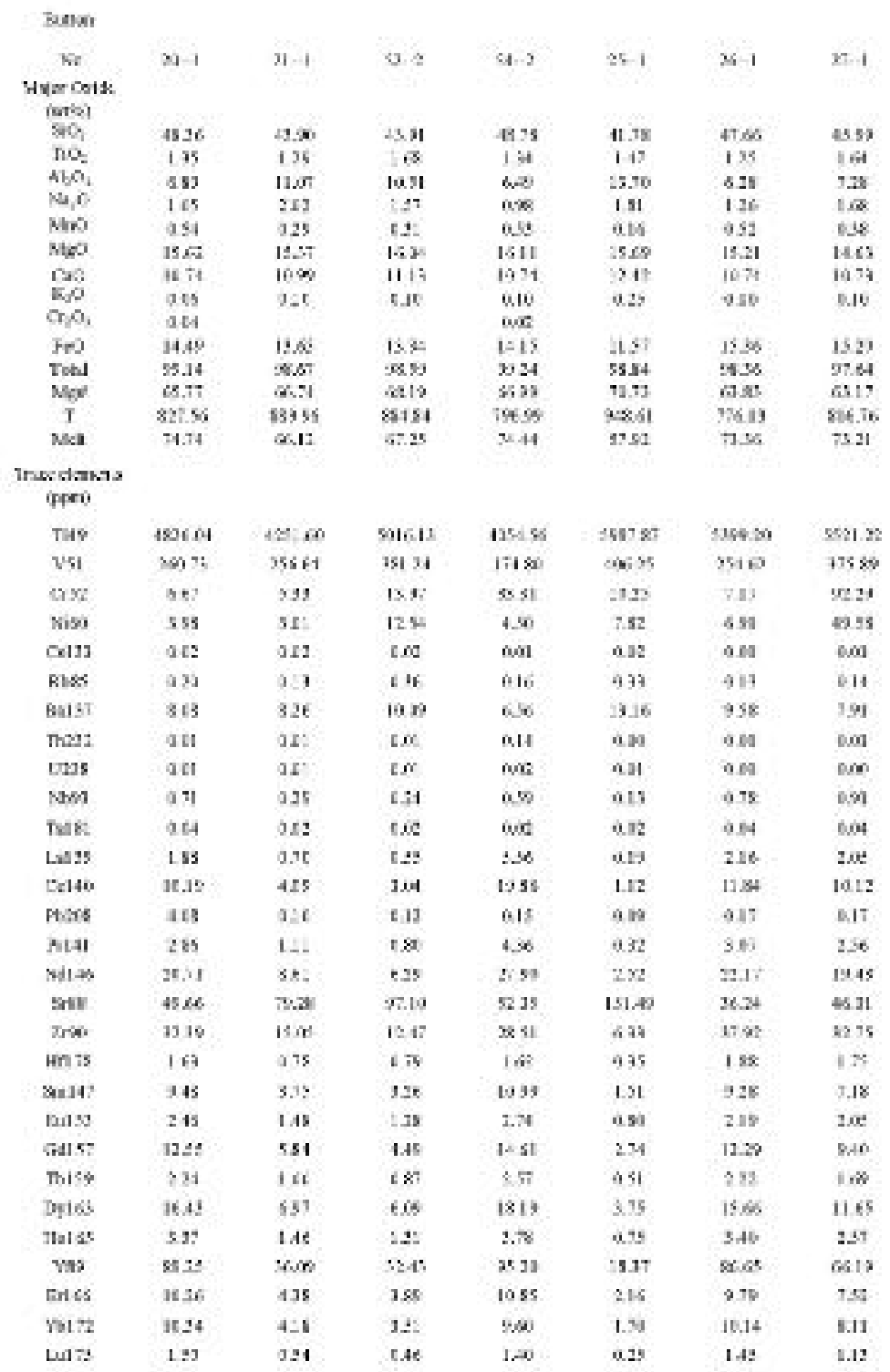




\begin{tabular}{|c|c|c|c|c|c|c|c|}
\hline \multicolumn{8}{|l|}{ Banxi } \\
\hline $\mathrm{Ne}$ & $23-2$ & 1 & $\therefore 3$ & $1-1$ & 5.2 & 7.3 & 9.4 \\
\hline \multicolumn{8}{|c|}{$\begin{array}{c}\text { Hylar Coist: } \\
\text { fortel }\end{array}$} \\
\hline \$C, & 4530 & 24.21 & 25.35 & $4: 24$ & $1: 20$ & 4e.gT & 4491 \\
\hline no: & 137 & 176 & 145 & $1: 7$ & 134 & $17 x$ & 126 \\
\hline $\mathrm{AbO}_{2}$ & $5 \leq 3$ & sat & $10=$ & $7 w$ & 6ss & 752 & 1031 \\
\hline$N, 0$ & 122 & $2 x$ & 200 & 1.5 & 153 & 100 & 2.06 \\
\hline Mró & ass & 3.45 & 122 & (6) & ass & 995 & c.2T \\
\hline Mteo & 1921 & $12 . \%$ & $1<10$ & 1557 & 23.19 & 11.78 & 1372 \\
\hline D.: & is 58 & $10 \times 1$ & 1087 & 1957 & 300 & $\Delta 76$ & 1113 \\
\hline $\mathrm{k} \rho 0$ & ass & 0.45 & 5.19 & u. & $a \neq$ & va & 5.1: \\
\hline$\alpha_{1} \sigma_{2}$ & & $3 \times 2$ & & we & $a n 2$ & & \\
\hline Fed & 34.48 & $160 \mathrm{e}$ & $1<30$ & 15.45 & -510 & 1736 & $15 \$ 3$ \\
\hline Tow & 5s.18 & Trso & $\operatorname{ss} v$ & 3757 & דנימ & 5...5 & 97.t? \\
\hline Mse & $\operatorname{css} \pi$ & woit & 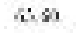 & SI 21 & 53.75 & $\cos$ & 6122 \\
\hline $\mathbf{T}$ & 731.29 & 55413 & ssiss & 81656 & Xas.9? & 975,12 & SEs.to \\
\hline Mea & $73 \geq 0$ & ก॥ม & Gat & 34.12 & 73.10 & To.rs & 67.51 \\
\hline \multicolumn{8}{|c|}{$\begin{array}{c}\text { inosdansas } \\
\text { oppei }\end{array}$} \\
\hline TuQ & 165550 & & & & & & \\
\hline vil & $10 x$ & & & & & & \\
\hline cras & it $\approx 2$ & & & & & & \\
\hline xiss & 434 & & & & & & \\
\hline Cels & all & & & & & & \\
\hline Rlss & ats & & & & & & \\
\hline Balst & ses & & & & & & \\
\hline $\mathrm{m} 2 \mathrm{si}$ & $a t$ & & & & & & \\
\hline cons & $a c t$ & & & & & & \\
\hline $\mathrm{Nm}$ & $a 72$ & & & & & & \\
\hline Tak: & acs & & & & & & \\
\hline Losas & 221 & & & & & & \\
\hline Deluo & II: & & & & & & \\
\hline pt:Gs & ala & & & & & & \\
\hline ALII & $3: 1$ & & & & & & \\
\hline Silas & 29.11 & & & & & & \\
\hline siv & 1930 & & & & & & \\
\hline$\pi$ rax. & 3360 & & & & & & \\
\hline unis & 165 & & & & & & \\
\hline Yasu? & 315 & & & & & & \\
\hline Dalss & 237 & & & & & & \\
\hline Gat15: & 13.16 & & & & & & \\
\hline miss & 211 & & & & & & \\
\hline D5163 & 1314 & & & & & & \\
\hline That 25 & 351 & & & & & & \\
\hline vas & ונתמ & & & & & & \\
\hline Fines & Itsa & & & & & & \\
\hline nin & It 24 & & & & & & \\
\hline Lut: & $1 \geq 3$ & & & & & & \\
\hline
\end{tabular}




\begin{tabular}{|c|c|c|c|c|c|c|c|}
\hline \multicolumn{8}{|l|}{ Banxi } \\
\hline $\mathrm{Ne}$ & 101 & $11=$ & 13.1 & 14.1 & $|A|$ & $13=2$ & 30 \\
\hline \multicolumn{8}{|l|}{$\begin{array}{c}\text { Hyar Coist } \\
\text { fortel }\end{array}$} \\
\hline 80 & 49.5 & 27.46 & 22.35 & A $3 t$ & 45.01 & 48.07 & 4255 \\
\hline no: & 152 & 166 & 13 & 10 & 15 & 978 & 17 \\
\hline $\mathrm{AbO}_{2}$ & 23 & $5 s 2$ & I0:- & $=8$ & 3.25 & $7 s$ & $12: 5$ \\
\hline$N, 0$ & 152 & 1.11 & 235 & $1 / A$ & 231 & 137 & 3.11 \\
\hline Mino & ais & 355 & 122 & $\mathrm{Nat}$ & ass & $9 . A 1$ & 5.14 \\
\hline Mtoo & 123 & $13 \mu$ & $1: n$ & 1555 & 22.73 & 11.65 & 13.55 \\
\hline s.: & is ed & in 8 & $11 x$ & 1931 & 373 & 1078 & $\| 69$ \\
\hline 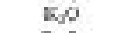 & $a s s$ & $3<5$ & 5.12 & 0.11 & ass & ges & 6.7 \\
\hline$\alpha_{1} \sigma_{1}$ & kro & & & wo & & OH & 100 \\
\hline$F+9$ & 1350 & 16.24 & 1,35 & $1=35$ & 2539 & 1405 & 154 \\
\hline Total & 55.2 & 953 & y.ss & $x>3$ & 5184 & $\operatorname{st} x T$ & rest \\
\hline 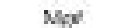 & siss & 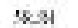 & 6.16 & S1 95 & 3898 & 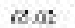 & 6595 \\
\hline $\mathbf{I}$ & 73231 & 75355 & $811-5$ & $8 i s 06$ & satil & 322.13 & Sts $\leq S$ \\
\hline Maca & $\pi .54$ & 7.11 & atso & $2 \times 21$ & נות & T.es & 6023 \\
\hline \multicolumn{8}{|l|}{$\begin{array}{c}\text { Tnes damsas } \\
\text { 'ppeit }\end{array}$} \\
\hline \multicolumn{8}{|l|}{ Tus } \\
\hline \multicolumn{8}{|l|}{ vst } \\
\hline \multicolumn{8}{|l|}{ eryz } \\
\hline \multicolumn{8}{|l|}{ Kisy } \\
\hline \multicolumn{8}{|l|}{ Celsu } \\
\hline \multicolumn{8}{|l|}{ RLss } \\
\hline \multicolumn{8}{|l|}{ Balst } \\
\hline \multicolumn{8}{|l|}{$\mathrm{m} 2 \mathrm{~s}$} \\
\hline \multicolumn{8}{|l|}{ ens } \\
\hline \multicolumn{8}{|l|}{$\mathrm{Nm}$} \\
\hline \multicolumn{8}{|l|}{ Tak: } \\
\hline \multicolumn{8}{|l|}{ L.sas } \\
\hline \multicolumn{8}{|l|}{ telso } \\
\hline \multicolumn{8}{|l|}{ Pt:ss } \\
\hline \multicolumn{8}{|l|}{ ALII } \\
\hline \multicolumn{8}{|l|}{ Silas } \\
\hline \multicolumn{8}{|l|}{ siv } \\
\hline \multicolumn{8}{|l|}{$\pi x$} \\
\hline \multicolumn{8}{|l|}{ Hnts } \\
\hline Susta? & & & & & & & \\
\hline Dulso & & & & & & & \\
\hline Gat5: & & & & & & & \\
\hline nilse & & & & & & & \\
\hline Dys 63 & & & & & & & \\
\hline Tatas & & & & & & & \\
\hline vas & & & & & & & \\
\hline Rorles & & & & & & & \\
\hline nin & & & & & & & \\
\hline LuI: & & & & & & & \\
\hline
\end{tabular}




\begin{tabular}{|c|c|c|c|c|c|c|c|}
\hline \multicolumn{3}{|l|}{ Batext } & \multicolumn{5}{|c|}{$\frac{100.710 .15 .}{25}$} \\
\hline $\mathrm{Ne}$ & $12-5$ & $3 i-1$ & $;-3$ & $5-1$ & $11-2$ & 12.1 & 35.2 \\
\hline \multicolumn{8}{|c|}{$\begin{array}{c}\text { Hyar Colsk } \\
\text { fortel }\end{array}$} \\
\hline 80 & 41.06 & $2 \boldsymbol{k} ; \boldsymbol{K}$ & 2452 & vis7 & 1532 & 41,02 & 4e13 \\
\hline no: & $1: 5$ & as & 681 & $0 x_{i}$ & 919 & 958 & $6 \infty$ \\
\hline$A b O_{2}$ & 1354 & 5s? & 723 & 7.78 & 7.3 & $11 \%$ & $124:$ \\
\hline$N, 0$ & 217 & $1: 1$ & 811 & 1,08 & 125 & 160 & 1,20 \\
\hline Mino & ass & $0 \times s$ & $5: 2$ & $0 \rightarrow 0$ & asj & ant & 5.15 \\
\hline Mteo & $13 \div 8$ & 1422 & 10.13 & 1553 & 243 & $13 x 2$ & 1365 \\
\hline se: & 11 is & 27 & 1135 & $11>5$ & 131 & $168 \%$ & $1>0$ \\
\hline 5,0 & $a: 3$ & $3 x 4$ & 508 & 0.12 & $a v$ & 926 & 60 \\
\hline${ }^{\prime} \sigma_{1}$ & an & $a r i$ & & 601 & & 963 & \\
\hline Fed & 12.16 & 18.50 & $1<2 \%$ & $1=35$ & dis & 1295 & 11.53 \\
\hline Total & $24: 1$ & $9 \pi \mu$ & sesto & 3531 & נירי & ras & 9745 \\
\hline Msex & $u \geq 8$ & बे.: & $\therefore 12$ & st as & C12s & ress & cais \\
\hline $\mathbf{T}$ & 935.45 & 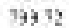 & $162 \leq 5$ & $i x$ ic & $w_{0}^{5}, 99$ & 39135 & s54. \\
\hline Maka & 31.11 & $\pi / \pi$ & ros & 925 & 7256 & \&.06 & GS:L \\
\hline \multicolumn{8}{|c|}{ 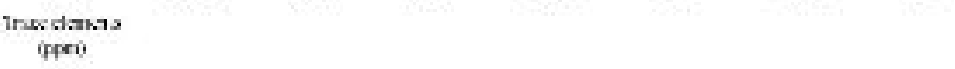 } \\
\hline Tus & & & wors & 16e: is & 36236 & 3400.16 & Q7hs: \\
\hline vil & & & 5457 & 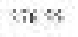 & $18: 57$ & 18159 & 50767 \\
\hline cryz & & & 8.28 & $103 !$ & avy & on & jats \\
\hline Kiss & & & 254 & 6.24 & 257 & 955 & 1853 \\
\hline Celsu & & & $c x$ & noi & a.d2 & 9.68 & $\omega x$ \\
\hline Rls & & & 63 & 628 & 911 & 411 & 62 \\
\hline Balst & & & 3,65 & $9 \infty$ & PAs & 734 & 1221 \\
\hline $\mathrm{m} 2 \mathrm{i}$ & & & $6 x$ & $\infty 01$ & aat & 96 & $\infty$ \\
\hline eass & & & $t n$ & $\mathrm{~mol}$ & ast & $96 \mathrm{~A}$ & $m$ \\
\hline $\mathrm{Nm}$ & & & 68 & $n \pi$ & $0 s$ & 021 & wes. \\
\hline nak: & & & tis & we & a.s & 9.81 & wes \\
\hline Lasas & & & 220 & $1 . x$ & 1.25 & 0.5: & 0.28 \\
\hline Deluo & & & 5.77 & toss & 812 & 228 & $1 . A 2$ \\
\hline Pt:ces & & & t.15 & 015 & 912 & $9 \Leftrightarrow$ & 6.16 \\
\hline ALII & & & 229 & 1.4 & 233 & 938 & 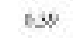 \\
\hline Silas & & & $1 \times y z$ & 1035 & $5: 534$ & $\Delta \times$ & ges \\
\hline shy & & & 51.25 & 451 & $21 . A 6$ & 112:3 & 345.76 \\
\hline$\pi \times n$ & & & $2 x \mathrm{x}$ & $7 i 13$ & xas & irst & Eis \\
\hline ints & & & 17 & 18 & 165 & 475 & 631 \\
\hline Mast? & & & 122 & 8.13 & $x=52$ & $5 \mathrm{n}$ & ISP \\
\hline Dulso & & & 2. & 2.21 & 233 & 192 & 6.7 \\
\hline Gat5? & & & 11.51 & 105t & 30 & 421 & 13s \\
\hline nilses & & & 211 & isi & 371 & 113 & bet \\
\hline DF5163 & & & 15.41 & 1235 & 123 & 8.60 & $90 i$ \\
\hline Thatas & & & 3.14 & $2 \%$ & 294 & 151 & wa \\
\hline vas & & & a. $\mathrm{ka}$ & $72 a$ & noce & 413 & 1531 \\
\hline rincs & & & 5.78 & 810 & 720 & 514 & in \\
\hline $\min$ & & & 522 & $8 \times \infty$ & 40 & 453 & 1.24 \\
\hline LaI? & & & :as & $1.2 x$ & 1.91 & 020 & $6 x$ \\
\hline
\end{tabular}




\begin{tabular}{|c|c|c|c|c|c|c|c|}
\hline Batext & $\begin{array}{c}218.1 W-14 \cdot \\
18\end{array}$ & & & 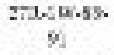 & & & \\
\hline $\mathrm{Ne}$ & $\sin +2.1$ & 218 t. 1 & $315 \sin 3$ & $520,17=?$ & $5 x-15$ is i & sonat is & $\sin 75: 20=$ \\
\hline \multicolumn{8}{|c|}{$\begin{array}{c}\text { Wyar Colst: } \\
\text { fortel }\end{array}$} \\
\hline 80 & $43 x 0$ & 26.4 & 2459 & 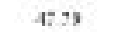 & 1251 & 473 & $\Leftrightarrow x$ \\
\hline no: & 212 & 155 & $y$ & 1 in & 117 & 132 & 101 \\
\hline $\mathrm{AbO}_{4}$ & It: 1 & ביות & 7.1: & wese & $6+3$ & 7.4 & eve \\
\hline $\mathrm{Na}, 0$ & 275 & 150 & $i x$ & 1.4 & $1 \leqslant$ & 139 & 136 \\
\hline Nino & a:g & ass & 54 & $0=0$ & ats & 9.46 & 6.48 \\
\hline Mteo & $13 s 0$ & 12.ri & 1291 & 1395 & 2396 & $13.6 \mathrm{at}$ & 18.to \\
\hline se: & 1116 & $10 A^{\circ}$ & $10 \%$ & 1921 & 358 & $16 \times ?$ & $10 \leq 3$ \\
\hline$B=0$ & ags & 328 & 53 & 0.14 & ata & 913 & 0.14 \\
\hline${ }^{\prime} \sigma_{1}$ & & ar: & & & $a 12$ & & \\
\hline Fed & $13 x$ & 1812 & $1: 2 z$ & 1535 & 534 & $158 i$ & 15 ts \\
\hline Total & 55.6 & $\operatorname{senc}$ & $x-z_{2}$ & 3515 & 55.28 & 5.17 & TS43 \\
\hline Mex & are & ent & 5 & S1 as & a $5 x$ & wor & $61 \mathrm{cs}$ \\
\hline $\mathbf{T}$ & $86 x$ & SSt S1 & $8 \times 3.15$ & tiges & son:53 & 83.13 & $751 \mathrm{xd}$ \\
\hline Maca & $c c .18$ & $\pi \pi$ & 73,17 & 7253 & 7136 & 7200 & 71.75 \\
\hline \multicolumn{8}{|c|}{$\begin{array}{c}\text { Tnes daskas } \\
\text { cppeit }\end{array}$} \\
\hline Tus & 1824:1 & $3325: 23$ & 1165258 & 10า7. & אit 172 & 5.3.:25 & 356t is \\
\hline vil & 6711 & 19257 & $: 5+3$ & $106+10$ & $5 \& 43$ & 3219 & $x y<5$ \\
\hline eryz: & $35 \times 6$ & $35:$ & $2 u s$ & wan & $=n$ & $11 \geq$ & $2 \pi$ \\
\hline Kiss & $35 \leq 6$ & $16 x$ & 189 & $A M H$ & 3.45 & 592 & 4.T2 \\
\hline Cals & 191 & 256 & th & as & 0.22 & 027 & 0.20 \\
\hline Rlsk & $36 \mathrm{H}$ & 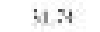 & $x y$ & $1 ; 35$ & 2058 & $10 \% 6$ & 8.80 \\
\hline Balst & 96 & $9-2$ & 638 & $6 \%$ & ans & 962 & 60 \\
\hline $\mathrm{m} 212$ & $a t$ & $a x 2$ & $c m$ & $\operatorname{son}$ & as & 9.62 & $\cos$ \\
\hline ens & all & arc & $e n$ & $\min$ & & 9.67 & $m$ \\
\hline $\mathrm{Nm}$ & 17 & Ixs & 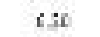 & ה & 1.15 & 121 & 1.2 \\
\hline nak: & acs & & tis & 604 & a.s & ane & $6 \omega$ \\
\hline Lasas & 445 & $17 \mu$ & $14 \pi$ & $2 \mu$ & $3+3$ & $25 \mathrm{~s}$ & $3: 3$ \\
\hline Deluo & 74: & $\omega \varkappa C$ & S.AI & 14:2 & 2451 & $13, \pi$ & 1623 \\
\hline pt:ses & 135 & IIf & t35 & 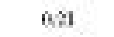 & als & 9.18 & 6.14 \\
\hline ALAI & 285 & 1231 & 11.16 & $2 \alpha$ & 5.85 & 332 & 400 \\
\hline Silas & 1538 & 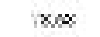 & wess & $4: 4$ & $2 x>2$ & 29.48 & zits \\
\hline an & 207.55 & 3.7 & $\pi .4$ & $45 \times 7$ & $42 x y$ & 4.7 & 4at? \\
\hline 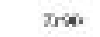 & tives & xos & $92 n$ & dict & 1570 & 47 & 5555 \\
\hline unis & 20 & 75 & 10 & : 1 & 819 & 293 & $x+7$ \\
\hline Yust? & ses & $24 x$ & Znti & 2.8 & 23.88 & 934 & 1222 \\
\hline Dalso & 213 & $4 \mathrm{IC}$ & 15 & 2es & 272 & 242 & 2.91 \\
\hline Ga15: & 217 & se:7 & $x=$ & $1: 13$ & 356 & 1401 & 1615 \\
\hline mises & 145 & 175 & 15 & $s ;$ & $\geqslant s ?$ & 273 & 28 \\
\hline Dyst6s & 952 & 34.72 & 365 & 1636 & 25.64 & 16.61 & 1961 \\
\hline That 25 & 15 & 625 & txt & 200 & 3.4 & 392 & 4.11 \\
\hline vas & 45.18 & $15>12$ & 17ses & $n \leq t$ & $\operatorname{sas} 2$ & ns: & $16 \pi$ \\
\hline rortes & 512 & Iscet & 15: & 1021 & 201 & 10.12 & 1215 \\
\hline ทitz & $4 \% 5$ & $18.5:$ & Iito & $4 x$ & 2139 & 956 & 11.25 \\
\hline Luat: & 20.4 & $2: 2$ & 220 & $1 \approx 0$ & 1.42 & 1.42 & $12 x$ \\
\hline
\end{tabular}




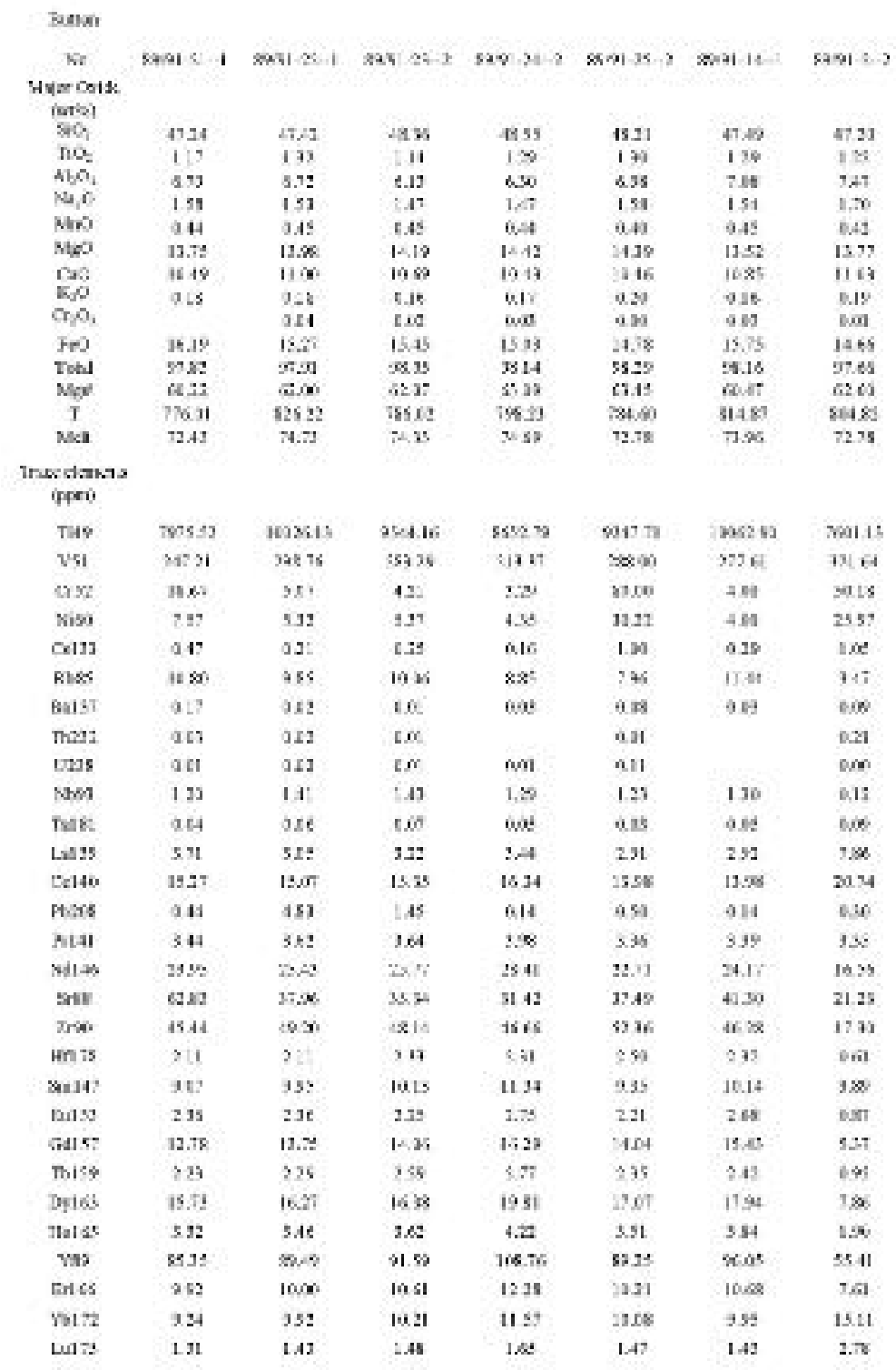




\begin{tabular}{|c|c|c|c|c|c|c|c|}
\hline Banxt & $\begin{array}{c}\text { bet-w-18. } \\
2 t+12=2\end{array}$ & $\begin{array}{l}158 .-1 W \cdot 18- \\
312 N=4\end{array}$ & 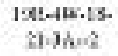 & 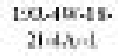 & $\begin{array}{c}298-4 W-76 \\
73.18-3\end{array}$ & 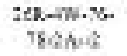 & 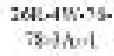 \\
\hline $\mathrm{Nr}$ & i & 5 & $\mathrm{~s}$ & 2 & 11 & 11 & is \\
\hline \multicolumn{8}{|c|}{$\begin{array}{c}\text { Wyar Cols: } \\
\text { fortel }\end{array}$} \\
\hline 80 & 4h.1T & $23 x$ & 23.15 & $\mathrm{n} \pi$ & 1321 & 47.17 & as 93 \\
\hline no: & 321 & 367 & 87 & S st & 231 & 116 & 115 \\
\hline $\mathrm{AbO}_{2}$ & 12.20 & sJ: & 127 & $\because / 84$ & $: 2.44$ & 727 & 6.28 \\
\hline$N, 0$ & 235 & $2 x 6$ & $2 n$ & ist & 231 & 123 & 1,16 \\
\hline Mro & a:s & 325 & tus & 0.14 & $a \mathrm{ta}$ & 9.19 & $5.1 \%$ \\
\hline Mteo & 1306 & $10.5:$ & $\operatorname{lan}$ & 1228 & 29.42 & 1400 & 1535 \\
\hline se. & 116 & $10: 31$ & 1916 & 1451 & 317 & 1067 & jas? \\
\hline $\mathrm{k}, 0$ & a.2 & 124 & 529 & $v: s$ & az? & 919 & 0.12 \\
\hline$c_{1} \sigma_{1}$ & abs & & & & $9 M$ & & \\
\hline Fed & 34.48 & 198 & Des) & 1531 & 2.41 & $148 ?$ & 1547 \\
\hline Tow & 5251 & $x=0$ & $\operatorname{san}$ & $x, 45$ & 54.24 & tx:st & 200 \\
\hline $\mathrm{MSO}$ & $a .70$ & ; & 49 & 591 & C2.12 & a.N & 6550 \\
\hline $\mathbf{T}$ & $9 \times 25$ & $539-3$ & $8 x 253$ & $\sin .12$ & $9: 8 x+4$ & $n+e$ & 76.65 \\
\hline Mala & 62.91 & ras. & posi & 5757 & Hat & $7 \infty$ & 7234 \\
\hline \multicolumn{8}{|c|}{$\begin{array}{c}\text { Tnoedankas } \\
\text { cppeit }\end{array}$} \\
\hline Tas & $165 \sin$ & 1712520 & 13751 & 150533 & $16 m: 22$ & issen & x:18 27 \\
\hline vsi & 6256 & 31574 & sitif & 18518 & ¿si को & Nes of & 3 is it \\
\hline eryz & $x+3$ & $4: 2$ & 9.2 & 4.44 & $5 n$ & SE: & 9.2 \\
\hline xiss & 345 & 5s: & 124 & 7.91 & 2014 & 422 & 9.72 \\
\hline Cals & agt & a.19 & c.25 & wo & 0.57 & 939 & 0.15 \\
\hline RLs & 406 & $10 \%$ & $x+2$ & $2 \geq 51$ & 3865 & 1175 & 1031 \\
\hline Balst & $9+3$ & 352 & $w$ & $6 \times$ & a.s & 905 & 606 \\
\hline $\mathrm{m} 212$ & $a t$ & ar & $\operatorname{cog}$ & 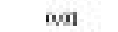 & aม & 96 & we \\
\hline Eoss & act & & $\mathrm{esc}$ & we & & asc & $a n$ \\
\hline $\mathrm{Nm}$ & 121 & 455 & 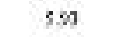 & 30 & 211 & oss & 1,43 \\
\hline nak: & ary & $3=1$ & $\operatorname{tat}$ & 6.14 & $a v$ & 962 & $6 \alpha$ \\
\hline Lasas & 223 & $14.2 \mathrm{~N}$ & Iuts & $4 \pi$ & 2.27 & 592 & $3 x$ \\
\hline Deluo & 223 & 3.12 & 23.59 & 1933 & $: 5.27$ & 14.27 & 17.55 \\
\hline pt:ss & a:s & 935 & [33 & 0.16 & 93 & 960 & 7,3 \\
\hline ALAI & 213 & $10 z=$ & S & 4.43 & A.15 & 252 & 4.16 \\
\hline Silas & 1910 & $4 . x$ & $\times 19$ & s) 35 & 2547 & 2000 & abs \\
\hline any & 121.23 & $\Delta .01$ & 57.31 & 315 & $136 \mathrm{as}$ & 1.5.5t & 35.15 \\
\hline $\sin x$ & $5 s, 6 i$ & 117 is & 102 45 & 11 & 6ast & 1597 & ses? 57 \\
\hline Hnis & 253 & 57 & 57 & $1 \infty$ & 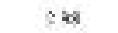 & 153 & 34 \\
\hline Mast? & A:L & $z=0$ & m.s & 113 & 23.3 & 752 & 1023 \\
\hline Dulso & 155 & $42 x$ & 1.70 & $2 x$ & 251 & 153 & 2.44 \\
\hline Ga15? & 95 & is:7 & $2: 2:$ & 1.452 & 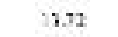 & 10,65 & 1400 \\
\hline mises & $1 \mathrm{H}$ & $d 7 c$ & $7 x$ & siti & $\geqslant 17$ & 17 & $1 \%$ \\
\hline D5163 & 965 & $34: 5$ & 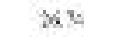 & 1831 & 3.78 & $11, \theta$ & 174 \\
\hline Jatas & $20 \%$ & sst & $2 x$ & 2.st & 2.93 & 2.94 & 9.47 \\
\hline vas & 9241 & דיצ & 11552 & xa as & 7128 & $6 x$ & 2145 \\
\hline Fines & 557 & 150.9 & 1/ats & 1130 & 323 & 747 & lacs \\
\hline Miz & $5: 2$ & Isut & ISts & wot & 6,97 & 792 & tacs \\
\hline LuT: & 252 & 28 & 224 & $13 x$ & $a \cdot 4$ & $1 / \mathrm{Na}$ & $1 . A 8$ \\
\hline
\end{tabular}




\begin{tabular}{|c|c|c|c|c|c|c|c|}
\hline Batax & $\begin{array}{c}3512+2=76 \\
78016\end{array}$ & 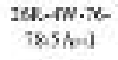 & 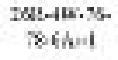 & $\begin{array}{c}270.1 w-118 \\
32: 1\{-1\end{array}$ & $2 n-1$ & $3 A-2$ & $4 x-2$ \\
\hline $\mathrm{Nr}$ & & 2 & \& & 4 & $\because 7$ & 79 & u \\
\hline \multicolumn{8}{|c|}{$\begin{array}{c}\text { Wyar Colsk } \\
\text { fortel }\end{array}$} \\
\hline 80 & tובו & $27 x$ & 24.45 & 4539 & wes & 49.48 & 0655 \\
\hline no: & 078 & 355 & 145 & $1 \times$ & 112 & 140 & x46 \\
\hline$A b O_{2}$ & $5: 3$ & 555 & res & wese & $6+1$ & 734 & 7.12 \\
\hline$N, 0$ & ais & $1: 1$ & 211 & 1.21 & 127 & 139 & 2.47 \\
\hline $\mathrm{M} / \mathrm{NO}$ & 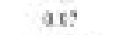 & 325 & tal & 626 & a.2 & 919 & 6.15 \\
\hline Mteo & 135:A & $12 / 2$ & $1: 4$ & $1<15$ & 2354 & 13.94 & 1567 \\
\hline s: & 257 & toro & 108 & 195 & 2091 & 1066 & 1055 \\
\hline 5,0 & & $3=3$ & 5.12 & 6.11 & arz & 910 & 5.14 \\
\hline${ }_{r} \sigma_{1}$ & ats & $3 x 1$ & & & ass & & 601 \\
\hline Fol & It: & 14.2 & $1<31$ & $1=35$ & .584 & 1487 & 143 \\
\hline Total & 54 & twe & s.s1 & 2532 & $59: 3$ & 2030 & 937 \\
\hline$M g x$ & 93.13 & ต. & 61,5 & 5221 & 02.23 & a.s & 6219 \\
\hline $\mathbf{T}$ & & $3955 ?$ & TS5.2E & 74.75 & 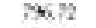 & 97.23 & 194.19 \\
\hline Mala & & 72.6 & 7285 & 7245 & 437 & 7.36 & 7253 \\
\hline \multicolumn{8}{|c|}{ 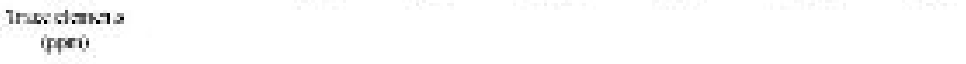 } \\
\hline TuQ & 1803.17 & 9015.0 & $a x=0$ & $6120 \leqslant 1$ & 10hic 13 & $\operatorname{ses} 5 \cdot 2$ & cesses \\
\hline vil & से is & $x+23$ & 0535 & 8714 & 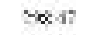 & 25167 & 375 if \\
\hline eryz & 1 sats & 43. & 324 & $2: 24$ & $s, w$ & $3 i s$ & 23 \\
\hline kiss & 36.17 & 551 & $t: 1$ & sos. & 531 & 442 & 6.30 \\
\hline Cels1 & & 9.1 & $\operatorname{lig}$ & a.2 & $a y$ & 927 & wa \\
\hline RLSS & ars & $n=8$ & $5 \pi$ & $\dot{x} \geqslant$ & 913 & ict? & 1555 \\
\hline Balst & $a t$ & 353 & 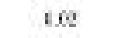 & $0 \%$ & $9 x 2$ & 954 & eis \\
\hline $\mathrm{m} 221$ & & $a r:$ & {$[x$} & we & ast & 961 & $b x$ \\
\hline eoss & & ar & $t n$ & $m i$ & & 962 & an \\
\hline $\mathrm{Nm}$ & $a c 2$ & $12 x$ & 5.15 & $1 \therefore$ & 1.24 & 122 & 1.30 \\
\hline nat: & ans & $0: 1$ & 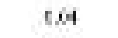 & $\omega x$ & 2.4 & 9.44 & 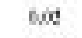 \\
\hline Lasas & $a: 3$ & 221 & $2 x$ & $2 . x$ & 225 & 3.64 & 331 \\
\hline Deluo & $a: 2$ & 12.12 & 13.50 & $13 \pi$ & $22: 1$ & $13.5 \mathrm{~s}$ & 1423 \\
\hline Pt:Gs & a 62 & רנם & t35 & 613 & 918 & 417 & 6.9 \\
\hline ALII & $0 \leq 2$ & 258 & 2ני & 2.11 & 5,3 & $32)$ & ה. \\
\hline Sil 20 & 10 & wer. & $2 \pi$ & 21 s: & II & 2250 & rs $2 y$ \\
\hline sur & באת & 472 & $\mathrm{ses}$ & 3521 & דיצבי & 5797 & 55.53 \\
\hline 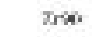 & 935 & 40 & $\Leftrightarrow \mathrm{V}$ & 1267 & 1238 & ast & 466 \\
\hline Hnis & 017 & 157 & if & 100 & 177 & 201 & $3 \alpha$ \\
\hline Yast? & $a: 3$ & S.AZ & 124 & $x / 20$ & $x \rightarrow 1$ & 831 & 536 \\
\hline Duss & 225 & $2: t$ & $2 x$ & 2.11 & 213 & 212 & $2 . A K$ \\
\hline Gat5? & $a s 1$ & $1 \mathrm{I} x \mathrm{C}$ & 11.8 & 1233 & 12.41 & 11. & 1355 \\
\hline milse & a.s & 151 & 34 & 197 & $\hat{A R}$ & $16 i$ & $2 \times 4$ \\
\hline D5163 & $1: 3$ & $14: 2$ & $1<3 \mid$ & 1365 & 3.64 & $19.6 ?$ & 1613 \\
\hline That 25 & 0.24 & $5 \pm 1$ & 310 & 2.21 & $3 . n$ & 294 & 3.46 \\
\hline vas & 559 & whe & $n \geq 2$ & $77 \leq 2$ & 5193 & Ttais & sass \\
\hline Rates & 967 & 156 & $5 . \pi$ & $s: 8$ & xal & 311 & 1015 \\
\hline ritz & ast & SS: & $1: 3$ & $x=0$ & 8.53 & 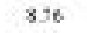 & 5.14 \\
\hline LaI: & 203 & 123 & 2.1s & 1.18 & 1.80 & 122 & $2.2 x$ \\
\hline
\end{tabular}




\begin{tabular}{|c|c|c|c|c|c|c|c|}
\hline Batsi & $2 k-9$ & $\tan \cdot 1$ & $12 . \cdot 1$ & $x \in-2$ & $n+1$ & $10 x-1$ & $11 k-1$ \\
\hline $\mathrm{Nr}$ & 17 & ii & if & $\infty \theta$ & $5 a$ & 57 & ss \\
\hline \multicolumn{8}{|c|}{$\begin{array}{c}\text { Hyis Colsk } \\
\text { fortel }\end{array}$} \\
\hline 80 & 496 & 46.4 & 24.15 & 451 & 4sas & 47.17 & 47.15 \\
\hline no: & 172 & 13 & 13 & 10 & 175 & 136 & $10 i$ \\
\hline$A b O_{2}$ & 503 & BAE & $5 x$ & $7 \infty$ & 3.27 & 552 & e.xa \\
\hline$N, 0$ & 129 & 1.tit & $\therefore 35$ & ise & 152 & 13 & $1 . x$ \\
\hline Nino & 923 & $3: 5$ & 513 & 0.2 & a.s & 922 & c.t1 \\
\hline Mteo & 14.40 & 112 & $1: 26$ & loss & 23.41 & 11000 & $136 ?$ \\
\hline se: & is it & 1031 & $10 \times 2$ & 1957 & 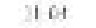 & 1072 & 1075 \\
\hline $\begin{array}{l}\mathrm{r}_{j} \rho \\
\mathrm{c}_{0} \mathrm{o}_{2}\end{array}$ & act & $3-6$ & $\begin{array}{l}5.19 \\
5.3\end{array}$ & u. : & ass & ay & 8.12 \\
\hline Fen & $340 \%$ & 183 & 15.51 & 1536 & 2.154 & 15.18 & 150 \\
\hline Total & $s \in$ & 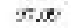 & ss.s & $x: 52$ & 59.01 & 27,00 & 9::5 \\
\hline Msex & 6.72 & $\sin$ & ma & SEAS & 62.28 & $\mathrm{ar}$ & 6203 \\
\hline $\mathbf{T}$ & $7 \times 36$ & 39254 & Tst St & $i s+9]$ & sta.95 & $2 \times 3.18$ & 17406 \\
\hline MaAa & 72.72 & 7.6 & 7280 & 9243 & 7121 & TAt & 71.54 \\
\hline \multicolumn{8}{|c|}{$\begin{array}{c}\text { Tnes daskas } \\
\text { cppeit }\end{array}$} \\
\hline Tus & 12satas & & & & 1200050 & 911535 & xai 7 \\
\hline vil & 450 as & & & & $: 7757$ & Wa 50 & 36746 \\
\hline eryz & sis & & & & $5 \times 3$ & $3 \pi$ & $3 x$ \\
\hline xises & S4s & & & & 623 & $\operatorname{sen}$ & 4.14 \\
\hline Colsu & a92 & & & & ass & ננינ9 & 0.21 \\
\hline RLSS & 1171 & & & & 3351 & 458 & 1034 \\
\hline Balst & $9: 3$ & & & & $a x 2$ & 9.54 & $e x$ \\
\hline $\mathrm{m} 2 \mathrm{n}$ & $a x 2$ & & & & ast & 962 & $\sin$ \\
\hline eass & ats & & & & & & and \\
\hline $\mathrm{Nm}$ & 115 & & & & 1.37 & 131 & 134 \\
\hline nak: & aes & & & & $a x$ & ate & 604 \\
\hline Lasas & 20 & & & & 257 & 3.45 & $3 \pi$ \\
\hline Deluo & $12 x 6$ & & & & 21.04 & 19.21 & 14.35 \\
\hline pt:ses & ass & & & & 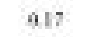 & 261 & 6.16 \\
\hline ALII & 252 & & & & $22 ?$ & 3.45 & $3 \Delta \%$ \\
\hline Silas & aty & & & & 23 & 229 & ress \\
\hline sur & $22 s 2$ & & & & st 32 & 34.17 & 3452 \\
\hline$\pi \times n$ & 030 & & & & v251 & is $x$ & 44 \\
\hline Hn ts & 153 & & & & 16 & 294 & $3 \alpha$ \\
\hline Yast? & st & & & & 9.9 & 9.4 & 5.4 \\
\hline Dulso & 293 & & & & 232 & 229 & 136 \\
\hline Gat5? & 1921 & & & & IST & 1258 & 1253 \\
\hline nilses & 265 & & & & 216 & 213 & 316 \\
\hline D5163 & $15 \leqslant 4$ & & & & 1236 & 1482 & $153 ?$ \\
\hline Thatas & 412 & & & & 254 & 380 & 3.24 \\
\hline vas & ss.74 & & & & 0200 & sax & $965 s$ \\
\hline Fints & 31.13 & & & & 22.12 & 357 & nse \\
\hline Mitz & $3 t .16$ & & & & 423 & 351 & 5.2 \\
\hline Lut: & 133 & & & & 1.27 & 131 & 138 \\
\hline
\end{tabular}




\begin{tabular}{|c|c|c|c|c|c|c|c|}
\hline Batixn & 12.6 .1 & $12 x-2$ & $19 \mathrm{~h}-2$ & $29 \dot{n}-1$ & $1 \times x-1$ & $18 x-1$ & $13 k-2$ \\
\hline $\mathrm{Nr}$ & 57 & 62 & $a$ & $\alpha$ & 67 & $\omega$ & $\pi$ \\
\hline \multicolumn{8}{|c|}{$\begin{array}{l}\text { Hyar Colst: } \\
\text { furtel }\end{array}$} \\
\hline 80 & 46.11 & 4.6 & 27.90 & wiss & 1951 & 46.21 & 44 \\
\hline no: & 178 & 135 & 104 & $1 ; 6$ & in & 135 & 18 \\
\hline$A b O_{2}$ & 73 & 5s & $4:$ & $6 x$ & 6.35 & 550 & 9.20 \\
\hline $\mathrm{N}, \mathrm{O}, \mathrm{.}$ & 10 & 136 & 37 & $1 . \infty$ & 117 & 130 & 2.47 \\
\hline $\mathrm{M} / \mathrm{NO}$ & a:s & 323 & 5.4 & 6.16 & 024 & 926 & e.tz \\
\hline Mteo & 1318 & 12.8 & $1: 72$ & $15: 51$ & 24.20 & $13.6 \mathrm{~T}$ & 1337 \\
\hline $\mathrm{Sa}$ & 1646 & $100^{0}$ & 105 & 1954 & $3 a$ & $10 \%$ & 1031 \\
\hline 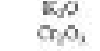 & act & $3-1$ & 5.1: & $\begin{array}{l}6.14 \\
601\end{array}$ & $a r z$ & 914 & $\begin{array}{l}5.14 \\
601\end{array}$ \\
\hline$F+3$ & $34: 1$ & 18.24 & $15.7 \%$ & 1523 & 2521 & 1581 & 15.4 \\
\hline Total & 5.75 & $x / \infty$ & $x=$ & $x 33$ & SSA: & 5.90 & ass. \\
\hline Mgrt & 6.16 & ต. & a1.2. & (5) & 1200 & ros: & caes \\
\hline $\mathbf{T}$ & $7353:$ & 39353 & 53918 & $|\dot{x}| \times 0$ & 756.55 & 97375 & 159.16 \\
\hline Mea & 71.72 & 7.10 & 71.80 & 7255 & 7126 & 7.19 & 7212 \\
\hline \multicolumn{8}{|c|}{$\begin{array}{c}\text { Tnesedankas } \\
\text { cppeit }\end{array}$} \\
\hline Tus & stilsa & wrove & 27117 & 5x: 31 & & $\sin \alpha \operatorname{sis}$ & wran \\
\hline vil & rys: & 39517 & 5677 & : 15 & & 201375 & 3668 \\
\hline $\operatorname{cry} z$ & s:s & $5=8$ & 95 & $2 x$ & & 342 & $3,4]$ \\
\hline Kiss & 411 & 5.16 & 4. & $4 / \theta$ & & 258 & $4 x$ \\
\hline Colsu & 021 & $a x t$ & c.15 & 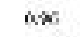 & & 021 & we \\
\hline Rlss & 458 & 36 & 64? & 94 & & 864 & 1012 \\
\hline Balst & 962 & 353 & $t e$ & $6 \%$ & & $9 k 5$ & $\cos$ \\
\hline $\mathrm{m} 212$ & $a t 1$ & $a r:$ & & 801 & & $9 \mathrm{KA}$ & $\infty 01$ \\
\hline cons & alt & ard & $t n$ & $m i$ & & 9.84 & $m$ \\
\hline $\mathrm{Nam}$ & 12 & 136 & 19 & 1.27 & & 131 & 1.27 \\
\hline nak: & ats & 3.4 & tie & $w e$ & & $9 s$ & 604 \\
\hline Lasas & 273 & 5A: & $2: 0$ & $2 / W$ & & 421 & 2.7 \\
\hline Cel4o & 1320 & 18.12 & 13. 25 & 1631 & & 1734 & 13.31 \\
\hline Pt:crs & 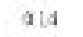 & $0: 5$ & t.13 & 1.10 & & 4.17 & 6.19 \\
\hline ALII & 323 & sst & gas & $2 \infty$ & & $3 x$ & 3.16 \\
\hline$x+120$ & 2326 & $3 \%$ & Z2s & $2: 2$ & & $20 x 1$ & $\mathrm{rezs}$ \\
\hline sty & 46.77 & 34.4 & 38.77 & 3755 & & 4.19 & 5025 \\
\hline 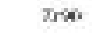 & 156 & $3 \pi$ & $6 \mathrm{v}$ & ta 41 & & 4597 & 4861 \\
\hline Hnis & 216 & 167 & $8 x$ & $8 \%$ & & 216 & 311 \\
\hline Masu? & $3: 4$ & 358 & 52: & by & & 999 & 500 \\
\hline Dulso & $2: 3$ & $23 t$ & 2.19 & 2.40 & & 233 & 2.15 \\
\hline Gat5: & 1238 & $14: \%$ & 1272 & 1475 & & 11.58 & $12 \mathrm{CH}$ \\
\hline nilse & 203 & 275 & $2 \mathrm{if}$ & Sai & & 218 & $3 \pi$ \\
\hline Df163 & $14 \leq 1$ & 16.8 & 15.45 & 1737 & & 1580 & $15: 1$ \\
\hline Tlatas & $5 t 5$ & 525 & 323 & $2 \beta s$ & & 5.42 & 3.12 \\
\hline vas & 5287 & 20.01 & sits & $2 ; 13$ & & \%o. & 923 \\
\hline Fin es & 2: 14 & ins & s.ds & 1041 & & 759 & $5 n$ \\
\hline $\min$ & 353 & 351 & $52 t$ & 1024 & & 1023 & 54 \\
\hline Lut? & $1: 3$ & t.A2 & 220 & 1.20 & & 142 & 1.28 \\
\hline
\end{tabular}




\begin{tabular}{|c|c|c|}
\hline Banx & anc.1 & 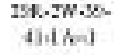 \\
\hline $\mathrm{Nr}$ & 27 & 31 \\
\hline \multicolumn{3}{|c|}{$\begin{array}{l}\text { Wyar Colsk } \\
\text { furtel }\end{array}$} \\
\hline 80 & 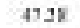 & 4.7 \\
\hline no: & 132 & 365 \\
\hline $\mathrm{AbO}_{2}$ & s:1 & IWe \\
\hline $\mathrm{N}_{1} \mathrm{O}$ & 123 & $23:$ \\
\hline Mino & 023 & 1:: \\
\hline Mteo & $3 \mathrm{AHA}$ & 12.0 \\
\hline s.a & 1646 & 100 \\
\hline 5,0 & ast & 393 \\
\hline${ }^{\prime} \sigma_{2}$ & ats & ars \\
\hline Ine & 34.6 & 12.28 \\
\hline Total & $5+2$ & wse \\
\hline Mser & 6.32 & $\omega x$ \\
\hline $\mathrm{I}$ & $80: \mathrm{V}$ & $10 * 17$ \\
\hline Mea & 7127 & 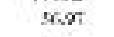 \\
\hline \multicolumn{3}{|c|}{$\begin{array}{c}\text { Trasedangas } \\
\text { cppeit }\end{array}$} \\
\hline Tas & sasice & 154103 \\
\hline vil & $431+6$ & 5126 \\
\hline $\operatorname{erg} z$ & 593 & 2.9 \\
\hline Kiss & 54 & $13 x$ \\
\hline Cals & ant & arc \\
\hline Rlss & ari & abs \\
\hline Balst & +53 & 3900 \\
\hline $\operatorname{mosi2}$ & $a n$ & ary \\
\hline eons & & ar \\
\hline $\mathrm{Nm}$ & 127 & 293 \\
\hline nak: & act & $3: 4$ \\
\hline Lasas & $2 \mathrm{es}$ & 535 \\
\hline Celuo & 1224 & $21 \Omega$ \\
\hline ptors & ats & a): \\
\hline ALII & 305 & 7.7t \\
\hline Silas & $2+x$ & 31.6 \\
\hline sev & 27.46 & $155 \mathrm{es}$ \\
\hline 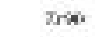 & 4940 & 8191 \\
\hline Hnis & 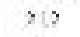 & $17 c$ \\
\hline Yast? & $7 \mathbf{m}$ & Itwi: \\
\hline Dalso & 24 & $\sin$ \\
\hline Ga15? & $n s a$ & $14.1 \%$ \\
\hline mises & 159 & 2. 5 \\
\hline D5163 & 1315 & 1400 \\
\hline matas & 252 & 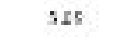 \\
\hline vas & 7se & 2.16 \\
\hline Entes & (3) & 125 \\
\hline Mizz & 335 & $2 x t$ \\
\hline LuT: & $1: 5$ & 121 \\
\hline
\end{tabular}


Appendix V. Majer, trace clement and iso6oje natios of elesta from Site 205 and Site 1438.

\begin{tabular}{|c|c|c|c|c|c|c|c|c|c|}
\hline$\$ 2$. & $\begin{array}{l}155 \cdot 54-1- \\
15.1 .99\end{array}$ & $\begin{array}{c}2 \times-34-3 \cdot \\
12-25\end{array}$ & $\begin{array}{l}25 t \cdot 55-1 \\
122 \cdot 124\end{array}$ & $\begin{array}{l}1.755 .5-1 . \\
1.5 .118\end{array}$ & $\begin{array}{c}255-26-3 . \\
70.52\end{array}$ & $\begin{array}{l}25 e \cdot 5-5.1- \\
76.28\end{array}$ & 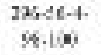 & $\begin{array}{c}2 \times-613-1- \\
3-11\end{array}$ & $\begin{array}{l}35 x-59-1- \\
151.166\end{array}$ \\
\hline \multicolumn{10}{|c|}{$\begin{array}{l}\text { Nans couste } \\
\text { Pn'si }\end{array}$} \\
\hline $\mathrm{so}_{2}$ & 2458 & $5: 45$ & & & ใิ.7 & 45.16 & is 41 & 5211 & 27.52 \\
\hline Tn. & 92 & 07 & & & 351 & 251 & $9 x_{2}$ & $c s c$ & I Ca \\
\hline$+1_{1} x_{3}$ & 548 & 1827 & & & +43 & $15 \%$ & 1332 & $2 \leqslant s ?$ & we:5: \\
\hline$* 0$ & S. $x$ & $3 . \pi$ & & & 3.8 & 24 & 205 & 254 & 553 \\
\hline H.: & $a x$ & 607 & & & 2.27 & 367 & anes & $\mathrm{cm}$ & 369 \\
\hline $\mathrm{MgN}$ & $2 \times s$ & 2.20 & & & 211 & 522 & $6=9$ & $2 x$ & 345 \\
\hline 30 & 245 & 5.36 & & & 2.31 & 1232 & ; $1 \mathrm{at}$ & 5.36 & 54 \\
\hline$K_{i} \mathrm{C}$ & s. $x$ & 2.49 & & & tw & $3: 9$ & $a z 2$ & 5.18 & 326 \\
\hline $1 / \rho$ & $a+3$ & C.A1 & & & $a z=$ & 155 & 065 & c.Tz & 243 \\
\hline $\mathrm{re}_{\mathrm{e}} \mathrm{O}_{\mathrm{i}}$ & הI & $\mathrm{CN}$ & & & 25 & 157 & $2 \mathrm{CA}$ & $t 28$ & 1011 \\
\hline skpt & 1210 & 15.25 & & & $13 \times$ & $\$ \leqslant 37$ & $528\}$ & $43 x_{2}^{2}$ & isos \\
\hline \multirow{2}{*}{\multicolumn{10}{|c|}{$\begin{array}{l}\text { Jas } \\
\text { dervex }\end{array}$}} \\
\hline & & & & & & & & & \\
\hline \multicolumn{10}{|l|}{ mil } \\
\hline i. & an & $5 \% 7$ & & & 282 & 31 & $7 \infty$ & $1: 26$ & $\ln x$ \\
\hline Bs: & 1.99 & $2.4 S$ & & & 1.35 & 312 & wy & 124 & 125 \\
\hline 58 & $31<0$ & $x \geqslant+2$ & & & 1,0 & $x \leq 5$ & 7151 & $1: 25$ & $\{x<\}$ \\
\hline $1 i$ & 49150 & $+\pi: 0-4 !$ & & & $2 x+36$ & $24: 33 y$ & $49 x \geq 25$ & $41.2 .3 y$ & $20 \times 0=0$ \\
\hline$y$ & 36.61 & $164 x$ & & & $11:-47$ & $32 \times 25$ & 245.77 & $15[1]$ & $22 n$ \\
\hline c) & 15.16 & f. 13 & & & 22.12 & 213.52 & 22.8 & & \\
\hline 6 & 130 & $1 x$ & & & $: 620$ & 31.78 & דיני & $105:$ & 1818 \\
\hline 19 & $2 \leqslant 16$ & $1: 54$ & & & sin & 39,8 & $25 \mathrm{~A}$ & tis & $10 x$ \\
\hline$a$ & 2510 & วา а & & & {$[93]$} & 366 & $55 \mathrm{WH}$ & 2075 & $160 \mathrm{~s}$ \\
\hline is & et. & hes & & & 4,08 & $s+2 y$ & 1260 & y:ss & $x i z$ \\
\hline$a$ & 2:.11 & 16.75 & & & :4.73 & 14.11 & 2553 & $\cdots 27$ & 12,24 \\
\hline es & ass & 1.79 & & & 1.19 & 322 & ass & 6.74 & 30 \\
\hline 3b & se:3s & sist? & & & es.ts & 135 & 420 & 250 & 273 \\
\hline bs. & $9.4 \times$ & (2) $8:$ & & & 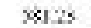 & 27.55 & 12.10 & $\therefore z$ & 91.34 \\
\hline $\mathrm{n}$ & 131 & $1 / 16$ & & & $7+\infty$ & 155 & 1.75 & 0.73 & בדנ \\
\hline u & In & 395 & & & 1.73 & 153 & $\alpha z 3$ & $33 t$ & 33 \\
\hline th & 2 & $\csc$ & & & 53 & 251 & 201 & 2.74 & 233 \\
\hline$T_{0}$ & $9 \times 3$ & CH & & & $a n$ & 21 & 91. & 616 & 264 \\
\hline L & $28 \times 8$ & 2. $n$ & & & 20 & 24.12 & $11: 3$ & $2 \times 15$ & sit \\
\hline 30 & 5438 & whas & & & 3532 & 35.50 & 4145 & 35548 & $\operatorname{sen} 6$ \\
\hline $\mathrm{ft}$ & -25 & 9,41 & & & 2.58 & 245 & 3.13 & $3 w$ & 14 \\
\hline $\mathrm{Dr}$ & .57 & sat & & & $\therefore 7$ & 96 & Sus & 207 & is \\
\hline$\$ w$ & $2+\infty$ & seso & & & 1200 & 24.42 & 2484 & $12 \times 58$ & $12: 3$ \\
\hline $\mathrm{sr}$ & 72031 & 36500 & & & 3061 & ב & $=00-1$ & $3: 353$ & 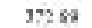 \\
\hline in & 100.14 & Je40: & & & 552) & 32 & 152 ? & is: & $\times 16$ \\
\hline IIr & $\therefore 5$ & jas & & & 255 & 159 & $1 x t$ & 2.16 & 212 \\
\hline sit & 535 & 1.41 & & & $\therefore 48$ & $3 \$ 1$ & $6 \neq 5$ & $8 \%$ & 12t \\
\hline $\mathrm{T}$ & 1.75 & 224 & & & ass & 233 & 167 & 759 & 123 \\
\hline al & $6 x$ & 4.48 & & & $2 \%$ & $12 \times 6$ & $x: i$ & +4 & 454 \\
\hline $\mathrm{n}$ & $0 \times 5$ & c.71 & & & as & 225 & (3) & 727 & 3 \\
\hline$x y$ & 532 & $1 x 7$ & & & 235 & 11,78 & 80 : & $42 x$ & 563 \\
\hline 3 & 1.21 & c.9s & & & as: & $1: 9$ & $\therefore \Rightarrow$ & $1: 22$ & 169 \\
\hline $\mathrm{Y}$ & 316 & $x$ a d & & & $15 \leqslant 5$ & 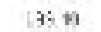 & 73. & 12655 & 1596 \\
\hline b & 5.25 & 2.0 & & & L. & 10.61 & $\Delta x:$ & 5230 & 282 \\
\hline b & 534 & $3 \times 8$ & & & 235 & $3: .14$ & 615 & $3 \div 45$ & 369 \\
\hline 1. & uts & CA7 & & & 43 & iss & $x \geqslant 1$ & 120 & 243 \\
\hline 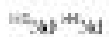 & asi:ss & 237217 & เรมา & astuce & & as1:se & & & asisos \\
\hline mexther & assoic & רונינב35, & [.ssut & a.suzb & & a.eว & & & ase:0 \\
\hline
\end{tabular}




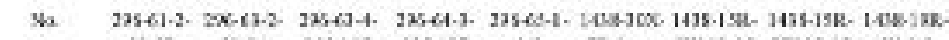

\begin{tabular}{|c|c|c|c|c|c|c|c|c|c|}
\hline & 20.32 & $2 . .35$ & 11 -215 & 165.127 & as & 7f.iesp & $2 \mathrm{w}-3.15$ & $36.13-15$ & cwex \\
\hline $\begin{array}{c}\text { Xajw Obade } \\
|r| \leqslant \mid\end{array}$ & & & & & & & & & \\
\hline $\mathrm{xO}_{2}$ & es.as & M.5s & 614 & tt is & 2120 & & $\omega . n$ & 45.20 & 5723 \\
\hline The & 95 & 680 & $19 \%$ & $0 \omega$ & 275 & & ast & 111 & $n \infty$ \\
\hline $\mathrm{A}_{1} \mathrm{~N}_{3}$ & 1324 & 1881 & 116 & 196 & 297 & & $1 \leqslant a$ & 1758 & 1302 \\
\hline$x, 0$ & $(s)$ & 322 & 2,28 & 257 & $1.5 s$ & & $3 x$ & 251 & $1 x:$ \\
\hline Whs & 927 & $\operatorname{crs}$ & 697 & 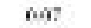 & 927 & & 26 & 927 & 69 \\
\hline $\mathrm{Mg}=\mathrm{O}$ & 1.34 & 920 & 291 & 180 & $8 \leq 5$ & & $20^{3}$ & stit & 6is \\
\hline 20 & 3. & 72 & 2.25 & 630 & 7.51 & & 43 & 1230 & $2 \mu$ \\
\hline $\mathrm{K}_{1} \mathrm{E}$ & 280 & tes & eis & 0.25 & 1.15 & & 392 & 012 & 000 \\
\hline l'a & $a+s$ & (.). & $a s=$ & wst & $a+s$ & & 335 & $1+43$ & wo \\
\hline $\mathrm{r}_{\mathrm{c}, \mathrm{O}_{\mathrm{H}}}$ & 52 & 5.17 & 2ast & 6.11 & 225 & & 74 & 254 & 600 \\
\hline Mkt & 36 35 & $4.5 ?$ & 3459 & 3552 & 5955 & & $5 s i c$ & $45.0 \pi$ & $52 \mathrm{tt}$ \\
\hline $\begin{array}{l}\text { Thes } \\
\text { derverx }\end{array}$ & & & & & & & & & \\
\hline inal & & & & & & & & & \\
\hline L. & 3156 & 6.15 & דיר & 9.8 & 2325 & & 575 & 213 & 1759 \\
\hline bi: & 1.55 & :e4 & 1.25 & 635 & a.ss & & 315 & 132 & $\omega x$ \\
\hline 58 & $15: 9$ & 3216 & 3556 & $31<$ & 1354 & & 311 & 1) 43 & is 48 \\
\hline li & 204574 & $x 2720$ & 2ty 1 & $3 e 3132$ & 427569 & & $3 / 22: 8$ & 2503.14 & 278esa \\
\hline$v$ & 9471 & 16531 & 131.96 & $\operatorname{sic} 6$ & $20 \%$ & & (5) 34 & $2 \mathrm{~W} 12$ & 79 \\
\hline $\mathrm{E}:$ & & & & & 114.19 & & & : 2.17 & \\
\hline$\infty 6$ & as: & $1 \therefore \infty$ & 561 & كנבנ: & $213 x$ & & ISA & 31100 & 1553 \\
\hline $\mathrm{Ni}$ & 295 & 545 & $t e s$ & +15 & $25+2$ & & $11 \%$ & 9.31 & 2575 \\
\hline$\alpha$ & $2 n$ & 567 & 1312 & 0.9 & 3215 & & 35.8 & 33.12 & 2755 \\
\hline is & 164.31 & 1.26 & \&As? & t 85 & $S S . A]$ & & a.s. & 1532 & 4334 \\
\hline$a$ & 2423 & $1<.50$ & 842 & 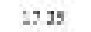 & $: 252$ & & 12.67 & de.7e & $13 \mathrm{co}$ \\
\hline \& & $a \neq s$ & 6.16 & 061 & 039 & $a 3_{2}$ & & 353 & 0.43 & 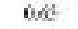 \\
\hline wb & פית & $|\alpha 2|$ & 5273 & 605 & 2.99 & & 160 & 794 & 1151 \\
\hline Ba. & 300.27 & 143,47 & 214.76 & $16 x=6$ & $2+182$ & & iss 15 & 25531 & $35 y$ \\
\hline $\mathbf{n}$ & 20 & tA: & $1: 22$ & a.zs & 0.57 & & $1 \mathrm{ts}$ & 255 & $1, A$ \\
\hline u & 1.13 & C35 & 67 & $6 a ?$ & adi & & 30 & 033 & 64 \\
\hline \$ & 456 & דוה & 2.12 & 1 A. 7 & $1.3 ;$ & & 167 & 251 & 3.26 \\
\hline $\mathrm{Ta}$ & 93 & $\cos$ & 617 & 695 & $a s s$ & & 265 & 922 & CH \\
\hline a & 1932 & 11.25 & 2362 & 2346 & 2.15 & & $3 \times 2$ & $y=8$ & $1 . \pi 8$ \\
\hline 56 & $12 \pm 0$ & 321 & 15.43 & 313 & 2351 & & 13.50 & 195.13 & 4.61 \\
\hline ft & 297 & 258 & $\therefore \pi$ & 2.20 & 1.77 & & $3: 5$ & 235 & 205 \\
\hline DT & 5.95 & 1.47 & 602 & 2,32 & 4 & & 262 & 13.58 & $a s$ \\
\hline 2wd & 28.54 & 21.29 & $3: 63$ & 2354 & 23.47 & & I & 10261 & 2.2 \\
\hline 5 & 12087 & 15767 & $2: 80$ & 350.10 & 181 a & & 1595 & $N 271$ & 16.50 \\
\hline घ & $19: 3$ & 61.51 & $1: 1.50$ & 8557 . & 4536 & & 20036 & $12=11$ & 164.20 \\
\hline IIr & 5.37 & 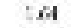 & $40 ;$ & 2.47 & 1.20 & & 327 & 352 & +תiz \\
\hline 81 & 631 & 6.72 & 9.13 & 532 & 7.51 & & 363 & 19.15 & 0.78 \\
\hline na & 1.56 & : $\pi t$ & 1.11 & 2.90 & 225 & & 353 & 613 & wow \\
\hline a) & 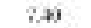 & $8 \mu$ & 2133 & $22 \geqslant 3$ & t.s. & & $38:$ & 28.09 & 1.10 \\
\hline I & 1.22 & $: 24$ & $1: x 2$ & 2.25 & I.SH & & 364 & -23 & 0.16 \\
\hline$\partial y$ & 2.99 & $\{.4\}$ & 1177 & 446 & $13 / 3$ & & 40 & $30 \%$ & 1,71 \\
\hline $2 b$ & 1.26 & $2 n$ & 2.97 & 2.55 & 211 & & 251 & 6.43 & 02 \\
\hline$\gamma$ & 5261 & $\$ 15$ & sach & $575 t$ & ES If & & $\mathrm{Nis}$ & 2500 & (2) \\
\hline B & 421 & 2.10 & $r .50$ & 865 & $x \rightarrow y$ & & 203 & 1293 & 1,0 \\
\hline $2 b$ & 5.33 & 195 & $7 / 43$ & 869 & $5: 27$ & & 253 & 16,6 & 3.At \\
\hline In & a.s & c.ti & 1.01 & 1.17 & a.s & & 34 & $2+3$ & $w=0$ \\
\hline 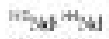 & & & (2)13) & (2) & & $\operatorname{csin}$ & as1\$10 & & เ2136 \\
\hline "hen & & & tasazt & c.38029 & & $62525: 86$ & axwat & & 6.75321 \\
\hline
\end{tabular}




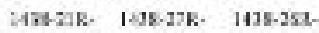

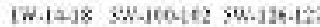

\begin{tabular}{|c|c|c|c|}
\hline \multirow{2}{*}{\multicolumn{4}{|c|}{ 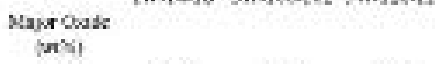 }} \\
\hline & & & \\
\hline $\mathrm{xO}_{2}$ & 631 & $2 \times .52$ & a.4. \\
\hline Tho. & 96 & 66 & 958 \\
\hline$+1_{1} \hat{N}_{3}$ & 616 & 21.72 & 15.23 \\
\hline$* 0$ & 3.5 & 206 & 360 \\
\hline Whs & aม? & 607 & 66t \\
\hline $\mathrm{M}_{5} \mathrm{O}$ & 276 & 4.68 & $38 x$ \\
\hline$\Delta 0$ & A.55 & 12.67 & 4.72 \\
\hline$K_{1} \in$ & 1.t. 2 & 0.14 & 048 \\
\hline ly & ati & DST & 036 \\
\hline $\mathrm{rc}_{\mathrm{C}} \mathrm{O}_{\mathrm{H}}$ & 455 & 5.24 & 799 \\
\hline Nisti & 12.40 & $503 t$ & 4857 \\
\hline \\
\hline \multirow{2}{*}{\multicolumn{4}{|c|}{$\begin{array}{l}\text { dervare } \\
\text { enal }\end{array}$}} \\
\hline & & & \\
\hline L. & 735 & 54 & $11 \%$ \\
\hline is: & $1 . n$ & 0.4 & 1.18 \\
\hline 58 & 135 & sise & 1581 \\
\hline 1i & 241395 & $5184.5 ?$ & 291235 \\
\hline$\eta$ & $16.7 x$ & 33366 & 96.59 \\
\hline $\mathbf{c}$ & 2.14 & 12.73 & ase \\
\hline$\omega_{0}$ & 1251 & 2.15 & 11.2 \\
\hline $\mathrm{ki}$ & 231 & 1961. & 959 \\
\hline$a$ & IK:61 & sis & $48 \mathrm{~N}$ \\
\hline is & 51.14 & 6.az & s6. 18 \\
\hline$a$ & 2532 & 1647 & $18 . \pi$ \\
\hline os & as? & 615 & 039 \\
\hline wb & 2950 & 131 & 10.57 \\
\hline$B$ & $1,4,0$ & so:23 & 28.51 \\
\hline $\mathbf{n}$ & 3.55 & 627 & ฮn \\
\hline u & an & 028 & 934 \\
\hline M & 251 & 2.47 & 121 \\
\hline$T_{0}$ & 918 & 60 & 967 \\
\hline La & 2221 & 32.44 & $32 \%$ \\
\hline 80 & 2520 & $\infty 31$ & 359 \\
\hline$t \mathrm{t}$ & 2.4 & 248 & 152 \\
\hline DT & $\therefore 10$ & 1004 & 139 \\
\hline $24 \mathrm{j}$ & 2521 & $=434$ & 712 \\
\hline 5 & 212,22 & 3700 & 22367 \\
\hline घ & 10.5 .12 & $\Delta 40 \mathrm{~s}$ & Itsed \\
\hline iIr & $\therefore 5$ & $x: 3$ & 313 \\
\hline Sil & 295 & 1064 & 268 \\
\hline ne & as: & 1.91 & aes \\
\hline a) & s.ts & 1035 & 201 \\
\hline $\mathrm{n}$ & $a+5$ & 261 & $9 A 2$ \\
\hline$x_{y}$ & 823 & 536 & 331 \\
\hline sh & $a s$ & 200 & $0 \times 4$ \\
\hline $\mathrm{Y}$ & 271 & 5113 & 8178 \\
\hline 口 & 1.31 & 498 & $15 \%$ \\
\hline $2 b$ & sits & 4.14 & 2.49 \\
\hline 1. & uss & $0 \pm 6$ & 0.42 \\
\hline 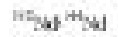 & asisce & & 0512 \\
\hline then ther & a.sous & & 0.25525 \\
\hline
\end{tabular}




\section{CONCLUSIONS}

\subsection{Model for Oligocene Evolution and Rifting based on Site 296 and Site 1438}

DSDP Site 296 and IODP Site 1438 record the evolution of early to late Oligocene ( $\sim 28$ to $36 \mathrm{Ma}$ ) magma compositions in the northernmost segment of Izu-Bonin Mariana arc (segment 1 of Ishizuka et al., 2011b) before arc rifting and opening of the Shikoku Basin. Overall, melt compositions determined from glasses, clasts, and melt inclusions and inferred from mafic minerals show a wide range of trace element variation in basaltic compositions, suggesting that diverse primary magmas existed during this time and were derived from depleted to enriched mantle sources. Mantle sources became more enriched with time because of the input of pelagic sediments from the subducting Pacific plate. Differentiation of the basaltic magmas to felsic compositions retained the original incompatible trace element features but was affected by crystallization of accessory minerals like apatite and or amphiboles. Simultaneous intrusive and extrusive activity during this time led to crustal thickening, which may have aided in stabilizing amphiboles in magma at depth during the later periods.

Based on the mineralogical and geochemical changes seen along the stratigraphic sections between the cores (Fig 5-1) the following evolution can be interpreted:

- The base of Site 296 are volcanic sandstones-breccias. These were eroded from the ridge and thus may contain fragments of older Eocene IBM volcanics, which indicates a possible volcanic-plutonic connection between the tonalites and some dacitic volcanism (Stage A in Fig 5-2)

- With increasing crustal thickness and increasing water contents of the magma, amphiboles became stable. High water contents also led to the crystallization of 
anorthite rich plagioclase and suppression of primitive orthopyroxenes in these magmas. Diverse primary magmas existed, both slightly LREE enriched and depleted. Magma compositions became tholeiitic as inferred from clinopyroxenes. (Stage B in Fig 5-2)

- Increasing signs of rifting related magmatism but still at high water contents. At Site 296, high Mg\# clinopyroxenes are observed accompanied by increasing $\mathrm{Nb}$ concentrations and the appearance of MORB like clinopyroxenes. Amphiboles from Site 1438 change from slightly enriched to depleted in LREE/MREE ratios but enriched in fluid mobile elements like $\mathrm{Ba}$ and $\mathrm{Rb}$.

- During this stage there were some late-stage enriched arc magmas (enriched in LREE and $\mathrm{Nb}$ ) which gave rise to some mafic to intermediate amphibole bearing magmas. (Stage C in Fig 5-2). This is not observed in Site 1438 sediments as the subduction shifted eastward and debris from this stage did not arrive at the AmamiSankaku basin.

- Magmas from the top of unit 2 Site 296 become again depleted possibly due to increased rifting, intrusion of MORB-like decompression melts and decreasing subduction input (Stage D in Fig 5-2). 


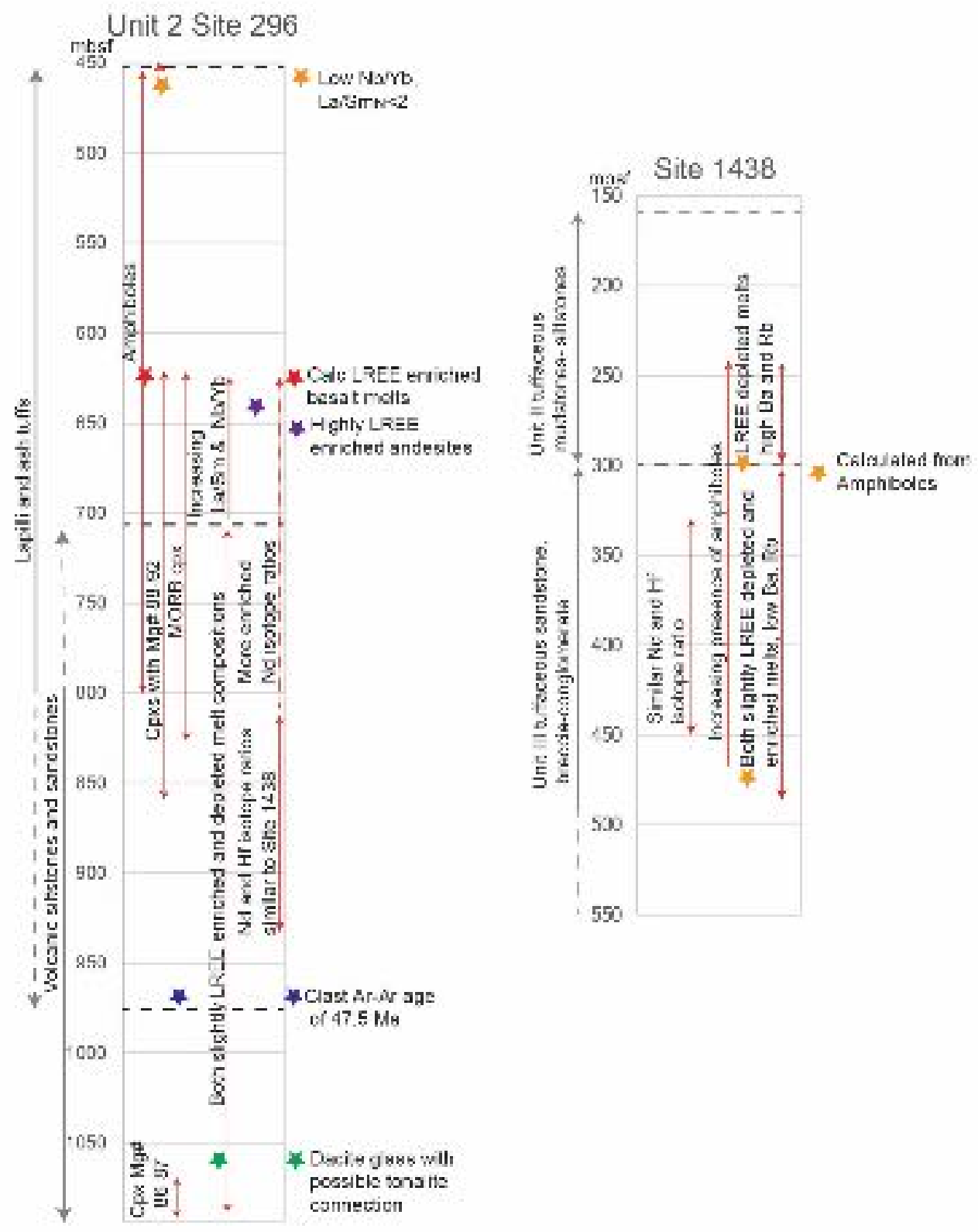

Figure 5-1 Stratigraphic section studied from both Sites 296 and 1438 and the changes in mineralogy and geochemistry observed 


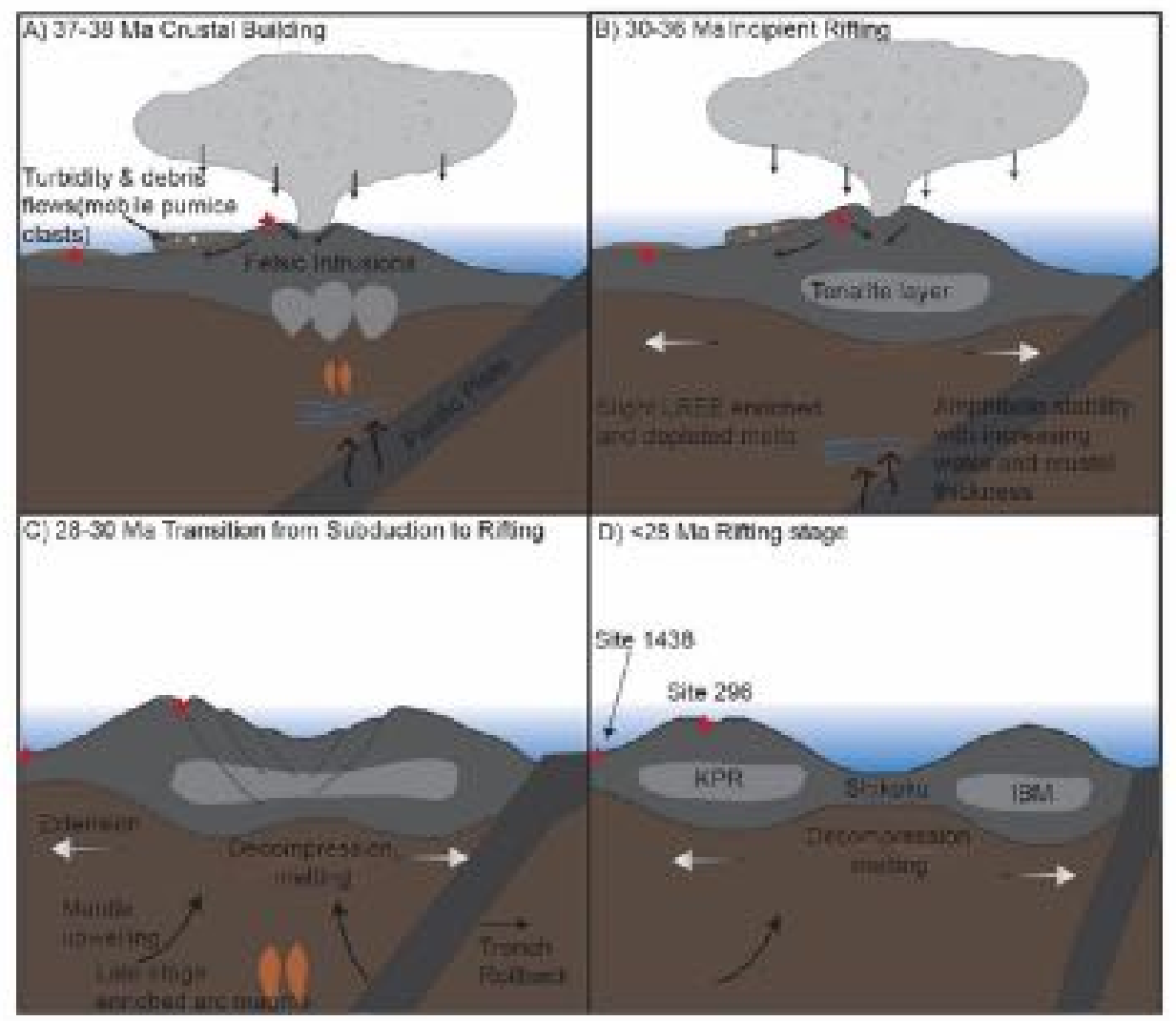

Figure 5-2 Schematic diagram showing the possible magma evolution of the northernmost IBM prior to rifting

\subsection{Implication for the Evolutionary History of Izu Bonin arc}

The Izu-Bonin Mariana arc has been one of the best places to study and understand intraoceanic arcs. The extended nature of the arc has allowed scientists to explore and discover early subduction rocks like boninites, in addition to understanding the evolution of marginal basins and remnant arcs. This study was conducted to understand the evolution of the first Izu-Bonin arc and any changes that may indicate the initiation of rifting. Postrifting, around $20 \mathrm{Ma}$ ago, the resurgence of arc volcanism in the IBM are currently being studied in the rear arc side of the active Izu-Bonin arc, where depleted tholeiitic and calc- 
alkaline arc magmas are erupting. This research suggests that during rifting of an arc, magma composition may become more tholeiitic with the intrusion of decompressions melts along with arc melts, which may be of enriched type.

From the previous research on the IBM arc and this study, the early evolution observed in the Izu-Bonin arc until the first rifting events are such:

- IBM started with lithospheric subsidence around $50 \mathrm{Ma}$ ago; during this time, forearc was magmatically active with the eruption of FABs and boninites. Site 1438 located on the rear arc side does not have significant evidence for boninites, indicating that boninites perhaps were restricted in the forearc region.

- Around $45 \mathrm{Ma}$, there was a transition from subsidence to subduction, which may have led to the eruption of some high $\mathrm{Mg}$ andesite, as exposed in Bonin Ridge escarpment.

- The first arc was established around $43 \mathrm{Ma}$ with the start of subduction, new evidence from Site 296 and Site 1438 suggests that early arc magma was dominated by calcalkaline magma type instead.

- Rifting at least in the north may have been in multiple stages, leading to crustal thinning and intrusion of decompression melt, which led to the eruption of tholeiitic magma in the later stages.

- Contemporaneously there were highly enriched calc-alkaline magmas which formed at the same time as the MORB like melts

- Following rifting and formation of the Shikoku basin, there was no further activity on the KPR; all magmatic activity shifted to the east. 


\subsection{Future Research Direction}

- To get a better age constraint for the time of evolution using mineral dating method. Dating biotite grains in the sediments from Site 296 can help to define the timing of events and prove that there has not been much reworking in the core section; the same thing can be done in Site 1438 if required to re-establish the ages.

- To test the early evolution in other segments of KPR. Site 1201 and Site 448, which lies in the southern section, coincides with the Oligocene Mariana arc. These sites can be revisited, and a similar research approach can help to establish the evolution along the arc.

- Oxides like chromites were not analyzed in this study, but their mineral chemistry is significant in understanding their genesis and the mantle condition during formation. Therefore, in addition to mafic minerals, chromites can help to understand the evolution of the IBM system. 


\section{APPENDIX I.}

\section{Sample Description}

\section{DSDP Site 296}

DSDP Site 296 is located on a terrace on the west side of the Kyushu Palau ridge at a water depth of 2920 meters. The drilled section consists of $1087 \mathrm{~m}$ of sediments and sedimentary rocks, which were, divided into two major lithological, Units 1 and 2, by the shipboard scientific party (Ingle et al. 1975). Unit 1 is $453 \mathrm{~m}$ thick (Cores 1-47) and is subdivided into 7 subunits (1A-1G). These consist of foraminifera rich nannofossil clays and nannofossil oozes with interbedded volcanic ash layers. Ash layers and layers of unconsolidated volcanic silt and sand are predominant in the bottom sections of Unit 1, especially subunits $1 \mathrm{~F}$ and $1 \mathrm{G}$ (cores $31-48$ ). Biostratigraphic ages from the nannofossils indicate ages of late Oligocene to Late Pleistocene for Unit 1. Unit 2 is $634 \mathrm{~m}$ thick (Cores 48-65) and consists of two lithologies, defined by the shipboard party: 1) tuffs and lapilli tuffs and 2) volcanic sandstones and siltstones. The Unit is not subdivided. The biostratigraphic age of the sediments ranges from early to late Oligocene (Ingle et al., 1975). An Ar-Ar age of a basalt clast in Core 63 was dated at 47.5 Ma (Ozima et al., 1977), indicating some material is significantly older than the depositional ages of the sediments. The overall interpretation of the drilled section at Site 296 was that Unit 2 represented volcanic debris shed from the KPR during its major eruptive phase before rifting, and that Unit 1 represented volcanic and pelagic sediment deposited following rifting as the ridge subsided below sea-level. Study of ash layers in the upper units of Unit 1 by Donnelly et al. (1975) suggested a possible origin as airfall from surrounding subaerial volcanoes not located on the KPR. 
For this study, samples were selected in order to be able to isolate fresh glass shards, mineral grains and clasts large enough to analyze individually for geochemical analysis. A total of 92 samples were taken from the Site 296 cores at the former DSDP West Coast Repository in La Jolla, CA by R. Hickey-Vargas in 1991. Selection was based on core summaries in the DSDP Leg 31 Initial Reports and direct examination. This is a summary of all samples from the drilled section that were collected, including cores that were too fine-grained for use in this study.

\section{Cores 25- 35}

These are classified as nannofossil chalks with ash layers. - Materials are mainly buff to light grey colored clay to silt sized unconsolidated or loosely consolidated sediments, consisting mainly of foraminifera, and variable amounts of volcanic glass and lithic fragments present as ash layers with minor quantity of feldspars, micas, magnetite and clay minerals. These sediments (16 samples) belong to subunit $1 \mathrm{E}$ and top of unit $1 \mathrm{~F}$ have an age of Early Miocene to Late Oligocene. Samples taken from Cores 28 to 35 are from interbedded ash layers. Such samples have high quantity of volcanic glass and fewer foraminifera including a few samples with high radiolarian content and appear as poorly consolidated sand to silt sized sediments. Both felsic and mafic lithic fragments are present and become abundant in the lower cores. No samples were analyzed. 


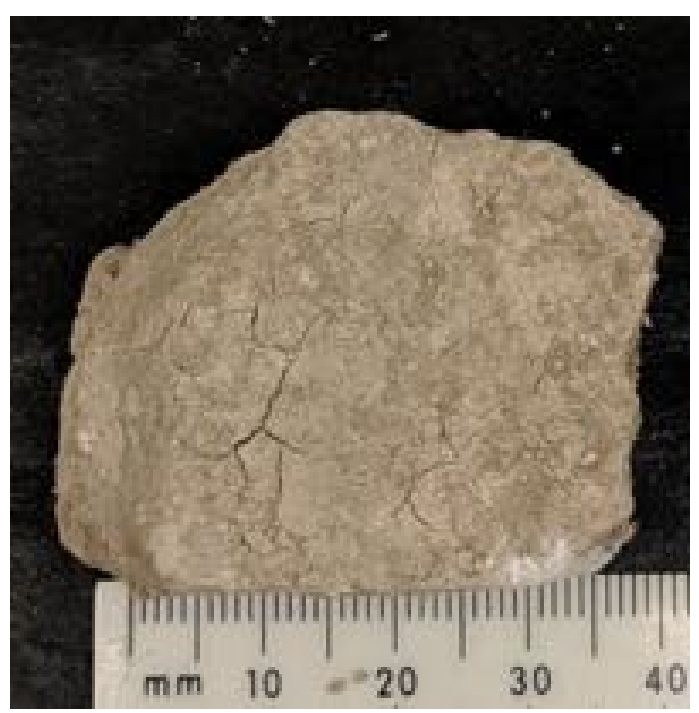

\section{Core 36-38}

These are classified as clay rich nannofossil chalks with volcanic ash. Cored rocks change from buff to grey colored consolidated sediment with patches of dark, clay rich horizons and light-colored chalks. Four samples taken from these cores consist of sand-sized volcanic glass and minerals in a silty-clay matrix. All the samples are from ash layers so has high content of glass and other volcanic minerals. Grain size becomes coarser and the matrix is more clayey in deeper intervals. The samples belong to bottom of unit $1 \mathrm{~F}$ and top of unit $1 \mathrm{G}$ and are Late Oligocene in age. No samples were analyzed.

\section{Core 39-40}

These are classified as nannofossil chalk with volcanic ash. - Eleven samples were taken from these cores. There is general decrease in nannofossil content compared with to cores 36 to 38 and samples are more clay rich than light colored chalks. Samples are dark greyblack to dark grey-brown mainly unconsolidated sediments with interspersed and varying amount of light grey poorly consolidated sediments, possibly nannofossil chalk. Sample are from or close to ash layers and consist mainly of volcanic glass and feldspars with 
minor nannofossils and heavy minerals. All samples are from the middle of Unit $1 \mathrm{G}$ and are late Oligocene in age. There is an increase in the chalk content from Core 39 to 40. Samples from top of Core 40 are sandy siltstone and contain equal buff and dark grey sediments which becomes slightly intermediate beige-grey color loosely consolidated sediments down the core. No samples were analyzed.

\section{Core 41-47}

These are classified as clay rich nannofossil chalks with volcanic ash. Nine samples were taken from these cores. Samples are beige to light grey colored nannofossil chalk and dark grey-black colored clay rich chalk units with interbedded ash layers. Sediments are either consolidated or unconsolidated, with varying amount of volcanic glass, lithics and minerals like feldspar, pyroxene and magnetite in a matrix of chalk and clay. Samples are late Oligocene and are at the bottom of Unit $1 \mathrm{G}$. The size of the volcanic grains increase down the core from silt to sand size and the amount of clay to chalk varies. Sample 47-1-117119 present at the base of Unit $1 \mathrm{G}$ is a light grey-beige colored rock with sand sized grains

of glass, pyroxene and feldspar in a silty clay matrix made up of nannofossil chalk and clay was analyzed for minerals and glass.

Intervals analyzed are: 47-1 (117-119) were disaggregated and glass shards and mineral grains were analyzed

\section{Cores 49-50}

These are classified as lapilli tuffs. - Three samples were taken from these cores. Samples are dark to medium grey-black tuffaceous sandstones with some tan colored sediments in a sand-silt sized matrix. They consist of mafic and felsic volcanic lithic fragments with loose volcanic minerals like feldspars and pyroxene and oxides with glass shards and minor 
quantity of amphibole.

Intervals 49-1 (24-27) and 50-1 (122-124) were disaggregated and glass shards and mineral grains loose in matrix were analyzed.

\section{$\underline{\text { Core } 52}$}

This is classified as a clay and ash rich nannofossil chalk. One sample was taken from the core. Sample 52-1 (139-141) is a laminated sedimentary rock; the layers are light to dark grey in color with interbedded nannofossil chalk and ash layers. Some grains are sand to silt size in a silt-clay sized matrix. There is a sharp contact between the ash and chalk layer and sedimentary features produced by current.

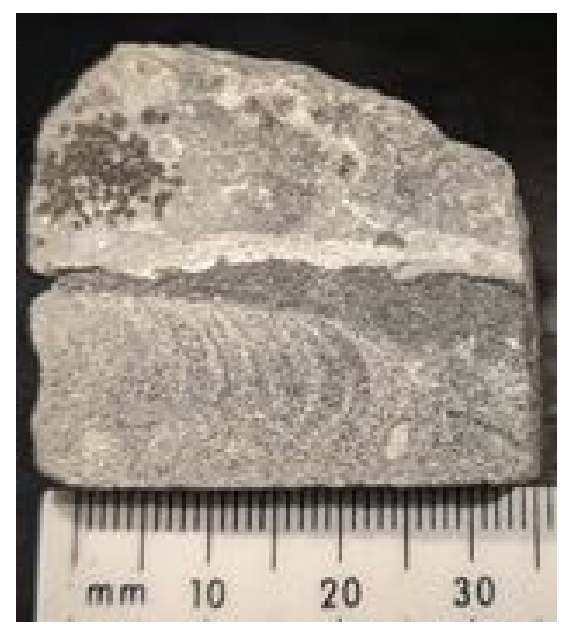

\section{$\underline{\text { Core } 54}$}

This is classified as lapilli tuffs and ash tuffs. Six samples were taken from this core. These are dark grey to olive green breccias with a clay and vitreous matrix. Both felsic and mafic volcanic lithic fragments are present, mafic clasts are more angular than the pumice clasts. In the matrix, volcanic minerals also occur as loose grains. Minerals include feldspars and pyroxenes with amphiboles and oxides. Fresh glass shards are also seen within the 
sediments. Amphiboles are not very abundant (less than 5\%) but are most abundant in this core compared with others.

Intervals analyzed are: 54-1 (115-119), 54-1 (140-143), 54-3 (17-20) and 54-3 (23-26) were disaggregated and minerals and glass were picked and analyzed. Clast from 54-1 (115-119) and 54-2 (23-25) was cut out and analyzed.

\section{Core 55}

This is classified as a lapilli tuff. Three samples were taken from this core. These are breccia with large andesite clasts (up to $5 \mathrm{~cm}$ ). Two of the three clasts are hornblende andesite and the other is a pyroxene andesite (Ingle et al., 1975). The groundmass is made up of mineral grains of feldspar, augite and oxide are found in a relatively fresh to slightly altered groundmass made up of mainly glass with some altered plagioclase and clays. The clasts were cut from the matrix and powdered for elemental analysis.

Intervals analyzed are: Clast was cut out from 55-1 (115-118), 55-1 (133-135) and 55-1 $(122-124)$ and analyzed

\section{Core 56}

These are classified as lapilli tuffs and ash tuffs. - Nine samples were taken from this core. Except one sample, these are poorly sorted olive green breccias with predominantly large mafic clasts and smaller pumice clasts. In the matrix, loose volcanic minerals and glass can be seen in a clayey-silty matrix. One sample from Section 5 is a buff colored graded nannofossil chalk. The grading is from slightly coarser ash layer upward to a very fine chalk.

Intervals analyzed are: 56-5 (93-95) was disaggregated and loose minerals were analyzed. Clast was cut out from 56-1 (70-72), 56-1 (76-78) and 56-4 (98-100) and analyzed 

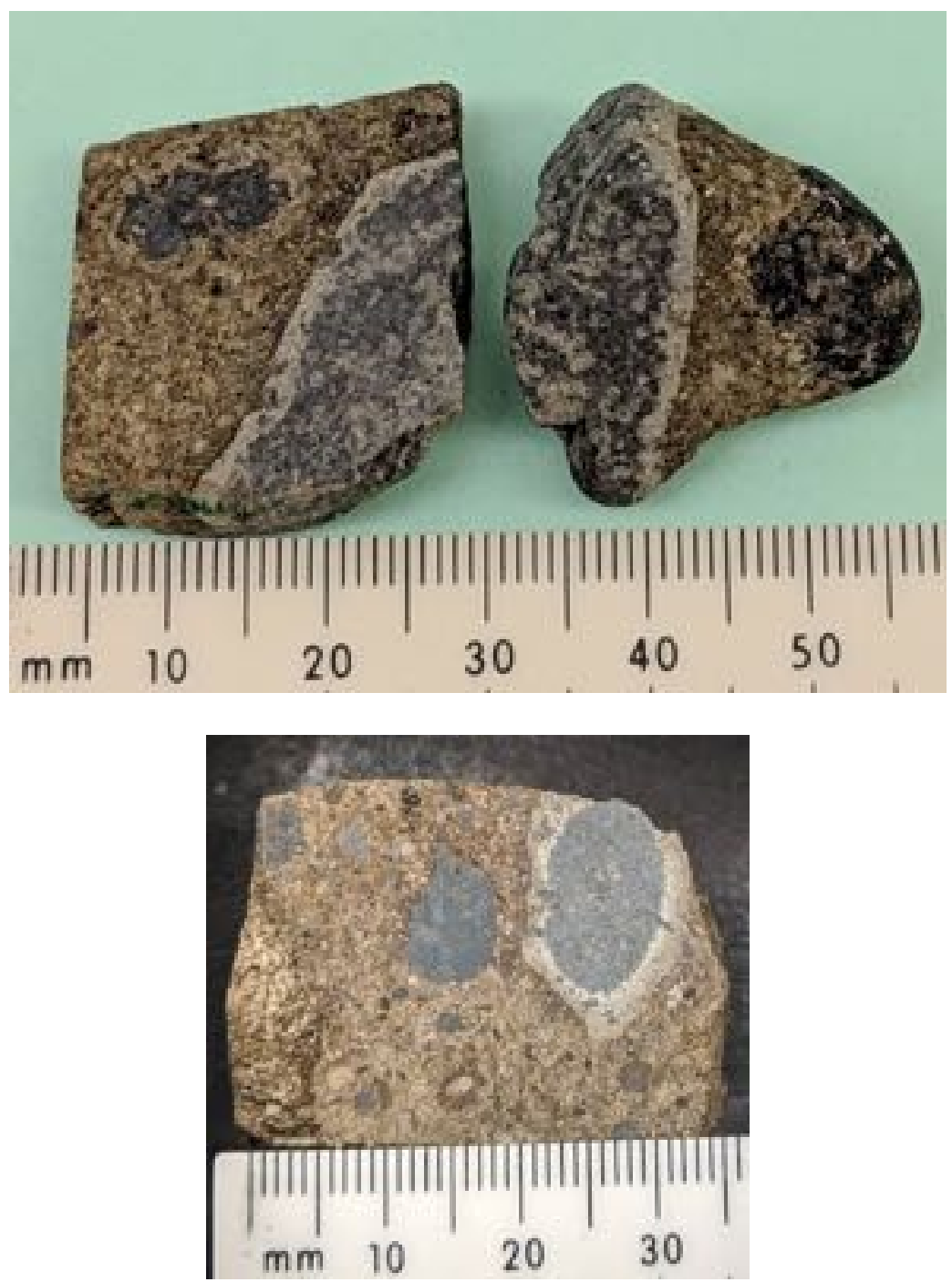

\section{$\underline{\text { Core } 57}$}

These are classified as lapilli tuffs and ash tuffs. Six samples were taken from this core. They are poorly sorted light olive green to grey breccias with both mafic and pumice clasts. Compared with Core 56, there are more pumice grains in this section, and some of the mafic clasts in this section have been altered to clay. Sample 57-2 (97-100) has the most amphiboles found within Site 296 samples studied. Sample 57-3 (38-40) is graded sandstone, with coarse sand-sized lithic fragments in silty clayey matrix to finer fragments in a more clayey matrix. 


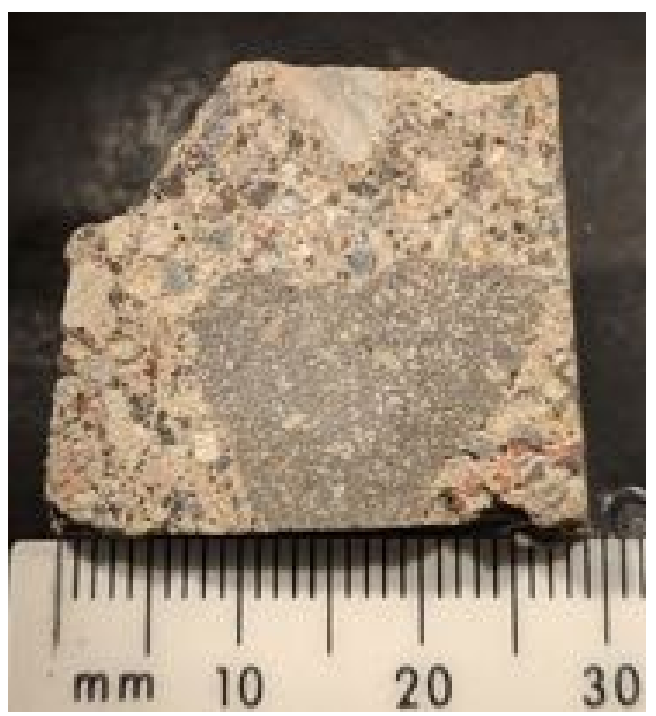

Intervals analyzed are: 57-1 (23-26), 57-2 (97-100) and 57- 3 (38-40) was disaggregated and loose minerals were analyzed

\section{Core 59-60}

These are classified as lapilli tuffs and volcanic siltstone. -Four samples were taken from these cores. These are light to dark gray poorly sorted clast-supported breccias with angular to subangular lithic fragments. Lithic fragments include pumice, aphyric basalts, scoria andesites in a silty to sandy grey matrix. Other volcanic minerals are also present in the matrix including fresh feldspars and pyroxene. These are the lowermost samples where amphiboles are seen at Site 296 . Core 60 samples are slightly more altered than those in Core 59, the pumices have altered to clays.

Intervals analyzed are: 59-1 (89-91), 59-1 (98-101) and part of 60-1 (8-11) were disaggregated and minerals and glass in the matrix were analyzed. Clast was cut out from 60-1 (8-11) and 60-1 (101-105). 


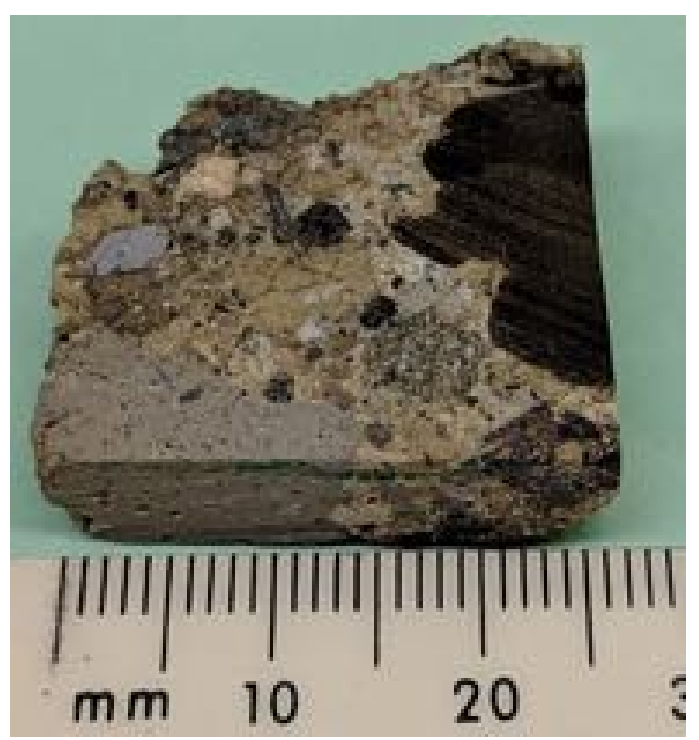

\section{Core 61-62}

These are classified as ash and lapilli tuffs with volcanic siltstones and sandstones. -Five samples taken from these cores are medium to dark grey poorly sorted breccia with angular to subangular clasts, which are medium to large sized pumice clast and smaller mafic clasts in an altered glassy matrix. Fresh feldspars and pyroxene can also be seen in the groundmass of the clasts. One sample from Core 62, section 2 is a fine-grained breccia with equally abundant mafic and felsic clasts.

Intervals that were used for analysis are: 61-1 (39-41) and 61-2 (38-40) were disaggregated and minerals and glass in the matrix were analyzed. Clast was cut out from 61-2 (30-32) and analyzed. 


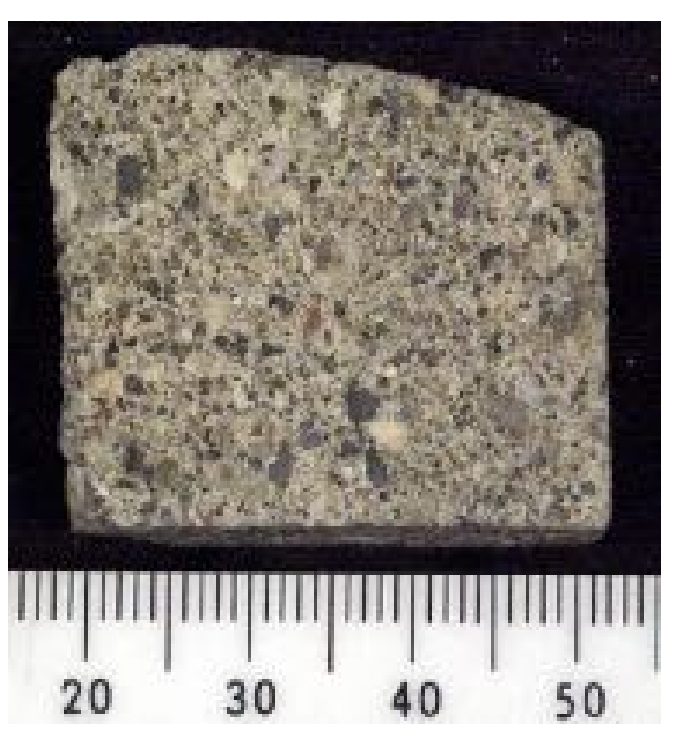

\section{$\underline{\text { Core } 63}$}

These are classified as lapilli tuff and volcanic sandstones. Seven samples from Core 63 were taken. These are like Cores 61-62; medium to dark grey poorly sorted breccias with big pumice clasts and medium sized mafic clasts $(0.5 \mathrm{~cm})$ in an altered glassy matrix. Fresh volcanic glass and minerals are common in the matrix.

Intervals that were used for analysis are: 63-1 (146-149), 63-2 (31-34), 63-3 (36-38) and 63-3 (140-143) were disaggregated and minerals and glass in the matrix were analyzed. Clast cut out from 63-2 (31-34) and 63-4 (112-115) were analyzed. 


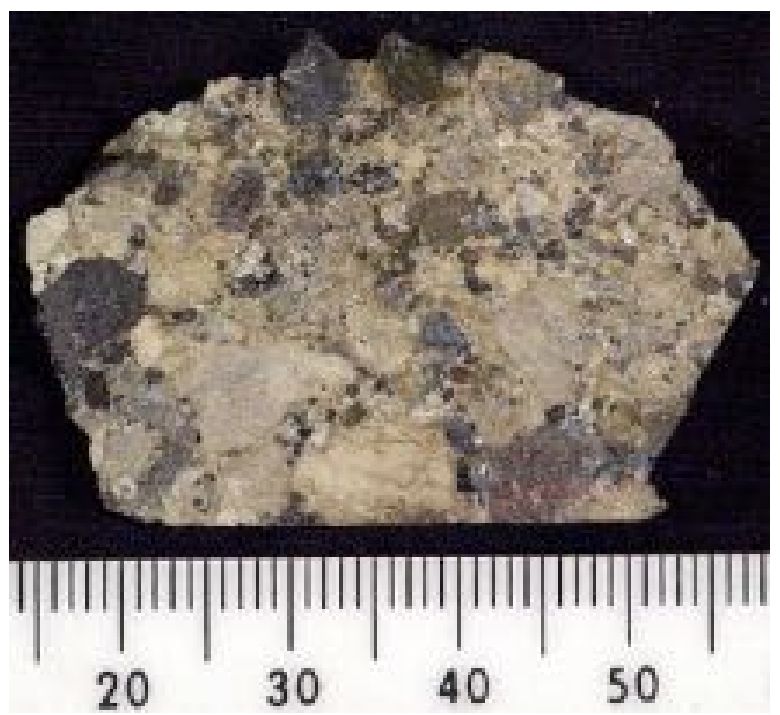

\section{Core 64}

These are classified as volcanic siltstone and sandstone. Four samples were taken; these are medium to fine grained medium grey breccias and one is a coarse sandstone. The clasts are poorly sorted, sub-angular mainly pumice and microcrystalline or porphyritic basalts in altered glass and clay matrix.

Intervals that were used for analysis are: 64-3 (119-121) were disaggregated and minerals and glass in the matrix were analyzed. Clast cut out from 64-3 (125-127) was analyzed

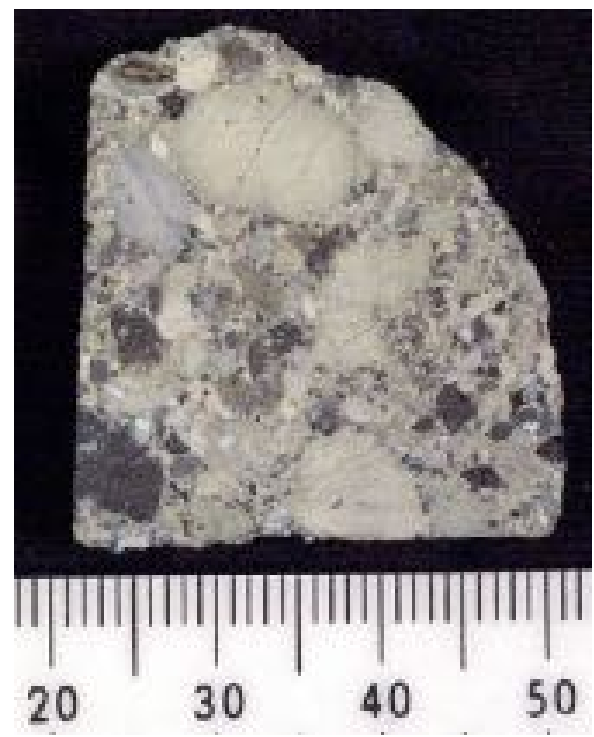




\section{$\underline{\text { Core } 65}$}

This is classified as a volcanic siltstone. -Four samples were taken from the core. The samples are olive green breccias or sandstone. Clasts are angular, poorly sorted and consist of pumice, scoria, aphanitic or porphyritic basalts, pyroxenes, and altered feldspars in an olive green clay matrix.

Intervals that were used for analysis are: 65-2 (84-87) were disaggregated and minerals and glass in the matrix were analyzed. Clast cut out from 65-1 (0-3) was analyzed.

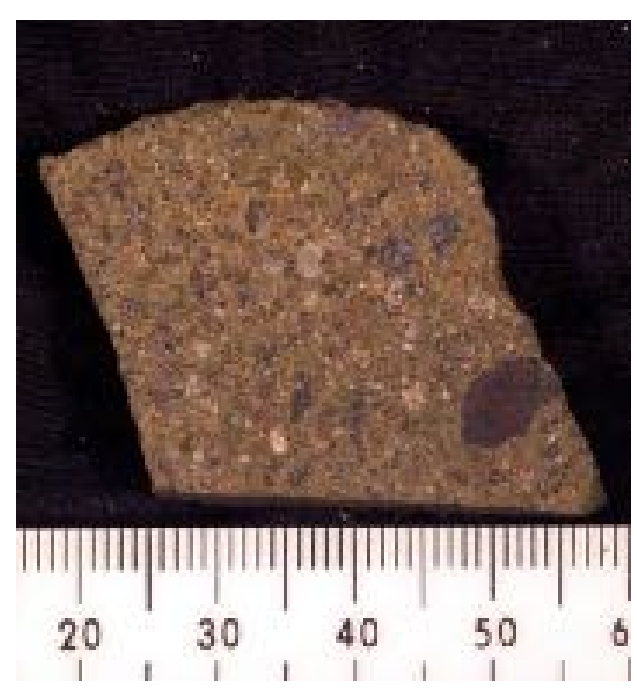

\section{IODP Site 1438}

IODP Site 1438 is located about $230 \mathrm{~km}$ to the SW of Site 296 in the Amami Sankaku Basin. Drilling recovered $1461 \mathrm{~m}$ of sediment sequences and $150 \mathrm{~m}$ of oceanic basement. The sedimentary sequence was divided into 4 lithological units (I-IV) based on texture, compactness and proportion of rock types. As described by Arculus et al. (2015) Unit I is 
$160 \mathrm{~m}$ thick recent to latest Oligocene tuffaceous mud and clay with discrete ash beds; Unit II is $139 \mathrm{~m}$ thick Oligocene tuffaceous siltstone and fine sandstones; Unit III is $1046 \mathrm{~m}$ Oligocene to Eocene tuffaceous sandstone, mudstone and breccia, and finally Unit IV is $100 \mathrm{~m}$ thick Eocene mudstones and tuffaceous siltstones, sandstones and breccia. In this study, we focused on Unit II and part of the upper Unit III (Until core 30) of Oligocene age to correlate and compare the results from Site 296. The basis for sample selection was the same as for Site 296 cores. Samples with glass, mineral or lithic fragments large enough to isolate and analyze individually were favored. The full set of 59 samples were selected by R. Hickey-Vargas in 2014 as a Leg 351 shipboard scientist. E. Samajpati selected the subset of samples used in this study.

\section{$\underline{\text { Unit II }}$}

Six samples were taken from Unit 2. They are all unconsolidated sediments with a few clasts in the sediments. The color of the sediment down the core goes from dark greybrown to dark grey which also reflects the amount of clay in the samples. The upper sediments are more clayey, which becomes siltier and then grades downward into fine sand. The sediments contain variable amounts of clay minerals, volcanic fragments like scoria and pumice grains and mineral grains of pyroxene, feldspars, Fe-oxides and amphibole. Amphibole-rich layers are found in the two bottom fine sand layers (30X-6W (86-88) and 30X-7W (13-15)) which also had small pumice clasts. 


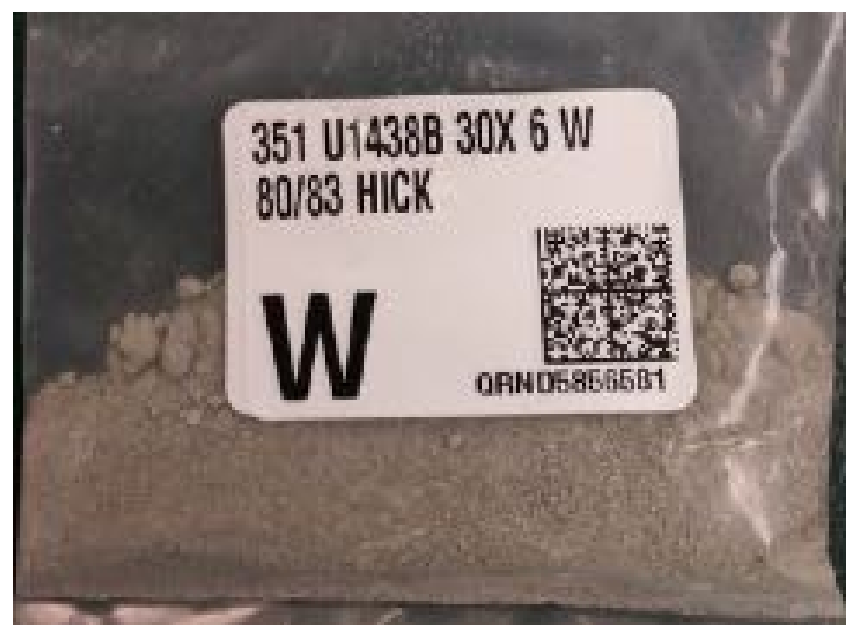

\section{$\underline{\text { Unit III }}$}

Fifty-three samples were taken from Unit III cores 12R through 30R. The samples studied extend through Core 30 (about $500 \mathrm{~m}$ below sea level), representing the later stage of the volcaniclastic sequence which correlated with Site 296. A focus for sample selection for this study was the presence of amphibole, which could be readily analyzed for both major and trace elements. Broadly, in this section there are two kinds of sedimentary rocks: 1) medium to coarse grained breccias, which have pumice as the main clast and 2) finegrained breccias with few pumice clasts and mainly small granular mafic clasts. Mineral grains also appear individually in the matrix, including feldspars and pyroxenes. Coarsegrained pumice bearing breccias are the dominant rock type, the fine-grained breccia appears in between and might be a part of an upper graded sequence. Amphibole grains were occasionally observed within pumice clasts. Fresh large glass shards and large mafic clasts are not very common and mostly absent in the upper section of Unit III. The clasts are poorly sorted, the coarse-grained pumice bearing breccias are clast supported whereas the fine grained breccias are matrix supported. The matrix is dark grey brown color consisting of clay, silt and altered glass. 
Fourteen samples from Unit III, from different intervals and different lithology, both pumice and non-pumice bearing, were selected for analysis. These are 12R-3W (90-100), 14R-2W (51-53), 17R -1W (82-86), 19R-4W (18-21), 21R-1W (14-18), 26R-2W (76-78), 27R-1W (89-91), 27R-1W (118-121) AND 29R-2W (39-41) were disaggregated and minerals and glass were picked for analysis. Two clasts from 15R-3W (13-15) and one clast from 19R-4W (0-3), 21R-1W (14-18), 26R-5W (126-127) and 27R-3W (100-102) were cut out and analyzed.
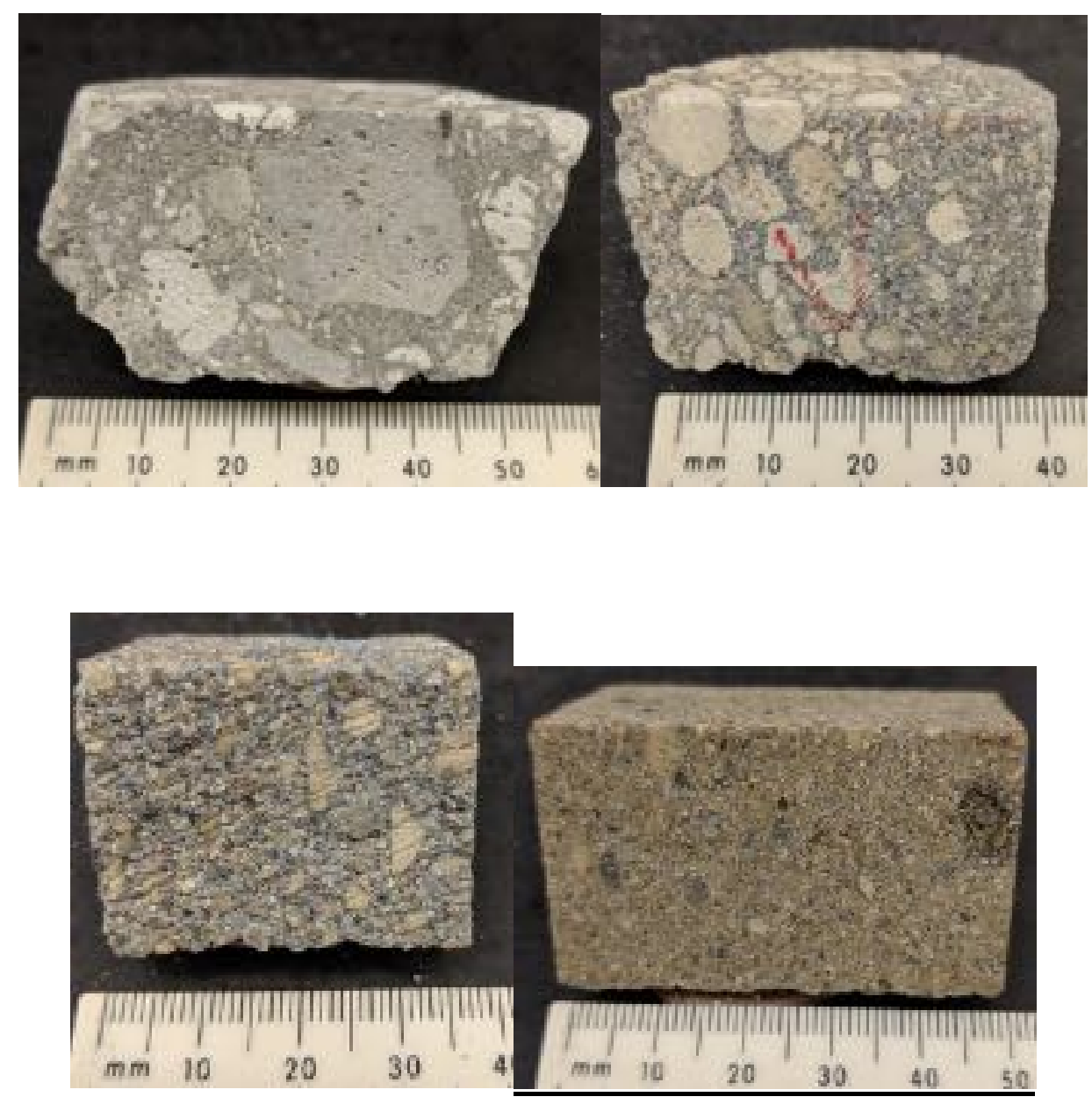


\section{References:}

Arculus, R., Ishizuka, O., Bogus, K., et al., 2015, International Ocean Discovery Program Expedition 351 preliminary report; Izu-Bonin-Mariana Arc origins; continental crust formation at an intraoceanic arc; foundation, inception, and early evolution; 30 May30 July 2014: Preliminary Report (International Ocean Discovery Program), v. 351.

Donnelly, T.W., 1975, Neogene explosive volcanic activity of the western Pacific; sites 292 and 296, DSDP Leg 31: Initial Reports of the Deep Sea Drilling Project, v. 31, p. $577-597$.

Ingle, J.C.,Jr, Karig, D.E., Bouma, A.H., et al., 1975, Site 296: Initial Reports of the Deep Sea Drilling Project, v. 31, p. 191-274.

Ozima, M., Kaneoka, I., and Ujiie, H., 1977, (super 40) Ar- (super 39) Ar age of rocks, and the development mode of the Philippine Sea: Nature (London), v. 267, no. 5614, p. 816-818. 
VITA

\section{ESHITA SAMAJPATI}

2009-2012

B.S., Geology

University of Calcutta

Kolkata, India

2012-2014

M.S., Applied Geology

Indian Institute of Technology

Mumbai, India

2014-2017

M.S. enroute

Florida International University

Miami, Florida

Dec 2017

Travel Grant, CASE and E\&E department

2014-2020

Teaching and Research Assistant

Florida International University

Miami, Florida

Summer 2019

FIU Dissertation Year Fellowship

Dec 2019

Travel Grant, GPSC

Dec 2019

Travel Grant, CASE and E\&E department

$2017-2020$

Doctoral Candidate

Florida International University

Miami, Florida

\section{PUBLICATIONS AND PRESENTATIONS}

- Manuscript under revision in Island Arc journal, titled "Samajpati E., HickeyVargas R. Geochemistry of Volcanic Glass from Oligocene Detrital Sediments at DSDP Site 296, Kyushu Palau Ridge: Interpreting the Magmatic Evolution of the Early Northern Izu Bonin Mariana Island Arc."

- Manuscript to be submitted to Contributions of Mineralogy and Petrology, titled "Samajpati, E., Hickey-Vargas R. Early Arc history of the IBM from volcanic minerals and melt inclusions from DSDP Site 296: a mineral-melt partition approach." 
- Manuscript submitted in GSA Bulletin "Marsaglia et al. IODP Drilling Reveals the Sedimentary Record of Nascent IBM Arc Development"

- Samajpati, E., Hickey-Vargas R. Interpreting the late Oligocene Izu Bonin arc from DSDP Site 296 and IODP Site 1438 sediments. American Geophysical Union, Fall Meeting. San Francisco. December 9-13, 2019.

- Samajpati, E., Hickey-Vargas R. Reconstruction of Late Oligocene Izu-Bonin Arc Magmas from Mineral-Melt Partitioning. Goldschmidt, Boston. August 12-17, 2018.

- Samajpati, E., Hickey-Vargas R. Insights into the Early to Late Oligocene IzuBonin Mariana Arc Magmatic History from Volcanic Minerals and Glass within Volcaniclastic Sediments of IODP Site U1438 and DSDP Site 296. American Geophysical Union, Fall Meeting. New Orleans. December 11-15, 2017. 